PEDRO JOSÉ DA SILVA

\title{
ESTRUTURA PARA IDENTIFICAÇÃO E AVALIAÇÃO DE IMPACTOS AMBIENTAIS EM OBRAS HIDROVIÁRIAS
}

\author{
Tese apresentada à Escola Politécnica da \\ Universidade de São Paulo para obtenção do \\ Título de Doutor em Engenharia.
}

v. 1 


\section{PEDRO JOSÉ DA SILVA}

\section{ESTRUTURA PARA IDENTIFICAÇÃO E AVALIAÇÃO DE IMPACTOS AMBIENTAIS EM OBRAS HIDROVIÁRIAS}

Tese apresentada à Escola Politécnica da Universidade de São Paulo para obtenção do Título de Doutor em Engenharia.

Área de Concentração:

Engenharia Hidráulica

Orientador:

Prof. Titular

Giorgio Brighetti 


\section{RESUMO}

A crescente preocupação com questões ambientais, contemporaneamente, pode ser entendida como uma tendência nebulosa, resultado de uma expressão muito rica de significado e muito mais conveniente para nós, que vivemos sem o distanciamento histórico, pois torna menos definitiva, sob uma perspectiva futura, às adjetivações realizadas, expressão esta identificada como globalização. A globalização conduz a uma natureza propagandista, direcionada à preservação e não à conservação da porção bio-geo-física do meio ambiente, que se refere, em especial, neste trabalho às águas contidas nos rios. A natureza propagandista das questões ambientais, nos faz crer que muitos dos impactos ambientais em um curso d'água, são devidos ao uso das águas e, principalmente quando este uso é para a navegação. A contenda do impacto ambiental, devido ao uso d'água para navegação, não é assunto esgotado quando se aborda somente o Gerenciamento do Recurso Hídrico, ele vai muito além, tem sua origem na Bacia Hidrográfica e, portanto é abordado no Gerenciamento da Bacia Hidrográfica. No desenvolvimento desta tese, será possível perceber, que entre os vários modais de transporte, a navegação fluvial, é a menos impactante ambientalmente, pois, até a via é de origem natural e não antropogênica, como em alguns outros modais. A necessidade da execução de obras hidroviárias, pode ser entendida em algumas situações como parte integrante de um Programa de Mitigação de Impactos Ambientais, não no rio, mas sim na bacia hidrográfica, que pelo não atendimento ou pela inexistência de um plano diretor, sofreu uma ocupação desordenada, resultando em inúmeros impactos ambientais nas porções do meio ambiente. Os capítulos apresentados a seguir, no corpo desta tese, estão vinculados entre si, pois, entendemos que só o estudo simultâneo nos permitirá obter a minimização dos impactos ambientais na bacia hidrográfica, bem como a minimização dos impactos ambientais quando da execução das obras hidroviárias.

Palavras-chave: impacto ambiental, preservação, conservação, navegação fluvial, hidrovia, bacia hidrográfica, recurso hídrico, obras hidroviárias. 


\begin{abstract}
The growing concern about the environmental questions nowadays, can be understood as a nebulousness tendency, a result of a very rich expression of meaning and more convenient to us, who live without the historical distance, because it makes less definite under a future perspective, such expression is identified as globalization. Globalization conducts to a propagandist nature, towards preservation and not the conservation of the bio-geo-physics of the environment, that refers specially in this work about the water in rivers. The propagandist nature of the environmental questions, make us believe that most of the environment impacts in a flow of water, are due to water usage and mainly when this usage is navigation. The dispute of the environmental impact, due to the usage of water to navigation, is not a exhausted subject when talking only about the Hydric Resources Management, it is beyond, it has its origin at the River Basin and is discussed at the River Basin Management. In this theses it will be possible to notice that among the several means of transportation, the fluvial shipping is the less impactant because even the mean is natural and not anthropogenic like in other means. The necessity of hydrographic basin can be understood in some situations as a part of a Environmental Impacts Mitigation Program, not only in the river but in the river basin, that by the no consideration or because it does not exist a director plan, they suffered a disordered occupation, resulting in several environmental impacts. The chapters presented here are all interconnected, because we understand that only the simultaneous study will allow us to get the decrease of impacts at the river basin, as well as the decrease the environmental impact when performing the hydrographic basin.
\end{abstract}

Key words: water usage, environmental impact, preservation, conservation, fluvial shipping, waterway, river basin, hydric resources, hydrographic basin. 


\section{SUMÁRIO}

VOLUME I

RESUMO

ABSTRACT

LISTA DE FIGURAS ix

LISTA DE TABELAS X xvi

LISTA DE ABREVIATURAS Xvii

LISTA DE SÍMBOLOS X

$\begin{array}{ll}\text { APRESENTAÇÃO } & 01\end{array}$

\section{BAPÍTULO 1. INTRODUÇÃO}

$\begin{array}{ll}\text { 1.1. Justificativa } & 05\end{array}$

1.2. Relevância Social $\quad 08$

1.3. Revisão Bibliográfica $\quad \mathbf{1 0}$

1.3.1. Dos Documentos Clássicos $\quad \mathbf{1 0}$

1.3.2. Dos Documentos Específicos $\quad \mathbf{1 2}$

1.4. Relevância Científica 17

1.5. Objetivos

1.5.1. Objetivo Gera 1

1.5.2. Objetivos Específicos

\section{GAPÍTULO 2. ORIGEM DAS HIDROVIAS}

2.1. Histórico $\quad \mathbf{2 0}$

2.2. Evolução das Hidrovias $\quad 23$

2.3. A Rede de Hidrovias Interiores no Brasil $2 \mathbf{2 5}$

2.3.1. Desenvolvimento das Hidrovias Interiores no Brasil $\mathbf{2 5}$

2.3.2. Situação das Hidrovias Interiores no Brasil 29

2.3.2.1. Bacia do Sul - Hidrovias do Sul 31

2.3.2.2. Bacia do Paraná -Tietê 35

2.3.2.3. Bacia do Paraguai $\quad 40$

2.3.2.4. Bacia do São Francisco $\quad 44$ 
2.3.2.5. Bacia Amazônica 48

2.3.2.6. Rio Tocantins e Araguaia $\quad \mathbf{5 4}$

2.4. Situação das Hidrovias Interiores no Mundo

\section{BAPITULO 3. Modais de Transporte}

3.1. Transporte $\quad \mathbf{6 6}$

3.2. Massa Econômica

3.3. Tipos de Transporte $\quad \mathbf{6 6}$

3.4. Integração dos Modais de Transporte $\quad \mathbf{7 0}$

3.5. Dados Notáveis sobre o Transporte Hidroviário 75

\section{GAPÍTULO 4. MÉTODOS DE PREVISÃo DE ANÁLISE DE DADOS}

4.1. Identificação das Variáveis $\quad 77$

4.1.1. Variável Independente $\quad 77$

4.1.2. Variável Dependente $\quad \mathbf{7 8}$

4.1.3. Variáveis Controladas $\quad \mathbf{7 8}$

4.2. Tipo de Pesquisa

4.3. Previsão de Coleta de Dados

4.4. Instrumento de Coleta de Dados

\section{GAPÍTULO 5. DESENVOLVIMENTO DA PESQUISA}

5.1. Variável Independente - Hidrovias Interiores $\quad \mathbf{8 1}$

5.1.1. Tipos Clássicos de Embarcações Fluviais $\quad \mathbf{8 1}$

5.1.1.1. Cronologia dos Tipos de Embarcações $\quad \mathbf{8 8}$

5.1.2. Canal Navegável x Hidrovia

5.1.3. Portos e Construções Portuárias - Infra-estrutura Hidroviária 98

5.2. Variável Dependente - Impactos Ambientais

5.2.1. Impacto Ambiental - Identificação e Definição 109

5.2.1.1. Definição $\quad \mathbf{1 0 9}$

5.2.1.2. Identificação $\quad \mathbf{1 1 2}$

5.2.2. Análise de Impactos Ambientais $\quad \mathbf{1 1 4}$

5.2.3. Métodos de Avaliação de Impactos Ambientais $\quad \mathbf{1 1 4}$ 
5.2.3.1. Método "ad hoc"

5.2.3.2. Método das Listagens de Controle (Check-list)

5.2.3.3. Redes de Interação

5.2.3.4. Superposição de Cartas

5.2.3.5. Método dos Modelos de Simulação

5.2.3.6. Matrizes de Interação

5.2.3.7. Método da Análise Benefício - Custo

5.2.3.8. Método da Análise Multiobjetivo

5.2.3.9. Seleção da Metodologia

5.2.4. Proposição de Medidas Mitigadoras

5.2.5. Programa de Acompanhamento e Monitoramento dos Impactos Ambientais125

5.2.6. Os Usos d'água e os Impactos Ambientais

5.2.7. Identificação dos Impactos Ambientais por Ambientalistas, Especialistas e

Pesquisadores, devido a Hidrovia

5.2.7.1. O Termo Ambientalista

5.2.7.2. Obras Hidroviárias para a Implantação da Hidrovia

5.2.7.3. Tráfego de Comboios de Chatas - Impactos Ambientais

5.2.7.4. Acidentes e Encalhes - Impactos ambientais

5.2.7.5. Ondas e/ou Maior Velocidade do Fluxo D’água - Impactos ambientais144

5.2.7.6. Alteração na Qualidade D'água

5.3. Variável Controlada

\subsubsection{Morfologia Fluvial}

5.3.2. Obras Hidráulicas

5.3.3. Os Efeitos da Globalização nas Obras Hidroviárias

5.3.4. Classificação de VAN RAALTEN - Tipos de Obras Hidroviárias

5.3.5. Classificação Proposta - Tipos de Obras Hidroviárias

5.3.5.1. Gerais ou de Normalização

5.3.5.1.1. Desobstrução e Limpeza

5.3.5.1.2. Limitação dos Leitos de Inundação

5.3.5.1.3. Fechamento dos Braços Secundários

5.3.5.1.4. Proteção das Margens 
5.3.5.3. Regularização dos Leitos

5.3.5.4. Derrocamento

5.3.5.5. Dragagem

5.3.5.6. Canais Artificiais

5.3.5.7. Obras de Canalização dos Cursos D'água

5.3.6. Estudo das Principais Obras Hidroviárias

5.3.6.1. Proteção das Margens

5.3.6.1.1. Proteção Direta (Contínua)
a) Redução do Ângulo de Talude (Retaludamento)
177

b) Revestimento das Margens

179

c) Obras de Sustentação

5.3.6.1.2. Proteção Indireta (Descontínua)

a) Espigões $\quad \mathbf{2 6 7}$

b) Diques $\quad 291$

c) Soleiras de Fundo $\quad 294$

d) Umbrais de Fundo $\quad 294$

e) Retificação de Meandros $\quad 295$

f) Regularização dos Leitos $\quad 303$

g) Derrocamento $\quad 315$

h) Dragagem $\quad \mathbf{3 2 0}$

i) Canais Artificiais 343

j) Canalização dos Cursos D'água 346

\section{GAPÍTULO 6. CORRELAÇÕES ENTRE AS VARIÁVEIS}

6.1. As Correlações

6.2. A Advertência

6.3. Impacto Ambiental - Enunciação

6.4. Detalhamento e Classificação dos Impactos Ambientais $\mathbf{3 5 2}$

6.5. Planilhas Ambientais - Modelos a partir das Correlações 356

- Planilha № 01 - Tipo de Obra Hidráulica Fluvial (Rio sem Intervenção) 
Planilha № 02 - Tipo de Obra Hidráulica Fluvial (Rio com Intervenção)

ॠProteção Direta da Ribanceira

Planilha № 03 - Tipo de Obra Hidráulica Fluvial

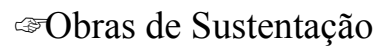

Planilha № 04 - Tipo de Obra Hidráulica Fluvial

박oteção Indireta - Espigões

Planilha № 05 - Tipo de Obra Hidráulica Fluvial

ำProteção Indireta - Diques

Planilha № 06 - Tipo de Obra Hidráulica Fluvial

* Retificação de Rios Sinuosos e Meandros

Planilha № 07 - Tipo de Obra Hidráulica Fluvial

merrocamento e Dragagens

Planilha № 08 - Tipo de Obra Hidráulica Fluvial

ॠR्:Regularização do Leito

6.6. Resultado do Questionamento

6.7. Modelo de Planilhas Ambientais - Instrumento para a Identificação de Impactos Ambientais

Planilha № 01 - Tipo de Obra Hidráulica Fluvial (Rio sem Intervenção) $\leftrightarrow$ Proteção das Margens

Planilha № 02 - Tipo de Obra Hidráulica Fluvial (Rio com Intervenção)

↔Proteção Direta da Ribanceira

Planilha № 03 - Tipo de Obra Hidráulica Fluvial

๓⿴囗十⺝ Obras de Sustentação

Planilha № 04 - Tipo de Obra Hidráulica Fluvial

ॠProteção Indireta - Espigões

432

Planilha № 05 - Tipo de Obra Hidráulica Fluvial

सProteção Indireta - Diques

Planilha № 06 - Tipo de Obra Hidráulica Fluvial

Retificação de Rios Sinuosos e Meandros

Planilha № 07 - Tipo de Obra Hidráulica Fluvial

따맘ocamento e Dragagens

Planilha № 08 - Tipo de Obra Hidráulica Fluvial 


\title{
GAPÍTULO 1. MATERIAL E MÉTODOS
}

7.1. Metodologia

7.2. Local de Estudo

7.3. Delineamento do Local de Estudo

472

7.4. Delineamento do Estudo das Ações Propostas e Impactos Ambientais

7.5. Previsão da Coleta de Dados

7.6. Método de Pesquisa

7.7. Tipo de Pesquisa 474

7.7. Modalidade da Pesquisa

\section{BAPÍTULO 10. ANEXOS}

\author{
Anexo A - Legislação Ambiental \\ Anexo B - Geossintéticos \\ Anexo C - Comparação entre Obras Hidroviárias
}

482

489

490

BAPÍTULO 11. BIBLIOGRAFIA 


\section{LISTA DE FIGURAS}

Figura 1 - Sistema estuarino - lagunar de Cananéia-Iguape 27

Figura 2 - Integração entre os sistemas de transporte $\quad 70$

Figura 3 - Embarcação fluvial e suas dimensões 83

Figura 4 - Transporte fluvial - granéis líquidos 84

Figura 5 - Transporte fluvial - granéis sólidos $\quad 85$

Figura 6 - Transporte fluvial - granéis sólidos $\quad 86$

Figura 7 - Transporte fluvial - carga rodante $\quad 87$

Figura 8 - Embarcação fluvial - empurrador $\quad 89$

Figura 9 - Embarcações fluviais - comboios de empurra 90

Figura 10 - Configurações do comboios e sua eficiência 91

Figura 11 - Dispositivos de sinalização e segurança 97

Figura 12 - Dispositivos de sinalização e segurança 99

Figura 13 - Bóias de amarração de comboios $\quad 100$

$\begin{array}{ll}\text { Figura } 14 \text { - Segurança de navegação } & 101\end{array}$

Figura 15 - Segurança de navegação: comunicações 102

Figura 16 - Portos fluviais - terminais 103

Figura 17 - Portos fluviais - instalações industriais 104

Figura 18 - O degelo é responsável pela alteração no valor da vazão, $\begin{array}{ll}\text { contribuindo nos períodos de cheia } & 110\end{array}$

Figura 19 - Impacto ambiental - implantação de um terminal hidroviário acompanhado do desenvolvimento regional 138

Figura 20 - Impacto ambiental - terminais hidroviários integrados e a formação de um pólo hidroviário industrial 139

Figura 21 - Impacto ambiental - pólo hidroviário industrial 139

Figura 22 - Impacto ambiental - destruição da vegetação ciliar 141

Figura 23 - Impacto ambiental - locais degradados pelo embate das embarcações 142

Figura 24 - Impacto ambiental - formação de ondas com o tráfego de 
embarcações

Figura 25 - Canal revestido em concreto 153

Figura 26 - Canal com margens revestidas 154

Figura 27 - Trecho em montanha do rio Paranapanema 156

Figura 28 - Curso d'água com características de rio aluvionar $\quad 157$

Figura 29 - Curso d'água com características de rio intermediário 157

Figura 30,31, 32 - Desenhos e rios meandrantes e modelo experimental 161

Figura 33 - Modelo idealizado de meandro 162

Figura 34 - Proteção das margens: vista parcial da contenção e proteção de margem da foz do Rio Itajaí-Açu, em Itajaí (SC) 172

Figura 35 - Proteção das margens: vista aérea parcial do revestimento dos taludes laterais do canal do Itá, em Santa-Cruz (RJ) 172

Figura 36 - Retaludamento 179

Figura 37 - Proteção direta - Faxina: obras de proteção de margens 181

Figura 38 - Proteção direta - Faxina: construção 182

Figura 39 - Proteção direta - Enrocamento (pedra arrumada e lançada) 186

Figura 40 - Proteção direta - Localização do filtro de transição 187

Figura 41 - Proteção direta - esquema de um colchão Reno 190

Figura 42 - Proteção direta - colchão Reno: preparação e colocação do colchão Reno na obra 191

Figura 43 - Proteção direta - colchão Reno - enchimento do colchão

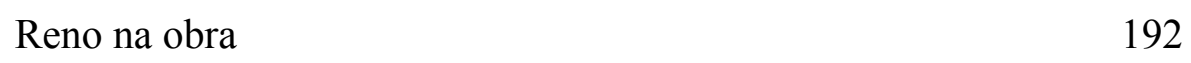

Figura 44 - Proteção direta - colchão Reno - enchimento do colchão Reno na obra e, recuperação da vegetação 192

Figura 45 - Proteção direta - colchão Reno - fechamento do colchão

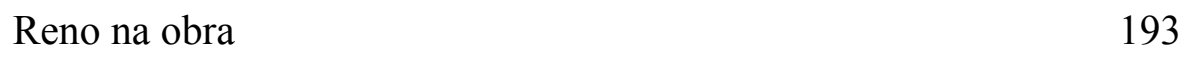

Figura 46 - Proteção direta - colchão Reno - revestimento executado a seco

Figura 47 - Proteção direta - colchão reno - revestimento executado em presença d'água 
Figura 48 - Proteção direta - colchão Reno com mástique de betume aplicado no local da obra

Figura 49 - Proteção direta - colchão Reno com mástique de betume aplicado fora do local da obra

Figura 50 - Proteção direta - bolsacreto/colchacreto

Figura 51 - Proteção direta - colchacreto - elementos de um colchacreto 203

Figura 52 - Proteção direta - bolsacreto - especificação técnica 208

Figura 53 - Proteção direta - peças pré-moldadas de concreto armado

Figura 54 - Proteção direta - proteção das margens com pneus usados

Figura 55 - Sistema Eco-estrutural pneumático - muro de contenção

Figura 56 - Cobertura vegetal da margem taludada

Figura 57 - Proteção direta - o papel da cobertura vegetal

Figura 58 - Desmatamento e variação esquemática da estabilidade de taludes e encostas

Figura 59 - Cobertura vegetal - inclusive canais gramados

Figura 60 - Cobertura vegetal \& Blocos de rocha

Figura 61 - Secção transversal típica do revestimento de solo-cimento

Figura 62 - Ábaco para determinação da largura da camada

horizontal e da espessura mínima do revestimento

Figura 63 - Proteção direta - geomanta tipo "flatback"

Figura 64 - Proteção direta - geomanta tipo "tridimensional"

Figura 65 - Proteção direta - biomanta

Figura 66 - Proteção direta - geotêxtil não tecido

Figura 67 - Proteção direta - geomembrana: revestimento de canal de irrigação

Figura 68 - Proteção direta - geomembrana: bacia de armazenamento de água para irrigação

Figura 69 - Proteção direta - geobarras

Figura 70 - Proteção direta - geocélulas 
Figura 71 - Obras de sustentação - terra armada: placas pré-moldadas de concreto

Figura 72 - Obras de sustentação - terra armada:

tardoz da escama $\mathrm{x}$ armadura

Figura 73 - Obras de sustentação - sistema terramesh 249

Figura 74 - Muro de gravidade $\quad 251$

Figura 75 - Muro atirantado $\quad 251$

Figura 76 - Muro de flexão 253

Figura 77 - Muros de contraforte $\quad 254$

Figura 78 - Obras de sustentação - gabiões: detalhe de enchimento de gabiões, apoiados sobre plataforma de sacos

Figura 79 - Obras de sustentação - gabiões: vista de execução de muro em gabiões 256

Figura 80 - Proteção direta: esquema do gabião saco 258

Figura 81 - Proteção direta - gabião saco: colocação em presença d'água 260

Figura 82 - Proteção direta - gabião saco: espigão 261

Figura 83 - Proteção direta - rimo bloco $\quad 262$

Figura 84 - Crib - wall - A 263

Figura 85 - Paredes diafragma: etapas de execução 264

Figura 86 - Estacas - prancha 265

Figura 87 - Paredes de estacões 266

Figura 88 - Notação adotada nas Tabelas XVIII e XIX 272

Figura 89 - Proteção indireta - tipos de espigões 273

Figura 90 - Proteção indireta - espigão tipo martelo 274

Figura 91 - Proteção indireta - colocação de um espigão, quando a margem não está muito elevada 276

Figura 92 - Proteção indireta - colocação de um espigão, quando a margem está muito elevada 276

Figura 93 - Proteção Indireta - detalhe e exemplos de aplicações de $\begin{array}{ll}\text { espigões } & 278\end{array}$ 
Figura 94 - Proteção Indireta- localização e comprimento dos primeiros espigões, na margem de rio a ser protegida

Figura 95 - Proteção Indireta - Detalhe da orientação dos espigões

Figura 96 - Proteção Indireta - Deposição de sedimentos, devido a construção de espigão de troncos, vedado com varas finas, favorecendo a formação de uma nova margem

Figura 97 - Proteção Indireta - seção de espigão de bolsas empilhadas

Figura 98 - Proteção Indireta - principais problemas de estabilidade com seções compostas por bolsas

Figura 99 - Proteção Indireta - espigões impermeáveis - disposição de geotubos

Figura 100 - Proteção Indireta - espigões impermeáveis - processo de enchimento de geotubos

Figura 101 - Proteção Indireta - espigões impermeáveis - posição de geotubo

Figura 102 - Proteção Indireta - espigão permeável, confeccionado com madeira e bambu

Figura 103 - Proteção Indireta - espigões permeáveis - confeccionados com madeira: troncos e/ou tábuas

Figura 104 - Proteção Indireta - transporte de pedras para a construção de espigões permeáveis

Figura 105 - Proteção Indireta - construção de espigão permeável com troncos e pedras

Figura 106 - Proteção Indireta - exemplos de espigões permeáveis, usados no Japão

Figura 107 - Proteção Indireta - gaiolas de arame (gabiões) para encerrar pedras pequenas

Figura 108 - Proteção Indireta - localização e funcionamento de espigões 
Figura 109 - Proteção Indireta - Vista em planta da localização e funcionamento de espigões $\quad 290$

Figura 110 - Proteção Indireta - Dique - modalidade de construção

Figura 111 - Proteção Indireta - construção de diques em troncos de madeira

Figura 112 - Proteção Indireta - construção de diques com troncos e tábuas

Figura 113 - Proteção Indireta - prolongamento do espigão: exemplo de soleira de fundo

Figura 114 - Proteção Indireta - umbrais de fundo

Figura 115 - Retificação de rio meandrante, novo traçado

Figura 116 - Retificação de rio meandrante, corte direto

Figura 117 - Retificação de meandro - canal piloto

Figura 118 - Retificação de rio meandrante - canal piloto

Figura 119 - Regularização do leito

Figura 120 - Regularização dos leitos - melhoramento do perfil transversal; planta e perfis típicos de duas curvas sucessivas

Figura 121 - Concentração das águas em um único leito - planta

Figura 122 - Concentração das águas em um único leito - seção transversal

Figura 123 - Regularização dos leitos - identificação dos parâmetros geométricos médios

Figura 124 - Regularização dos leitos - Disposição em planta dos diques e espigões - planta

Figura 125 - Regularização dos leitos - Disposição em planta dos diques e espigões - seção AA

Figura 126 - Regularização dos leitos - Disposição em planta dos diques e espigões - seção BB

Figura 127 - Regularização dos leitos - Disposição em planta dos diques e espigões, num rio - planta 
Figura 128 - Derrocamento típico 316

Figura 129 - Derrocamento típico e dragagem 316

Figura 130 - Derrocador de Percussão - derrocador de queda livre 319

Figura 131 - Dragagem de manutenção $\quad 321$

Figura 132 - Dragagem de um curso d'água 322

Figura 133 - Draga auto transportadora 327

Figura 134 - Draga de alcatruzes $\quad 335$

Figura 135 - Draga de colher 336

Figura 136 - Draga de colher 336

Figura 137 - Draga de clamshell 337

Figura 138 - Draga de sução e recalque com desagregador 338

Figura 139 - Draga de sução e recalque com desagregador 339

Figura 140 - Movimentação da draga 339

Figura 141 - Draga de sução e recalque com tubulação flutuante 343

Figura 142 - Obras de transposição 346 


\section{LISTA DE TABELAS}

Tabela I - Classificação dos rios para navegação no Brasil 30

Tabela II - Gabaritos propostos para oficialização 30

Tabela III - Rede hidroviária no Brasil 60

Tabela IV - Rede hidroviária no mundo $\quad 65$

Tabela V - Via para cada modalidade de transporte 69

Tabela VI - Relação de custos entre os sistemas de transportes $\quad 70$

Tabela VII - Custos envolvidos na operação de transporte 72

Tabela VIII - Comparação entre os modais de transporte 73

Tabela IX - Combustível consumido no transporte de cargas por $\begin{array}{ll}\text { modo } & 74\end{array}$

$\begin{array}{lll}\text { Tabela X - Quadro comparativo de transporte } & 74\end{array}$

Tabela XI - Custos sócio-ambientais de transporte 74

$\begin{array}{lll}\text { Tabela XII - Emissão de poluentes } & 75\end{array}$

Tabela XIII - Larguras - U.S. Army C.E. 93

Tabela XIV - Principais categorias de demanda de água 128

Tabela XV - Hidráulicos notáveis e suas contribuições 164

Tabela XVI - Rios brasileiros e intervenções de engenharia 168

Tabela XVII - Velocidades permissíveis para canais cobertos por vegetação 221

Tabela XVIII - Distâncias entre eixos (espaçamento) de espigões 271

Tabela XIX - Distâncias entre eixos (espaçamento) de espigões 271

Tabela XX - Proposta de valoração para os impactos ambientais Classificados 457

Tabela XXI - Geossintéticos e principais funções 489

Tabela XXII - Comparação entre as obras de proteção direta e indireta 490 


\title{
LISTA DE ABREVIATURAS
}

\author{
$\boldsymbol{A}$ \\ ANA - Agência Nacional das Águas \\ ABCP - Associação Brasileira de Cimento Portland \\ AHIMOC - Administração das Hidrovias da Amazônia Ocidental \\ AHIMOR - Administração das Hidrovias da Amazônia Oriental \\ AHIPAR - Administração da Hidrovia do Paraguai \\ AHITAR - Administração da Hidrovia do Tocantins \\ AHSFRA - Administração da Hidrovia do São Francisco \\ B \\ BR - Petróleo Brasileiro S.A. \\ C \\ CONAMA - Conselho Nacional do Meio Ambiente \\ CIH - Comité Intergubernamental de la Hidrovia Paraguay- Paraná \\ CENAT - Comissão Executiva da Navegação do Tietê \\ CESP - Companhia Energética do Estado de São Paulo \\ CONSTRUSERV - Sistemas de Controle de Erosão e Comércio Ltda \\ COPASA - Companhia de Saneamento de Minas Gerais \\ D \\ DAEE - Departamento de Águas e Energia Elétrica \\ DEPVIA - Depvia Engenharia e Consultoria Ltda; \\ $\boldsymbol{E}$ \\ EIA - Estudo de Impacto Ambiental; \\ ELETROSUL - Centrais Elétricas do Sul do Brasil S.A; \\ EUA - Estados Unidos da América do Norte; \\ $\boldsymbol{F}$ \\ FRANAVE - - Companhia de Navegação do São Francisco;
}


FUNAI

$$
\boldsymbol{G}
$$$$
\text { GPS }
$$

H

HERMASA

HP

I

ISO

IBC

ICM

\section{M}

MINTER

MERCOSUL

MW

$N$

NBR

O

ONG

$\boldsymbol{P}$

PORTOBRAS

PEAD

PET

PP

PVC
- Fundação Nacional do Índio

- Global Positioning System

- Hermasa Terminal (Brazshipping Itacoatiara)

- Horse-power

- International Organization for Standardization;

- International Business Communications;

- Imposto sobre Circulação de Mercadorias

- Ministério dos Transportes

- Mercado Comum do Sul

- Megawatt

- Correspondência № ${ }^{\mathrm{o}}$ Inmetro com o $\mathrm{N}^{\mathrm{o}} \mathrm{ABNT}$

- Organização Não Governamental

- Portos Brasileiros;

- Polietileno de Alta Densidade;

- Poliéster;

- Polipropileno Soldado de Alta Densidade;

- Cloreto de polivinila 
$R$

RIMA - Relatório de Impacto Ambiental

$S$

SGA - Sistema de Gestão Ambiental

SBN - Serviço de Navegação da Bacia do Prata

SEMA - Secretária Especial do Meio Ambiente

$T$

TVA - Tennessee Valley Authorithy

TKMU - Tonelagem por Quilômetro Útil

TDW - Total Deadweight

TPB - Tonelagem de Porte Bruto

$U$

URSS - União das Repúblicas Socialistas Soviéticas

U.S.Army.C.E- United States Army Corps of Engineers

UNESP - Universidade Estadual Paulista

$\boldsymbol{V}$

VW - Volkswagen

W

WWF - World Wildlife Fund 


\section{LISTA DE SÍMBOLOS}

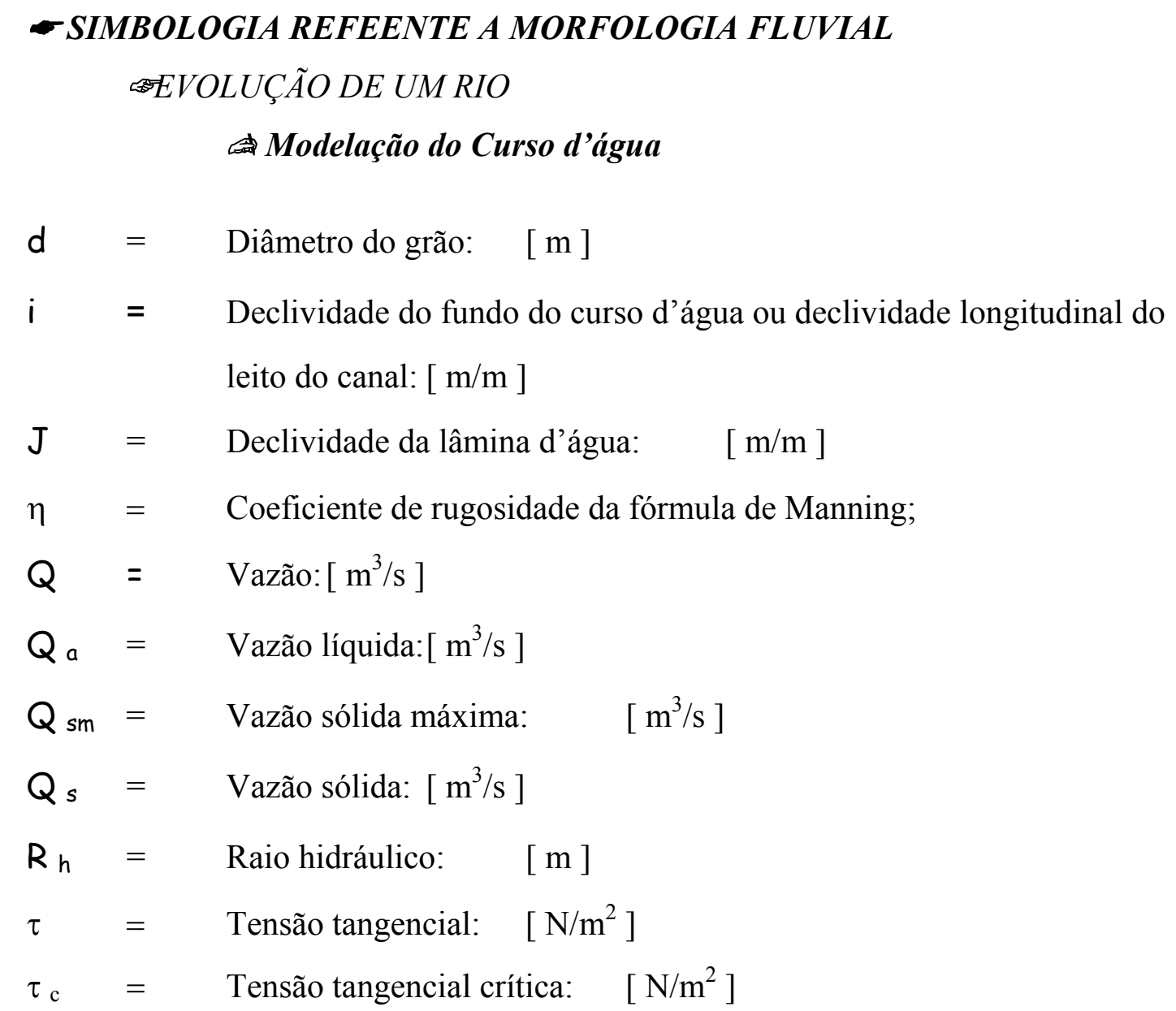

\section{Caracterização do Meandro}

$\mathrm{W}=$ Largura do canal: $[\mathrm{m}]$

$\lambda=$ Comprimento da onda: $[\mathrm{m}]$

$\mathrm{L}=$ Comprimento do canal: $[\mathrm{m}]$

$r_{c}=$ Raio de curvatura: $[\mathrm{m}]$ 
- SIMBOLOGIA REFEENTE A PROTEÇÃO DAS MARGENS

खPROTEÇÃO DIRETA

Revestimento das Margens: Solo-cimento

$\begin{array}{lll}v & = & \text { Espessura da camada horizontal acabada: [ } \mathrm{m}] \\ w & = & \text { Largura da camada horizontal: } \quad[\mathrm{m}] \\ t_{n} & =\text { Espessura mínima do revestimento: }[\mathrm{m}] \\ \mathrm{d} & =\text { Distância vertical mínima entre o topo da barragem e o nível d'água } \\ \text { máximo: } & {[\mathrm{m}]}\end{array}$

SIMBOLOGIA REFEENTE A REGULARIZAÇÃO DOS LEITOS ↔REGULARIZAÇÃO DOS RIOS DE FUNDO RESISTENTE

$R_{h}=$ Raio hidráulico da seção transversal do canal: [ $\mathrm{m}$ ]

$C=$ Coeficiente de Rugosidade de Chézy ou Coeficiente de Resistência

$Q=$ Vazão que está escoando pelo canal: $\quad\left[\mathrm{m}^{3} / \mathrm{s}\right]$

$\mathbf{V}=$ Velocidade média do escoamento: $[\mathrm{m} / \mathrm{s}]$

$A=$ Área da seção transversal molhada, do canal: $\quad\left[\mathrm{m}^{2}\right]$

$\mathrm{J}=$ Declividade da lâmina d'água: $\quad[\mathrm{m} / \mathrm{m}]$

$\mathrm{i}=$ Declividade do fundo do curso d'água ou declividade longitudinal do leito do canal: $\quad[\mathrm{m} / \mathrm{m}]$

$\mathrm{L}=$ Largura entre as margens: $[\mathrm{m}]$

$\mathrm{h}=$ Profundidade do canal: $[\mathrm{m}]$ 
Agora, que nos encontramos à margem do rio, de modo a iniciar a nossa viagem, seria prudente aceitar $\mathrm{o}$ conselho de Hesíodo.

“Tratem de nunca atravessar as águas dos rios de curso eterno sem antes lhes ter dirigido uma prece, de olhos fitos em suas esplêndidas correntes, sem antes molhar suas mãos em sua onda agradável e límpida" (Commelin, 1997).

Oferecida ao deus fluvial, Tibre. 


\section{APRESENTAÇÃO}

Vivemos uma época onde a vida de ontem é diferente da vida de amanhã, pois, num período que separam dois dias consecutivos, ocorrem grandes transformações, o ritmo dessas transformações vem se acelerando cada vez mais. As ciências, as artes e, a tecnologia, não vivem mais separadas, temos um corpo, onde cada uma delas, é um membro. As informações se multiplicam e vão se tornando cada vez mais complexas, disponíveis, mas não entendidas. São frutos daquele corpo: a globalização, a nova ordem mundial, os conflitos raciais e étnicos, a questão ambiental, a produção de alimentos, a fome de milhões de pessoas, o desenvolvimento tecnológico, o desemprego, a urbanização e a qualidade de vida nas cidades, a saúde, a educação, o envelhecimento da população, o comércio internacional, o aumento da dívida dos países pobres, o empobrecimento dos países ricos, o desenvolvimento na guerra e, tantos outros (Quirino, 1999; Irias \& Wright, 1999).

A Universidade, neste momento, no seu significado mais geral, assume importância fundamental, pois guarda informações do passado, explica o presente e permite prever o futuro, como se fosse um deus secundário, daqueles da mitologia. É esta Universidade que permite entender e explicar, a essência desta tese, nos seguintes capítulos:

\section{CAPÍTULO 1 - INTRODUÇÃO}

A forma adotada para abordar o tema: Estrutura para Identificação e Avaliação de Impactos Ambientais em Obras Hidroviárias, reside no tratamento em separado de cada assunto que constitui o tema, pois tem-se verificado que existe muito desconhecimento de assuntos específicos, mais importantíssimos, pois constituem-se no diferencial entre o que é certo e o que é errado. As relevâncias, social e científica, demonstram que ao se tratar o assunto com o devido conhecimento haverá uma "desmistificação". 
O mito criado no Brasil, em relação as hidrovias, pelos Países do Norte ou Ricos, principalmente países da América Anglo-Saxônica, ao cair, permitirá aos Países Pobres, principalmente países da América Latina, uma melhora na qualidade de vida, tomando para si, a conservação do meio ambiente.

\section{CAPÍTULO 2 - ORIGEM DAS HIDROVIAS}

Os recursos naturais correspondem ao conjunto de fatores disponíveis na natureza, que podem ser transformados em riquezas para suprir as necessidades ou aspirações de consumo de uma sociedade. Entre esses recursos, a porção água, confinada em rios, foi utilizada, perdendo-se nos tempos imemoriais das primeiras civilizações, que apresentavam como manifestações da cultura do homem, a navegação. Neste capítulo, navegaremos serpenteando o tempo, reaprendendo a sábia utilização d'água como meio de transporte do homem.

\section{CAPÍTULO 3 - MODAIS DE TRANSPORTE}

A tradução de termos tais como: planejamento e gerenciamento, para o presente, então atualizados como logística e gestão, talvez sejam suficientes para trazer aos nossos dias a viabilidade que o país apresenta à navegação fluvial. Este capítulo identifica a viabilidade de cada modalidade e, indica o caminho para o modal identificado como navegação fluvial.

\section{CAPÍTULO 4 - MÉTODOS DE PREVISÃO DE ANÁLISE DE DADOS}

O método de previsão de análise de dados, consiste na apresentação do problema de pesquisa, que neste estudo, inicialmente, se apresenta como uma suposição duvidosa. O método, é a estrutura desta pesquisa, o arranjo lógico do conjunto das preposições, que no desenvolvimento da pesquisa, demonstra ser verdadeira a suposição inicialmente duvidosa. 


\section{CAPÍTULO 5 - ESTUDO DAS VARIÁVEIS INTERVENIENTES}

O desenvolvimento da pesquisa, é o estudo minucioso de cada variável, de modo a quebrar mitos, recuperar conceitos que foram esquecidos com o desaparecimento dos grandes mestres. Acreditamos que em determinados instantes, o desenvolvimento de uma determinada variável, tornou-se básica, evidente e exaustiva, mas demos continuidade, pois, o tema abordado é multidisciplinar. Procura-se preencher uma lacuna da melhor forma possível, construindo-se um elo de ligação entre uma área do conhecimento e outra, com uma linguagem simples e ao alcance de todos que venham futuramente a se interessar pelo assunto.

\section{CAPÍTULO 6 - CORRELAÇÕES ENTRE AS VARIÁVEIS}

As correlações entre: variável independente (hidrovia) x variável dependente (impactos ambientais), variável independente (hidrovia) x variável controlada (obras hidroviárias), variável dependente (impactos ambientais) x variável controlada (obras hidroviárias), têm como objetivo permitir a elaboração do material identificado por planilha ambiental, que será utilizada, como instrumento de coleta de dados.

\section{CAPÍTULO 7 - MATERIAIS E MÉTODOS}

Um trabalho só é considerado científico, quando é passível de reprodução. $\mathrm{O}$ capítulo material e métodos, fornece informações, por escrito, de modo a permitir que outro pesquisador, de igual competência, possa reproduzi-lo.

\section{CAPÍTULO 8 - DISCUSSÃO}

A discussão consiste na interpretação do "resultado" obtido com a devolução do instrumento de coleta de dados, isto é, “planilhas ambientais". 


\section{CAPÍTULO 9- CONCLUSÃO}

Nesse instante da pesquisa, apresenta-se uma síntese pessoal sobre o tema, as possíveis questões, encaminhamento, soluções, problemas que foram suscitados pelo assunto abordado.

\section{CAPÍTULO 10 - ANEXOS}

Nesse capítulo, estão contidas informações importantes e, em geral, longas e detalhadas em demasia, que se incluídas no próprio texto truncariam a leitura. Os anexos detalham informações, sem as quais o texto principal ficaria incompleto ou sem uma fundamentação ou exemplificação necessária.

\section{CAPÍTULO 11 - BIBLIOGRÁFIA}

Esse capítulo diz respeito às obras que foram lidas, durante o trabalho, porém não foram citadas no texto.

\section{CAPÍTULO 12 - REFERÊNCIAS BIBLIOGRÁFICAS}

Neste capítulo, fazemos referências àquelas obras que foram explicitamente citadas e, portanto, usadas durante o trabalho no próprio texto.

\section{CAPÍTULO 13 - GLOSSÁRIO}

Neste capítulo, apresentamos uma relação de palavras de uso restrito, acompanhadas das respectivas definições, com o objetivo, sendo esta tese multidisciplinar, de esclarecer aos profissionais das diferentes áreas do conhecimento o significado dos termos empregados. 


\section{CAPÍtul01.}

\section{NTRODURẼO}

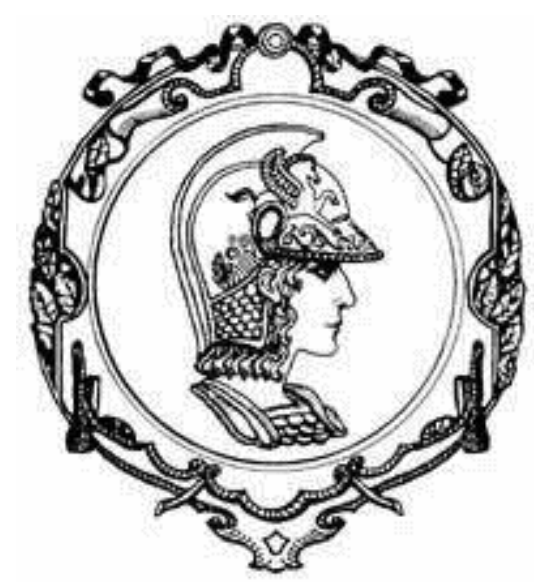

\section{MINERVA ,}

Filha de Júpiter. Após ter devorado Métis, ou a Prudência, Júpiter sentiu uma terrível dor de cabeça e recorreu a Vulcano, Deus do fogo, que lhe abriu o cérebro com uma machadada. De seu cérebro saiu Minerva, perfeita e vestida de armadura ( Commelin, 1997).

Preside às artes ornamentais e úteis, tanto da mulher, como fiação, tecelagem e trabalhos de agulha, como do homem, como da agricultura e navegação (Bulfinchi, 2001).

Deusa da guerra, das ciências e das artes, da sabedoria, permita-me navegar pelo conhecimento, empresta-me vossa sabedoria, de modo a me permitir tecer, como homem e mortal, essa tese, fazendo ciência. 


\subsection{JUSTIFICATIVA}

A observação das complexas relações do homem com o seu planeta, pode ser revelada através da ocupação do espaço. Imagine um filme da população, passado a cada década, qual seria o espanto ao saber que a população mundial duplicava a cada 1000 anos, mas o espaço de tempo para esta duplicação foi diminuindo ao longo dos anos, de 200 para 80, para 45 anos, sendo que as projeções de duplicação em 25 anos não foram confirmadas (Freiria \& Garcia, 2001).

Neste início de século, somos seis bilhões de pessoas no mundo, sendo que, quatro bilhões dormem diariamente com fome e, países como China e Índia, juntos, abrigam $40 \%$ deste mundo de pessoas. Esta população ocupa $70 \%$ das terras do planeta e, os $30 \%$ restantes, referem-se a matas e florestas.

Segundo as projeções, em apenas treze anos deveremos acrescentar ao planeta, mais 1 bilhão de pessoas; para os anos 2025 e 2050 a população mundial será 8 e 9 bilhões respectivamente. Espera-se que a partir desse ponto a população estabilize ou diminua, devido à escassez dos recursos naturais do planeta, pois a capacidade não atende uma população maior que 12 bilhões.

Utópico, seria acreditar, que esta população não crescerá mais, que as florestas e matas não serão ocupadas por elas e, que ninguém mais dormirá com fome.

A estes bilhões de pessoas, deverá ser permitido a somatória de todos os fatores positivos ou ao menos de parte significativa dos mesmos, que determinado meio reúne para a vida humana em conseqüência da interação sociedade-meio ambiente e, que atinge a vida como fato, de modo a atender as suas necessidades somáticas e psíquicas, assegurando índices adequados ao nível qualitativo da vida que se leva e do meio que a envolve. 
A medida que melhora a qualidade de vida das pessoas, aumentam suas exigências, suas necessidades. Evitar estes aumentos, é fácil, é só manter a população na miséria!

Brasil, um país potencialmente rico, somos donos de uma das maiores redes hidrográficas do mundo, mas não a utilizamos corretamente. Esse mesmo Brasil, possui um enorme potencial de produção de grãos no interior de seu continente (Zona Centro-Oeste), e a hidrovia em sincronismo com os outros modais, conectaria as áreas produtoras com a frota oceânica; se assim o fizéssemos, estaríamos ocupando espaço privilegiado no comércio exterior, pois os produtos dos setores primário (pecuária, agricultura, pesca e mineração) e secundário (automóveis e outros) seriam imbatíveis no mercado internacional. Cabe ressaltar, que a hidrovia é um modal extremamente competitivo, menos impactante quando comparado aos outros modais, e de menor custo de implantação.

O cenário futuro, é altamente favorável ao setor primário, no mercado global, principalmente ao que se refere a produção de grãos. Os três países em desenvolvimento que estão despontando na produção de grãos: China, Índia e Brasil. Há porém um cenário previsto no qual China e Índia terão problemas para manter suas produções, por escassez de recursos hídricos. Prevê-se que o Brasil, naquele instante pode assumir a liderança em condições privilegiadas (Camargo Junior, 1999).

O Brasil insere-se no grupo de países com o menor índice de aproveitamento de suas vias potencialmente navegáveis, ao contrário dos EUA e da Europa com os maiores índices de utilização de vias fluviais (Portobrás, 1989).

Essa pobreza, pode ser expressa em bilhões de reais, como exemplo, podemos citar a perda anual na colheita e comercialização de nossas safras agrícolas. Em 1996, o nosso saldo de pobreza cresceu em R\$ 1,6 bilhões. Desperdiçados naquele ano, entre a porteira da fazenda e o consumidor. As causas, de tanto desperdício, são muitas, pois são diretamente proporcionais as nossa ignorância e as nossas atitudes. A causa maior está no transporte pré e pós-colheita. 
Brasil, deve assumir em 2003 o posto de maior exportador mundial de soja, superando pela primeira vez os Estado Unidos, segundo informações do ministro da agricultura, Roberto Rodrigues. O país também baterá recorde na colheita do produto, estimada em 52,209 milhões de toneladas, 24,6\% acima dos 41,916 milhões de toneladas da safra anterior (O Estado de São Paulo, 12 de agosto de 2003).

Projeções feitas pela ONU apontam que o Brasil tem o potencial de se tornar o maior produtor agrícola mundial nos próximos doze anos. A avaliação faz parte do relatório anual de commodities, preparado pela Conferência da ONU sobre Desenvolvimento e Comércio (Unctad). O Brasil conta com nada menos do que 90 milhões de hectares de terras potencialmente aráveis, virgens e que poderiam ser usadas sem que se tenha de cortar uma só árvore, afirma o documento, de cerca de 330 páginas e que se baseia em dados de 2001 e 2002 (O Estado de São Paulo, 09 de julho de 2003). O transporte da produção de soja, pode ser expresso da seguinte maneira: cerca de $63 \%$ desse produto, são transportados por rodovia, $24 \%$ por ferrovia e apenas $13 \%$ por hidrovia. Isso torna o custo do transporte de grãos no país um dos mais elevados do mundo, comprometendo a competitividade do produto brasileiro no mercado externo.

Segundo o ministro da agricultura, Roberto Rodrigues, há a necessidade de ampliar-se o número de armazéns alfandegados no interior do país para possibilitar que produtos já vendidos para o exterior sejam estocados até que sejam embarcados para mercados estrangeiros. O objetivo seria tirar um pouco a pressão sobre os portos, que presenciam filas imensas para o carregamento de navios com produtos agrícolas que serão exportados. Os locais, adequados, para a criação desses armazéns são aqueles nas regiões produtoras de grãos e próximos às redes ferroviárias, desta forma, assim que o navio atracasse no porto brasileiro, o produto seria transportado do interior diretamente para o navio, sem precisar esperar no porto. Um dos locais para a implantação desses armazéns é Ponta Grosa (O Estado de São Paulo, 2003). 
Diferentemente daquilo que é dito, a realidade demonstra que a área plantada cresceu 14,8\% em 13 anos, isto é, 1,2\% por ano. Mas a produção física cresceu $107,6 \%$ no período, ou $6,3 \%$ por ano, em média, sendo então, o aumento da produtividade função da tecnologia e, não de um irresponsável desmatamento nesse período, os agricultores sofreram descasamento de renda com os planos Collor e Cruzado e enfrentaram esse problema investindo em tecnologia e aumentando produtividade.

Não podemos importar uma literatura técnico-ambientalista, fundamentada no não atropelamento de peixes pelas embarcações e, que não nos permite ver que a navegação interior, oferece a possibilidade de transportar grande quantidade de carga de uma só vez e, que a combinação de dois ou mais modais de transporte, é a melhor solução econômica quando se trata de longas distâncias.

\subsection{RELEVÂNCIA SOCIAL}

Brasil, possuidor e dono da maior reserva mundial de recursos hídricos continentais (Camargo Junior, 2000), dispõe do dobro da água de superfície dos americanos e cerca de $80 \%$ a mais que países com dimensões continentais como o Canadá e China, isto sem mencionar as variações climáticas que congelam as águas dos continentes do Hemisfério Norte e impedem a navegação dos rios daqueles países em praticamente metade do ano, não a utiliza, isto é, não nos permitem utilizar, nos fazem acreditar que o "comboio fluvial, irá atropelar peixes" ou as "placas de sinalização das hidrovias estressarão os pássaros, atrapalhando sua reprodução" (Dreer, 2001). As hidrovias, trazem além dos impactos ambientais desfavoráveis, que podem ser minimizados, enorme impacto ambiental favorável, entre os quais podemos destacar: desenvolvimento da agricultura e geração de empregos.

Os países produtores de grãos, que dominam o comércio exterior de grãos, a muito sabem que a aceitação das hidrovias deixou de ser uma questão técnica e passou a ser uma questão política. Existe uma política externa de manutenção da 
miséria; subitamente a expressão “desenvolvimento sustentável”, deixou de ser veiculada nos meios de comunicação, pois este desenvolvimento só é atingido através do tripé, "fauna e flora, poluição e finalmente miséria". Quantas vezes escutamos a expressão "celeiro do mundo", é isto que somos, a nossa competitividade é agrícola. A medida que escoa-se os produtos agrícolas, do campo para os mercados, interno e externo, através das hidrovias, há um aumento da competitividade agrícola.

A manutenção da miséria é algo extremamente simples, uma das formas é facilitar a implantação de modal(is) de transporte em nada compatível com o país e, dificultar a presença e/ou a consulta a uma parcela da engenharia nacional, com conhecimento das questões ambientais, quando da elaboração dos estudos preliminares para a definição do(s) modal(is) de transporte, de fato, compatíveis com o país. Assim, a política externa nos impõe um modelo de transporte e a consequente manutenção da miséria. Acredita-se que, para atingir-se o desenvolvimento sustentável o primeiro passo a ser dado é em direção a irradicação da miséria e, os passos seguintes nos conduzirão a preservação e conservação da fauna e flora e uma conseqüente minimização da poluição.

Não seria demais lembrar que a população desse país, jovem, não é mais, e grande número dos nossos profissionais das diversas áreas do conhecimento, são pessoas com idade igual ou superior a sessenta anos, viveram projetos e são guardiães de grandes conhecimentos.

Socialmente, deveria ter existido um período, de modo a permitir a transferência desses conhecimentos, através da formação de equipes multidisciplinares. Infelizmente esse período não ocorreu e os motivos são vários , mas o econômico se sobrepõe aos demais. Períodos como este, nos fizeram perder o "bonde" do desenvolvimento, aqui diríamos sim, que períodos como este nos fizeram perder o "barco" do desenvolvimento.

A relevância social, desta pesquisa, reside no fato de não deixar a manutenção da miséria aumentar ainda mais a nossa miséria social. Ao contrário do que se diz, a engenharia nacional está consciente das questões e dos problemas ambientais 
e, está desenvolvendo projetos onde a viabilidade ambiental é um dos parâmetros a ser atendido.

\subsection{REVISÃO BIBLIOGRÁFICA}

A identificação dos trabalhos existentes, entendendo-se por trabalhos: livros, leis, teses, dissertações e qualquer documento existente na literatura à respeito do tema da presente pesquisa, demandou diversas etapas de trabalho, que desenvolveram-se ao longo da pesquisa. Estas etapas, foram sintetizadas em dois itens: a) documentos considerados clássicos, ou seja, aqueles referentes ao conhecimento geral (universal) e; b) documentos específicos, são aqueles que representam o conhecimento recente, referindo-se especificamente a questões do tema estudado.

\subsubsection{DOS DOCUMENTOS CLÁSSICOS}

Dentre os documentos denominados de clássicos, tiveram destaque na estruturação dos conhecimentos utilizados para o desenvolvimento da presente pesquisa:

- ÁGUAS DOCES NO BRASIL (Rebouças et al., 1999). A presente obra traz a apresentação e a análise dos nossos potenciais de água doce, compreendendo chuvas, águas superficiais - fluxos dos rios, lagoas, áreas encharcadas, águas subterrâneas, suas interações com o meio ambiente natural, em geral e, antrópico em particular. Por sua vez, o trabalho analisa a problemática da água doce nos diferentes setores da atividade da economia, os aspectos da saúde pública, de saneamento básico, aspectos institucionais e jurídicos, as necessidades de monitoramento, os aspectos culturais e o seu papel como fator de turismo. $\mathrm{O}$ capítulo 12, oferece um amplo entendimento do que é a navegação fluvial, delineando as perspectivas nos médio e longo prazos, ressaltando as seis bacias hidrográficas, no Brasil, mais importantes. 
- DREDGING AND DREDGED MATERIAL DISPOSAL (U.S.Army Corps of Engineers, 1983). A presente obra, fornece informações referentes a intervenção de engenharia, indireta no rio, que compreende a remoção, transporte e a análise das diferentes alternativas de disposição final do material resultante da dragagem.

- FLUVIAL PROCESSES IN RIVER ENGENEERING (Chang, 1987). A obra permite entender a seqüência de estados que ocorrem em um rio, que transformase ou evolui.

- HIDRÁULICA (Quintela, 2000). A obra permite entender o conjunto de técnicas ligadas a condução de água.

- HIDRAULIQUE FLUVIALE (Graf; Altinakar, 1993). Esta obra permite obter conhecimentos dos princípios gerais que regem os cursos de água.

- KOKEI UEHARA - DOMADOR DE RIOS (Pereira, 1994). Este livro, é o primeiro de uma série, galeria de retratos de professores da Escola Politécnica. É a história da vida exemplar do Prof. KOKEI UEHARA, onde nesta tese, destacamos os capítulos: “A OBRA “ e "O LEGADO INTANGÍVEL”.

- MANUAL DE HIDRÁULICA GERAL (Lencastre, 1972). A obra permite recuperar os conceitos fundamentais que regem a "condução da água". Tem por pretensões constituir-se em um "livro útil" para a pesquisa e ser um instrumento de trabalho, destinado principalmente a projetos de hidráulica.

- MANUAL DE HiDRÁUliCA (Azevedo Neto et al., 1998). A presente obra permite estudar o comportamento d'água e outros líquidos quer em repouso quer em movimento.

- OPEN CHANNEL FLOW (Chaudhry, 1993). A obra permite obter conhecimentos que regem o escoamento em canais artificiais.

- RIVER AND CHANNEL REVESTMENTS - A DESIGN MANUAL (Escarameia, 1998). A obra fornece conhecimentos referentes a intervenção de engenharia, direta, no rio. 
- RIVER ENGINEERING (Petersen, 1986). Esta obra é um compêndio, guarda conhecimentos referentes a intervenção de engenharia, direta e indireta, no rio, entendidas nessa tese como obras hidroviárias.

- TRAITÉ D’HYDRAULIQUE FLUVIALE APPLIQUÉE: CÓURS D’EAU NON NAVIGABLES (Quesnel, 1980). Este livro aborda os conceitos fundamentais referentes a Hidráulica Fluvial, bem como a sua aplicação em obras fluviais.

- TÉCNICA E ECONOMIA DE TRANSPORTE (Albanese, 1987). A obra, apresenta os conceitos básicos referentes aos diversos modais de transporte; fornecendo comparativos que permitem a escolha do modal adequado a cada situação.

- TRANSPORTE FLUVIAL E MARÍTIMO (Del Grande, 1989). A obra, apresenta os conceitos básicos referentes ao transporte fluvial e marítimo.

\subsubsection{DOS DOCUMENTOS ESPECÍFICOS}

A identificação dos documentos denominados específicos, exigiu diversos levantamentos de literatura, que são destacados abaixo, com o objetivo de verificar e aferir a existência de textos e pesquisas semelhantes àquela que ora é proposta, sendo a abordagem abaixo desdobrada em itens específicos em que se procura sumarizar as informações e suas origem.

Assim este segmento da revisão bibliográfica está orientado para uma avaliação direta das contribuições que o tema proposto possa ter recebido ao longo dos anos, bem como as indicações de lacunas que ainda estão por carecer o esforço de novas pesquisas. Dentre os documentos denominados de específicos, tiveram destaque na estruturação dos conhecimentos utilizados para o desenvolvimento da presente pesquisa:

- A PROCEDURE FOR EVALUATING ENVIRONMENTAL IMPACT (Leopold et al., 1971). Nesta obra são apresentados os procedimentos/métodos para a avaliação dos impactos ambientais, causados ao meio ambiente, pela ação do homem. 
- CÓDIGO DE ÁGUAS (Vieira, 1996). A obra, faz a apresentação da legislação referente ao uso das águas no Brasil, de acordo com a tendência atual, permitindo ao poder público controlar e incentivar o aproveitamento econômico das águas.

- Decreto $\mathrm{n}^{\mathrm{O}}$ 3.411, de 12 de abril de 2000. Regulamenta a Lei $\mathrm{n}^{\mathrm{0}}$ 9.611, de 17 de fevereiro de 1998. - Transporte Multimodal de Cargas.

- DESENVOLVIMENTO E MEIO AMBIENTE. As Estratégias de Mudança da $A G E N D A 21$ (Barbieri, 1997). Esta obra, traz a reflexão todos aqueles que não perderam a capacidade de indignar-se frente a miséria, à degradação ambiental e todas as suas formas de exclusão social. Nos faz ver, se a humanidade produz mazelas que tornam incerto seu próprio futuro, também tem sido capaz de produzir instrumentos para superá-las - A AGENDA 21, refere-se a estes instrumentos.

- DYNAMIQUE FLUVIALE (Lebreton, 1974). Este livro, aborda em uma das suas partes os impactos ambientais no recurso água, devido a obra hidroviária de retificação no curso d'água.

- ENVIRONMENTAL IMPACT OF WATER RESOURCES PROJECTS (Canter, 1985). Este livro é organizado de forma a apresentar estudos de impactos ambientais devido a projetos de: drenagem; irrigação; reservatórios; canalização do recurso água. São citados como locais de estudo: São Francisco; Mississipi; Washington; Califórnia; Florida e outros. São identificados impactos na fauna e flora aquáticos, bem como, impactos nas características: físicas; químicas e biológicas do recurso água, devido àqueles projetos.

- ENVIRONMENTAL IMPACT ASSESSMENT (Munn, 1975). A obra apresenta um conjunto de informações, de modo a capacitar os profissionais das diversas áreas do conhecimento humanos a desenvolver habilidades para a avaliação dos impactos ambientais.

- ENVIRONMENTAL IMPACT ASSESSMENT (Canter, 1977). A obra apresenta um conjunto de informações, de modo a capacitar os profissionais das diversas áreas do conhecimento humano a desenvolver habilidades para a avaliação dos impactos ambientais. 
- ENVIRONMENTAL IMPACT ASSESSMENT (Jain, et al., 1993). A obra apresenta um conjunto de informações, de modo a capacitar os profissionais das diversas áreas do conhecimento humano a desenvolver habilidades para a avaliação dos impactos ambientais.

- ENVIRONMENTAL IMPACT ASSESSMENT. (Petry \& Boeriu, 1999). Esta obra fornece informações e procedimentos, para identificação e avaliação das conseqüências de uma atividade humana sobre os meios físico, biótico e antrópico, no sentido de propor medidas mitigadoras para os impactos negativos, promovendo o aumento de seus benefícios.

- ENVIRONMENTAL IMPACT ASSESSMENT - ANNEX. . (Petry \& Boeriu, 1999). Este trabalho, sobre a fundamentação conceitual da obra acima citada, é um valoroso caderno de identificação de impactos ambientais; riquíssimo em exemplos de empreendimentos, relacionando-os com as alterações ambientais decorrentes da sua implantação.

- environmental eCOlogy. the ecological efFEcts of POLLUTION, DISTURBANCE E OTHER STRESS (Freedman, 1995). A obra permite entender os efeitos da poluição no complexo físico-biologico e, as alterações que ocorrem na relação dos organismos entre si e, com o seu ambiente físico.

- ESTUDOS DE IMPACTO AMBIENTAL (Tommasi, 1993). Esta obra é, acima de tudo, uma introdução aos EIA, através de uma síntese bibliográfica. Procura contribuir para a iniciação de um fascinante sistema de avaliação de projetos de desenvolvimento e de sua compatibilização com um efetivo desenvolvimento sustentado.

- HIDROVIA - Uma Análise Ambiental Inicial da Via Fluvial Paraguai - Paraná (Bucher et al., 1994). Devido a falta de informação técnica e dados básicos sobre a área e as possíveis conseqüências ambientais do projeto, bem como às veementes discussões que desperta, existe o risco de que o debate sobre a Hidrovia se transforme numa inútil discussão política, outra falsa dicotomia entre empregos versus ambiente natural, com o qual ninguém se beneficiaria. 
Este relatório objetiva, portanto, elevar o nível da discussão concernente à Hidrovia ao nível técnico.

- IMPACTO AMBIENTAL - ASPECTO DA LEGISLAÇÃO BRASILEIRA (Mirra, 1998). A obra, apresenta os principais aspectos da legislação brasileira sobre EIA, à luz dos textos normativos e legais em vigor e da interpretação da doutrina especializada e da jurisprudência que vem se formando ao longo dos últimos anos.

- INTRODUCTION TO ENVIRONMENTAL ENGINEERING (Davis; Cornwell, 1991). A obra tem por finalidade favorecer o conhecimento dos conceitos básicos das ciências do ambiente, preparando engenheiros e outros profissionais de forma a causar os menores impactos possíveis sobre Os recursos naturais, quando do exercício das suas atividades profissionais.

- ISO 14001 - MANUAL DE IMPLANTAÇÃO (Cajazeira, 1998). Identifica-se neste trabalho, a finalidade do estabelecimento de um roteiro para incorporar a função ambiental dentro da gestão do empreendimento, através de requisitos mínimos estabelecidos de forma organizada. Há o fornecimento de um guia simples e prático para a iniciação nos requisitos da Norma ISO 14001.

- Lei no 5.357, de 07/12/67. Estabelece penalidades para embarcações e terminais marítimos ou fluviais que lançarem detritos ou óleo em águas brasileiras.

- Lei $\mathrm{n}^{\mathrm{o}}$ 9.433, de janeiro de 1977. Determinou os fundamentos, objetivos, diretrizes e instrumentos para o Gerenciamento de Recursos Hídricos.

- Lei n⿳0 6.938, de 31/08/81. Dispõe sobre a Política Nacional do Meio Ambiente, seus fins, mecanismos de formulação e aplicação ( com redação dadas pelas Leis n⿳⺈ 7.804, de 18/07/89 e 8.028, de 12/04/90).

- Lei n⿳0 9.605, de fevereiro de 1998. A Lei do Meio Ambiente. Dispõe sobre as sanções penais e administrativas derivadas de condutas e atividades lesivas ao meio ambiente, e dá outras providências.

- Lei $\mathrm{n}^{0}$ 9.611, de 19 de fevereiro de 1998. Dispõe sobre o Transporte Multimodal de Cargas. 
- Lei n⿳0 9.984, de 17 de julho de 2000, dispõe sobre a criação da Agência Nacional de Águas - ANA, entidade federal de implementação da Política Nacional de Recursos Hídricos e de Coordenação do Sistema Nacional de Gerenciamento de Recursos Hídricos, e dá outras providências.

- NBR 9896. Esta Norma define os termos nos estudos, projetos, pesquisas e trabalhos em geral relacionados à poluição das águas.

- O TRATAdo DE COOPERAÇÃo AMAZÔNiCA COMO INSTRUMENTO INSTITUCIONAL E LEGAL PARA O GERENCIAMENTO DE RECURSOS HÍDRICOS DA BACIA AMAZÔNICA (Cabral; Setti, 2001). Dispõe sobre a Bacia Amazônica, definindo-a e apresentando suas características, bem como descrevendo as etapas do desenvolvimento do tratado de cooperação.

- Portaria Interministerial $n^{0} 1$, de 23/01/78. Recomenda que a classificação e o enquadramento de águas federais e estaduais para efeito de seu controle, deverão levar em conta as condições existentes de produção de energia hidrelétrica e de navegação.

- RESOluÇÃo CONAMA (Conselho Nacional do Meio Ambiente) nº 1, de 23 de janeiro de 1986. Dispõe sobre a necessidade de se estabelecerem definições, as responsabilidades, os critérios básicos e as diretrizes gerais para o uso e implementação da Avaliação de Impacto Ambiental como um dos instrumentos da Política Nacional do Meio Ambiente.

- RESOlUÇÃO CONAMA (Conselho Nacional do Meio Ambiente) nº 4, de 18 de setembro de 1985. Dispõe sobre Reservas Ecológicas, definindo as áreas marginais e cursos d'água, lagoas e outros reservatórios superficiais, as quais tem uso do solo controlado pela desapropriação total ou através do disciplinamento das atividades nas mesmas (faixas de proteção de recursos hídricos). 
- RESOluÇÃo CONAMA (Conselho Nacional do Meio Ambiente) no 20, de 18 de junho de 1986. Estabelece a classificação das águas doces, salobras e salinas do território nacional, em noves classes, segundo seus usos preponderantes. (Esta Resolução revogou as Portarias MINTER 13, de 15 de janeiro de 1976, e 536, de 7 de dezembro de 1976).

- SISTEMA DE GESTÃo AMBIENTAL EM TERMINAIS HIDROVIÁRIOS E COMBOIOS FLUVIAIS: Contribuição para o Desenvolvimento Sustentável na Hidrovia Tietê-Paraná (Camargo Junior, 2000). O objetivo geral deste estudo, é a estruturação de um Sistema de Gestão Ambiental - SGA, definindo normas e procedimentos técnicos de monitoramento e controle da qualidade ambiental em torno dos terminais hidroviários e comboios fluviais a partir da análise do Meio Físico. De forma a propor uma leitura abrangente que beneficie sua aplicação pela administração de terminais e órgãos gestores da navegação fluvial, elegeram-se as normas da série ISO 14000 como referência, versão mais moderna dos conceitos internacionais de qualidade ambiental aplicada a empreendimentos de natureza variada.

- SUSTAINABLE DEVELOPMENT: A GUIDE TO OUR COMMOM FUTURE (World Commision on Environment and Development, 1990). É uma obra, um guia, que permite conhecer o desenvolvimento não predatório, com o objetivo de preservar a terra para as gerações futuras; não desperdiçar matérias primas, etc.

\subsection{RELEVÂNCIA CIENTÍFICA}

A pesquisa em questão traz novos conhecimentos para a área científica, pois um levantamento bibliográfico, indica que as pesquisas realizadas até a presente data têm creditado as hidrovias, a produção de alterações desfavoráveis ao meio ambiente ou em alguma de suas porções físicas. 
Os impactos ambientais desfavoráveis, têm conduzido a realização de estudos para viabilizar outro(s) modal(is) de transporte e, a defesa da não aprovação de novos Projetos de Hidrovias. Impactos ambientais desfavoráveis, devido as Hidrovias, são incontestáveis, mas devemos lembrar que os rios brasileiros apresentam características naturais, favoráveis ao transporte de passageiros e cargas, e que a preservação que deseja-se aplicar a eles de forma a impedir qualquer intervenção com vista ao aproveitamento econômico, tem como conseqüência imediata a impactação ambiental.

A preservação, através de placas, onde se lê: “ÁREA DE PRESERVAÇÃO”, é o caminho mais rápido para esta impactação, exemplos, são inúmeros. Preservar, exige investimentos.

Os novos caminhos para a área científica, residem na conservação, isto é, a sábia utilização dos rios, segundo o qual, o homem deve buscar a manutenção do equilíbrio biológico entre as suas necessidades e, a capacidade a longo prazo, da natureza, para satisfazê-las. Questões como se obter esse equilíbrio, são freqüentemente apresentadas. A resposta, a essas questões, reside no fato que devemos estar atentos, de modo a não cometer um erro para corrigir outro.

Antes de vetar-se um Projeto de uma nova Hidrovia, deveríamos sim, procurar nos erros a solução para futuros acertos, e não estar recomeçando , partindo para outros modais de transporte, sem conhecer os seus futuros impactos ambientais desfavoráveis, talvez não exista meio ambiente suficiente para esta nova tentativa.

As Hidrovias, que deram origem a Impactos Ambientais, desfavoráveis, devem ser analisadas de modo a verificar se elas atendem aos estudos de viabilidade técnica, econômica, financeira, jurídica, política, social e ambiental, somente assim

obteremos conhecimentos relevantes cientificamente, a defesa das Hidrovias, como um modal de transporte importante para o nosso país.

\subsection{OBJETIVOS}




\subsubsection{OBJETIVO GERAL}

O objetivo geral desta pesquisa, será definir uma estrutura, composta por um sistema e um modelo. O sistema consistirá num esquema ou procedimento que inter-relacionará: entrada ( entendida como dados/informações da questão a ser abordada); habilidade (entendida como a capacidade para trabalhar com os dados/informações); saída (consiste na resposta para a questão). Enquanto o modelo, será a representação do comportamento do sistema. Esta estrutura permitirá identificar os impactos ambientais das obras hidroviárias (navegação interior), bem como a sua valoração de modo a permitir uma melhoria das condições de navegabilidade de um curso d'água, e definir os procedimentos a serem adotados, permitindo assim a consolidação da sua viabilização. Este trabalho, não se constitui num estudo para identificação e valoração dos impactos ambientais da hidrovia como um todo.

\subsubsection{OBJETIVOS ESPECÍFICOS}

O problema de pesquisa, nos conduz aos seguintes objetivos específicos:

Apresentar uma proposta para classificar os tipos de obras hidroviárias;

Identificar os impactos ambientais relacionados às obras hidroviárias;

Elaborar, com bases científicas, uma planilha ambiental, relacionando as obras hidroviárias e os impactos ambientais, delas provenientes, o que permitirá uma (avaliação quantitativa) valoração dos impactos ambientais e das ações propostas;

Definir um método, isto é, uma lógica no modo de agir, operacionalizando o empreendimento - hidrovia, e consequentemente, descartar a sua desativação como empreendimento;

Definir de uma técnica, ou seja, um instrumento que em conjunto com o método venha a garantir a sustentabilidade do empreendimento;

Abordar o "negócio" hidrovia, dentro da gestão ambiental. 


\section{Capítulo 2.}

\section{A MitOLOGIA NóRDiCA E O RIO}

As lendas nórdicas, segundo as narrativas mitológicas dos povos escandinavos (EDAS), não havia no princípio, nem céu em cima nem terra embaixo, mas apenas um abismo sem fundo e um mundo de vapor no qual flutuava uma fonte. Dessa fonte saíram doze rios e, depois de eles terem corrido até muito distante de sua origem congelaram-se e, tendo as camadas de gelo se acumulado uma sobre as outras, o grande abismo se encheu. A sul do mundo de vapor, havia um mundo de luz, do qual uma viração quente soprou sobre o gelo, derretendo-o. Os vapores elevaram-se no ar e formaram nuvens, das quais surgiu Ymir, o gelo gigante, e sua geração, e a vaca Audumbla, cujo leite alimentou o gigante. Essa vaca, alimentava-se lambendo o gelo de onde retirava a água e o sal. Certo dia, quando estava lambendo as pedras de sal, surgiram os cabelos de um homem; no segundo dia toda a cabeça e, no terceiro, todo o corpo, que tinha grande beleza, agilidade e força. O novo ser era um deus e dele e de sua esposa, filha da raça dos gigantes, nasceram os três irmãos, Odin, Vili e Ve, que mataram o gigante Ymir, formando com seu corpo a terra, com seu sangue os mares, rios e lagos, com seus ossos as montanhas, com seus cabelos as árvores, com seu crânio o céu e com seu cérebro as nuvens carregadas de neve e granizo. Com a testa de Ymir, os deuses formaram a Midgard (terra média), destinada a tornar-se a morada do homem (Bulfinch, 2000). 


\section{2.}

\section{ORIGEM DAS HIDROVIAS}

\subsection{HISTÓRICO}

A água sempre teve uma importância vital para o desenvolvimento da humanidade.

Desde os primórdios da civilização moderna, a prosperidade de uma região foi conseqüência de suas relações econômicas com outras regiões em função do transporte.

Durante milhares de anos, rios e lagos foram estradas naturais por onde o ser humano colonizou novas terras e por onde as populações fixadas às suas margens escoaram sua produção. Ao longo dos séculos, segundo Freeman et al. (1992), o ser humano buscou aperfeiçoamento baseado em três fatores:

- Complementaridade: interações espaciais de uma região com outra;

- Oportunidade: intervenção entre duas regiões ou locais;

- Transferibilidade: medição de custos e tempo de transporte, sempre buscando otimizar suas características operacionais: de carroças a caminhões; de balões a aviões; de trilhas a auto-estradas; de rios navegáveis a hidrovias, etc.

Ao longo dos rios desenvolveram-se as grandes civilizações, que fazem parte da história. É o caso dos egípcios, que evoluíram por milhares de anos ao longo do rio Nilo, é também o caso das civilizações dos caldeus, babilônios e assírios, ao longo dos rios Tigre e Eufrates.

O principal uso humano dos rios sempre foi a retirada de água para o consumo próprio, para animais e para a irrigação, mas é também da época das primeiras civilizações que se tem notícia dos primeiros transportes de carga e pessoas, com embarcações movidas a remo ou a vela. 
A origem da navegação perde-se nos tempos imemoriais, tudo parece indicar, que teria sido uma das mais antigas manifestações de cultura do homem. O primeiro meio de transporte foi o próprio homem, mas a flutuação de troncos nas águas, deve ter sugerido a primeira utilização de meios de transporte, mais rápido e mais fácil.

Do tronco flutuando à confecção das primeiras canoas, devem ter passado milhares de anos, as primeiras embarcações foram certamente, simples canoas, pirogas e pelotas, constituídas por troncos de árvores escavadas ou pele de animais às quais se davam formas côncavas com armações convenientes de varas. As primeiras notícias de embarcações primitivas, denominadas pelotas, algumas ainda hoje utilizadas, datam do período paleolítico. Na Europa, em alguns museus, encontramse exposta pelotas, de $10 \mathrm{~m}$ a $28 \mathrm{~m}$ de comprimento, atribuídas à idade da pedra polida.

Os egípcios já se utilizavam de embarcações de madeira, de formas bastante evoluídas, com propulsão a vela e a remo, usadas principalmente para a guerra e o comércio. O delta do Nilo era cortado por canais onde se fazia um tráfego comercial notável, estendendo-se até a costa do Mediterrâneo.

No século XV antes de Cristo os Egípcios já tinham galeras de 35 metros de comprimento, que eram tripulados por 60 homens, utilizadas para o comércio, que se expandia até à Ásia. Datam dessa época as primeiras obras portuárias notáveis, principalmente no Mediterrâneo. Estas obras tinham como finalidade principal, a defesa das cidades e o abrigo das embarcações.

Devem-se aos povos da Ásia e principalmente aos Fenícios os maiores progressos da navegação nessa época. No século XII a.C., os Fenícios já mantinham relações com os povos do Mar Vermelho, atravessavam as colunas de Hércules (Gibraltar) e subiam pela costa da Europa até o Mar do Norte e Mar Báltico.

Com o povoamento da Europa, destacam-se como navegantes os Normandos, que estabelecidos no Norte da Europa assaltam as costas da Inglaterra e da França. Subindo pelo Sena, atacam Paris no ano 911 da nossa era. 
Na Europa, o povo que mais utilizou a via fluvial para deslocamentos com fins bélicos foi o povo Vicking. Eles atingiram a região de Moscou, adentrando pelos rios Elba e Reno.

As primeiras obras na Europa de que se tem notícia, com finalidade de melhorar a navegação datam do século X. Carlos Magno, no entanto, começou a primeira obra significativa antes, no início dos anos 800 . Essa obra consistia num canal visando a interligação das bacias do Reno e Danúbio.

Referências à obras de melhoramentos para fins de navegação datam do século XII, na China ( Câmaras do rio Yang-Tsé) e na França (Barragens no rio Lot).

No século XV surgiram na Europa as primeiras eclusas, pequenas, com uma operação rudimentar. Aparecem no canal de Briare ( rio Loire, na França ) e no rio Arno ( sofreu alterações do traçado para melhorar as condições de navegabilidade entre entre Florença e Pisa, na Itália ), de concepção de Leonardo da Vinci (1480).

A navegação marítima se desenvolveu rapidamente, sob a necessidade da expansão comercial, atingindo no século XV, a época dos grandes descobrimentos. Cristóvão Colombo e Vasco da Gama marcam incontestavelmente estas etapas das mais gloriosas na história da navegação.

No ocidente podemos constatar a importância dos rios como vias de comunicação, em função do surgimento de centros de comércio importantes como Londres, à margem do Tâmisa, Paris à margem do Sena, Hamburgo no rio Elba, assim como Roma, Amsterdã, Moscou, e muitas outras.

No continente americano surgiram as cidades de Nova Iorque, no rio Hudson, de Saint Louis, no rio Mississipi, Quebec, Toronto e Montreal, ao longo do São Lourenço, e, nos Grandes Lagos, Chicago e Detroit, todas originárias do desenvolvimento para o interior, com vias fluviais como meio de transporte.

$\mathrm{Na}$ América do Sul, Buenos Aires, Assunção, Porto Alegre, Belém e Manaus também tiveram origem em situação semelhante.

A invenção da máquina a vapor ( aproximadamente em 1800 ) e o diesel (no século XX) trazem novos conceitos na construção e na navegação. Nos primórdios, os barcos eram de madeira, a remo ou a vela, no período de1920 a 1930, desenvolve- 
se a construção metálica; em 1940, aparece o barco automotor padronizado; a partir de 1955, começam os "push-boats", comboios de empurra, impelidos pela traseira, com a concentração da propulsão, do comando e do governo, num único elemento que pode ser isolado ( o empurrador ), sendo as chatas um bloco compacto e inerte ( sem tripulação ).

Técnicos de alto gabarito se notabilizaram na hidráulica fluvial, como Fargue e Girardon, baseando seus estudos na adaptação dos cursos de água para a navegação.

\subsection{EVOLUÇÃO DAS HIDROVIAS}

Os rios sempre se constituíram como vias de "penetração e transporte"; as cidades se estabeleciam em suas margens.

As embarcações flutuavam livremente para jusante; na volta, ou seja, para montante, só eram utilizadas, quando da possibilidade de serem puxadas por cabos atados a animais ou homens ("halâge" = sirga), localizadas nas margens, devendo nessa situação, a declividade ser suave; podendo ainda nessa situação utilizar-se remo ou vela. Em trechos com correnteza, o barco era desmontado e vendido como lenha no porto terminal de jusante ( eram barcos de uma só viagem ).

O conceito sobre navegação, nos permite entender: o trajeto habitual feito por uma "nave", transportando cargas ou passageiros sobre a água ou ar; compreendendo também a orientação e o governo da nave, determinando as suas coordenadas (latitude e longitude) e sua direção (rumo), mediante observação com bússola, sextante, radar, cronômetro, rádio, goniômetro, etc.

O termo "navegação" engloba toda a técnica do transporte hidroviário ou seja:

aproveitamento, adaptação e construção das vias navegáveis, para o transporte hidroviário;

- construção das embarcações;

- condução das embarcações. 
Aos engenheiros civis, só tem interesse o primeiro aspecto do problema de navegação, sendo portanto o seu significado restrito, à técnica do melhoramento, construção, conservação, aparelhagem e exploração comercial das vias navegáveis e dos portos.

A navegação, quando englobar a técnica do transporte hidroviário, poderá ser classificada em: navegação interior e navegação marítima.

A navegação marítima estuda o melhoramento das barras, o melhoramento e aparelhamento dos portos, a sua exploração mecânica.

As vias de navegação marítima são os mares e os oceanos, só haverá problema para a navegação, nas áreas de pequena profundidade, junto à costa.

A navegação interior, estuda as obras necessárias à conservação e melhoramento das condições de navegabilidade, dos cursos de água naturais, o que compreende: a construção dos canais de navegação interior, a construção dos portos fluviais, a exploração comercial das redes e navegação interior.

As vias de navegação interior são: rios, canais artificiais, lagos naturais, reservatórios, estuários e regiões lagunares sob influência do mar.

Adotaremos neste trabalho, a partir do exposto as seguintes definições:

Rio Naturalmente Navegável - rio em estado natural que permite a navegação comercial.

Via Navegável Interior - rio com alguma interferência de engenharia (sinalização, balizamento, etc.), propiciando melhores condições para a navegação comercial.

- Hidrovia Interior - rio com maior ou menor grau de intervenção de engenharia, propiciando segurança a navegação diuturna a qualquer tempo para os veículos fluviais adequados aos padrões da via (sinalização, balizamento, carta eletrônica de navegação, navegação com GPS via satélite, estação de rádio controle, etc.), que atende a padrões específicos.

Trechos Homogêneos - são trechos que ao longo do seu percurso mantém as mesmas características técnicas. 


\subsection{A REDE DE HIDROVIAS INTERIORES NO BRASIL}

No passado, o litoral e as grandes bacias fluviais eram as vias francas onde, em pontos adequados e em função das suas virtualidades, podiam localizar-se certas atividades econômicas dependentes de um comércio longínquo.

O sistema de movimento aquaviário, fundamental na era pré-técnica do território brasileiro (1500-1870), é composto basicamente por três subsistemas: a navegação interior(ou hidroviária), a navegação de cabotagem e a navegação de longo curso (ou marítima). Esse sistema de movimento tem como características principais: do ponto de vista econômico, o baixo custo relativo de transporte e a grande capacidade de carga; do ponto de vista topológico, possui grande rigidez, pois depende da existência das hidrovias para circular; do ponto de vista temporal, apresenta como desvantagem em relação a todos os outros sistemas de movimento, pois não autoriza velocidades altas em seus deslocamentos.

No Brasil, o transporte fluvial, desde o século XVI, já assegurava as comunicações entre o Recife e Olinda e entre o Recife e os engenhos da várzea do Capibaribe.

Recife é uma das poucas cidades brasileiras que se edificaram de frente para o rio e mesmo quando, com a aceleração do fluxo comercial e da expansão urbana, as estradas passaram a determinar que as construções se voltassem para elas, " a rotina do habitante de casa, de chácara ou de sítio ficou assim proustianamente dividida entre os lados: o lado da estrada, que era agora o lado nobre; e o lado do rio, que era o dos fundo" (Santos \& Silveira, 2001).

Santos \& Silveira (2001), retrataram: O Brasil território e sociedade no início do século XXI, ao longo dos tempos, permitindo-nos verificar o atendimento de diferentes "necessidades humanas" a partir da hidrovia, daí seu desenvolvimento ser apenas uma questão de tempo.

\subsubsection{DESENVOLVIMENTO DAS HIDROVIAS INTERIORES NO BRASIL}


Particularmente, em nosso país, destaca-se o desenvolvimento para o interior a partir de São Paulo, iniciado pelos Bandeirantes. Estes, através dos rios Tietê, Paraná e os rios das bacias do Paraguai e Amazonas, na busca de ouro e pedras preciosas, realizaram expedições geradoras de novos povoados e vilas, o que expandiu as fronteiras do Brasil praticamente aos limites atuais. Inúmeras cidades brasileiras tiveram origem nas "bandeiras": Itu, Salto, Porto Feliz, Cuiabá e outras.

No Brasil, a região da cidade de Iguape, no litoral sul do estado de São Paulo, apresentava considerável desenvolvimento em função de produção agrícola, como arroz por inundação, e de mineração de metais preciosos, como o ouro. Todo o comércio era efetuado através do Porto de Iguape no Mar Pequeno, e o transporte de cargas se dava através do rio Ribeira de Iguape.

Uma das primeiras obras para navegação, um canal, realizado junto à foz do rio Ribeira de Iguape, teve conseqüências desastrosas ( neste ponto da tese, seria importante, identificar então, um primeiro exemplo de Impacto Ambiental, devido a uma Obra Hidroviária ).

Como se sabe, a costa sul do Estado entre a Ilha do Bom Abrigo e, a ponta de Icapara, é protegida por um longo banco de areia de $60 \mathrm{~km}$ de extensão chamada Ilha Comprida, abrigando um canal marítimo, o Mar Pequeno, em cujos extremos se encontram as cidades de Cananéia e Iguape. Ver figura 1. A navegação desse canal marítimo era franca, para embarcações até três metros de calado, que antigamente entravam e saiam livremente por ambas barras, de Cananéia e Iguape. Ver figura 1. 


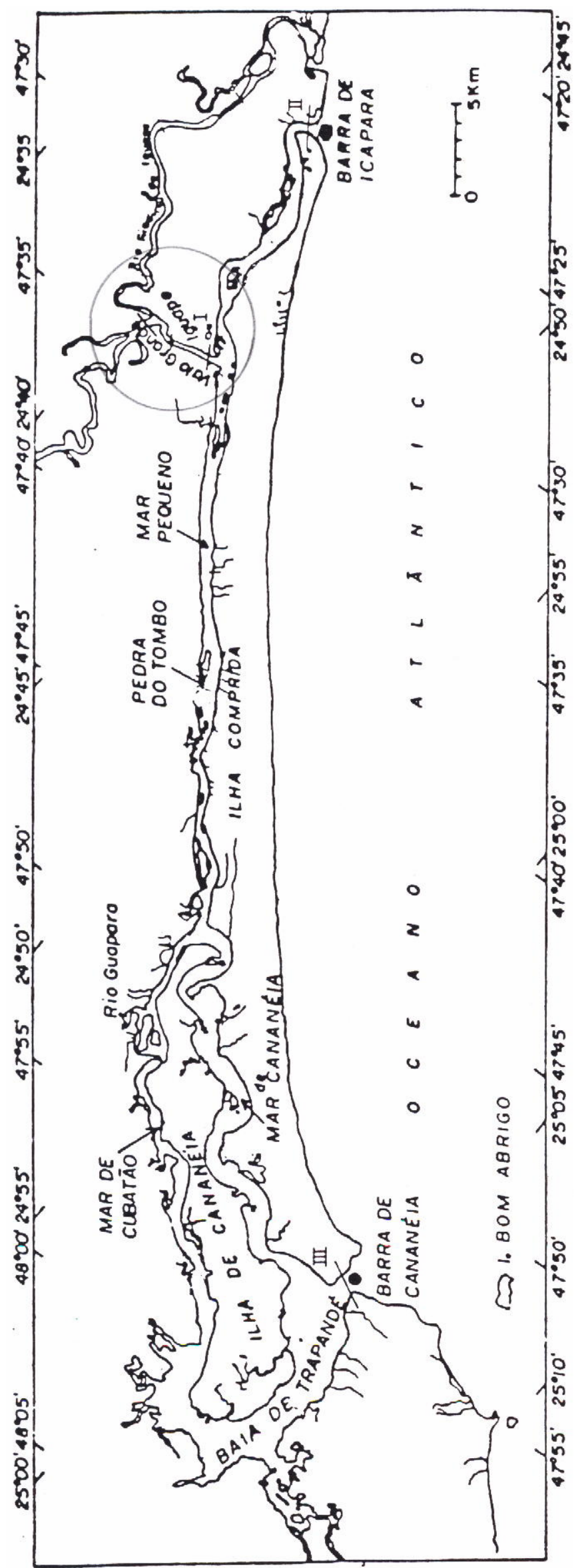

Figura 1 -

Sistema Estuarino Lagunar de Cananéia Iguape [Adaptação autorizada por Miyao \& Harari (1989) apud DAEE (1999)].

Rio Ribeira de Iguape, uma das primeiras obras para navegação. Abertura de Canal com conseqüências desastrosa.

Fonte: Nota Técnica 01Vertedouro da Barragem do Valo Grande Monitoramento do complexo Estuarino Lagunar de IguapeCananéia

DAEE- Abril 1999. (NT-OI-014/99).

Escola Politécnica da Universidade

São Paulo. 
O rio Ribeira, desaguava primitivamente em Barra da Ribeira ao norte da Barra de Icapara, a ligação da navegação marítima e fluvial, fazia-se através de um pequeno trecho de transporte terrestre, de cerca de $2 \mathrm{~km}$, ligando o "Porto Velho" a Iguape. O rio desembocava integralmente no Oceano Atlântico até 1837, pela Barra da Ribeira, cerca de $7 \mathrm{~km}$ ao norte da barra de Icapara.

No louvável intuito de melhorar essas condições, promovendo uma ligação das duas navegações, a fluvial e a marítima, eliminando-se transbordos e transporte terrestre, em 1840, adotou-se como solução a abertura de um canal artificial com as seguintes dimensões projetadas: 50 a 100 "palmos" do lado do mar, 50 a 60 "palmos" do lado do rio e 25 "palmos" de profundidade, isto é uma vala, daí o nome de "VALO".

O desnível existente entre as cotas dos níveis de água do rio e do mar, incrementada pela variação da maré, deram origem a um escoamento com alta velocidade, que começou a erodir o "valo" inicial", facilitando-se ao mesmo passo a entrada da maré.

Em 1852, o Presidente da Província queixava-se da fabulosa despesa de CR\$ 29.485,00 despendida na conservação do canal, cujas margens continuamente desbarrancavam, obrigando a obras de proteção.

O canal de 80 a 100 "palmos", foi erodido pela violência progressiva da corrente, apresentando largura de até 300 metros e, profundidade de até 19 metros, descarregando diretamente para o mar pequeno.

A abertura desse canal, entretanto, ampliando de maneira notável as vantagens da navegação no Ribeira de Iguape, teve influência perniciosa na ligação entre a bacia do rio e o extenso canal marítimo, que se estende pelo Mar Pequeno a Cananéia; daí pela Baía do Trapandé até o Canal do Ararapira e posteriormente pelo canal do Viradouro à Baia de Paranaguá no Estado do Paraná. Como conseqüência, tem-se o assoreamento rápido, pela descarga sólida e principalmente pela descarga acidental proveniente da abertura do canal, cujo volume de 9.000 .000 de metros de cúbicos, depositaram-se na própria baía de Iguape, no canal e na barra. 
A previsão desses resultados, evidentes à luz dos conhecimentos mais rudimentares de hidráulica fluvial (inacessíveis naturalmente aos administradores de Iguape daquela época) teriam aconselhado a abertura de um canal, por meio de dragagem, dimensionado de modo a atender as condições de estabilidade de margem e fundo, viável tecnicamente, mas economicamente inviável. Outra solução poderia ter sido apresentada, qual seja: uma eclusa intermediária, o que se constituiria numa obra tecnicamente e economicamente viáveis, mesmo naquela época

Com a modificação do regime do rio e deságue pela barra de Icapara tornou a barra de Cananéia, a única entrada para essa complexa rede de navegação que oferece segurança real para as embarcações, o que aumenta $120 \mathrm{~km}$, ao trajeto Iguape-Santos (Veras Junior, 1975).

\subsubsection{SITUAÇÃO DAS HIDROVIAS INTERIORES NO BRASIL}

O Brasil, embora seja potencialmente rico, é ainda economicamente pobre; um país pobre, que não têm se dedicado ao desenvolvimento da sua rede hidroviária, e parece que existem duas causas mais importantes para essa atitude, são elas:

- Causas geográficas - a zona mais desenvolvida do Brasil se localiza entre os estados de Espirito Santo e Rio Grande do Sul. É exatamente nessa região que existe uma cordilheira que acompanha a costa brasileira bem próxima ao mar e com grande altura, que é a Serra do Mar.

Causas históricas - o Brasil foi colônia de Portugal até 1822, exatamente na época da grande revolução ferroviária no mundo e então se achava, que era o meio de transporte ideal. Não existiu, no Brasil, uma época que identifica uma fase hidroviária.

O Brasil conta com uma vasta rede navegável, avaliada em cerca de 50.000 $\mathrm{km}$. A nossa rede de navegação interior natural, é uma das maiores do mundo, e engloba todas a áreas a serem desenvolvidas em anos futuros. Desde o começo da República existem estudos onde os rios são partes essenciais; em 1906 foi executada 
(eng. ${ }^{\circ}$ Costa Gama) a eclusa Rio Branco no rio Caí (RS) de 37,0 x 8,85 x 1,5 m remodelada em 1930 e ainda em uso.

Com a obsessão ferroviária e, em seguida, rodoviária, a hidroviária foi posta de lado, e hoje, infelizmente, continua tímida. Planos, que não saíram do papel, foram elaborados em 1946, 1969, 1973, etc.

O DEPVIA, responsável pelas vias navegáveis, dividiu sua área de atuação em seis bacias, a saber: Bacia do Sul, Bacia do Paraná - Tietê, Bacia do Paraguai, Bacia do São Francisco, Bacia Amazônica, Bacia Tocantins e Araguaia.

A classificação dos rios para navegação no Brasil, bem como os gabaritos propostos para a oficialização, encontram-se apresentados nas Tabelas I e II.

Tabela I - Classificação dos rios para navegação no Brasil.

\begin{tabular}{llc}
\hline Classe & \multicolumn{1}{c}{ Características } & $\begin{array}{c}\text { Profs. (m) } \\
75 \% \text { do tempo }\end{array}$ \\
\hline I/Especial & com navegação marítima & ---- \\
II & grande potencial, boca de $32 \mathrm{~m}$ & $>2,5$ \\
III & potencial médio, boca $16 \mathrm{~m}$ & $>2,0$ \\
IV & menor potencial, boca de $11 \mathrm{~m}$ & $>1,5$ \\
V & potencial reduzido & ---- \\
\hline
\end{tabular}

Fonte: Rebouças et al. (1999)

Tabela II - Gabaritos propostos para oficialização (em metros)

\begin{tabular}{lllc}
\hline Classe & Calado Definitivo & Luz & Largura do Canal \\
\hline I & função das embarcações & & \\
& marítimas & ----- & ---- \\
II & 4,5 & 15,0 & 128 \\
III & 3,5 & 10,0 & 64 \\
IV & 2,5 & 7,0 & 44 \\
V & sem definição & ----- & ---- \\
\hline
\end{tabular}

Fonte: Rebouças et al. (1999) 
A seguir serão abordadas as características das principais hidrovias brasileiras em operação, inseridas nas respectivas bacias hidrográficas.

\subsubsection{Bacia do Sul - Hidrovias do Sul, segundo Rebouças et al. (1999)}

A navegação interior no Rio Grande do Sul, tanto de cargas como de passageiros, floresceu no período compreendido entre os anos 1940 e 1950, entrando a seguir em decadência, por diversos motivos, entre eles: deficiências sazonais de calado dos cursos d'água, evolução do porte de veículos rodoviários, melhoria da malha rodoviária e ferroviária, e a política e legislação trabalhista diferenciada para a navegação interior.

No final do período, compreendido entre os anos de 1950 e 1960, a comunidade local e o setor público, percebendo as vantagens da reativação do transporte hidroviário interior, promoveram a elaboração do Plano Hidroviário do Rio Grande do Sul, aprovado pela Resolução 16 do Conselho Hidroviário do Estado, em 29 de março de 1961.

A partir, do início do período compreendido entre os anos 1970 e 1980, foram executadas com recursos públicos principalmente da União, através dos extintos DNPVN - Departamento Nacional de Portos e Vias Navegáveis e da PORTOBRÁS - Empresa de Portos do Brasil S.A. , as obras das barragens eclusadas do Anel de Dom Marco e Amarópolis, no rio Jacuí, e Bom Retiro do Sul, no rio Taquari, além de obras de dragagem e derrocamento nos canais de navegação ao longo daqueles rios.

A barragem eclusada de Fandango, juntamente com as obras citadas acima, deram novo impulso ao transporte hidroviário do Rio Grande do Sul, tornando-o uma atividade econômica importante para o desenvolvimento do estado.

\subsection{A rede fluvial}

A rede fluvial da região sul é constituída por duas bacias. A bacia da Lagoa dos Patos, também denominada bacia Oriental, e a bacia do rio Uruguai. 
Os rios Jacuí e seu principal afluente, o Taquari, mais os rios Gravataí, Sinos e Caí, que formam o Guaíba, além das Lagoas dos Patos e Mirim, interligadas pelo canal de São Gonçalo, fazem parte da bacia da Lagoa dos Patos. A bacia do rio Uruguai, não apresenta vias navegáveis naturalmente no seu trecho em território nacional, mas apenas em seu trecho inferior, um dos seus principais afluentes é o rio Ibicuí, que mesmo não apresentando boas condições de navegabilidade, pode se tornar uma hidrovia de interligação, caso venham a ser viabilizados os projetos hidráulicos entre Argentina e Brasil.

\subsection{Caracterização socioeconômica}

Bacia da Lagoa dos Patos

Síntese: Na hidrovia do Jacuí x Taquarí movimenta-se cerca de 1.500 mil toneladas de carvão, movimenta-se 1 milhão de toneladas de cereais e derivados.

Estados: Rio Grande do Sul.

$\begin{array}{lll}\text { Extensões aproximadas: } & \text { Navegáveis } & -600 \mathrm{~km} \\ & \text { Potenciais } & -700 \mathrm{~km} \\ & \text { Total } & -1300 \mathrm{~km}\end{array}$

Rios: Jacuí, Taquarí, Lagoa dos Patos e Lagoa Mirim.

A bacia da Lagoa dos Patos ocupa uma área de $160.000 \mathrm{~km}^{2}$ que na sua totalidade abrange cerca de 54\% a área territorial do Estado do Rio Grande do Sul. Nesta bacia, onze rios são de interesse para a implantação hidroviária.

A área possui uma agricultura bastante desenvolvida, onde predomina $\mathrm{o}$ cultivo da soja, do milho, do trigo e do arroz. O setor agropecuário exerce forte influência sobre os setores secundário e terceário.

As atividades industriais estão concentradas nos municípios de: Rio Grande; Gravataí, Canoas, Bento Gonçalves, Caxias do Sul, São Leopoldo, Esteio, Porto 
Alegre e Novo Hamburgo. No eixo Porto Alegre - Pelotas há expressiva concentração de indústrias de beneficiamento de arroz.

Na região de Caxias do Sul predominam indústrias do vinho, metal-mecânica e de mobiliário; na região de Santa Cruz do Sul, as indústrias do fumo; no Vale dos Sinos, o setor coureiro-calçadista e no Vale do Gravataí, o setor metal-mecânico.

Uma forte característica da área é que tanto na estrutura agrária quanto no porte das indústrias, o predomínio é da pequena propriedade.

Os recursos minerais representam a melhor opção para o desenvolvimento dessa região, onde já existem atividades de mineração, explorando ferro, chumbo, cobre, calcário, calcita, granito, talco, dolomita e carvão.

- Bacia do Rio Uruguai

Sintese: $\quad$ Estados: Rio Grande do Sul e Santa Catarina.

$\begin{array}{llll}\text { Extensões: } & \text { Navegáveis } & - & 0 \mathrm{~km} \\ & \text { Potenciais } & - & 1200 \mathrm{~km} \\ & \text { Total } & - & 1200 \mathrm{~km}\end{array}$

Rios: Uruguai e Ibicuí.

A bacia do rio Uruguai, em território nacional ocupa uma área de 178.235 $\mathrm{km}^{2}$, situa-se na sua maior parte, cerca de $73 \%$, no Rio Grande do Sul, ficando o restante em território do estado de Santa Catarina.

$\mathrm{Na}$ bacia encontram-se principalmente, atividades agropecuárias. As principais culturas da região são a soja, o arroz, o trigo e o milho. Cerca de $80 \%$ da produção total de grãos do estado de Santa Catarina estão concentrados nesta bacia e aproximadamente $60 \%$ do tal da produção do Rio Grande do Sul.

2.3.2.1.3. Navegação Atual e intermodalidade 
A navegação interior é praticada nos rios Jacuí (232 km); Gravataí (9 km); Guaíba (50 km); na Lagoa dos Patos (260 km, de Itapoã aos molhes da barra em Rio Grande); e no canal de São Gonçalo (74 km), para embarcações de 2,50 m de calado, e no Vale dos Sinos, cai para 1,50m de calado.

A rede ferroviária é toda em bitola métrica, com extensão total de $3.638 \mathrm{~km}$, ligando-se ao Sistema Regional Curitiba em Marcelino Ramos e Laje. Mantém intercâmbio com as ferrovias da Argentina, em Uruguaiana/Passo de Los Libres e com as ferrovias do Uruguai, em Santana do Livramento/Rivera e Jaguarão/Rio Branco. A ferrovia conta ainda com os terminais portuários de longo curso: o de Rio Grande, marítimo, e os de Porto Alegre e Pelotas, fluviais.

As rodovias integrantes do sistema do porto fluvial alimentador de Estrela, o principal da hidrovia, têm nas BR - 285 e 386 os seus grandes corredores, com condições de absorverem a demanda de transporte prevista até o ano de 2002.

\subsection{Perspectivas futuras}

O transporte hidroviário que era intenso, movimentando cerca de $50 \%$ a $60 \%$ das safras agrícolas, em 1999, sofreu concorrência de outros meios de transportes na movimentação de grãos com destino ao Porto de Rio Grande, principalmente, para o mercado externo.

O Porto de Estrela, além do crescimento vegetativo esperado nas cargas tradicionais, está se aparelhando para uma nova fase, com a implantação de um terminal de contêineres, para movimentação de fumo, móveis, calçados e vinho para a exportação.

Ainda no horizonte de curto prazo, são boas as possibilidades de movimentação de calcário agrícola na rota Cachoeira do Sul - Estrela, tendo já se iniciado o transporte em pequena escala.

Quanto à Cachoeira do sul, o governo do estado está implantando no local instalações portuárias de desembarque, pois a região já dispõe de dois terminais 
privativos para embarque de granéis agrícolas e óleos vegetais. Está prevista também a instalação de equipamentos para descarga de derivados de petróleo.

$\mathrm{O}$ aspecto mais negativo na situação atual, e sem grandes perspectivas a curto prazo, é a situação do Terminal de Carvão de Charqueadas. As desativação do Programa de Mobilização Energética e a total falta de uma política governamental para a utilização do carvão mineral diminuíram muito a movimentação naquele terminal.

A médio prazo, um dos principais projetos envolve o abastecimento de carvão mineral para a Usina Termelétrica Jacuí, da ELETROSUL - Centrais Elétricas do Sul do Brasil S.A., que consumirá cerca de 1.100 .000 toneladas anuais de carvão, a serem fornecidos pelas hidrovias.

\subsubsection{Bacia do Paraná - Tietê, segundo Rebouças et al.(1999)}

2.3.2.2.1. Síntese: Navegável entre Itaipú e São Simão, escoa cereais, madeira e gado, para Porto Epitácio ( São Paulo), a hidrovia do Tietê é objeto de estudos detalhados.

A hidrovia interior, em questão, foi preparada para ser navegável nos seguintes trechos e extensões:

Rio Piracicaba - afluente da margem direita do Tietê, desde a confluência com o rio Tietê, até $22 \mathrm{~km}$ a montante.

Rio Tietê - desde a cidade paulista de Conchas até a confluência do Tietê com o Paraná, numa extensão de 554 km.

Rio Paranaíba - desde o sopé da barragem da Usina Hidrelétrica de São Simão até a confluência do rio Paranaíba com o rio Paraná, numa extensão de 180 km.

- Rio Grande - desde o sopé da barragem da Usina de Água Vermelha, até a confluência do Rio Grande com o Rio Paraná, numa extensão de 59 km.

Rio Paraná - desde a confluência dos Rios Grande e Paranaíba, que formam o rio Paraná, até a barragem da Usina Hidrelétrica de Itaipú, numa extensão de 800 km. 
Canal de Pereira de Barreto - liga o lago da barragem da Usina Hidrelétrica de Três Irmãos, no rio Tietê, ao rio São José dos Dourados, afluente da margem esquerda do rio Paraná, no Estado de São Paulo, numa extensão de 53 km, sendo 36 km no rio São José dos Dourados e 17 km no Canal pereira Barreto, propriamente dito.

$\begin{array}{lll}\text { Extensões: } & \text { Navegáveis } & -1900 \mathrm{~km} \\ & \text { Potenciais } & -2900 \mathrm{~km} \\ & \text { Total } & -4800 \mathrm{~km} .\end{array}$

Rios: Paraná, Tietê, Paranaíba, Grande, Ivaí e Ivinhema.

Situada entre Centro-Oeste, Sudeste e Sul do Brasil, a bacia hidrográfica do rio Paraná, do qual o rio Tietê é tributário, insere-se na região de maior desenvolvimento agro-industrial do país e da América Latina.

No Brasil, a bacia e seu hinterland relativo à navegação abrange os estados de São Paulo, Goiás, Minas Gerais, Mato Grosso do Sul e Paraná. Nessa área encontrase, hoje, mais de $25 \%$ da população brasileira, sendo que se arrecada cerca de $75 \%$ do ICMS - Imposto sobre Circulação de Mercadorias e Serviços de toda a nação.

O desenvolvimento da navegação na bacia do Paraná, em conjunto com as dos rios Paraguai e Uruguai, vem sendo considerado fundamental para o MERCOSUL, isto é, a integração de mercados entre Brasil, Argentina, Paraguai e Uruguai.

A bacia do rio Paraná, teve nas últimas décadas, seu potencial hidroenergético enormemente desenvolvido e, dessa forma, a navegação fluvial vem se beneficiando, podendo aumentar calados e tamanho dos calados, diminuindo-se os custos de transporte fluvial.

O porte da bacia do Paraná permite vislumbrar grandes extensões navegáveis. Atualmente, realizada a integração entre as regiões Norte e sul do rio Paraná, ou seja, 
de São Simão a Guaíra, com o Tietê, têm-se já à disposição, mais de $2.000 \mathrm{~km}$ de hidrovia, que tendem a crescer, com o desenvolvimento da navegação dos afluentes.

\subsection{Rede fluvial}

O rio Paraná, em conjunto com os rios Paraguai e Uruguai formam um complexo fluvial de inestimável potencial hidroviário na região Sul da América Latina.

O rio Paraná, o curso d'água de maior destaque na área, é formado em território nacional pelos rios Paranaíba e Grande, nas divisas entre os estados de Mato Grosso do Sul, Minas Gerais e São Paulo, e se desenvolve por mais de 4.000 km de extensão, até sua foz, perto do mar, onde suas águas, somadas às do Uruguai vêm a formar o grande deságue no oceano conhecido como rio do Prata.

O grande rio Paraná, com vazões de alguns mil, a várias dezenas de milhares de metros cúbicos, sempre foi uma via fluvial de excelente condições naturais, com exceção de cerca de $60 \mathrm{~km}$ a montante de Guaíra, as "Sete Quedas", hoje afogadas pelo reservatório de Itaipu.

Os maiores afluentes do rio Paraná na margem esquerda são o Iguaçu, o Ivaí, o Paranapanema e o Tietê. Na margem direita destacam-se os rios Dourados, Inhandu Guazu, Verde, Sucuriu, Corumbá e Ivinhema.

Todos esses afluentes têm condições de navegação, pelo menos em dezenas de quilômetros a partir da foz, sendo que alguns já se encontram canalizados por aproveitamentos hidrelétricos, como o rio Paranaíba, o Grande, o Tietê e o Paranapanema.

Desses, no entanto, apenas o Tietê tem aproveitamento com fins múltiplos, isto é, junto com o aproveitamento hidroenergético se construiu uma eclusa, garantindo a navegação de comboios de grande porte.

No rio, Tietê, em cerca de 700 km, das proximidades de São Paulo à sua foz, no rio Paraná, encontra-se apenas o rio Piracicaba, como afluente com algum destaque, possuidor de potencial hidroviário. As possibilidades desses afluente, no 
entanto, são modestas, apenas algumas dezenas de quilômetros, até a cidade de mesmo nome.

\subsection{Caracterização Socioeconômica}

A região de influência da bacia do Paraná e Tietê, tem, na área nacional, forte tradição agrícola.

Os estados de São Paulo, Paraná e, recentemente, áreas do Mato Grosso do Sul e do país vizinho, Paraguai, vêm ampliando áreas de cultura, principalmente com cultivo de soja, trigo e cana-de-açúcar.

A população, na área de influência nacional da hidrovia, talvez chegue a 40 milhões de habitantes, cuja maior parte se encontra nos conglomerados urbanos, em função da enorme industrialização havida, principalmente, no estado e na cidade de São Paulo.

A área da cidade de São Paulo e outras próximas como Campinas, Piracicaba e Sorocaba, formam o complexo industrial transformador de montante da hidrovia Tietê-Paraná, além de, em conjunto com um sem números de outras cidades, várias conurbadas, formarem o maior e mais variado mercado consumidor do País.

Se por um lado, a hidrovia Tietê-Paraná tem papel da maior importância no escoamento da produção das áreas de expansão nos estados do Centro-Oeste, por outro lado, as áreas de cultivo do hinterland da hidrovia necessitam de calcário, fertilizantes, combustíveis e produtos semi-industrializados, passíveis de serem transportados via navegação, em geral, com origem em São Paulo e outras regiões de montante do sistema de navegação fluvial. Essas necessidades se completam criando fluxo de carga hidroviável nos dois sentidos.

Em números redondos, nas proximidades do ano 2000, os grãos, a soja, o farelo e trigo, apresentavam uma participação maior que 30\% no conjunto de cargas de jusante para montante da bacia; madeira e gado perfaziam mais de $20 \%$ da carga na mesma direção; já o calcário e fertilizantes perfaziam $40 \%$ da carga de retorno, de 
montante para jusante; os combustíveis formavam cerca de $10 \%$ e o aço e outros granéis pesados participavam com cerca de $15 \%$ do total da carga na mesma direção.

Esses volumes adicionados às cargas de materiais de construção, principalmente areia, e a cana-de-açúcar, levará a bacia do Paraná a ter, em 2005, pelas previsões anuais, um fluxo da ordem de 16 milhões de toneladas, cuja maior parte, mais da metade, também circulará pelo rio Tietê.

\subsection{Navegação Atual e Intermodalidade}

O rio Paraná, em território brasileiro, vem sendo navegado há muitos anos, formando-se especialmente, um corredor de grãos, madeira e gado, voltado para São Paulo, em conexão com as ferrovias que atingem as suas margens. Estas ferrovias, há muito tempo realizando a intermodalidade, atingem a barranca do rio Paraná em duas localidades, tradicionais quanto ao transbordo de grãos: Porto Epitáceo e Porto Panorama.

A navegação no rio Paraná, desenvolveu-se a corrente livre, com comboios formados por quatro ou seis chatas, de comprimento variando entre 20 e $40 \mathrm{~m}$, com boca, ou seja, largura, da ordem de $8 \mathrm{~m}$. O calado praticado, face a presença de alguns baixios, tem sido de até $1,70 \mathrm{~m}$.

\subsection{2.. . Perspectivas futuras}

A navegação no sistema Tietê - Paraná deverá aumentar rapidamente, em futuro próximo, à medida em que se desenvolvam mais áreas agrícolas e se intensifique o intercâmbio internacional na bacia.

A navegação entre os rios Tietê e o Paraná se fará com embarcações predominantemente do tipo Tietê, uma vez que são essas as dimensões menores das eclusas da hidrovia.

Infelizmente, no início da implantação das obras para navegação no Tietê e no Paraná, à época, o intercâmbio entre os dois rios e o funcionamento como uma só 
bacia hidroviária não foi perfeitamente compreendido, prevalecendo uma visão mais particular de cada rio e, daí, dois gabaritos de eclusas tão diferentes, que levam ao difícil aproveitamento maximizado, em termos de equipamento naval.

Novas obras deverão ser realizadas na região após o término da Usina de Porto Primavera, no Paraná. Brevemente ter-se-á Santa Maria da Serra, no Piracicaba, e em futuro mais distante Ilha Solteira, Ilha Grande e, finalmente, Itaipu. Essa última exigindo um sistema de transposição para $120 \mathrm{~m}$ totais de desnível, realizando, por fim, a grande integração com baixo Paraná e Paraguai.

\subsubsection{Bacia do Paraguai, segundo Rebouças et al. (1999)}

2.3.2.3.1. Síntese - A montante de Ladário/Corumbá escoa junto com seu afluente Cuiabá, a pecuária do Pantanal, a agricultura de Cáceres e o cimento de Corumbá; a jusante de Ladário transporta-se minérios: ferro, manganês e cimento, no comércio internacional do Brasil e Bolívia para o Paraguai e a Argentina.

O tratado da Bacia do Prata, firmado em Brasília/DF, em 23 de abril de 1969 por chanceleres dos cinco países da Bacia do Prata: Argentina, Brasil Bolívia, Paraguai e Uruguai, constitui-se no marco fundamental da implantação da hidrovia Paraguai- Paraná.

Em setembro de 1989, os Ministros das Obras Públicas e de Transportes dos países da Bacia do Prata, acordaram em criar o "Comité Intergubernamental de la Hidrovia Paraguay-Paraná (CIH)”, encarregado-o de realizar projetos pontuais, determinar a prioridade das obras a realizar e estudar a compatibilização da legislação aplicável a hidrovias, dos países da Bacia do Prata. O CIH tem sua sede em Buenos Aires, capital da República da Argentina.

Estados: Mato Grosso do Norte, Mato Grosso do Sul, Paraná

$$
\begin{aligned}
& \text { Extensões aproximadas: } \quad \text { Navegáveis }-1280 \mathrm{~km} \\
& \text { Potenciais }-1815 \mathrm{~km} \\
& \text { Total } \quad-3095 \mathrm{~km}
\end{aligned}
$$


Rios: Paraguai, Cuiabá, Miranda, São Lourenço, Taquari e Jauru.

O rio Paraguai, em função da sua ligação com o mar através do rio Paraná e o estuário da Prata, e das características da sua topografia suave, vem sendo navegado praticamente desde o início da colonização espanhola, originando o aparecimento de várias cidades ao longo do seu curso, tais como Assunción, a capital do Paraguai, Porto Murtinho, Cáceres, Corumbá, no Braisl e já no Rio Paraná, Rosário, Santa Fé e Paraná, na Argentina.

A bacia do rio Paraguai, em território brasileiro tem cerca de $350.000 \mathrm{~km}^{2}$ e é constituída em grande parte, por uma formação de planície interior de muito baixa declividade, área esta conhecida como pantanal, onde um sem número de lagoas perenes e temporárias, em conjunto com encharcamento generalizado do solo, funciona como um grande reservatório de regulação do rio.

O Pantanal constitui um vasto ecossistema ainda em condições muito próximas das naturais, uma vez que a região tem sido mantido isolada do assédio humano em face da dificuldade de acesso.

O rio Paraguai, no entanto, percorre regiões produtoras de minério e de expansão de fronteiras agrícolas, de tal sorte que a sua navegação tradicional em conjunto com a do rio Paraná, tende a se expandir, realizando a integração moderna dos mercados do sul do continente

\subsection{A Rede Fluvial}

O regime de cheias do rio Paraguai é de peculiar complexidade, em função da retenção e conseqüente regularização, realizada pelo Pantanal. Dessa forma, apesar da estação chuvosa na bacia ocorrer entre setembro e abril, enquanto em Cáceres as cheias ocorrem de dezembro a janeiro, as cheias em Corumbá se verificam só no outono, com níveis máximos entre maio e junho e mínimos no final do ano.

O rio Paraguai tem suas nascentes na Chapada dos Parecis, estado de Mato Grosso, Brasil, em uma altitude de cerca de 400 m. Após se desenvolver por cerca de 
$2.600 \mathrm{~km}$, dos quais $1.700 \mathrm{~km}$ encontram-se em território brasileiro, deságua no rio Paraná.

O rio Paraguai, após percorrer $412 \mathrm{~km}$ em território brasileiro, torna-se por 48 $\mathrm{km}$, fronteira entre Brasil e Bolívia, o chamado corredor de Massapeti. A seguir, faz fronteira entre o Brasil e o Paraguai por cerca de $330 \mathrm{~km}$, quando então entra em território paraguaio, onde se encontra com o importante afluente Piocomayo, divisa com a Argentina. A partir desse ponto o rio Paraguai serve por $378 \mathrm{~km}$ de divisa entre o próprio Paraguai e Argentina, quando então encontra o rio Paraná.

\subsection{Socioeconomia e Cargas Atuais}

As principais cargas são os minérios de manganês e ferro, o cimento: tanto na forma final como na forma de clinquer, gado e cereais em especial o arroz. No final da década de 80 , as cargas transportadas pelo rio somavam cerca de meio milhão de ton./ano.

As características peculiares da bacia do rio Paraguai, incluídas as dificuldades de construção de estradas e ferrovias, na área do pantanal, faz do rio a opção natural de transporte da economia regional. O curso principal bem como vários afluentes, serve também para o deslocamento das populações assentadas na bacia.

Os mercados consumidores do sul da bacia, em especial na Argentina, demandam os produtos originados a montante, pressionando, dessa forma o desenvolvimento hidroviário.

\subsection{Navegação Atual e Intermodalidade}

Entre o rio Apa e Corumbá, totalizando cerca de $600 \mathrm{~km}$, e entre essa cidade e Cáceres, por mais 720 km, o rio Paraguai apresenta boas condições para a navegação fluvial. 
Pontos críticos para a hidrovia, acentuados em águas baixas, ocorrem a jusante de Corumbá entre os km 1.338 e 1.343, passo Pima; km 1.322, passo Camila e km 1.285, passo Santa Fé. A montante de Corumbá, entre Descalvado e Cáceres ocorrem trechos ainda mais críticos, com profundidades mínimas inferiores a $1 \mathrm{~m}$.

Em termos de classificação hidroviária nacional segundo a metodologia da antiga PORTOBRÁS, entre a foz do rio Apa e a do rio Cuiabá considera-se a hidrovia como Classe II e a montante da foz do rio Cuiabá até Cáceres se classifica como hidrovia Classe III.

Ao longo de todo o trecho foi implantada a sinalização e balizamento com placas e faróis, serviço esse realizado e mantido pela Marinha do Brasil.

Grande parte da frota comercial, de maior porte, do rio Paraguai pertence ao Serviço de Navegação da Bacia do Prata - SNBP, empresa atualmente vinculada ao Ministério dos Transportes.

O trecho compreendido entre a cidade sul-matogrossense de Corumbá e a matogrossense de Cáceres, numa extensão de $672 \mathrm{~km}$, onde a embarcação tipo é comboio de empurra (quatro chatas e um empurrador) de $108 \mathrm{~m}$ de comprimento, 24 $\mathrm{m}$ de largura (boca) e 1,2 m de calado máximo em períodos de águas mínimas, corresponde a uma classe, e a outra, a jusante de Corumbá, numa extensão de 2770 km, cuja embarcação tipo é um comboio de empurra (dezesseis chatas e um empurrador) com $280 \mathrm{~m}$ de comprimento, $48 \mathrm{~m}$ de largura (boca) e 3,0 $\mathrm{m}$ de calado em águas mínimas.

As peculiaridades da bacia, das quais o Pantanal se coloca como da maior importância, levam a alguns pontos de integração modal da bacia, ou seja, as poucas estradas e ferrovias alcançam o rio em poucos lugares: no Sul, em Porto Murtinho, a ligação intermodal poderá se dar pela proximidade da ferrovia Campo Grande a Ponta Porã; no Centro, na região do Pantanal, em Corumbá, é possível a conexão com a ferrovia, hoje já privatizada, que liga São Paulo à Bolívia, algumas rodovias se entrecruzando nessa região: ao Norte, na região de Cáceres têm-se hoje algumas estradas importantes, como a BR - 174 e a 070, porém, em futuro próximo ter-se-á a 
ferrovia Ferronorte, atualmente em implantação, ligando a área aos mercados do Sudeste.

\subsection{Perspectivas Futuras}

A navegação com calado de 2,7 m no rio Paraguai depende de algumas obras, compostas por dragagens, derrocamentos e algumas retificações, incluindo corte de meandros, aos quais têm por objetivo a obtenção da profundidade mínima, e condições de canal, para o comprimento e largura do comboio-tipo. Essas obras, no entanto, aumentando a seção hídrica, sob o nível d'água atual, têm possibilidade de remodelar os atuais limites de leito móvel do curso d'água, provocando eventuais modificações no ecossistema pantaneiro. Grande dificuldade, no entanto, reside na obtenção, através de estudo confiável, de valores realistas de modificações dos nas na região do Pantanal.

A polêmica sobre a influência das obras no ecossistema pantaneiro se arrasta por alguns anos, provocando embargos judiciais. Poderiam ou deveriam se proceder a um minucioso estudo, incluindo modelo reduzido, de forma a se poder projetar compensações dos rebaixamentos dos níveis de água, dada a abertura de canais por derrocamento. Essas compensações poderiam ser realizadas com a introdução de perdas de carga localizadas ou distribuídas, usando-se o próprio material resultante dos derrocamentos, entre outras soluções.

\subsubsection{Bacia do São Francisco, segundo Rebouças et al. (1999)}

2.3.2.4.1. Síntese - Com $1400 \mathrm{~km}$ navegáveis entre Pirapora e Juazeiro, transporta cerca de 1.500 mil toneladas de madeira, álcool, gipsita e cimento, complementação de portos (ampliação e equipamento).

Estados: Minas Gerais, Bahia, Pernambuco e Sergipe.

Extensões aproximadas: Navegáveis $\quad-1400 \mathrm{~km}$

Potencial $\quad-2700 \mathrm{~km}$ 


\section{Total}

$-4100 \mathrm{~km}$

Rios: São Francisco, Grande e Corrente.

O rio São Francisco é o maior rio da área Centro-Nordeste do país, sendo naturalmente, o eixo principal da ligação entre Minas Gerais, Bahia e Pernambuco.

A sua área de abrangência em termos de potencial de captação de carga local é imensa, ultrapassando $600.000 \mathrm{~km}^{2}$, com uma população superior a 5 milhões de habitantes.

O hinterland da hidrovia, no entanto, é muito maior, dada a conexão modal ferroviária, a Sudeste, em Pirapora (MG) e a $1.200 \mathrm{~km}$ ao Norte, em Juazeiro e Petrolina. Do ponto de vista de acesso aos portos, no Sudeste a integração se dá com Vitória/Tubarão, no Espírito Santo, e no Nordeste existe a possibilidade de integração total com os portos de Suape e Fortaleza.

A região é caracterizada por desenvolvimento primário, agrícola, sendo que na área de Barreiras, no rio Grande, afluente do São Francisco, vem se desenvolvendo com destaque o cultivo de grãos, basicamente a soja.

A atividade secundária na região é principalmente, de indústria de transformação e extrativismo mineral. Destacam-se os municípios de Pirapora, Montes Claros, Juazeiro e Petrolina, onde se têm distritos industriais e a região de Araripe, em Pernambuco, onde se encontram enormes reservas de gipsita.

O rio São Francisco é tido hoje como interessante alternativa para o transporte de produção agrícola dos cerrados e do oeste baiano, da gipsita, para as áreas de industrialização, bem como dos produtos agro-industriais do pólo de Juazeiro/Petrolina para o Sul.

Hoje, algumas centenas de milhares de toneladas são transportadas no rio, por ano, envolvendo os produtos acima.

O desenvolvimento da navegação vem ocorrendo, principalmente, em função da expansão agrícola que ocorre no país nos últimos anos.

\subsection{A Hidrovia}


A hidrovia do São Francisco é basicamente constituída por dois grandes trechos: o reservatório de Sobradinho e o trecho de montante, fora do remanso dessa barragem, que se faz presente com menores profundidades no trecho final de Minas Gerais entre Ibotirama e Pirapora.

No lago de Sobradinho é usual a navegação com calado livre chegando a 2,5 m; com restrições de formação de comboio, apenas para a travessia da eclusa da barragem, cujas dimensões são de $17 \mathrm{~m}$ de largura, por cerca de $130 \mathrm{~m}$ úteis de comprimento, realizando 32,5 m de transposição vertical.

À jusante de Sobradinho se atinge Petrolina e Juazeiro, que são pontos finais do transbordo das cargas na direção Nordeste, e iniciais das que rumam para o sul.

A montante de Ibotirama, na direção de Januária e finalmente em Pirapora, as condições de navegabilidade não são das melhores, ocorrendo bancos de areia móveis e grande variação de profundidade entre estiagens e cheias. Nas estiagens, nessa região, o calado das chatas menores, com $32 \mathrm{~m}$ de comprimento, passa de $1,35 \mathrm{~m}$, a menos de $1 \mathrm{~m}$ por vezes.

A retenção de Três Marias, barramento importante à montante de Pirapora, na época de águas baixas, acentua os baixios desse trecho. Por vezes, faz-se necessária a abertura extraordinária de comportas para aumentar níveis nesse estirão, possibilitando a passagem ou até mesmo o desencalhe de embarcações.

Obras nesse trecho foram programadas, e melhorias de fundo e instalação de melhores equipamentos de transbordo também foram planejadas, para os Portos de Pirapora, Ibotirama, Petrolina e Juazeiro.

Cabe ressaltar que o São Francisco, é um rio de leito migratório, com clássico exemplo de insucesso de obra hidráulica: na década de 50 foi construída uma eclusa de navegação no Salto de Sobradinho/Ba, que não se tornou operacional por migração lateral das margens do São Francisco.

Tal eclusa, hoje se encontra a cerca de $1 \mathrm{~km}$ a jusante da atual barragem de Sobradinho, como monumento ao desconhecimento do rio São Francisco, pelos engenheiros da época e, à falta de estudos hidromorfológicos, embasadores do projeto da referida eclusa. 
Nos nossos dias, com computadores cada vez mais capazes e velozes, a modelagem matemática tem-se constituído em uma importante ferramenta à disposição da engenharia, notadamente da engenharia hidráulica.

Assim, o setor hidroviário interior federal, pretende modelar morfologicamente trechos do rio São Francisco e a construção de algumas obras hidráulicas, objetivando conhecer como estas interagem com o curso d'água e quais seriam suas conseqüências morfológicas e ambientais.

\subsection{Anastomosamento do São Francisco}

O desmatamento indiscriminado da bacia do rio São Francisco, inclusive de trechos da mata ciliar, tem aumentado a quantidade de sedimentos da calha do rio, num acelerado processo de anastomosação, uma vez que a capacidade de transporte de sedimentos de um curso d'água é limitada. Cada vez mais, a quantidade de sedimentos que é carreada para o leito do rio São Francisco é maior do que sua capacidade de os transportar.

O desmatamento também influi no processo de anastomosação do rio, pela alteração do regime fluvial, que passa a ser caracterizado por fortes enchentes e acentuadas vazantes.

A administração da Hidrovia do São Francisco tem efetuado grandes campanhas de dragagem nos trechos anastomosados. Esses serviços de dragagem procuram aumentar as profundidades do canal de navegação, retirando material depositado pelo rio e despejando-o na própria calha fluvial.

\subsection{A Exploração do Transporte}

A realização do transporte na área vem sendo efetivada tradicionalmente pela FRANAVE - Cia. de Navegação do São Francisco. Essa empresa possui uma quantidade apreciável de chatas, basicamente de até $45 \mathrm{~m}$ de comprimento , $8 \mathrm{~m}$ de 
boca e, com calado máximo de 2,5 m. Estas chatas, têm sido melhor aproveitadas através de processos de afretamento para exportadores de grãos.

Até há alguns poucos anos, competia com a FRANAVE a Cia. Imbirussu Navy, que paralisou suas atividades na área por volta de 1993. Essa empresa, no entanto, após mudança do grupo detentor do comando, passa por reestruturação, devendo voltar às atividades muito brevemente.

\subsubsection{Bacia Amazônica, segundo REBOUÇAS et al. (1999)}

2.3.2.5.1. Síntese - Apresenta $20.000 \mathrm{~km}$ de vias navegáveis, onde se prevê um transporte de 10 milhões de toneladas, incluindo bauxita do rio Trombetas, madeira de Rondônia e Tucuruí, sal-gema do rio Tapajós, gás natural do rio Juruá e carga geral (Amazonas e afluentes).

Estados: Amazonas, Pará, Acre, Rondônia, Roraima e Amapá.

$\begin{array}{lll}\text { Extensões aproximadas: } & \text { Navegáveis } & -18.300 \mathrm{~km} \\ & \text { Potencial } & -723,5 \mathrm{~km} \\ & \text { Total } & -19.023,5 \mathrm{~km}\end{array}$

Rios: Solimões, Amazonas, Negro, Teles Pires, Branco, Madeira, Guaporé, Purus, Jurua e Tapajós.

A bacia Amazônica, uma das maiores bacias hidrográficas do mundo, ocupa mais de $40 \%$ do território brasileiro, estendendo-se pelo países limítrofes ao Norte e Nordeste do Brasil, quais sejam: Bolívia, Peru, Colômbia, Venezuela, Guianas e Suriname.

No território nacional, a bacia é dividida entre os estados do Pará, Amazonas, Acre, Rondônia, Amapá e Roraima.

Trata-se, ainda, de uma das poucas áreas do planeta com imensa variedade biótica, formada por enorme quantidade de vegetação, em equilíbrio ecossistêmico próprio, no qual se destaca o papel da água. 
Quantidades hídricas de monta inigualável, podem ser observadas na região, tanto na forma de caudalosos e extensos rios como de nuvens e umidade atmosférica.

A vocação natural da Amazônia, no que se refere a modal de transporte é, sem dúvida, a forma hidroviária. Cerca de $18.300 \mathrm{~km}$ de rios são potencialmente navegáveis na área, com gabaritos de navegação de porte, sendo que embarcações marítimas, com calado superior a $10 \mathrm{~m}$, podem trafegar todo o ano, pelo Amazonas, por parte do Solimões, além das porções de jusante de alguns grandes tributários.

A densidade de cursos d'água naturalmente navegáveis, características da região, idêntica a da bacia do Tocantins e Araguaia, é de cerca de $1 \mathrm{~km}$ de canal francamente navegável, para cada $200 \mathrm{~km}^{2}$ de território. Esse valor, mesmo não sendo constante em toda a área, uma vez que parte dos estados de Mato Grosso e Pará, menos servida, é expressivo da vocação hidroviária.

\subsection{Rede Fluvial}

A rede fluvial da Amazônia é uma das maiores do mundo, tanto em extensão quanto em volume de água.

O principal curso d'água é o Amazonas, cuja vazão média anual esta estimada em $222.000 \mathrm{~m}^{3} / \mathrm{s}$, o que lhe assegura o título de maior rio do mundo em vazão. A parte de montante do Amazonas, em território nacional, denominado de Solimões, é o segundo trecho importante da área, em porte e em vazão.

Os principais tributários do Amazonas, com características compatíveis com a navegação fluvial de grande porte são, na margem esquerda, o rio Iça, o Branco, o Negro e o rio Trombetas.

Na margem direita, desenvolve-se maior número de afluentes: o rio Juruá, o Purus, o Mamoré - Madeira, o Tapajós e o Xingu. Esses dois últimos tributários, juntamente com o baixo Amazonas, têm sido considerados em separado, para efeito de administração hidroviária, como Bacia Ocidental, enquanto todo o restante a montante do Tapajós é tratado separadamente como Bacia Oriental. 
O regime das águas na bacia Amazônica é, principalmente, função do regime de chuvas e da sua distribuição espacial. Há pequena influência, também, do degelo dos Andes, mais sensível nas regiões de montante.

A porção meridional da bacia Amazônica é costumeiramente, submetida a maior pluviosidade entre os meses de novembro a abril, enquanto as áreas setentrionais têm chuva nos outros meses, de abril a setembro. Essa alternância, quando não ocorre, é responsável por cheias extraordinárias e agressivas ao meio ambiente.

Em determinadas ocasiões, associadas às cheias, pedaços de margens, de volumes consideráveis, são destacados e, muitas vezes, em função da vegetação presente, transformam-se em pequenas ilhas flutuantes. Essas ocorrências podem se transformar em ameaça à navegação e instalações portuárias nas áreas de maior desenvolvimento hidroviário.

As pequenas declividades de linha d'água, predominantemente encontradas na bacia, garantem velocidades adequadas à navegação, em todos os quase 20 mil quilômetros de potencial hidroviário.

Finalmente, cabe observar que o porte da bacia, implica fenomenologia própria, sendo encontradas situações diversas em pontos diferentes dos cursos d'água. Por exemplo: cheias defasadas ao longo do Amazonas, em função dos regimes dos tributários, ou ondas de maré, que levam simultaneamente a elevação em alguns lugares e rebaixamento do nível d'água em outros.

\subsection{Navegação e Embarcações}

O Amazonas/Solimões tem extensão total de cerca de $6.500 \mathrm{~km}$, dos quais $3.100 \mathrm{~km}$ em território brasileiro, totalmente navegáveis.

A morfologia, sem muitas variações neste trecho, garante até $11 \mathrm{~m}$ de calado nas águas altas e no mínimo $8 \mathrm{~m}$ nas águas baixas, o que permite o trânsito de embarcações marítimas. 
O trecho do baixo Amazonas, que inclui a sua foz, tem largura da ordem de $150 \mathrm{~km}$, estendendo-se entre Belém e Manaus com cerca de $1.500 \mathrm{~km}$. As mares de sizígia nesse trecho chegam a $4 \mathrm{~m}$ de amplitude.

A navegação marítima é franca nesse trecho, havendo alguns estirões, no entanto, onde o canal é sinuoso exige habilidade nas manobras com grandes navios.

Esse primeiro trecho de jusante tem, no Departamento de Portos e Hidrovias do Ministério dos Transportes, a classificação de Classe I/Especial.

O trecho seguinte, já Solimões, entre Manaus e Tabatinga, tem $1.600 \mathrm{~km}$, sendo percorridos por embarcações de até $8 \mathrm{~m}$ de calado nas cheias, que passa a $4 \mathrm{~m}$ na estiagem, entre os meses de julho e outubro. Esse segundo trecho também é considerado Classe I/Especial.

O terceiro trecho, já quase saindo do território nacional tem cerca de $250 \mathrm{~km}$, e permite cerca de 1,50 m de calado a maior parte do tempo, porém apresenta alguns baixios importantes.

No que se refere aos afluentes, o Trombetas, até o porto Trombetas, e o Tapajós, ambos em uma extensão de pouco mais de $100 \mathrm{~km}$ a partir do Amazonas, permitem a navegação de vasos oceânicos, obtendo, portanto a classificação de Classe I/Especial.

No percurso Madeira - Mamoré logo a montante de Porto Velho são encontradas muitas dificuldades em águas baixas, constituídas por algumas formações rochosas no Madeira e por bancos de areia no Mamoré. Além dessas formações, em qualquer período tem-se o problema de troncos e galhos flutuantes arrancados, formando ilhas flutuantes ou encalhados em determinados pontos do curso d'água.

Para que tal via navegável seja considerada uma hidrovia, definida para a embarcação tipo Madeira, por ex: Comboio Maggi, com 20.000 toneladas, desde Porto Velho até Itacoatiara; com as seguintes características: comboio de empurra composto de quatro chatas e um empurrador, comboio com comprimento de $200 \mathrm{~m}$, boca (largura) com 16 m e calado de 2,5 m no máximo em águas mínimas, ela ainda deverá ter: 
Os níveis d'água de projetos definidos, ou sejam, os níveis a partir dos quais a probabilística profundidade mínima é definida;

Obras de melhoramentos da via, como dragagens e derrocamentos, reprojetados e implementados;

- Cartas de navegação confeccionadas;

- Balizamento e sinalização de margens melhoradas.

$\mathrm{Na}$ margem esquerda, destacam-se o Branco e o Negro. Este último permitindo navegação oceânica no seu trecho de jusante até o deságüe do rio Branco, ou seja, por cerca de $300 \mathrm{~km}$.

Quanto ao rio Branco desde o rio Negro até Boa Vista em Roraima, isto é, por cerca de 450 km, apresenta-se na condição de Classe II/Grande Potencial.

Com relação aos outros afluentes, na margem direita destacam-se o Juruá, o Purus e o Madeira, todos navegáveis por centenas de quilômetros, na condição de Classe II/Grande Potencial, permitindo calado de $2 \mathrm{~m}$ quase todo o tempo.

Entre esses afluentes, o rio Madeira, e o rio Mamoré formam uma notável hidrovia em extensão, desenvolvendo-se por cerca de $2.000 \mathrm{~km}$ navegáveis, metade na condição de Classe II e metade na condição de Classe III, ou seja de médio potencial, contando-se com calado de 1,20 m, pelo menos e largura de comboio de $16 \mathrm{~m}$, a maior parte do tempo.

Quanto às embarcações, ocorre a predominância de pequenos armadores, ou seja uma quantidade expressiva de proprietários de uma ou duas embarcações pequenas.

Várias empresas operam no trecho principal Amazonas - Solimões, sendo que as maiores são a ENASA - Empresa de navegação da Amazônia e, a DI GREGÓRIO, privatizada.

Merece destaque o transporte de granéis sólidos, constituído por soja. O transporte percorre o sentido de exportação, de Porto Velho no Madeira a Itacoatiara, no Amazonas, onde se instala um terminal para transbordo para navios oceânicos, 
com até 60.000 toneladas de capacidade. A Cia Hermasa, operadora do sistema, previu, para o ano de 1999, um volume de exportação de 550.000 toneladas de soja.

\subsubsection{Socioeconomia e Cargas Atuais}

A bacia Amazônica, por sua extensão e dificuldades inerentes ao ambiente hostil à penetração humana, tem sido ocupada parcimoniosamente, muitas vezes sob condições econômicas específicas e incentivadas pelo estado, como foi a criação da Zona Franca local.

A população na região Norte é superior a 10 milhões de habitantes, segundo o censo de 1991,e se concentra, principalmente em Belém, Manaus, Macapá, Santarém, Porto Velho, Rio Branco, Boa Vista, Castanhal e mais uma dezena de cidades de maior porte.

No passado, a produção extrativista vegetal prevaleceu em toda região, destacando-se a castanha-do-Pará, a madeira e a borracha, como produtos de maior interesse. A borracha foi, na Amazônia, a maior fonte de divisas obtida no mercado externo, principalmente no início do século, durante o chamado ciclo do látex, ou da borracha. A situação atual, no entanto, é muito diversa, além dos produtos acima, tradicionais, são exportados: pimenta-do-reino, cacau, tecido de juta, palmito, camarão e peixe. No que se refere a minérios, a região exporta bauxita, do rio Trombetas, caulim e celulose, da área do projeto Jari, minério de manganês, da Serra do Navio, alumínio produzido pela Albrás, em Vila do Conde e o minério de ferro, de Carajás, embarcado no porto marítimo de Itaqui, no Maranhão, para onde é levado por ferrovia.

Incluindo todos os modais de transporte, o corredor amazônico transportou, em 1985, 13.755 .000 ton. De carga, composta por $41 \%$ de granéis sólidos, $26 \%$ de granéis líquidos e 33\% de carga geral. Presentemente, no que se refere a minérios, os potenciais estimados na área são os seguintes: 4,6 bilhões de toneladas de bauxita; 18 bilhões de toneladas de hematita; 1 bilhão de toneladas de minério de cobre, associadas a 4 milhões de toneladas de manganês e outras tantas de níquel, estanho, 
cassiterita, ouro fluvial, minérios estratégicos de ocorrência rara, petróleo e gás com potenciais ainda não estimados.

Essas enormes reservas potenciais de minérios, vultosas em valor econômico, levam a cenários futuros de transporte onde a hidrovia, sem dúvida terá lugar de destaque.

\subsubsection{Rios Tocantins e Araguaia, segundo Rebouças et al. (1999)}

\subsection{Síntese : $\quad$ Estados: Tocantins, Maranhão e Goiás.}

$\begin{array}{lll}\text { Extensões aproximadas: } & \text { Navegáveis } & -2200 \mathrm{~km} \\ & \text { Potenciais } & -1300 \mathrm{~km} \\ & \text { Total } & -3500 \mathrm{~km}\end{array}$

Rios: Tocantins, Araguaia e das Mortes.

A bacia dos rios Tocantins - Araguaia se desenvolve no sentido sul/norte, na região Central do Brasil e tem todas as características de uma via natural de penetração do desenvolvimento, não fosse a existência de obstáculos no seu trecho médio entre Tucuruí e a confluência dos dois rios, e as corredeiras no Rio Araguaia nos primeiros $150 \mathrm{~km}$.

De maneira geral, fora os obstáculos indicados, os rios são navegáveis sem restrições no período das chuvas e apresentam algumas deficiências, especialmente de calado no período da seca.

A região é rica em minerais, a criação de gado é extensiva e grande parte de sua bacia tem solo que se presta para a produção de grãos, em especial a soja e o arroz.

A bacia hidrográfica do Tocantins - Araguaia, dada a sua importância para o desenvolvimento da região Central do Brasil, foi escolhida para a implantação de hidrovias em programas governamentais. Em função de ações judiciais, no entanto, propostas por organizações ambientalistas, envolvendo reservas indígenas, o desenvolvimento das hidrovias na bacia está sendo retardado. Apesar de estar 
sinalizada em grande parte com bóias, ainda não foi possível viabilizar o tráfego de comboios de porte.

\subsection{Rede Fluvial}

A bacia hidrográfica dos rios Tocantins - Araguaia tem cerca de 776.000 $\mathrm{km}^{2}$. É uma bacia alongada no sentido sul/norte, é formada pelos rios Tocantins e Araguaia e seu principal afluente, o rio das Mortes.

$\mathrm{O}$ rio das Mortes escoa paralelo ao rio Araguaia na sua margem esquerda. Apresenta um leito bem encaixado, com um traçado retilíneo com poucos pontos críticos, isto é, afloramentos rochosos e bancos de areia. Tem oscilações máximas do N.A. entre os períodos de chuva e estiagem de 4,0 $\mathrm{m}$ e declividade média que varia de $5,27 \mathrm{~cm} / \mathrm{km}$ a $7,7 \mathrm{~cm} / \mathrm{km}$. O transporte de sedimentos é de pequena monta, o que explica a falta de bancos de areia de maior expressão em todo seu trecho.

$\mathrm{O}$ rio Araguaia, na mesma região à montante da confluência com o rio das Mortes, apresenta declividade baixa e é encaixado, com margens estáveis sem bancos de areia, desde a região da Barra do Garças até a foz do rio Claro, e possui alguns afloramentos rochosos. À montante de Registro de Araguaia começam a aparecer os primeiros bancos de areia, observando-se uma mudança em suas características morfológicas. Com a formação dos bancos, o leito sofre um alargamento, mas apresenta um leito maior, retilíneo e um leito menor mais curvilíneo, em função das ilhas.

Após a confluência com o rio das Mortes, no leito maior, retilíneo, observa-se o aumento de ilhas e bancos de areia. Neste trecho o rio apresenta maior mobilidade observando-se restos de canais abandonados, formando lagos marginais alongados. Apesar dos bancos serem instáveis, de maneira geral sempre estão na mesma região. Depois de Santa Maria das Barreiras, passando por Conceição do Araguaia, até Xambioá, na extensão de $273 \mathrm{~km}$ aparecem afloramentos rochosos, transversais ao rio, em forma de cordões, ou travessões de extensão variável. Normalmente, estão submersos em águas altas e nas águas baixas faz-se necessária a navegação através 
dos "portões", que são brechas abertas pela água nos afloramentos. Estes afloramentos aparecem em longos estirões, ou seja, trechos de rio de 40 a $50 \mathrm{~km} \mathrm{sem}$ obstáculos rochosos.

A partir de Xambioá até próximo à sua foz com o rio Tocantins, o rio Araguaia tem o seu mais difícil trecho para a navegação fluvial, que é a existência de quatro corredeiras entre as quais se destaca a de Santa Isabel, que podemos considerar impossível de ser navegada com segurança por comboios de grande capacidade. Os problemas maiores não se referem à falta de calado, no período de estiagem, mas sim ao complexo direcionamento do escoamento que se faz com velocidades elevadas no período de águas médias, além da existência de inúmeros obstáculos distribuídos caoticamente ao longo de todo o trecho.

Para vencer estes obstáculos estavam previstas barragens de aproveitamento múltiplo, que por enquanto se tornam inviáveis por motivos econômicos e ambientais. A solução preconizada, em meados de 1999, é a construção de canais no próprio leito do rio, eliminando os obstáculos e os escoamentos caóticos. Para atenuar as altas velocidades, pretende-se introduzir obstáculos submersos, que aumentam a perda de carga,. Esse é sem dúvida o trecho mais crítico em toda hidrovia.

Após Marabá, atinge-se o remanso do reservatório de Tucuruí, que é atualmente o maior obstáculo artificial à navegação, pois ainda, até 1999, não foram construídas as duas eclusas que compõem a escada projetada para a sua transposição.

Atualmente os projetos estão em revisão e recursos já foram liberados para o início das obras, com a construção das duas eclusas e do canal intermediário.

No seu trecho final de $280 \mathrm{~km}$, até próximo a Belém, o rio não apresenta obstáculos relevantes para a navegação durante todo o ano para calado de até 2,50 metros.

O rio Tocantins apresenta obstáculos entre Imperatriz e Estreio e Miracema do Tocantins. Presentemente, estuda-se a barragem de Lajeado, a montante do rio que, embora venha a ser construída inicialmente sem eclusa, deve promover 
regularização de descargas, melhorando as condições de escoamento do rio e sua navegabilidade.

Na hidrovia Araguaia - Tocantins poderemos ter em breve um total de 2.126 $\mathrm{km}$ navegáveis incluindo os 425 do rio das Mortes e mais os $715 \mathrm{~km}$ do rio Tocantins, entre sua foz e a cidade de Imperatriz.

\subsection{Aspectos Socioeconômicos}

A bacia do Araguaia - Tocantins, em função de sua extensa área ocupada no sentido sul/norte, pode ser dividida em três regiões de características distintas, em função do seu solo e recobrimento vegetal.

Assim, a norte temos a zona Amazônica com características de mata fechada, com grandes riquezas florestais e minerais, além de seu potencial hidroelétrico.

No sul, uma zona de cerrado com grandes áreas agricultáveis, onde vem se expandindo a fronteira agrícola da produção de grãos, tais como soja, milho e arroz.

$\mathrm{Na}$ zona central temos como principal atividade a pecuária extensiva e merece estudos específicos para melhor definir a sua vocação e uso mais adequado.

No total estimam-se 50.000 hectares agricultáveis e 30.000 hectares de pastagens em toda a bacia.

No final da década de 80, na área de influência das hidrovias (rio das Mortes e Alto Araguaia) colheu-se cerca de 1.000 .000 de toneladas de soja e estima-se que o potencial da área seja da ordem de 15.000 .000 de toneladas.

Além de ferro, ouro, cobre, manganês e bauxita existentes na região Norte, há grandes depósitos de calcário dolomita, capazes de suprir a necessidade de corretivos de solo para a região.

\subsection{Integração Modal}

Na região Sul, não existe um sistema ferroviário que se ligue à hidrovia. Os pontos mais próximos são Goiânia, Anápolis ou Brasília. Ao Norte temos a estrada 
de ferro de Carajás, que cruza o rio Tocantins em Marabá, e é uma opção para a intermodalidade de transporte, viabilizando a alternativa dos portos da região de São Luís.

A Ferrovia Norte - Sul, ligada à ferrovia de Carajás, em Açailândia, no ano de 1999, termina em Imperatriz, mas está em expansão até Estreito.

O sistema rodoviário é pouco desenvolvido destacando-se a BR 158 (Belém-Brasília), que corre paralela aos dois rios. Esta rodovia, conserva distância da ordem de $150 \mathrm{~km}$ dos rios Araguaia e Tocantins, com poucas ramificações asfaltadas.

No sul da bacia, entre Nova Xavantina, Barra do Garça e Aruanã, a malha rodoviária é mais densa, embora igualmente precária.

\subsection{Embarcações}

A embarcação tipo para o qual a hidrovia vem sendo preparada é um comboio de empurra composto de quatro chatas e um empurrador. Esse comboio tem 108,00 $\mathrm{m}$ de comprimento, $16 \mathrm{~m}$ de boca (largura) e calado $1,5 \mathrm{~m}$ no máximo em águas mínimas.

As questões ambientais, até 1999, ainda sob óticas muito restritivas, têm produzido ações de embargo, tal ponto que em 1997 apenas uma única viagem hidroviária foi feita entre Nova Xavantina e Xambioá.

\subsection{Perspectivas}

A hidrovia Araguaia - Tocantins é uma hidrovia com extenso trecho navegável naturalmente, com necessidade de obras de pequena monta, e dois trechos críticos, que são: as corredeiras entre Xambioá e a confluência dos dois rios, e as obras de transposição em Tucuruí. Estas obras estão com seus projetos executivos em andamento, em 1999. 
É a hidrovia com maior perspectiva de evolução rápida no País, em função de sua extensão, possibilidade de impulsionar o desenvolvimento da região Central do Brasil e posição de portos exportadores, que se aproximam do Hemisfério Norte, como Belém e São Luís. Este último fato, implicando em menores fretes para a colocação de produtos nos mercados americano e europeu.

Infelizmente, no entanto, até 1999, organizações ambientalistas, principalmente as internacionais, têm de forma radical e pouco embasada, por vezes com interesses não perfeitamente claros, conseguindo atrasar a realização da hidrovia. Presentemente, esta situação se repete em outras hidrovias do país.

A Tabela III, apresenta uma síntese da rede hidroviária no Brasil. 
Tabela III - Rede Hidroviária no Brasil

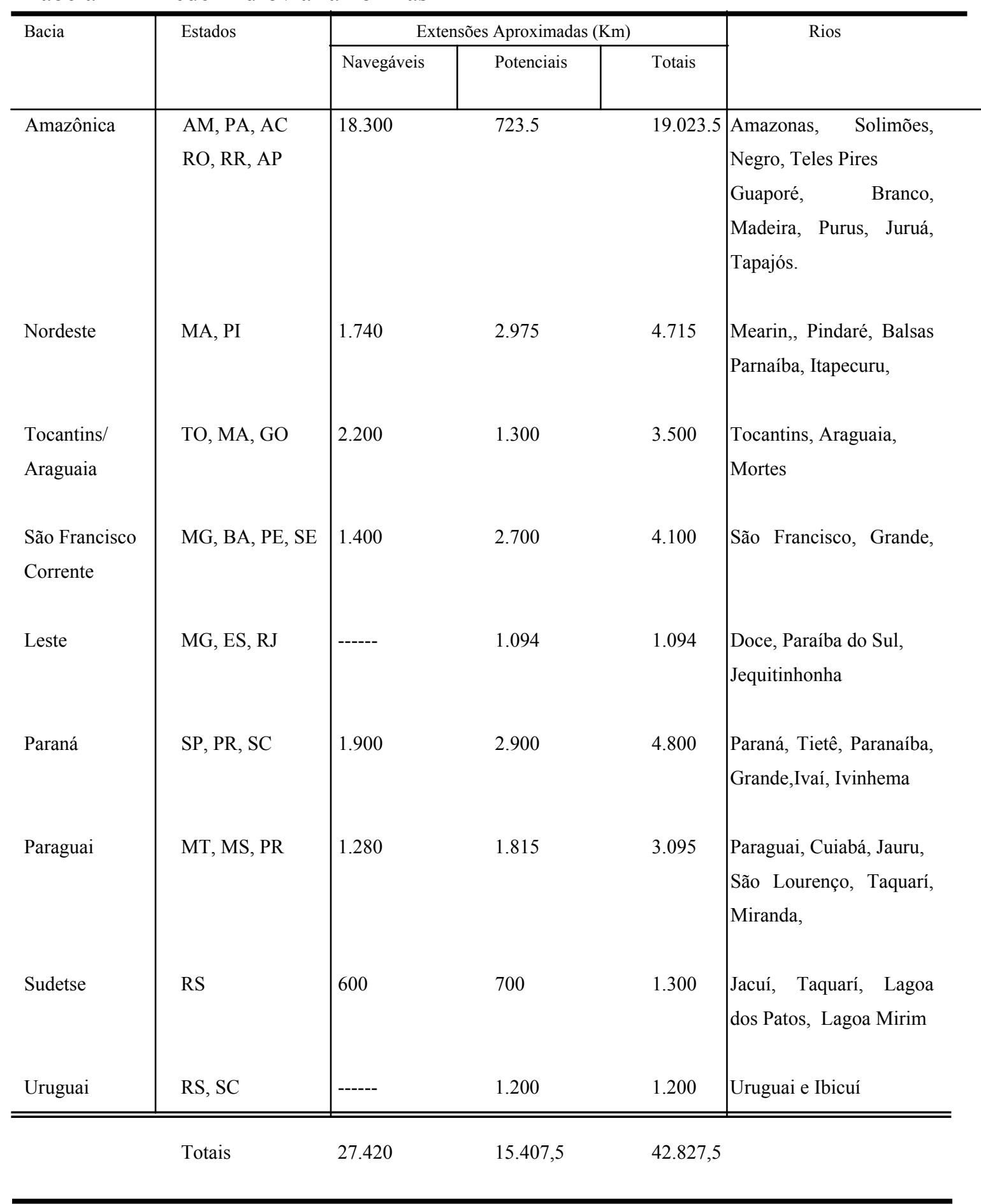

Fonte: IBC - International Business Communications. (2001). Conferência : Operação do transporte hidroviário no Brasil. 
Segundo Santos; Silveira (2001), os subsistemas de movimento hidroviário são divididos em cinco ( para efeito de controle do Ministério do Transporte) quais sejam: a Bacia Amazônica, a Bacia do São Francisco, a Bacia do Sudeste, a Bacia Leste e a Bacia do Prata.

Adotamos nesta pesquisa, a divisão dos subsistemas de movimento hidroviário apresentado por Rebouças et al. (1999).

\subsection{SITUAÇÃO DAS HIDROVIAS INTERIORES NO MUNDO}

Com o melhor entrozamento e coordenação com os outros meios de transporte, no século passado, a navegação fluvial teve um desenvolvimento notável, que foi caracterizado pela construção de grandes obras de dimensões gigantescas.

De um total de 450 mil quilômetros de vias navegáveis interiores existentes no mundo, na década de 1980 eram efetivamente utilizadas cerca de 190 mil quilômetros, nos quais eram transportadas anualmente, 2,2 bilhões de toneladas de cargas, principalmente carvão, petróleo, combustíveis líquidos, fertilizantes, ferro, aço e materiais de construção. Desse total, cerca de 57\% era movimentado pelos EUA, 25\% pela Rússia e a extinta União Soviética, 10\% pelos países da Europa Ocidental e os $8 \%$ restantes pelo resto do mundo.

Os maiores índices de aproveitamento de hidrovias (percentual de uso da rede potencial), encontra-se na Europa Ocidental e nos EUA. A Rússia e os países do extinto bloco soviético utilizavam, na época, $31 \%$ de seu potencial e os países da Ásia apenas cerca de $8 \%$, de acordo com os dados disponíveis. A utilização de vias navegáveis no mundo é de tal forma vantajosa que, mesmo em países de inverno rigoroso, como Rússia e o Canadá, rios que congelam por vários meses são programados para aproveitamento em seus períodos de boa navegabilidade.

2.4.1. PAIS - ESTADOS UNIDOS, segundo Del Grande (1989) 
O transporte de carga por via fluvial corresponde a $18 \%$ do total, existindo transbordos planejados com ferrovias e rodovias.

\subsubsection{Características}

- O transporte por hidrovia corresponde a mais de 200 milhões de toneladas por ano;

São 152 mil km de hidrovias, isto é, 1.316 t / km;

- Embarcações : chatas de 1000 t até 10.000 t de carga;

- Embarcações: comboios rígidos de empurra de até 40.000 t;

- Ao longo dos rios, encontram-se instaladas $60 \%$ de novas indústrias;

- Exemplos de algumas hidrovias implantadas:

Canal Eril, entre o lago e o rio Hudson (1817/1825), ligou os Grandes Lagos ao Oceano Atlântico, baixando o frete para 1/7, isto é, de US\$100/t para US\$15/t);

Hidrovia Chicago - New Orleans, extensão 2.300 km;

Hidrovia Pittsburg - New Orleans, extensão 3.000 km;

Hidrovia Duluth (L. Superior) - rio São Lourenço, extensão 4.000 km (largura igual a $184 \mathrm{~m})$;

L Hidrovia TVA (Rio Tenessee/Ohio e Mississipi - 1933/1950) - com aproveitamento múltiplo: navegação, energia elétrica, regularização, irrigação e lazer). Apresentou os seguintes dados:

마을estimentos: US\$ 1 bilhão;

toferta de empregos: aumento de 105\% ( de 448 mil para 920 mil);

哦Custo/percápita para a população do Vale = US\$ 9,00;

$\leftrightarrow$ Aumento da renda da população do Vale = US\$ 136,00;

䟚Indústrias novas no Vale $=01$ terminal de carga $/$ cada $10 \mathrm{~km}$;

샂essurgimento da agricultura: gerou dividendos para o povo;

哦Carga transportada $=33$ milhões de t/ano.

2.4.2. PAIS - CANADÁ, segundo Del Grande (1989) 
Tendo em vista o frio (gelo), o transporte se desenvolve somente durante quatro meses por ano; a navegação se restringe ao rio São Lourenço, com um transporte de cerca de 25 milhões de toneladas, sendo que, desse total 10 milhões são do comércio interno.

\subsubsection{EUROPA}

A pequena área dos países europeus, em relação às áreas das bacias hidrográficas, fez com que houvesse alguma dificuldade, no início da evolução da navegação interior. O planejamento é feito por uma associação internacional permanente de navegação junto a comissão econômica européia .

A ligação das cabeceiras do rio Danúbio às cabeceiras do rio Reno, por meio de um canal de partilha Rhein-Lein - Donau-Kanal - Ludwig-Kanal, inteiramente artificial (consta principalmente da canalização do rio Mein, afluente da margem direita do rio Reno) que se constitui numa das grandes obras hidráulicas da engenharia moderna, ficam ligados a Alemanha, a Austria, a Tchescoslovaquia, a Hungria, a Iugoslávia, a Bulgária e a Romênia à França, à Bélgica e à Holanda. Ficam assim ligados por uma via de navegação interior os mares Negro e do Norte.

O tipo característico da via de navegação interior e internacional é o sistema do Danúbio-Reno.

Há a uniformização do calado para 2,5m no mínimo e embarcações automotoras para 1350 t de carga, mínimo. Em 1988 o transporte foi de cerca de 80 milhões de toneladas.

\subsubsection{PAIS - FRANÇA, segundo Del Grande (1989)}

Tem mais de duzentos anos de transporte fluvial organizado. O seu relevo é propício ao transporte hidroviário. O rio Reno, para o mar do Norte; o rio Sena para o canal da Mancha; o rio Rodano para o Mediterrâneo. 
O sistema de hidrovias, é baseado principalmente nos grandes rios: Sena, Meusa, Rodano, Reno, Garona e Loire. As primeiras viagens (cereais e vinhos) de Paris para Marselha, quando completadas, o barco (sem propulsão), era vendido como lenha. Para a Bélgica e Holanda havia as embarcações a vela denominadas "peniches".

No início do século XIX, houve a melhoria da rede com a interferência do ministro Freycinet, adotando a peniche "padrão" (38,5 x 5,0 x 1,5 m) para $300 \mathrm{t}$, adaptando eclusas e canais para esse gabarito.

Na década de 20, com o motor a diesel, começam os automotores; em 1946, há a modernização com a adoção do gabarito "Chaland" $(82 \times 8,35 \times 2,5 \mathrm{~m})$ para 1.500 t, portos para barcos de até 3.000 t e comboios de chatas até 10.000 t. partindo de Paris ou da Basiléia (Suiça), os navios vão até Roterdam.

\subsubsection{PAIS - ALEMANHA, segundo Del Grande (1989)}

Liga-se o Reno com o Danubio, através do rio Mein, completando-se a ligação com o Mar Negro (U.R.S.S).

Foram transportados em 1988 cerca de 75 milhões de toneladas, entre granéis sólidos (cereais, carvão, minério, fertilizantes, etc.), granéis líquidos (derivados de petróleo e óleos vegetais) e também grandes volumes (turbinas, etc.).

“O mundo já comprovou a viabilidade empresarial da navegação fluvial. Europa, Estados Unidos e muitos outros países transportam por hidrovia 2,5 bilhões de toneladas anuais, o dobro da movimentação brasileira de carga" (IBC International Business Communications. (2001). Conferência : Operação do transporte hidroviário no Brasil).

Em síntese, é possível apresentar como panorama das hidrovias do mundo, no que se refere a extensão hidroviária, a Tabela IV. 
Tabela IV - Rede Hidroviária no Mundo

\begin{tabular}{lc} 
País & Extensão Hidroviária (em km) \\
\hline EUA - Canadá & 40.000 \\
Europa - Rússia & 146.000 \\
França & 6.600 \\
Holanda & 5.371 \\
Bélgica & 1.508 \\
Alemanha & 4.300 \\
\hline Fonte: IBC - International Business Communications. (2001). \\
Conferência : Operação do transporte hidroviário no Brasil.
\end{tabular}




\section{Capítulo 3.}

\section{O BARCO E A MITOLOGIA}

Barca, canoa, bote, barco, simbolizam freqüentemente a travessia do Reino dos Vivos para o Reino do Mortos, ou vice-versa; é encontrada nas concepções míticas de muitos povos. Na mitologia grega, por exemplo, o barqueiro Caronte coloca as almas em uma barca sobre o rio que forma a fronteira com o Reino dos Mortos (Estige ou Aqueronte). Segundo a concepção egípcia, o deus solar Rá velejava pelo céu durante o dia, em uma barca diurna; e durante a noite, em uma barca noturna, pelo Reino dos Mortos. Muito difundida é a comparação da lua crescente ou minguante (meia-lua) com uma barca. Devido à sua forma que permite navegar para qualquer direção, a barca foi também uma personificação de Jano, o deus romano bifronte (Lexikon, 1978).

\section{O NAVIO E O CRISTIANISMO}

Nave, é o símbolo da viagem e da travessia e, portanto, também da vida, da viagem da vida. No cristianismo, o navio, freqüentemente relacionado com a arca de Nóe, simboliza a Igreja, que atravessa com segurança as vagas dos perigos mundanos. A forma arquitetônica das igrejas ( indicadas pelas designações: nave central, lateral e transversal ) foi comparada também, em seus pormenores, a um navio; encontram-se também altares em forma de navio (Lexikon, 1978). 
3.

MODAIS DE TRANSPORTE

\subsection{TRANSPORTE}

É a movimentação de massa entre dois pontos A e B. Estes pontos são chamados de origem e destino, sendo que a origem é o ponto onde se inicia o deslocamento da massa e, destino o seu término.

Desde épocas remotas, que o binômio civilização x transporte vem mantendo uma estreita correlação. Podemos afirmar que a civilização de um povo continua estreitamente ligada a seu sistema de transporte, quer circulando suas riquezas, quer circulando seus exércitos como meio de defesa ou ataque, quer proporcionando livre troca de mercadorias com outras nações.

\subsection{MASSA ECONÔMICA}

É tudo que pode ser transportado, tendo ou não valor venal. Podemos efetuar transporte de esgoto de uma cidade da orla marítima para alto mar, onde correntes marítimas o levam para mais longe, neste caso o esgoto não tem valor nenhum, é jogado fora e este transporte não tem rentabilidade nenhuma.

O transporte comum de mercadorias (cargas), que é citado nesta tese, entre a origem e o destino, ao contrário, tem renda (lucro) e a mercadoria tem valor, sendo que o transportador é responsável pela perda desta.

Os motivos que influenciaram no desenvolvimento dos meios de transporte são: Diferenças geográficas; Especialização; Localização da população; Relações comerciais; Objetivos políticos e militares, etc.

\subsection{TIPOS DE TRANSPORTE, segundo Valente (1975)}

O transporte de massa pode ser feito de diversas maneiras, através de caminhões; automóveis; aviões; navios; trens, etc. 
Os tipos de transporte, segundo o meio em que eles se desenvolvem podem apresentar a seguinte classificação, se bem que não seja perfeita é, mais ou menos, universalmente aceita: Transporte por via hídrica: fluvial e marítimo; Transporte por via aérea; Transporte por via terrestre: ferroviário, rodoviário e ductoviário.

Os primeiros tipos de transporte que surgiram foram os fluviais, feitos com barcaças através de rios, lagos e mares. Com a construção das estradas, especialmente as construídas pelos romanos, surgiram os transportes rodoviários, e com o surgimento das primeiras locomotivas em 1800, começa então o transporte ferroviário. Somente no século passado, com o progresso da aviação começou a existir o transporte aéreo.

Entre os outros tipos de transporte, podemos destacar:

Pipelines (Ductovias) - que é bastante antigo, datando da época dos romanos, que já transportavam a água por meio de aquedutos (transporte por gravidade). Hoje em dia o transporte de líquidos (fluídos) é feito sob pressão, podendo ser assim vencidas diferenças de níveis, por exemplo o oleoduto entre Santos e São Paulo, mineroduto entre Belo Horizonte e Angra dos Reis

- Teleférico - é um sistema de transporte em que a carga ou veículo é pendurado num cabo que lhe serve de suporte. É utilizado em transporte de minérios ou de calcários para fábricas de cimento e em alguns casos, como atração turística (Bondinho do Pão de Açúcar). Nas indústrias como a V.W. do Brasil chega-se a trabalhar com peças que circulam em vários níveis.

- Metropolitano - é um meio de transporte rápido, específico para pessoas, operando com grandes volumes de tráfego urbano. Sua utilização é característica de regiões urbanas de alta densidade populacional e o tipo mais conhecido é o de estrutura viária igual a de uma ferrovia subterrânea. Nas regiões centrais, normalmente, ele se desenvolve em galerias subterrâneas a fim de não perturbar o tráfego de superfície. 
Hovercraff - o hovercraff, tem sido citado em alguns estudos como sistema de transporte, mas neste trabalho o entenderemos como veículos que se deslocam acima das águas, porém entre eles há um colchão de ar. São movidos por motor a hélice e, são usados para o transporte de pessoas, por exemplo, na Europa, na travessia do Canal da Mancha há linhas regulares para o transporte de passageiros entre a Inglaterra e a França. Estão em estudos hovercrafff para o transporte de carga.

Em relação às vias das diversas modalidades de transporte, para o modal aquaviário é um dos sistemas que tem sua via já pronta natureza, a não ser em casos particulares de canais. Da mesma maneira temos também o transporte aeroviário e o sistema de colchão de ar que não tem necessidade de construção de vias. Para o transporte rodoviário, ferroviário e ductoviário a construção da via deve existir.

Em relação ao meio, só para o transporte ductoviário é que não precisamos de veículos, pois o fluído se transporta por si próprio dentro da via, isto é o duto.

$\mathrm{Na}$ Tabela V, citam-se as principais modalidades de transporte, a via onde é feito o transporte, o meio com o qual é feito e os terminais na origem e no destino. 
Tabela V - Via para cada Modalidade de Transporte

\begin{tabular}{|c|c|c|c|}
\hline Modalidade & Vias & Meio & Obras e Terminais \\
\hline Aquaviário & $\begin{array}{l}\text { Oceanos, Mares } \\
\text { Rios, Lagos, Canais }\end{array}$ & $\begin{array}{l}\text { Embarcações, } \\
\text { Navios }\end{array}$ & $\begin{array}{l}\text { Portos ( Docas, } \\
\text { Cais ) }\end{array}$ \\
\hline Ferroviário & $\begin{array}{l}\text { Via Permanente: } \\
\text { Plataforma, Lastro } \\
\text { Dormentes, Trilhos }\end{array}$ & $\begin{array}{l}\text { Veículos } \\
\text { Ferroviários: } \\
\text { Locomotivas e } \\
\text { Vagões }\end{array}$ & $\begin{array}{l}\text { Estações } \\
\text { Ferroviárias; } \\
\text { Passageiros e } \\
\text { Cargas }\end{array}$ \\
\hline Rodoviário & $\begin{array}{l}\text { Pavimento: } \\
\text { Sub-base, Base } \\
\text { Revestimento }\end{array}$ & $\begin{array}{l}\text { Veículos } \\
\text { Rodoviários: } \\
\text { Caminhões; Ônibus } \\
\text { e Cargas }\end{array}$ & $\begin{array}{l}\text { Estações } \\
\text { Rodoviárias } \\
\text { Passageiros } \\
\text { e Automóveis }\end{array}$ \\
\hline Aeroviários & Atmosfera & $\begin{array}{l}\text { Aviões, Aeronaves } \\
\text { Helicópteros }\end{array}$ & Aeroportos \\
\hline Ductoviário & Dutos & Fluídos & $\begin{array}{l}\text { Depósitos e } \\
\text { Estações de } \\
\text { Bombeamento e } \\
\text { Aquecimento } \\
\text { (se necessário) }\end{array}$ \\
\hline Colchões de Ar & $\begin{array}{l}\text { Oceanos, Mares } \\
\text { Lagos }\end{array}$ & $\begin{array}{l}\text { Veículo provido } \\
\text { de um sistema de } \\
\text { Geração de ar }\end{array}$ & Portos e Estações \\
\hline
\end{tabular}

Fonte: ALBANESE, Vicenzo. (1987).

Em relação ao custo da implantação a Tabela VI, exprime as relações aproximadas de custo entre os diversos sistemas de transportes. 
Tabela VI - Relação de custos entre os sistemas de transportes.

\begin{tabular}{ll}
\hline Modalidade & Relação \\
\hline Ductovia & 1 \\
Aquavia & 3 \\
Ferrovia & 5 a 9 \\
Rodovia & 9 a 15 \\
Aerovia & 100 \\
\hline Fonte: ALBANESE, Vicenzo. (1987).
\end{tabular}

\subsection{INTEGRAÇÃO DOS MODAIS DE TRANSPORTE}

Hodiernamente, há a necessidade de se prever para certas regiões um certo planejamento de transporte, em geral, de maneira a se obter uma integração perfeita entre os diversos tipos de transporte, possíveis. Ver figura 2.

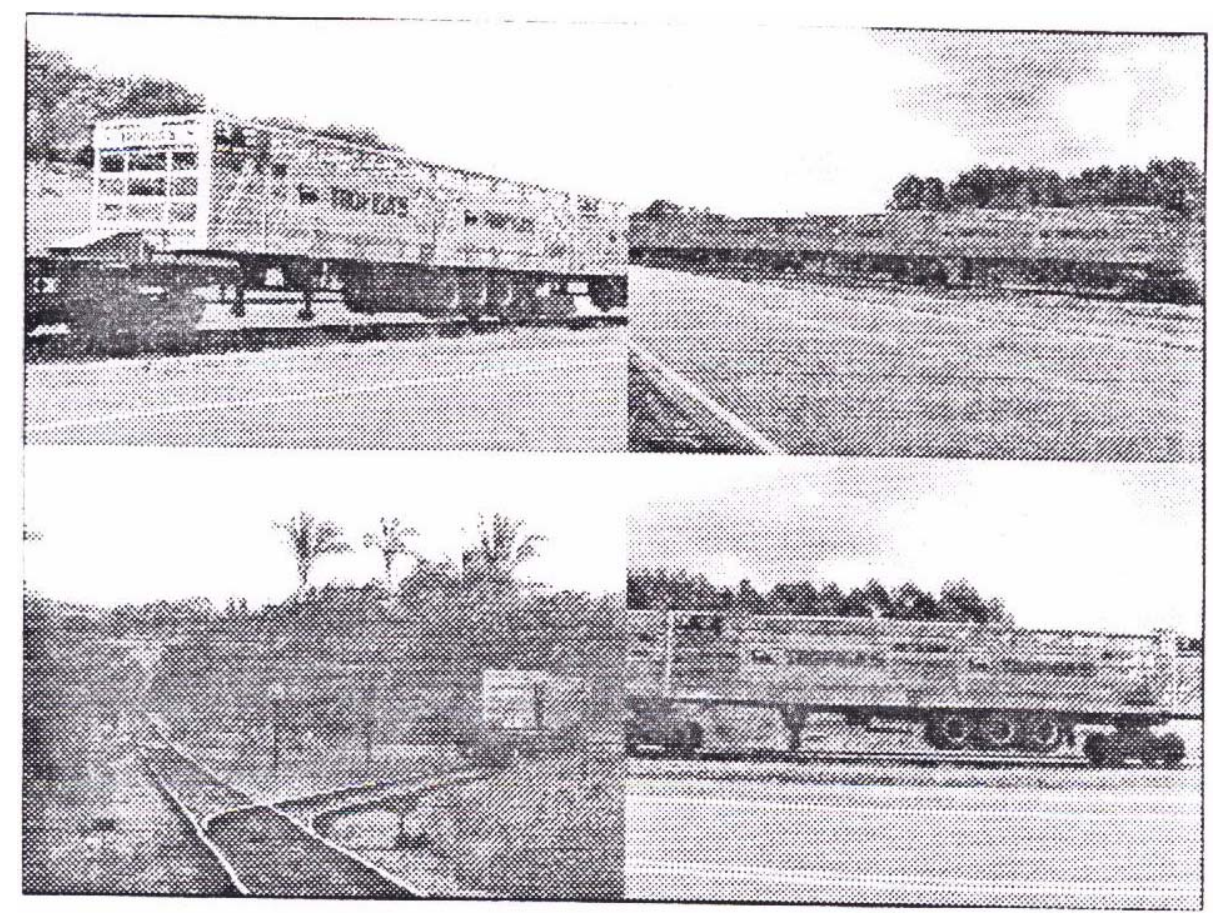

Figura 2 - Integração entre os modais de transporte.

Fonte: IBC - International Business Communications. (2001).

Conferência : Operação do transporte hidroviário no Brasil. 
A necessidade já referenciada anteriormente, é definida, como Logística: estuda a estocagem e distribuição de mercadorias de um sistema de transporte; na verdade, envolve todo o projeto e desenvolvimento, obtenção, armazenamento, transporte, distribuição, reparação e escoamento de material, para fins operativos ou administrativos. Podemos citar ainda a Macrologística, entendida como a integração econômica do continente, considerando a infra-estrutura de energia, comunicação e transporte. A Logística, atualmente aplicada aos transporte deu origem a "Logística de Transporte", isto é: a arte de levar um bem (ou pessoa) de um ponto a outro da forma mais segura, eficiente, em menor tempo e ao menor custo.

Para o atendimento da "Logística de Transporte", surgem os conceitos de Transporte Intermodal e Transporte Multimodal.

Entenderemos o Transporte Intermodal, como sendo o transporte de mercadorias feito (transferido) entre duas modalidades diferentes de transporte e, o Transporte Multimodal, como sendo o transporte de mercadorias feito por pelo menos duas modalidades diferentes de transporte.

Os fundamentos de uma integração dos modais de transporte são:

A livre escolha do usuário dentro das possibilidades;

- O custo marginal mínimo da produção (Transportes);

Os preços dos transportes convergindo para o ótimo econômico;

Eliminação da concorrência atribuindo a cada sistema o que lhe compete.

O estudo da integração das modalidades de transporte, exige o conhecimento das características mais importantes de cada modal, a saber:

Ferrovias - apresenta menor resistência a propulsão, relativa flexibilidade e grande segurança. Apresenta vantagens para o transporte de grandes massas a distâncias razoáveis. 
Rodovia - apresenta a vantagem de grande flexibilidade e horário livre. O usuário tem total liberdade e grande flexibilidade em seu transporte. Apresenta vantagem para pequenas distâncias e cargas médias. Proporciona maiores velocidades.

Hidrovias - vantagens de alto volume de carga para longos percursos. Apresenta a vantagem da menor potência por tonelada transportada em relação aos demais meios de transporte. É um meio de transporte lento.

Aerovias - sua principal característica é a alta velocidade de transporte. Sua utilização é notada para cargas pequenas de alto valor e que necessitam rápido transporte.

Pipelines - fluência máxima de carga. Boa segurança. Sua principal vantagem é no transporte contínuo de líquidos quando o volume total diário é máximo.

A partir do exposto, podemos concluir que Ferrovia, Hidrovia e Rodovia, devem atuar como modais de transporte integrados, garantindo assim maiores rendimentos financeiros para todos os modais.

Um exemplo, desses rendimentos financeiros, esta baseada na análise de custos envolvidos na operação e transporte por hidrovias e sua relação com os custos de outros modais, a saber:

Tabela VII - Custos envolvidos na operação dos modais de transporte

\begin{tabular}{lc}
\hline Modal & $\begin{array}{c}\text { Valor do Frete } \\
\text { custo }(\mathrm{R} \$ / \mathrm{t} . \mathrm{km} *)\end{array}$ \\
Hidroviário & 0,009 \\
Ferroviário & 0,016 \\
Rodoviário & 0,056 \\
(“Tonelada por km transportado) & \\
\hline Fonte: IBC - International Business Communications. (2001). \\
Workshop: Modelos estrangeiros e nacionais de operação de hidrovias.
\end{tabular}


A integração dos Modais de Transporte, teria como efeito imediato a redução dos valores de frete em todos os modais.

A seguir serão apresentados alguns quadros comparativos entre os modais de transporte, de modo que se tenha o conhecimento do limites técnicos e econômicos de cada modal.

Tabela VIII - Comparação entre os modais de transporte

\begin{tabular}{|c|c|c|c|c|}
\hline \multirow[t]{2}{*}{ MODAL } & \multicolumn{2}{|c|}{ LITROS/ } & \multirow[t]{2}{*}{$\mathrm{HP} / \mathrm{t}$} & \multirow{2}{*}{$\begin{array}{c}\mathrm{US} \$ / 1000 \\
\mathrm{TKMU}\end{array}$} \\
\hline & 1000 & $\mathrm{TKMU}^{(1)}$ & & \\
\hline CABOTAGEM & & 2 & $0,35^{(2)}$ & 6,0 \\
\hline HIDROVIA & & 5 & 0,30 & 8,0 \\
\hline FERROVIA & & 10 & 0,50 & 16,0 \\
\hline RODOVIA & & 56 & 7,40 & 32,0 \\
\hline \multicolumn{5}{|c|}{ 1) Tonelagem por quilômetro útil (TKMU). } \\
\hline \multicolumn{5}{|c|}{ 2) Navios de $35.000 \mathrm{TDW}^{(3)}$} \\
\hline \multicolumn{5}{|c|}{ 3) Total deadweight (TDW) ou Porte ou } \\
\hline \multicolumn{5}{|c|}{ Tonelagem de Porte Bruto (TPB): representa } \\
\hline \multicolumn{5}{|c|}{ o peso necessário para levar a embarcação } \\
\hline \multicolumn{5}{|c|}{ do calado mínimo ao calado máximo } \\
\hline \multicolumn{5}{|c|}{ 4) Cabotagem - é o transporte dentro } \\
\hline do próprio $p$ & r ex.: l & Manaus/San & & \\
\hline
\end{tabular}

Fonte: IBC - International Business Communications. (2001).

Conferência: Operação do transporte hidroviário no Brasil. 
Tabela IX - Combustível Consumido no Transporte de Carga por Modo Cada mil Toneladas . km transportados consomem:

\begin{tabular}{|c|c|}
\hline Caminhão de grande tonelagem & 18,5 litros \\
\hline Ferrovia Paulista & 12,0 litros \\
\hline E.F. Vitória a Minas (Vale do Rio Doce) & 3,8 litros \\
\hline Hidrovia Tietê & 3,0 litros \\
\hline Hidrovia comboio de 20 ton. & 2,5 litros \\
\hline
\end{tabular}

Tabela X - Quadro Comparativo de Transporte.

\begin{tabular}{lccc}
\hline MODAIS & $\begin{array}{c}\text { RODOVIÁRIO } \\
\text { (Caminhão) }\end{array}$ & $\begin{array}{c}\text { FERROVIÁRI O } \\
\text { (Vagão) }\end{array}$ & $\begin{array}{c}\text { HIDROVIÁRIO } \\
\text { (Barcaça) }\end{array}$ \\
\hline CAPACIDADE $(\mathrm{t})$ & $25(\mathrm{t})$ & $50(\mathrm{t})$ & $1000(\mathrm{t})$ \\
UNIDADES P/ & & & 1 \\
MESMA CARGA & 40 & 20 & 6,80 \\
CUSTO OPERACIONAL & 21,50 & 11,50 & 10 \\
VELOCIDADE MÉDIA & 80 & 40 & \\
$\quad($ km / h) & & & $>1000$ \\
$\quad$ DISTÂNCIA & 300 & 1000 & \\
COMPETITIVAS $(\mathrm{km})$ & & & \\
\hline
\end{tabular}

Fonte: www. caceres.com.br/adilsonreis

Tabela XI - Custos Sócio-Ambientais de Transporte

( Inclui: Acidentes; Poluição Atmosférica e Sonora; Consumo d'água e de Espaço ).

Modais

Rodoviário

Ferroviário

Hidroviário
US\$/ 100 ton./ km

US\$ 3,20

US\$ 0,74

US\$ 0,23

Dados: Fonte: IBC - International Business Communications. (2001).

Conferência - Operação do transporte hidroviário no Brasil. 
Tabela XII - Emissão de Poluentes

( Movimentação de 1,0 ton./1000 km)

\begin{tabular}{llcc}
\hline Veículo & \multicolumn{2}{c}{$\begin{array}{c}\text { Hidrocarbono Dióxido de Carbono } \\
\text { (em gramas) }\end{array}$} & $\begin{array}{c}\text { Óxido Nítrico } \\
\text { (em gramas) }\end{array}$ \\
\hline Empurrador de & & & \\
Barcaças & 21,00 & 46,66 & 123,64 \\
Caminhão & 146,97 & 443,23 & 2376,46 \\
\hline
\end{tabular}

Dados: Fonte: IBC - International Business Communications. (2001).

Conferência - Operação do transporte hidroviário no Brasil.

\subsection{DADOS NOTÁVEIS SOBRE O TRANSPORTE HIDROVIÁRIO}

Sob o Aspecto Econômico

Modal de competitividade ímpar, quando se trata de transportar grandes volumes de carga ( $>500.000$ t/ano) a grandes distâncias ( $>500 \mathrm{~km}$ ).

Com poucas intervenções e investimentos, dezenas de milhares de quilômetros de nossa malha viária ficariam disponíveis para a navegação durante o ano todo. Racionaliza potência dos motores. Com 1 HP se pode movimentar:

5 ton. por Hidrovia

0,5 a 1 ton. por Ferrovia

0,15 a 0,20 ton. por Rodovia

Obs. Atribuindo-se índice 100 para a Hidrovia, a relação $(H / F / R)$ ficaria $(100 / 10$ a $20 / 3$ a 4$)$.

Mobiliza maior carregamento de uma só vez:

Hidrovia: até 50.000 ton.

¿ Ferrovia: até 1.500 ton.

Rodovia: até 40 ton.

Relação: 100 / 3 / 0,08

Com isso, fica reduzido o número de operações de carga/descarga. 
Sob o aspecto Econômico/Ambiental

Diminui a exaustão de recursos naturais:

Łansumo de Combustível: Relação (H/F/R: 100/300/500-800)

Ł Peso necessário para transportar 1 ton. de carga útil:

Relação (100/225/214)

Łompo de vida útil:

$\rightarrow$ Q Quando da operação:

Łoluição do ar: Relação (100/177 - 199/330)

Łível de ruído: Relação (100/900/200)

× Contaminação do sítio ocupado: Relação (100/100/540)

Acidentes Fatais: Relação (100/175/4.000)

Fonte: IBC - International Business Communications. (2001). Conferência - Operação do transporte hidroviário no Brasil. 


\section{Capítulo 4.}

\section{MÉTODOS DE PREYISÃO DE ANÁLISE DE DADOS}

\section{O RIO E O MOITARÁ}

\section{MOITARÁ}

Como o rio que vai

E quando volta traz sabedoria

Como o calor que vai

E quando volta fecunda terra

\section{MOITARÁ}

Canto, Magia, Encanto

Ritual de encontro

Encontro de magia

Magia de encanto

Que se eterniza na tradição

$\mathrm{Na}$ emoção

Na troca

No ritual

Na beleza do corpo

Enfeitado de urucum

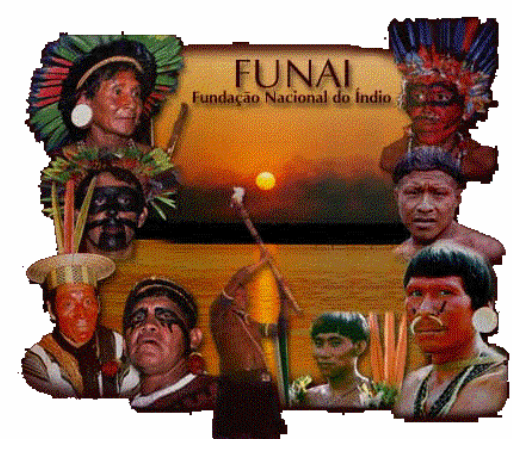

Como a semente lançada ao chão

Quando volta traz fartura

Como o encontro que se faz

Resultando a cultura

Encontro de gente mágica

Guardiães da sabedoria perene

Que se partilha no silêncio, no olhar

$\mathrm{Na}$ fumaça de um velho pataguá
Moitará

Uma troca de coisas

De sabedorias

De poesias

De rituais

De magias

De emoções

De cantigas

De sons

De tradições

De energias 


\section{4.}

\section{MÉTODOS DE PREVISÃO DE ANÁLISE DE DADOS}

\subsection{IDENTIFICAÇÃO DAS VARIÁVEIS}

Entenderemos nesta tese, os constructos ou propriedades que serão estudadas como variáveis. Empregaremos, portanto, o termo variável para nos referirmos aos fenômenos em estudo. Ao longo da pesquisa enfatizaremos três tipos de variáveis, a saber: variável independente, variável dependente e variável controlada (Oliveira, 1984).

\subsubsection{VARIÁVEL INDEPENDENTE}

O rio em estado natural, que antes permitia a navegação comercial, dentro de um determinado estágio de desenvolvimento do país, era capaz de promover a auto recuperação da porção bio-geo-física do meio ambiente que lhe era comum.

O desenvolvimento das cidades, trouxe não somente o aumento da utilização dos rios naturalmente navegáveis, mas também um grande número de alterações em algumas das partes da porção bio-geo-física do meio ambiente, onde o rio é parte componente.

A presença, agora, dos impactos ambientais, deve-se principalmente a inexistência de alguma interferência de engenharia, propiciando melhores condições à navegação comercial. Em algumas situações, já se faz necessário um grau maior de intervenção de engenharia, propiciando segurança a navegação diuturna a qualquer tempo para os veículos fluviais adequados aos padrões da via.

A utilização crescente do rio em estado natural para a navegação, exige proporcionalmente um grau maior de intervenção de engenharia, originando a hidrovia interior, identificada nesta tese como a causa do problema da pesquisa ou Variável Independente. 


\subsubsection{VARIÁVEL DEPENDENTE}

O estudo das alterações, que numa unidade inclui todos os organismos de uma determinada área, interagindo com o meio físico, de forma a originar um fluxo de matéria e energia, pode sofrer, principalmente por ação antrópica (nesta tese entenderemos a ação antrópica como sendo a hidrovia), é definida como impacto ambiental.

Os impactos ambientais, sobre: o meio físico, meio biológico, ecossistemas naturais, o meio sócio-econômico, constitui-se no efeito dentro do problema de pesquisa, identificado nesta tese como Variável Dependente.

\subsubsection{VARIÁVEIS CONTROLADAS}

Sabemos que em dado momento, um número fantasticamente grande de fatores podem estar determinando um fenômeno. Porém, em qualquer pesquisa torna-se necessário controlar todas as outras variáveis. Se isso fosse possível, poderíamos concluir que uma mudança na Variável Dependente - Impacto Ambiental, seria devido apenas a nossa Variável Independente - Hidrovia.

A minimização da interferência das variáveis estranhas, na pesquisa poderá ser obtida a partir da identificação de quais variáveis estranhas podem estar presentes na situação de pesquisa, isto é, quais variáveis deveriam ser controladas.

As variáveis estranhas que convergem simultaneamente para a Variável Independente e para a Variável Dependente, são identificadas nesta tese como Variável Controlada, sendo nesta tese as obras hidroviárias.

As obras hidroviárias, serão entendidas como sendo aquelas necessárias a implantação e operação de uma hidrovia, com intervenção direta ou indireta no rio navegável. Serão abordadas nesta pesquisas, as seguintes obras: gerais ou de normalização, desobstrução e limpeza, limitação dos leitos de inundação, fechamento de braços secundários, proteção das margens, retificação de meandros, dragagens e derrocamentos, regularização dos leitos, canalização dos cursos de água. 


\subsection{TIPO DE PESQUISA}

A presente tese, de um modo geral, concebe o produzir conhecimentos, no sentido de chegar a novas descobertas. Para tanto faz-se necessário: observar, realizar experiências, construir instrumentos, descobrir leis, estabelecer previsões, procurar explicações, elaborar teorias, conceitos, submeter hipóteses a testes, escrever e publicar resultados, tentar finalmente que a tecnologia aplique este estudo. A isto chama-se Ciência, que é um empreendimento humano complexo, como o que será visto nesta tese. Para muitos, Ciência e Pesquisa são vistos como atividades inseparáveis. Só se faz Ciência mediante a realização de um conjunto de investigações controladas, no qual se tem domínio ou acesso ao fenômeno que estamos estudando, isto é, só se faz Ciência quando se faz Pesquisa (Oliveira, 1984).

A pesquisa desenvolvida nesta tese, avançará além da descrição, investigará se existe algum tipo de relação entre os eventos estudados, isto é, se os eventos analisados variam simultaneamente, no tempo e espaço. O tipo de pesquisa a ser apresentada, é exemplo de pesquisa correlacional.

\subsection{PREVISÃO DE COLETA DE DADOS}

A coleta de dados será fundamentada na Fonte e no Sujeito. Entenderemos a Hidrovia como sendo a Fonte e os Profissionais vinculados ao tema desta tese, como o Sujeito.

\subsection{INSTRUMENTO DE COLETA DE DADOS}

Nesta pesquisa serão utilizados os seguintes instrumentos para a coleta de dados:

Devido a existência de dados registrados, clássicos e específicos, válidos e autênticos, tais como: livros; normas técnicas; leis; revistas técnicas; jornais, etc. , será realizada uma pesquisa em documentos. 
Devido ao fato de existirem pessoas que possuem informações e estando disponíveis, será possível coletar os dados pelo método de questionamento, onde serão utilizados: questionários, testes e escalas. A interação entre o sujeito e o pesquisador será impessoal, tendo em vista que as questões serão impressas e o sujeito as responderá por escrito.

- Havendo a possibilidade de se presenciar e registrar o evento, a observação, também será um método de coleta de dados, que dependendo da situação apresentada poderá ser utilizada. 


\section{Capítul0 5.}

\section{ESTUDO DAS VARIÁVEIS INTERRENIENTES}

\section{OS RIOS E SEUS SÍMBOLOS}

Nas medalhas, os Rios são colocados à direita ou à esquerda, conforme corram para o Oriente ou para o Ocidente. Às vezes, os rios de cursos sinuosos são representados sob a forma de serpentes. No caso dos rios que vão dar diretamente no mar, dá-se preferência à figura de uma mulher, de um rapaz imberbe, ou mesmo de uma criança. Cada rio tem seu atributo que o caracteriza, e que, em geral, é escolhido entre os animais que habitam a região que banha, entre as plantas que crescem às suas margens, ou entre os peixes que vivem em suas águas (Lexikon, 1978).

\section{O RIO DOS GREGOS E ROMANOS}

Em Função de sua importância para a fertilidade, o rio costumava ser venerado como divindade: por exemplo, os gregos e os romanos viam-no respectivamente como um deus masculino local. De maneira geral, ele está estreitamente ligado à água. A fluidez faz dele o símbolo do tempo e da transitoriedade, Mas também da constante renovação (Lexikon, 1978).

\section{O RIO NO BUDISMO E NO HINDUÍSMO}

A confluência de todos os rios para o mar simboliza a união da individualidade e do absoluto: por exemplo, no budismo e no hinduísmo, na qualidade de símbolo da inserção no nirvana (Lexikon, 1978).

\section{O RIO NO JUDAÍSMO}

No judaísmo, o rio que desce das montanhas foi interpretado como um símbolo da graça celeste. A concepção dos quatro rios do Paraíso é encontrada no judaísmo e no cristianismo, mas também na Índia; na iconografia cristã, eles nascem geralmente de uma colina sobre a qual se encontram Cristo ou o Cordeiro de Deus, simbolizando os quatro Evangelhos (Lexikon, 1978). 
5.

\section{ESTUDO DAS VARIÁVEIS INTERVENIENTES}

\subsection{VARIÁVEL INDEPENDENTE - HIDROVIAS INTERIORES}

Segundo a legislação brasileira, os rios e as demais porções d'água brasileiras são classificadas em quatro grupos, segundo seu uso: águas públicas ( uso comum e dominicais, ou seja, quando se situam em terras que se constituem patrimônio do poder público ); águas comuns ( pequenos cursos não navegáveis, em função do direito de todos suprirem as primeiras necessidades); águas particulares (nascentes e todas as águas situadas em terrenos particulares e não classificadas nos outros grupos de classes) e águas comuns de todos ( qualquer porção d'água quando seu uso é restrito às primeiras necessidades, ou seja, para beber, higiene, consumo doméstico e dessedentar animais ).

As hidrovias interiores, segundo a legislação brasileira, desenvolvem-se em águas classificadas, como águas públicas.

Estudar uma hidrovia interior, ao contrário do que se pensa, não consiste apenas em estudar o transporte em si, mas deve-se ir muito além, considerando em outros pontos, por exemplo: a bacia hidrográfica, o rio, as embarcações, os portos fluviais ( terminais hidroviários ) e não se deixando aqui de citar os impactos ambientais, etc.

Nos capítulos desta tese, identificados por variáveis, abordamos os diversos elementos que constituem uma hidrovia interior.

\subsubsection{TIPOS CLÁSSICOS DE EMBARCAÇÕES FLUVIAIS}

Embarcação, é o nome genérico dado a uma construção flutuante sobre a água que é utilizada para o transporte de carga, passageiros e tripulação. Há também as denominações: 
Vaso - do latim "Vascellum" - vaso pequeno ou urna, uma coisa que pode ser usada para conter e transportar substâncias.

$\mathrm{Nau}$ - do grego "Naos" - barco com capacidade de navegar.

Nave - do latim "Navis" - barco com capacidade de navegar.

Navio - denominação mais geral - do latim "navigium”, inicialmente significando grupo de barcos que navegavam juntos, a um destino determinado. Sua classificação pode ser bastante diversificada, tendo-se em conta o fim a que se destina.

As embarcações fluviais, possuem grande capacidade de carga útil. Suas dimensões, mais importantes são, Ver Figura 3:

$-\mathrm{L}=$ comprimento;

- B = boca ( largura );

c = calado ( na água );

$\sim \mathrm{p}=\operatorname{pontal}($ altura total $)$.

O transporte fluvial caracteriza-se por uma relativa movimentação lenta de mercadorias em grande quantidade e com baixo valor unitário, embora possam haver exceções, dependendo basicamente de incremento tecnológico. Cargas transportadas por hidrovias são classificadas da seguinte forma (Camargo Júnior, 2000):

- Granéis líqüidos - álcool, derivados de petróleo, melaço de cana-de-açúcar, etc.,

(Ver Figura 4);

- Granéis sólidos - areia, soja, calcário, milho, minérios, etc. (Ver Figuras 5 e 6):

- Cargas gerais - caixaria, paletizada, contentorizada, etc.;

- Carga Rodante - Roll on - roll off - carretas rodoviárias; composições ferroviárias, (Ver Figura 7).

Segundo Camargo Júnior (2000), o Instituto de Pesquisas Tecnológicas, em 1998, desenvolveu uma série de especificações para embarcações fluviais cuja conceituação pode ser aplicada na maioria das hidrovias brasileiras: 
Embarcações de turismo;

Automotores para transporte de carga geral;

Comboios de empurra - com os seguintes tipos de chata:

wex Chata graneleira;

- Chata para transporte de combustível com casco duplo;

呵Chata roll-on e roll-off para transporte de carretas;

(a) Chata para transporte de gado em pé

\section{Embarcação vazia}

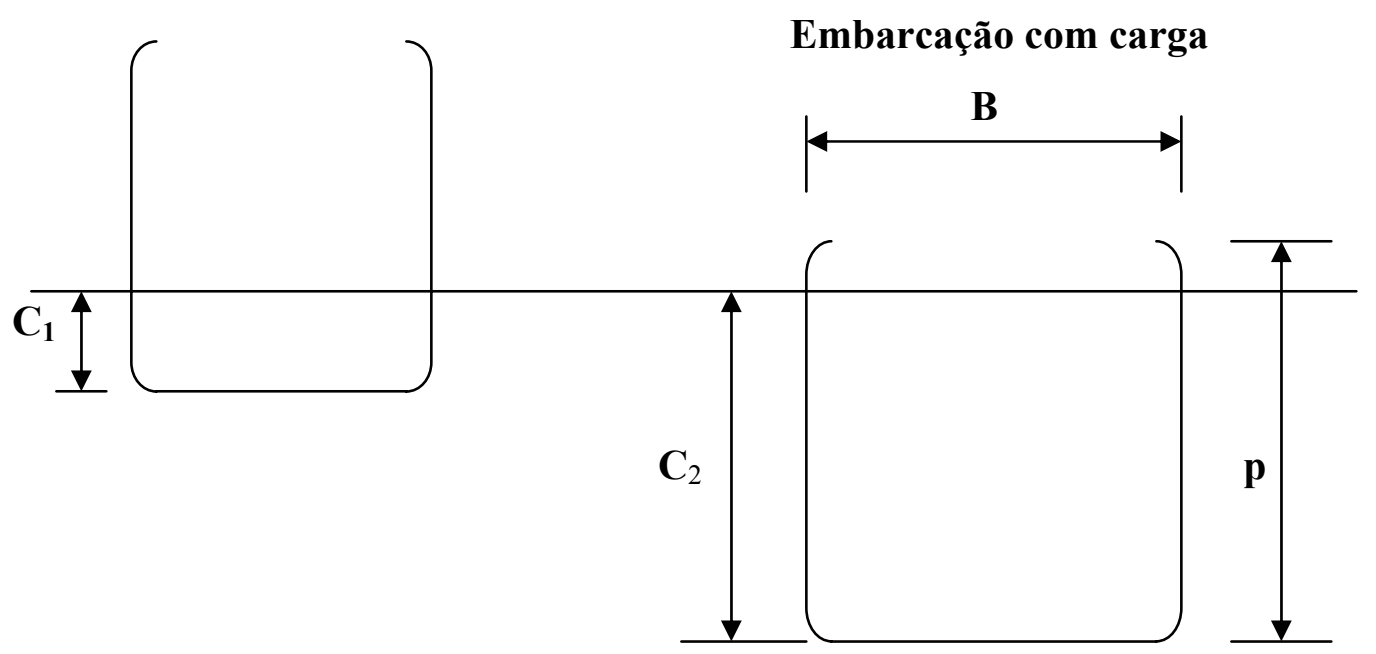

Dimensões da Embarcação

$\mathbf{L}=$ Comprimento

$\mathbf{B}=$ Boca ( largura )

$\mathbf{C}=$ Calado ( na água $)$

$\mathbf{P}=$ Pontal ( altura total )

Figura 3 - Embarcação fluvial e suas dimensões

Fonte: GRANDE, Dilvio Del. (1989). 
BARCACAS OIL / LIQQUIDOS

\begin{tabular}{c|l|l|l|l|l}
\hline \hline $\begin{array}{c}\text { Barcaças Tipo } \\
\mathrm{C}\end{array}$ & $\begin{array}{l}\text { Comprimento } \\
59.70 \mathrm{~m}\end{array}$ & $\begin{array}{l}\text { Boca } \\
11.30 \mathrm{~m}\end{array}$ & $\begin{array}{l}\text { Pontal } \\
3.00 \mathrm{~m}\end{array}$ & $\begin{array}{l}\text { Calado } \\
2.65 \mathrm{~m}\end{array}$ & $\begin{array}{l}\text { TDWCC } \\
1.400 \text { Ton. }\end{array}$ \\
\hline $\mathrm{N}$ & $30.00 \mathrm{~m}$ & $11.30 \mathrm{~m}$ & $3.00 \mathrm{~m}$ & $2.70 \mathrm{~m}$ & 720 Ton. \\
\hline \hline
\end{tabular}

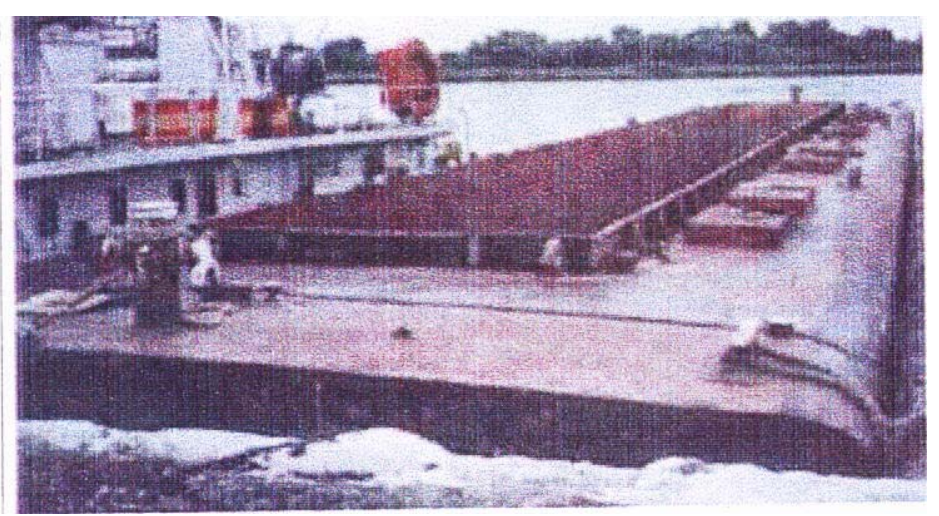

Barcaça Tipo C

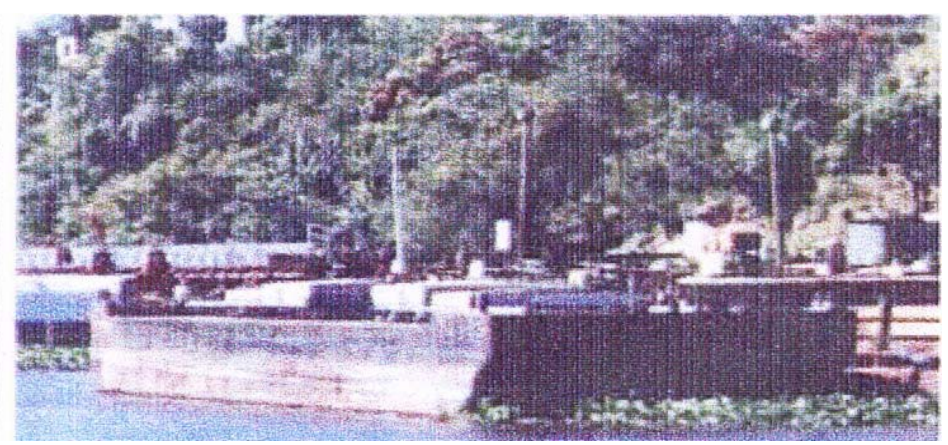

Barcaça Tipo N

Figura 4 - Transporte fluvial - Granéis Líquidos

Fonte: Home Page. http://www.cinconav.com.br 


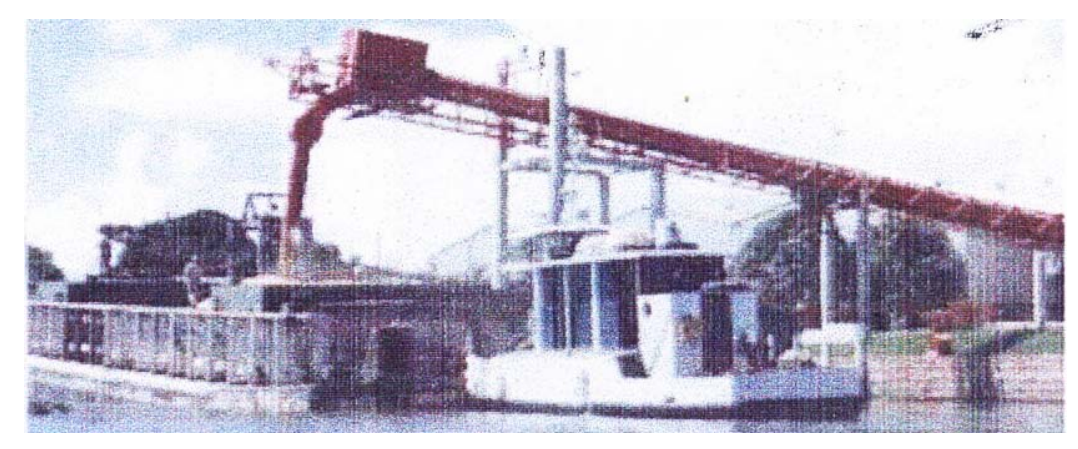

CARREGAMENTO DE EMBARCAÇÃO COM GRANÉIS SÓLIDOS

\begin{tabular}{l|c}
\hline \hline \multicolumn{2}{|c}{ Principais Características } \\
\hline \hline Comprimento & $14.16 \mathrm{~m}$ \\
Boca & $3.75 \mathrm{~m}$ \\
Pontal & $1.27 \mathrm{~m}$ \\
Potência & $316 \mathrm{HP}$ \\
Motores & Scania \\
Cap. Comboio & 1 Barcaça \\
\hline \hline
\end{tabular}

Figura 5 - Transporte fluvial - Granéis Sólidos Fonte: Home Page. http://www.cinconav.com.br 
BARCACAS BULK / GRÃOS

\begin{tabular}{c|l|l|l|l|l}
\hline \hline $\begin{array}{c}\text { Barcaças Tipo } \\
\mathrm{T}\end{array}$ & $\begin{array}{l}\text { Comprimento } \\
55.90 \mathrm{~m}\end{array}$ & $\begin{array}{l}\text { Boca } \\
11.00 \mathrm{~m}\end{array}$ & $\begin{array}{l}\text { Pontal } \\
3.60 \mathrm{~m}\end{array}$ & $\begin{array}{l}\text { Calado } \\
3.96 \mathrm{~m}\end{array}$ & $\begin{array}{l}\text { TDWCC } \\
1.500 \text { Ton. }\end{array}$ \\
\hline $\mathrm{V}$ & $50.50 \mathrm{~m}$ & $10.00 \mathrm{~m}$ & $3.60 \mathrm{~m}$ & $3.55 \mathrm{~m}$ & 1.400 Ton. \\
\hline \hline
\end{tabular}
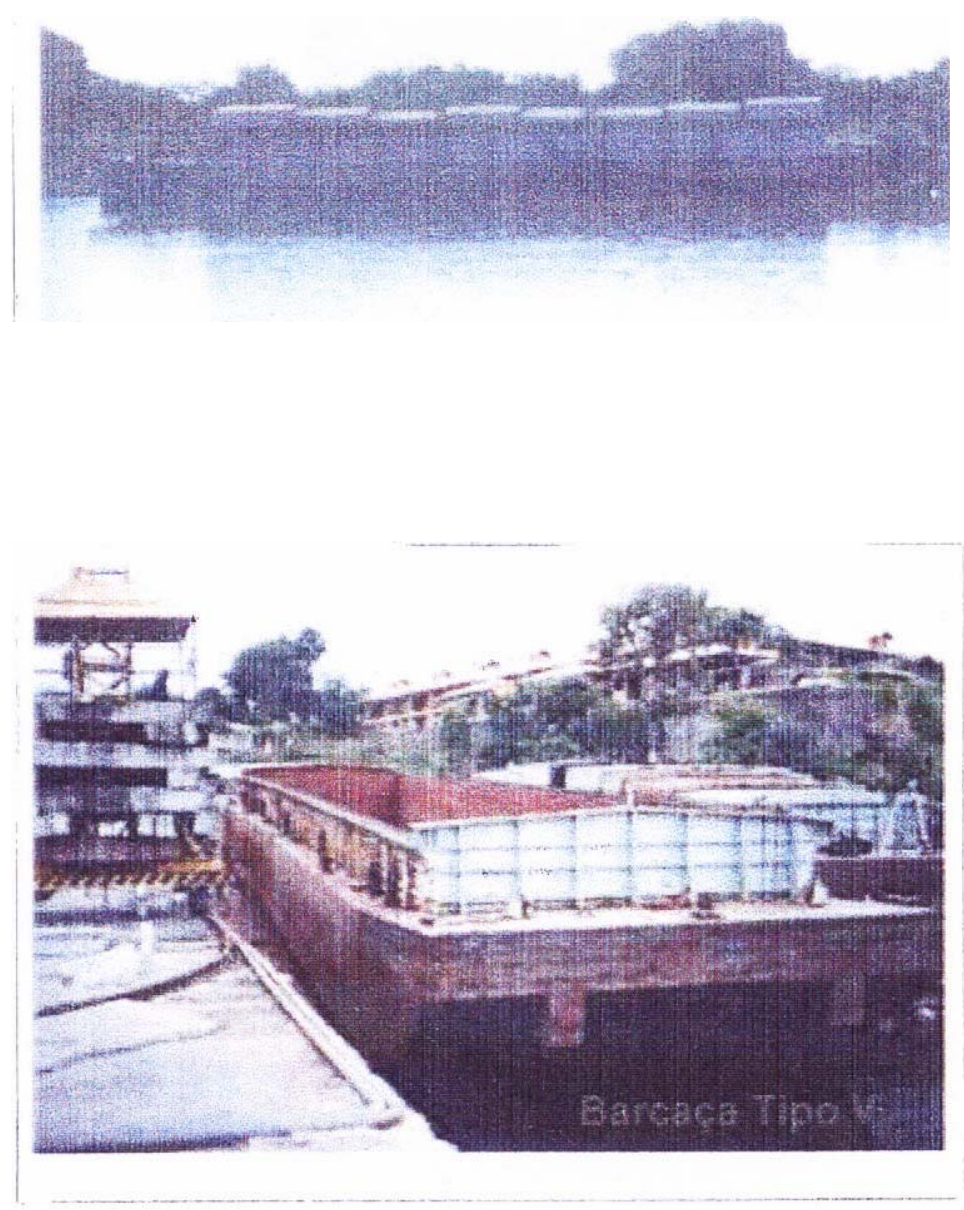

Figura 6 - Transporte fluvial - Granéis Sólidos

Fonte: Home Page. http://www.cinconav.com.br 

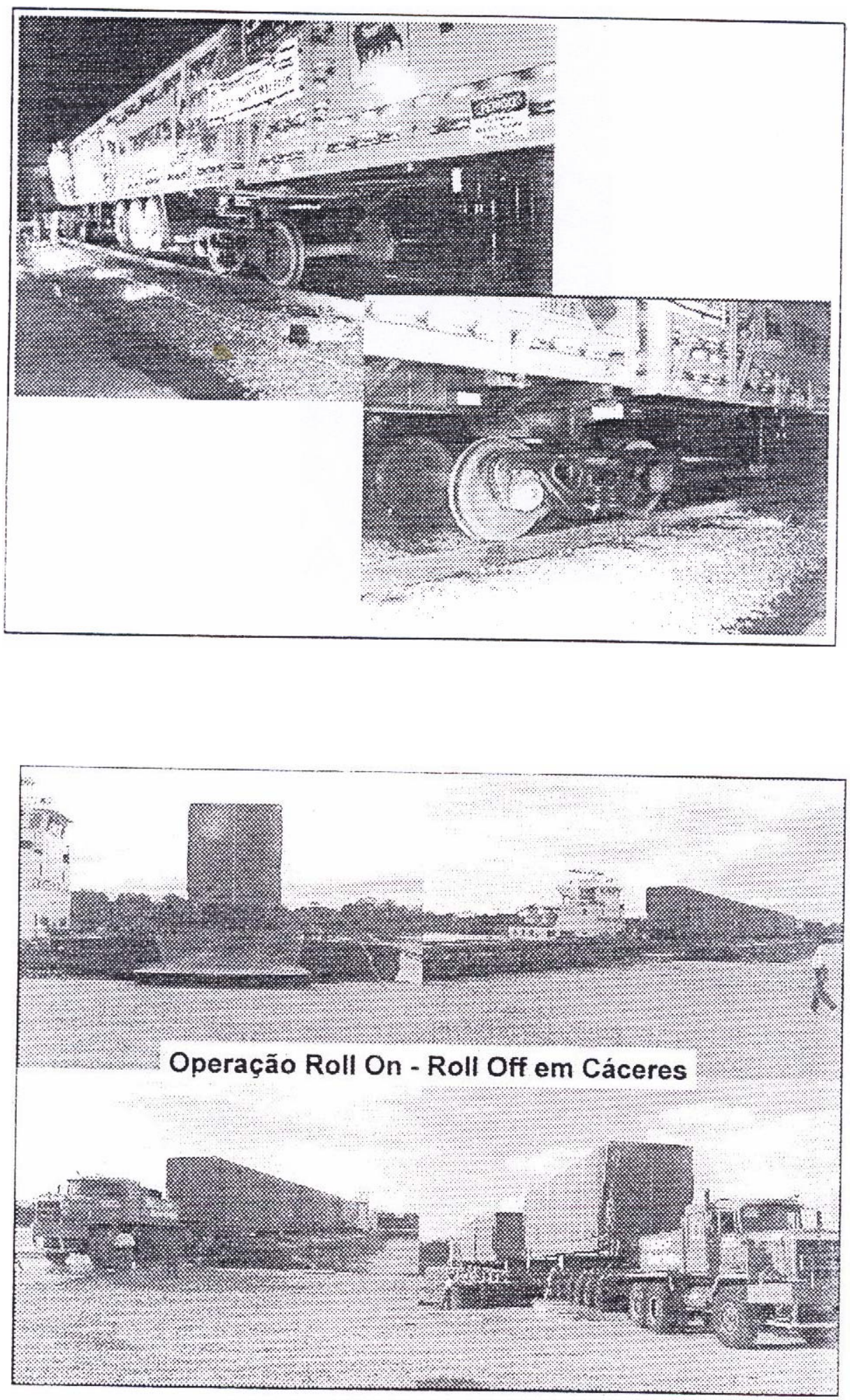

Figura 7 - Transporte fluvial - Carga rodante

Fonte: IBC - International Business Communications. (2001).

Conferência : Operação do transporte hidroviário no Brasil. 
O volume de uma embarcação fluvial, assemelha-se ao volume de um paralelepípedo, onde: $\mathrm{V}=\mathrm{L} \times \mathrm{B} \times \mathrm{p}$. A carga ocupa $0,8 / 0,9$ do volume total.

A padronização do tipo de embarcação barateia o custo do transporte. Assim, há:

1. Padrão Europeu (automotor):

1.1. Peniche ( Francês - antigo ) - 38,5 x 5,00 x 1,80 m, com calado de 1,5 m, cuja capacidade de carga é para $280 \mathrm{tf}$ ( coef. $=0,80$ ).

1.2. Chaland ( moderno ) - com $82,0 \times 8,35 \times 3,0 \mathrm{~m}$, com calado de 2,5 m, cuja capacidade de carga é para $1.500 \mathrm{tf}$ ( coef. $=0,75)$.

2. Padrão Americano - consiste num comboio de chatas ( elementos inertes ), constituindo um conjunto sólido, com um empurrador único, centralizando o comando e o direcionamento.

O tipo CENAT/CESP, em nossos dias não mais utilizados, provinha do modelo americano, constando de chatas (duas a duas ) de 5,5 m de largura, com um empurrador de $200 \mathrm{HP}$, comboio limitado pelo gabarito das eclusas.

\subsubsection{Cronologia dos Tipos de Embarcações}

Nos primórdios os barcos eram de madeira, a remo ou a vela; a invenção da máquina a vapor em $\pm 1800 \mathrm{e}$, do motor diesel em \pm 1900 , trouxeram novos conceitos na construção e na navegação; neste século em \pm 1920 , desenvolveu-se a construção de embarcações metálicas; o barco automotor padronizado, surge em 1940; em 1955, começam os "push-boats", comboios de empurra, impelidos pela traseira, com a concentração da propulsão, do comando e do governo, num único elemento que poderia ser isolado (o empurrador), sendo as chatas um bloco compacto e inerte, sem tripulação (Del Grande, 1989).

A embarcação identificada por comboio de empurra, apresenta uma redução do atrito entre a água e a nave. Para se movimentar a mesma carga o comboio de puxa, 
necessita duas vezes mais potência (HP), que o comboio de empurra. Ver Figuras 8, 9 e 10. No comboio de puxa, há uma quantidade maior de atrito.

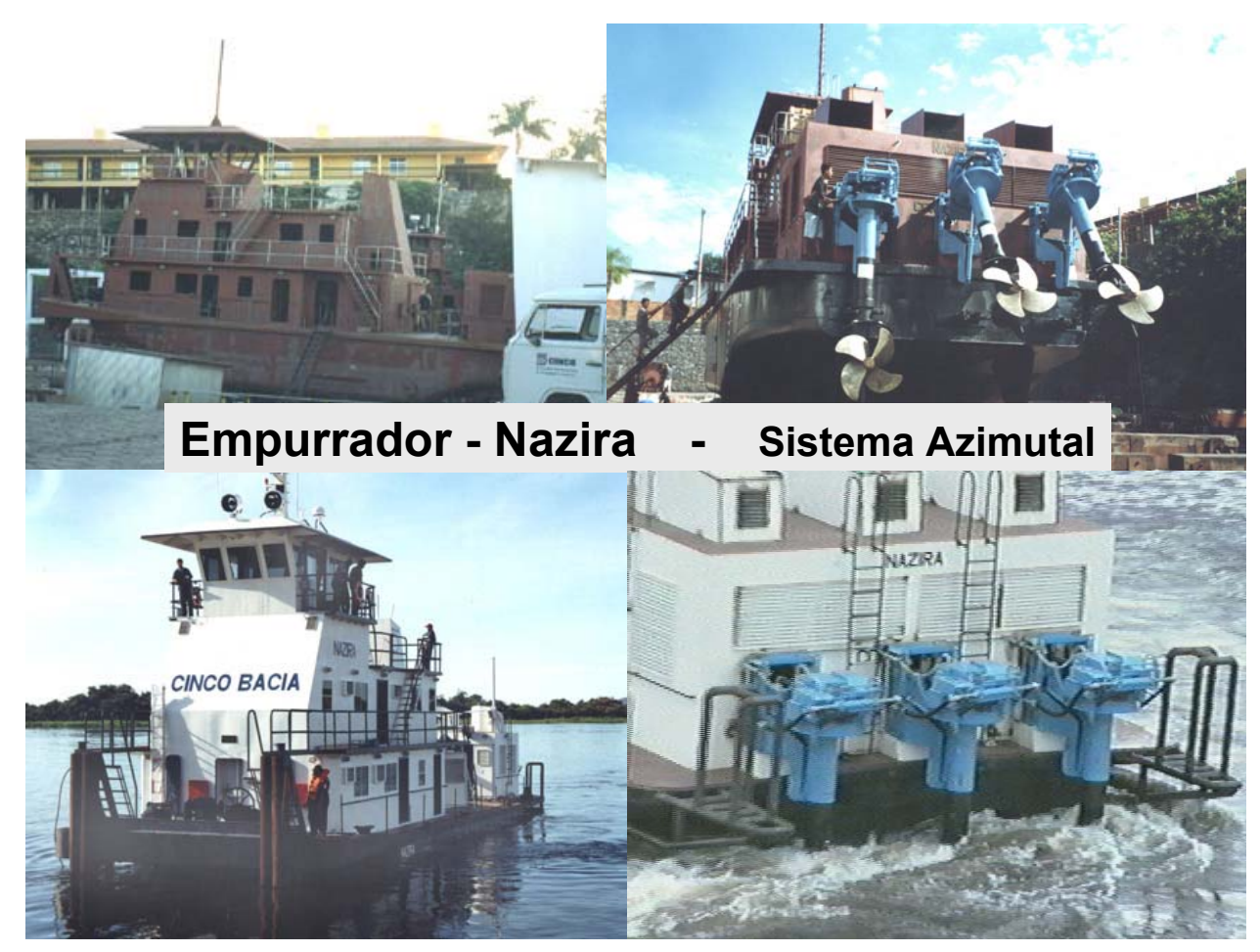

Figura 8 - Embarcação fluvial - Empurrador

Fonte: Home Page. http://www.cinconav.com.br 


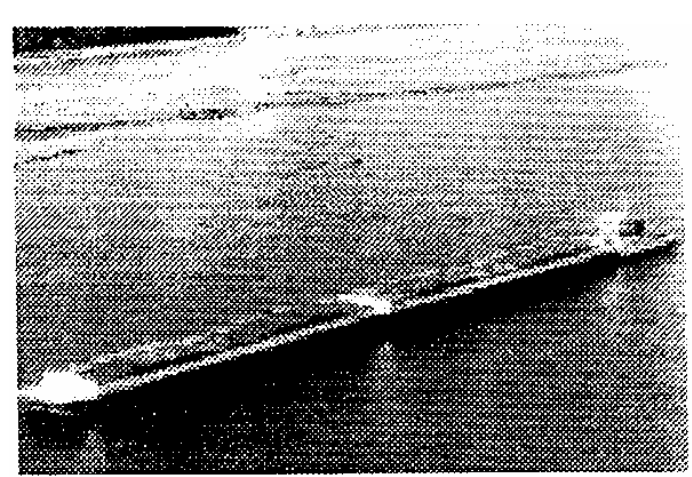

QUINTELLA

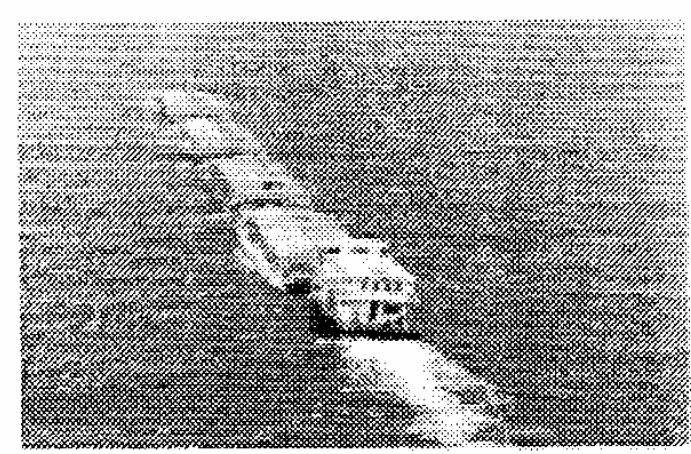

SARTCO-ADH

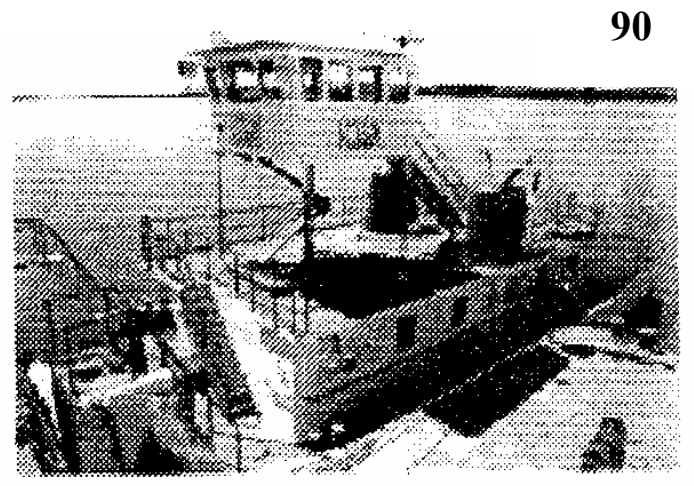

QUINTELLA

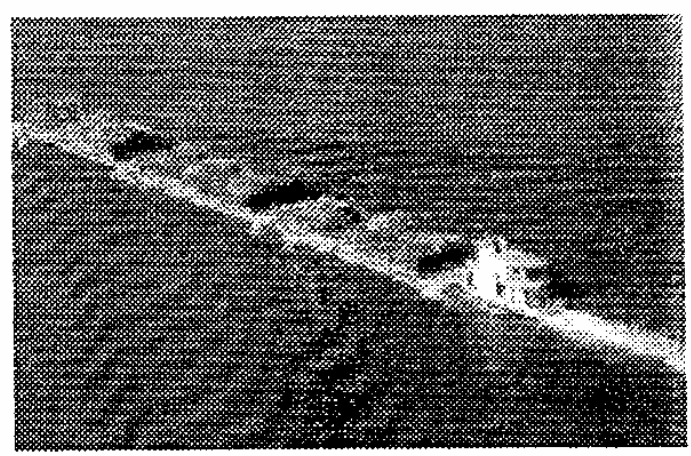

DIAMANTE-COSAN

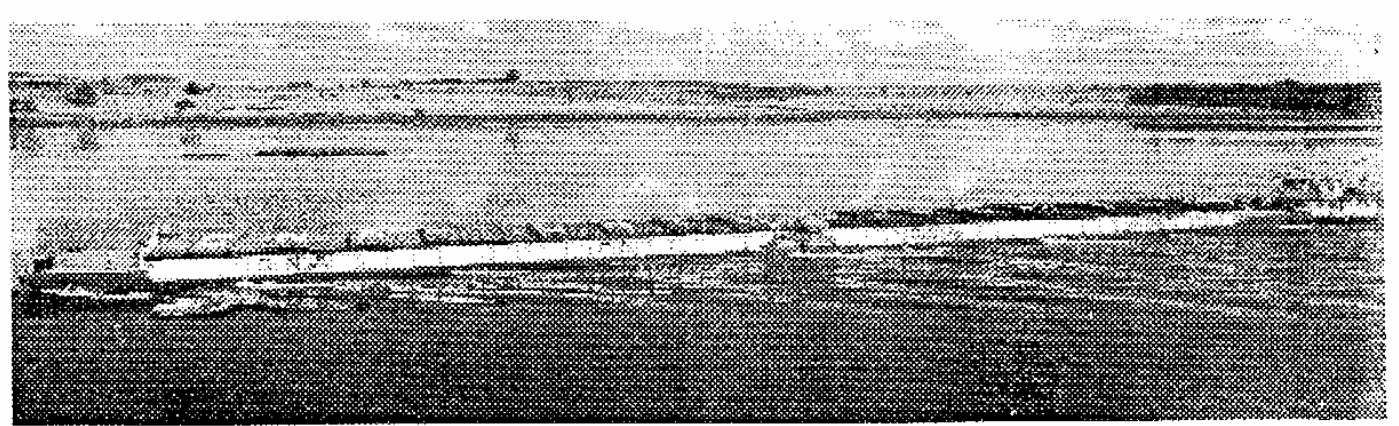

\section{CNA.LIBRA}

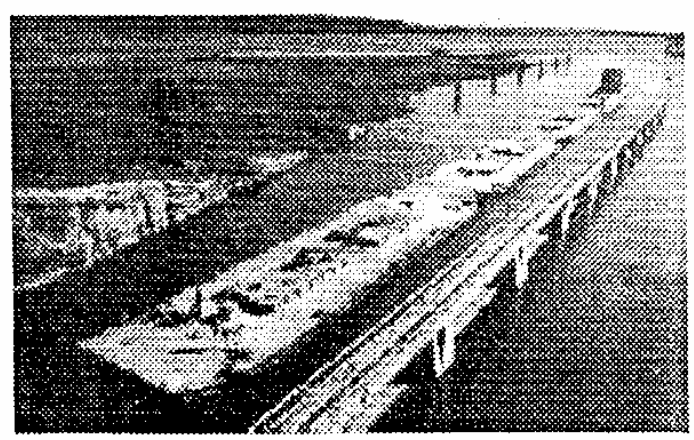

SARTCO-ADM

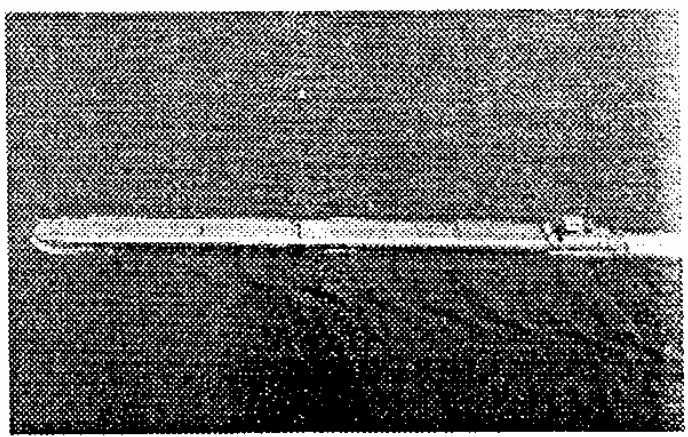

EPN-TORQUE

Figura 9 - Embarcações fluviais - Comboios de Empurra

Fonte: IBC - International Business Communications. (2001).

Conferência: Operação do transporte hidroviário no Brasil. 
A

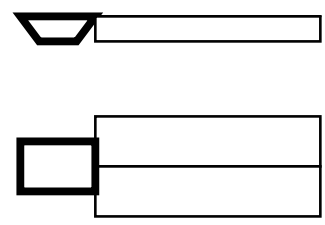

B

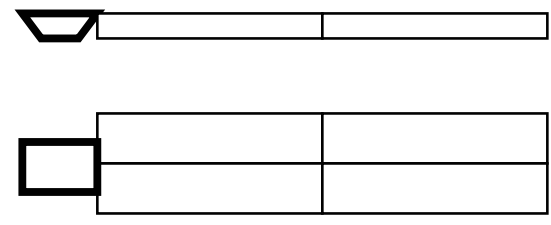

C

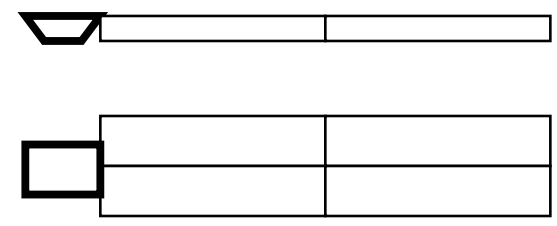

F

$\square$ L

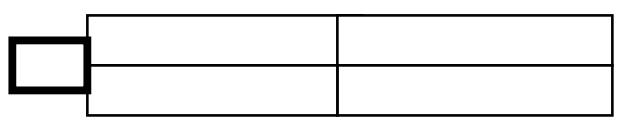

G

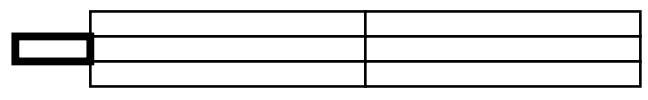

CONFIGURAÇÕES DE COMBOIOS FLUVIAIS TESTADOS EM LABORATÓRIOS DE HIDRODINAMMICA NAVAL COM AS RESPECTIVAS CURVAS DE RESISTÊNCIA PE (KW) $X$ VELOCIDADES (NÓS)

D
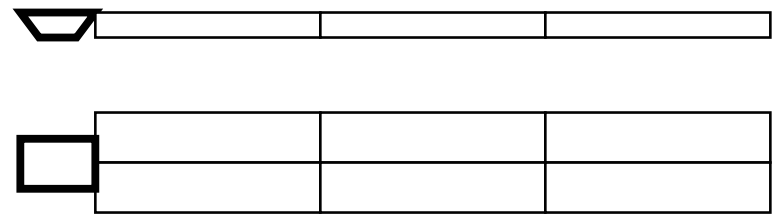

$\mathbf{E}$
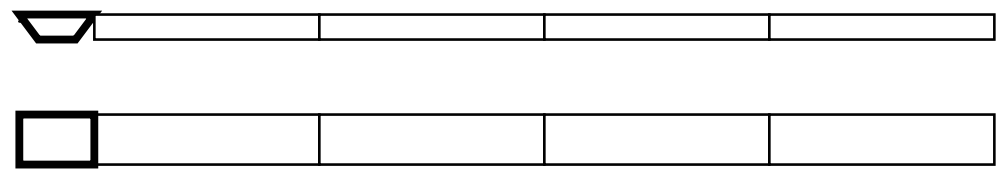

POTÊNCIA EFETIVA DE ACÔRDO COM OS TESTES DE RESISTÊNCIA PARA DIFERENTES CONFIGURAÇÕES DE COMBOIOS FLUVIAIS

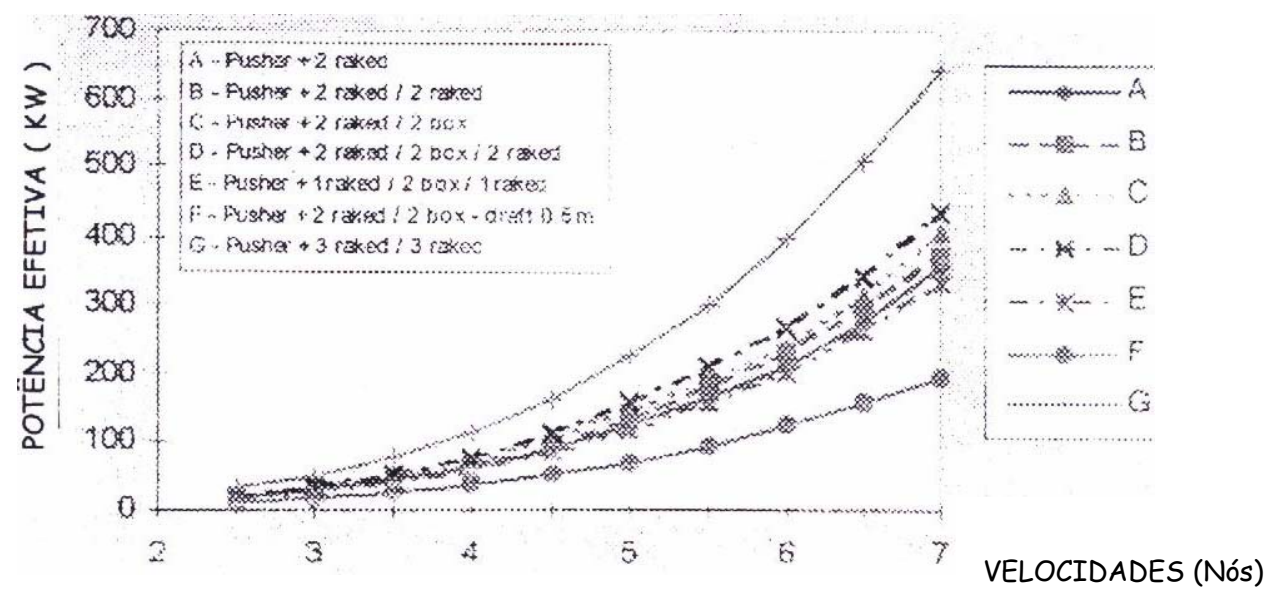

Figura 10 - Configurações dos comboios e sua eficiência.

Fonte: IBC - International Business Communications. (2001).

Workshop: Modelos estrangeiros de nacionais de operação de hidrovias. 
Quanto a vida útil de uma embarcação, que é aproximadamente 50 anos, seria interessante destacar que $60 \%$ da vida útil, isto é, 30 anos a embarcação permanece esperando em portos (terminais) para carga e descarga e 40\% da vida útil, isto é, 20 anos o navio cumpre sua finalidade, que é o transporte.

\subsubsection{CANAL NAVEGÁVEL X HIDROVIA}

O conceito de rio navegável só tem sentido quando definido o tipo e as dimensões da embarcação que deve trafegar em ritmo contínuo e seguro, transportando cargas e/ou passageiros em caráter comercial. Complementarmente há obras de sinalização para os limites laterais do canal e o direcionamento (diurno e noturno). Uma hidrovia pode ser implantada em rios navegáveis de fluxo livre ou confinado.

Rios de fluxo livre, são aqueles cujo regime fluvial não foi alterado pelo homem e seus métodos construtivos, tais como o Rio Amazonas ou o Rio Araguaia, ambos com padrão anastomosado. Por outro lado, do ponto de vista da navegação, a declividade do relevo, exige às vezes que em alguns trechos do rio sejam construídas barragens munidas de eclusas para regularizar o fluxo natural das águas, reduzindo a velocidade da corrente e aumentando a profundidade média da calha de forma a torná-los plenamente navegáveis. Em conseqüência, criam-se desníveis com águas acumuladas a montante do barramento no que se convencionou definir como reservatório e que só podem ser transpostos através de processos de eclusagem (Oliveira \& Brito, 1998).

Os rios que dispõem de reservatórios passam a classificados como rios de fluxo confinado, como no caso do Rio Tietê e Rio Paraná.

\subsubsection{Largura mínima do canal}

No Brasil, segundo a moderna técnica de navegação, por empurra, a largura mínima normal deverá ser: 
Para tráfego em um sentido (proibido os cruzamentos e ultrapassagens) - 2,2 vezes a boca da embarcação (largura total do comboio);

Para tráfego em dois sentidos - 4,4 vezes a boca da embarcação (largura total do comboio);

Casos excepcionais - quando o balizamento for bastante denso em trechos retos, de pequena extensão, como passagem de baixios, entrada de portos etc., e onde obrigatoriamente a velocidade de navegação seja reduzida, as larguras mínimas para o canal, podem ser reduzidas até 1,5 a largura do comboio.

- Em pontes novas - o vão livre recomendado depende de estudos específicos, por exemplo: em reservatórios da CESP - Cia Energética do Estado de São Paulo - temse chegado à conclusão de que os vãos livres devem ser maiores que os usuais, sem cruzamentos, talvez 3 vezes a largura do comboio-tipo. É usual, também em estruturas preexistentes, como antigas pontes a execução de estruturas-guia auxiliares que permitem o apoio da embarcação na passagem, possibilitando aceitar-se valores do vão livre, próximos da largura do comboio.

O US Army Corps of Engineers recomenda uma folga mínima de 40 pés $(12,19 \mathrm{~m})$ entre o limite da via e o comboio, se não houver cruzamento, e se houver, essa folga passa a ser de 20 pés $(6.10 \mathrm{~m})$, mais uma folga mínima entre os comboios em cruzamento de 50 pés $(15,24 \mathrm{~m})$.

Para trechos retos, segundo Rebouças et al. (1999), o US Army Corps of Engineers, sugeriu como larguras mínimas:

Tabela XIII - Larguras - U.S. Army C.E.

\begin{tabular}{|c|c|c|}
\hline \multirow[t]{2}{*}{ Largura da boca } & \multicolumn{2}{|c|}{ Largura do Canal (pés/metros) } \\
\hline & com cruzamento & sem cruzamento \\
\hline $105 / 32$ & $300 / 91.4$ & $185 / 56.4$ \\
\hline $70 / 21.3$ & $230 / 70$ & $150 / 45.7$ \\
\hline $50 / 15.3$ & $190 / 58$ & $130 / 39.6$ \\
\hline
\end{tabular}

Fonte: Rebouças et al. (1999) 


\subsubsection{Profundidade Mínima do Canal}

$\mathrm{Na}$ via canalizada, por barragens, as restrições de profundidade ocorrem principalmente nas proximidades a jusante das obras e nos acessos aos portos locais de transbordo. Estando o fundo em seu estado natural, com irregularidades normais, pode-se admitir uma folga de 0,30 m no fundo (pé do piloto), isto é, calado máximo acrescido de 0,30 m. Em canais artificiais, em locais onde haja grande probabilidade de assoreamento e em seções muito restritas e fundo rochoso é recomendável adotar uma folga mínima de $0,50 \mathrm{~m}$, isto é, calado máximo acrescido de $0.50 \mathrm{~m}$, por motivos de segurança. Esta condição mínima é para poucos pontos (isolados), pois há uma redução de rendimento propulsório (velocidade menor) e aumento do consumo de combustível.

Em trechos longos, para evitar perda muito grande de tempo, conseqüente do percurso em longa extensão, com velocidade reduzida devido ao efeito de aumento de resistência em águas rasas, as folgas nas profundidades, devem se maiores; $1 \mathrm{~m}$ ou mais (Brighetti, 2000).

\subsubsection{3. Área Mínima da Seção Transversal}

A área da seção transversal, não deverá influir na propulsão. Segundo experiência européia, a área molhada da seção transversal da via fluvial deve ultrapassar 6 vezes a área da seção mestra molhada da embarcação ou do comboio em trânsito. No caso de cruzamentos ou ultrapassagens muito freqüentes, o ideal seria que a área molhada fosse 10 vezes superior à área de cada embarcação ou comboio (Del Grande, 1989).

\subsubsection{Raios Mínimos de Curvatura e Sobrelargura}

Sobrelargura é o aumento necessário da via para que a embarcação efetue o seu posicionamento oblíquo em relação à rota para poder descrever a curva. 
Considerando-se comboios com sistemas normais de lemes e possibilidades de manobras com auxílio de propulsores, os raios de curvatura não deverão ser inferiores a 10 vezes o comprimento do comboio. Em canais artificiais e, de um modo em geral, em águas restritas lateralmente e locais de tráfego com velocidades reduzidas, os raios de curvatura poderão ser inferiores aquele valor, desde que seja conservada em toda a curva uma sobrelargura mínima igual ao quadrado do comprimento do comboio (L), dividido pelo dobro do raio de curvatura (R), portanto, teremos: $\mathrm{S}=\mathrm{L}^{2} / 2 \mathrm{R}$.

A redução do raio de curvatura abaixo do valor mínimo indicado corresponderá a uma redução de velocidade (Del Grande, 1989).

Reduções de Velocidades: $\quad \mathrm{R}=8 \mathrm{~L} \Rightarrow \mathrm{V}=0,875 \mathrm{~V}$;

$$
\begin{aligned}
& \mathrm{R}=7 \mathrm{~L} \Rightarrow \mathrm{V}=0,750 \mathrm{~V} \\
& \mathrm{R}=6 \mathrm{~L} \Rightarrow \mathrm{V}=0,626 \mathrm{~V} ; \\
& \mathrm{R}=5 \mathrm{~L} \Rightarrow \mathrm{V}=0,500 \mathrm{~V} .
\end{aligned}
$$

No que se refere a aspectos dinâmicos e obras existentes na hidrovia, destacam-se:

\subsubsection{Velocidade Máxima da Água}

Partindo-se de uma velocidade cruzeiro da ordem de 12 a $14 \mathrm{~km} / \mathrm{h}$ para as embarcações em água parada, conclui-se que a velocidade máxima das águas que as embarcações podem vencer na subida, em um trecho restrito, com regime de potência máxima das máquinas, é da ordem de $4 \mathrm{~m} / \mathrm{s}$, excepcionalmente poderão ser vencidas velocidades da ordem de $5 \mathrm{~m} / \mathrm{s}$, sem auxílio externo, em um período curto de tempo, o que se traduz em consumo máximo, na contra corrente . Para a descida (a favor da corrente), a restrição de velocidade prende-se aos problemas de dirigibilidade (controle da direção), sendo em geral aceitas velocidades de fluxo da ordem de metade das velocidades acima.

Ter-se-á ainda que considerar de forma especial a velocidade do líquido em canais de águas restritas, uma vez que em seções restritas as velocidades de fluxo 
bloqueiam o movimento da embarcação, prejudicando o rendimento propulsivo e, desta forma, aumento o custo do transporte. Considerando-se condições ideais de rendimento e gasto de combustível minimizado, a velocidade máxima das águas, em longos trechos hidroviários deve limitar-se a $2 \mathrm{~m} / \mathrm{s}$ (Brighetti, 2000).

\subsubsection{Altura Livre sob Pontes e sob Interferências}

A navegação por empurra obriga a cabine de comando empurrador a alcançar alturas consideráveis para conseguir a visibilidade necessária. O uso sistemático de radar contribui para que haja exigência de maior altura livre. Nos Estados Unidos, adota-se como altura livre (luz) das pontes sobre o nível máximo navegável o valor de $15 \mathrm{~m}$. No Tietê, adotou-se a altura livre mínima igual a $7 \mathrm{~m}$, altura livre que tem sido adotada em outros rios do Brasil, sendo considerado, hoje, um valor antigo, pois, parece insuficiente, sendo preferível adotar um valor em torno de 9 a $10 \mathrm{~m}$, se não for possível atingir os $15 \mathrm{~m}$, já preconizados para os grandes rios nacionais.

Nestes casos, pode-se prever pontes móveis. Hoje em dia tem-se disseminado a solução da cabine retrátil (rebaixável) ou rebatida dos empurradores, passando a ser limitação a carga sob o convés. Ver Figura 11.

\subsubsection{Largura de Vãos de Pontes}

No que diz respeito à largura dos vãos de pontes, determina-se que o vão livre em pontes, nos trechos retos, seja igual a largura mínima do canal, acrescida de $5 \mathrm{~m}$; não havendo cruzamento sob o vão a largura mínima poderá ser de 2 vezes a boca da embarcação acrescida de $5 \mathrm{~m}$; nos trechos em curva deve ser feito um estudo especial. A cultura nacional, pouco experiente na matéria e o nível pouco desenvolvido da mão-de-obra em atividades de suporte à navegação, leva a recomendação de sempre se prever a proteção de pilares ou, no mínimo, a sinalização de segurança superdimensionada. Ver Figura 11 (Rebouças et al., 1999). 

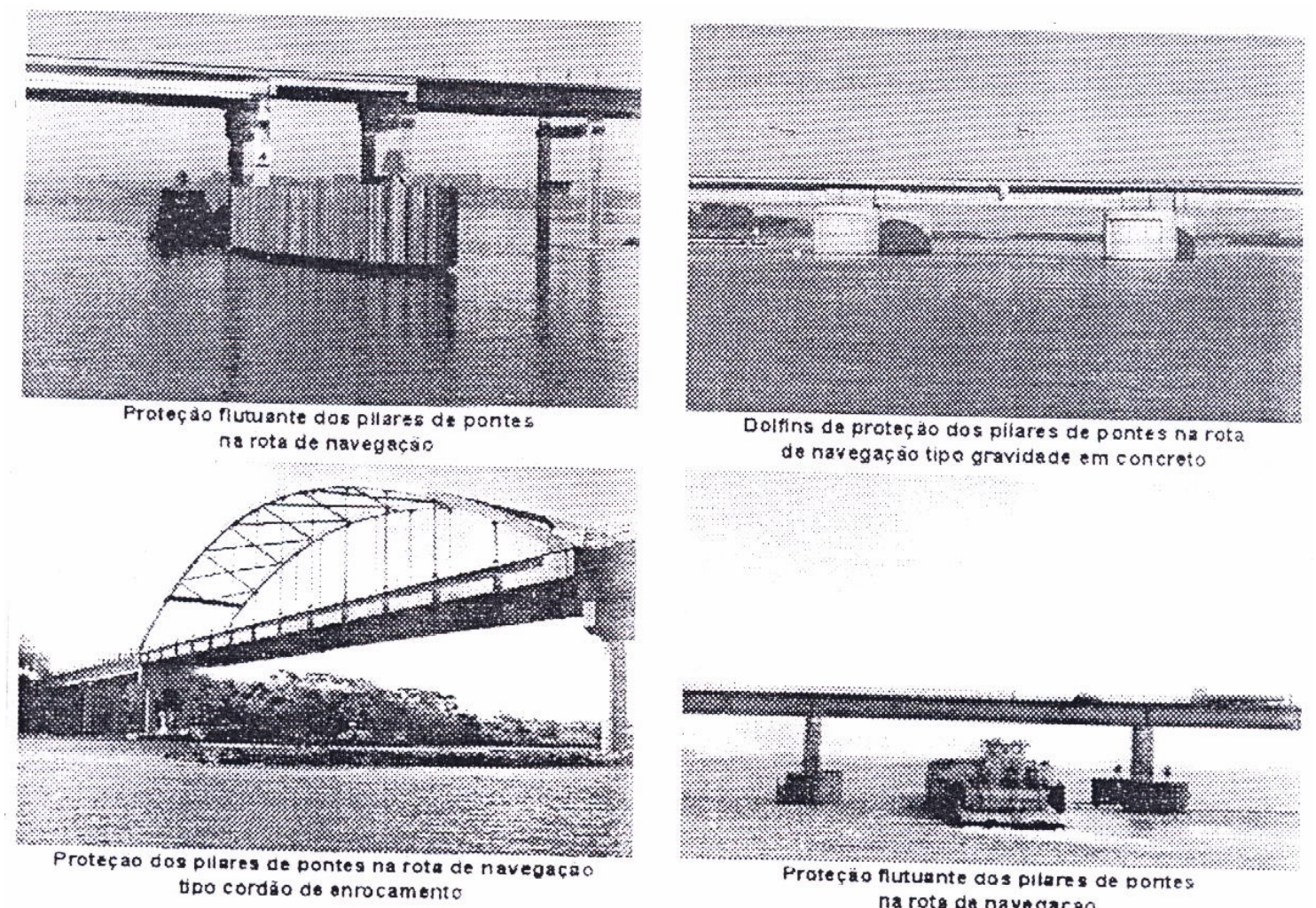

Dolitins da proteç zo dos pilares de pontes na rota do nazegaça tipo gravidade em concreto

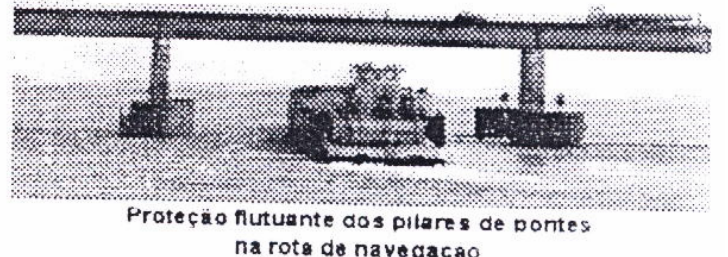

na rota de navecacao

Figura 11 - Dispositivos de sinalização e segurança.

Fonte: IBC - International Business Communications. (2001).

Conferência: Operação do transporte hidroviário no Brasil.

\subsubsection{Sinalização para os Limites Laterais do Canal e o Direcionamento (diurno e noturno)}

Entrementes, à falta de expressões como hidrovias interiores artificiais, para denominar aquelas que não eram navegáveis e que adquiriram essa condição em função de obras de engenharia, e hidrovias interiores melhoradas, para caracterizar as que tiveram suas condições de navegação ampliadas, usa- se genericamente a expressão hidrovias interiores para designar as vias navegáveis interiores que foram balizadas e sinalizadas para uma determinada embarcação tipo. Isto é, àquelas que oferecem boas condições de segurança às embarcações, suas cargas e passageiros ou tripulantes e que dispõem de cartas de navegação. 
Deve-se observar que balizamento de uma via aquática é entendido como sendo basicamente as bóias de auxílio à navegação, que demarcam o canal de navegação, e como sinalização, as placas colocadas nas margens dos rios para orientação dos navegantes. As cartas de navegação, são mapas delimitadores das rotas de navegação. Ver Figuras 12, 13 e 14.

O conhecimento das reais características de um rio, dá-se por etapas. Como primeiro etapa, é imprescindível um preciso levantamento hidrológico e batimétrico do rio, pois as informações normalmente são insuficientes e reduzem as margens para uma navegação otimizada. São pesquisas de alto custo inicial, porém inexpressivas frente aos benefícios resultantes. Como exemplo destas pesquisas, podemos citar o Rio Madeira, onde os levantamentos são realizados "particularmente" há oito anos e, são uma das bases do sucesso da eficiente navegação da Hermasa (IBC, Conferência, 2001).

Tecnologia de ponta, como Ecossondas Bidirecionais dotadas de feixes de até $120^{\circ}$, permitem que faixas com larguras de 80 a $200 \mathrm{~m}$, de fundo de rio, sejam levantadas com velocidade de até 12 nós. Todo o processamento, a partir da batimetria fluvial com utilização do GPS, é realizado a bordo da embarcação, que possui uma central de processamento de dados, com imediata disponibilização das correções de curso da "hidrovia" por meio informatizado, com rota corrigida gravada em Cd-Rom. Exemplos destas embarcações são: a lancha "Parecis" e, as embarcações da Cinco Bacia. Ver Figura 15.

\subsubsection{PORTOS E CONSTRUÇÕES PORTUÁRIAS - INFRA-ESTRUTURA HIDROVIÁRIA}

Porto, lugar tranqüilo e de águas calmas onde os navios podem promover as atividades de carga e descarga de mercadorias e passageiros.

Um porto serve de interligação entre os transportes terrestres e aquaviários pelo uso adequado de suas instalações, tais como: canal de acesso; cais; armazéns e equipamentos. Ver Figuras 16 e 17. 

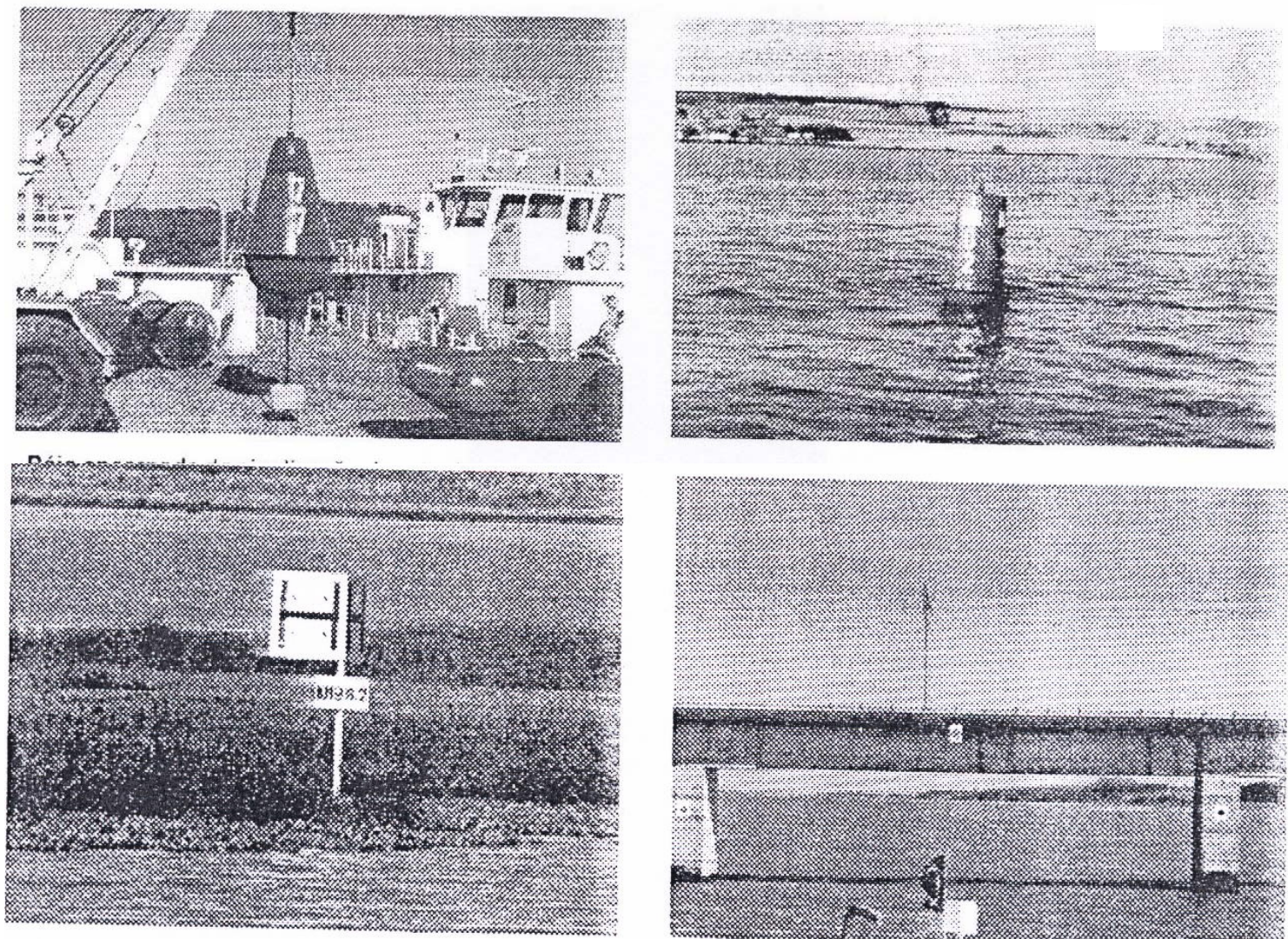

Baliza de Sinalizaçăo de Margẹm

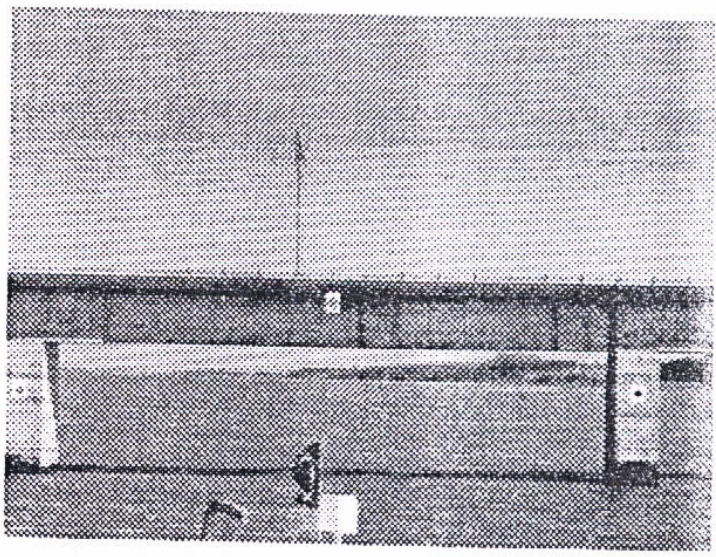

Placas de Sinalizacào de Pontes

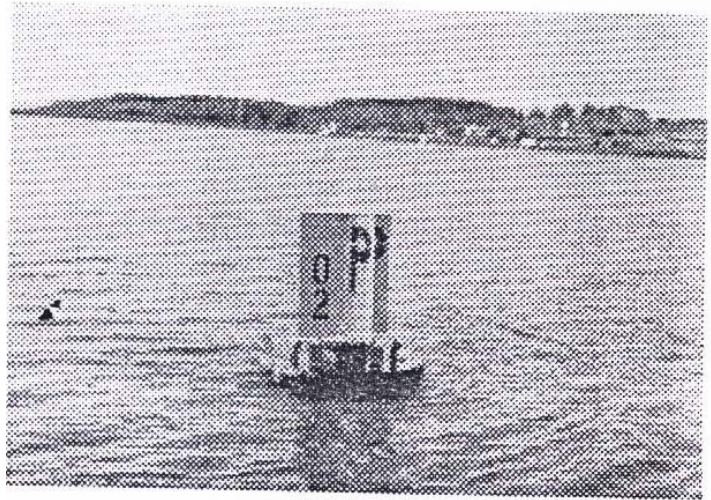

Bóia de sinatizsçao do Ponto de Psrzda Oobrigstóris - PPO

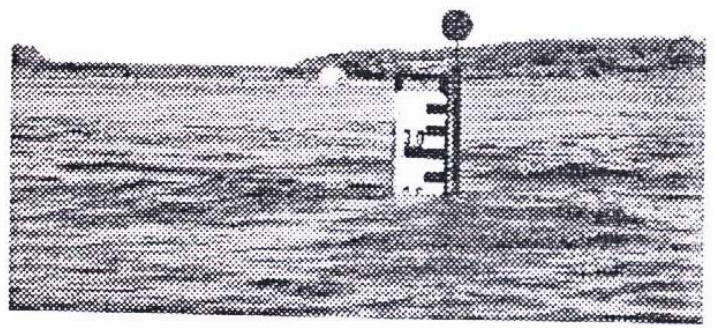

Regua de medição do nivel de navegação

Figura 12 - Dispositivos de sinalização e segurança.

Fonte: IBC - International Business Communications. (2001).

Conferência: Operação do transporte hidroviário no Brasil. 

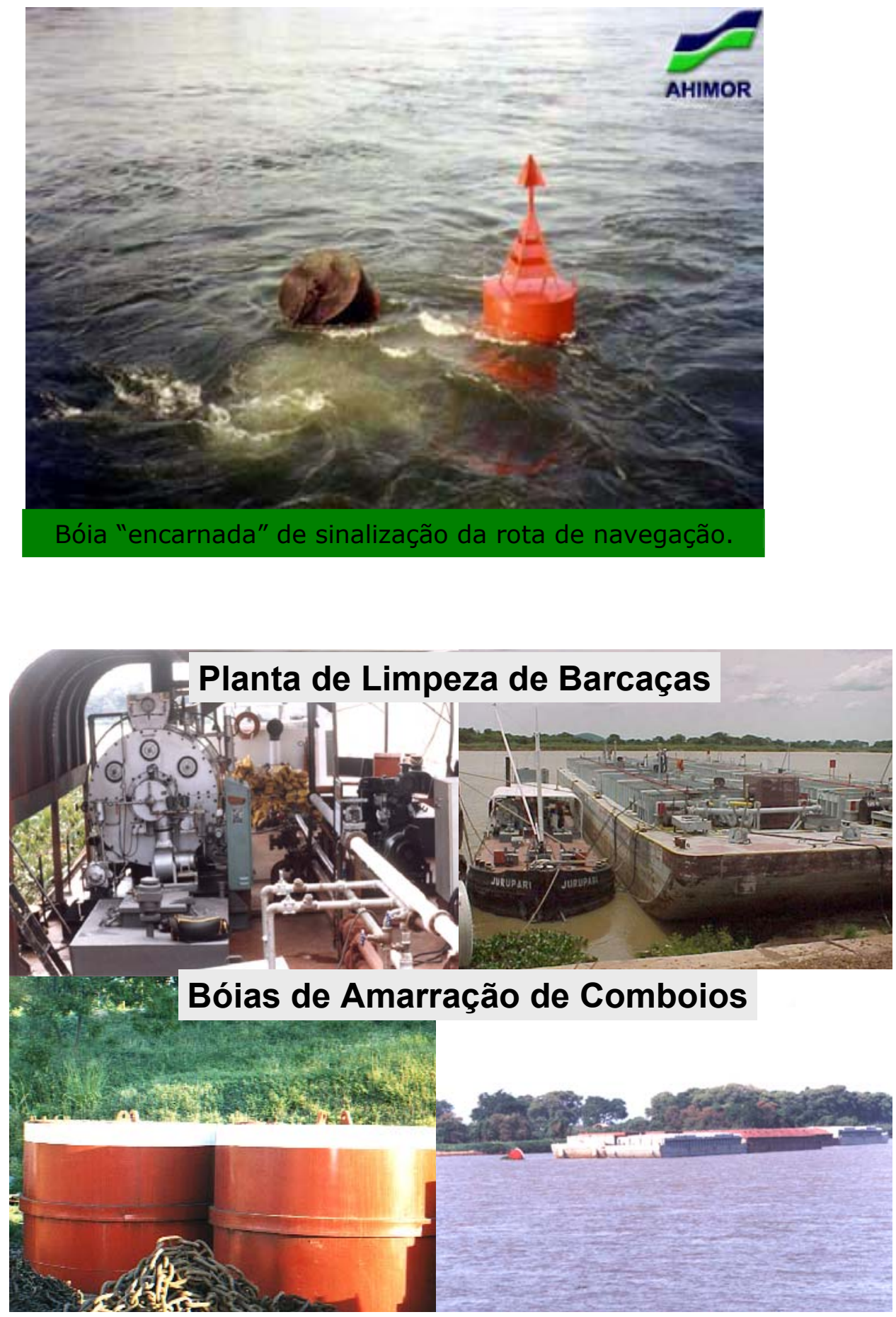

Figura 13 - Bóias de amarração de comboios.

Fonte: IBC - International Business Communications. (2001).

Workshop: Modelos estrangeiros e nacionais de operação de hidrovias. 


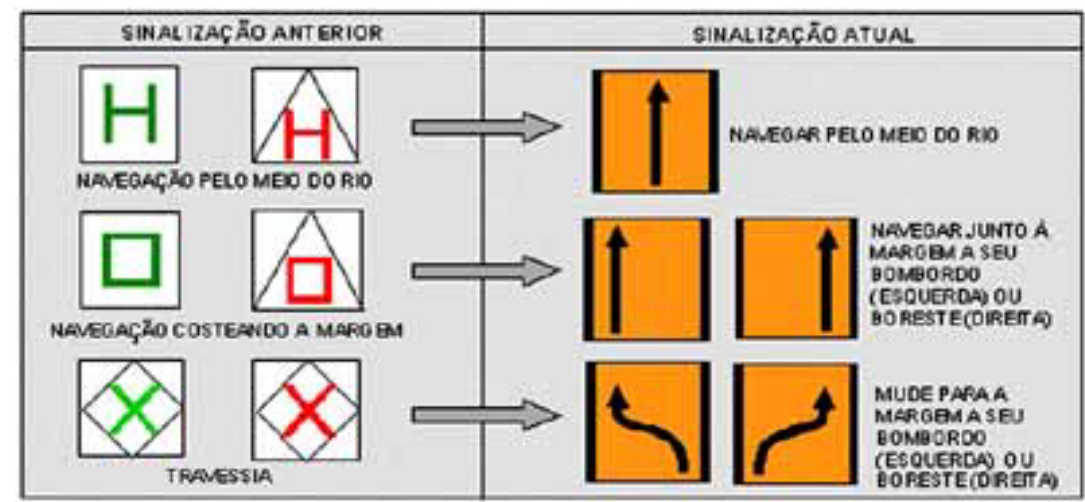

Nesse serviço de Implantação do balizamento do baixo Tocantins foram atualizados os sinais náuticos do referido trecho.

\section{Melhoria da navegabilidade da Hidrovia}

* Limpeza de vegetação ( principalmente camalotes )

* Sinalização dos canais de navegação para navegação noturna

* Definição dos pontos de fundeio com colocação de bóias de amarração

* Melhoramento do leito do Rio: dragagens de manutenção, derrocamentos em passos específicos que representam riscos à navegação

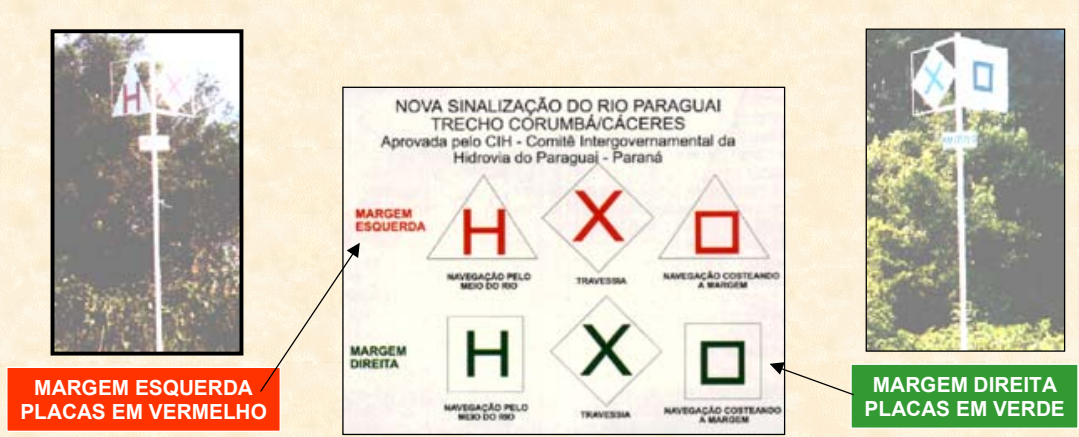

Figura 14 - Segurança da Navegação

Fonte: Home Page. http://www.caceres.com.br/adilsonreis 

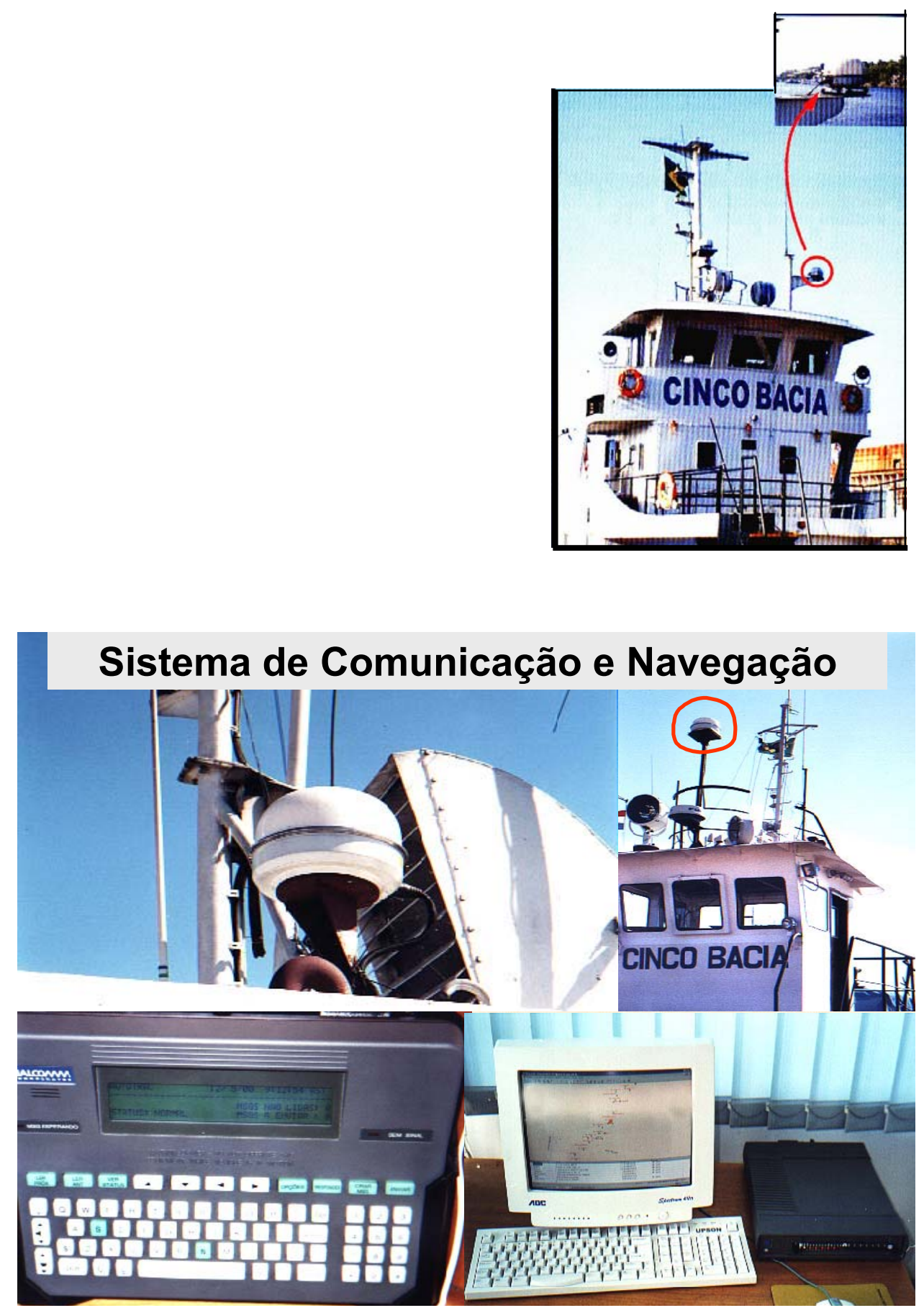

Figura 15 - Segurança da navegação: comunicações

Fonte: IBC - International Business Communications. (2001).

Workshop: Modelos estrangeiros e nacionais de operação de hidrovias. 

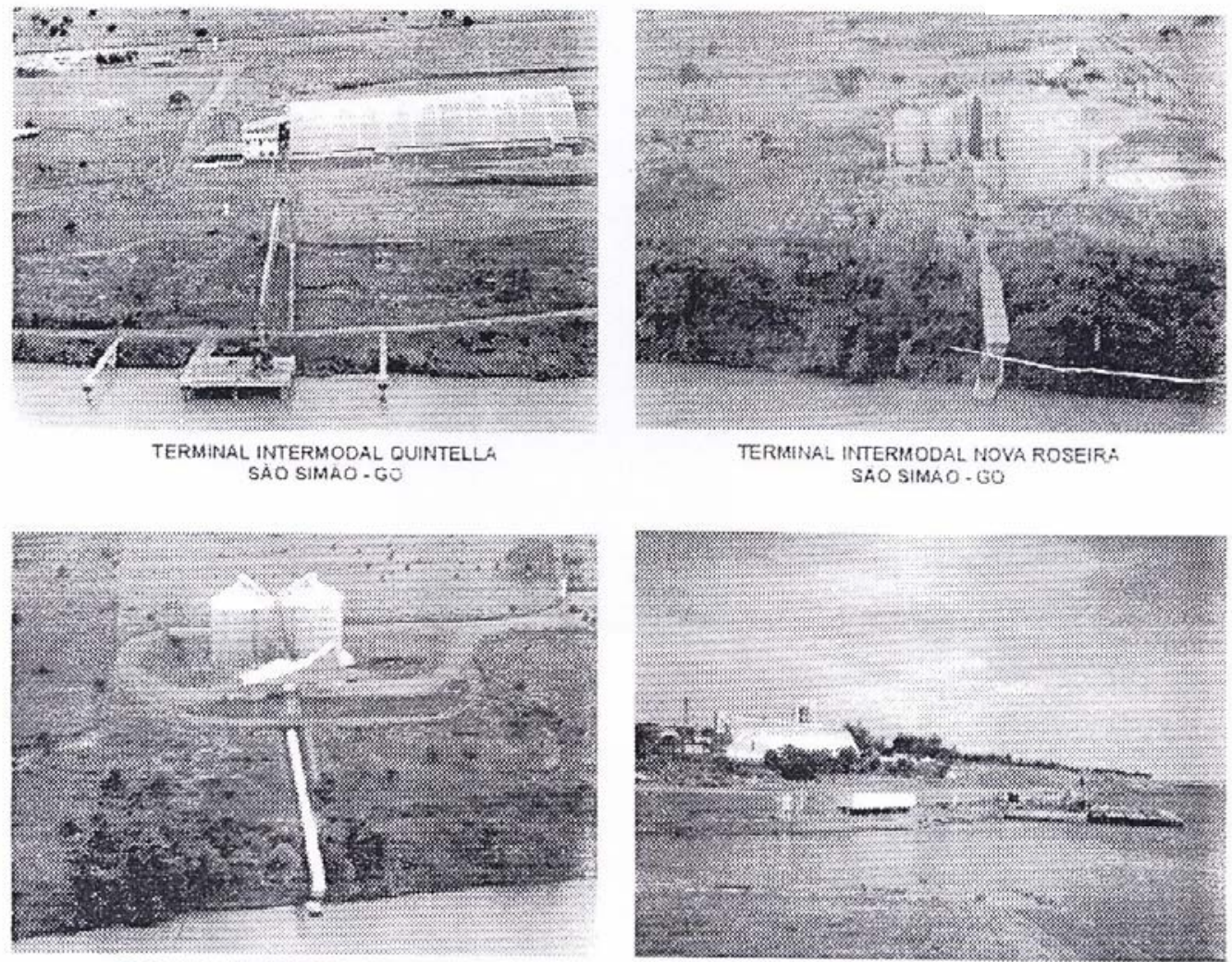

TERMINALL INTERMODAL

SAO SIMAO-GO

PRESIDENTE EPITACIO - SP

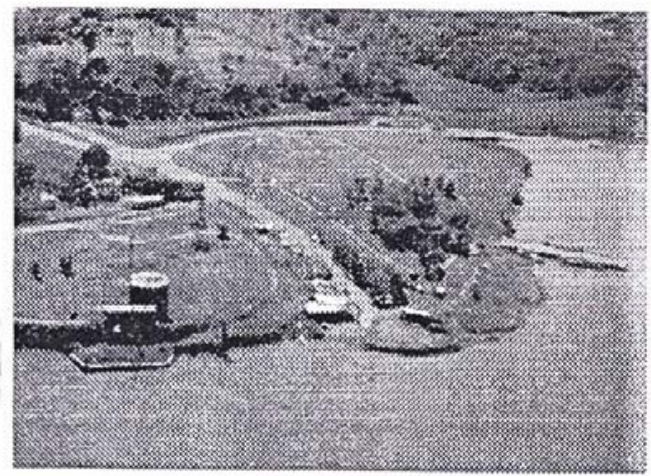

TERMINAL INTERIAODAL ADMISARTCO SALTO DEL GUAYRA - PY

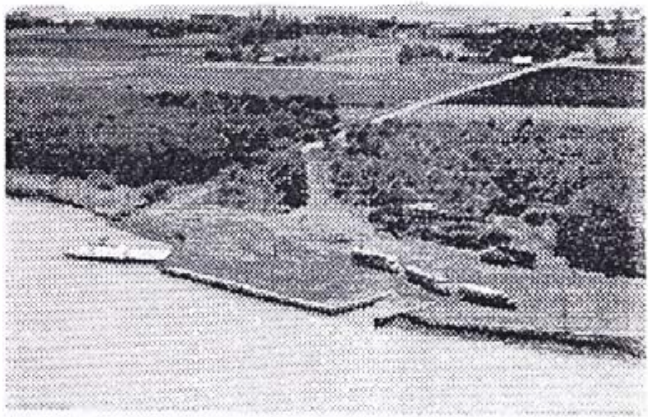

TERMINAL INTERIMODAL ADMISARTCO SANTA HELENA.PR

Figura 16 - Portos Fluviais - Instalações Industriais

Fonte: IBC - International Business Communications. (2001).

Conferência: Operação do transporte hidroviário no Brasil. 


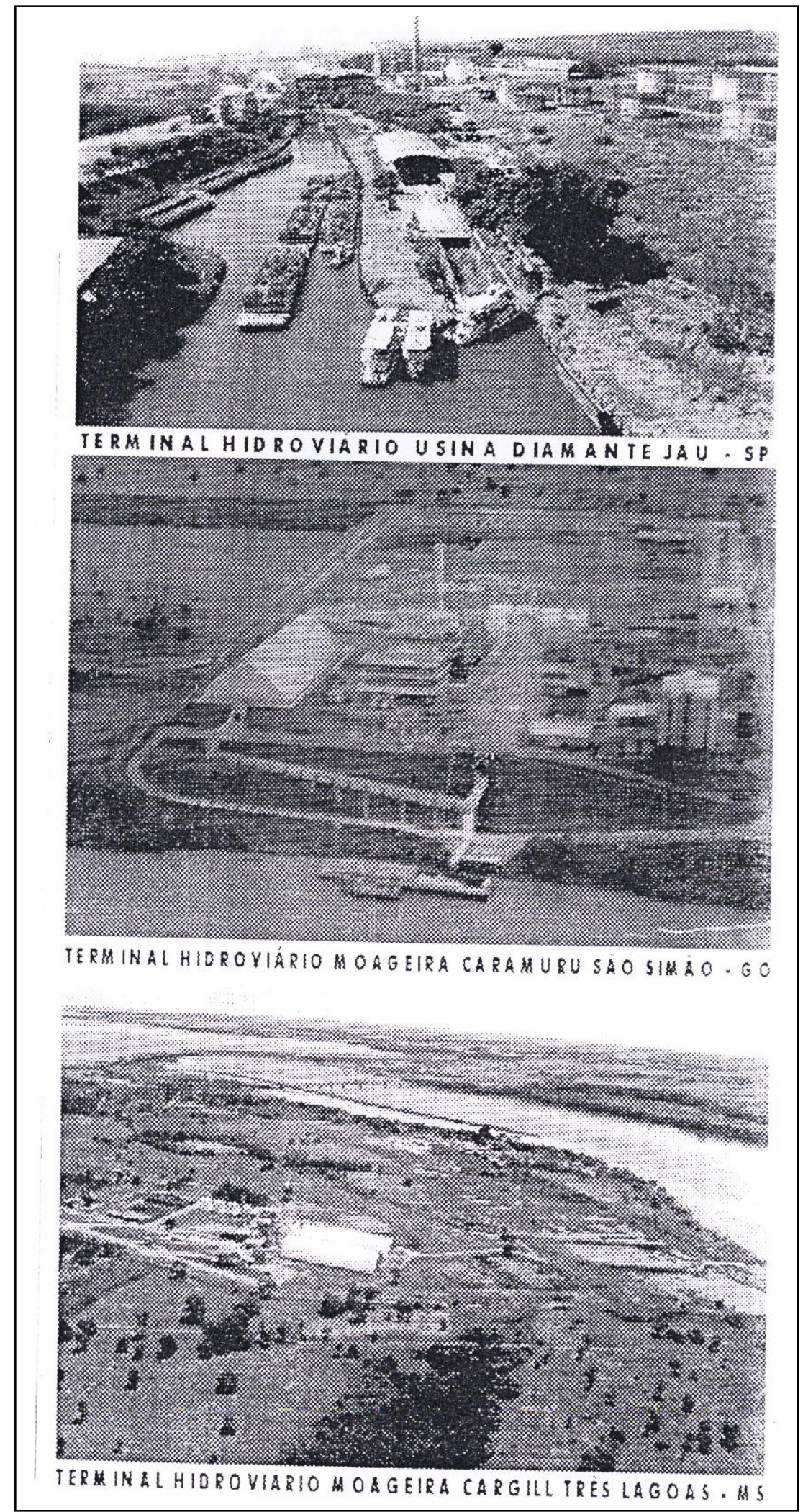

104

Figura 17 - Portos Fluviais - Instalações Industriais.

Fonte: IBC - International Business Communications. (2001).

Conferência: Operação do transporte hidroviário no Brasil. 
Cerca de $98 \%$ do movimento de cargas do comércio internacional do Brasil, em peso, se faz através de portos.

\subsubsection{Estudos Sucintos Dos Portos}

Alguns especialistas, não aceitam o emprego do termo "porto", quando o assunto abordado é a hidrovia, substituindo-o, então, por "terminal hidroviário".

A hidrovia, leva nada a lugar nenhum, daí a necessidade da implantação de uma infra-estrutura denominada terminal hidroviário.

Segundo Camargo Júnior (2000), a infra-estrutura identificada como terminal hidroviário, implantada na margem de uma hidrovia tem como propósito permitir a carga e a descarga de comboios e outras naves fluviais. Terminais hidroviários podem ser classificados como multimodais, integrando este modal aos demais modais de transporte e intermodais, que articulam a hidrovia a modais específicos. Ambos podem ser especializados ou não, manejando granéis sólidos, granéis líquidos, containers, cargas vivas, roll on - roll off, etc. Podem ser integrados a outros terminais e disporem de um distrito industrial na sua área de retro-porto, formando pólos industriais-hidroviários, ou estarem dispersos ao longo das margens de uma hidrovia e portanto isolados. O uso de terminais especializados é o mais comum em todo mundo. Neles, atracam comboios de carga formados por chatas barcaças, além de navios e outras naves fluviais.

É possível afirmar que os terminais hidroviários caracterizam-se por sua simplicidade, funcionalidade e baixo custo de implantação [calado; amplidão; comunicação (transbordo); topografia não acidentada], constituindo-se basicamente de um pier de atracagem e um conjunto de dolphins. No entanto, uma vez em operação, eles demandam infra-estrutura logística de retro-porto, passando a representar os módulos operativos que viabilizam o fluxo de mercadorias transportadas pelo rio em comboios cujo valor patrimonial pode ultrapassar dezenas de milhões de dólares. 
O principal sentido em se atribuir a terminais hidroviários uma função de elo entre o modal de transporte e o desenvolvimento regional, reside no fato de que há uma tendência expontânea e intrínseca à atividade hidroviária de agregar armazéns e unidades de transformação e beneficiamento nas suas áreas anteriores, ou de retroporto, gerando verdadeiros distritos industriais. A combinação de diversos terminais integrados ao florescente distrito industrial forma o pólo hidroviário industrial.

5.1.3.1.1. Medidas para a Expansão do Transporte Fluvial, segundo Del Grande (1989)

- Política sã quanto ao pessoal: salários normais, funções não parasitas e legislação adequada ( com justiça comum ).

Modernização das técnicas de transporte e dos equipamentos de transbordo: navegação em comboios rígidos com um empurrador; dispositivos de propulsão à hélice em pequeno calado ( com forte declividade ).

Melhoramentos das vias naturais: como retificação de meandros, barragens, obras de transposição, balizamentos, etc.

Incentivos à iniciativa privada: para instalação de unidades industriais junto à hidrovia, construção e exploração de portos especializados por particulares ( o retorno vem com o ICM).

\subsubsection{Classificação dos Portos, segundo Albanese (1989)}

A apresentação da classificação dos portos, tem por finalidade demonstrar que: em um porto, onde ocorre o movimento cargas é "contentorizadas", este porto do ponto de vista comercial, é entendido como um terminal.

\subsection{Ponto de Vista Geográfico}

Exterior - Aberto para o Mar ( Oceânicos );

- Interior - Não são Abertos para o Mar ( Mediterrâneo ). 


\subsection{Ponto de Vista Geográfico}

Lagunares - numa lagoa; exemplo: Rio Grande.

- Fluviais - no curso de um rio; exemplos: Porto Epitácio, Manaus. Ver Figura 16.

- Flúvio- marítimos - na foz de um rio; exemplos: Itajaí, Laguna, Marselha.

- Mediterrâneos - ligados ao mar por um canal; exemplos: Santos, Amsterdã.

- Oceânicos - voltados para o mar; exemplos: Natal, Salvador.

\subsection{Ponto de Vista Comercial}

Terminais - Containers;

Graneis - produtos soltos.

น Sólidos: cereais ( há a necessidade de silos ) carvão.

딴́ㅁoidos: petróleo e seus derivados suco de laranja (citrosuco)

Carga Geral

\subsection{Ponto de Vista de Recursos Financeiros}

Refere-se aos recursos financeiros para a formação do porto.

Privados - são exemplos: Santos; Salvador; Belém; Manaus.

Governos Estaduais - são exemplos: Rio Grande; Porto Alegre; Paranaguá.

Governo Federal - aplicado através dos concessionários.

\subsubsection{Evolução Típica de um Porto Convencional, segundo Albanese (1989)}

Investigações feita de há muito, mostram que as melhorias nas instalações e nos equipamentos de carga são reflexos do progresso na "zona de influência do porto" e da construção de novas naves. 
Partindo do porto primitivo, situado num "embaiamento" da foz de um rio, deve-se planejar e estudar:

- Extensão da faixa de acostamento - pelo lado dos investimentos o número de cais deve ser pequeno, mas pela parte dos navios com tempo de espera para acostar, o problema tem valores inversos. Um número apropriado pode ser obtido do estudo de distribuição das chegadas de navios e do tempo gasto nos seus atendimentos nos berços; essas chegadas obedecem ( de acordo com casos observados ) uma distribuição de Poisson ou da teoria das filas: chegadas independentes, probabilidade da chegada de um navio dentro do intervalo de tempo e independência do fenômeno quanto à origem de observação.

- Método de determinação do comprimento ótimo do cais - aqui deve-se considerar duas parcelas importantes: o capital empregado e a aquisição de equipamento; além disso, analisa-se o aumento do custo do manuseio das cargas, face às distâncias maiores a serem percorridas.

- Problemas de manutenção de calado - poucos são os portos que possuem condições naturais de profundidade. Estudos de geologia, hidrografia, climatologia são ligados ao problema de deposição de sedimentos, sempre ligados à análise física do meio. Para o equacionamento do problema "assoreamento", executam-se programas de - levantamentos batimétricos, detalhamento das margens, medição e estudo do material em suspensão e de fundo, medições de correntes; esses programas tem como objetivos: localizar e delimitar as zonas preferenciais de assoreamento; possibilitar conhecimentos das condições de ocorrência desse fenômeno. Economicamente, o custo desses serviços varia com o cubo do aumento da profundidade (fator crítico); é possível planejar canais dragados que provoquem correntes "limpadoras", mas deve-se estimar se elas vão depositar em outras áreas; pode-se concluir que a complexidade do problema da dragagem ( e o custo ) e o critério desses estudos não devem sobrepor-se às condições operacionais do porto. 


\subsection{VARIÁVEL DEPENDENTE - IMPACTOS AMBIENTAIS}

\subsubsection{IMPACTO AMBIENTAL - IDENTIFICAÇÃO E DEFINIÇÃO}

\subsubsection{Definição}

Todo curso de água, de extensão mais ou menos considerável, que se desloca de um nível mais elevado para outro mais baixo, aumentando progressivamente seu volume até desaguar no mar, num lago, ou noutro rio, e cujas características dependem do relevo, do regime de águas, segundo Pereira (1994), é sempre temporário. Certas alterações só podem ser notadas quando se comparam os "cursos" que o rio assume ao longo dos milênios ou eras. Porém, por mais pachorrento que ele seja, seu trabalho de erodir os obstáculos que o fazem curvar-se é constante, incessante, e às vezes relativamente abrupto. Pode acontecer de após ter vencido a resistência de um terreno rochoso, ele encontrar solo predominantemente arenoso ou argiloso, e deslocar a margem curva em período relativamente curto. Se o avanço se der no rumo de uma cidade, o prazo de alguns anos para atingi-la pode ser tão exíguo para medidas corretivas que a situação configura emergência.

Em o domador de rios, Kokei Uehara, narrou que algo assim vinha ocorrendo na região de Santa Cruz de la Sierra, na Bolívia. O Rio Grande ia estendendo um cotovelo de seu leito menor no rumo da vila de Pailón, onde em períodos de cheia, já provocava alagamentos pelo refluxo de afluentes e outros fatores, tais como o degelo da Cordilheira dos Andes. Ver Figura 18. Os bolivianos recorreram a engenheiros da Poli. Uma equipe chefiada pelo Prof. Kokei Uehara, efetuou obras para reconduzir o rio a curso mais seguro e estável, por baixo de uma ponte da ferrovia Corumbá-Santa Cruz de la Sierra. A fixação do leito do rio sob a ponte mantém-se até hoje.

A intervenção no curso do rio, por vezes é um procedimento obrigatório, frente às exigências para atender as necessidades básicas do homem, quais são: habitar, circular, trabalhar e recrear. 
A apresentação deste fato, na pesquisa, tem único objetivo, qual seja: caso na região identificada por Santa Cruz de la Sierra, não houvesse a cidade e nem fossem realizadas obras para a fixação do leito do rio, o trabalho realizado pelo rio, na obra de deslocamento de sua margem, seria um Impacto Ambiental, na área ainda inabitada?

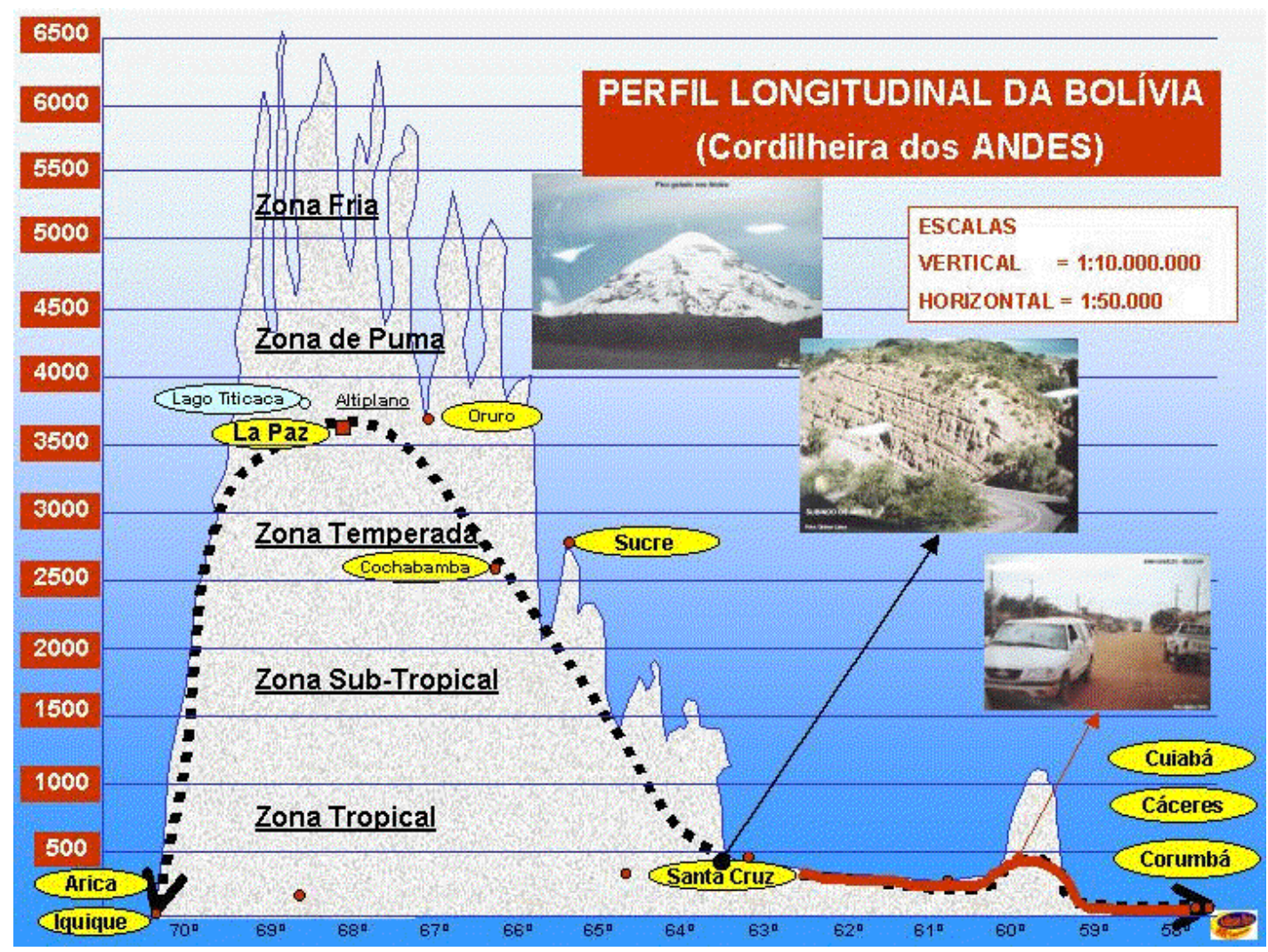

Figura 18 - O degelo é responsável pela alteração no valor da vazão, contribuindo nos períodos de cheia.

Fonte: http://www.caceres.com.br/adilsonreis 
A resposta para essa questão talvez resida na própria definição de Impacto Ambiental, qual seja:

Definição $\mathrm{N}^{0} .01$

Segundo Tommasi (1993), de acordo com o enfoque funcionalista, “impacto é qualquer fator ou perturbação que tende a desequilibrar o estado de equilíbrio instável em que se encontra um sistema ". Já, de acordo com um enfoque estruturalista, “impacto são aqueles fatores, ou condições de um sistema, que levam a mudanças estruturais do mesmo ".

Impacto Ambiental é uma alteração física ou funcional em qualquer dos componentes ambientais. Essa alteração pode ser qualificada e, muitas vezes, quantificada. Pode ser favorável ou desfavorável ao ecossistema ou à sociedade humana.

Definição $\mathrm{N}^{0} .02$

Segundo o artigo $1^{0}$. da Resolução $\mathrm{n}^{0} 01$ do CONAMA (1986), Impacto Ambiental é, “ qualquer alteração das propriedades físicas, químicas e biológicas do meio ambiente, causada por qualquer forma de matéria ou energia, resultantes das atividades humanas que, direta ou indiretamente afetam: a saúde, a segurança e o bem estar da população; as atividades sociais e econômicas; a biota; as condições estéticas e sanitárias do meio ambiente; a qualidade dos recursos ambientais ".

Definição $\mathrm{N}^{0} .03$

Há um impacto ambiental quando uma ação ou atividade produz uma alteração, favorável ou desfavorável, no meio ou em algum dos componentes do meio.

O impacto ambiental pode ser definido como a diferença entre a situação do meio ambiente, tal como resultará depois da realização do projeto e a situação futura desse meio, sem a realização desse projeto. (Libanori, 1995) 


\subsubsection{Identificação}

A navegação dos rios é o meio de transporte de mercadorias mais antigo, seguramente anterior à tração desenvolvida por terra. Esse fato decorre da simplicidade de se deixar a corrente natural carregar algum tipo de flutuante com a carga a transportar, o que, além de esforço mínimo, não agride o meio ambiente.

Outros meios de transporte ancestrais, como a tração animal, exigiram execução de trilhas e caminhos muito agressivos ao meio ambiente, na sua porção física, pois expunham o solo à erosão.

Além de ser a via natural, pronta pela natureza para servir ao transporte, os rios também abastecem as populações e suas culturas agrícolas, o que explica o desenvolvimento das civilizações, mesmo as litorâneas, ao longo dos vales dos rios.

Como qualquer setor da atividade humana, o crescimento é responsável pela progressão da interferência no meio ambiente. Entenderemos nessa pesquisa, por Meio Ambiente: “Local (águas, ar ou solo), onde se desenvolve a vida dos homens, animais, plantas ou microrganismos, devido a um conjunto de circunstâncias externas, que se caracteriza não só pelas propriedades físicas, químicas e biológicas desse local, mas também por outros fatores que regem a vida, como os relacionados às associações dos seres vivos, a aspectos de ordem cultural, legal, etc."

O Brasil é dotado de uma significativa rede hidrográfica, não distribuída uniformemente em seu território. Há alguma deficiência de descarga líquida na região Nordeste, devido à não uniformidade das chuvas, e, por outro lado, na região Norte, a bacia Amazônica, que é uma das maiores do mundo em termos de superfície e de extensão de seus rios, produz enormes descargas líquidas, perenemente.

$\mathrm{Na}$ região Sudeste, rios que deságuam no mar em território nacional apresentam obstáculos, como cachoeiras e corredeiras a poucos quilômetros da sua foz. Outros rios têm seu direcionamento para o interior, cruzando países vizinhos, como Paraguai, Argentina e Uruguai, antes de atingirem o mar. Essas situações são desfavoráveis para a integração da navegação fluvial com a marítima. 
Para que um curso de água navegável seja considerado como uma hidrovia interior, significa que há intenção, deliberação de mantê-lo ou dotá-lo de condições atuais ou futuras que possibilitem seu uso como hidrovia. Isso significa integração à infra estrutura de transportes interiores adotada, isto é, perfeita interligação com os outros modais, ou seja ferroviário, rodoviário e dutoviário.

Dessa forma, hoje, a navegação interior, exige, na maior parte das vezes, a execução de obras nas vias de navegação interior, pois, são necessárias à conservação e melhoramento das condições de navegabilidade, dos cursos de água naturais.

As vias de navegação interior são: rios, canais artificiais, lagos naturais, reservatórios, estuários e regiões lagunares sob influência do mar.

Tem-se considerado, em trabalhos internacionais e nacionais, as Hidrovias, uma via de transporte de pessoas ou carga, causador de impactos ao meio ambiente. Nessa pesquisa, o Impacto Ambiental será definido como: “ a diferença entre a situação do meio ambiente, tal como resultará depois da realização do projeto e a situação futura desse meio, sem a realização desse projeto".

Há um impacto ambiental, quando uma ação ou atividade produz uma alteração, favorável ou desfavorável, no meio ou em algum dos componentes do meio.

Nesta pesquisa, estudaremos somente os impactos no meio ambiente, creditados a execução de obras nas vias de navegação interior. Os impactos devido ao transporte de cargas com potencial poluidor ou contaminante, não é objeto desta pesquisa, pois nesta situação, o efeito impactante da carga, independe do modal de transporte.

Os impactos ambientais abordados serão:

- Impacto sobre a sociedade;

Impacto sobre a infra-estrutura rural e urbana;

Impacto sócio-cultural;

Impacto sobre o meio físico

- Impacto sobre o meio biológico. 
Os impactos ambientais, uma vez devidamente abordados, cabe a esta pesquisa demonstrar a viabilidade da conservação do meio ambiente a partir das hidrovias, o que é possível, a partir de Programas de Mitigação, traçados ainda quando do desenvolvimento dos Estudos Gerais para a Execução da Hidrovia bem como do Tipo de Hidrovia, a ser adotado.

\subsubsection{ANÁLISE DOS IMPACTOS AMBIENTAS}

A análise dos Impactos ambientais compreende : identificação, valoração e interpretação dos prováveis impactos ambientais nas fases de planejamento, implantação, operação e, se for o caso, de desativação do empreendimento, sobre os meios físicos, biológico e antrópico, devendo ter determinados e justificados os horizontes de tempo considerados.

Os impactos deverão ser analisados nas áreas de estudo definidas para cada um dos seguintes fatores ambientais: meio físico, meio biológico, meio antrópico, podendo, para efeito de análise, ser considerado, segundo Mota (1995), como:

- Impacto diretos e indiretos;

- Impactos benéficos (positivos) e adversos (negativos);

- Impactos temporários, permanentes e cíclicos;

- Impactos imediatos, a médio e longo prazo;

- Impactos reversíveis e irreversíveis;

Impactos locais, regionais e estratégicos

\subsubsection{MÉTODOS DE AVALIAÇÃO DE IMPACTOS AMBIENTAIS}

A pesquisa bibliográfica analisada, demonstra que muitos pesquisadores dizem ocorrer o impacto ambiental, na situação por ele pesquisada, mas não há nada de sólido, onde se possa de fato avaliar o impacto. Nessa linha, procuramos acrescentar a estas pesquisas um elemento palpável, de modo a nos permitir avaliar a 
extensão do impacto ambiental, sendo esse elemento a adoção de um MÉTODO DE ESTUDO DE IMPACTO AMBIENTAL.

Há, hoje, um consenso de que nenhum método, isoladamente pode avaliar de forma completa o impacto de um projeto, ou seja comparar alternativas, organizar, resumir, sintetizar toda informação gerada num estudo, é a melhor avaliação.

Segundo Tommasi (1993), há mais de 50 métodos visando: coletar , analisar, comparar e organizar informações sobre os impactos ambientais de um dado projeto.

Os Métodos para Avaliar Impactos Ambientais, são entendidos como aqueles que visam coletar, analisar, avaliar, comparar e organizar informações sobre os impactos ambientais de um dado projeto. Esses métodos procuram, inclusive, avaliar as condições futuras ambientais, procurando, assim prever seus comportamentos, em decorrência dos efeitos induzidos por um projeto.

Já as técnicas de previsão de impacto ambiental são aquelas que visam avaliar as condições futuras de determinados aspectos ambientais.

Iremos analisar, sucintamente os métodos mais amplamente utilizados, com uma breve discussão de suas principais vantagens e desvantagens, de modo a nos permitir adotar um ou mais, nessa pesquisa.

\subsubsection{Método "ad hoc"}

Consiste na reunião de um grupo multidisciplinar de técnicos, com o maior grau de experiência possível no tipo de "projeto de desenvolvimento" em análise, para, numa primeira abordagem, avaliar os efeitos das alternativas daquele projeto.

É mais uma abordagem inicial, onde são levantados os aspectos mais importantes a serem analisados. Geralmente não tem como objetivo, fazer uma listagem exaustiva de todas as ações propostas e fatores a serem analisados, mas assegurar que os fatores ambientais relevantes não sejam omitidos. Podem ocorrer algumas dificuldades tais como subjetividade, tendenciosidade da coordenação do grupo e da escolha de seus membros, de acordo com Silveira \& Moreira (1985) apud Tommasi (1993). 
Em resumo, apresentam:

- Como vantagens - simplicidade de aplicação, reduzida exigência quanto a dados e informações; e

como desvantagens - não permitem projeções e previsões ou a identificação de impactos de segunda ordem.

\subsubsection{Método das Listagem de Controle (Check-list)}

Consiste, basicamente numa lista de fatores ambientais que devem ser considerados, sistematicamente, em relação ao projeto proposto para determinar inicialmente, se os mesmos irão sofrer modificações com a implantação do projeto. Permite identificar as principais conseqüências de uma ação, assim como, hierarquizar, estimular as avaliações de possíveis impactos. Não permite, porém, identificar impactos de segunda ordem.

Entre as diversas listagens de controle, a do "Battelle Columbus Laboratory" da Bacia do Rio Mekong do Instituto de Urbanismo de Washington, está entre as mais conhecidas.

Segundo Silveira \& Moreira (1985) apud Tommasi (1993), as listagens de controle foram os primeiros métodos para avaliar os impactos ambientais.

As principais variantes do Método das listagens, em grau crescente de complexidade e detalhamento nas respostas que propiciam, são apresentadas a seguir:

5.2.3.2.1. Listagens descritivas, segundo Braga et al. ( 2002)

As listagens de caráter puramente descritivo são bastante utilizadas para orientar a elaboração das avaliações de impacto ambiental, relacionando ações, componentes ambientais e respectivas características que podem ser alteradas. Podem também conter informações sobre técnicas mais adequadas de medição e previsão para os indicadores ambientais selecionados, bem como sobre a ponderação 
relativa dos impactos. Entretanto, não permitem o cotejo de alternativas mediante a quantificação dos impactos. Exemplos dessas listagens encontram-se descritos em Braga et al. (2002).

\subsection{Listagens comparativas, segundo Braga et al. ( 2002)}

Esse tipo constitui-se numa evolução das listagens anteriores, mediante a incorporação de critérios de relevância aos indicadores ambientais característicos do estado ambiental alterável pelos impactos.

A relevância do impacto é explicada numericamente (ou por meio de letras ) em relação ao nível de impacto considerado significativo. Em alguns modelos do método a relevância leva em conta também a duração do impacto. Habitualmente, a intensidade cresce com o número ou a ordem alfabética da letra.

Um exemplo de listagem comparativa foi desenvolvido para os Estados Unidos e passou a ter largo emprego internacionalmente. O US Forest Service desenvolveu uma listagem associada a critérios de relevância, composta por fatores ambientais, bem como socioeconômicos, qualidade de água e hábitats da vida selvagem, acompanhados de fatores desejáveis ou que sejam padrão para cada um deles. Essa listagem encontra-se descrita em Silveira \& Moreira (1987).

Quando o impacto previsto ultrapassa os valores desejáveis estabelecidos, emerge uma situação a ser considerada na análise ambiental, à luz de critérios de relevância.

Como principais características desse método podemos destacar:

- Os critérios de relevância, os fatores ambientais e os padrões estabelecidos dependem das características do empreendimento; e

- A dimensão temporal é considerada.

Mediante a aplicação desse método é possível estabelecer a hierarquia dentre as alternativas quanto aos impactos que cada uma introduz sobre os diversos componentes (ou elementos) ambientais.

Exemplos dessas listagens, encontram-se descritos em Braga et al. (2002). 
5.2.3.2.3. Listagens em questionário, segundo Braga et al. ( 2002)

Nesse tipo de listagem, procura-se contornar uma falha dos métodos anteriores, que consideram os impactos de um projeto isoladamente, sem levar em conta suas interdependências. Várias perguntas são elaboradas visando contornar a desvantagem da listagem puramente descritiva.

A listagem é subdividida em categorias genéricas (ecossistema terrestre, vetores de doenças e outras), para as quais são organizados questionários acompanhados de instruções para seu preenchimento, bem como de classificação do impacto resultante das ações neles descritas.

Exemplos dessas listagens encontram-se descritos em Braga et al. (2002).

\subsection{Listagens ponderais, segundo Braga et al. (2002)}

Constituem uma evolução consolidada das listagens de controle comparativas com ponderação. O modelo que melhor representa o método é conhecido como método Battelle.

O método é baseado na listagem de parâmetros ambientais. A importância relativa de cada um dos parâmetros em relação à soma dos impactos do projeto é dada pela atribuição de pesos. Tanto a distribuição de pesos entre os parâmetros quanto o desenvolvimento das funções e valores dos índices de qualidade ambiental associados ao estado de cada parâmetro são obtidos com auxílio de uma equipe multidisciplinar. O método de avaliação ambiental de Battelle (Columbus Lab. - US Bureau of Reclamation), inicialmente formulado para utilização em aproveitamentos de recursos hídricos, é exemplo típico de listagem ponderal e possui as seguintes características principais:

- É abrangente e seletivo ao mesmo tempo;

- É bastante objetivo para a comparação de alternativas;

- Não permite a interação dos impactos;

- Permite previsão de magnitude pelo emprego de escala normalizada de valores; e 
Não distingue a distribuição temporal

Esse modelo é constituído por 78 parâmetros representativos de componentes ambientais (18 ecológicos, 17 estéticos, 24 físico-químicos e 19 sociais). A cada um deles está associado um peso previamente definido que estabelece sua importância relativa em face dos demais na constituição dos impactos.

A cada parâmetro corresponde um índice de qualidade ambiental normalizado numa escala que varia entre 0 e 1 , estabelecido caso a caso por equipe multidisciplinar ou adotados a partir de casos similares relatados anteriormente.

O somatório dos produtos dos índices de qualidade pelos pesos dos respectivos parâmetros constitui o valor relativo do impacto calculado para cada alternativa.

Exemplos dessas listagens encontram-se descritos em Braga et al. (2002).

\subsubsection{Método das Rede de Interações}

Permite identificar ações e inter-relações. Visualiza, também, as interações entre ações e impactos relacionados com as cadeias de impactos. Não é porém, recomendado para grandes ações de caráter regional, pois pode ficar muito grande; não é de natureza quantitativa e, geralmente, não tem capacidade para identificar retroalimentações. Permite, unicamente, identificar os efeitos de ações externas sobre os fluxos de energia de um sistema ambiental.

As vantagens desse método, provêm da identificação do conjunto de ações que contribuem para a magnitude de um impacto, facilitando, assim, a previsão dos mecanismos de controle ambiental que deverão ser implementados para atuar preferencialmente sobre as causas potenciais de sua deterioração.

Devido à maneira como são construídas, as redes de interação têm normalmente uma limitação: só abrangem os impactos negativos. 


\subsubsection{Método da Superposição de Cartas}

Segundo Silveira \& Moreira (1985) apud Tommasi (1993), este método teve origem nas cartas de aptidão e cartas de restrição, respectivamente, de Ian Mettarg e de J. Tricart. Cada uma dessas cartas se refere a um aspecto (tema) ambiental, como: tipo de solo, de cobertura vegetal, de cursos hídricos, do grau de poluição, de erosão, etc.

Desenhadas em transparências permitem a sobreposição e, assim, que se avalie, simultaneamente, diversos aspectos ambientais. Se houver necessidade de se superpor muitas cartas, pode-se utilizar um computador (computação gráfica).

Um ambiente apresentará, sempre limitações e oportunidades para um dado projeto de desenvolvimento; além disso, apresenta também diferentes graus de sensibilidade e variações, induzidas pelo projeto (Tommasi, 1993). Estes aspectos poderão ser mapeados para cada fator ambiental, com diferentes gradações de cor. Por exemplo, uma área mais sensível deveria ser indicada em coloração intensa e, a menos sensível, com menor intensidade. Superpondo-se todas as transparências, podemos encontrar a melhor localização para um dado projeto.

\subsubsection{Método dos Modelos de Simulação}

Os Modelos de Simulação são modelos matemáticos com a finalidade de representar, o mais próximo possível da realidade, a estrutura e funcionamento dos sistemas ambientais, explorando as relações entres o seus fatores físicos. biológicos e socioeconômicos. Eles são estruturados com base na definição de objetivos, escolha de variáveis e estabelecimento de suas inter-relações, discussão e interpretação dos resultados.

É, teoricamente, o melhor método, devido à sua capacidade preditiva, com a possibilidade de utilização de uma grande quantidade de dados, possibilitando também identificar necessidades adicionais de pesquisa e estudar as relações entre fatores físicos, biológicos e sócio-econômicos. 
É, porém, um método caro, que exige capacitação, trabalho, tempo e custos disponíveis, dependendo muito da qualidade das informações disponíveis, de acordo com Ogawa \& Mitsch (1979) apud Tommasi (1993), que nem sempre podem ser consideradas homogêneas.

Em síntese, o método dos modelos de simulação, apresentam como principais desvantagens para o seu emprego:

Dificuldade de encontrar dados em disponibilidade ou de obter com a presteza e a representatividade necessárias os dados requeridos para o desenvolvimento e calibração do modelo;

- Freqüente necessidade de empregar relações simplificadas entre as variáveis intervenientes, seja por razões de complexidade dos fenômenos representados, seja por insuficiência de seu conhecimento ou por limitações computacionais;

Dificuldade de incorporar fatores, tais como os estéticos, sociais e outros; e

Possibilidade de induzir o processo de decisão.

Apesar dessas restrições, os modelos de simulação são extremamente versáteis na comparação de alternativas, permitem projeções temporais, promovem a comunicação interdisciplinar e incorporam as relações de varíaveis, algumas vezes de extrema complexidade.

\subsubsection{Método das Matrizes de Interação}

Este é um modelo dos mais utilizados em avaliação dos impactos ambientais. A primeira desta matrizes foi a de Leopold et al. (1971) apud Tommasi (1993), desenvolvida nos Estados Unidos para projetos de mineração. Esta matriz tem sofrido numerosas adaptações, que permitem sua utilização em grande variedade de projetos. Consiste basicamente, numa listagem bidimensional, organizada num quadro, em que são enumerados horizontal e verticalmente, os fatores ambientais assim como as ações do projeto. É um método barato, mais muito informativo, que permite comparações fáceis. Se, porém, envolver um grande número de informações, 
fica difícil de ser analisado. Não considera as alterações entre impactos, nem os impactos indiretos (esta é a principal crítica a este método).

Os impactos potenciais induzidos por determinada ação sobre um fator ambiental são assinalados na matriz por meio de um traço em diagonal, no quadro correspondente à interação dos mesmos.

Quando o impacto for positivo, pode-se assinalar o quadro com um sinal $(+)$; caso seja negativo, com um sinal (-). Além disso, as duas características são: importância e magnitude descritas com valores de 1 a 10 .

Sob a matriz e ao lado direito da mesma há um espaço para se computar a soma da "importância" e "magnitude" de cada ação sobre os fatores ambientais.

A matriz de Leopold et al. (1971) apud Tommasi (1993), possui alguns defeitos, além dos já mencionados, tais como aqueles relacionados por Bolea (1977) apud Tommasi (1993):

Um mesmo impacto pode ser considerado duas vezes, já que não se estabelece o princípio da exclusão e não relaciona os fatores segundo efeitos finais;

Não é seletivo, pois, não estabelece um sistema para centralizar a atenção nos aspectos mais críticos do impacto. Além disso, não distingue entre efeitos a curto e a longo prazo, mas pode-se preparar matrizes segundo uma escala de tempo;

A avaliação fica a critério de quem usa a matriz, sofrendo, assim, de uma certa subjetividade. Por isso, seu uso para previsão e interpretação e consequentemente, para decisões finais torna-se mais difícil.

\subsubsection{Método da Análise Benefício - Custo, segundo Braga et al. (2002)}

A analise benefício-custo é um método de avaliação de projetos de largo emprego há cerca de meio século. Surgido inicialmente como uma resposta às necessidades do esforço de guerra, mostrou-se posteriormente um auxiliar bastante útil no processo de reorganização e dinamização da economia mundial. Desde então vem sendo continuamente utilizado na avaliação e otimização de projetos em vários 
setores, devendo-se destacar sua ampla utilização no campo dos aproveitamentos hídricos por tratar-se de um dos segmentos do ambiente.

Fundamentalmente, a Análise Benefício-Custo propõe-se a computar os custos e os benefícios de um projeto ou de suas alternativas, visando compará-los e ordená-los por meio da relação Benefício-Custo ou do Benefício Líquido (diferença entre os benefícios e os custos) que lhes correspondem. A prática consagrou a segunda das variantes como a mais adequada nas avaliações para as quais os aspectos ambientais são importantes.

Simples em princípio, a aplicação da Análise Benefício-Custo apresenta entretanto várias dificuldades, nem sempre superáveis. Em resumo, essas dificuldades prendem-se à avaliação, sob um mesmo padrão de medida (monetário), dos bens e serviços ambientais gerados (benefícios ambientais) e dos bens e serviços utilizados ou comprometidos pelo projeto (custos ambientais).

\subsubsection{Método da Análise Multiobjetivo, segundo Braga et al. (2002)}

Um dos pontos cruciais da chamada Análise Multiobjetivo é justamente a definição dos objetivos a serem considerados em uma determinada situação decisória. Nesse sentido, a literatura é bastante controversa quanto às definições. Alguns autores da área de gestão de recursos hídricos, por exemplo, costumam definir objetivos e propósitos. Objetivos seriam reservados para aspectos relativos à maximização de eficiência econômica, minimização de impactos ambientais, maximização do bem-estar social etc. Propósitos estariam ligados a, por exemplo, geração de energia elétrica, irrigação, abastecimento doméstico, lazer etc. Ou seja, um determinado objetivo poderia ser alcançado pela execução de uma obra com propósitos múltiplos .

Em geral, um problema multiobjetivo pode ser estruturado na forma de uma hierarquia. Define-se meta como sendo uma intenção ou um objetivo muito genérico que pode ser atendido por objetivos mais específicos que são quantificados por atributos. 
Objetivos refletem as aspirações do decisor (ou decisores) em relação ao atendimento de uma determinada meta. Um determinado objetivo pode ser alcançado pela sua maximização ou minimização. Atributos permitem avalizar como um determinado objetivo está sendo alcançado. Desse modo, atributos podem ser entendidos como um aspecto mensurável de julgamento pelo qual uma variável de decisão pode ser caracterizada. Essa caracterização pode assumir a forma cardinal, quando é possível estabelecer-se uma escala numérica de comparação ( por exemplo, reais, metros, g/l etc.), e ordinal, no caso em que é possível somente a ordenação, sem a possibilidade de estabelecer-se uma comparação numérica. Por exemplo, o grau de proteção contra cheias pode ser mensurado como alto, médio, baixo e insuficiente, sem graduação entre eles.

\subsubsection{Seleção da Metodologia, segundo Braga et al. (2002)}

A definição da metodologia a ser empregada para a avaliação dos impactos ambientais é tarefa específica de cada caso que se apresenta e deve partir da comparação entre os métodos de aplicação correntes. Esses métodos, utilizam técnicas diversas para a qualificação e quantificação desses impactos, bem como para o cotejo de alternativas de projeto.

A análise de cada um dos métodos anteriormente apresentados evidencia os diferentes graus de subjetividade envolvidos na sua aplicação e as possíveis dificuldades de quantificação para cada caso específico.

O diálogo entre o profissional com formação ambiental e versado nessas metodologias e o especializado nas técnicas envolvidas no desenvolvimento do empreendimento (tanto na construção como na operação) ainda é o melhor caminho para a seleção dos métodos a serem utilizados na avaliação do impacto ambiental.

\subsubsection{PROPOSIÇÃO DE MEDIDAS MITIGADORAS}


As medidas que visam minimizar os impactos adversos, identificados e quantificados no item anterior, serão explicitadas e classificadas, segundo a:

- Sua natureza: preventivas ou corretivas;

- Fase do empreendimento em que deverão ser adotadas: planejamento, implantação, operação e desativação e para o caso de acidentes;

- Fator ambiental a que se destina: físico, biológico ou sócio-ecnômico;

- Prazo de permanência de sua aplicação: curto, médio ou longo;

- Responsabilidade por sua implementação: empreendedor, poder público, ou outros.

Serão mencionados os impactos adversos que não possam ser evitados ou mitigados.

\subsubsection{PROGRAMA DE ACOMPANHAMENTO E MONITORAMENTO DOS IMPACTOS AMBIENTAIS, segundo Tommasi (1993) \& Mota (1995)}

Nesta fase do estudo serão apresentados os programas de acompanhamento das evoluções dos impactos ambientais positivos e negativos, causados pelo empreendimento, considerando as fases de planejamento, implantação, operação e desativação, quando for o caso e de acidentes, incluindo, conforme o caso:

Indicação e justificativa dos parâmetros selecionados para a avaliação dos impactos sobre cada um dos fatores ambientais considerados;

Indicação e justificativa da rede de amostragem, incluindo seu dimensionamento e distribuição espacial;

- Indicação dos métodos de coleta e análise de amostras;

- Indicação e justificativa da periodicidade de amostragem, para cada parâmetro, segundo os diversos fatores ambientais;

- Indicação e justificativa dos métodos a serem empregados no processamento das informações levantadas, visando retratar o quadro da evolução dos impactos ambientais acusados pelo empreendimento. 


\subsubsection{OS USOS MÚLTIPLOS D’ÁGUA E OS IMPACTOS AMBIENTAIS}

A água, é o recurso natural, que depois do ar, apresenta tantos usos legítimos. Em nossa vida social e industrial, os recursos hídricos são utilizados para múltiplos fins e, tem-se obtido como resultado desse uso, uma ação de impacto ambiental nesta porção bio-geo-física do meio ambiente. São os principais usos d'água:

- Abastecimento doméstico;

Abastecimento industrial;

Irrigação;

Dessedentação de animais;

- Preservação da fauna e flora;

- Recreação e lazer;

- Geração de energia;

- Navegação, e

Diluição de despejos.

As categorias de demanda de água, acham-se inseridas em três classes, conforme Tabela XIV. São elas:

- Infra-estrutura social: refere-se às demandas gerais da sociedade nas quais a água é um bem de consumo final;

Agricultura e aquicultura: refere-se às demandas de água como bem de consumo intermediário, visando a criação de condições ambientais adequadas para o desenvolvimento de espécies animais ou vegetais de interesse para a sociedade,

- Industrial: demandas para atividades de processamento industrial e energético nas quais a água entra como bem de consumo intermediário.

Quanto à natureza da utilização existem três possibilidades:

Consuntivo - refere-se aos usos que retiram a água de sua fonte natural, diminuindo suas disponibilidades quantitativas, espacial e temporalmente. 
Não consuntivo - refere-se aos usos que retornam à fonte de suprimento, praticamente a totalidade da água utilizada, podendo haver alguma modificação no seu padrão temporal de disponibilidade quantitativa.

- Local - refere-se aos usos que aproveitam a disponibilidade de água em sua fonte sem qualquer modificação relevante, temporal ou espacial, de disponibilidade quantitativa. 
Tabela XIV- Principais categorias de demanda de água.

\begin{tabular}{|c|c|c|}
\hline Categorias & Demandas & Natureza \\
\hline Infra-estrutura social & $\begin{array}{l}\text { dessedentação } \\
\text { navegação } \\
\text { usos domésticos } \\
\text { recreação } \\
\text { usos públicos } \\
\text { amenidades }\end{array}$ & $\begin{array}{l}\text { consuntivo } \\
\text { não-consuntivo } \\
\text { consuntivo } \\
\text { não-consuntivo } \\
\text { ambos } \\
\text { não-consuntivo }\end{array}$ \\
\hline $\begin{array}{l}\text { Agricultura e } \\
\text { aquicultura }\end{array}$ & $\begin{array}{l}\text { agricultura } \\
\text { piscicultura } \\
\text { pecuária } \\
\text { uso de estuários } \\
\text { irrigação } \\
\text { conservação de banhados }\end{array}$ & $\begin{array}{l}\text { consuntivo } \\
\text { não-consuntivo } \\
\text { consuntivo } \\
\text { não-consuntivo } \\
\text { e local } \\
\text { consuntivo } \\
\text { local }\end{array}$ \\
\hline Industrial & $\begin{array}{l}\text { arrefecimento } \\
\text { mineração } \\
\text { hidroeletricidade } \\
\text { processamento industrial } \\
\text { termoeletricidade } \\
\text { transporte hidráulico }\end{array}$ & $\begin{array}{l}\text { consuntivo } \\
\text { não-consuntivo } \\
\text { não-consuntivo } \\
\text { consuntivo } \\
\text { consuntivo } \\
\text { consuntivo }\end{array}$ \\
\hline $\begin{array}{l}\text { Em todas as } \\
\text { categorias acima }\end{array}$ & $\begin{array}{l}\text { transporte, diliuição e } \\
\text { depuração de efluentes }\end{array}$ & não-consuntivo \\
\hline $\begin{array}{l}\text { Proteção } \\
\text { (preservação, } \\
\text { conservação e } \\
\text { recuperação) }\end{array}$ & $\begin{array}{l}\text { consideração de valores } \\
\text { de opção de uso, de existência } \\
\text { ou intrínseco }\end{array}$ & $\begin{array}{l}\text { não-consuntivo } \\
\text { e local }\end{array}$ \\
\hline
\end{tabular}

Fonte: PORTO, Rubem La Laina, et al. ( 1997). Técnicas quantitativas para o gerenciamento de Recursos Hídricos. 
As demandas referentes à proteção das águas satisfazem a uma categoria mais complexa de necessidade da sociedade moderna, relacionadas com as suas vinculações com o ambiente natural. Elas podem preconizar a preservação do meio hídrico, significando sua manutenção no estado natural, ou pela conservação, significando a manutenção no estado corrente, ou pela recuperação, quando implica na melhoria da qualidade corrente, quando alguma alteração já poderá ter ocorrido em relação ao estado natural. As demandas previamente analisadas enfocam a água como recurso, com valor de uso. No caso de demandas ambientais agora analisadas existem outros tipos de valores sociais que devem ser considerados:

- O valor de uso potencial da água - é aquele derivado do seu uso potencial para promover o bem-estar da sociedade. Ele se contrapõe ao valor de uso que se refere ao uso corrente. No caso em tela a referência é a de um uso futuro provável. Esta classe de valor pode ser associada à estratégia de preservação de opções, tendo em vista a incerteza inerente ao futuro de longo prazo, que poderá tornar certos bens relacionados com as água com valor social expressivo. Tal situação ocorreria na proteção de um banhado em face de sua diversidade biológica, como fonte de possíveis riquezas no futuro. Quando o objetivo é a preservação para as futuras gerações, este valor pode ser denominado valor de herança ou legado.

- O valor intrínseco - é aquele associado aos recursos hídricos, independente da possibilidade de seu uso, corrente ou potencial, para promover o bem estar da sociedade. Aceita-se aqui a premissa filosófica de que não cabe ao ser humano a valoração do ambiente, pois ele possui um valor em si. Alternativamente, existem valores estabelecidos pela sociedade em uma base de " não uso" , que determinam uma satisfação social pela simples existência de um bem ambiental (valor de existência). Para estes valores, a preservação de um rio (estado natural) teria um valor intrínseco ou de existência, mesmo que nenhum uso corrente ou potencial pudesse ser atribuído às suas águas.

- Conflitos de usos da água - no passado as pequenas necessidades hídricas podiam ser atendidas pelas disponibilidades naturais sem maiores investimentos que aqueles necessários para a captação da água. O desenvolvimento econômico foi mais 
intenso nas regiões de relativa abundância de água. O aumento populacional e o próprio desenvolvimento econômico acabaram por reduzir as disponibilidades em alguns locais e por tornar atraentes outras regiões carentes de água, exigindo maiores investimentos para obtê-las. A sociedade moderna ampliou consideravelmente a diversidade de usos das águas. O quadro tornou-se complexo com o aparecimento de demandas conflitantes. Nas regiões industrializadas, de exploração mineral e de concentração populacional, ocorre a degradação das águas estabelecendo conflitos com usuários que necessitam condições qualitativas melhores. Os conflitos de uso das águas podem ser classificados como:

- Conflitos de destinação de uso: esta situação ocorre quando a água é utilizada para destinações outras que não aquelas estabelecidas por decisões políticas, fundamentadas ou não em anseios sociais, que as reservariam para o atendimento de necessidades sociais, ambientais e econômicas; por exemplo, a retirada de água de reservas ecológicas para irrigação.

- Conflitos de disponibilidade qualitativa: situação típica de uso em corpos de água poluídos. Existe um aspecto vicioso nestes conflitos pois o consumo excessivo reduz a vazão de estiagem deteriorando a qualidade das águas já comprometidas pelo lançamento de poluentes. Esta deterioração por sua vez, torna a água ainda mais inadequada para consumo.

- Conflitos de disponibilidade quantitativa: situação decorrente do esgotamento da disponibilidade quantitativa devido ao uso intensivo. Exemplo deste conflito ocorre quando o uso intensivo de água para irrigação impede outro usuário de captá-la, ocasionando em alguns casos esgotamentos de reservas hídricas. Este conflito pode ocorrer também entre dois usos não-consuntivos: operação de hidrelétrica estabelecendo flutuações nos níveis de água e acarretando prejuízos à navegação.

Em conjunto com esses conflitos ocorrem incrementos das demandas hídricas devido ao aumento populacional, agravando o problema de abastecimento, particularmente nas regiões semi-áridas. 
O uso múltiplo das águas pode ser uma opção inicial, mas é também uma conseqüência natural do desenvolvimento econômico. A integração harmônica destes usos é a opção existente e que tem como alternativa conflitos entre usuários.

As alterações apresentadas no recurso água, devido ao seu uso para navegação fluvial, muitas vezes fazem parte da: morfologia fluvial, ação das ondas devido ao vento e muitas vezes da ação das marés, e não do uso d'água, como se procura fazer acreditar, inviabilizando a utilização desse recurso de forma sustentável.

Verifica-se, então, o quão importante é definir quais são as alterações devido exclusivamente ao uso d'água para navegação interior e, as alterações devido, a por exemplo, especificamente a morfologia fluvial.

A partir do exposto, nesta pesquisa, passamos a identificar os impactos ambientais, nas várias porções do meio ambiente, devido ao uso d'água para navegação interior ( hidrovias ), bem como as alterações que ocorrem nesse meio devido a morfologia fluvial.

\subsubsection{IDENTIFICAÇÃO DOS IMPACTOS AMBIENTAIS, POR “AMBIENTALISTAS, ESPECIALISTAS E PESQUISADORES”, DEVIDO A HIDROVIA.}

Os impactos ambientais, apresentado nesta parte da pesquisa, no recurso água, foram identificados nos seguintes trabalhos:

- VIANA, Gilney (2001). A polêmica sobre a hidrovia Paraguai-Paraná e o Porto de Morrinhos. Capítulo 5; item 5.1. Retrato da Navegação no alto Rio Paraguai, de autoria da ONG World Wildlife Fund. Capítulo 6. Textos básicos sobre o rio Paraguai, Hidrovia e Pantanal; item 6.1. Pantanal mato-grossense: bases ecológicas para a análise e discussão dos impactos ambientais do projeto hidrovia ParaguaiParaná, de autoria da Dra. Carolina Joana da Silva. 
- BUCHER, Enrique H., BONETTO, Argentino, BOYLE, Terence, et al. (1994). Hidrovia: Análise ambiental inicial da via fluvial Paraguai-Paraná. Humedales para Las Américas, Manomet, Massachusets, USA e Buenos Aires, Argentina.

- CAMARGO JUNIOR, Antonio. (2000). Sistema de gestão ambiental em terminais hidroviários e comboios fluviais: contribuições para o desenvolvimento sustentável na hidrovia Tietê-Paraná. Rio Claro/SP. (Tese de doutorado. Instituto de Geociências e Ciências Exatas da Universidade Estadual Paulista/UNESP).

IBC International Business Communications. (2001). $1^{o}$ Fórum Nacional Impacto ambiental na implantação de hidrovias no Brasil. São Paulo.

\subsubsection{O Termo Ambientalista}

Nos trabalhos científicos, alguns termos referentes aos sujeitos de pesquisa, já, são consagrados, entre eles podemos destacar: especialistas e pesquisadores. Entendendo-se por:

Especialista - Segundo Ferreira (1986), é a "pessoa" que se consagra com particular interesse e cuidado a certo assunto.

- Pesquisador - Segundo Ferreira (1986), que ou aquele que desenvolve investigação e estudo, minudentes e sistemáticos, com o fim de descobrir ou estabelecer fatos ou princípios relativos a um campo qualquer do conhecimento.

A evolução do homem, traz consigo novos termos para a identificação de “pessoas”, que segundo Carvalho (1981), exageram na preocupação de manter a preservação da intangibilidade dos ambientes naturais, enunciadas, então, como Ambientalistas. 


\subsubsection{Obras Hidroviárias para a Implantação da Hidrovia.}

$\mathrm{Na}$ implantação de uma hidrovia de fluxo livre, as obras hidroviárias contribuem para o aparecimento e evolução, dos seguintes impactos ambientais, de acordo com Camargo Júnior (2000):

- Desequilíbrio fluvial, traduzido no aumento das taxas de assoreamento em trechos significativos do rio, como por exemplo pode ser citada a Hidrovia Tocantins - Araguaia.

- O aporte de sedimentos é proveniente da erosão gerada pela remoção da cobertura vegetal e pela movimentação de solo, aleatória, nas margens do rio em que se pretende implantar a obra.

- Em hidrovias de fluxo confinado, como a Hidrovia Tietê - Paraná, a construção de barragens e eclusas promove alteração dinâmica das vertentes marginais do lago formado, recuando-as e causando a incisão dos rios, com a inexorável intensificação de processos erosivos, até que a dinâmica superficial reencontre seu ponto de equilíbrio.

- A navegabilidade torna-se restrita nas desembocaduras dos cursos d'água tributários, uma vez que a rede de drenagem continua sendo a principal fonte de aporte de sedimentos.

- Independentemente de sazonalidades, a combinação de um delicado equilíbrio da dinâmica fluvial, com os efeitos deletérios do uso e ocupação da zona lindeira, sobre um solo e rocha extremamente susceptíveis à erosão, causa desafio a capacidade de planejamento dos órgãos gestores da hidrovia. A medida que o assoreamento se torne incontrolável e irreversível, poderá ocorrer o colapso da navegação.

5.2.7.2.1. Dragagem de Sedimentos - Impactos Ambientais, segundo Silva (2001) apud Viana (2001) 
- Perda de qualidade visual de unidades de paisagem; substituição de unidades de maior diversidade por outras de menor diversidade.

- Aumento na velocidade do fluxo das águas, alteração dinâmica do pulso de inundação, perda de ecossistemas como baías vazantes, corixos, em função do abaixamento do nível d'água, remoção de substâncias tóxicas do sedimento para a coluna d'água, deterioração da qualidade d'água, diminuição da produtividade de algas.

- Contaminação das redes alimentares, destruição de hábitats da fauna bentônica, diminuição da complexidade das redes alimentares; aumento da mortandade de peixes por asfixia e intoxicação; perda da diversidade de espécies de fitoplâncton, bentos e peixes; decréscimo na densidade de organismos aquáticos.

- Além do aprofundamento do canal, a remoção do material pode alterar a composição e o tamanho da partícula do material do leito.

- A turbidez e os sólidos em suspensão aumentarão devido à perturbação do fundo e a maior velocidade da corrente durante e após a dragagem. Qualquer mudança na velocidade e turbidez, causada pela dragagem ou passagem de comboios de chatas, poderá reduzir o hábitat disponível para alguns grupos de espécies.

5.2.7.2.2. Corte de Meandro - Impactos Ambientais, segundo Silva (2001) apud Viana (2001)

- Aumento da erosão e da velocidade do fluxo das águas;

- Destruição de hábitats;

- Modificações nas rotas de migração de peixes.

\subsection{Balizamento - Impactos Ambientais}

- Impacto positivo no ordenamento e na segurança da navegação atual. (Silva, 2001). 
5.2.7.2.4. Deposição do Material Dragado - Impactos Ambientais, segundo Silva (2001) apud Viana (2001)

- Aumento do material em suspensão;

- Perda de hábitats;

- Existem várias possibilidades de que ocorram diferentes impactos, dependendo do material dragado ser descarregado na água, numa praia próxima ou embarcado para outra localidade. As principais são:

- Se o material dragado volta a ser lançado ao rio é possível que ocorra uma série de impactos secundários similares aos que resultam da ressuspensão do material durante a dragagem.

O material dragado depositado, linearmente, ao longo do canal principal, poderá resultar numa margem emersa. A margem emersa resultante poderá ser ocupada por assentamentos humanos, sem nenhum controle ou planejamento prévio.

5.2.7.2.5. Preenchimento de Curvas - Impactos Ambientais, segundo Silva (2001) apud Viana (2001)

- Aumento da velocidade do fluxo das águas;

- Destruição dos hábitats.

5.2.7.2.6. Derrocamento (Remoção de Rochas) - Impactos Ambientais, segundo Silva (2001) apud Viana (2001)

- Aumento na velocidade do fluxo das águas;

- Diminuição da fase aquática e aumento da fase terrestre das áreas inundáveis;

- Diminuição da disponibilidade de água para consumo e atividades econômicas; 
- Ampliação dos efeitos da concentração/diluição de nutrientes, aumento da exportação da biomassa e nutrientes, aumento de material em suspensão e resíduos sólidos na coluna d’água, decréscimo da produtividade de fitoplânctonica.

5.2.7.2.7. Estruturas para a Manutenção de Canais - Impactos Ambientais, segundo Bucher et al. (1994)

Os diques emergentes, submersos e muros de contenção das barrancas, são estruturas físicas construídas para manter a profundidade dos canais. A construção de tais estruturas causa a alteração do hábitat, alteração da vegetação das margens do rio, cria áreas de alta velocidade d'água bem como remansos localizados com baixa velocidade. Em muitos locais o canal principal poderá se dividir em um ou em vários canais secundários anastomosados. A descarga e a profundidade do canal navegável, podem ser incrementados mediante o fechamento de alguns dos sub-canais no local em que se separam do canal principal. O fechamento desses canais laterais poderia alterar de modo severo as áreas úmidas as quais alimentam.

A construção do canal e as operações de manutenção da limpeza e remoção de troncos, simplificam, em grande medida a estrutura física e a complexidade do hábitat do canal. Estas operações incluem a remoção de estruturas que retém entulhos orgânicos, que propiciam tanto o hábitat para os organismos aquáticos como retém a matéria orgânica, que é por eles processada.

5.2.7.2.8. Estruturas para Controle D’água - Impactos Ambientais, segundo Bucher et al. (1994)

O conjunto dos impactos que resultam da construção de estruturas de controle d'água, são similares aos causados pela dragagem: a suspensão de sedimentos e uma série de produtos químicos industriais associados à preparação e manejo do local 
(assim como da própria construção). Estas substâncias incluem petroquímicos, pesticidas, fertilizantes, metais pesados, aditivos de solo e materiais para construção.

As estruturas para controle d'água, podem alterar o regime hídrico de várias formas, tais como: retardando a descarga natural do rio, inundando os remansos e criando condições de ambientes inundáveis mais permanentes (U.S.Army Corps of Engineers, 1978). Outro impacto físico é causado pela eclusa de navegação que permite a passagem de uma embarcação mediante a criação de uma área localizada onde se verifica uma flutuação de velocidade d'água relativamente alta. Além disso, as eclusas de navegação podem impedir a passagem de peixes.

5.2.7.2.9. Portos e Terminais - Impactos Ambientais, segundo Bucher et al. (1994)

Os impactos associados à construção de terminais variam dependendo do local específico e dos tipos de mercadorias embarcados e/ou desembarcados no local. Usualmente, as áreas úmidas são aterradas convertendo o hábitat de áreas úmidas em hábitat terrestre urbanizado. Ocorrerão impactos se forem necessárias dragagens para permitir o acesso das naves. Tais impactos podem incluir mudanças na qualidade d'água, perda de hábitat aquático raso, perda de bentos e perda de hábitat no local de deposição do material dragado.

A construção e operação de terminais, quando realizadas junto aos canais laterais, provocam um aumento no tráfego de naves.

A qualidade d'água pode ser afetada pela construção e operação dos terminais através de:

- Erosão durante a construção;

- Contaminação pela erosão do material da dragagem sedimentado no leito do rio, o qual pode conter substâncias contaminantes;

- Derramamentos acidentais das naves nas vizinhanças do porto e terminais, devido a colisões ou naufrágios. 
De acordo com Camargo Júnior (2000), o principal sentido em se atribuir a terminais hidroviários uma função de elo entre o modal de transporte e o desenvolvimento regional, reside no fato de que há uma tendência expontânea e intrínseca à atividade hidroviária de agregar armazéns e unidades de transformação e beneficiamento nas suas áreas anteriores ou retro-porto, gerando verdadeiros distritos industriais. A combinação de diversos terminais integrados ao florescente distrito industrial forma o pólo hidroviário industrial. Este induz a instalação de empresas prestadoras de serviços no seu entorno, como restaurantes industriais, empresas de segurança, de processamento de dados, postos de gasolina, etc. Ver Figuras 19, 20 e 21.

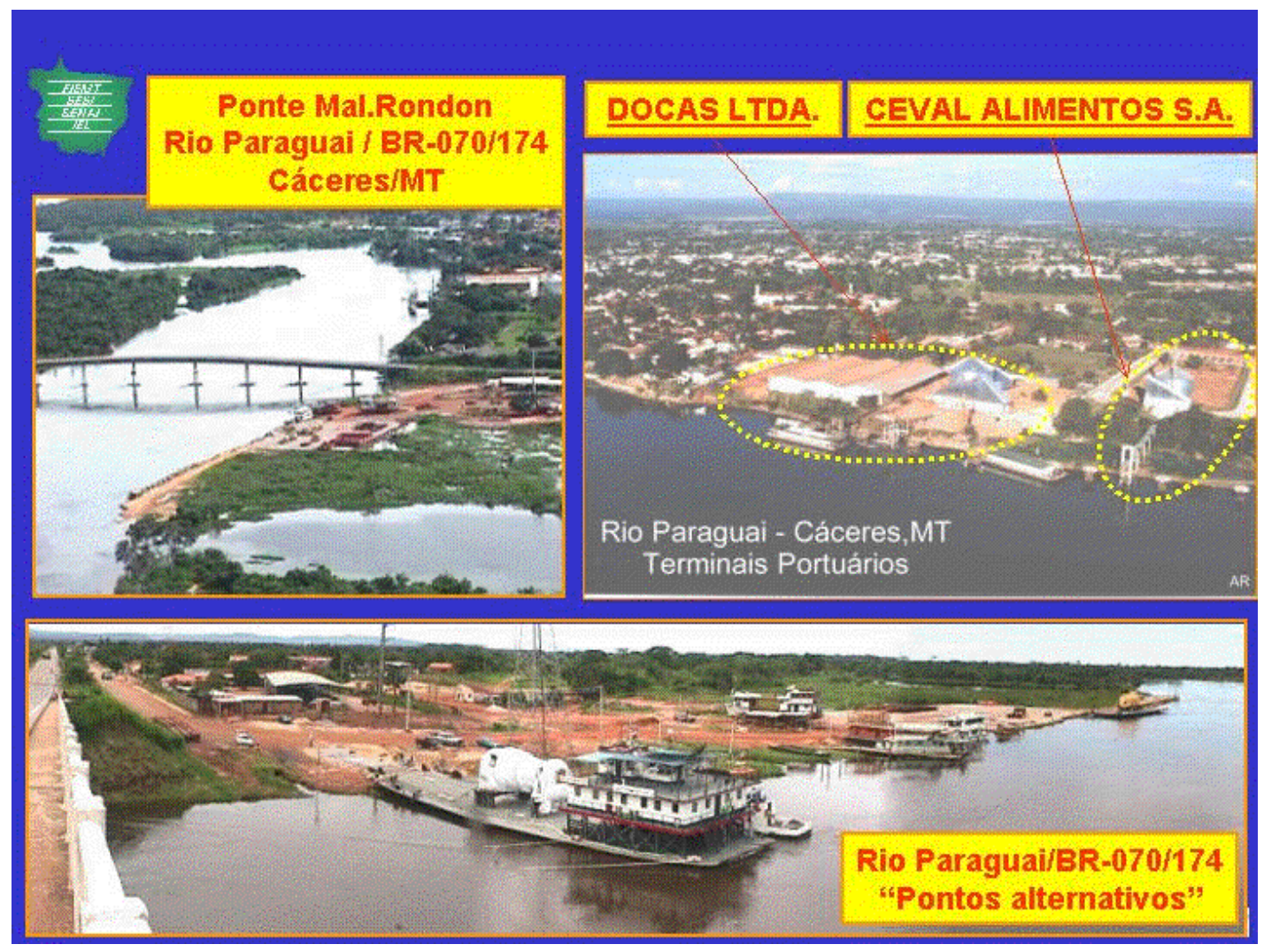

Figura 19 - Impacto Ambiental: Implantação de um terminal hidroviário acompanhado do desenvolvimento regional.

Fonte: http://www.caceres.com.br/adilsonreis 


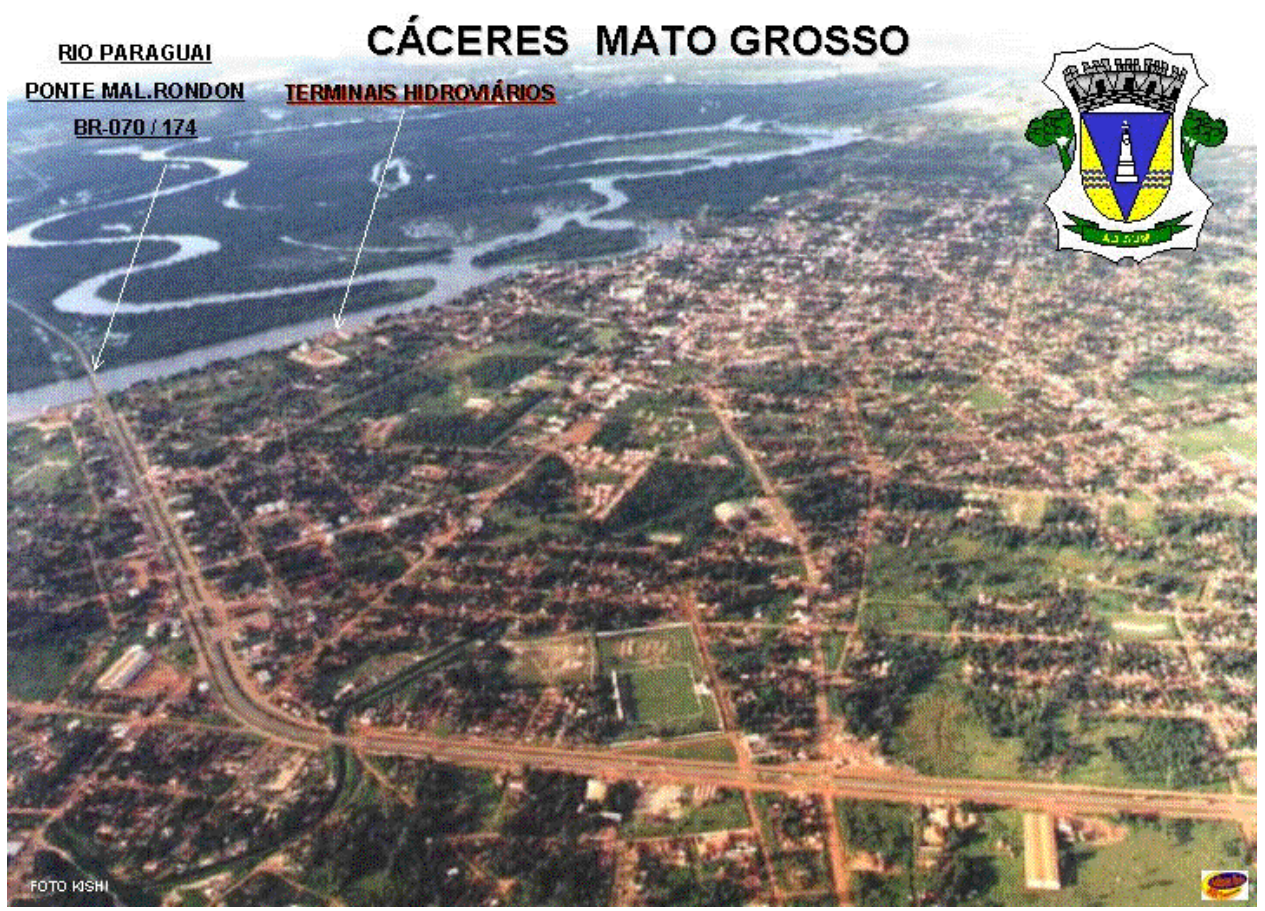

Figura 20 - Impacto Ambiental : Terminais hidroviários integrados e a formação de um polo hidroviário industrial.

Fonte: http://www.caceres.com.br/adilsonreis

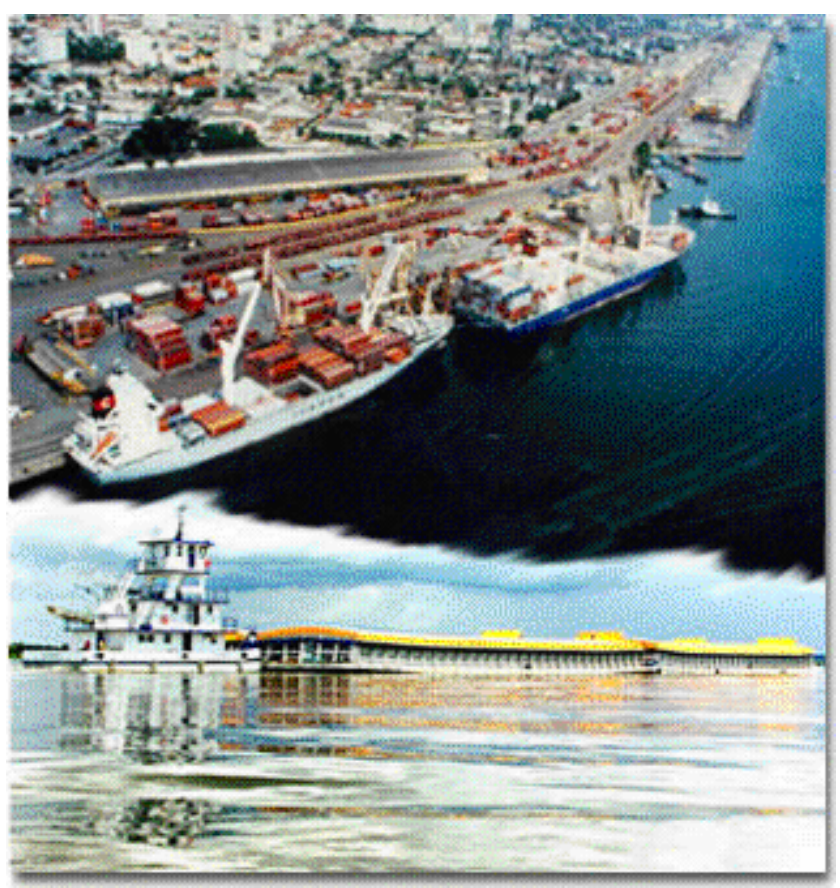

Figura 21 - Impacto Ambiental : Pólo hidroviário industrial

Fonte: http://www.transportes.gov.br 


\subsubsection{Tráfego de Comboios de Chatas - Impactos Ambientais}

Todos os hábitats aquáticos são impactados pelo tráfego de comboios de chatas (Bucher et al., 1994)

Existe uma série de fatores associados à passagem de embarcações que impactam o ambiente físico e a biota. A magnitude do impacto, depende do tamanho, velocidade e freqüência da passagem de tais embarcações, bem como do tamanho relativo do canal de navegação (Bucher et al.,1994)

O movimento dos comboios de chatas contribuem para a redistribuição dos sedimentos ao causar uma movimentação adicional de sedimentos no canal principal, nos canais laterais e remansos, segundo Bhowmik et al. (1981) apud BUCHER et al. (1994) demonstram que o rastro provocado pela passagem de embarcações suspende os sedimentos nas margens do canal e os depositam no canal de navegação, além de alterar de forma significativa a velocidade d'água. O aumento da velocidade se deve, fundamentalmente, à passagem do casco submerso da chata e à ação das hélices do rebocador. As mudanças de velocidades, tanto atrás como lateralmente, causam turbulência (Bucher et al., 1994)

A operação do rebocador pode gerar vários tipos adicionais de impactos físicos diretos, sendo o arrasto de organismos em direção às hélices, o aspecto de maior importância (Bucher et al., 1994)

Dependendo da profundidade do canal, a passagem dos comboios de chatas, pode criar velocidade suficiente para mobilizar substrato de grande tamanho, como cascalho, o que pode erodir o canal (Bucher et al., 1994)

As matas ciliares ao longo do rio, são destruídas por ação dos comboios de empurra, principalmente nas curvas. Como exemplo desta destruição, podemos citar os $100 \mathrm{~km}$ de matas ciliares do rio Paraguai, segundo WWF (2001) apud Viana (2001). Ver Figura 22.

Os efeitos provocados pelos barcos tipo "voadeiras" ( são embarcações pequenas e rápidas que provocam ondas de alta freqüência e energia, junto às margens, acabando por favorecer a desagregação das partículas nos limites da lâmina 
de água com os barrancos ), somam-se àqueles causadas pelas embarcações de carga, comboios, tornando as margens côncavas ainda mais suscetíveis à erosão e, como conseqüência temos o assoreamento do rio. Exemplo do descrito, ocorre no rio Paraguai, segundo WWF (2001) apud Viana (2001).

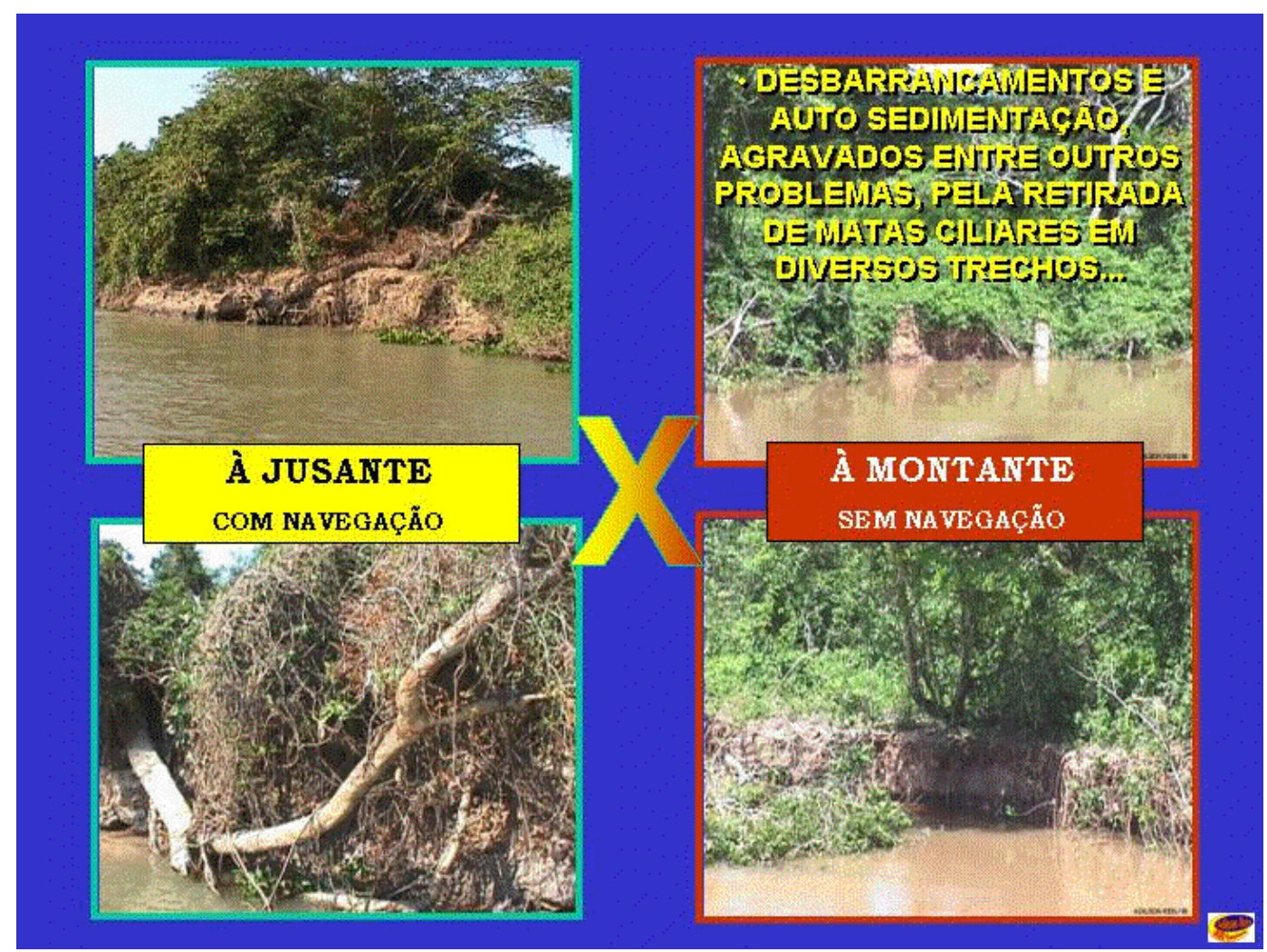

Figura 22 - Impacto Ambiental : Destruição da vegetação ciliar.

Fonte: http://www.caceres.com.br/adilsonreis

Em trechos, onde o rio apresenta aumento significativo da largura observamse locais degradados pelo embate das embarcações. Essas áreas são mais freqüentes nas curvas, o que pode indicar o uso das margens côncavas como elemento auxiliar de manobras de comboios. O que se tem verificado, é a utilização das margens como "guia" para que os comboios possam realizar suas manobras, segundo WWF (2001) apud Viana (2001). Ver Figura 23. 
A destruição de estruturas arqueológicas ou de material arqueológico ou mesmo a descontextualização dos mesmos, representa perda de informações que, uma vez ocorrida, não há forma de recuperação ou resgate. As recorrentes colisões das barcaças utilizadas no transporte de carga e que são tradicionais em comboio por um empurrador, desmontam os barrancos e removem trechos da mata ciliar, destruindo tais sítios, segundo WWF (2001) apud Viana (2001).

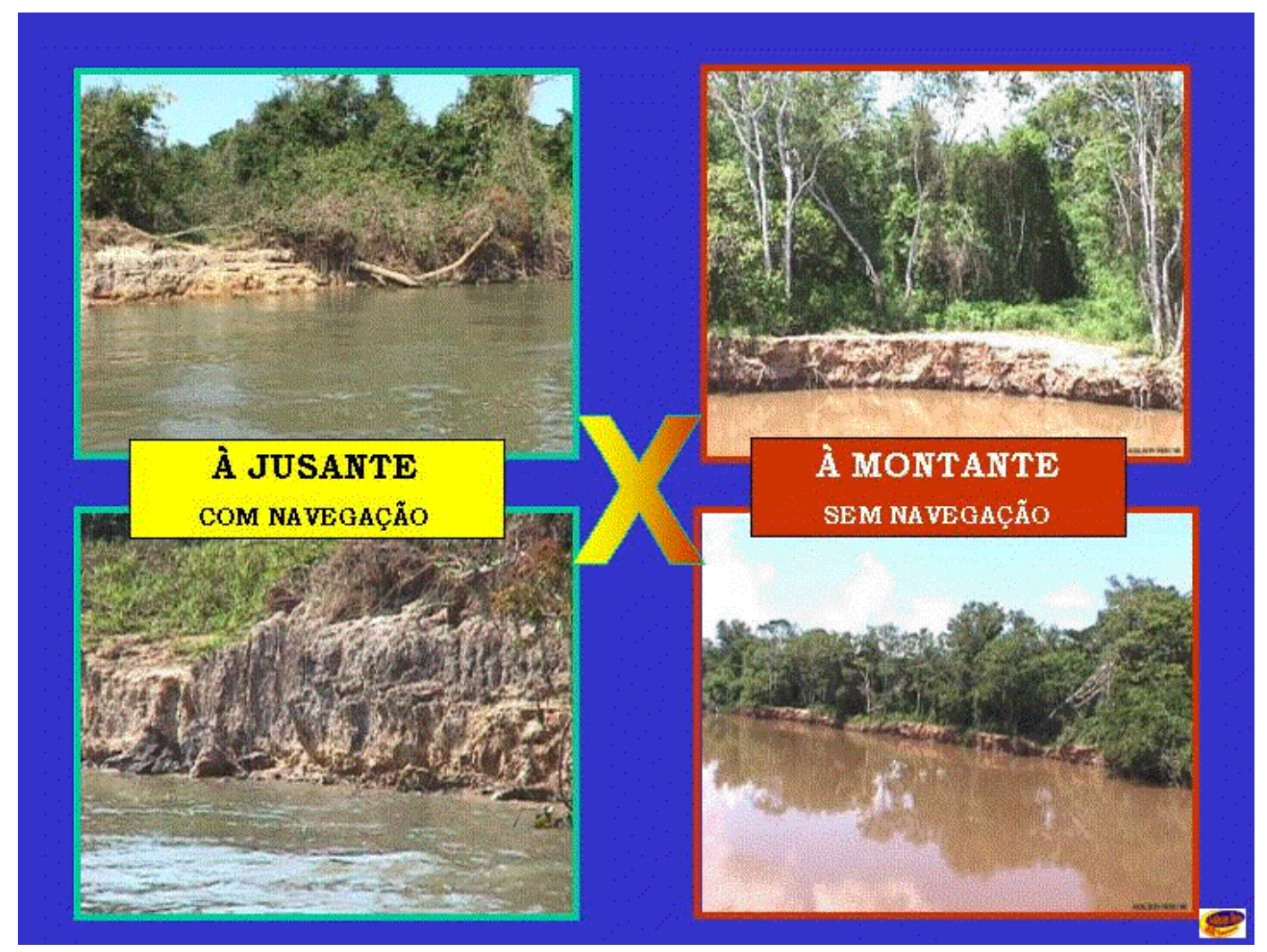

Figura 23 - Impacto Ambiental : Locais degradados pelo embate das embarcações.

Fonte: http://www.caceres.com.br/adilsonreis

5.2.7.3.1. Suspensão e Deposição de Sedimentos - Impactos Ambientais, segundo Bucher et al. (1994) 
Os aumentos de velocidade causados pelos movimentos das embarcações removem os sedimentos do fundo, aumentando assim a carga de sedimentos em suspensão. Uma alta sinuosidade, margens erodíveis, pequena profundidade e sedimentos de fundo particularmente finos, favorecem a ressuspensão de sedimentos, segundo Simons et al. (1981) apud Bucher et al. (1994). Os canais mais rasos, são mais suscetíveis à turbulência induzida pelas embarcações do que os canais maiores e profundos.

A deposição de sedimentos degrada e destroi os hábitats dos remansos e bordas do canal principal ao diminuir a profundidade e, em alguns casos, alterar os substratos de modo adverso reduzindo desta forma a aptidão para o crescimento de plantas, organismos bentônicos, etc.

Os sedimentos em suspensão provenientes de várias fontes, incluindo a navegação fluvial, sedimentam em canais laterais e águas calmas. A sedimentação, tem produzido praias que são utilizadas para a alimentação, por aves limícolas e plantas de solos úmidos que colonizam ou são semeadas sobre as praias barrentas.

O aumento da sedimentação resultante do aumento dos sólidos em suspensão, tem importância mesmo a grandes distâncias das fontes.

\subsubsection{Acidentes e Encalhes - Impactos Ambientais, segundo Bucher et al. (1994)}

Os acidentes e encalhes estão destinados a acontecer numa via fluvial dado um certo tempo e um certo nível de tráfego. Os derramamentos acidentais de materiais tóxicos ou perigosos, originados pelo movimento das chatas nos lugares de fretagem ou nos terminais, podem causar danos significativos ao meio ambiente. $\mathrm{O}$ incremento nos níveis de tráfego de chatas, obviamente, aumentará a probabilidade de acidentes.

Os derramamentos de substâncias tóxicas, tais como, o petróleo e seus derivados, fertilizantes (especialmente amoníaco) e substâncias químicas industriais são os que, provavelmente, terão impactos mais sérios. 


\subsubsection{Ondas e/ou Maior Velocidade do Fluxo de Água - Impactos} Ambientais, segundo Bucher et al.(1994)

A ação das ondas e/ou maior velocidade do fluxo d'água aceleram a erosão das margens em áreas estáveis e desprotegidas. Ver Figura 24

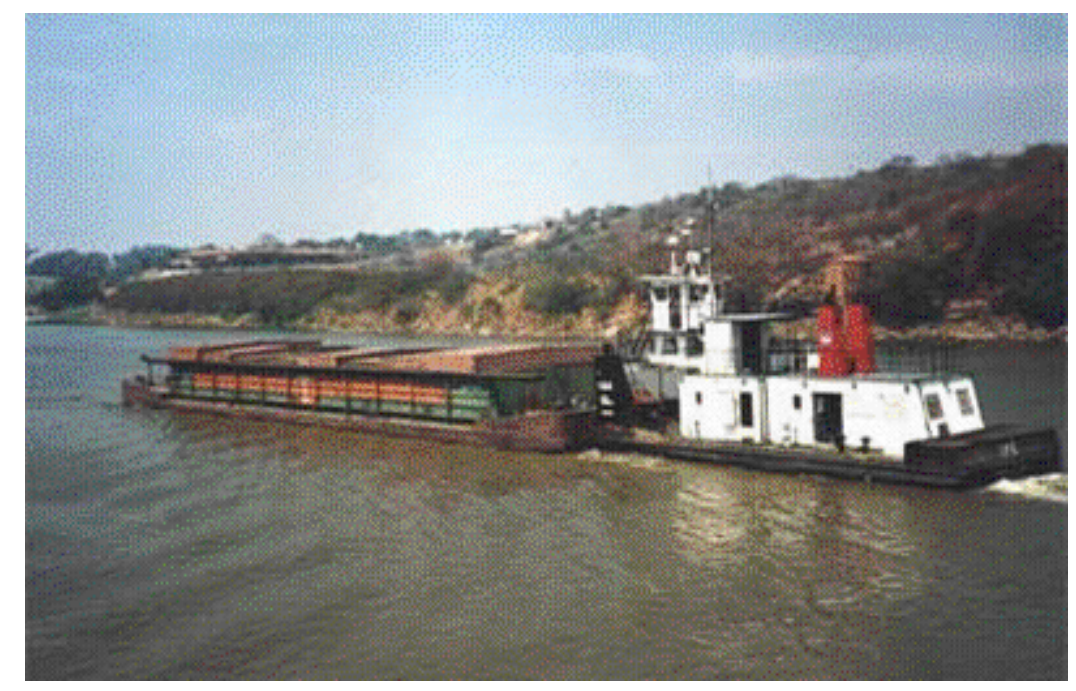

Figura 24 - Impacto Ambiental : Formação de ondas com o tráfego de embarcações. Fonte: http://www.cinconav.com.br

As ondas, de qualquer origem, incluindo aquelas geradas pelos comboios de chatas, erodem as margens, contribuindo para maiores níveis de sedimentos em suspensão e turbidez próximo das margens. A taxa deste impacto é uma característica específica do local e, geralmente, desconhecida. Onde quer que existam problemas de erosão, é muito provável que, com o aumento no tráfego de embarcações, eles se tornem mais pronunciados.

A erosão das margens, leva, finalmente, a perda de vegetação terrestre. Esta vegetação auxilia na estabilização da margem e também proporciona hábitat para a vida silvestre. Se a margem é íngreme, as ondas que a alcançam podem subir ou chocar-se contra ela dependendo da inclinação. 
Segundo Gates \& Herbich (1977); Balanin \& Bykov (1975); Stelczer (1981), apud Bucher et al.(1994), observaram que as ondas geradas por rastros eram suficientemente importantes de modo a causar erosão das margens, ao longo dos canais de navegação.

\subsubsection{Alterações na Qualidade da Água}

Em geral o tráfego de embarcações afeta a qualidade da água. Os sedimentos são contaminantes de grande importância e têm um papel crucial na determinação da qualidade da água ao transportar ou armazenar vários contaminantes químicos e afetar a turbidez e as concentrações de oxigênio dissolvido. Qualquer impacto da navegação sobre a sedimentação implica, portanto, numa correspondente alteração na qualidade da água, segundo Lubinski et al. (1981) apud Bucher et al. (1994). Tanto as partículas depositadas como as em suspensão proporcionam uma grande superfície de contato, permitindo que os contaminantes solúveis, tais como chumbo, mercúrio, cádmio, níquel e arsênico fiquem aderidos à superfície da partícula através de trocas iônicas, segundo Lubinski et al. (1981) apud Bucher et al. (1994).

Pode-se esperar um aumento da contaminação como resultado de um incremento dos resíduos urbanos e industriais, a operação regular dos barcos e os derramamentos acidentais. A contaminação da água proveniente dos resíduos dos barcos e a limpeza das chatas constitui outra fonte potencial de contaminação. (Bucher et al., 1994)

A liberação acidental de grandes quantidades de substâncias químicas tóxicas no sistema aquático constitui-se numa ameaça de grande magnitude para os recursos naturais e a saúde humana. Em 1980, uma chata carregada com pentaclorofenol, afundou no rio Mississipi, causando grande mortandade de peixes, segundo Delaume et al. (1983) apud Bucher et al. (1994). Somada aos derramamentos massivos catastróficos, haverá uma extensa contaminação da água associada às descargas provenientes dos navios, às atividades terrestres associadas ao transporte e ás várias 
mudanças no uso do solo induzidas pela construção da via fluvial. (Bucher et al., 1994) 


\subsection{VARIÁVEL CONTROLADA}

\subsubsection{MORFOLOGIA FLUVIAL}

A ausência de conhecimento dos princípios gerais regendo os cursos d'água, tem resultado muitas vezes em obras contraproducentes, daí a necessidade de primeiro entender o RIO, e posteriormente escolher a obra adequada à melhoria das condições de navegabilidade. Atendendo a este fim, é necessário que se tenha conhecimento da morfologia fluvial.

A morfologia fluvial, é definida como sendo o estudo da conformação dos leitos dos cursos d'água que evoluem livremente, no solo escavado ou sobre os depósitos sedimentares, resultante da deposição de sedimentos por eles transportados.

Os cursos d'água; a que nos referimos no parágrafo acima, são definidos como rios, apresentando como partes constituintes: o curso d'água ou o volume do próprio líquido corrente; o leito ou álveo e as margens. Essa definição das partes que constituem um rio, tem importância fundamental ao se tratar a condição jurídica dos rios, segundo Müller (1995).

O estudo dos cursos d'água, naturais ou artificiais, é realizado pela hidráulica fluvial, área específica dentro da morfologia fluvial.

Os cursos de água podem ser comparados a "Elementos Vivos", nos quais a largura, o traçado e a profundidade evoluem regidos por leis bem definidas, porém muitas vezes difíceis de serem equacionadas.

As leis definidas e equacionadas para um determinado curso de água, de maneira geral não podem ser extrapoladas para outros cursos de água, porque seus parâmetros característicos são diferentes e podem variar no tempo e no espaço, são eles:

Bacia Hidrográfica: forma; topografia; geologia; recobrimento vegetal; regime hidrológico, etc.;

Leito: traçado; largura; profundidade; rugosidade, etc.; 
Transporte de Sedimentos: por arraste de fundo (carreagem); por suspensão; por saltitação; características dos sedimentos;

Regime de Vazões.

O equilíbrio atingido lentamente pelo rio ao longo dos séculos, pode ser rompido de várias formas, desde uma atuação direta no seu leito como indireta na bacia.

Esse equilíbrio que exigiu tantos anos para ser atingido pode ser rompido num pequeno espaço de tempo. São exemplos: alterações de recobrimento da bacia hidrográfica; construção de barragens ( Assuan no Rio Nilo ).

A execução de obras que visam a estabilidade ou melhoria de um curso de água, exigem o conhecimento das Leis que regem o seu equilíbrio ou a sua evolução.

O Engenheiro, deve se esforçar para conhecer e utilizar estas Leis em seu proveito ao invés de procurar conter ou combater a natureza, quando são necessárias obras.

\subsubsection{Evolução de um Rio}

Uma parte das águas precipitadas, rolando desordenadamente a princípio, sobre a superfície da terra (águas livres), reúnem-se aos poucos para formar as torrentes, que concentrando-se por sua vez, ao longo dos talvegues, formavam os rios, trabalhando continuamente o modelado da litosfera, no sentido do aplainamento geral da superfície, pelo desgaste das elevações e aterro das depressões, até um certo limite final, em que a força erosiva da corrente em cada ponto tornando-se igual à resistência do terreno, haja atingido um estado de equilíbrio no perfil do rio.

Os rios são formados por leitos tortuosos com seções irregulares; através do tempo, mudam sua forma e percurso, devido ao fenômeno da erosão e assoreamento, que são funções direta da altura da lâmina e da velocidade das águas e dos sedimentos transportados. 
Até William Morris Davis, admitiam-se os rios como elementos estáveis da crosta terrestre. Esse ilustre geógrafo americano, demonstrou o contrário, isto é, os rios sofrem uma evolução natural, que ele comparou com muita propriedade, à evolução dos seres vivos, chamando de Ciclo Vital dos Rios, a sucessão de fases pelas quais um rio, como um indivíduo, passa da sua mocidade à velhice e decrepitude, atravessa a fase áurea e construtiva da maturidade.

Morris comparou a mocidade, a primeira fase, tumultuária, em que as águas antes de fixar definitivamente o talvegue em que devem correr, escavam desordenadamente o terreno, formando depósitos que serão carreados nas cheias posteriores, até que, fixado definitivamente o leito, aos regimes torrenciais se vão substituindo os regimes calmos permanentes. O rio trabalha então o seu perfil, procurando atingir a curva de equilíbrio; não se notam mais desmoronamentos e nem as modificações bruscas.

É o trabalho construtivo da maturidade que dura até ser alcançado o perfil de equilíbrio. Continuando o processo, a matéria sólida transportada principalmente pelos afluentes que não atingiram ainda o seu perfil definitivo, se vai depositando na parte baixa dos cursos, formando as grandes várzeas de sedimentação, ao longo das quais o rio, sem declividade, perde suas energias e, incapaz de manter um traçado próprio, divaga ao sabor dos menores obstáculo.

É a fase da velhice da decrepitude que, como as demais, avança de jusante para montante até a morte dos rios, quando pela migração indefinida das linhas de partilha, se confundem as bacias, e os sistemas orográficos se transformando numa rede de canais. A concretização desta fase necessita de tempo, isto é, vários séculos.

Entenderemos nesta tese, que a evolução de um rio, apresenta três fases distintas, quais sejam: formação; modelação e estabilidade (equilíbrio).

\subsection{Formação}

É o início do curso d'água e, a definição de sua bacia hidrográfica. A formação compreende: 
Escoamento das águas pluviais para as linhas de maior declive (talvegues);

- Predominância da erosão e abrasão, com aprofundamento do leito e assoreamento.

\subsection{Modelação}

É a tendência ao equilíbrio. É a fase propriamente dita da formação do curso de água.

Nesta evolução surgem os "Pontos Fixos" que são denominados "Níveis de Base" . A alteração dos "Níveis de Base", pode provocar o reinicio da modelação.

Na modelação, temos o encontro dos seguintes efeitos:

Ação - do escoamento;

Reação - do material do leito.

Os princípios que regem a Modelação dos cursos d'água, são os seguintes:

- Princípio da Saturação: um curso d'água com uma vazão líquida “Q $Q_{a}$ ”, tendo a capacidade de transportar uma certa vazão sólida máxima " $\mathrm{Q}_{\mathrm{sm}}$ " e, recebendo numa seção, uma vazão “Q", terá:

- Assoreamento de parte do material (sedimentação),

$\mathrm{Se}$ "Q $\mathrm{Q}_{\mathrm{s}}$ " > "Q $\mathrm{sm}$ ";

- Equilíbrio, se "Q $\mathrm{Q}_{\mathrm{s}}$ " $=$ "Q $\mathrm{Q}_{\mathrm{sm}}$ ";

- Erosão ou Seleção do material:

Se "Q ${ }_{\mathrm{s}} " \quad<$ "Q $\mathrm{Qsm}$ " (tendência), se o material do leito permitir, ocorrem: erosão; diminuição da declividade; e formação de meandros $(i \cong 0,1 \mathrm{~m} / \mathrm{km})$.

Sendo " $\mathrm{Q}_{\text {sm }}$ ", , função da vazão líquida “Q $\mathrm{Q}_{\mathrm{a}}$ ”, e dos parâmetros característicos do trecho: $\mathrm{i} ; \mathrm{R}_{\mathrm{H}} ; \mathrm{d} ; \eta$, etc. 
- Princípio das Declividades: para uma determinada vazão líquida, a declividade de equilíbrio é tanto maior, quanto maior for a "turbidez" d'água ( "Q $\mathrm{Q}_{s}$ " " $\mathrm{Q}_{\mathrm{a}}$ ”) e menores forem $\mathrm{C}$ (curvatura) e $\mathrm{R}_{\mathrm{H}}$; teremos:

$\mathrm{Se}$ "Q $\mathrm{Q}_{\mathrm{s}}$ " > "Q $\mathrm{\text {sm}}$ "; haverá assoreamento e aumento da declividade. Leitos retilíneos $\mathrm{i} \cong 0,5 \mathrm{~m} / \mathrm{km}$ a $0,6 \mathrm{~m} / \mathrm{km}$, para mais.

- Princípio da Seleção: existindo condições de sedimentação, esta se inicia com os materiais maiores ( mais graduados - maior diâmetro ); a erosão se inicia ao contrário, com os materiais mais finos;

น Se numa seção chegar material com granulometria maior que a existente, estes passam a ser substituídos por quantidades iguais de material mais fino.Portanto, alcançado o equilíbrio observa-se:

As declividades e a granulometria decrescem de montante para jusante.

A capacidade de transporte da corrente, decresce de montante para jusante.

\subsection{Estabilidade}

É o equilíbrio entre os efeitos: Ação do escoamento e Reação do material do leito.

A tendência ao equilíbrio pode ocorrer por Erosão ou Assoreamento, sendo que a primeira é mais estável.

a) Vazão Formativa

Ao se falar sobre estabilidade de um leito, sempre se menciona um ajuste entre algumas variáveis geométricas do material do fundo e da vazão liquida que permanece constante. 
Nos canais de irrigação não revestidos pode-se chegar a ter vazões que permanecem quase constantes durante um ciclo natural e que quando variam, o fazem dentro de limites estreitos. Não ocorre o mesmo com as correntes naturais, onde a vazão sofre variações notáveis ao longo de um ano com respeito ao outro. Entretanto, em um rio aprecia-se que tenha uma largura e declividade que permaneçam quase constantes e que ao variar a vazão, o parâmetro mais afetado é a profundidade. Desta forma pode-se falar de uma VAZÃO FORMATIVA DO RIO, por comodidade, se considera representativa de todo hidrograma anual.

Alguns autores consideram como vazão formativa a vazão máxima que é capaz de escoar no leito principal sem transbordar (capacidade hidráulica máxima do leito principal). Essa definição se aplica a rios de planície, porque nos rios encaixados, esta definição não procede.

b) Tipos de Estabilidade de um Rio

- ESTABILIDADE ESTÁTICA

A estabilidade estática em um curso d'água, ocorre quando um fluxo não afeta nem o fundo e nem as margens, deste curso. Portanto, não há erosões e a forma do leito não varia com o tempo, ou só de forma inapreciável.

\section{ESTABILIDADE DINÂMICA}

A estabilidade dinâmica pressupõe que todo o fluxo escoe por uma única seção que, portanto, coincide com a definição de "canal de regime", proposto pela "Teoria de Regime". 
A estabilidade morfológica, apresenta-se nos rios que não foram modificados por fatores humanos, qualquer que seja a forma em que a vazão líquida e sólida passam por ele. Dentro dessa classificação incluem-se os rios naturais que tem estabilidade estática ou dinâmica, incluindo aqueles com ilhas, bifurcações, etc.

c) Estudo das estabilidades - Graus de Liberdade

Um escoamento pode ter um ou vários graus de liberdade dependendo das características de seus contornos.

Um grau de liberdade

Ocorre quando o fundo e as paredes são rígidas, não havendo interação entre o fluxo e a fronteira, exceção de sua rugosidade. Quando uma corrente tem um grau de liberdade, o tirante é a única incógnita, e só requer uma equação de resistência (equação do escoamento) para obtê-la. São exemplos de um grau de liberdade, canais de concreto e rios onde o escoamento não é capaz de mover nenhuma partícula do fundo ou das margens. Está associado a uma estabilidade estática. Ver figura 25.

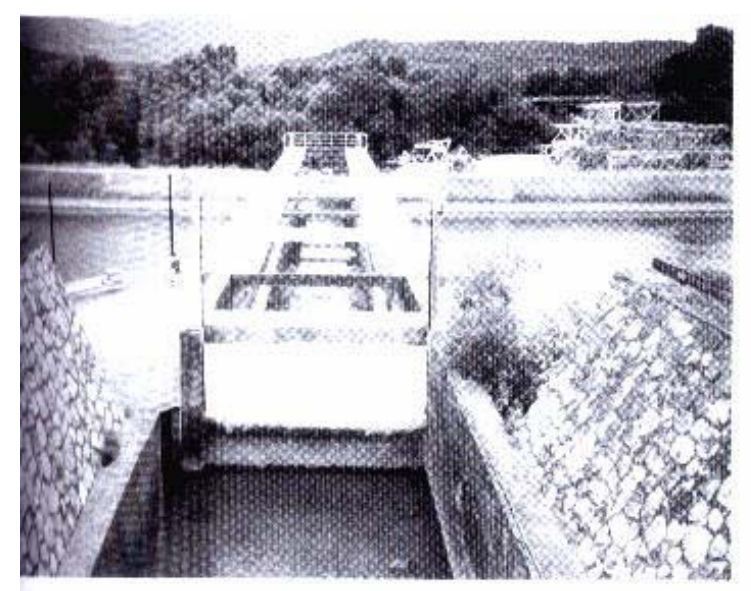

Figura 25 - Canal revestido em concreto ( Canal de la Durance, França )

Fonte: BAPTISTA; COELHO. (2002). 
Dois graus de liberdade

Ocorre quando o fundo e as paredes são rígidas, porém transporta água e sedimentos. Assim, para uma combinação da vazão líquida e da vazão sólida ajustarse-á sempre a mesma declividade e a mesma profundidade, para o qual se requer duas equações, de modo a obter-se essas variáveis, a saber: uma de resistência para o fundo móvel e uma de transporte de sedimentos.

São exemplo de dois graus de liberdade, os rio se encontram na natureza com margens muito resistentes (rios encaixados), ou ambas as margens são protegidas. Estando em equilíbrio, pode ser associado a estabilidade dinâmica. Ver figura 26.

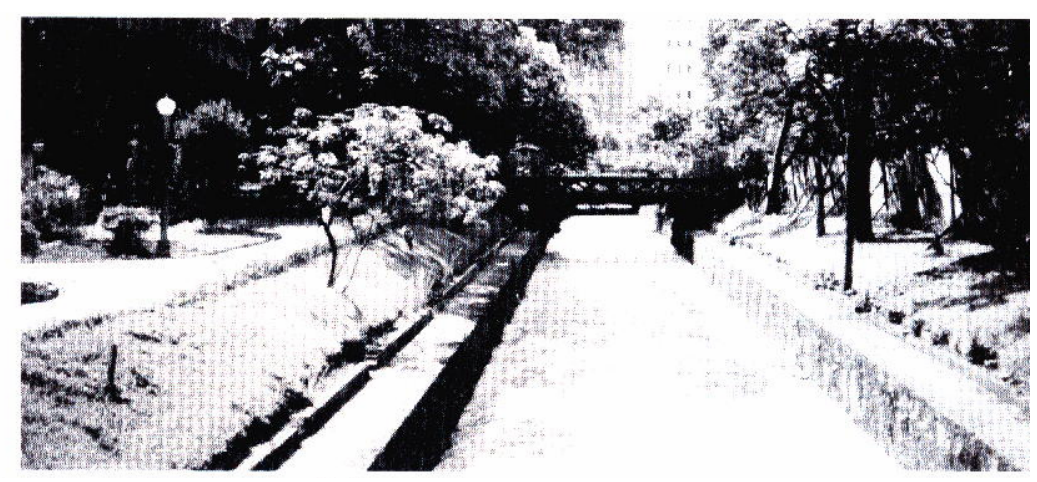

Figura 26 - Canal com margens revestidas (Poços de Calda - MG)

Fonte: BAPTISTA; COELHO. (2002).

Três graus de liberdade

Ocorre quando um escoamento forma um leito sobre o material que pode ser transportado pelo fluxo. De modo que ao se escoar uma mesma vazão líquida/sólida, ajustar-se-á a largura, a profundidade e a declividade do leito, necessitando-se de três equações para obter essas variáveis. Um exemplo de três graus de liberdade é quando o rio apresenta suas margens erodíveis. Estando em equilíbrio pode ser associado a estabilidade dinâmica. 
Quatro graus de liberdade

Definido por alguns autores, o quarto grau se apresenta quando uma corrente tem a possibilidade de desenvolver meandros. A observar que o desenvolvimento de meandros é em parte conseqüência da necessidade que tem o rio de aumentar seu comprimento quando a declividade que requer para transportar o líquido e os sedimentos é menor que a declividade geral do leito, no sentido do escoamento. Além das equações de escoamento e transporte de sedimentos, para a determinação das variáveis, há a necessidade de alguma relação da geometria do meando. Estando em equilíbrio eqüivale a estabilidade morfológica.

\subsubsection{Classificação dos Rios}

A distribuição em classe e/ou grupos, dos rios, segundo sistema ou método de classificação, tem por objetivo identificar os diferentes tipos de rios, permitindo assim o conhecimento das principais características de cada tipo, o que será de fundamental importância para a definição do tipo de obra hidroviária, que este rio possivelmente poderá vir a receber.

5.3.1.2.1. Rios de Montanha - o trecho montanhoso de um rio, dá-se junto a sua nascente. Tem regime torrencial; a erosão é intensa e é retrograda para montante; seção bem definida; material do leito grosseiro (blocos); apresenta um grau de liberdade e, o talvegue tende a avançar (migração e sinuosidade) podendo ocorrer fenômenos de captura (um rio de nível mais baixo pode capturar um de bacia mais elevada). Ver figura 27. 


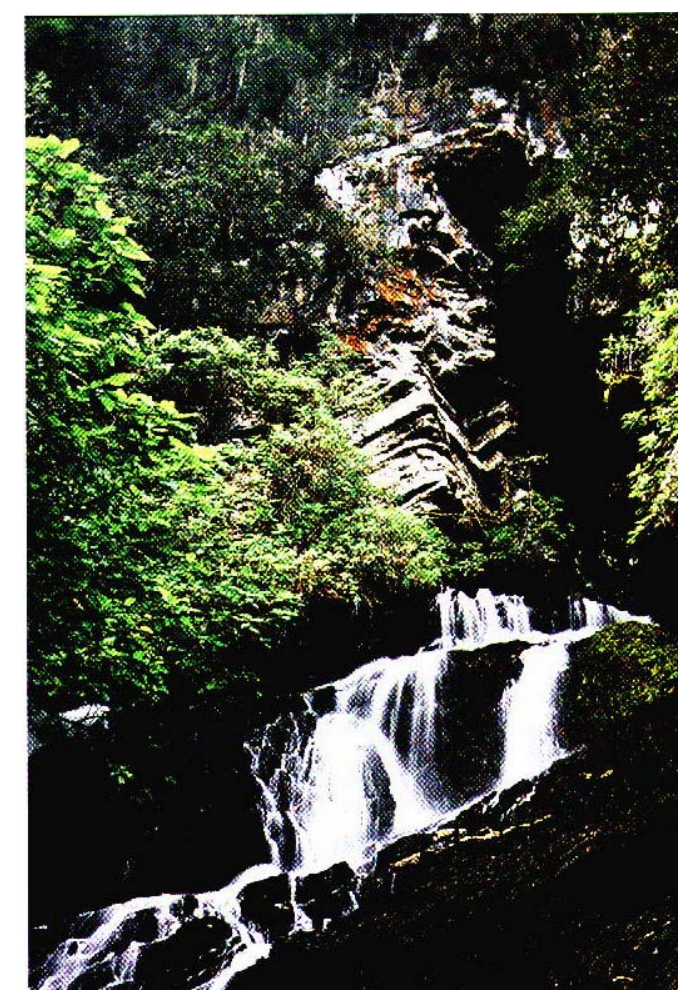

Figura 27 - Trecho em montanha do rio Paranapanema.

Fonte: ZOCCHI. (2002).

5.3.1.2.2. Rios Aluvionares - o trecho aluvionar de um rio, dá-se na sua parte média, onde há a maturidade do rio. $\mathrm{O}$ vale é ocupado pelo material sólido vindo do trecho montanhoso com granulometria menor para jusante; o rio se desenvolve sobre sedimentos por ele depositado em outras épocas; apresenta três graus de liberdade; geralmente há dois álveos (seção de enchente e de estiagem); o equilíbrio ocorre quando $\tau$ ( tensão tangencial que tende a arrancar as partículas sólidas do leito móvel $)<\tau_{\mathrm{c}}$ (tensão tangencial crítica); há tendência da discriminação da declividade com o aumento do traçado; pode haver o aparecimento de meandros. Ver figura 28 . 


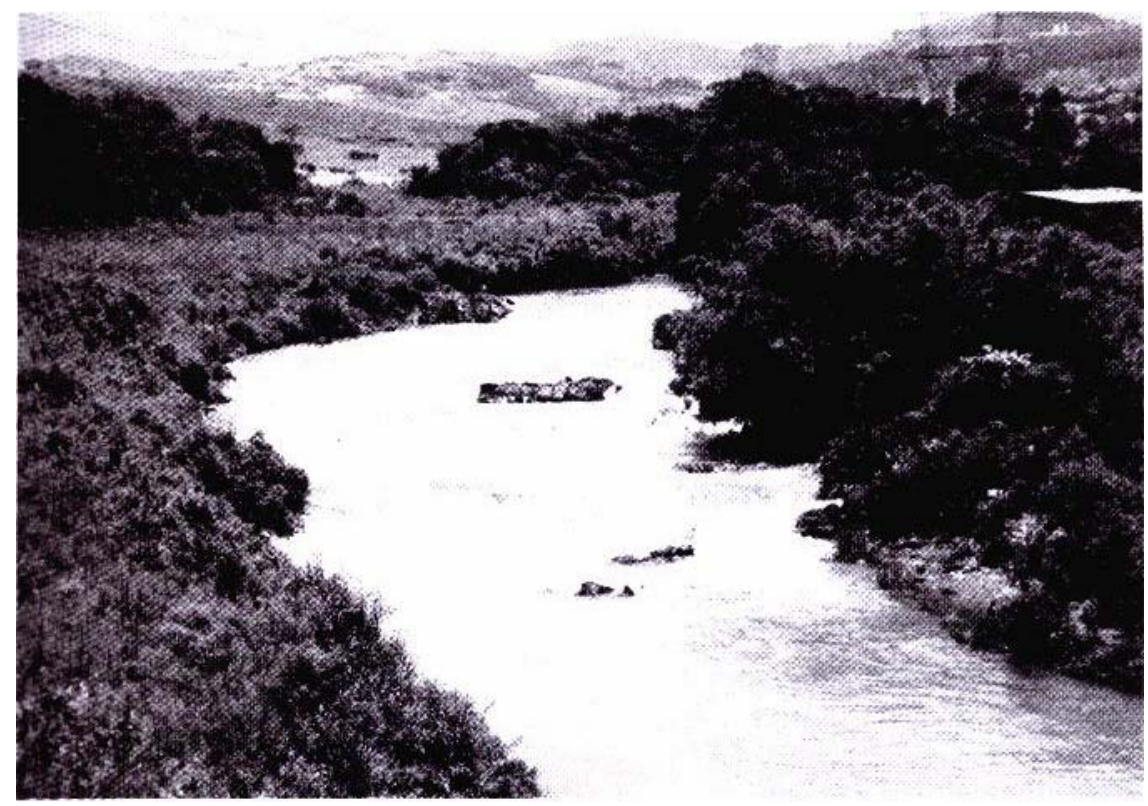

Figura 28 - Curso d'água com características de rio aluvionar.

Fonte: BAPTISTA; COELHO. (2002).

5.3.1.2.3. Rio de Planície ou intermediário - o trecho de planície de um rio, é a conformação mais antiga (estável), o rio se desenvolve sobre um leito por ele erodido (margem estável; leito estável); apresenta dois ou três graus de liberdade; o rio pode modelar o leito maior nas enchentes; somente o material do leito maior é aluvionar; não há assoreamento, mas apenas pequenas erosões. Ver figura 29.

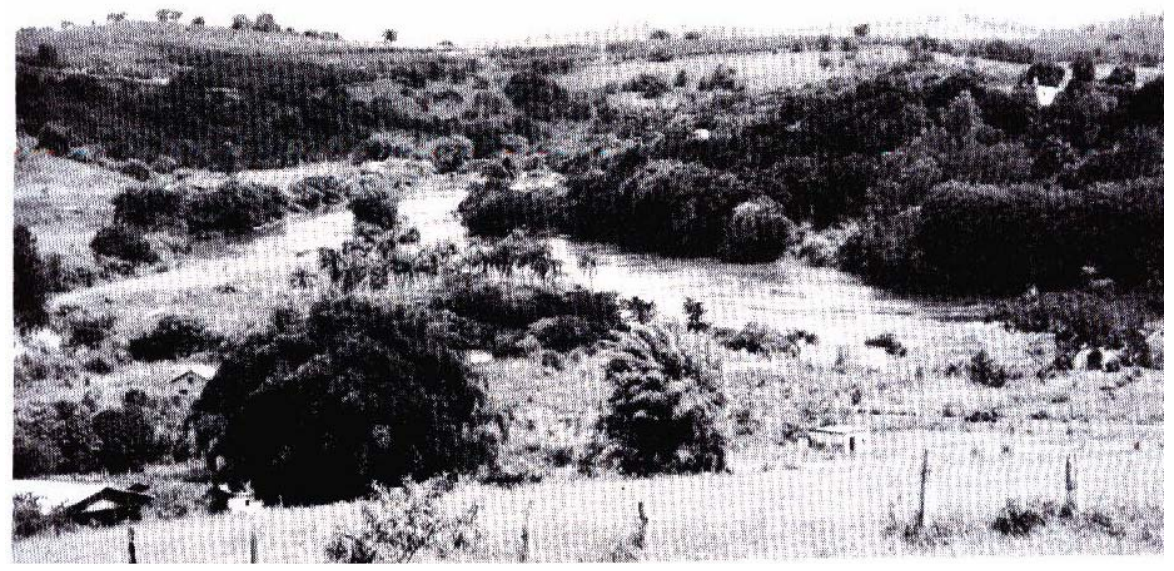

Figura 29 - Curso d'água com características de rio intermediário.

Fonte: BAPTISTA; COELHO. (2002). 
Alguns pesquisadores classificam os rios da seguinte maneira:

- RIO RETILÍNEO - J = i $\cong 0,5$ a 0,6 m/km.

É um rio com material mais resistente; maior granulometria; maior compacidade e coesão e, menor índice de vazios.

RIO MEANDRANTE $-\mathrm{J}=\mathrm{i} \cong 0,1 \mathrm{~m} / \mathrm{km}$.

Qualquer irregularidade no rio retilíneo, produz inflexão dos filetes do meio líquido com erosão nas margens do leito, o que produz nova inflexão com erosão na outra margem e então, o encurvamento do leito; há diminuição da declividade e da força erosiva; o rio busca uma posição de equilíbrio.

As curvas, que parecem não avançar no seu caminho são chamadas de "meandros"; elas sofrem migração para jusante com o tempo e provocam problemas na navegação fluvial; nas cheias, as alças podem cortar o meandro trazendo como conseqüências: aumento de “ J" e de “ $\tau$ ”, com a formação de novos meandros, sem atingir o equilíbrio; no corte formam-se "lagoas em crescente". Apresentam quatro graus de liberdade.

RIO INDEFINIDO - J = i variável $\cong 0,1 \mathrm{~m} / \mathrm{km}$.

É o que existe normalmente na foz, com grande transporte de sólidos e variação conseqüente da declividade.

\subsubsection{Estudo dos Rios Meandrantes}

Sob o enfoque da navegação, os rios meandrantes representam um alongamento exagerado das vias navegáveis, encarecendo os transportes, quando não os dificulta pela exagerada sinuosidade do traçado, ou pela caprichosa distribuição 
dos bancos de material particulado. A intervenção direta ou indireta das obras de engenharia, no rio meandrante, exige o entendimento do meandro, de modo que a intervenção venha a provocar alterações benéficas no curso do rio. Ver figuras 30 e 31.

\subsection{Origem dos Meandros}

Ao observar o desenvolvimento do meandro, verifica-se que ele é em parte conseqüência da necessidade que tem o rio de aumentar seu comprimento, quando a declividade que requer para transportar o liquido e os sedimentos é menor que a declividade geral do leito, no sentido do escoamento. Definida por alguns autores, o quarto grau de liberdade se apresenta quando uma corrente tem a possibilidade de desenvolver meandro. Ver figura 32.

$\mathrm{Na}$ definição de meandro, faz-se referência a: "qualquer irregularidade no rio retilíneo, produz inflexão", isto é, uma mudança de direção, de rumo, pois o rio antes reto, agora vai "virar" ou "dobrar", a causa desta inflexão deu origem as seguintes hipóteses:

\section{Hipótese de Influência da Natureza}

Irregularidades Locais, tais como a possível presença de pedregulhos, árvores caídas, torrões, barreiras argilosas, etc. . Esta "proposta" não é considerada causa principal porque em ensaios laboratoriais em que foram utilizados canais em condições ideais para um escoamento retilíneo, houve a formação de meandros.

\section{Hipótese de Processo Contínuo da Erosão}

Os meandros comumente se formam em aluviões, mas mesmo quando ocorrem em outros meios, eles são invariavelmente formados por um processo 
contínuo de erosão, transporte e depósito do material que compõe o meio. O material é erodido da parte côncava do meandro, transportado para jusante e depositado na parte convexa ou barra de um meandro ( em alguns casos devido a conformação da parte côncava e a velocidade do escoamento, parte desse material transportado pode ser depositada na parte côncava).

\subsection{Mecanismo de Formação de Meandros}

O mecanismo de mudança do curso do canal de um rio, está contido na capacidade da água em erodir, transportar e depositar o material do meio fluvial. Especialmente em uma curva, o gradiente de velocidade contra a margem do canal, causa turbilhões locais que concentram o dispêndio de energia e localizam a erosão.

Um modelo de escoamento imaginado em um meandro típico é mostrado na Figura 33. O lado esquerdo da ilustração indica os vetores velocidade em vários pontos para cinco seções transversais ao longo da curva.

$\mathrm{Na}$ curva, a força centrífuga é maior na água, que se move mais rapidamente próximo a superfície do que na água que se move mais lentamente próximo ao leito, então, haverá um sistema circulatório que se estabelece na seção transversal, com a superfície líquida mergulhando em direção ao leito próximo à margem côncava e, o leito do rio fugindo em direção à superfície próxima da margem convexa. Esta circulação junto com o movimento geral para jusante, gera um movimento helicoidal da água que transporta o material erodido da margem côncava para a direção da margem convexa onde é depositado, formando um banco (pointbar).

A erosão das margens côncavas e deposição nas margens convexas tende a fazer as curvas de meandro se mover lateralmente, atravessando o vale. 

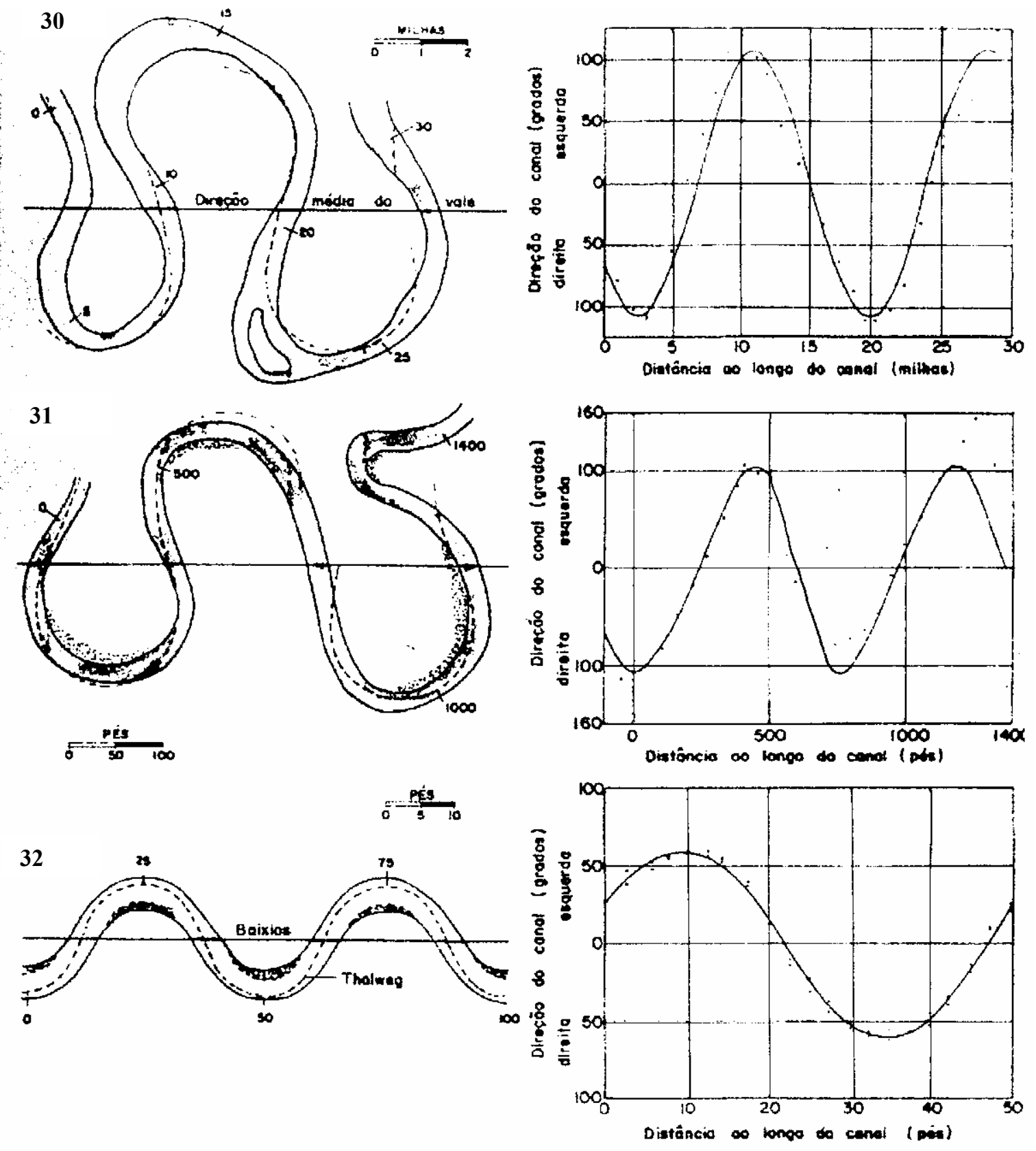

Figuras 30, 31 e 32. Os desenhos, à esquerda, mostram dois trechos típicos de meandros do rio Mississipi, perto de Greenville, Estado do Mississipi (30), e Blackrock Creek em Wyoming (31), permitem verificar a dificuldade à navegação, devido a exagerada sinuosidade do traçado, e um trecho de um meandro experimental formado em um meio homogêneo em laboratório (32). Medidas da direção angular com relação à direção média do vale, faz-se em intervalos regulares ao longo da linha central dos dois meandros naturais e ao longo do talvegue, ou na parte mais profunda do canal do meandro experimental. Quando estas medidas são plotadas contra o comprimento de cada canal, as curvas fechadas resultantes aproximam-se de ondas senoidais (à direita). As correspondentes curvas seno-geradas são superpostas em seus respectivos desenhos do canal (curvas tracejadas).

Fonte: MENDES, João Batista. (1999). 


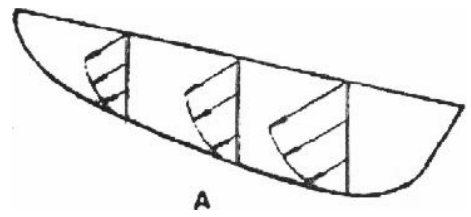

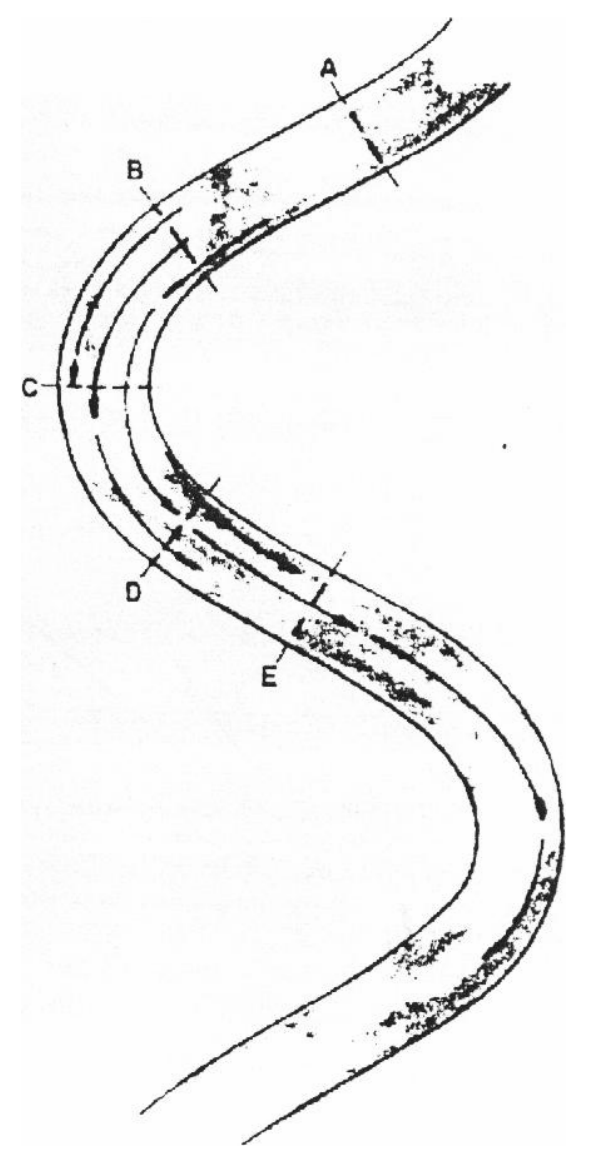

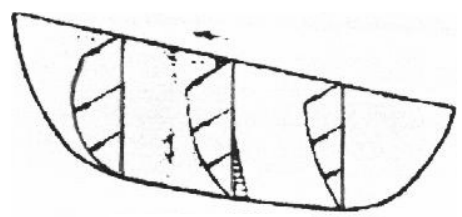

B

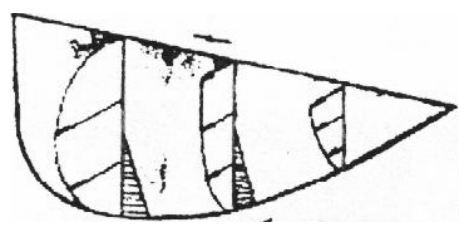

C

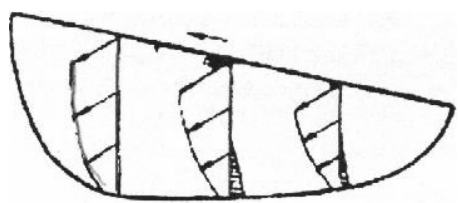

D

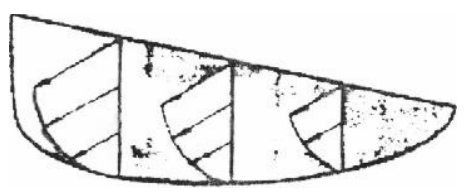

E

Figura 33 - Modelo idealizado, para permitir a visualização do escoamento em um meandro típico. As figuras à esquerda, no modelo, indicam Os vetores velocidade na direção do rio a jusante, em cinco seções transversais na curva; a componente lateral da velocidade é indicada pela área triangular com hachuras. A figura à direta, no modelo, mostra as linhas de corrente na superfície do meandro.

Fonte: MENDES, João Batista. (1999). 


\subsubsection{OBRAS HIDROVIÁRIAS}

\subsubsection{Histórico}

A água é essencial à vida, biologicamente falando, mas talvez a ausência dela tenha sido imprescindível ao desenvolvimento da vida inteligente.

As primeiras obras hidráulicas provavelmente, foram executadas antes que o homem fosse homem, Homo Sapiens. Tal qual, os castores e outros seres construtores, o homem primitivo já se envolvia com obras hidráulicas. Mas eram oriundas de uma inteligência instintiva do que fruto de reflexão. Muitos conceitos errôneos e a falta de transmissão do conhecimento, dentre outros, foram fatores que limitaram a evolução científica da hidráulica durante todo período, desde a antigüidade até o renascimento. É claro que vários outros fatores históricotecnológicos reforçaram esta limitação (Pereira, 1994).

A materialização da inteligência reflexiva, entretanto, só começou a tomar forma com as civilizações advindas do encontro d'água com o deserto. Ou seja, os Sumérios, e as demais culturas Mesopotânicas, e em especial o Egito, a dádiva do Nilo. Até etimologicamente Mesopotânia tem relação com a água (Pereira, 1994).

Diversas outras civilizações antigas deixaram vestígios, e mesmo obras intactas, no campo da hidráulica, desde a China até a América (Astecas, Incas, Maias e outros). Mas foram os grandes pensadores gregos que muito contribuíram para o desenvolvimento da ciência hidráulica, mas pouco realizaram em termos de grandes obras, devido entre outros fatores, ao desprezo pelo trabalho braçal. Coube aos romanos, povo de comportamento mais prático, a realização das grandes e inúmeras obras hidráulicas que até hoje marcam a paisagem do antigo império (Pereira, 1994).

Como exemplo de conceito errôneo pode-se citar o desconhecimento da alimentação dos rios pela água de chuva, o que, sob nossa ótica contemporânea, é bastante esdrúxulo. Foi somente no ambiente renascentista, com Leonardo da Vinci e outros, que esse enfoque obscuro começou a ser iluminado. A hidráulica, recebeu contribuições de inúmeros estudiosos ao longo de sua história, conforme pode ser visto na Tabela XV. 
Tabela XV - Hidráulicos notáveis e suas contribuições

\begin{tabular}{|c|c|c|}
\hline Nome & Origem e período & Contribuições principais \\
\hline ARQUIMEDES & $\begin{array}{l}\text { Siracusa } \\
287 \text { a. C - } 212 \text { a. C }\end{array}$ & $\begin{array}{l}\text { primeiro texto conhecido } \\
\text { sobre hidráulica }\end{array}$ \\
\hline LEONARDO DA $\boldsymbol{V I N C I}$ & $\begin{array}{l}\text { Itália } \\
1452-1519\end{array}$ & $\begin{array}{l}\text { elaborou estudos e projetos } \\
\text { dentro dos conceitos } \\
\text { atuais de Engenharia } \\
\text { Hidráulica }\end{array}$ \\
\hline $\begin{array}{l}\text { EVANGELISTA } \\
\text { TOR RICELLI }\end{array}$ & $\begin{array}{l}\text { Itália } \\
1608-1647\end{array}$ & $\begin{array}{l}\text { pioneiro de estudos } \\
\text { experimentais: estudos de } \\
\text { orifícios e jatos }\end{array}$ \\
\hline DANIEL BERNOULLI & $\begin{array}{l}\text { Holanda } \\
1700-1782 \\
\end{array}$ & $\begin{array}{l}\text { precursor de abordagem } \\
\text { teórica da hidráulica }\end{array}$ \\
\hline LEONHARD $\boldsymbol{E} \boldsymbol{U} \boldsymbol{L} \boldsymbol{E} \boldsymbol{R}$ & $\begin{array}{l}\text { Suíça } \\
1707-1783\end{array}$ & $\begin{array}{l}\text { equações gerais do } \\
\text { movimento dos fluídos } \\
\text { perfeitos }\end{array}$ \\
\hline ANTOINE $\boldsymbol{C H E ́} \boldsymbol{Z} \boldsymbol{Y}$ & $\begin{array}{l}\text { França } \\
1718-1798\end{array}$ & $\begin{array}{l}\text { estudos experimentais } \\
\text { relativos à resistência } \\
\text { ao escoamento }\end{array}$ \\
\hline $\begin{array}{l}\text { JEAN CHARLES DE } \\
\text { BORDA }\end{array}$ & $\begin{array}{l}\text { França } \\
1733-1799\end{array}$ & $\begin{array}{l}\text { estudo do escoamento junto } \\
\text { a embarcações, bombas } \\
\text { orifícios; expressões para } \\
\text { cálculo de perdas de carga } \\
\text { localizadas }\end{array}$ \\
\hline $\begin{array}{l}\text { LOUIS MARIE HENRI } \\
\text { NAVIER }\end{array}$ & $\begin{array}{l}\text { França } \\
1735-1836\end{array}$ & $\begin{array}{l}\text { contribuição teórica à } \\
\text { hidrodinâmica }\end{array}$ \\
\hline $\begin{array}{l}\text { GASPARD GUSTAVE } \\
\text { DE CORIOLIS }\end{array}$ & $\begin{array}{l}\text { França } \\
1792-1843\end{array}$ & $\begin{array}{l}\text { aceleração em sistemas } \\
\text { em rotação; introdução } \\
\text { de coeficientes para } \\
\text { velocidade }\end{array}$ \\
\hline $\begin{array}{l}\text { GEORGE GABRIEL } \\
\text { STOCKES }\end{array}$ & $\begin{array}{l}\text { Irlanda } \\
1819-1903\end{array}$ & $\begin{array}{l}\text { equações gerais do } \\
\text { escoamento }\end{array}$ \\
\hline
\end{tabular}


Tabela XV - Hidráulicos notáveis e suas contribuições (continuação)

\begin{tabular}{|c|c|c|}
\hline Nome & Origem e período & Contribuições principais \\
\hline $\begin{array}{l}\text { JEAN-CLAUDE BARRÉ } \\
\text { DE SAINT } \boldsymbol{V} \boldsymbol{E} \boldsymbol{N} \boldsymbol{A N \boldsymbol { T }}\end{array}$ & $\begin{array}{l}\text { França } \\
1797-1886\end{array}$ & escoamento não permanente \\
\hline $\begin{array}{l}\text { HENRI-PHILIBERT- } \\
\text { GASPARD DARCY }\end{array}$ & $\begin{array}{l}\text { França } \\
1803-1858 \\
\end{array}$ & $\begin{array}{l}\text { escoamento em meios } \\
\text { porosos e em tubulações }\end{array}$ \\
\hline $\begin{array}{l}\text { LUDWIG-JULIUS } \\
\boldsymbol{W E I S B A C H}\end{array}$ & $\begin{array}{l}\text { Alemanha } \\
1806-1871\end{array}$ & $\begin{array}{l}\text { contribuições experimentais } \\
\text { concernentes à resistência } \\
\text { ao escoamento }\end{array}$ \\
\hline WILLIAM FROUDE & $\begin{array}{l}\text { Inglaterra } \\
1810-1879\end{array}$ & $\begin{array}{l}\text { modelagem física em } \\
\text { hidráulica }\end{array}$ \\
\hline ROBERT MANNING & $\begin{array}{l}\text { Irlanda } \\
1816-1897\end{array}$ & $\begin{array}{l}\text { proposição e divulgação de } \\
\text { expressões de resistência ao } \\
\text { escoamento em canais } \\
\text { abertos }\end{array}$ \\
\hline ORBORNE REYNOLDS & $\begin{array}{l}\text { Irlanda } \\
1842-1912\end{array}$ & $\begin{array}{l}\text { conciliação de resultados } \\
\text { experimentais e teóricos }\end{array}$ \\
\hline JOSEPH BOUSSINESQ & $\begin{array}{l}\text { França } \\
1842-1929\end{array}$ & $\begin{array}{l}\text { contribuição teórica ao } \\
\text { estudo de coeficientes de } \\
\text { velocidade e turbulência }\end{array}$ \\
\hline BORIS В AKHMETTEF & $\begin{array}{l}\text { Rússia } \\
1880-1951\end{array}$ & $\begin{array}{l}\text { ressalto hidráulico e energia } \\
\text { nos escoamentos livres }\end{array}$ \\
\hline VEM TE $\boldsymbol{C H O} \boldsymbol{W}$ & $\begin{array}{l}\text { China } \\
1919-1981\end{array}$ & $\begin{array}{l}\text { consolidação e divulgação } \\
\text { da hidráulica e hidrologia }\end{array}$ \\
\hline
\end{tabular}

Fonte: BAPTISTA \& COELHO. (2002).

Em 1760, com a criação da École des Ponts et Chaussées, em Paris, é que foi iniciada a sistematização dos conhecimentos de forma hoje conhecida como engenharia, isto é: a arte de aplicar conhecimentos científicos e empíricos e certas habilitações específicas à criação de estruturas, dispositivos e processos que se utilizam para converter recursos naturais em formas adequadas ao atendimento das necessidades humanas. 
Ao desenvolvimento tecnológico acrescenta-se a interação de uma série de fatores de natureza política, social e econômica, resultando então no surgimento de obras com finalidades múltiplas. Exemplo fundamental é a criação nos Estado Unidos da T.V.A. - Tennessee Valley Authorithy, na década de 1930, aplicação direta do "New Deal", que por sua vez é conseqüência da grande depressão, que se origina do Laissez - Faire, resultante político-econômico gerado pela I Guerra Mundial.

Nesse contexto a Engenharia já não pode mais atuar apenas na construção das obras; torna-se patente a necessidade de articulação de todo um contexto que envolve aspectos naturais, geo-biológicos, sociais, econômicos e políticos. Surge então mais explicitamente a Engenharia de Recursos Hídricos, que é responsável pela articulação intersetorial dentro desse contexto (Pereira, 1994).

$\mathrm{O}$ estudo que se desenvolve nesta tese, tem por base o Gerenciamento da bacia hidrográfica, entendido como o gerenciamento realizado na unidade de planejamento da bacia hidrográfica, sendo portanto relativo a toda relação existente dentro do espaço definido (solo, ar, água, flora, fauna, clima e outros) e não o Gerenciamento de recursos hídricos, entendido como o gerenciamento que refere-se apenas ao aspecto água.

\subsubsection{OS EFEITOS DA GLOBALIZAÇÃO NAS OBRAS HIDROVIÁRIAS}

\subsubsection{O Sofisma}

Um sofisma, é um argumento que parte de premissas verdadeiras, ou tidas como verdadeiras, e chega a uma conclusão inadmissível, que não pode enganar ninguém, mas que se apresenta como resultado de regras formais do raciocínio, não podendo ser refutado.

$\mathrm{Na}$ apresentação - ESTRUTURA PARA IDENTIFICAÇÃO E AVALIAÇÃO DE IMPACTOS AMBIENTAIS EM OBRAS HIDROVIÁRIAS, neste capítulo da tese identificaremos alguns argumentos que partem de premissas 
verdadeiras, ou tidas como verdadeiras, pois muitas situações demonstram o desconhecimento, por parte dos mais diversos profissionais, inclusive engenheiros, das obras hidroviárias, e infelizmente, arbitram contra elas.

Assim como em capítulos anteriores, faz-se necessário, principalmente, procurar explicações e conceitos, agora, relacionados as obras hidroviárias. Acreditamos desta maneira estar concebendo o produzir conhecimentos.

\subsubsection{CLASSIFICAÇÃO DE VAN RAALTEN - Tipos de Obras Hidroviárias}

Poucos são os cursos d'água que, em condições naturais apresentam, em trechos satisfatoriamente longos, características que possibilitem o tráfego contínuo e seguro de embarcações de porte, capazes de realizar transporte de cargas com caráter comercial. Alguns rios, como o Amazonas, Madeira, São Francisco, Paraná, Paraguai e outros, apresentam-se naturalmente navegáveis, isto é, são rios em estado natural que permitem a navegação comercial por extensões de centenas ou mesmo de mais de um milhar de quilômetro, mas naturalmente, não podem ser considerados hidrovias interiores.

O rio, quando recebe alguma interferência de engenharia, tal como: sinalização, balizamentos, levantamento batimétrico etc., propiciando-lhe melhores condições à navegação comercial, é definido como via navegável interior.

Um grau maior de intervenção de engenharia, no rio, proporcionando-lhe total segurança para a navegação comercial diuturna, a qualquer tempo, para os veículos fluviais (embarcação tipo) adequados aos padrões da via ( sinalização, balizamento, carta eletrônica de navegação, navegação com GPS, estação de rádio controle, etc.) dependendo das características do rio, para atendimento dessas condições, fazem-se necessárias obras hidroviárias de maior ou menor magnitude, permitindo, então, definir este rio como hidrovia interior.

São exemplos destes rios e, das intervenções de engenharia, os dados apresentados na Tabela XVI. 
Tabela XVI - Rios brasileiros e intervenções de engenharia

\begin{tabular}{l|l}
\hline Rios & Obra \\
\hline - São Francisco & Desobstrução do canal de navegação \\
- Paraguai & Dragagem de manutenção \\
- Tocantins & Dragagem e derrocamento \\
- Baburé- Jacareacanga & Dragagem e derrocamento \\
- Baixo Tapajós & Dragagem e derrocamento \\
- Atuá e Anajás & Dragagem e derrocamento \\
& Escavação do canal artificial de ligação \\
& Dragagem do canal artificial de ligação \\
& Execução de Diques de Contenção \\
- Anajás & Retificação de meandros \\
\hline
\end{tabular}

Fonte: Home Page: http:// www.ahimor.gov.br; www.ahipar.gov.br; www.ahsfra.gov.br; $\underline{\text { www.ahitar.com.br; } \text { www.ahimoc.com.br }}$

Entenderemos, neste trabalho, por obras hidroviárias, a intervenção de engenharia, direta e indireta no rio, de modo a resultar em obras civis, que permitam a implantação e operação de uma hidrovia.

As obras executadas no rio, podem quebrar o equilíbrio do rio, resultando em impactos ambientais. Equilíbrio estudado no capítulo 5, item 5.3.1.1.2. Modelação.

Identificar os impactos ambientais provenientes do desequilíbrio do rio, devido a execução de obras hidroviárias, relacionar estes impactos a sua respectiva origem ou obra (etapa da pesquisa desenvolvida no Capítulo 6: CORRELAÇÃO ENTRE AS VARIÁVEIS ), exige o conhecimento de quais são estas obras.

Genericamente, existem quatro tipos de obras hidroviárias, de acordo com Van Raalten (1981) apud Camargo Junior (2000), sendo elas:

- Obras Simples - demolição e retirada de obstáculos (desenrocamento) e sedimentos (desassoreamento) para viabilizar a navegação. 
- Obras de fixação do leito e proteção de estruturas - aplicação de métodos construtivos tradicionais, como concretagem, enrocamento, atirantamento, aplicação de gabiões, espigões, muros-guia, etc., que fixam as margens e a calha do rio, que protegem pilares, vãos de pontes, entrada de eclusas, etc., promovendo a segurança da navegação.

- Obras de regularização de vazão - construção de obras como barragens. No caso da construção de barragens, são necessárias obras de transposição para as embarcações.

- Obras de canalização - tratam-se de obras de regularização do leito total de um rio, de interligação de rios ou de criação de ramais paralelos ao leito natural. O primeiro caso é muito comum em hidrovias européias. O canal de Bariri e o canal de Pereira Barreto, são exemplos de ramal paralelo e interligação (Oliveira \& Brito, 1998).

\subsubsection{CLASSIFICAÇÃO PROPOSTA - Tipos de Obras Hidroviárias}

Adequando-se a classificação de Van Raalten, a realidade brasileira, adotaremos nessa tese a seguinte classificação:

\subsubsection{Gerais ou de Normalização}

São obras locais visando problemas específicos, do tipo: trecho raso ou curva muito brusca ou margem instável; de modo geral visam o melhoramento dos cursos d'água e não influem no regime hidráulico ou morfológico do rio. Dificilmente são usadas sozinhas, sendo comum a sua utilização em conjunto com os outros tipos de obras. As principais obras de normalização são:

\subsection{Desobstrução e Limpeza}


Consiste na retirada de obstáculos estranhos ao leito, que dificultam o escoamento ou desviam os filetes líquidos. Geralmente são vegetais ou embarcações sossobradas. Utilizam-se embarcações destocadeiras e guindastes. Este tipo de obra não intervém no equilíbrio do rio, portanto, não produz impactos ambientais.

\subsection{Limitação dos Leitos de Inundação}

Tem a finalidade de facilitar a navegação, concentrando o escoamento num leito bem definido. Outra finalidade pode ser a de proteger os terrenos ribeirinhos.

As obras utilizadas neste caso são diques longitudinais. Podem ser construídos a seco, aproveitando o período de estiagem, localizados no leito menor e de maneira geral em argila (impermeável).

Cuidados devem ser tomados para a drenagem de área protegida, quando a mesma for utilizada para fins agrícolas. Outro cuidado, refere-se a concentração das vazões, principalmente, no regime de vazões excepcionais, que pode aumentar a capacidade erosiva das correntes, acarretando a erosão dos leitos.

Verificar-se que este tipo de obra, intervém no equilíbrio do rio, dando origem a impactos ambientais, que serão minimizados com a execução de obras complementares para a proteção do leito .

\subsection{Fechamento de Braços Secundários}

Este tipo de obra é utilizada para aumentar a profundidade num dos trechos dos braços do curso d'água, mediante o fechamento dos outros. O fechamento é efetuado através de obras permeáveis ou não, geralmente com altura até a cota mínima de navegação, ficando submersos para as vazões maiores. Estas obras, são pequenas barragens, que podem ser galgadas, devendo portanto ter a superfície protegida para evitar a sua destruição, ou soleiras de fundo. Podem ser construídas em enrocamento de pedras ou terra, com proteção na superfície ou ainda em estaqueamento simples ou duplo. Estas obras alteram o regime do rio na estiagem, 
pois ocorre a concentração das vazões em um único canal, podendo acarretar erosões no mesmo, e a deposição de materiais transportados no(s) trecho(s) de jusante. Em geral as alterações ambientais são locais, podendo ser minimizadas com a execução de obras complementares. O regime de escoamento do rio, praticamente não sofre alteração no período das cheias.

\subsection{Proteção das Margens}

De um modo geral denominaremos por margem a superfície inclinada do terreno em contato direto com a água ou imediatamente acima, distinguindo-se: a parte superior ou "berma", que só é atingida pelas enchentes excepcionais e que muitas vezes é constituída pelos diques de proteção contra inundações, a "ribanceira" ou "talude", entre o nível de estiagem mínima e o das enchentes normais e o "pé da margem" ou "base", a parte inferior. Abaixo do nível de estiagem, permanentemente submersa (Brighetti \& Almeida, 2002).

A ribanceira e o pé da margem são muitas vezes sujeitos a elevadas velocidades, sendo então submetidos a fortes erosões, sobretudo nas zonas inferiores que sustentam o talude, merecendo pois, maiores atenções e proteção (Brighetti \& Almeida, 2002).

A proteção das margens têm por finalidade:

Proteger os terrenos marginais (ribeirinhos), isto é, terrenos que ladeiam um curso de água ou que circundam um lago, beira, orla, da ação do escoamento e das ondas naturais ou artificiais;

- Reduzir a descarga sólida nos(as) cursos de águas naturais, hidrovias, canais [de irrigação, de drenagem, de adução (usinas)], etc. (Brighetti, 2000). Ver figuras 34 e 35.

A proteção das margens, tem como conseqüentes vantagens: redução dos bancos de areia; melhoria geral do escoamento; redução da erosão; aprofundamento do leito; fixação do leito navegável, etc. 


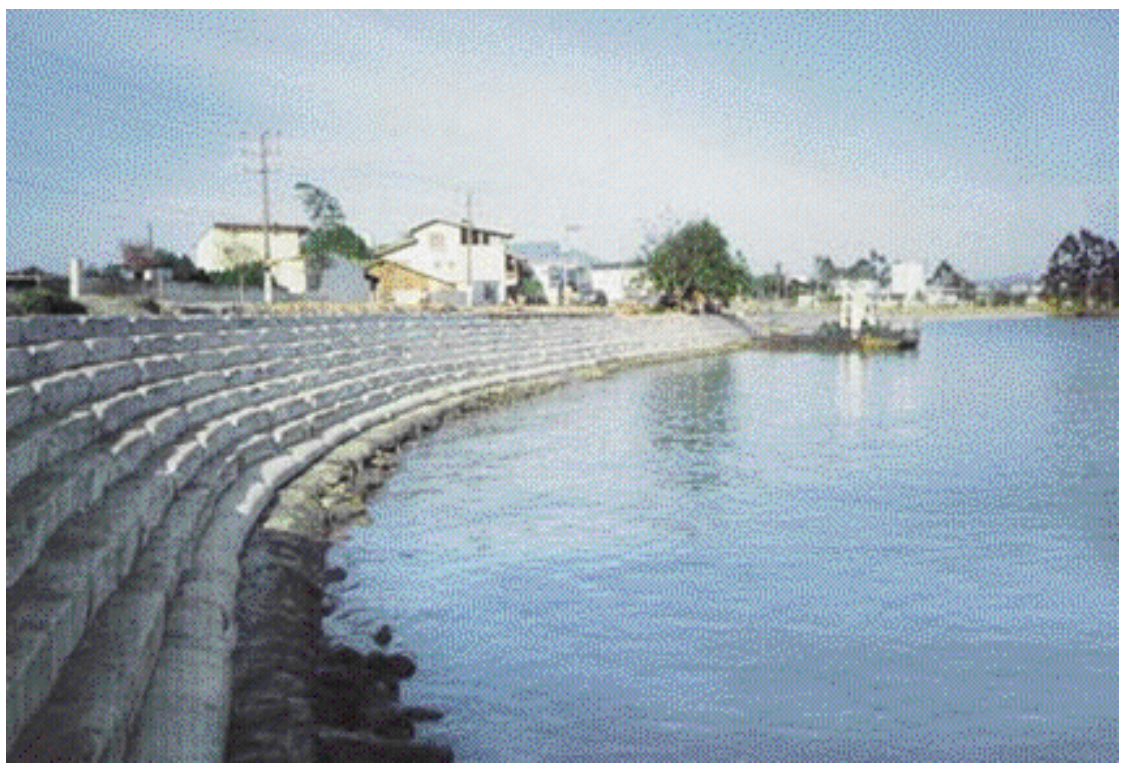

Figura 34 - Proteção das Margens: Vista parcial da contenção e proteção de margem da Foz do Rio Itajaí -Açu, em Itajaí (SC).

Fonte: http://www.bolsacreto.com.br

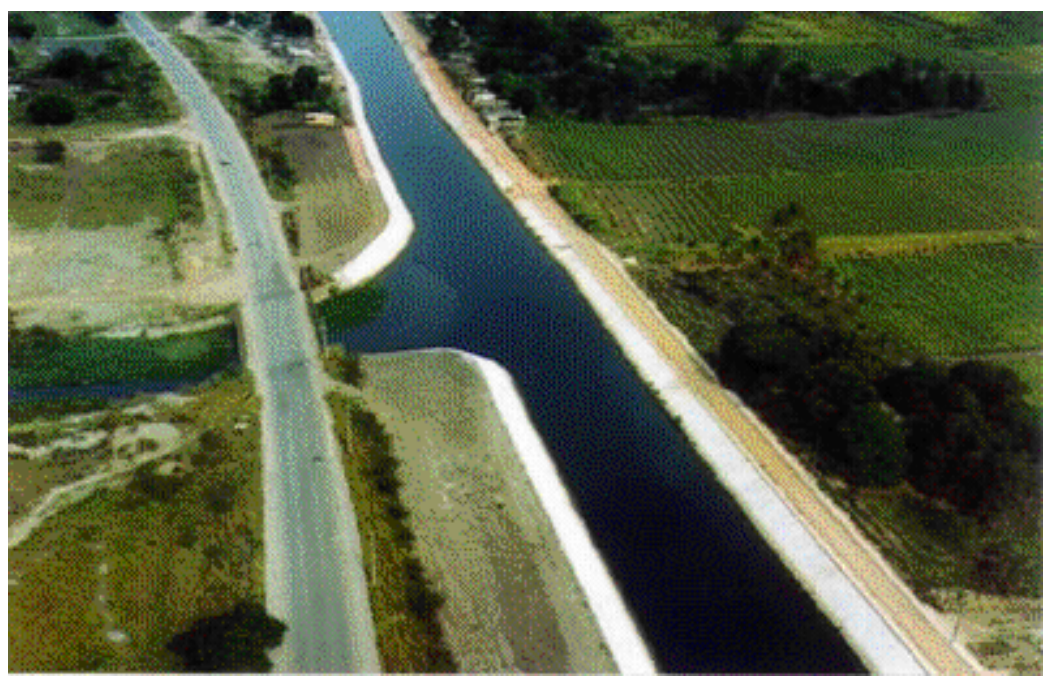

Figura 35 - Proteção das Margens: Vista aérea parcial do revestimento dos taludes laterais do canal do Itá, em Santa-Cruz (RJ).

Fonte: $\underline{\text { http://www.bolsacreto.com.br }}$ 
Escolher entre os diversos tipos de obras para a estabilização das margens, é uma missão difícil para o engenheiro, pois estamos protegendo a margem contra o que ?

Em cada situação é necessário procurar o revestimento (obra) que possui as exigências características de: permeabilidade ou impermeabilidade, robustez, flexibilidade, rugosidade, durabilidade e economia, e entre eles adotar o que melhor se adapte às necessidades da obra.

A proteção das margens, poderá ser obtida através da : proteção direta ou proteção indireta.

No caso de proteção contínua, não há alteração no equilíbrio do rio, e havendo a necessidade de revestimento do talude, o impacto será localizado naquele trecho de margem que recebeu o revestimento e será função do tipo de revestimento. Caso a margem, já se encontre sendo erodida, isto é, já impactada, a proteção contínua visa restabelecer o equilíbrio.

No caso de proteção indireta, com a utilização de espigões, reduz-se a seção hídrica, afetando o equilíbrio do rio.

\subsubsection{Retificação de Rios Meandrantes}

A retificação de rios meandrantes, consiste em melhorar os raios de curvatura do leito curvo do rio, melhorando as condições do escoamento, reduzindo o percurso para a navegação; baixando o nível d'água de enchentes e permitindo a recuperação de terrenos marginais. A retificação de meandros, só terá êxito a partir dos conhecimentos específicos dos meandros fluviais, tais como: origem dos meandros, mecanismos de formação de meandros, localização dos meandros, caracterização do meandro.

A retificação, altera o equilíbrio do rio, sendo portanto necessário a execução de obras complementares, para minimizar os impactos ambientais, que são entendidos como impactos locais. 


\subsubsection{Regularização dos Leitos}

As obras de regularização em um curso em um curso d'água, são definidas como sendo àquelas que visam a utilizar energia das águas para: fixar o leito, direcionando o escoamento ou concentrando o escoamento para melhorar as condições de navegabilidade, operação de tomadas de água, etc., modificando para tanto: a largura, as curvaturas, a profundidade e a direção de filetes de água. Normalmente são utilizadas para fixar o leito do curso d'água durante os meses de estiagem.

As obras de regularização dos leitos, intervêm no equilíbrio do rio, produzindo impactos ambientais, sendo necessário a execução de obras complementares para a minimização dos impactos ambientais.

\subsubsection{Derrocamento}

O derrocamento é a operação que consiste no desmonte ( fraturamento, rompimento ) de rochas, particularmente do leito de rios ou canais, para desobstruilos. Após desmonte, dá-se a remoção da rocha.

O desmonte da rocha, é feito com técnicas específicas, que consistem em romper o maciço, que pode se realizar, com a utilização de explosivos (ondas de choque), por percussão (marreta, soquete, ariete) ou por perfuração e percussão (martelete) e, finalmente promover a remoção do material rompido, que quando no leito de rios ou canais, será retirado através de dragas.

Geralmente estas obras têm como conseqüência o aumento da velocidade das águas e o rebaixamento do nível d'água a montante, resultando no desequilíbrio do rio, o que dá origem aos impactos ambientais, que deverão ser minimizados com a escolha adequada da técnica de execução bem como da escolha correta do equipamento, além da necessidade da execução de obras complementares. 


\subsubsection{Dragagem}

Entende-se por dragagem a retirada, transporte e disposição final, do material, que pode ser resultante do derrocamento, areias, siltes, argilas, etc., do leito dos rios ou não, por equipamentos adequados em cada operação.

Geralmente estas obras têm como conseqüência o aumento da velocidade das águas e o rebaixamento do nível d'água a montante, resultando no desequilíbrio do rio, o que dá origem aos impactos ambientais, que deverão ser minimizados com a escolha adequada da técnica de execução e bota-fora, bem como da escolha correta do equipamento.

\subsubsection{Canais Artificiais}

Entende-se por canais artificiais o ato de dirigir ou encaminhar o escoamento das águas, através de canos, valas ou canais fora do leito natural.

Os impactos ambientais das obras hidroviárias de canalização dos cursos d'água, ou execução de canais artificiais, estão relacionados a impactos na bacia, onde se implantará a obra, e não em um curso d'água, o que resulta em um estudo mais abrangente para a identificação dos impactos.

\subsubsection{Obras de Canalização dos Cursos D’água}

Estas obras hidroviárias, consistem na implantação de barragens a intervalos planejados, transformando o rio em uma série de patamares. A este tipo de obra, são atribuídos notáveis mudanças e modificações nos rios onde são construídas, em síntese provocam "grandes" impactos ambientais; uma contenda que não é objetivo desta tese. 


\subsubsection{ESTUDO DAS PRINCIPAIS OBRAS HIDROVIÁRIAS}

O desenvolvimento de nenhum outro capítulo, foi tão duvidosos e trabalhoso quanto ao capítulo "OBRAS HIDROVIÁRIAS". Dúvidas que residem no fato, que sendo este trabalho uma tese, haveria a necessidade ou não da apresentação de definições, conceitos e técnicas executivas, referentes àquelas obras.

A questão, ora apresentada, parece não ter uma única resposta, sendo ela função do "meio" que pretende-se alcançar e/ou disponibilizar, a presente tese. Sendo assim, caso este trabalho seja estudado numa área de concentração como Engenharia Hidráulica, mais especificamente Hidráulica Fluvial, é importante ressaltar que muitos, mas não todos os conceitos, definições e técnicas de execução, são de conhecimento e/ou domínio dos engenheiros que militam nesta área, havendo portanto a necessidade do desenvolvimento de um embasamento conceitual, não muito extenso.

As tendências mundiais, apontam para a necessidade de um desenvolvimento sustentável, o que nos faz crer que toda pesquisa será tão mais completa e atual, quanto maior o seu caráter multidisciplinar; assim sendo, investe-se esta tese do caráter multidisciplinar, podendo, então ser estudada por "pesquisadores" que não especificamente da Engenharia Hidráulica, havendo, porém, a necessidade de um embasamento conceitual mais amplo, de modo a dotar, biólogos, ecólogos, geólogos, geógrafos, administradores, economistas, advogados e outros, de conhecimentos de Engenharia Hidráulica, especificamente Hidráulica Fluvial. Seria importante ressaltar que é possível identificar-se nos outros capítulos a apresentação de um embasamento conceitual, procurando dotar o engenheiro hidráulico fluvial, de conhecimentos de biologia, direito, economia, ecologia, etc.

Uma justificativa quanto a extensão deste capítulo, faz-se necessário., pois a sua base é a Engenharia Hidráulica Fluvial; procurou-se não parafrasear definições, conceitos, textos e outras partes de trabalhos relacionados com a Engenharia Hidráulica Fluvial, enfim, evitar o plágio, segundo Vieira (1991), uma prática, que constitui-se em bandidismo acadêmico. Identifica-se ao longo deste capitulo, citações 
de pesquisadores, de modo a não nos permitir "inventar" justificativas, com o objetivo de validar esta pesquisa.

\subsubsection{Proteção das Margens}

Segundo Brighetti (2000), são aquelas obras executadas ou apoiadas diretamente no talude das margens. Nesta pesquisa, iremos considerar taludes naturais e taludes de cortes, diferentes.

Os taludes naturais, são definidos como superfícies inclinadas de maciços terrestres, rochosos ou mistos (solo e rocha), originados de processos geológicos e geomorfológicos diversos. Podem apresentar modificações antrópicas, tais como: cortes, desmatamentos, introdução de cargas, etc.

O talude de corte é entendido como um talude originado de escavações antrópicas diversas.

A proteção direta ou contínua corresponde ao revestimento da margem e do leito, protegendo-os contra as seguintes causas de instabilidade:

Aspectos Geotécnicos (Ações internas no maciço): Talude de equilíbrio; Saturação; Percolação do solo (dreno arenoso)

Aspectos Hidráulicos (Ações externas ao maciço): Ação do escoamento; Ação das ondas; Ventos; Embarcações; Operação de estrutura (comportas, válvulas, etc.)

\subsection{Proteção Direta (Contínua)}

a) Redução do Ângulo de Talude (Retaludamento)

Retaludamento, tem por objetivo aumentar a resistência do material, a partir da diminuição do ângulo de talude.

O controle do ângulo de retaludamento, dá-se, por exemplo, a partir da construção de um gabarito triangular, com sarrafo de madeira, cujos catetos obedecem à mesma relação do ângulo de retaludamento. Ver figura 36. 
Aplica-se o triângulo com a hipotenusa sobre a superfície do talude e colocase um nível de bolha sobre o cateto superior. Quando a bolha estiver centrada, a hipotenusa deve se assentar perfeitamente sobre o talude.

O retaludamento, deve ser executado em ângulo conveniente, isto, é deve-se considerar os efeitos da saturação.

A escavação e remoção do solo, faz-se com a utilização de equipamentos tais como:

四Lança retroescavadeira (back-showel) que executa a escavação no sentido de cima para baixo a medida que a escavação prossegue a máquina vai se deslocando em marcha à ré. A capacidade da caçamba é relativamente pequena e raio de alcance limitado. Esse equipamento é utilizado no corte de solo mais compactos, devido às grandes pressões que os dentes exercem sobre o terreno a ser escavado. Ver figura $\mathrm{n}^{\mathrm{o}} 36$.

Drag-line (draga de arrasto) que permite uma variação de ângulo entre $25^{\circ}$ e $40^{\circ}$; esse equipamento é aplicado no corte de materiais pouco compactos ou moles, mesmo que possuam altos teores de umidade. É o único equipamento, convencional, de terraplenagem que executa escavação dentro d'água e o que possui o maior raio de alcance. Ver figura 36.

Equipamentos como draga de arraste e lança retroescavadora, destinam-se à escavação abaixo do nível em que se encontram.

No retaludamento, é necessário a definição e fixação de uma nova vegetação de margem, em substituição a existente anteriormente. 


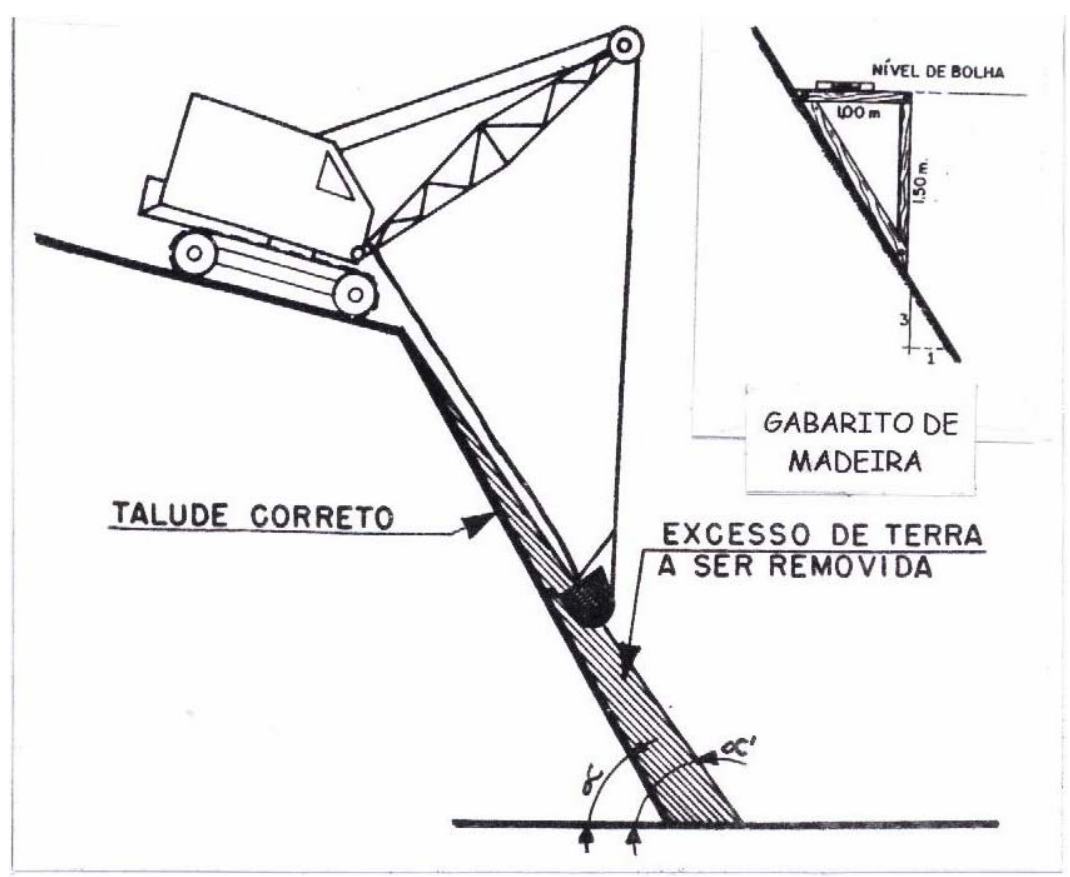

Escavação com Draga de Arrasto

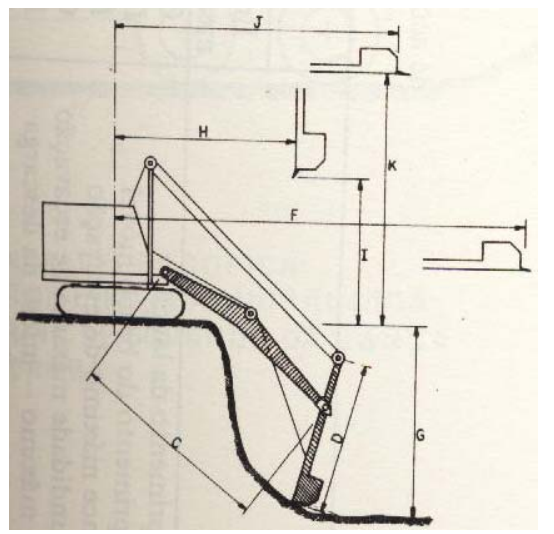

Escavação com Lança Retroescavadora

Figura 36 - Retaludamento

Fonte: RICARDO \& CATALANI. (1977).

b) Revestimento das Margens

O revestimento das margens tem como condição a estabilidade de um curso d'água, entendendo-a como o equilíbrio entre a ação do escoamento sobre o leito do 
rio e a resistência ao movimento (erosão) dos materiais (sedimento) que o constituem.

Este equilíbrio é atingido pela interação entre o escoamento da água e sedimentos provenientes da bacia hidrográfica contribuinte, considerando-se a evolução das seções, traçado e declividade dos cursos de água. O equilíbrio pode ser alterado naturalmente em função da ocorrência de grandes cheias, ou em função da evolução contínua do traçado (o que provoca retificações naturais no mesmo). De uma forma mais comum, a alteração no equilíbrio pode ocorrer através de:

- Intervenção direta - com obras no próprio curso de água, tais como: retificações, barragens, etc.;

- Intervenção Indireta - por ações na bacia hidrográfica que causem alterações no uso do solo, tais como: urbanização, mudanças de cultura, desflorestamentos, etc.

A solução para os cursos de água canalizados, consiste em definir um tipo de proteção que mais se adapte às condições locais, não somente quanto à resistência a ação do escoamento, mas também quanto a resistência às deformações do solo de base, que atenda as condições ambientais, rugosidade resultante, facilidade de execução, além do custo final da obra.

䟚Revestimentos simples

Consiste em revestir as margens, com os mais variados materiais e técnicas de revestimento, que resistam a tensão de arraste do escoamento e/ou ondas. Os principais tipos de revestimento são: substituição por material mais resistente (pedregulho, cascalho, pedra britada, etc.), plantação de gramíneas ou outros vegetais, colocação de faxinas e colchões de material vegetal (provisório, visando efeitos diversos), revestimento asfáltico (pintura asfáltica para impermeabilização e fixação dos grãos). 


\section{Zaxinas}

Entende-se por faxina, varas finas e flexíveis; ramos ou paus curtos com que se fazem feixes (assemelham-se a diques), entretecendo-as com outras varas horizontais mais grossas. Ver figura 37.

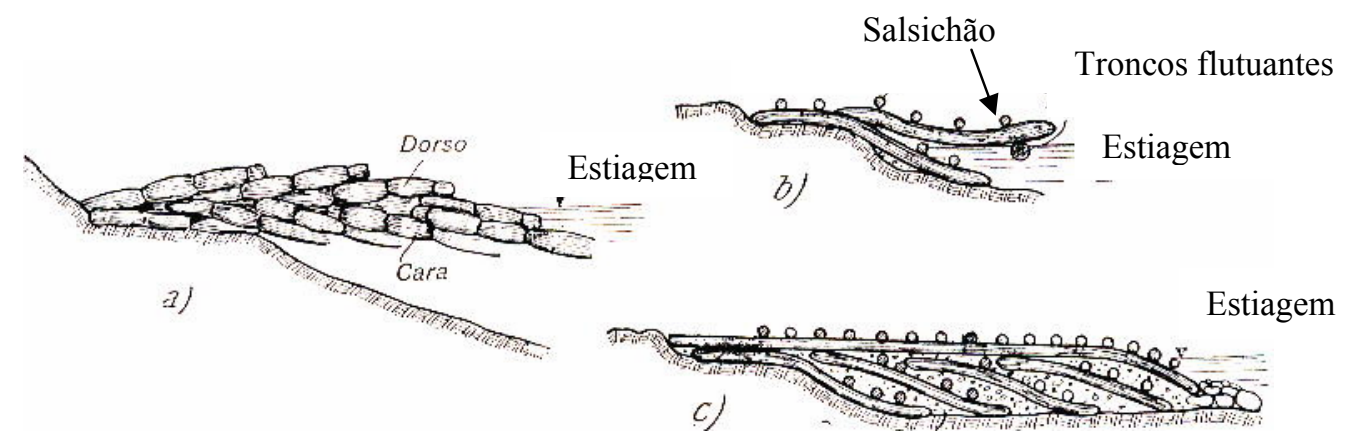

Figura 37 - Proteção Direta - Faxinas: obras de proteção de margens

Fonte: SCHOKLITSCH . (1935).

Embora as proteções com ramos, varas e ervas, sejam as menos permanentes de todos os tipos de proteção, apresentam certas dificuldades em sua construção. São recomendadas devido ao baixo custo inicial e, com uma boa conservação, podem ser mantidas em bom estado de funcionamento (Fendrich et al. 1997).

\section{\ Construção}

As varas finas e flexíveis são entretecidas horizontalmente a varas mais grossas, postes. Os postes são colocados a uma distância de aproximadamente $60 \mathrm{~cm}$, entre si, em buracos de aproximadamente $90 \mathrm{~cm}$ de profundidade e firmados por meio de cunhas. Os ramos são colocados do fundo para cima, sendo que os do fundo são mais longos e os topo mais curtos. Emprega-se uma grande quantidade de palha para fechar os intervalos entre os ramos existentes. Depois de um certo tempo a cerca, assim construída, perde a firmeza requerida, e se faz necessária a colocação de fileira adicional de postes. Ver figura 38. 
A duração média de uma cerca desse tipo, varia entre 3 e 5 anos, podendo ser maior se forem usados postes tratados (creosotados) e ramos e ervas de lenta putrefação. Apresentam a vantagem de utilizar pequena quantidade de material e desvantagem no controle de fugas, sendo preciso grande atenção para preencher as aberturas à medida que surgem (Fendrich et al. 1997).

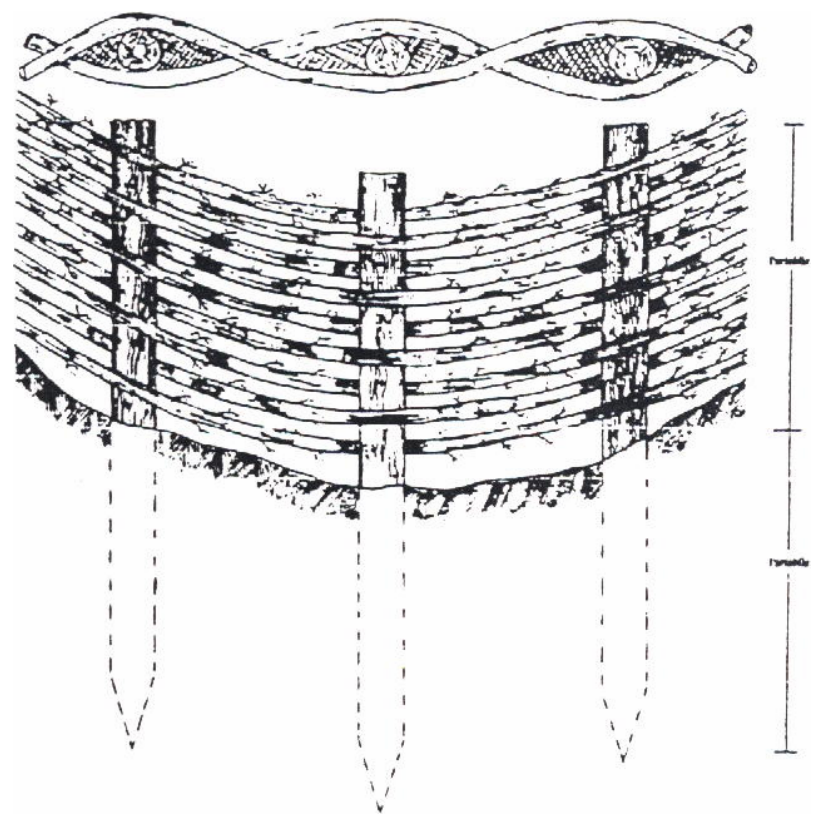

VISTA E SEÇÃO DA FAXINA

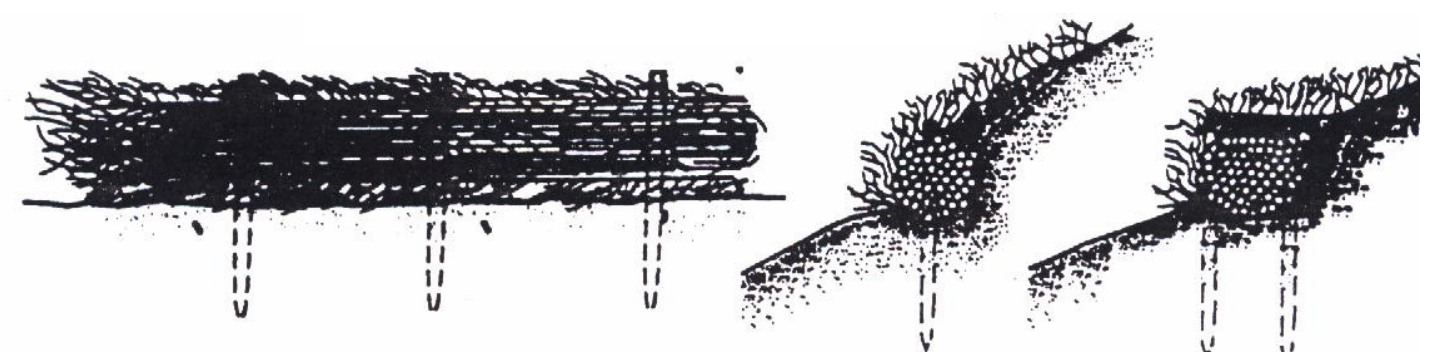

Figura 38 - Proteção Direta - Faxina: varas finas e flexíveis são entretecidas horizontalmente a varas mais grossas, postes, formando uma cerca.

Fonte: L'ACQUA . (2000). 


\section{Substituição do solo}

^ Remoção do Solo

É difícil concluir que havendo a ocorrência de solos com baixa resistência, com a presença de grandes porcentagens de matéria orgânica, ou mesmo a ocorrência de solos turfosos, impor-se alguma medida visando à estabilização da margem taludada.

Há vários processos para obter-se a estabilização da margem taludada, quando ocorrem as situações acima descritas, entretanto, descreveremos um dos mais adotados, pois, além de apresentar viabilidade técnica também apresentam viabilidade econômica (Ricardo \& Catalani, 1977).

凡 Execução da Remoção do Solo.

Este processo é aplicável quando a camada resistente é de pequena espessura, encontrando logo abaixo a camada resistente. A experiência tem demonstrado que até três metros de espessura, a remoção é o processo mais econômico e rápido de consolidação da margem, se comparado com outros métodos. A escavação, neste caso, é trabalho típico para as escavadeiras com "drag-line” que podem operar sobre a camada de topo, a qual, geralmente, apresenta um mínimo de suporte (Ricardo \& Catalani, 1977).

A substituição desse solo, dá-se devido a ruptura do talude por escorregamento de uma cunha de solo que se apoia sobre uma camada mais resistente. Na ocasião de chuvas intensas, o aumento da pressão devido a elevação do lençol freático, se traduz pelo aumento da pressão neutra, reduzindo sensivelmente a resistência ao cisalhamento e permitindo a formação de superfície de escorregamento que afeta a margem, levando-o à ruptura (Ricardo \& Catalani, 1977). 
O material de reposição deverá ser, de preferência, argila arenosa, de modo a permitir a percolação d'água. A porcentagem de areia permitirá a redução da pressão hidrostática, sobre a margem taludada.

\ Bota-fora

O material removido da margem taludada, por ser julgado tecnicamente inadequado para a constituição de aterro, deverá ser levado a um depósito ou botafora. De preferência, os "bota-foras" devem ser feitos ao longo do curso do rio, para tanto, é possível, por exemplo, tomar uma alça, resultante da retificação do curso d'água como bota-fora (Ricardo \& Catalani , 1977).

A utilização da alça, resultante da retificação do curso d'água como bota fora, resulta em alterações na porção bio-geo-física do meio ambiente, tais como: fauna e flora aquáticas, vegetação das margens e outros.

\section{Łos Pintura Asfáltica.}

\.mprimação

A imprimação, é uma aplicação do asfalto diluído (AD) de baixa viscosidade sobre uma superfície de uma base absorvente, tendo como objetivos principais, para este trabalho, aumentar a coesão da superfície pela penetração do material asfáltico empregado, impermeabilizar a camada (Petrucci, 1978).

$\rightarrow$ Material da Imprimação

O tipo de asfalto diluído usado é o ADM-1, no caso de superfícies com textura fechada (solo argiloso) e ADM-2 para superfícies com textura aberta (solo arenoso). 
A nomenclatura $\mathrm{ADM}$ ou $\mathrm{MC}$, tem por significado cimento asfáltico de petróleo, diluído, de cura média. Para uso, são aquecido a temperaturas de $60^{\circ} \mathrm{C}$ a $100^{\circ} \mathrm{C}$ (Petrucci, 1978).

Outra forma de se especificar o material a ser utilizado, é a adotada pelo IPT, ou seja, ADP (asfalto diluído de petróleo), tipo CM (cura média) - 30 ou CM - 70.

$\mathrm{O}$ asfalto diluído, é obtido adicionando-se um solvente ou diluente aos cimentos asfálticos de petróleo. O produto final tem menos viscosidade, facilitando as condições de emprego. A separação do diluente e do cimento asfáltico é denominado por analogia aos cimentos portland de "cura" (Petrucci, 1978).

Alguns cuidados deverão ser tomados com os materiais empregados na imprimação, tais como solventes (líquidos que dissolvem os compostos sólidos ou muitos viscosos, dando ao material a consistência adequada), entendidos como líquidos voláteis que evaporam, do material de imprimação, para a porção bio-geofísica do meio ambiente - AR, bem como o escoamento superficial das águas sobre a superfície que sofreu imprimação, promovendo o carreamento de material particulado asfáltico e óleo para a porção bio-geo-física do meio ambiente - ÁGUA, o que resulta em alterações de suas propriedades. A superfície imprimida, não poderá desenvolver ou receber revestimento vegetal.

$\leftrightarrow$ Enrocamento

N Apresentação

Os enrocamentos, ou rip-raps, consistem no simples revestimento de taludes com pedras ou blocos artificiais, objetivando a formação de um maciço de pedras arrumadas ou jogadas; ou blocos arrumados, destinados a proteger aterros, encostas, taludes, margens de rios, etc., dos efeitos da erosão, segundo Fendrich (1997). Ver figura 39.

As dimensões das pedras, são compatíveis com as velocidades de escoamento. A estabilidade dos revestimentos com enrocamentos é função de 
diversos aspectos, tais como a velocidade de escoamento, as condições de turbulência do fluxo, as propriedades físicas das rochas utilizadas, etc.
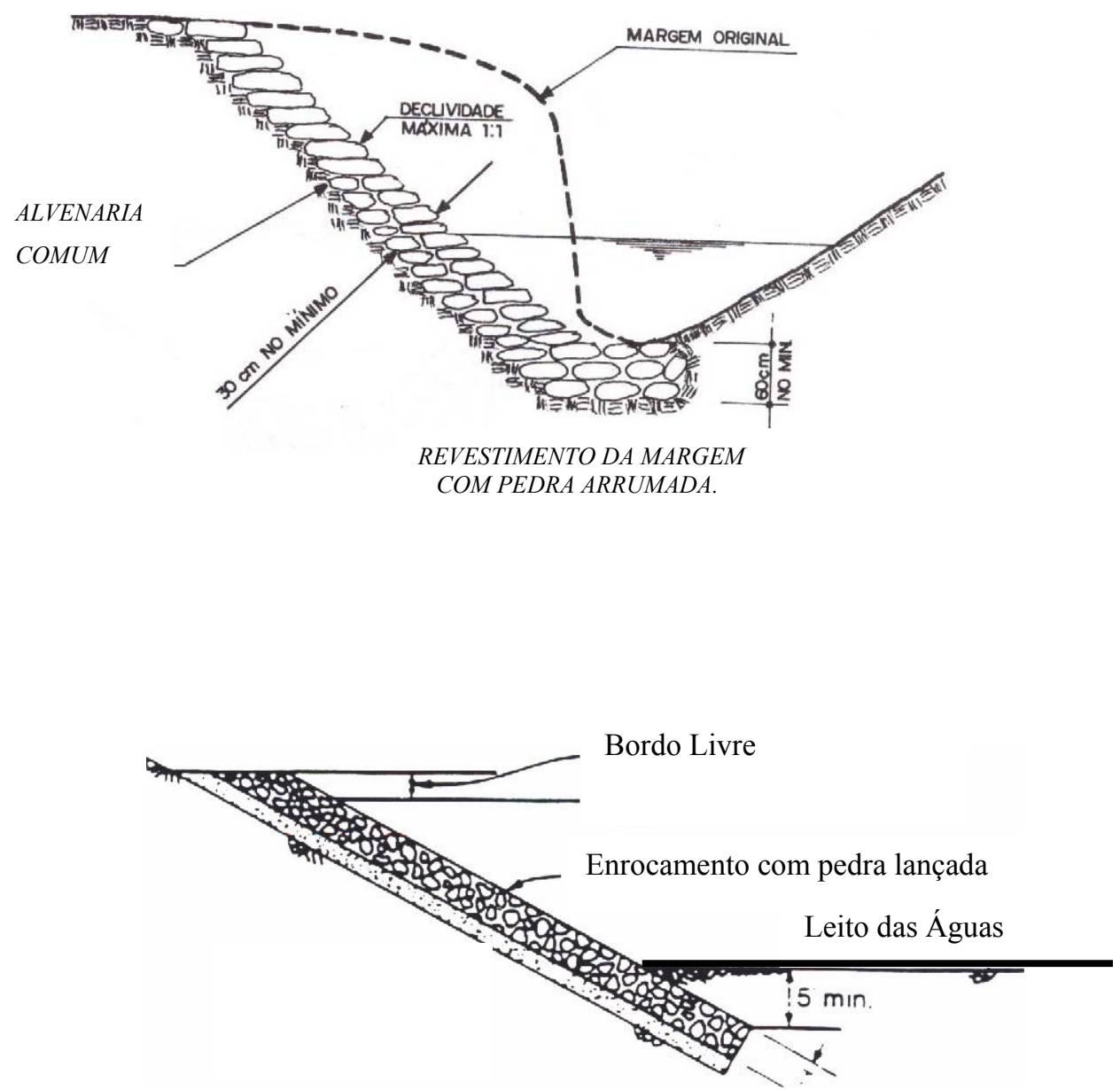

Figura 39 - Proteção Direta - Enrocamentos com pedras: arrumada e lançada Fonte: FENDRICH. (1997).

\. Filtros de Transição

Sempre que existir um enrocamento contendo lateralmente um talude, tornase necessário uma transição de granulometria impedindo o contato direto entre o solo e o enrocamento. Ver figura 40. O filtro de transição, localiza-se entre o enrocamento de proteção e a superfície do maciço (talude). (Rhodia, 1992) 


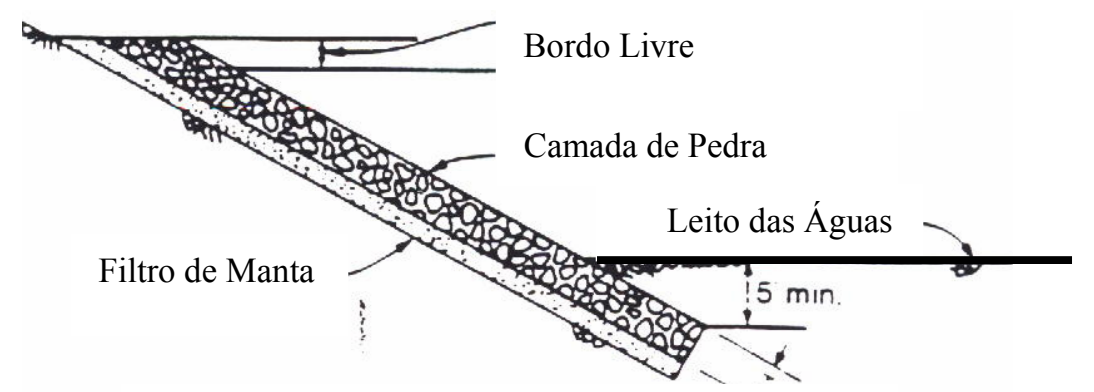

PROTEÇÃO DA MARGEM: RIP-RAP

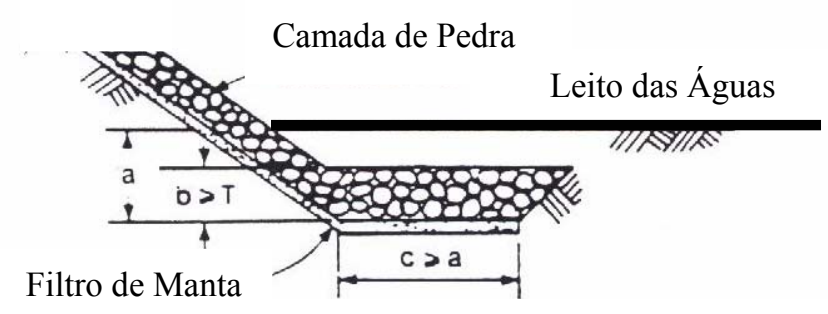

Figura 40 - Proteção Direta - Localização do Filtro de Transição no revestimento da margem. Fonte: BRIGHETTI. (2000).

A inclinação do talude, dificulta sensivelmente a execução de camadas filtrantes. Em primeiro lugar deverá ser obedecida a inclinação a ser dada para as camadas do filtro, além do que as espessuras correspondentes de cada camada, também, serão diferentes. Outro problema, é a construção dessas camadas sucessivas, com espessura determinada e constante, sobre o talude ora a seco ora imerso em água (Rhodia, 1992).

O filtro de transição, tem como finalidade impedir o carreamento das partículas do solo pelas forças de percolação, causando um vazio de forma tubular, onde as primeiras partículas que se deslocam deixam um espaço que favorece a convergência do fluxo de água para este local, acelerando o processo iniciado, identificado como "piping” (erosão tubular regressiva ou retroerosão). O piping poderá ocorrer pela ação da infiltração das águas precipitadas sobre o maciço de solo da margem, percolando pelo solo (ação interna) e originando o escoamento subterrâneo ou, pela ação das ondas (ação externa) sobre o enrocamento, resultando na percolação da água através das pedras, do filtro de transição e, 
finalmente através do solo da margem. Cessada a ação das ondas, a água percola no solo no sentido contrário a ação das ondas, ocorrendo o piping.

Nas situações descritas, o piping é evitado com a execução do filtro de transição, podendo ser executado com o emprego dos seguintes materiais: agregados, com uma transição de granulometria (areia de granulometria controlada); manta não tecida, exemplo: bidim.

\ Tipos de enrocamento, segundo Cirilo et al. (2001)

$\rightarrow$ Lançado (admite deformação do terreno)

\section{DEtapas}

$\rightarrow$ Verificar a tensão de arraste (Método das Tensões de Arraste) no talude do curso d'água. Sendo a tensão de arraste superior a tensão de arraste crítica, o canal será instável, necessitando, portanto, de proteção.

$\rightarrow$ Determinação do diâmetro médio das pedras, utilizando-se os critérios centrados na expressão, devida a Escarameia e Mays (Escarameia, 1998);

$\rightarrow$ Espessura dos enrocamentos, deve ser correspondente a cerca de 1,5 vezes o diâmetro máximo das pedras ou 2,0 vezes o diâmetro médio;

$\rightarrow$ Proteção na base do talude, é função da evolução do fundo;

$\rightarrow$ Filtro de transição - necessário quando a ação sobre o talude for externa, isto é, ondas e escoamento;

$\rightarrow$ Filtro Natural - necessário quando a ação sobre o talude for interna, isto é, percolação. Espessura das camadas nunca inferiores a $10 \mathrm{~cm}$.

$\rightarrow$ Filtro de Transição ou Filtro Artificial (geotêxteis) - deverão ser tomados cuidados quanto a perfuração e ou depósito de finos.

$\rightarrow$ Definir os limites de proteção, quanto a escoamento e ondas. 
$\rightarrow$ Arrumado (aceita pequena deformações do terreno)

D Economia de material (proteção e filtro);

D Dificuldade construtiva (a seco);

Denor rugosidade

D Mão-de-obra

맙 Gabiões Tipo Colchão (Colchão Reno), segundo Maccaferri (2000)

\. Apresentação

A escolha entre os diversos tipos de revestimento, é missão difícil para o engenheiro, pois em cada caso é necessário procurar os que possuam as exigidas características de permeabilidade ou impermeabilidade, robustez, flexibilidade, rugosidade, durabilidade e economia e entre eles adotar o que proporcione maior segurança.

Sem dúvida, os revestimentos flexíveis possuem um grande número de vantagens que os tornam preferidos, na maioria dos casos, aos rígidos e semi-rígidos.

Os revestimentos flexíveis, são utilizados na zona de maiores forças erosivas e principalmente sobre solo com alta capacidade de deformação. Estas erosões provêm, por vezes, de turbilhões, das correntes helicoidais nas curvas, dos efeitos de sucção das ondas e outros motivos. A proteção deve estender-se, em geral, a um certo trecho do rio até onde estes fatores de forte erosão subsistem e ser de um tipo suficientemente flexível para acomodar-se a possíveis erosões nos seus limites.

É importante ressaltar que a zona da margem permanentemente submersa, é a mais sujeita a erosões, apesar de nem sempre ser nessa zona, a ocorrência de maiores forças erosivas.

Entre os revestimentos flexíveis, os gabiões e colchões Reno ocupam uma posição de destaque. Ver figura 41. 

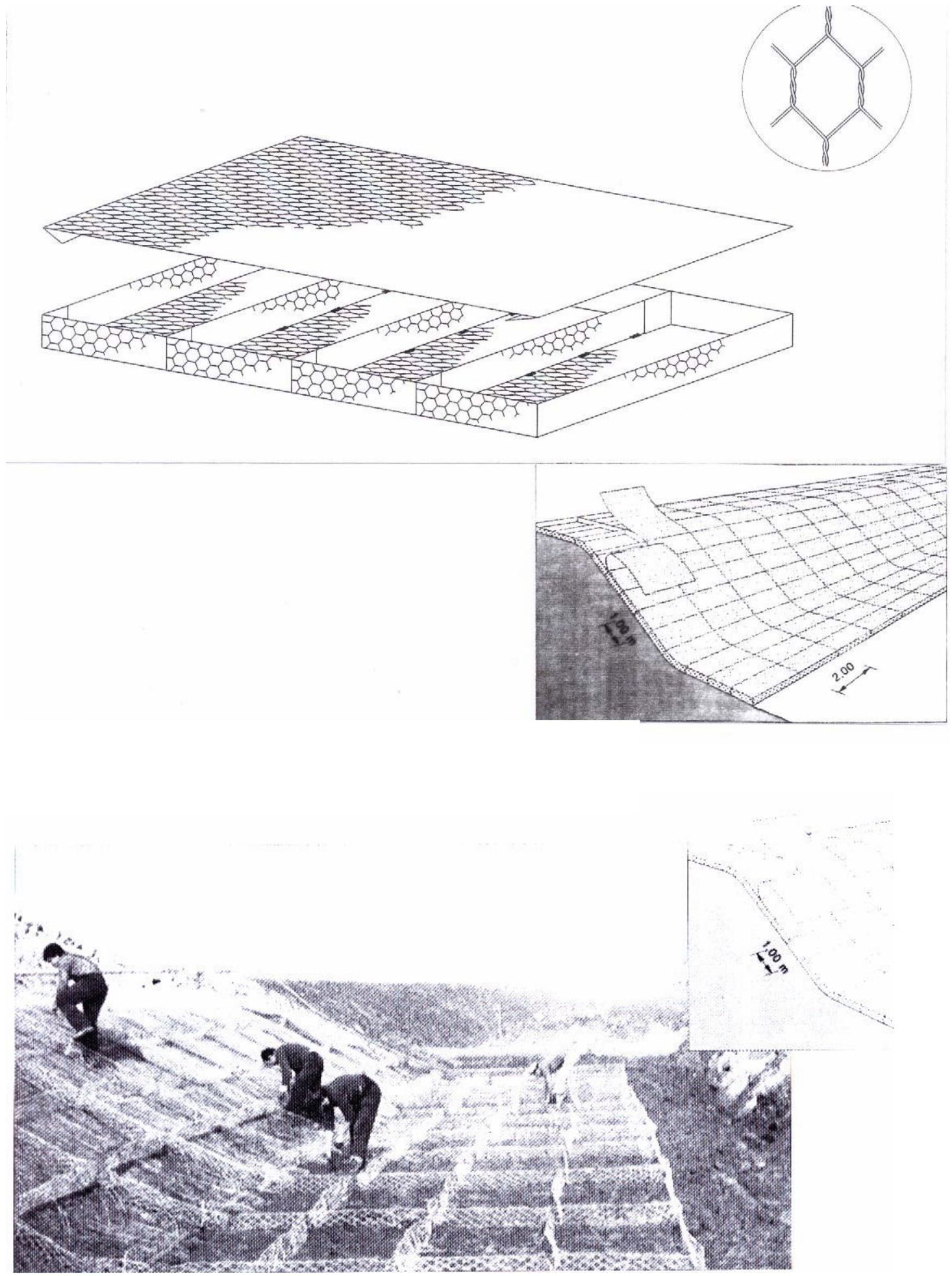

Figura 41 - Proteção Direta - Esquema de um colchão Reno.

Fonte: MACAFERRI. (2002). 
\ Colocação dos colchões Reno na obra

As várias operações de montagem e enchimento, podem ser simplesmente resumidas em:

$\rightarrow$ Preparação de cada colchão fora do local de utilização, ver figura 42;

$\rightarrow$ Colocação na obra e união dos colchões entre si, ver figura 42;

$\rightarrow$ Enchimento dos colchões com seixos ou pedras, ver figuras 43 e 44;

$\rightarrow$ Fechamento dos colchões mediante costura das tampas, ver figura 45 .
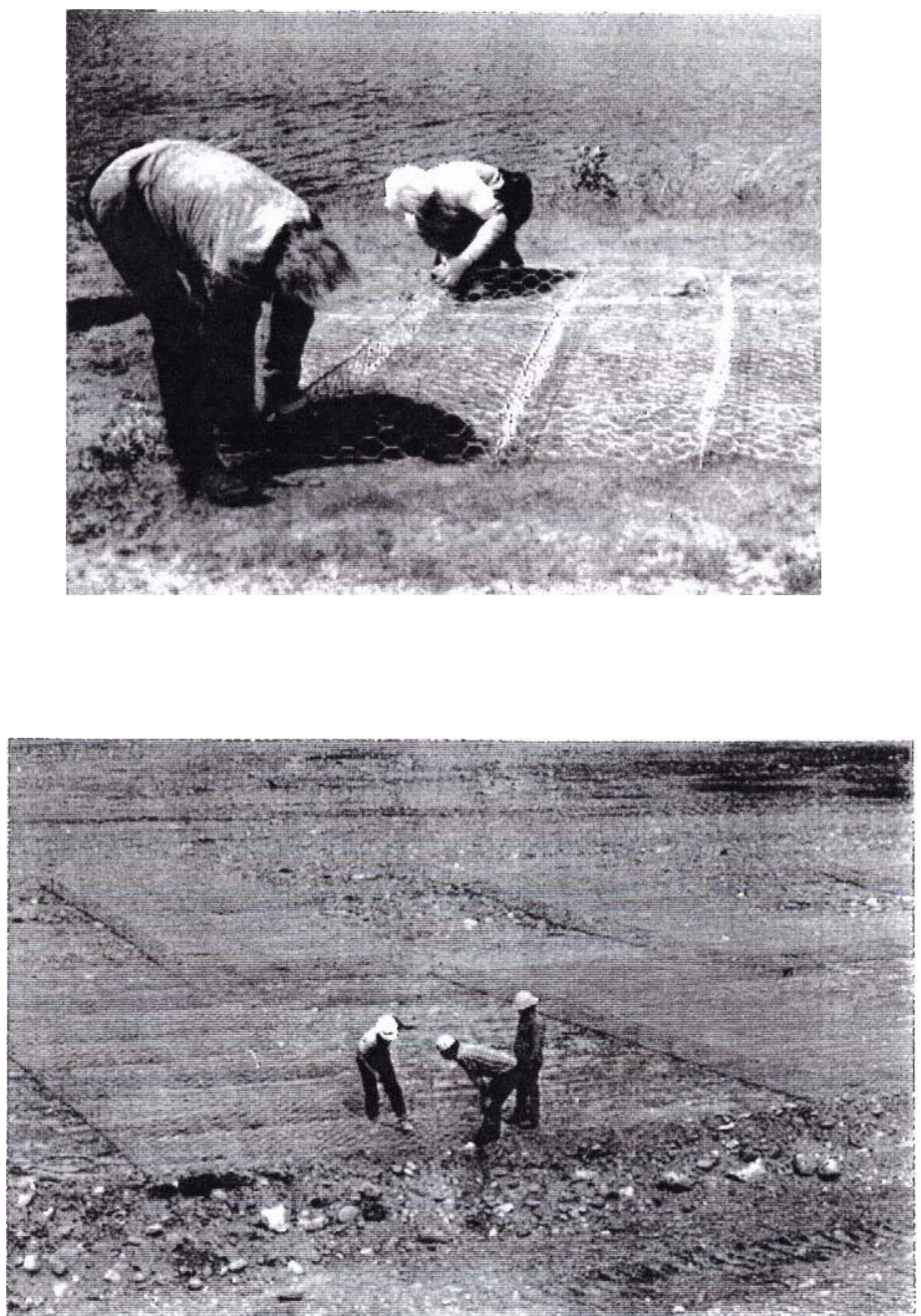

Figura 42 - Proteção Direta - Colchão Reno - Preparação e colocação do colchão Reno na obra. Fonte: MACCAFERRI. (2002). 


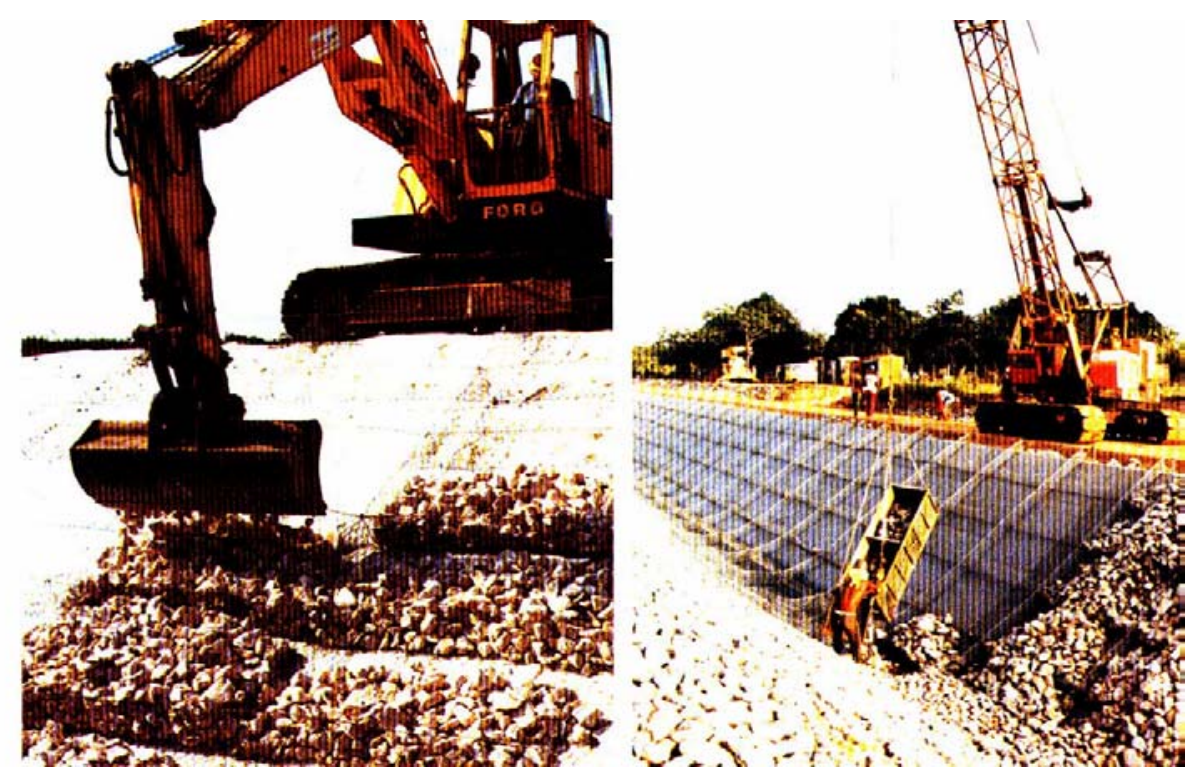

Figura 43 - Proteção Direta - Colchão Reno - Enchimento do colchão Reno na obra. Fonte: MACCAFERRI. (2002).
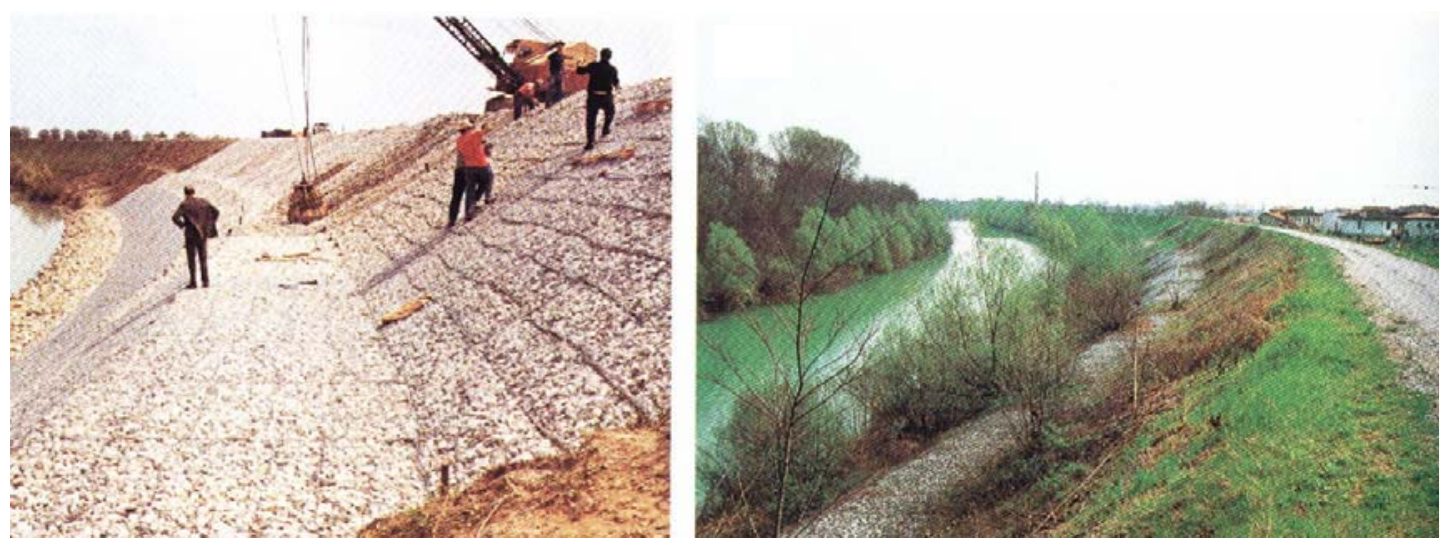

Figura 44 - Proteção Direta - Colchão Reno - Enchimento do colchão Reno na obra e, recuperação da vegetação, com minimização dos impactos ambientais.

Fonte: MACCAFERRI. (2002). 


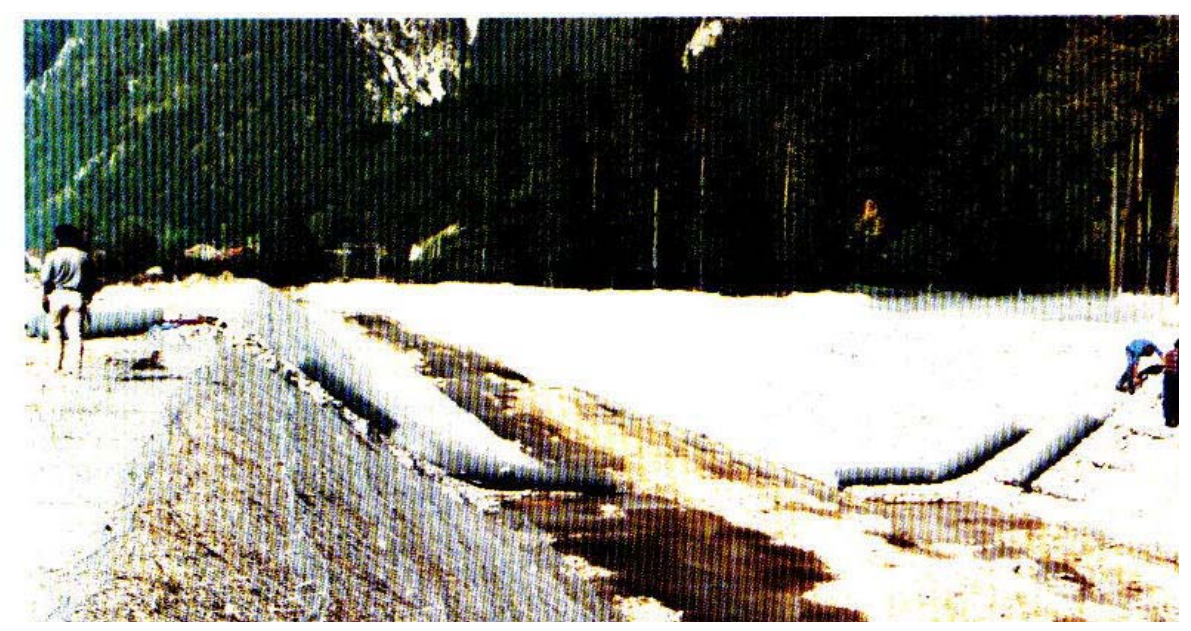

Figura 45 - Proteção Direta - Colchão Reno - Fechamento do colchão Reno na obra. Fonte: MACCAFERRI. (2002).

\ Classificação dos revestimentos

Com relação ao emprego do colchões Reno e gabiões para defesa e revestimento de canais e cursos d'água canalizados e suas possíveis aplicações considera-se, para simplificação, a seguinte classificação:

$\rightarrow$ Revestimentos executados a seco

Os revestimentos em colchões Reno e gabiões se apoiam diretamente sobre o solo a ser protegido, entretanto, é necessário que o mesmo seja suficientemente estável e que sua inclinação seja tal que não provoque riscos de deslizamento do revestimento. Contudo, nenhuma dessas condições se tornam obrigatória como seriam no caso dos revestimentos rígidos, visto que os revestimentos em colchões Reno ou gabiões podem adaptar-se às acomodações, mesmo consideráveis das margens. 
Os colchões Reno, geralmente, são colocados nas margens com a maior dimensão, transversal ao curso d'água, ou seja, com a maior dimensão ao longo da máxima declividade das margens e perpendicularmente a correnteza. Esta disposição não é todavia obrigatória; em certos casos se torna mais conveniente dispor os elementos longitudinalmente à correnteza como, por exemplo, nos revestimentos de fundo e, em casos de cursos d'água com notável velocidade. Na escolha entre esses dois métodos, pode-se levar em consideração a maior facilidade de colocação na obra e outras razões construtivas. Ver figura 46.

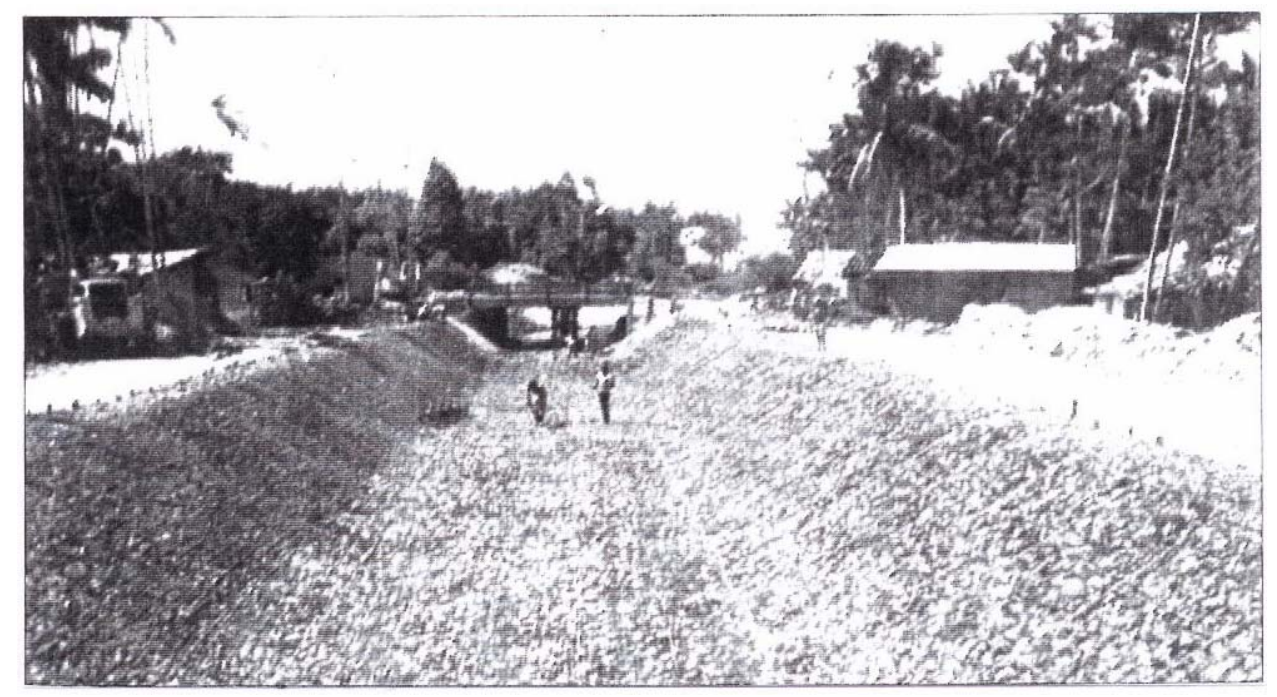

Figura 46 - Proteção Direta - Colchão Reno - Revestimento executado a seco.

Fonte: MACCAFERRI. (2002).

Normalmente os taludes de apoio são executados com inclinação de 1:1,5 e 1:2 segundo a natureza do solo, sendo a inclinação máxima usada em solos naturais argilosos de consistência razoável e a mínima em solos arenosos finos e sem coesão.

A resistência dos revestimentos em colchões Reno depende, além da resistência da rede metálica, também da espessura da estrutura e do tamanho das pedras de enchimento. Admitindo como representativa das solicitações às quais o revestimento será submetido, a "velocidade média" da corrente. Para uma dada velocidade da correnteza, o colchão Reno (estável) possui uma espessura 3 a 4 vezes inferior àquela que possui um revestimento em enrocamento (rip-rap). 
A maior velocidade suportada pelo revestimento, com segurança, sem haver movimento de pedras no interior do colchão é entendida como "velocidade crítica", e velocidade limite aquela também aceitável admitindo modestas deformações do colchão do Reno por movimento das pedras.

As forças de arraste no fundo, suportadas por um revestimento em colchão Reno são mais que o dobro daquelas admissíveis por um revestimento em enrocamento (rip-rap) da mesma granulometria. A resistência de um revestimento em enrocamento é oferecida somente pelas pedras, enquanto que a rede metálica permite ao colchão Reno trabalhar como um conjunto.

A notável redução na espessura do revestimento, que se obtém empregando colchões Reno em vez de enrocamento, assume particular vantagem econômica no caso de regularização de grandes rios, dada a proporção da obra e também do volume de material a empregar.

Quando o escorregamento é profundo e é necessária uma consolidação das margens, poderão ser obtidas ótimas soluções com obras mistas em colchão Reno e gabiões-caixa.

Em ambientes marítimos ou em presença de águas quimicamente agressivas ou poluídas é recomendável a utilização de colchões Reno e gabiões duplamente galvanizados revestidos com PVC.

$\rightarrow$ Revestimentos executados em presença de água

As defesas das margens a serem construídas abaixo do nível d'água são, habitualmente, executadas com pedras lançadas aleatoriamente (rip-rap) ou com a utilização de sacos de fibras vegetais tecidas preenchidos com pedras e lançados diretamente sobre as margens submersas.

As operações de colocação na obra apresentam por este motivo grande insegurança, sendo difícil obter uma distribuição uniforme do material sobre a superfície total a proteger; para reduzir o risco de que parte da margem fique com proteção insuficiente é necessário abundar na quantidade de pedras lançadas na obra. 
Além disso, as pedras, colocadas ao longo de uma margem inclinada, por ação da correnteza e de seu próprio peso, tendem a deslocarem-se para o fundo, deixando desprotegida a parte superior da margem; em caso de fundo lodoso, a base do revestimento não encontra um apoio sólido e vai aos poucos penetrando no solo, tornando-se indispensáveis freqüentes e custosas operações de reposição de revestimento.

A espessura do revestimento em colchões Reno, graças aos sistemas de lançamento controlado, não necessita ser aumentada em caso de colocação abaixo da água, diferindo dos revestimentos em enrocamento para os quais é normal um aumento de $50 \%$.

As dificuldades e os obstáculos que se apresentam na execução dos revestimentos de margens submersas com os métodos tradicionais são superados com o lançamento dos colchões Reno, através de pontões e ou de outras aparelhagens especiais. Ver figura 47.

$\rightarrow$ Revestimentos consolidados ou impermeabilizados com mástique de betume hidráulico

A combinação dos colchões Reno com mástique de betume para uso hidráulico resulta numa estrutura que reúne as características e a funcionalidade dos dois materiais. Em combinação com o mástique de betume, o colchão Reno, conserva, de fato, as suas características de flexibilidade, aumentando a compacidade do enchimento e portanto a eficácia protetora da estrutura. A aplicação do mástique de betume protege a malha metálica tanto da corrosão das águas salgadas ou quimicamente agressivas ou poluídas por descargas industriais, como também da abrasão provocada pelo transporte sólido.

A aplicação do mástique, para simples consolidação é limitada à quantidade necessária para unir o material de enchimento, reduzindo mas não eliminando a permeabilidade da estrutura, conservando assim as características funcionais dos colchões Reno. 
Para a impermeabilização, o mástique de betume deve preencher completamente os vazios entre as pedras de enchimento e recobrir de 20 a $30 \mathrm{~mm}$ a malha metálica, que é assim protegida do contato com a água e os agentes atmosféricos.

A preparação e colocação na obra do revestimento em colchões Reno, a tratar com mástique betuminoso, não apresenta diferenças substanciais ao que foi descrito anteriormente para os revestimentos não betumados. Também para os revestimento betumados recomenda-se não superar uma inclinação de 1:1,5 no plano de colocação.
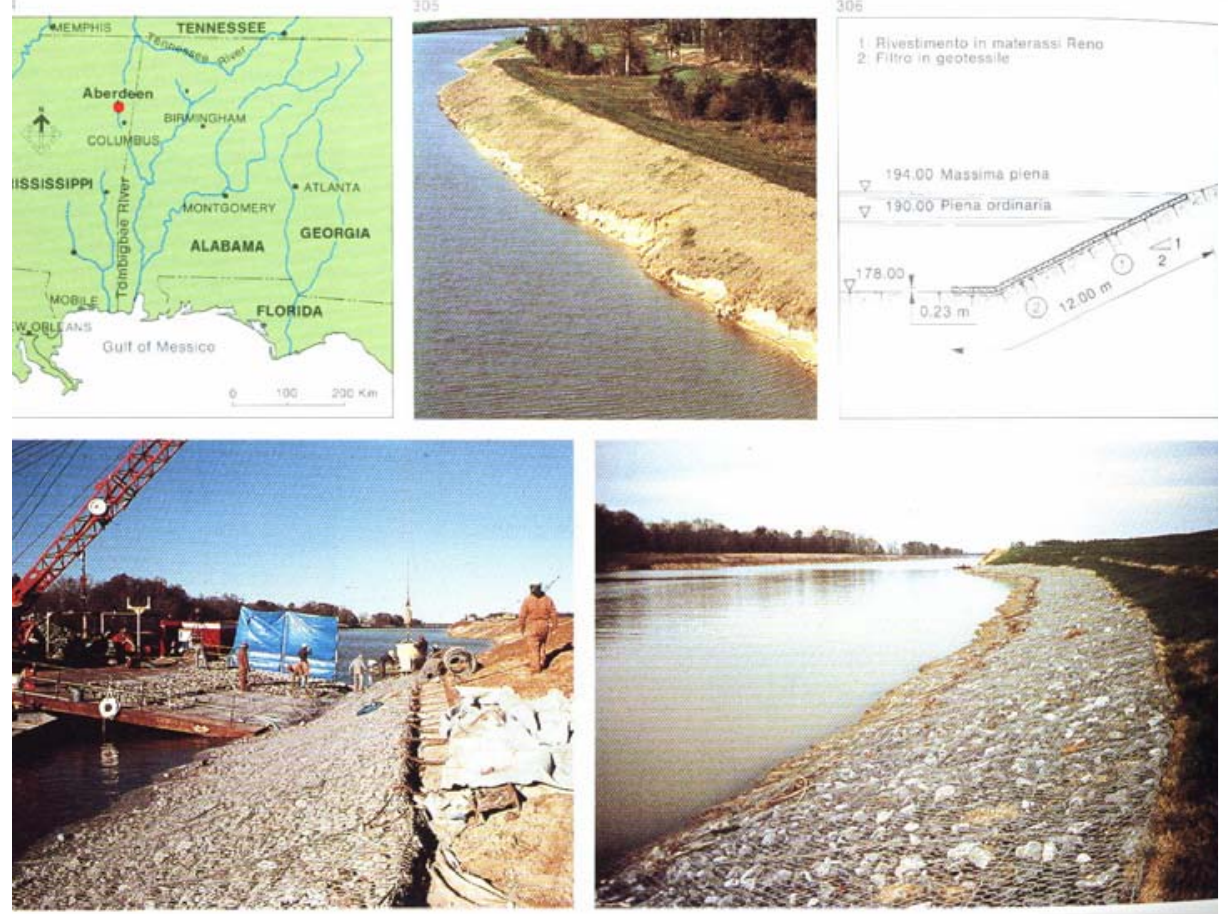

Figura 47 - Proteção Direta - Colchão Reno - Revestimento executado em presença d'água. Fonte: MACCAFERRI. (2002).

A aplicação no seco pode ser feita lançando diretamente o mástique do caminhão que o transporta utilizando uma simples canaleta. Se o caminhão não pode transitar no topo da margem, a aplicação na obra poderá ser feita com o auxílio de um guindaste e de uma apropriada caçamba térmica. Ver figura 48. 

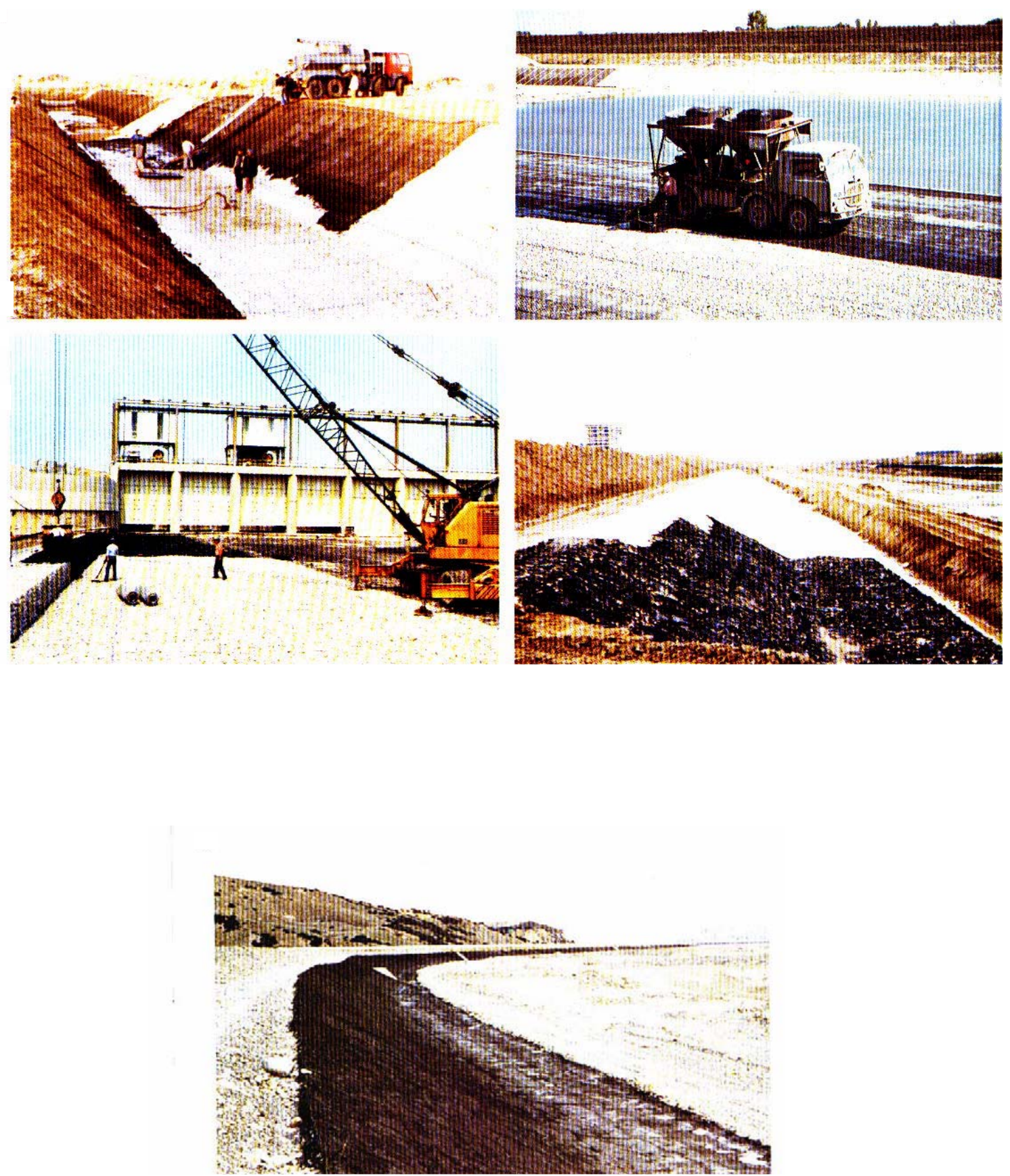

Figura 48 - Proteção Direta - Colchão Reno com mástique de betume, aplicado no local da obra. Fonte: MACCAFERRI. (2002). 
A aplicação em presença de água pode ser feita por gravidade para uma profundidade de até cerca de $2 \mathrm{~m}$, mediante lançamento direto.

O colchão Reno, quando preparado fora da obra, utiliza os chamados pontões. Sobre estes, as pedras para o enchimento do colchão e o mástique de betume são colocados com maior facilidade e regularidade que sobre superfícies inclinadas. Também a penetração do mástique é mais segura e uniforme.

O lançamento é simples e obtido com o deslizamento do elemento sobre a plataforma do pontão, oportunamente inclinada.

Os elementos podem ser colocados na obra sobrepondo as bordas de 0,40 a 0,60 m, evitando dessa maneira trabalhosas operações de união das juntas embaixo d'água. Outro sistema de lançamento dos elementos betumados preparados fora da obra utiliza guindaste.

Neste caso, as operações de execução da estrutura e a aplicação do mástique são as mesmas descritas anteriormente, com a única diferença que são executadas ao longo das margens em lugar de serem realizadas sobre o pontão. Ver figura 49. 

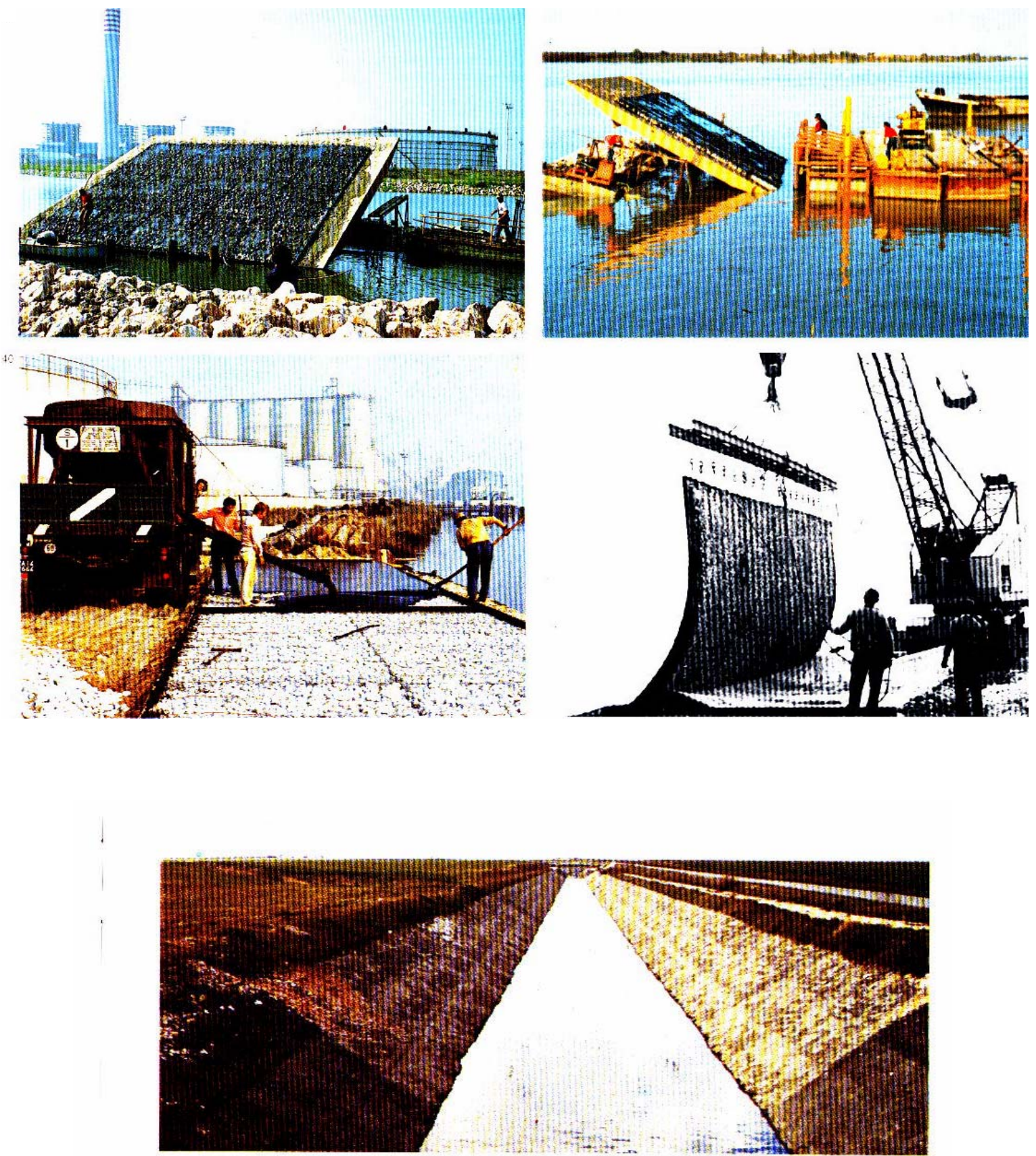

Figura 49 - Proteção Direta: Colchão Reno com mástique de betume, aplicado fora do local da obra. Fonte: MACCAFERRI. (2002). 
Colchacreto, segundo Construserv (2000)

^ Apresentação

Durante os últimos 20 anos, a CONSTRUSERV-Sistemas de Controle de Erosão e Comércio Ltda., vem trabalhando em diversas obras hidrogeotécnicas e durante esse tempo, desenvolveu alguns produtos de materiais poliméricos destinados a diferentes aplicações relacionadas com controle de erosão, canalização de córregos, proteção de margens, estabilização de taludes, pequenas barragens, espigões marítimos e fluviais, molhes, etc. Ver figura 50.

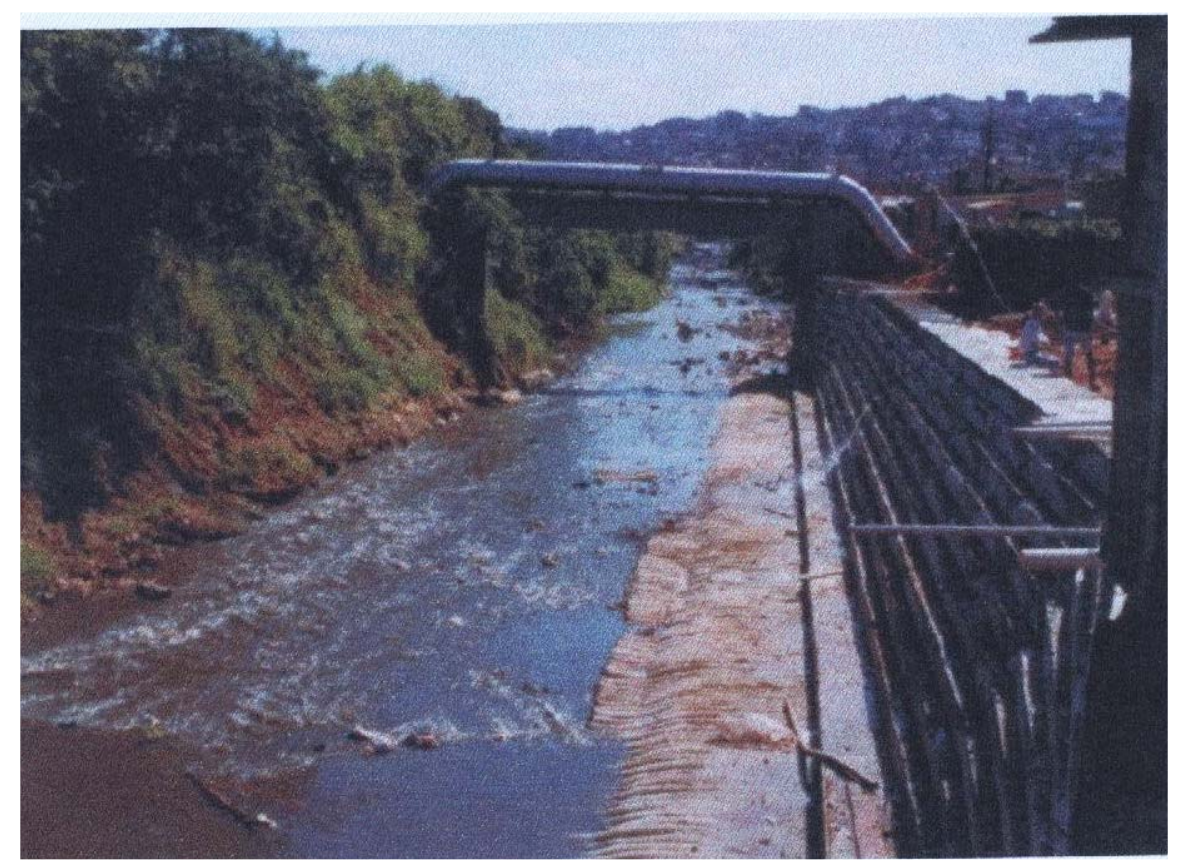

Figura 50 - Proteção Direta - Proteção de margem taludada: pé com bolsacreto e talude com módulos têxteis Colchacreto A-15. (Cliente - Prefeitura do Município de São Paulo). Fonte: CONSTRUSERV - Sistemas de Controle de Erosão e Comércio Ltda. Manual Técnico

Entre eles, destaca-se o sistema "COLCHACRETO" especialmente desenvolvido para aplicação em obras de controle de erosão e revestimento de canais. 
N Especificação técnica

Foram desenvolvidos dois produtos para diferentes aplicações, o tipo "A" e o tipo "E", em razão das características dos solos onde serão empregados. O "COLCHACRETO" tipo "A" é recomendado para solos de baixo valor de suporte orgânico e até expansivos, em virtude da sua excelente flexibilidade e da facilidade de adaptação e ajustes decorrentes da movimentação dos solos.

O tipo "E" tem características rígidas e, portanto, para solos de bom valor e boa estabilidade. Ver figura 51.

O "COLCHACRETO" tipo "A" é articulado e, portanto flexível e possui características auto-drenantes e o tipo "E" requer juntas internas de dilatação composta de tubos de PEAD (Polietileno de Alta Densidade) de diâmetro de acordo com a espessura do colchão e baterias de barbacãs para alívio de subpressão interna.

Ambos possuem mecanismos internos limitadores de espessura e definição de formas e podem ser fabricados para espessuras de 10 a 25 centímetros de revestimento.

A forma têxtil se compõe de simples módulo para moldagem de concreto, dentro ou fora d'água e é confeccionada em teares especiais com tecido sintético de combinação polimérica de fios de PP (Polipropileno), PEBD (Polipropileno de Baixa Densidade) e PA (Plástico), de 1200 denier, retorcidos e fibrilizados, com tensores internos de nylon de $2 \mathrm{~mm}$ e gramatura de $4,68 \mathrm{~g} / \mathrm{m}^{2}$. Realça-se, sobretudo, pelo fato de não permitir a entrada de água do exterior para o interior da forma têxtil e, por drenar o excesso de água do concreto, do interior para fora, garantindo assim a qualidade do concreto no que se refere à textura, estrutura, resistência aos ensaios de compressão e de durabilidade.

É moldado sempre “in loco” mesmo na presença de água, sem necessidade de ensecadeiras, desvios de cursos d'água ou bombeamento, com concreto fino usinado aditivado de diferentes resistências mecânicas, de acordo com a característica de 
cada obra, através de uma bomba específica, móvel, facilmente transportável e mangotes de recalques de $50 \mathrm{~mm}$.

A forma têxtil, por se tratar de mero módulo de moldagem, é descartável, e a resistência mecânica do concreto usinado é aferida por baterias de corpos de prova, moldados pelo sistema indeformado e submetido a ensaios de durabilidade.

Elementos de um COLCHACRETO TIPO - E

Esc. $1: 10$

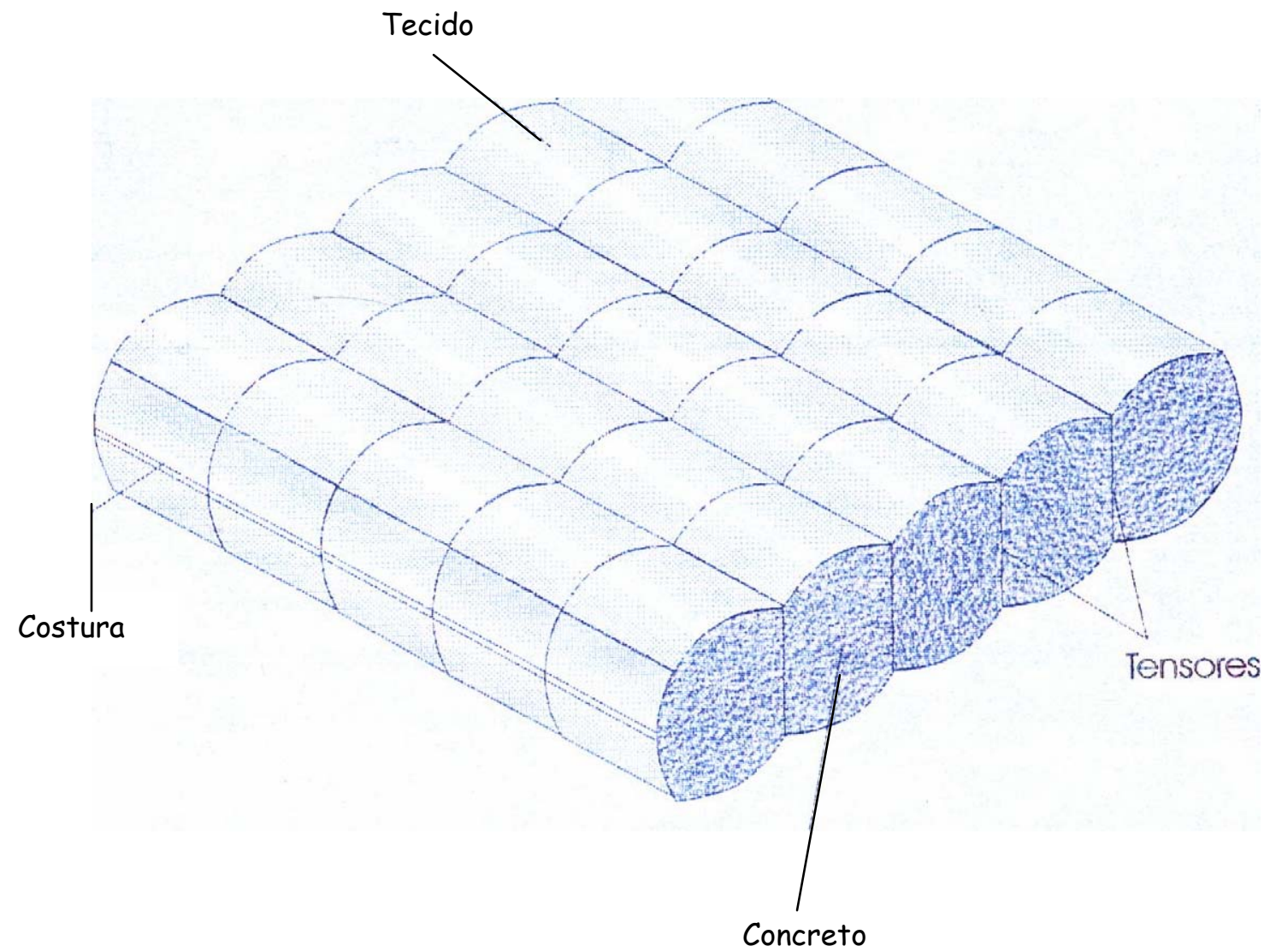

Figura 51 - Proteção Direta - Colchacreto - Elementos de um Colchacreto.

Fonte: CONSTRUSERV - Sistemas de Controle de Erosão e Comércio Ltda. Manual Técnico

Bolsacreto, segundo Construserv (2000)

\. Apresentação 
Bolsacreto é uma geoforma têxtil de vários tamanhos padronizados, confeccionada com tecido de combinações poliméricas, com fios de alta tração, retorcidos e fibrilizados, semi-permeável para moldagem "in-loco" dentro ou fora d'água, com micro concreto usinado, argamassa de cimento e areia ou solo-cimento injetável, sem necessidade de ensecadeiras, de corta-rio ou de esgotamentos.

Destaca-se, sobretudo, pelo dispositivo de microfiltragem "unifluxo", que garante a drenagem do excesso de água da massa de enchimento sem migração dos colóides (nata de cimento) e impede a entrada d'água do exterior da forma para dentro, garantindo a qualidade do concreto no que se refere a textura, estrutura, resistência à tração e resistência nos ensaios de durabilidade.

\ Vantagens construtivas

$\rightarrow$ Emprego de mão-de-obra local não qualificada;

$\rightarrow$ Uso de equipamento leve e facilmente transportável;

$\rightarrow$ Não requer acessos especiais, permitindo a concretagem de até $300 \mathrm{~m}$ do caminhão - betoneira, por meio de mangotes de diâmetro $50 \mathrm{~mm}$;

$\rightarrow$ Facilidade de reconstrução ou reparos, em casos de eventuais acidentes;

$\rightarrow$ Pode ser moldado com diferentes tipos de concreto fino, com argamassa de cimento e areia e até com solo-cimento injetável;

$\rightarrow$ Rapidez na execução, podendo absorver de 8 a 10 caminhõesbetoneira/dia/bomba.

N Especificações técnicas de bolsacreto, ver figuras 52.

$\rightarrow$ Escavação mecânica para implantação da obra

DA escavação (corte) deverá ser feita em taludes com inclinação e de forma a deixar patamares e degraus, se necessário. Este procedimento tem a finalidade de permitir 
melhor ligação entre o reaterro e o terreno natural, bem como facilitar a próxima execução ao aterro;

DQuando a escavação tiver atingido a cota prevista no projeto, deverá ser feita a regularização de fundo para receber o colchão de concreto, inclinado a $30^{\circ} \mathrm{em}$ relação ao plano horizontal e em seguida deverá ser iniciada a moldagem das formas têxteis;

Duando ocorrer a presença de argila orgânica mole, de baixo valor de suporte, esta deverá ser totalmente removida e substituída por rachão;

DEm qualquer caso, o material removido deverá ser depositado fora das bordas da vala, a uma distância mínima equivalente a profundidade da mesma, para evitar-se eventuais deslizamentos;

D Os materiais compostos de solos orgânicos ou contendo detritos vegetais, não poderão ser aproveitados, devendo ser depositado em bota-fora.

$\rightarrow$ Instalação e moldagem dos módulos bolsacreto

DAs formas têxteis Bolsacreto serão instaladas vazias, dentro ou fora d'água, sem necessidade de ensecadeiras, corta-rios, bombeamentos ou rebaixamento de lençol. Deverão ser instaladas manualmente, bem justapostas, de sorte que no momento da moldagem (enchimento), não estabeleça vazios na estrutura e permita formar o embricamento entre as peças, fundamental para melhorar a estabilidade do conjunto. O alinhamento externo deve ser observado rigorosamente na forma da topografia do projeto;

D A moldagem é feita através de uma bomba projetora de concreto fino, acoplada a uma linha de mangotes de diâmetro $50 \mathrm{~mm}$, a qual será conectada diretamente na válvula existente na forma têxtil;

D Os módulos têxteis serão moldados "in-loco" com concreto fino usinado de resistência mecânica ajustada para cada caso. $\mathrm{O}$ concreto poderá sair da usina com "slump" em torno de 5 a $6 \mathrm{~cm}$, devendo ser redozado na hora para ajustá-lo às 
condições de bombeamento, ficando com taxa de abatimento em torno de 12 a $15 \mathrm{~cm}$.

$\rightarrow$ Reaterro na interface do bolsacreto com a linha de escavação

D reaterro, na interface da estrutura de contenção e o talude escavado, deverá ser elaborado com pó de pedra. O material deverá ser lançado e espalhado em camadas horizontais de no máximo $30 \mathrm{~cm}$ e adensado com vibrador de imersão de $60 \mathrm{~mm}$, na presença de água relativamente limpa;

DO reaterro deverá atingir um grau de adensamento mínimo que contemple um peso específico entre 1,8 a $1,9 \mathrm{tf} / \mathrm{m}^{3}$;

DAs áreas em exploração ou em processo de adensamento, deverão estar bem limpas, podendo adotar "trincheiras" com emprego de sacos de areia;

DO projeto deverá contemplar um selo de argila ou concreto simples, para a proteção da superfície superior (crista) do reaterro adensado.

$\rightarrow$ Proteção do pé da sapata contra erosão

DTanto para os solos de relativo valor de suporte, quanto para as áreas onde houve reposição com rachão, deve-se especificar a proteção do pé da sapata de Bolsacreto, através de Colchacreto (colchão de concreto) articulado com $15 \mathrm{~cm}$ de espessura e largura mínima de 2,50 m úteis. Para os casos de solo de média capacidade de suporte, o colchão de concreto deve contemplar toda a largura da sapata, para as distribuições de cargas (tensões);

A moldagem desse colchão é feita com o mesmo concreto adotado para os módulos Bolsacreto e o sistema de enchimento é idêntico;

DEm hipótese alguma deverá deixar-se vazios, ou seja, forma têxtil sem enchimento com concreto, na zona da proteção do pé da sapata. 
$\rightarrow$ Drenagem sub-horizontal (barbacã)

A drenagem sub-horizontal para alívio da sub-pressão deverá ser exercida por uma bateria de barbacãs de geotêxtil de diâmetro $50 \mathrm{~mm}$, (salsichão), enchidos com brita n⿳⺈ 01 ;

D A instalação desses barbacãs será feita na justaposição entre os módulos de Bolsacreto, adotando-se o espaçamento de 5,40 m entre eles no sentido horizontal, ou seja uma sim uma não. No plano vertical adotar-se-á o espaço de $0,60 \mathrm{~m}$, sendo que os barbacãs ficarão locados de forma heterogênea;

D Não haverá necessidade de filtro de transição (geotêxtil) entre a interface da estrutura de Bolsacreto e o reaterro. 


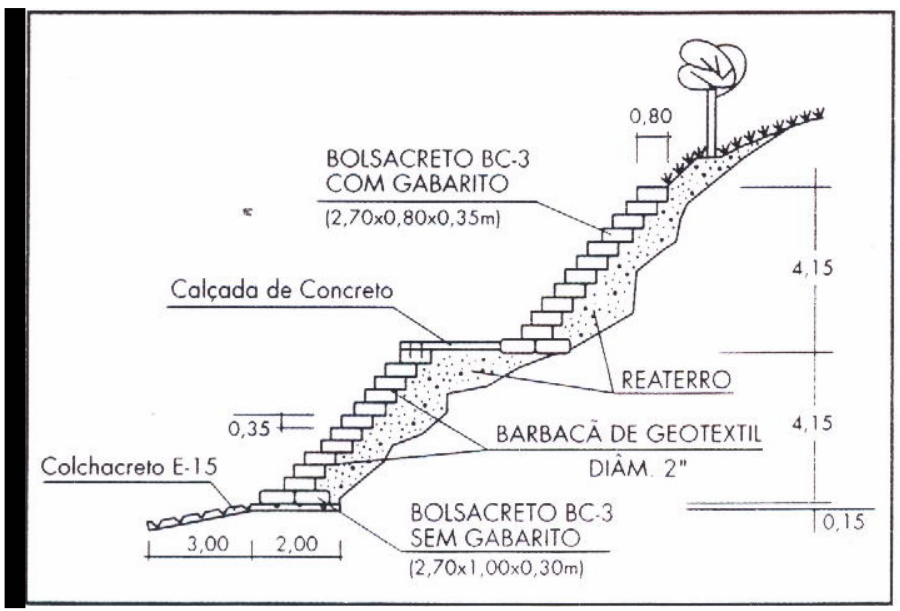

Contenção e proteção de margem com emprego de

Bolsacreto e Colchacreto.

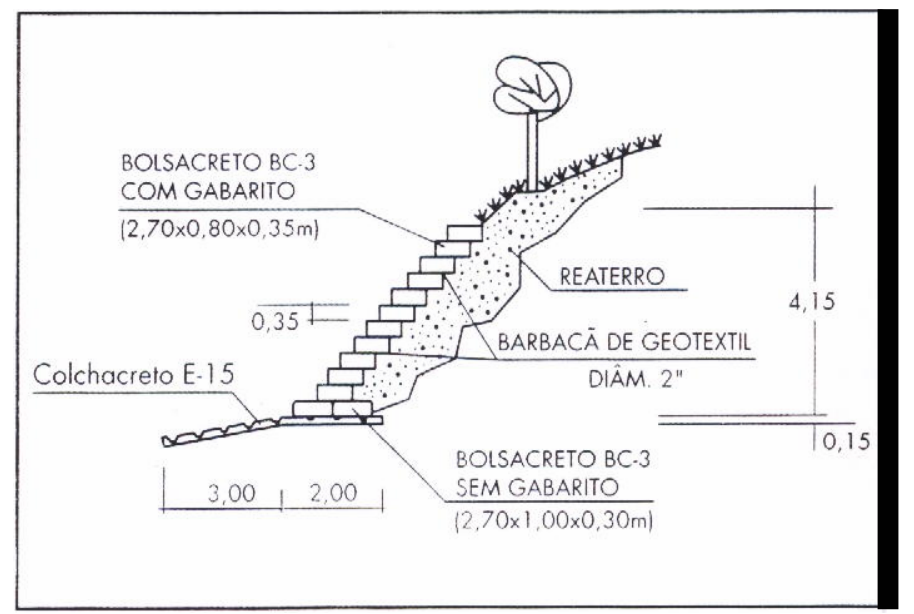

Contenção e proteção de margem com emprego de Bolsacreto e Colchacreto.

Figura 52 - Proteção Direta - Bolsacreto - Especificação técnica.

Fonte: Fonte: CONSTRUSERV - Sistemas de Controle de Erosão e Comércio Ltda. Manual Técnico

Revestimento em concreto, segundo Cirilo et al. (2001)

凡 Apresentação 
As margens revestidas com esse material, podem ser obtidas utilizando-se o concreto moldado "in loco", para obras de grandes dimensões, ou com o emprego de peças pré-moldadas, para obras de porte mais reduzido. Ocasionalmente utiliza-se ainda o concreto projetado.

A utilização do concreto é particularmente indicada para situações em que a faixa disponível para implantação da obra é reduzida. Com efeito, revestindo-se a margem com concreto, pode-se trabalhar com velocidades de escoamento mais elevadas, que possibilitam uma maior capacidade de vazão. O revestimento com concreto, é pouco exigente no que diz respeito à manutenção.

Łeças pré-moldadas em concreto armado, com seção cheia e vazada.

As peças pré-moldadas, ver figura 53, são confeccionadas em concreto armado, apresentando como características principais:

\ Resistência a meios agressivos, isto é, água do mar, águas residuárias (esgotos industriais e urbanos);

N Resistência a esforços mecânicos oriundos do transporte e colocação;

N Resistência a esforços mecânicos transmitidos pelo maciço terroso e/ou rochoso (margem). 
(2)
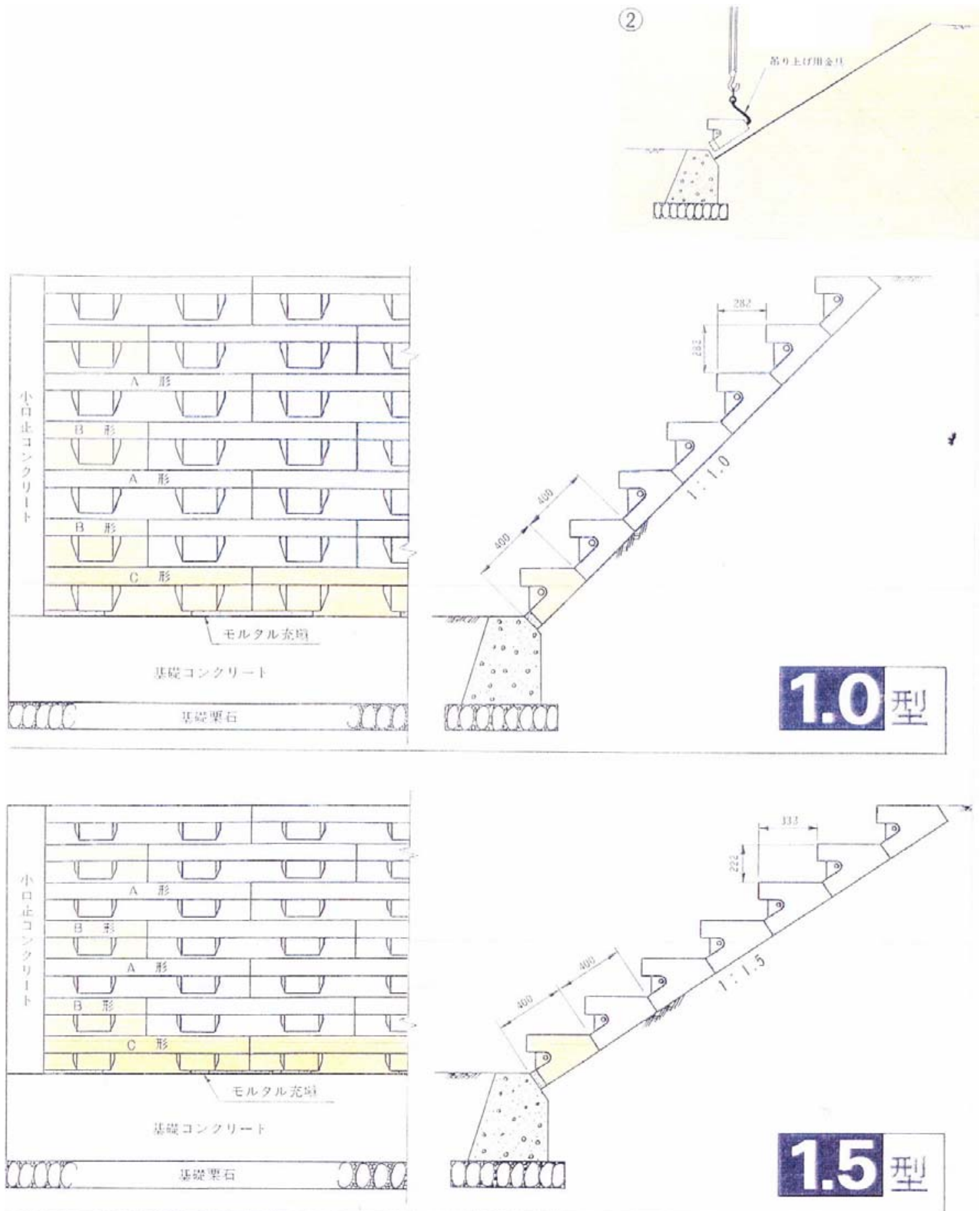

Figura 53 - Proteção Direta - Peças pré-moldadas de concreto armado.

Fonte: Manuais técnicos de produtos japoneses. 
Os revestimentos (obras) não convencionais, para a proteção das "margens taludadas" (Wolle, 2000), devido a ação do escoamento são:

Sistema Eco-estrutural pneumático, segundo Alves (1997)

Consiste na utilização de pneus velhos na construção pesada e civil. Os pneus são dispostos em camadas ou intercalados em determinados espaçamentos, formando colunas que são preenchidas com outros materiais, como cimento, pedras e entulho grosso.

Por meio desse sistema, pode-se executar o revestimento de margens (Ver figura 54), construir barragens (Ver figura 55), muros de arrimo e de contenção, aterros, alicerces, silos subterrâneos, escadarias e outras obras, onde os pneus funcionam como elemento estrutural. O Sistema Eco-Estrutural Pneumático, foi utilizado na barragem que a Companhia de Saneamento de Minas Gerais, Copasa, construiu no Ribeirão Santo Antônio, no município de Turmalina, vale do Jequitinhonha. A obra com 40 metros de extensão e seis metros de crista, utilizou 2.630 pneus, provenientes dos veículos da própria companhia. Este sistema permite a recuperação de grandes áreas degradadas, onde são depositados material estéril, entulho, terra e pneus, formando pequenas barreiras posteriormente revegetadas. 

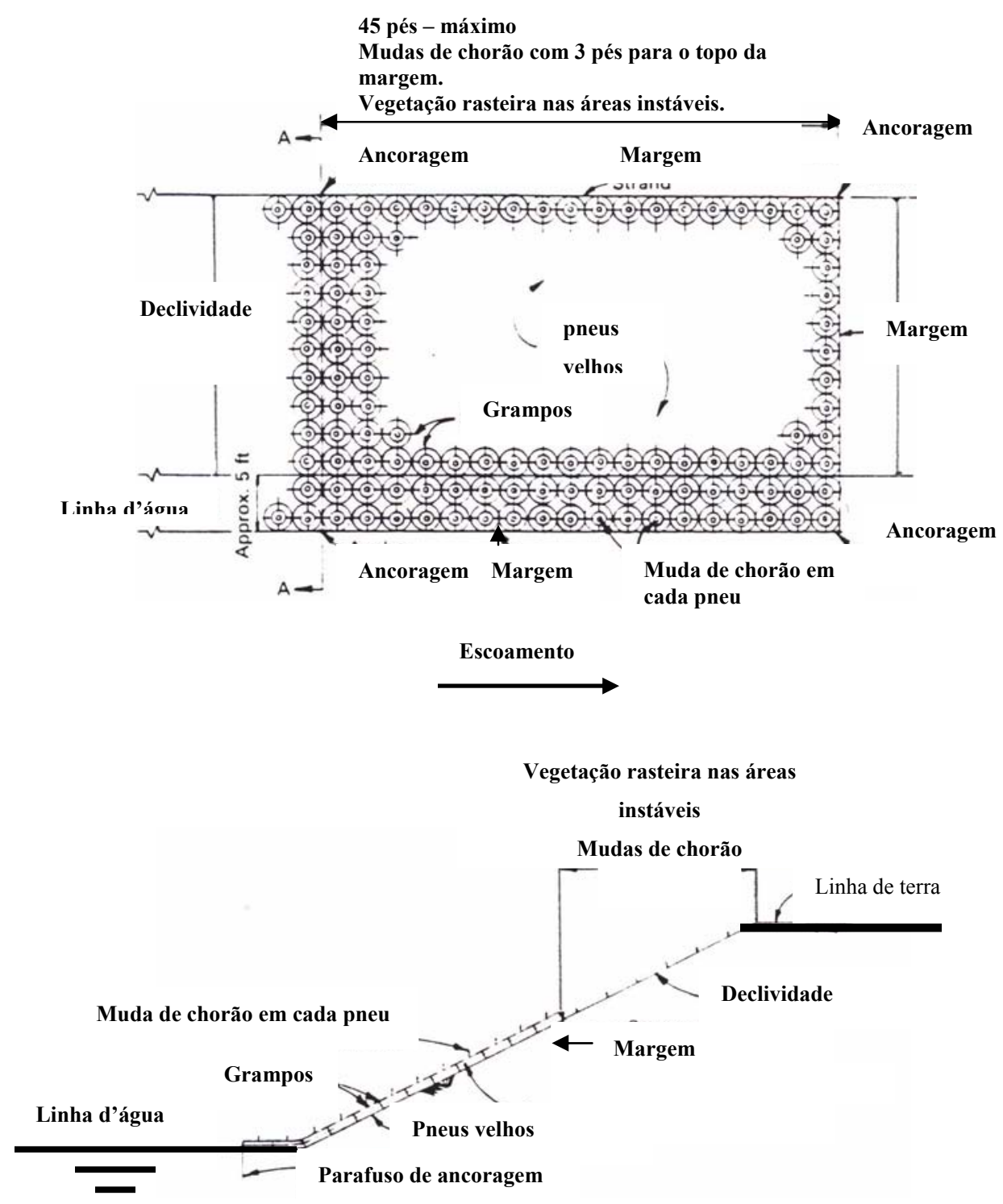

Figura 54 - Proteção Direta - Proteção das margens com pneus usados.

Fonte: PETERSEN. (1986). 


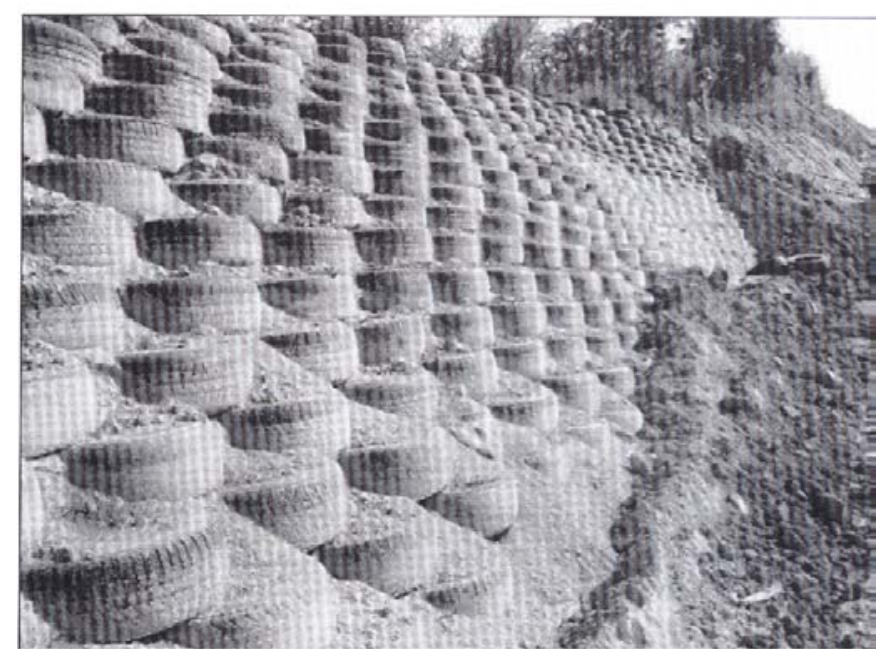

Muro de Contenção construído pelo Sistema Eco-Estrutural

Figura 55 - Sistema Eco-Estrutural Pneumático - Muro de Contenção.

Fonte: ALVES. (1987).

Cobertura Vegetal, segundo Guidicini \& Nieble (1983)

凡 Ação específica dos componentes da vegetação

Existe um consenso generalizado de que a vegetação desempenha um importante papel na proteção do solo e que o desmatamento pode propiciar não somente o aparecimento da erosão, mas também de movimentos coletivos de solos.

De um modo global, a atuação da vegetação se dá no sentido de reduzir a intensidade da ação dos agentes do clima no maciço natural, assim favorecendo a estabilidade dos taludes e encosta.

A ação específica dos diversos componentes da cobertura vegetal pode ser exposta como segue:

$\rightarrow$ Conjunto das copas e demais partes aéreas da vegetação atua de três modos principais: 
DInterceptando e defendendo o maciço da ação dos raios solares, dos ventos e da chuva. Os efeitos diretos desta proteção se dão no sentido de evitar bruscas variações na umidade e temperatura do solo do talude ou encosta, com claras vantagens do ponto de vista de estabilidade;

Detendo substancial volume d'água da chuva, através do molhamento da ampla superfície de folhagem, galhos, troncos e epífitas associadas. A eliminação desta água retida, na forma de vapor, eqüivale, na prática, a uma redução de igual volume na pluviosidade da área, em termos de volume de água que atinge o terreno;

DEliminado, na forma de vapor, grande volume d'água excedente do metabolismo vegetal, por meio da evapotranspiração. A parcela assim subtraída da água de infiltração reduz de modo benéfico a infiltração efetiva do maciço.

$\rightarrow$ Os detritos vegetais, em contínua acumulação no terreno da vegetação, atuam hidraulicamente sob quatro modalidades principais:

DImobilizando boa parte da água que atinge o terreno, através de sua alta capacidade de retenção, sendo este tanto mais significativo quanto mais espessa for a camada;

Dromovendo, juntamente com o sistema radicular de desenvolvimento superficial, o escoamento hipodérmico, graças a sua estrutura acamada, resultante da suave deposição de fragmentos planares e alongados;

D Frenando o escoamento superficial, em condições de máxima pluviosidade, permitindo assim a adução desta parcela de água para o regime de escoamento hipodérmico, e evitando os efeitos erosivos que poderiam comprometer a estabilidade. Nesta atuação, a camada de detritos alia-se à presença dos troncos e porções superficiais de raízes reptantes e tabulares; 
DSistema radicular promove a estabilização dos taludes e encostas, atuando sob dois aspectos principais, mecânico e hidráulico:

$\rightarrow \mathrm{O}$ aspecto mecânico pode se manifestar, diretamente, através da estruturação do solo, conferindo a este um acréscimo substancial de resistência ao cisalhamento e, indiretamente, através da continuidade de sua estrutura, verdadeira malha, que distribui no talude ou na encosta as tensões originadas em pontos críticos;

$\rightarrow \mathrm{O}$ aspecto hidráulico pode se manifestar, diretamente, através do estabelecimento do escoamento hipodérmico, que desvia e/ou reduz a intensidade da infiltração efetiva no maciço. Indiretamente, como parte da ação biológica, o sistema promove a sucção, com dois efeitos benéficos: criação de pressões neutras negativas, aumentando, assim, a coesão do solo e, finalmente, subtraindo, por sua vez, parte da água destinada à infiltração efetiva no maciço.

O escoamento superficial é desprezível nas condições de vegetações pluviais de encostas e taludes, pode-se admitir como de infiltração toda a água que atinge o terreno. Destaca-se, deste modo, o importante efeito de intercepção exercido pela vegetação.

O dossel de folhas intercepta, em média, 10 a 25\% da precipitação e, durante chuviscos de pequena duração, chega a deter $100 \%$ da chuva caída. Esta água é diretamente evaporada, não atingindo o solo, o que eqüivale a reduzir a pluviosidade de uma região a uma idêntica proporção.

A cobertura vegetal tem sido considerada como fator de estabilização de taludes e encostas não somente em relação à consumação de grandes escorregamentos, como também em relação a movimentos lentos de rastejo. Ver figuras 56 e 57. 
\. Efeitos favoráveis da cobertura vegetal

$\rightarrow$ Redistribuição da água proveniente das chuvas: as copas das árvores impedem, em parte, o impacto direto da chuva na superfície do terreno e retardam e diminuem a quantidade efetiva de água que se infiltra no solo;

$\rightarrow$ Além disso a evapotranspiração também retira água do solo;

$\rightarrow$ Acréscimo da resistência do solo devido às raízes: as raízes da vegetação de porte arbóreo podem aumentar a resistência do solo pelo reforço mecânico e pelo escoramento (raízes pivotantes e profundas).

太 Efeitos desfavoráveis da cobertura vegetal

$\rightarrow$ Efeito Alavanca: força cisalhante transferida pelos troncos das árvores ao terreno, quando suas copas são atingidas por ventos;

$\rightarrow$ Efeito Cunha: pressão lateral causada pelas raízes ao penetrar em fendas, fissuras e canais do solo ou rocha;

$\rightarrow$ Sobrecarga Vertical: causada pelo peso das árvores. Pode ter um efeito benéfico, ou não, na estabilidade, em vista da inclinação das encostas e taludes e das características do solo.

Os processos de instabilização de taludes e encostas tendem a se acelerar algum tempo após ao desmatamento. Logo em seguida à retirada das árvores, existe um acréscimo na estabilidade das encostas e taludes, devido a eliminação dos efeitos negativos como sobrecarga, efeito alavanca, etc. Contudo, este acréscimo de estabilidade tende a se perder com o tempo, com o apodrecimento das raízes e a eliminação do efeito de redistribuição de água de chuva. 
、 Efeito do desmatamento

O desmatamento de um talude ou de uma encosta implica numa série de fatores que tendem a reduzir o coeficiente de segurança do talude ou da encosta. Tais fatores são resumidamente:

$\rightarrow$ Cessação imediata do efeito estabilizador da floresta, como um todo, sobre as variações térmicas e climáticas, com evidentes reflexos negativos no comportamento dos solos frente às novas taxas de trabalho;

$\rightarrow$ Cessação imediata de todos os efeitos das partes aéreas: interceptação, retenção e evapotranspiração, com evidentes acréscimos na quantidade de água que atinge o terreno e na de infiltração;

$\rightarrow$ Perda, a curto prazo, por calcinação e erosão, dos efeitos da camada superficial de detritos (retenção, indução no escoamento hipodérmico e retardamento do escoamento superficial), incrementando a erosão e facilitando a infiltração;

$\rightarrow$ Elevação do lençol freático, como conseqüência da eliminação da atividade de evapotranspiração da cobertura vegetal, com possíveis reflexos no grau de saturação do solo superficial e aumento do peso;

$\rightarrow$ Perda, a médio prazo, dos efeitos mecânicos do sistema radicular, por deterioração dos tecidos vegetais, terminando por reduzir grandemente a coesão aparente induzida e, consequentemente, a própria resistência ao cisalhamento do maciço em questão. 
O sistema radicular das matas dos taludes e encostas faz com que os vazios entre os blocos de rocha, que compõem os solos superficiais, sejam literalmente preenchidos por raízes que os envolvem e mergulham para níveis inferiores.

Evidencia-se, assim, uma verdadeira malha de tecido lenhoso que amarra os blocos e estrutura os solos coluviais, mas que irá se desintegrar, ao cabo de um curto espaço de tempo, com o desaparecimento da vegetação. Ver figura 58.

Guidicini \& Nieble (1983) indicam em sua obra, diferentes prazos ao cabo do qual o sistema de raízes se decompõe, de forma que os taludes atinjam seu ponto crítico de resistência;

D Segundo Bishop e Stevens, o prazo ao cabo do qual o sistema de raízes se decompõe, de forma que os taludes atinjam seu ponto crítico de resistência é da ordem de quatro a cinco anos.

- Soares e outros e Ponçano e outros, verificaram na serra de Maranguape, a ocorrência de períodos de cerca de três anos entre a fase de desmatamento e o desencadeamento de movimento de massas em algumas áreas.

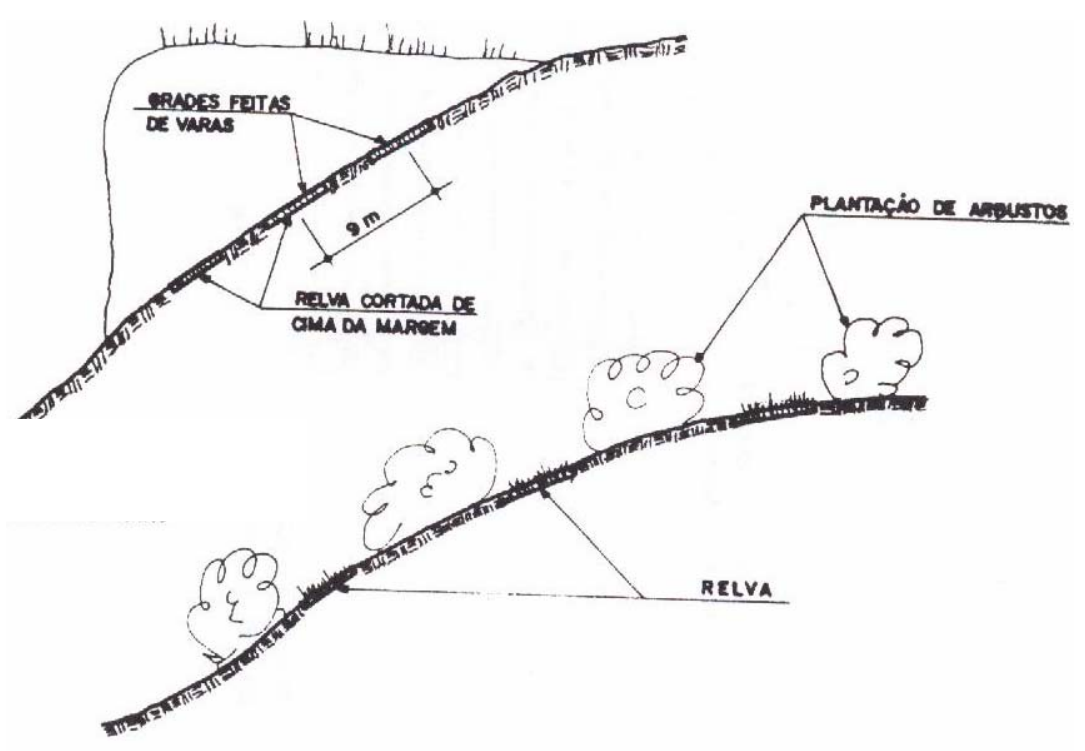

Figura 56 - Cobertura vegetal da margem taludada.

Fonte: FENDRICH. (1997). 


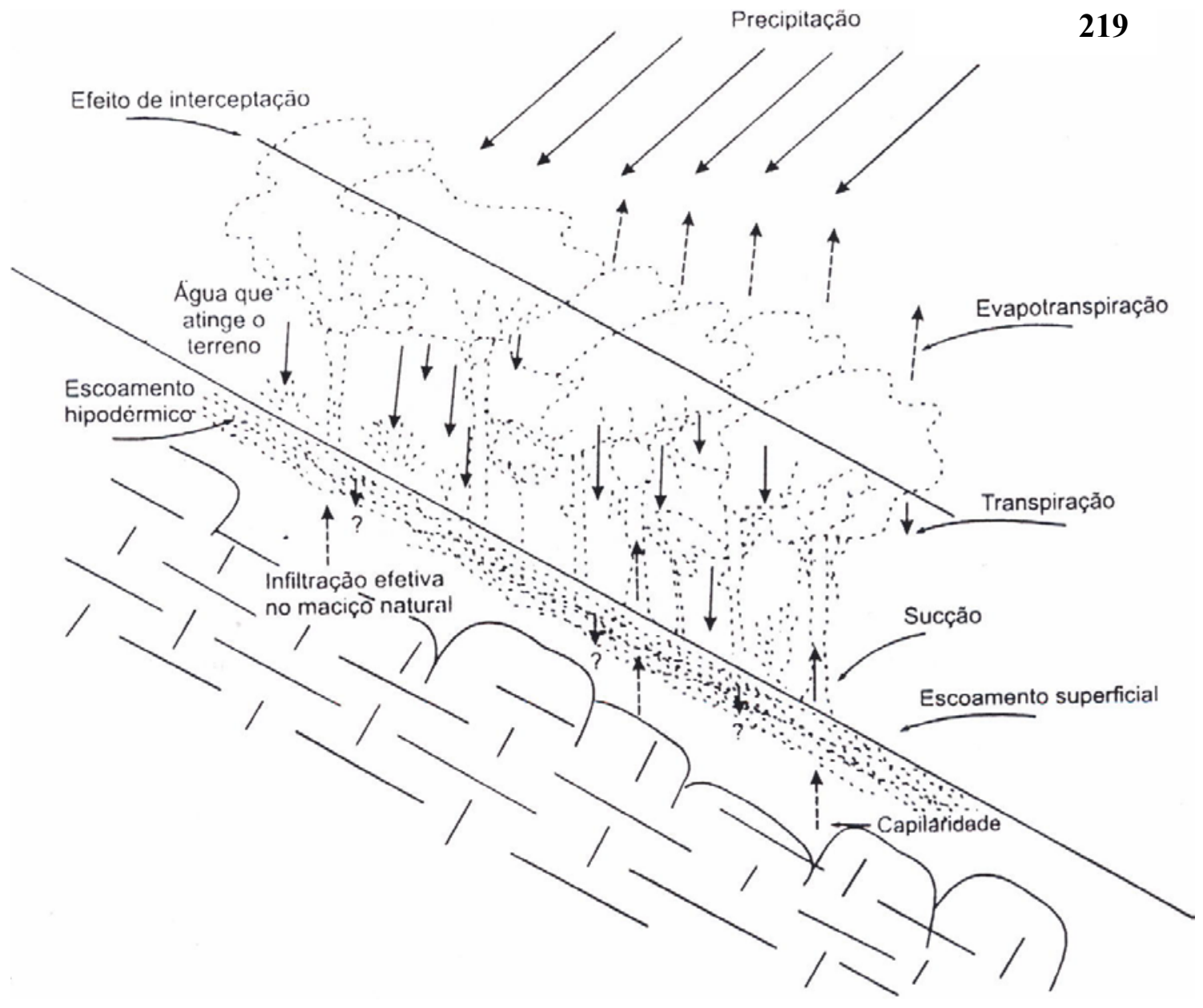

Figura 57 - Proteção Direta - O papel da cobertura vegetal.

Fonte: OLIVEIRA \& BRITO. (1988).

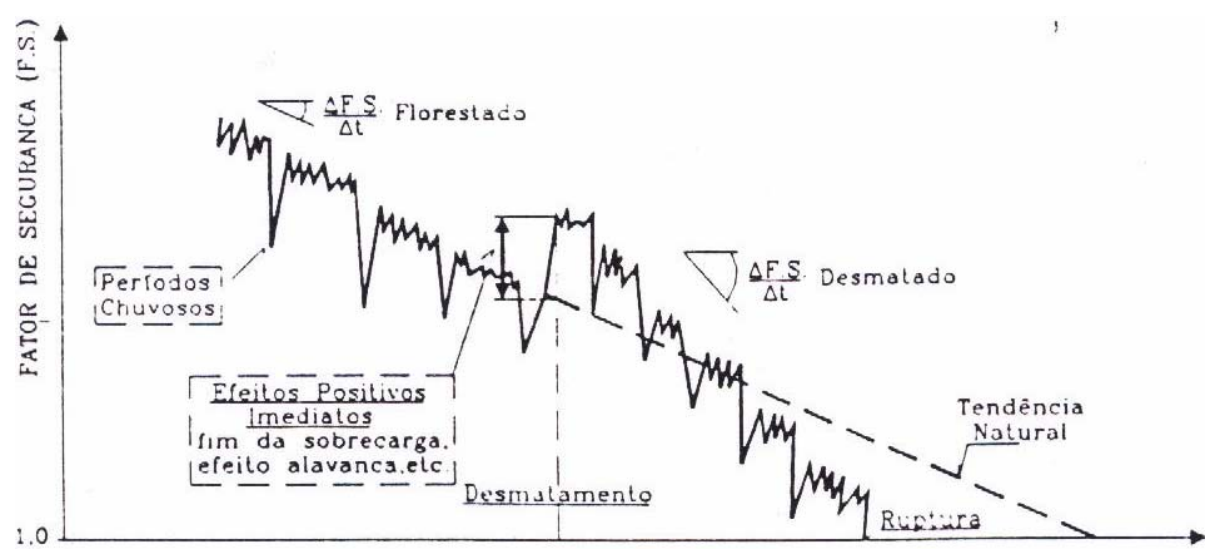

Figura 58 - Desmatamento e variação esquemática da estabilidade de taludes e encostas.

Fonte: OLIVEIRA \& BRITO. (1988). 
refCanais Gramados, segundo CIRILO et al. (2001)

Os canais gramados, merecem especial atenção, pois, são bastante interessantes, tanto pelo seu baixo custo de implantação como pelo aspecto estético. De forma similar aos canais em solo, os principais inconvenientes para seu emprego prendem-se às dificuldades de manutenção e as baixas velocidades de escoamento admissíveis, implicando em seções transversais de porte mais significativo. Ver figura 59.

Um critério básico importante para o projeto de canais gramados diz respeito às velocidades máximas permissíveis, conforme Tabela XVII, variáveis de acordo com as espécies vegetais utilizadas e com o solo adjacente. Outros critérios e indicações práticas para o projeto de canais gramados são os seguintes: os raios de curvatura devem ser maiores do que duas vezes a largura do canal; a borda livre mínima a adotar é de $0,30 \mathrm{~m}$; a inclinação dos taludes deve ser compatível com as características dos solos. 
Tabela XVII - Velocidades permissíveis para canais cobertos por vegetação.

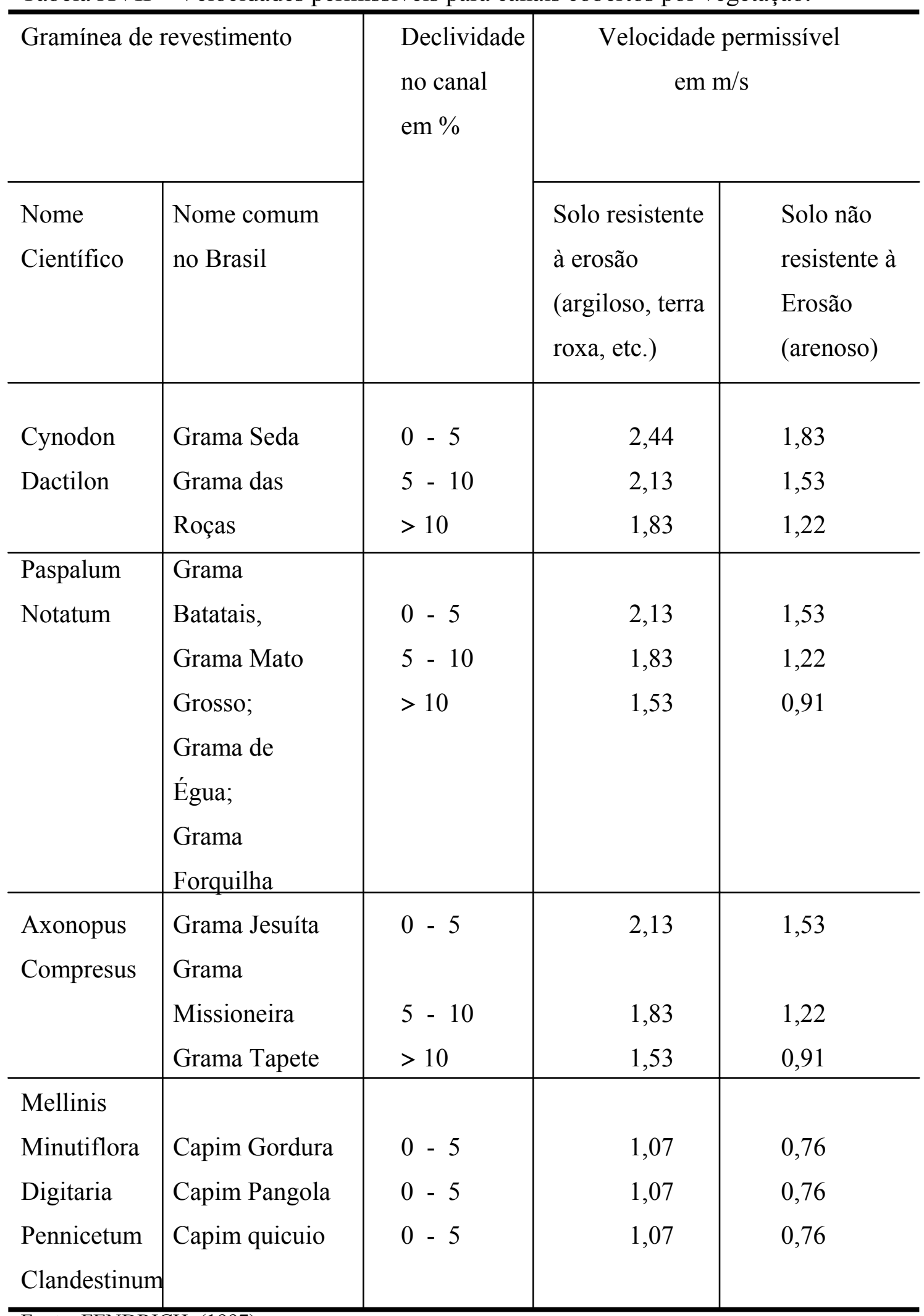




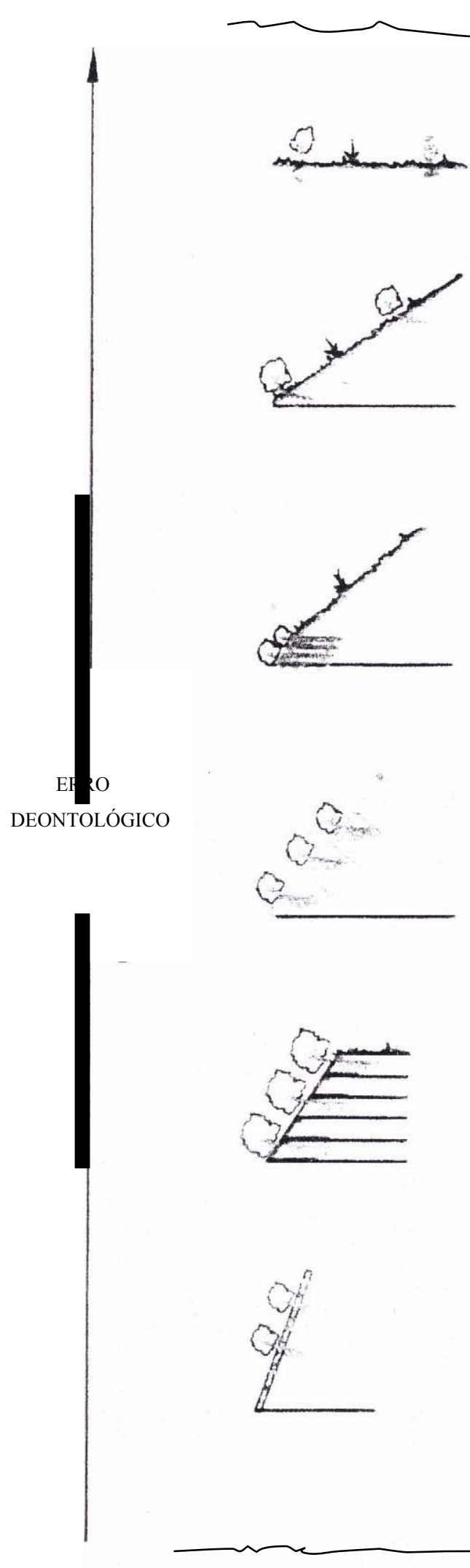

Nenhuma intervenção

$0^{\circ}$ - Vegetação

$35^{\circ}$ - Gradonate vrva

$40^{\circ}$ - Estacas Vivas

ERRC TÉCNIC

$50^{\circ}$ - Grade Viva

$50 \operatorname{grEda} \mathrm{v} \sim \mathrm{a}$

$60^{\circ}$ - Terra Reforçada

$70^{\circ}$ Georete

tridimensionale

Limite da Engenharia Naturalista

Figura 59 - Cobertura vegetal - inclusive canais gramados.

Fonte: L'ACQUA. (2000). 
Cobertura Vegetal \& Blocos de Rocha.

O sistema misto, Cobertura Vegetal \& Blocos de Rocha, reúne as características do enrocamento (blocos arrumados) e da cobertura vegetal. Ver figura 60 .

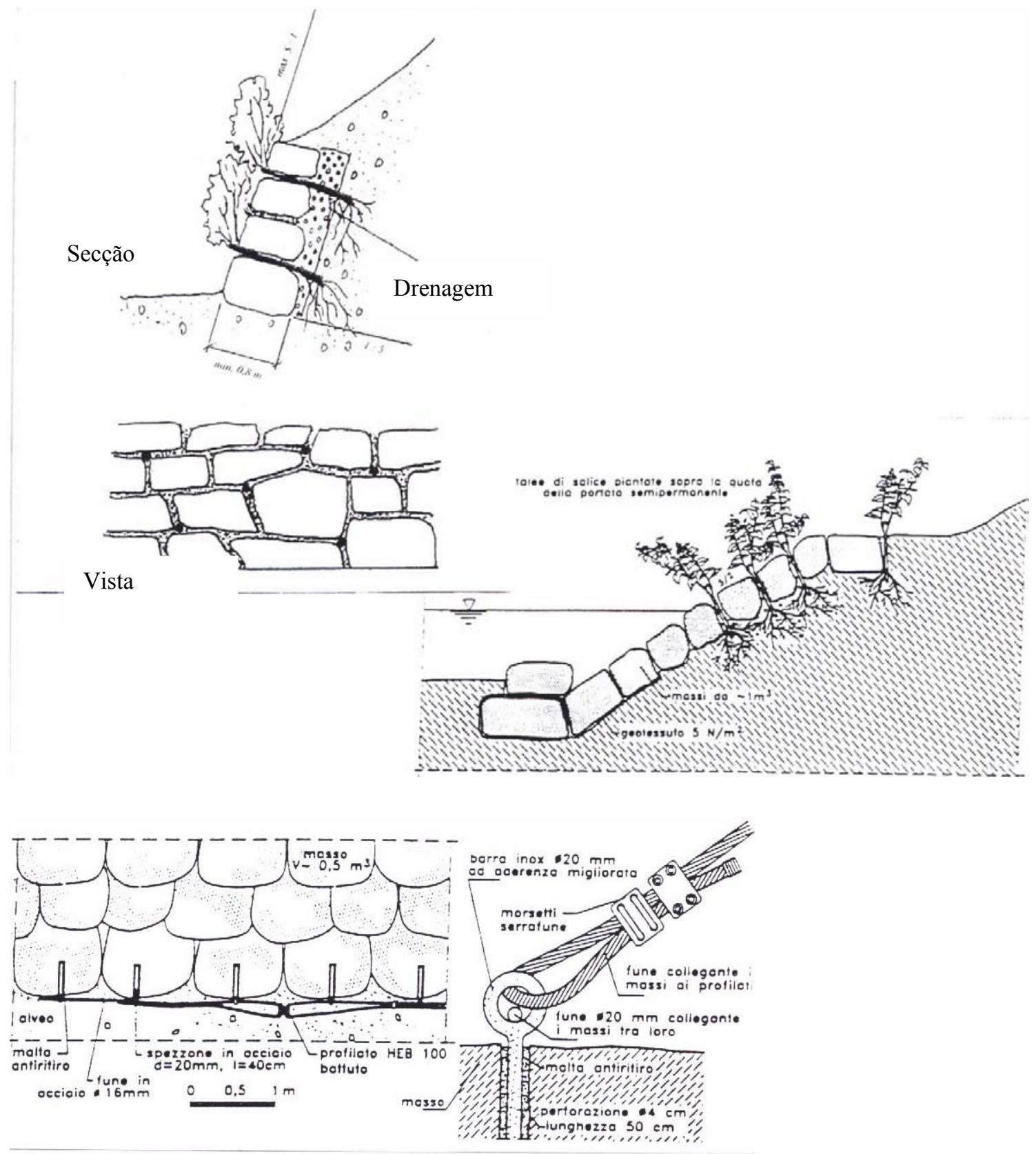

Figura 60 - Cobertura vegetal \& Blocos de rocha.

Fonte: L'ACQUA. (2000). 
Solo Cimento, segundo Pitta (2000)

O solo-cimento é constituído da mistura íntima compactada de solo, cimento e água, em proporções determinadas por ensaios prévios de laboratórios. Embora composto predominantemente de solo-natureza , na ordem de $90 \%$ ou mais, e aí está o fator economia, após tratado com cimento, esse solo adquire novas propriedades, perfeitamente identificadas através de características tecnológicas definidas pelos ensaios.

Estas novas características, de estabilidade e inalterabilidade, em presença de agentes ambientais (chuvas, temperatura, umidade do ar, etc.), de certa resistência mecânica e de durabilidade, permitem ao projetista o encontro de soluções interessantíssimas, dos pontos de vista técnico e econômico.

\Solo

Genericamente, qualquer solo pode ser estabilizado com solo cimento; entretanto, consideram-se econômicos os teores em peso até 10\% para o solocimento, sendo aconselhável, sempre que o solo venha a reclamar teores mais altos, corrigi-los com a mistura de outro material terroso, com características que permitam baixar essas porcentagens de cimento.

Ensaios realizados com alguns solos demonstram que os siltosos exigem teores elevados de cimento para se estabilizarem, enquanto que os sílico-argilosos, e mesmo alguns argilosos, apresentam resultados satisfatórios com baixos teores.

Em função da granulometria, os solos para emprego em bases tratadas com cimento podem ser classificados em três grupos, conforme descrito a seguir:

$\rightarrow$ Solos arenosos e pedregulhosos ( com cerca de $10 \%$ a $35 \%$ de silte + argila) - são os mais favoráveis à execução do solo-cimento. Não apresentam qualquer particularidade no processo de execução; são facilmente pulverizados, rápida e satisfatoriamente misturados com cimento e água. 
$\rightarrow$ Solos arenosos com deficiência de finos, são encontrados em algumas praias e bancos de areia. Permitem execução fácil, como os do grupo anterior, excetuando-se as fases de compactação e acabamento.

$\rightarrow$ Solos siltosos e argilosos, estes solos prestam-se também à execução do solocimento; todavia, quanto maior o seu teor de argila ativa, maior a dificuldade na fase de pulverização.

凡 Teor de cimento

A determinação do teor de cimento é feita para cada caso particular, através dos ensaios de durabilidade ou de resistência à compressão, conforme o tipo de solo e o método utilizado; estes processos são detalhados na publicação "Dosagem das misturas de solo-cimento - Normas de dosagem e Métodos de Ensaios" da ABCP.

\section{\ Projeto de revestimento}

O emprego de solo-cimento como revestimento ou proteção do paramento de montante de uma barragem de terra, de um dique ou de um reservatório não implica modificações nas condicionantes técnicas de projeto dessas estruturas; é pacífico, no entanto, que a impermeabilidade, a resistência aos esforços, a coesão e a baixa erodibilidade do solo-cimento acrescentam palpável melhoria na estabilidade do terrapleno.

O revestimento de solo-cimento pode ser afetado por duas ocorrências: o afundamento de peças contíguas(separadas pela trinca de retração), causado pelo recalque excessivo do aterro, e a ruptura provocada pela pressão hidrostática proveniente da infiltração demasiadamente rápida da água no maciço.

$\mathrm{O}$ projeto de revestimento de solo-cimento para barragens, diques e reservatórios prende-se à determinação das variáveis seguintes:

$\rightarrow$ Espessura da camada horizontal acabada (v);

$\rightarrow$ Largura da camada horizontal (w); 
$\rightarrow$ Espessura mínima do revestimento, medida perpendicularmente ao talude $\left(t_{n}\right)$;

$\rightarrow$ Inclinação do talude (1:s)

$\rightarrow$ Distância vertical mínima entre o topo da barragem e o nível d'água máximo (d).

O procedimento seguido baseia-se nos resultados de observações reais, nas características do processo construtivo e nos requisitos de segurança. As figuras $61 \mathrm{e}$ 62 , identificam quatro das variáveis citadas.

A espessura de cada plataforma horizontal acabada (v) é fixada, geralmente, entre $15 \mathrm{~cm}$ e $20 \mathrm{~cm}$. É desaconselhável a adoção de espessuras superiores a $20 \mathrm{~cm}$, posto que se tornaria difícil executá-las em camada singular sem que deixasse de comprometer as condições ótimas de compactação, impermeabilidade, coesão e resistência ao cisalhamento que o revestimento necessita mostrar. Isso porque raramente é possível conseguir plena aderência entre duas camadas executadas superpostas e sucessivamente, a não ser com o emprego de equipamentos requintados e com a tomada de medidas onerosas e, quase sempre, de eficácia duvidosa.

A largura das camadas horizontais (w) é função do tipo e do tamanho do equipamento de construção utilizado; varia de 2,0 m a 3,0 m. Quando se emprega, como é usual, o equipamento de pavimentação de solo-cimento, o valor típico é de $2,4 \mathrm{~m}$.

O revestimento de solo-cimento permite, facilmente, projetar declividades (1:s) bem mais acentuadas do que aquelas admissíveis nos casos em que se empregam outros tipos de materiais.

Para garantir a adequada proteção do maciço, pela resistência do solo-cimento à ação combinada da água represada e da chuva (molhagem), do sol e do vento (secagem) e do atrito com partículas sólidas em suspensão no fluxo (desgaste), é necessário existir uma certa espessura de cobrimento $\left(t_{n}\right)$. A experiência mostrou que espessuras de $30 \mathrm{~cm}$ de recobrimento são plenamente viáveis e eficientes. 


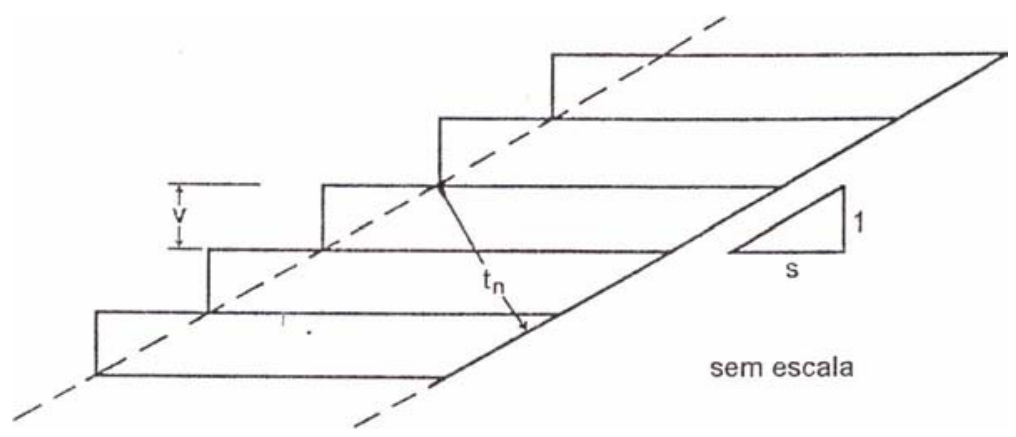

Figura 61 - Seção transversal típica do revestimento de solo-cimento.

Fonte: ABCP. (2000).

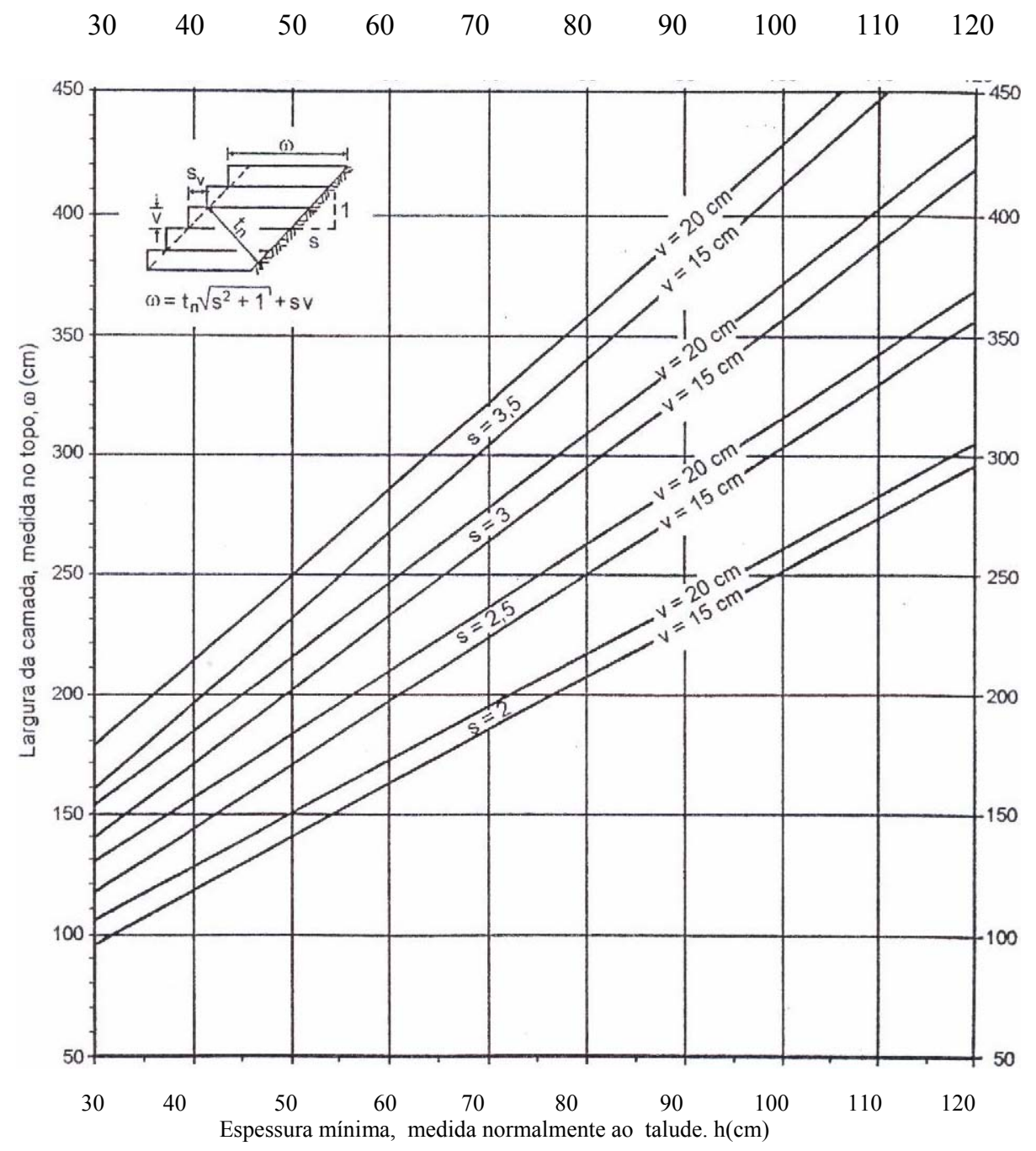

Figura 62 - Ábaco para a determinação de w ou $\mathrm{t}_{\mathrm{n}}$.

Fonte: ABCP. (2000). 
Geossintéticos

Os geossintéticos são uma nova família de materiais sintéticos empregados em geotecnia. O termo deriva de "geo", referindo-se a terra, e "sintéticos", relacionandose com a matéria-prima com que são fabricados. Os principais tipos de geossintéticos são: geotêxteis; geogrelhas, geomalhas; geomembranas; geocompostos; geocélulas outros geossintéticos (Hachich et al.,1998).

Geomanta

\. Apresentação

Um excelente produto para proteger o solo contra erosão superficial causada pela ação das águas e/ou ventos (ondas) é fornecido pela própria natureza "a vegetação", porém alguns problemas são muito sérios para serem resolvidos através de simples métodos "naturais" como a recuperação da vegetação ou a aplicação de produtos biodegradáveis, especialmente quando as ações erosivas são muito fortes ou quando o meio é muito inóspito.

Como é sabido, erosões provocadas pelo vento e pela água causam enormes inconvenientes e consideráveis danos. Torna-se então, necessário um sistema de reforço permanente, que evite a erosão sem causar dano ao homem ou ao meioambiente (Hachich et al.,1998).

Para tais situações, existe, a geomanta formada por filamentos espessos de poliamida (nylon) aleatoriamente dispostos formando um colchão tridimensional, sendo sua função confinar as partículas de solo, garantindo uma boa interação solo/material e a conseqüente estabilização da superfície revestida. Inicialmente protege o solo contra a erosão facilitando o crescimento da vegetação (propício a germinação de sementes) e, num segundo estágio, de forma permanente, atua como reforço para a camada vegetal. 
Uma densa camada composta por solo, raízes e filamentos se forma conferindo ao meio maior resistência, maior capacidade de reter as partículas finas do solo minimizando os riscos de erosões localizadas em taludes, margens, encostas, valas, canais, vertentes, aterros, áreas costeiras, e outras áreas vulneráveis à erosão.

\ Proteção de margens contra erosões, segundo Maccaferri (2000)

Uma vegetação densa e bem fixada é a base para proteção natural de margens contra erosão. Para isso, é necessário que tal vegetação apresente um bom sistema de raízes, podendo este ser reforçado por elementos artificiais ou por outros meios. Além de desempenhar proteção contra erosão, age como elemento de reforço para as raízes, proporciona baixo impacto ambiental, permitindo às margens uma rápida recuperação de sua paisagem natural, após sua aplicação.

\ Tipos de geomantas e, suas características, segundo Maccaferri (2000)

$\rightarrow$ Geomanta tipo flatback

A geomanta tipo "flatback", apresenta em uma das faces (a inferior) um elemento bidirecional, em monofilamentos de poliamida, termosoldados à estrutura tridimensional principal formando uma geomanta com capacidade de confinar materiais granulares. Ver figura 63.

Esta geomanta é toda produzida em nylon e apresenta, devido ao seu processo produtivo, elevado índice de vazios. Tal característica associada à presença da camada bidirecional em sua face inferior permite a formação de um colchão que preenchido com pedrisco ( 2 a $6 \mathrm{~mm}$ de diâmetro ) pode ser aplicado como revestimento em locais onde a vegetação não pode se desenvolver ( margens de cursos d'água com baixa velocidade e lagos, abaixo do nível d'água ). 

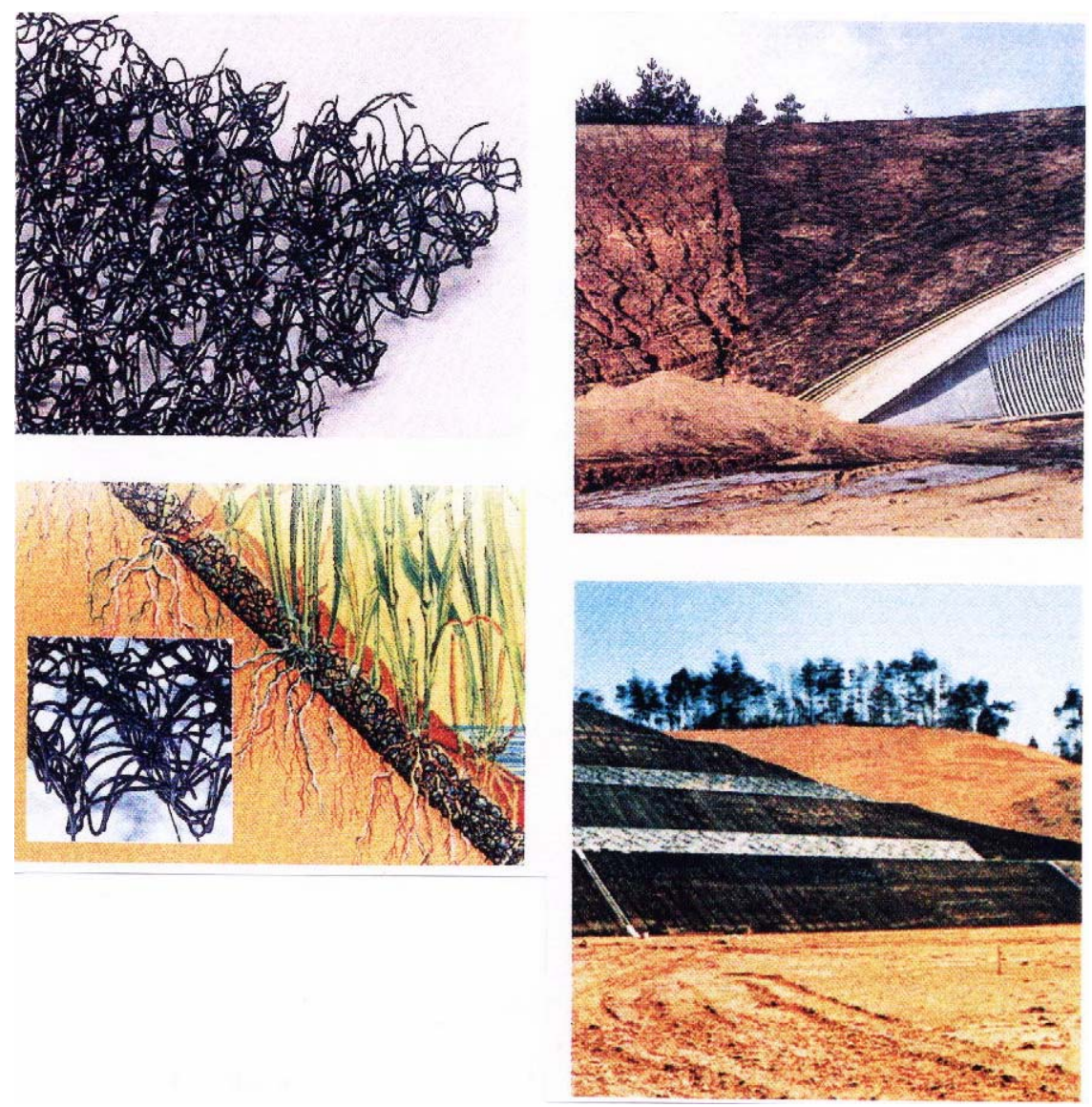

Figura 63 - Proteção direta - Geomanta tipo "flatback".

Fonte: MACCAFERRI. (2000).

DPropriedades da geomanta tipo flatback, segundo Maccaferri (2000)

$\rightarrow$ Excelente resistência nas uniões dos filamentos, devida a absoluta fusão;

$\rightarrow$ Resistente a todos os agentes químicos e biológicos normalmente encontrados no solo e na água;

$\rightarrow$ Alta resistência a intempéries e a fotodegradação (raios UV), devido a adição de Carbon Black e estabilizantes UV;

$\rightarrow$ Resistência térmica entre $-30^{\circ} \mathrm{C}$ e $+100^{\circ} \mathrm{C}$; pode ser instalado facilmente durante os períodos de inverno, não congela;

$\rightarrow$ Baixa inflamabilidade; aprovado para uso em túneis; 
$\rightarrow$ Não tóxico; aprovado para uso em reservatórios de água potável; é inerte e não contamina o meio-ambiente;

$\rightarrow$ Não possui valor nutritivo; a estrutura entrelaçada da geomanta é inconveniente aos roedores.

$\rightarrow$ Devido a sua capacidade de confinamento pode ser preenchido (coberto) com pedriscos de 2 a $6 \mathrm{~mm}$ de diâmetro, sendo utilizado desta forma como revestimento para canais de baixa velocidade (até $2,5 \mathrm{~m} / \mathrm{s}$ ). Para situações mais críticas, os vazios são preenchidos com uma mistura asfáltica.

$\rightarrow$ Geomanta tipo tridimensional

A geomanta tridimensional constituída por filamentos grossos dispostos aleatoriamente e soldados nos pontos de contato, apresentando índices de vazios superior a $90 \%$.

Coberta de solo ou pedra, protege a margem contra a erosão e facilita o crescimento, posterior e permanente, da vegetação. Ver figura 64. Reforça a camada vegetal, auxiliando na fixxação das raízes.

Enclausura as partículas do solo, garante uma boa interação entre o solo e a geomanta, estabiliza a superfície revestida, criando um ambiente propício para o crescimento das raízes. A densa camada composta por solo, raízes e filamentos, confere maior resistência e capacidade para reter as partículas finas, minimizando o risco de erosões.

É utilizada em canais de baixa velocidade ou nos locais com presença esporádica de água. Seu peso específico, superior a $1,0 \mathrm{kN} / \mathrm{m}^{2}$, facilita sua instalação abaixo do nível d'água já que não flutua, diferente das geomantas de polipropileno e polietileno.

As geomantas, se colocadas abaixo do nível d' água, devem ser enchidas com pedriscos. Se colocadas no seco, após a colocação de sementes com as espécies previstas preferivelmente autóctones, devem ser cobertas com solo fértil. 
Devem sempre ser fixadas ao solo com estacas de ferro para evitar movimentos, especialmente no primeiro caso.

A geomanta tridimensional é utilizada quando é requerido um revestimento com maior resistência, para locais onde haja maiores velocidades do fluxo de água ou maior duração dos períodos de cheia.
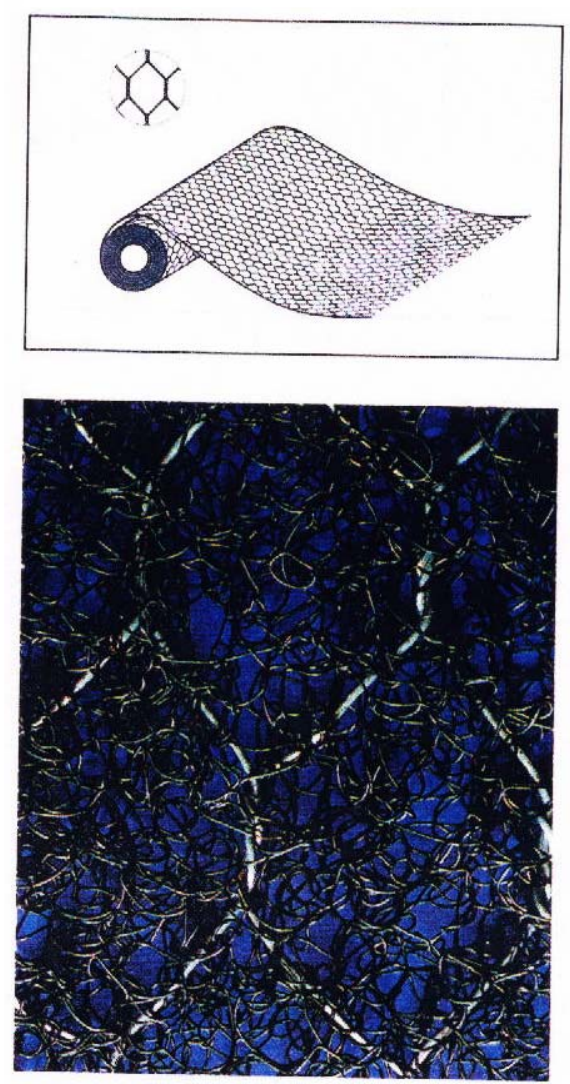

Figura 64 - Proteção direta - Geomanta tipo "tridimensional".

Fonte: MACCAFERRI. (2000). 
$\rightarrow$ Geomanta tipo "combinada"

É formada pela união de uma geomanta tridimensional de grande espessura e densidade e, uma rede de malha hexagonal de dupla torção, somando-se assim as características das geomantas e as características de resistência mecânica das redes metálicas. Esta combinação, fixada ao solo com estacas, pode suportar sem danos fluxo mais intensos, que podem arrastar, por exemplo, materiais em suspensão ou flutuantes, permitindo maior integridade da mesma contra impactos.

A geomanta, é um tipo de revestimento de margem, que permite a recuperação ou o desenvolvimento natural da vegetação.

$\rightarrow$ Biomanta, segundo Maccaferri (2000)

As biomantas, desenvolvem a mesma função que as geomantas, isto é, a proteção contra erosões superficiais, porém, por serem produzidas com materiais biodegradáveis, apresentam-se como uma solução de baixo impacto ambiental, pois se degradarão após o desenvolvimento da camada vegetal desejada. Ver figura 65.

A utilização da biomanta, para a proteção de encostas, constitui-se numa alternativa extremamente viável, pois atende várias viabilidades, inclusive a ambiental. 

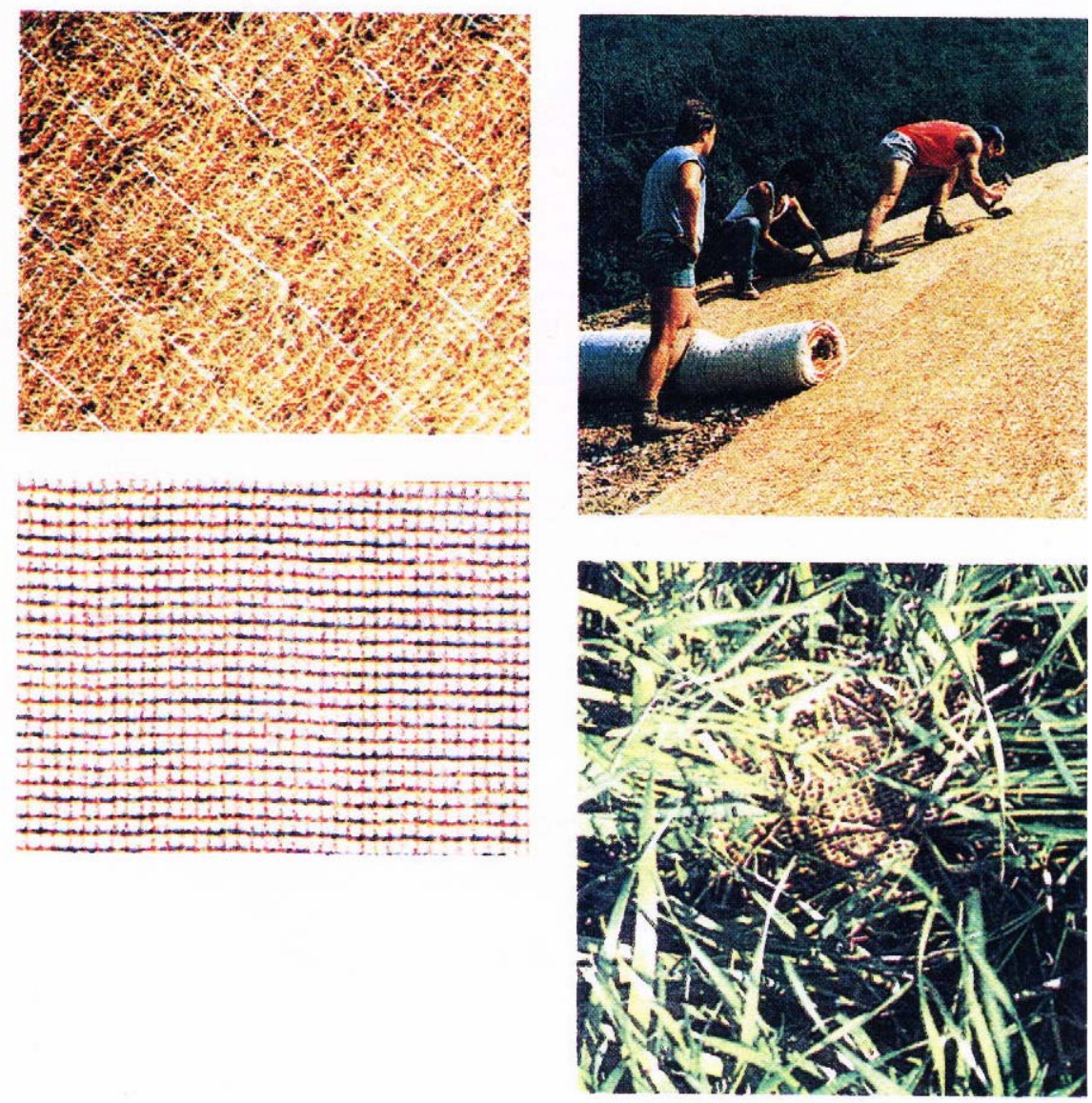

Figura 65 - Proteção direta - Biomanta.

Fonte: MACCAFERRI. (2000). 
Geotêxteis

\. Apresentação

Os geotêxteis são produtos têxteis flexíveis e porosos cuja principal característica relaciona-se com a sua capacidade de drenagem tanto por tecido quanto ao longo do mesmo. As fibras dos geotêxteis são produzidas pela fusão dos polímeros e posterior extrusão, conferindo-lhes a forma alongada característica. As fibras utilizadas na fabricação dos geotêxteis são as de monofilamento, as cortada, a de ráfia e a tipo filamento contínuo (Hachich et al.,1998).

Os geotêxteis classificam-se em tecidos e não tecidos, em função do arranjo estrutural das suas fibras. Nos geotêxteis tecidos, os fios, filamentos ou laminetes são entrelaçados segundo direções preferenciais com máquinas têxteis convencionais, enquanto para os geotêxteis não tecidos a interligação das fibras ou filamentos é feita de forma aleatória. Nos geotêxteis não tecidos, as fibras podem ser ligadas por entrelaçamento mecânico com agulhas (geotêxtil "agulhado"), por fusão parcial (geotêxtil "termoligado"), por meio de produtos químicos (geotêxtil "resinado") ou por reforço (geotêxtil "reforçado" através de costuras, fios de aço etc.). (Hachich et al., 1998)

Apesar da elevada permeabilidade ser uma das principais características dos geotêxteis, eles podem ser empregados nas mais diversas áreas. O geotêxtil não tecido, pode atuar como uma barreira altamente permeável, retendo partículas em movimento e permitindo a passagem de água. Pode ser aplicado em drenos, estruturas em gabiões, etc., exerce também funções de proteção e separação. Ver figura 66 . 


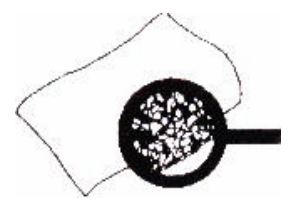

DETALHE - GEOSSINTÉTICO

GEOTÊXTIL - NÃO TECIDO
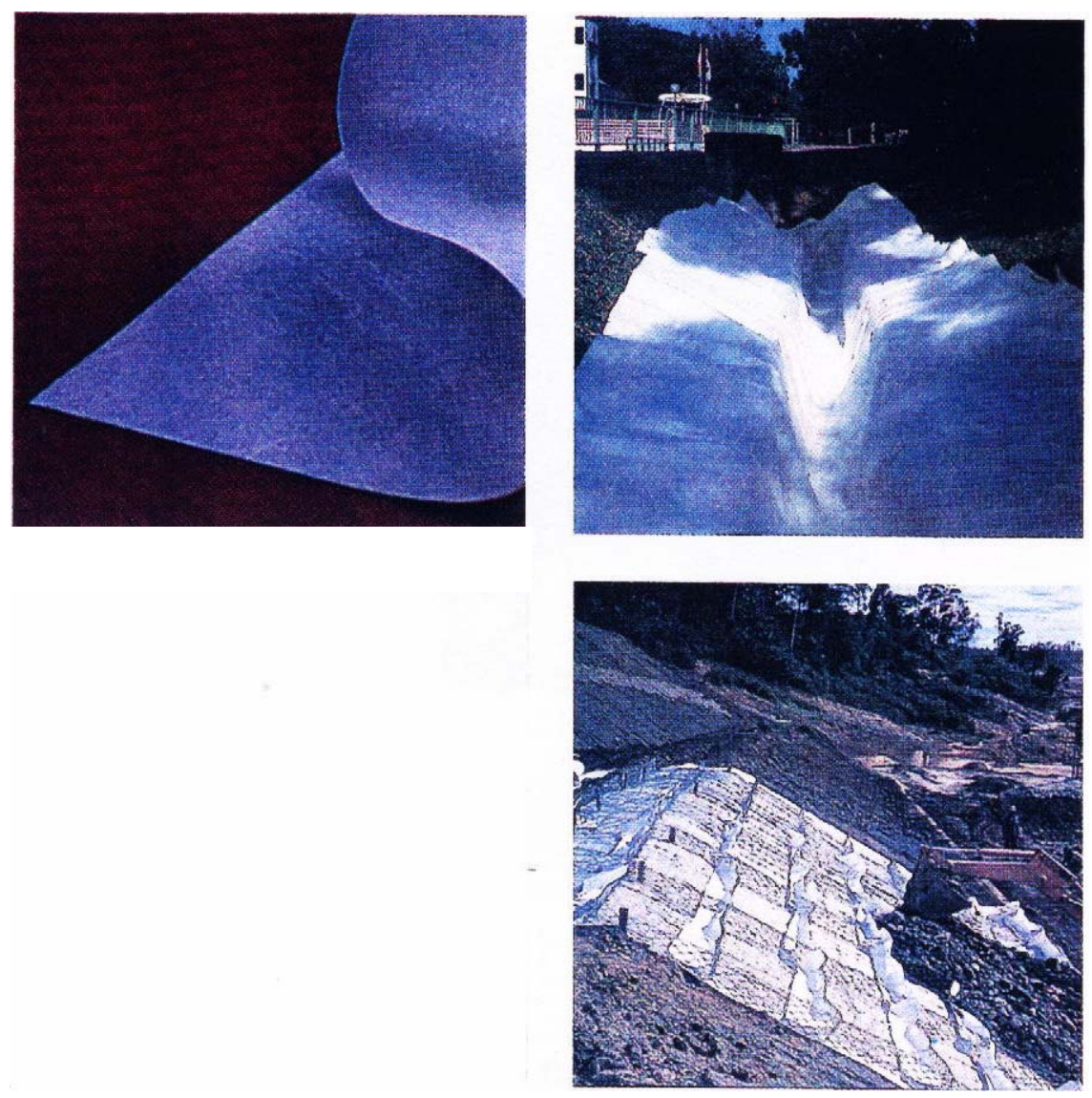

Figura 66 - Proteção direta - Geotêxtil não tecido.

Fonte: MACCAFERRI. (2000).
DETALHE - GEOSSINTÉTICO

GEOTÊXTIL -TECIDO 
urGeomalhas

\. Apresentação

As geomalhas, constituem-se nos geossintéticos mais recentes, produzidos a partir do PEAD. São estruturas planas em forma de grelha, constituídas de forma a apresentarem grande volume de vazios, utilizadas predominantemente como elementos drenante. Podem ser empregadas em conjuntos com geotêxteis ou geomembranas em suas faces superior ou inferior. Possuem grandes aberturas e resistência inferior à das geogrelhas (Hachich et al.,1998).

nfGeomembranas

\. Apresentação

As geomembranas constituem-se no segundo maior grupo de geossintéticos, após os geotêxteis. Em vendas nos Estados Unidos, elas se igualam aos geotêxteis, o que se deve às leis governamentais americanas que, a partir de 1982, exigem o seu emprego em locais de disposição de resíduos sólidos. As geomembranas são membranas de borracha ou de material plástico, impermeáveis e de pequena espessura, empregadas no revestimento ou cobertura de depósitos líquidos ou sólidos. Ver figuras 67 e 68.

A utilização das geomembranas, para a proteção do leito dos canais de irrigação, tem a função de impermeabilizar o leito, evitando perdas d'água nos canais de irrigação. A principal alteração na porção bio-geo-física do meio ambiente, provocada pelas geomembranas, é não permitir o desenvolvimento da vegetação. Quando não protegida por camada resistente, são facilmente danificados, inclusive pela longa exposição ao sol. 


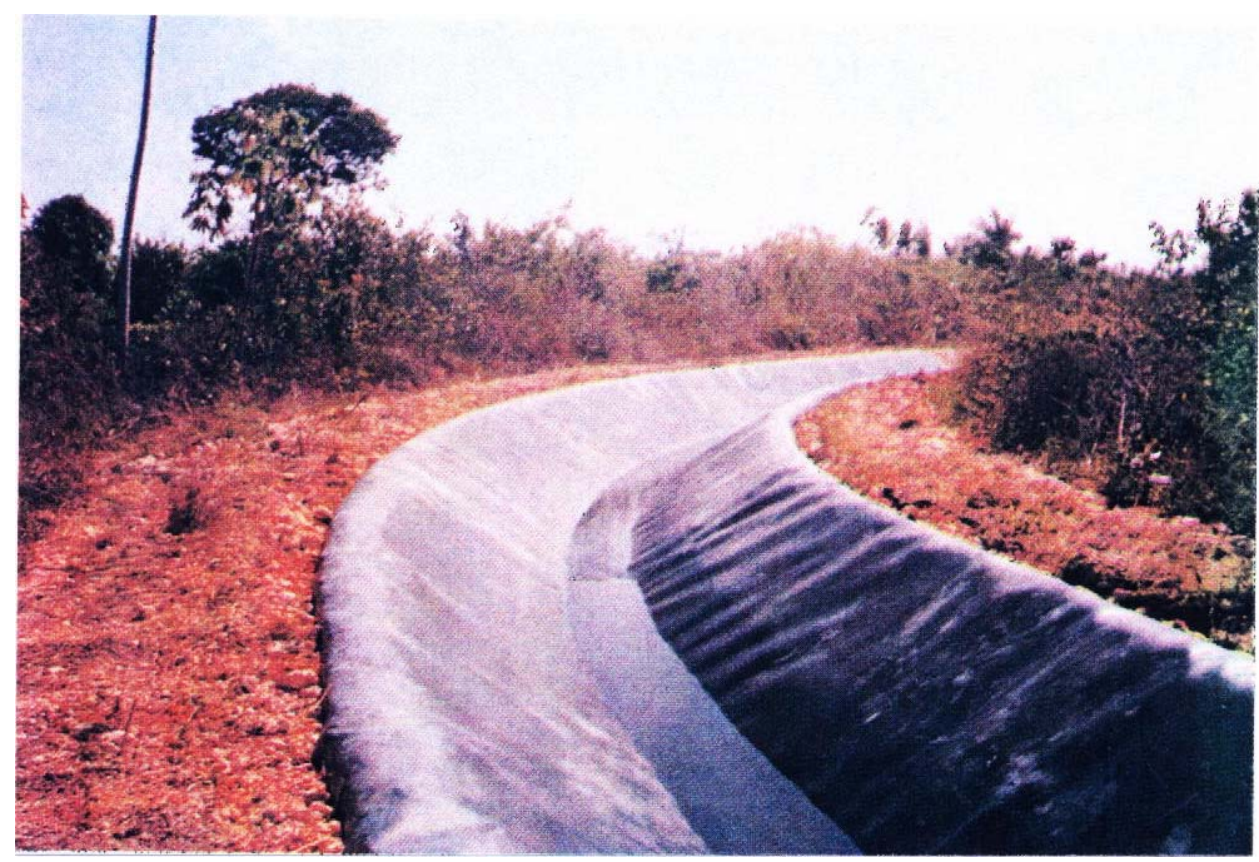

Figura 67 - Proteção direta - Geomembrana. Revestimento de canal de irrigação Fonte: ENGEPOL. (2000).

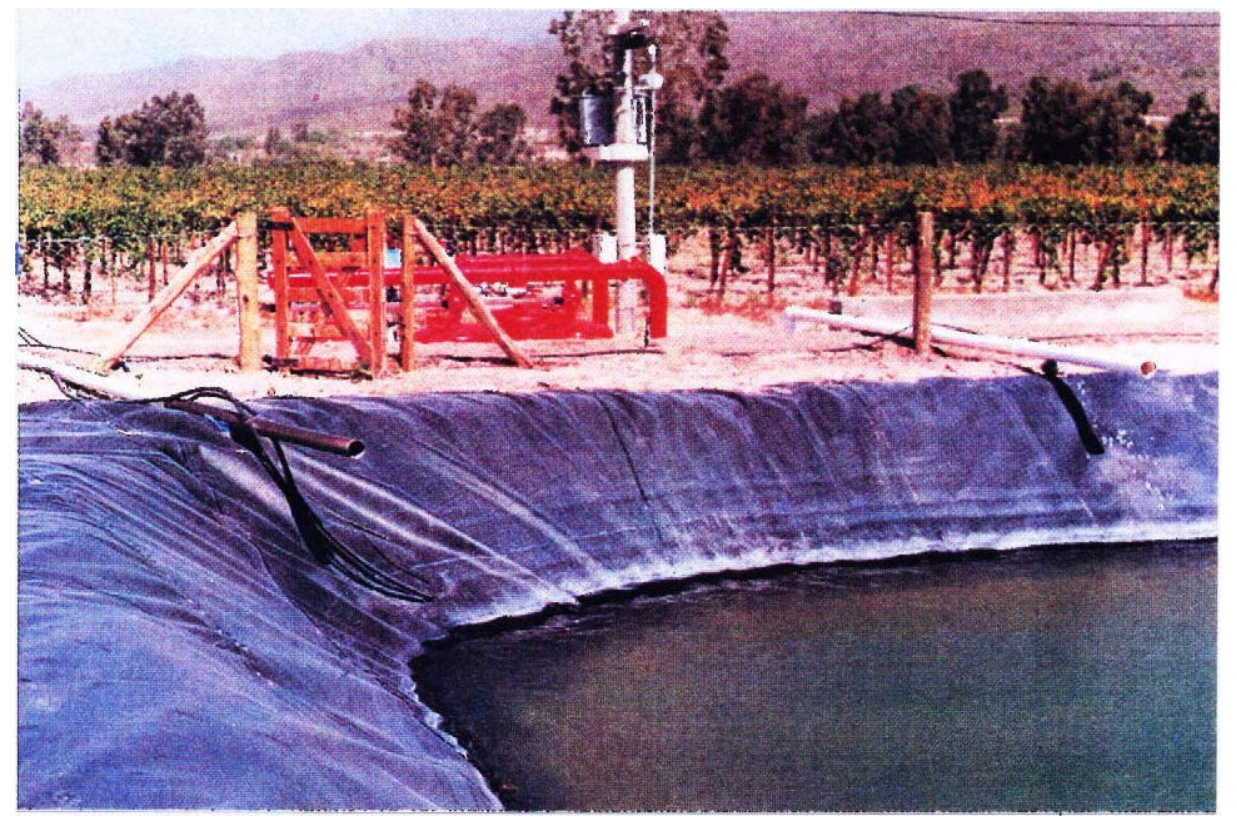

Figura 68 - Proteção direta - Geomembrana. Bacia de armazenamento de água para irrigação. Fonte: ENGEPOL. (2000). 
마Geocompostos, Geocélulas e outros Geossintéticos

N Apresentação

Os geocompostos são combinações entre geotêxteis, geogrelhas e geomembranas, podendo incorporar também membranas plásticas, cabos metálicos ou agulhamentos. As aplicações destes geocompostos são muito variadas.

Além desses, outros geossintéticos estão sendo desenvolvidos atualmente. Entre eles, destacam-se as geocélulas, que atuam como elementos de reforço, os geodrenos (tubos de drenagem) e as geobarras (tirantes de material sintético para reforço). Ver figura 69. As geocélulas devido as suas características, são normalmente empregadas como elemento de reforço de solos. As geocélulas constituem um sistema de confinamento celular tridimensional e flexível. As paredes das células são constituídas por tiras de polietileno, com superfícies rugosas e unidas entre si por meio de solda. As células podem ser preenchidas com solo, solo-cimento ou ainda concreto, em função da aplicação. Ver figura 70.
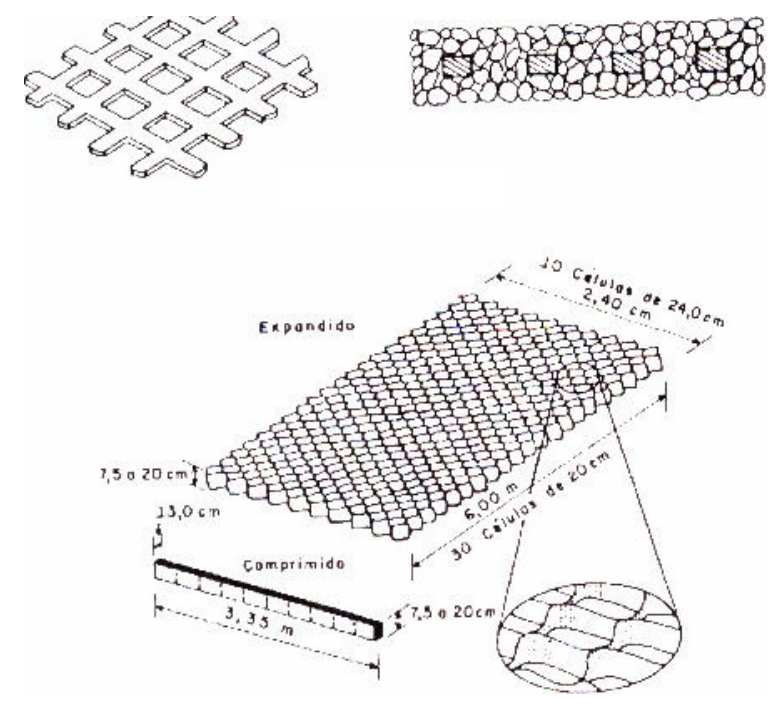

DETALHE - Exemplos de Geocompostos 

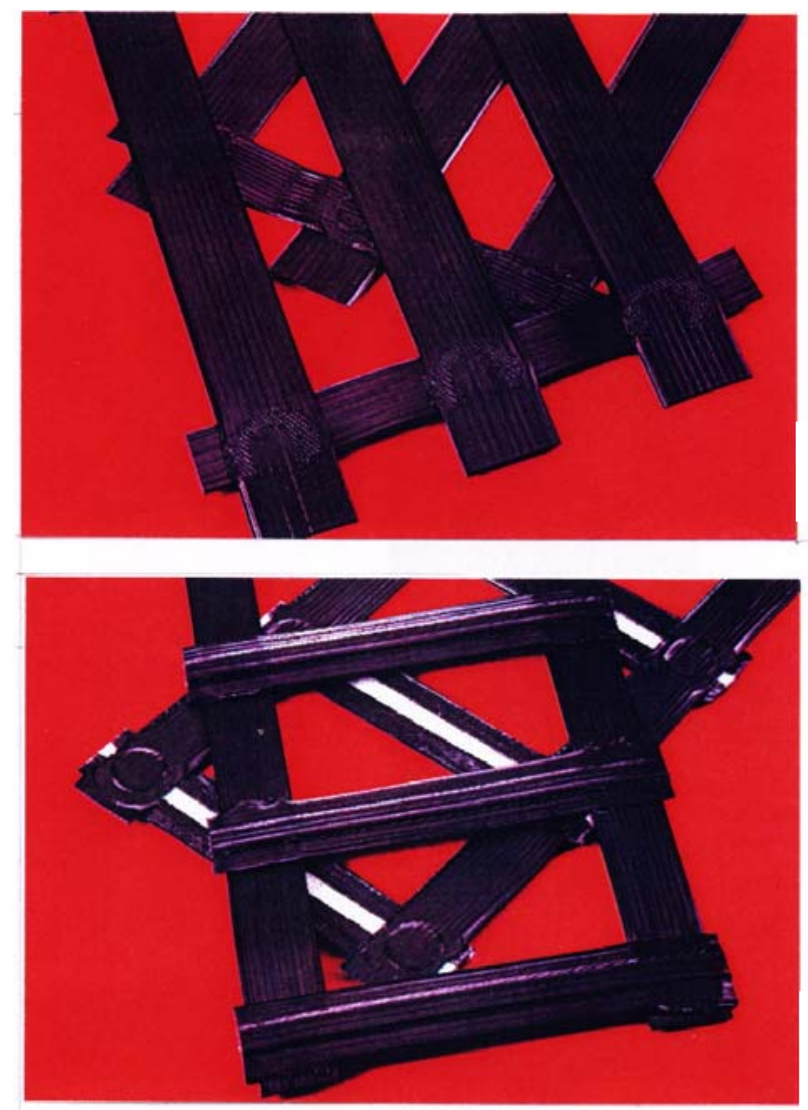

PARAGRID

Paradrain

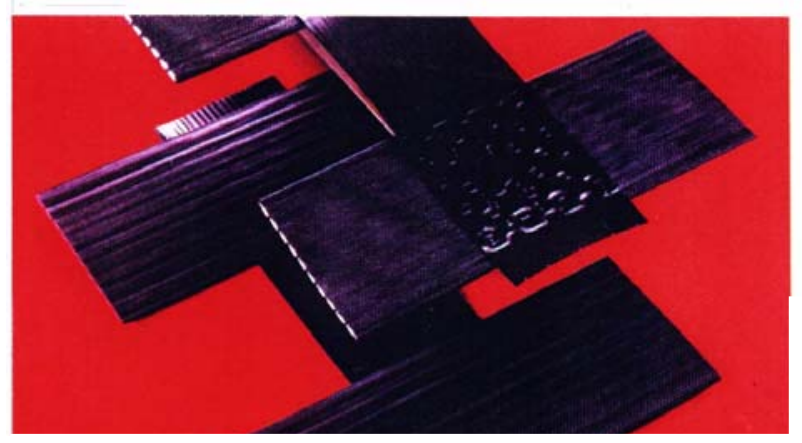

PARALINK

Figura 69 - Proteção direta - Geobarras (ParaGrid, ParaDrain e ParaLink).

Fonte: MACCAFERRI. (2000). 

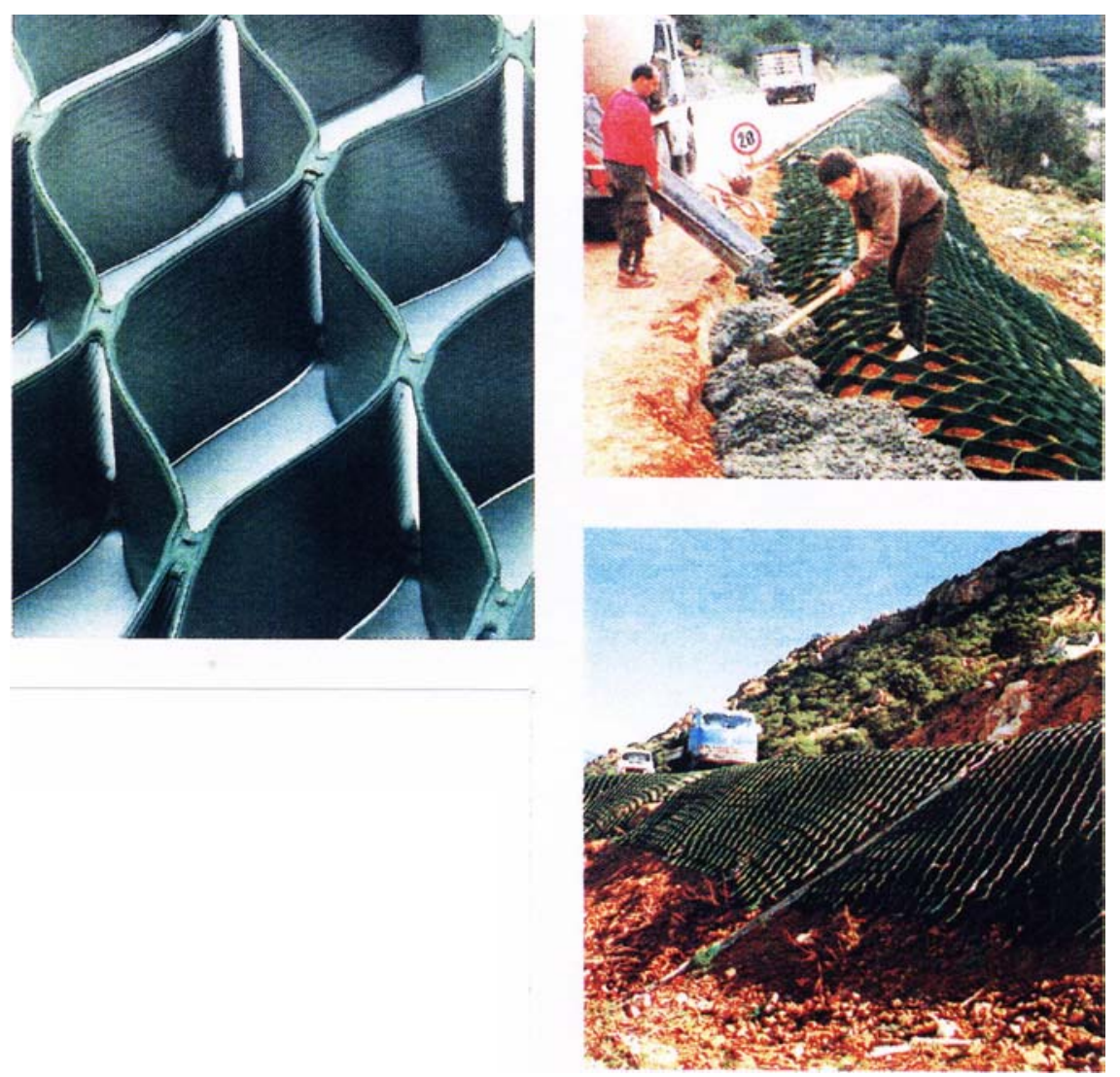

Figura 70 - Proteção direta - Geocélula.

Fonte: MACCAFERRI. (2000).

c) Obras de Sustentação

São todas as obras destinadas a contrapor-se a empuxos ou tensões geradas em maciço cuja condição de equilíbrio foi alterada por algum tipo de escavação, corte ou aterro. São exemplos de obras de contenção: reforços de terreno, muros e cortinas.

$\leftrightarrow$ Reforços de terreno

São construções em que um ou mais elementos são introduzidos no solo com a finalidade de aumentar sua resistência para que possa suportar as tensões geradas 
por um desnível abrupto (Hachich et al., 1998). Nesta categoria estudaremos a terra armada e o solo reforçado.

torra Armada, segundo Terra Armada (1981)

\. Apresentação

O processo TERRA ARMADA, inventado e patenteado mundialmente pelo engenheiro e arquiteto francês Henri Vidal, conta com a interação da terra e armaduras, onde a aderência entre as partículas de solo e as armaduras, representa papel fundamental, e confere ao material "TERRA ARMADA", uma importante coesão na direção das armaduras.

Utiliza a resistência interna da terra associada à de materiais de construção convencionais (aço e concreto), constituindo maciços auto-equilibrados. Os maciços de TERRA ARMADA são estruturas que, sem limitação construtiva de altura, contam com a colaboração da própria terra para resistir aos esforços externos (empuxos e ou sobrecargas). Têm variadas aplicações: obras de contenção; encontros portantes de pontes e viadutos; rampas de acesso a pontes e viadutos; diques de proteção; silos; reservatórios para líquidos; instalações industriais, residenciais, etc...

Suas principais vantagens técnico-econômicas são: fácil aplicação em obras de grande altura ou que suportem sobrecargas pesadas; grande flexibilidade dos paramentos, que permite aos maciços se adaptarem aos solos compressíveis de fundação, aceitando bem os recalques diferenciais intoleráveis para outras soluções; velocidade de execução igual à das obras de terraplanagem convencionais; eliminação de formas, andaimes, escoramentos, concretagem de estruturas "in situ" e terraplanagem manual; ótimo aspecto.

N Composição construtiva 
No processo, TERRA ARMADA, a característica importante é o atrito que se desenvolve no contato com as armaduras. Para maior simplicidade, a seleção do material terroso é feito em duas fases.

Primeiro pede-se atendimento a uma condição preliminar, suficiente mas não forçosamente necessária. A percentagem em peso seco de partículas menores que $0,074 \mathrm{~mm}$ (peneira $\mathrm{n}^{\mathrm{o}} 200$ ), deve ser inferior a $15 \%$.

Posteriormente, caso não seja atendida a condição preliminar, busca-se material que tenha ângulo de atrito terra-armadura maior ou igual a $22^{\circ}$. Este ângulo de atrito é medido por ensaio de cisalhamento direto rápido sobre amostras saturadas e não consolidadas.

$\rightarrow$ Armadura

A utilização de armaduras de materiais de tipos diversos, é prevista. No Brasil, consagrou-se o uso de armaduras de aço de baixo teor de carbono, galvanizadas com $60 \mathrm{~mm}$ ou $80 \mathrm{~mm}$ de largura e $3 \mathrm{~mm}$ de espessura.

A Maccaferri do Brasil Ltda., propõe a utilização de geogrelhas ( a geogrelha é uma estrutura plana em forma de grelha, com a existência de grandes aberturas que promovem o embricamento do solo pelas mesmas.

As geogrelhas são muito mais rígidas que os geotêxteis e, portanto, seu emprego é quase que exclusivamente para reforço, embora sejam utilizadas também como elemento de separação. As primeiras geogrelhas foram fabricadas na Inglaterra pela Netlon, e levadas para os EUA em 1982 pela Tensar, Os polímeros geralmente empregados na produção de geogrelhas são o polietileno, de alta densidade - PEAD -, o poliéster - PET -, e o polipropileno - PP.

As geogrelhas soldadas são estruturas planas obtidas a partir da soldadura de geotiras (Paragrid, Paradrain e Paralink), compostas por filamentos de poliéster de alto módulo elástico e excelente comportamento à fluência revestido em polietileno. 
Visando melhorar a interação solo/geogrelha, as geotiras são submetidas a um processo de calandragem que proporciona um acabamento texturizado à sua superfície. O núcleo de poliéster define as características mecânicas da geogrelha, enquanto o revestimento em polietileno tem a função de proteger o núcleo contra danos durante as operações de instalação e trabalho.

O polietileno, além de ser um polímero inerte, ou seja que apresenta excelente resistência a ataques químicos e biológicos, também não contamina o meio ambiente.

$\rightarrow$ Escamas

As escamas, são placas pré-moldadas de concreto que constituem pele ou paramento externo flexível. São empregadas escamas cruciformes, com espessura de $18 \mathrm{~cm}, 22 \mathrm{~cm}$ ou $26 \mathrm{~cm}$. A modulação básica das escamas em altura e largura é de $1,50 \mathrm{~m}$, com aproximadamente 1,5 toneladas.

As escamas são pré-moldadas em concreto com $\mathrm{fc}_{28}$ maior ou igual a $27 \mathrm{MPa}$. Ver figuras 71 e 72.

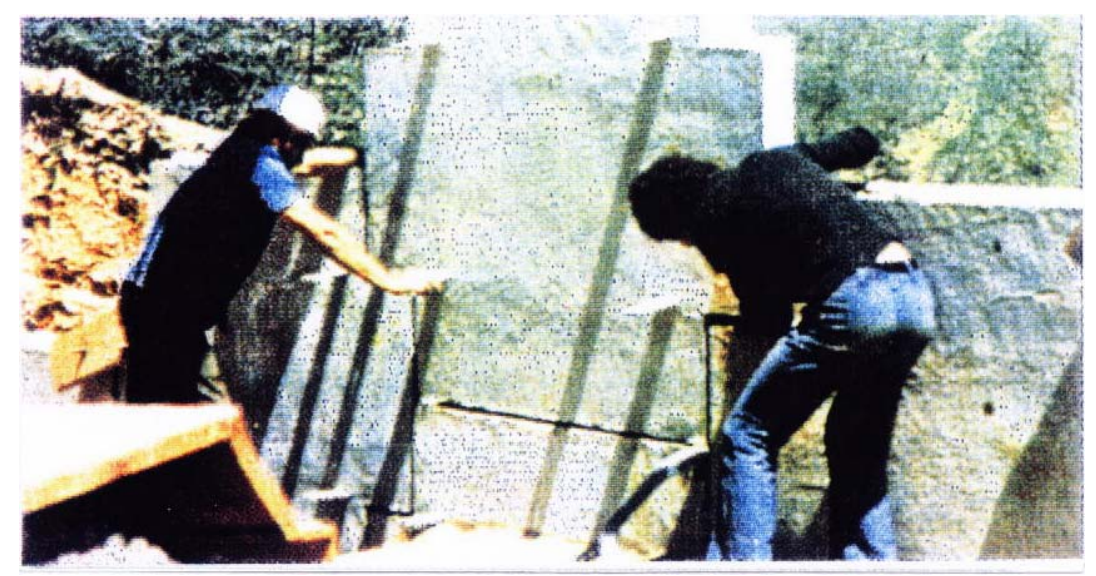

Figura 71 - Obras de Sustentação - Terra Armada: Escamas - Placas pré-moldadas de concreto. Fonte: TERRA ARMADA. (1982). 


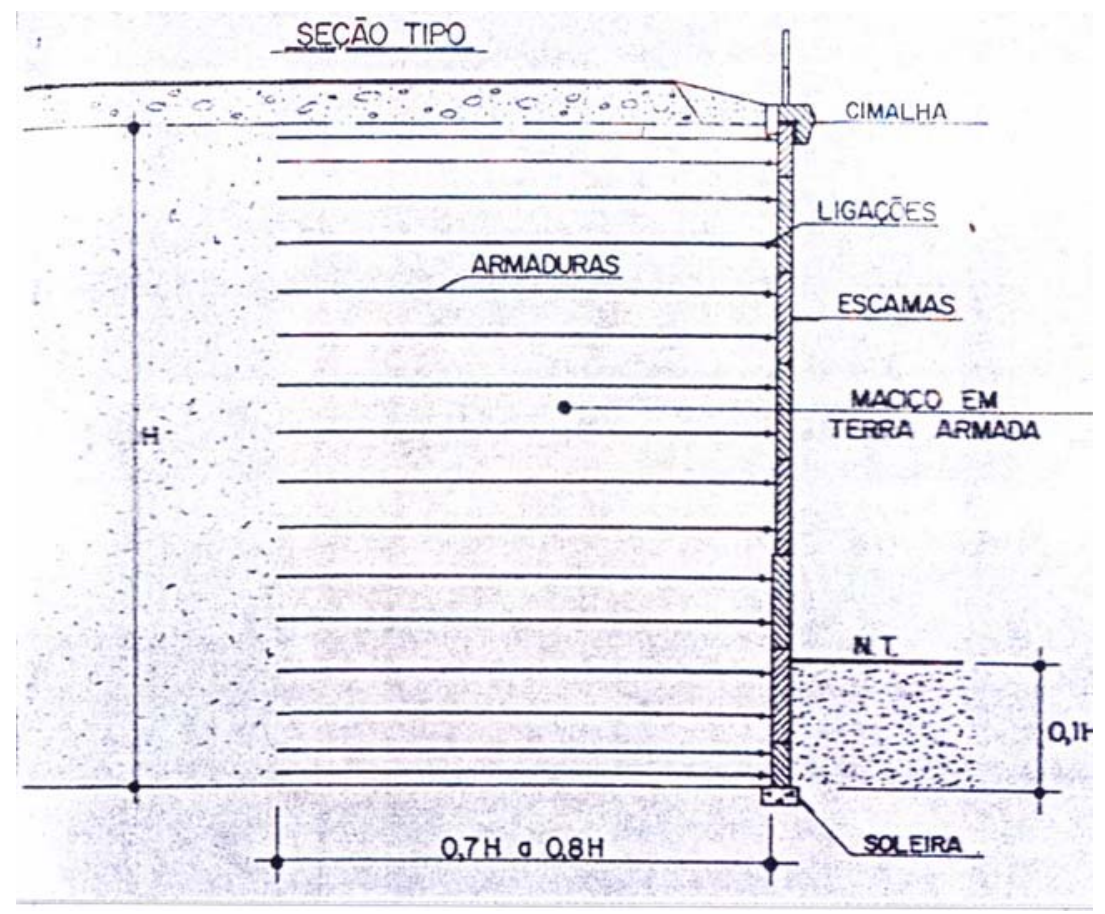

Figura 72 - Obras de Sustentação - Terra Armada: Tardoz da escama X Armadura.

Fonte: TERRA ARMADA. (1982).

$\rightarrow$ Juntas

Juntas horizontais de apoio de uma escama contra a outra. Juntas verticais filtrantes.

凡 Execução da obra

A montagem da TERRA ARMADA, pode ser feita por equipamentos e ferramentas usuais e simples. Não necessita de formas, escoramentos nem andaimes. Evita também espera para cura do concreto no canteiro. O aterro do volume armado é processado com os equipamentos normais de terraplanagem. 
As primeiras escamas de concreto (parte inferior), são montadas sobre uma soleira de concreto magro, sem função estrutural. As demais são colocadas nos espaços deixados pelas precedentes. Sustentam-se provisoriamente por um sistema de entalhes e encaixes de pinos e furos. As juntas de apoio são de cortiça, aglomeradas com epoxy. As juntas laterais são preenchidas com elementos filtrantes de espuma de poliuretano, constituindo-se em áreas drenantes.

A montagem, isto é, o posicionamento das escamas, das camadas de aterro e colocação de armaduras, se desenvolve camada por camada. Todo trabalho é feito sobre a camada anteriormente colocada, evitando-se portanto ocupar espaço do lado exterior. $\mathrm{O}$ aterro é espalhado com os equipamentos normais de terraplanagem. Entre dois leitos sucessivos de armaduras há uma distância vertical de $75 \mathrm{~cm}$, que permite espalhar e compactar a terra em camadas de espessura conveniente.

O reforço de solos, também, pode ser obtido com a inclusão de geosintéticos durante o processo de construção do maciço de solo, o que proporciona uma sensível melhora das características mecânicas do conjunto se comparadas aquelas apresentadas por um maciço de solo natural.

Esse ganho possibilita à combinação solo/geosintéticos suportar esforços consideravelmente maiores que aqueles suportados pelo solo não reforçado. Por exemplo, um talude reforçado pode ser construído com inclinação maior que o ângulo natural de repouso do solo que o compõe.

Sistema terramesh, segundo Maccaferri (2000)

\ Apresentação

A primeira estrutura documentada que apresentava uma combinação de gabiões e terreno armado foi construída em Sabah na Malásia em 1979. Um revestimento vertical de gabiões foi ancorado ao material de aterro por meio de tiras de aço. 
Com o objetivo de intervir, buscando garantir um reforço contínuo sobre o plano horizontal, se considerou oportuna a utilização de malhas de dupla torção em arames de aço para a substituição das tiras . Desta maneira se obtém armaduras longitudinais, contínuas e se alcança a mobilização não só do atrito contra a secção do fio metálico, mas sobretudo das propriedades mecânicas de travamento entre as partículas do material de aterro. Isto se deve à grande dimensão da abertura hexagonal da malha quando comparada ao diâmetro do fio, que se traduz num aumento geral da resistência do reforço, o que não ocorre com materiais que fornecem resistência somente pelo atrito.

\ Características do sistema terramesh

$\rightarrow$ Permeabilidade - que permite ao paramento externo garantir a drenagem do terreno, Ver figura 73.

$\rightarrow$ Flexibilidade - que garante à estrutura a capacidade de acompanhar os assentamentos do terreno mantendo a sua integridade estrutural.

$\rightarrow$ Versatilidade - que permite a construção de estruturas com paramento externo vertical, inclinado ou em degraus, segundo a necessidade. Buscando minimizar o impacto ambiental é possível inserir, durante a construção da estrutura Terramesh mudas de espécies vegetais nativas ou no caso do Terramesh Verde a aplicação de hidro-semeadura sobre o paramento da estrutura. Ver figura 73.

\section{N Composição construtiva}

Resistência, durabilidade e segurança são os principais requisitos que os materiais empregados para uma estrutura em solo reforçado devem possuir. Esses materiais devem fornecer garantias especiais para: 
$\rightarrow$ Proteção contra a corrosão devido a:

Agressividade do solo e/ou água;

DFenômenos de correntes vagantes;

Agentes Atmosféricos.

$\rightarrow$ Segurança contra danos provocados por:

Ações mecânicas geradas pelos esforços de compactação do solo;

Incêndio;

DAções de animais ou vandalismo.

\. Armadura

Todos os arames utilizados na fabricação dos elementos Terramesh e nas operações de costura, efetuadas com arame de diâmetro não inferior a 2,2 mm, aço com baixo carbono. Alem disso esses arames recebem forte zincagem para a sua proteção contra corrosão e são recobertos, depois da zincagem pesada, por uma camada de PVC com espessura nominal de aproximadamente $0,5 \mathrm{~mm}$.

\ Aterro estrutural

O aterro estrutural deverá ser constituído por solo de boa qualidade (granular e bem selecionado), com ângulo de atrito e poder drenante elevados, e sobretudo, que mantenha suas características inalteradas ao longo do tempo.

O lançamento e compactação do aterro são efetuadas empregando as técnicas, equipamentos e mão-de-obra tradicionais e de acordo com as especificações locais para construção do gênero. 
Solos com uma granulometria variável de $0,02 \mathrm{~mm}$ até $6 \mathrm{~mm}$, representam, em geral, valores ótimos para o material do aterro. São, todavia, admissíveis granulometrias maiores (próximas a $200 \mathrm{~mm}$ ), nestes casos se faz oportuno introduzir um fator adicional de segurança para a malha prevendo e considerando possíveis danos ao revestimento de PVC.

O emprego de materiais com elevado percentual de pedras superiores aos $100 \mathrm{~mm}$ (10 a 15\% no máximo) é de qualquer maneira desaconselhável, mesmo porque necessitam cuidados especiais que tornariam muito trabalhosos e custosos os trabalhos de compactação.

O elemento determinante para a avaliação da resistência e do poder de ancoragem da malha é o ângulo de atrito interno do solo a ser utilizado no aterro, o qual se aconselha que não seja inferior aos valores mínimos de $28^{\circ}$ a $30^{\circ}$.

O elemento de aterro deve ser lançado e compactado em camadas sucessivas com espessuras não superiores a $0,30 \mathrm{~m}$. A compactação do aterro junto ao paramento deverá ser efetuado com o auxílio de compactadores manuais (placas vibratórias, sapos, etc.), e o grau de compactação a atingir deverá estar de acordo com as normas especificadas para a obra. Geralmente na fase de projeto se assume uma compactação, que determine uma densidade mínima para o aterro, próximo aos $1800 \mathrm{~kg} / \mathrm{m}^{3}$.

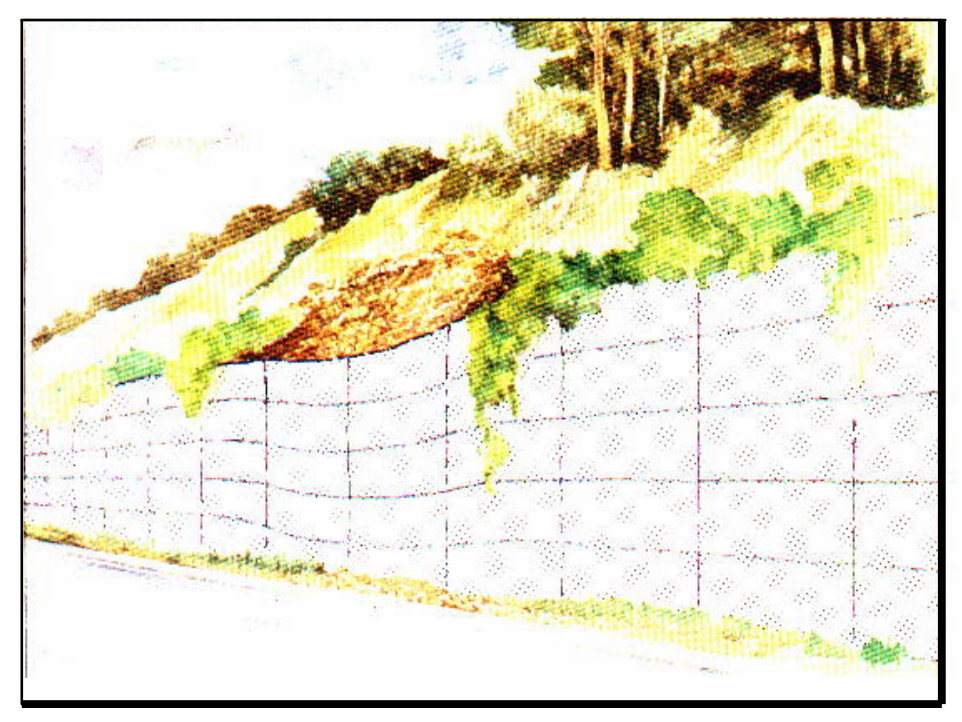

VISTA DE UMA APLICAÇÃO DO SISTEMA TERRAMESH 

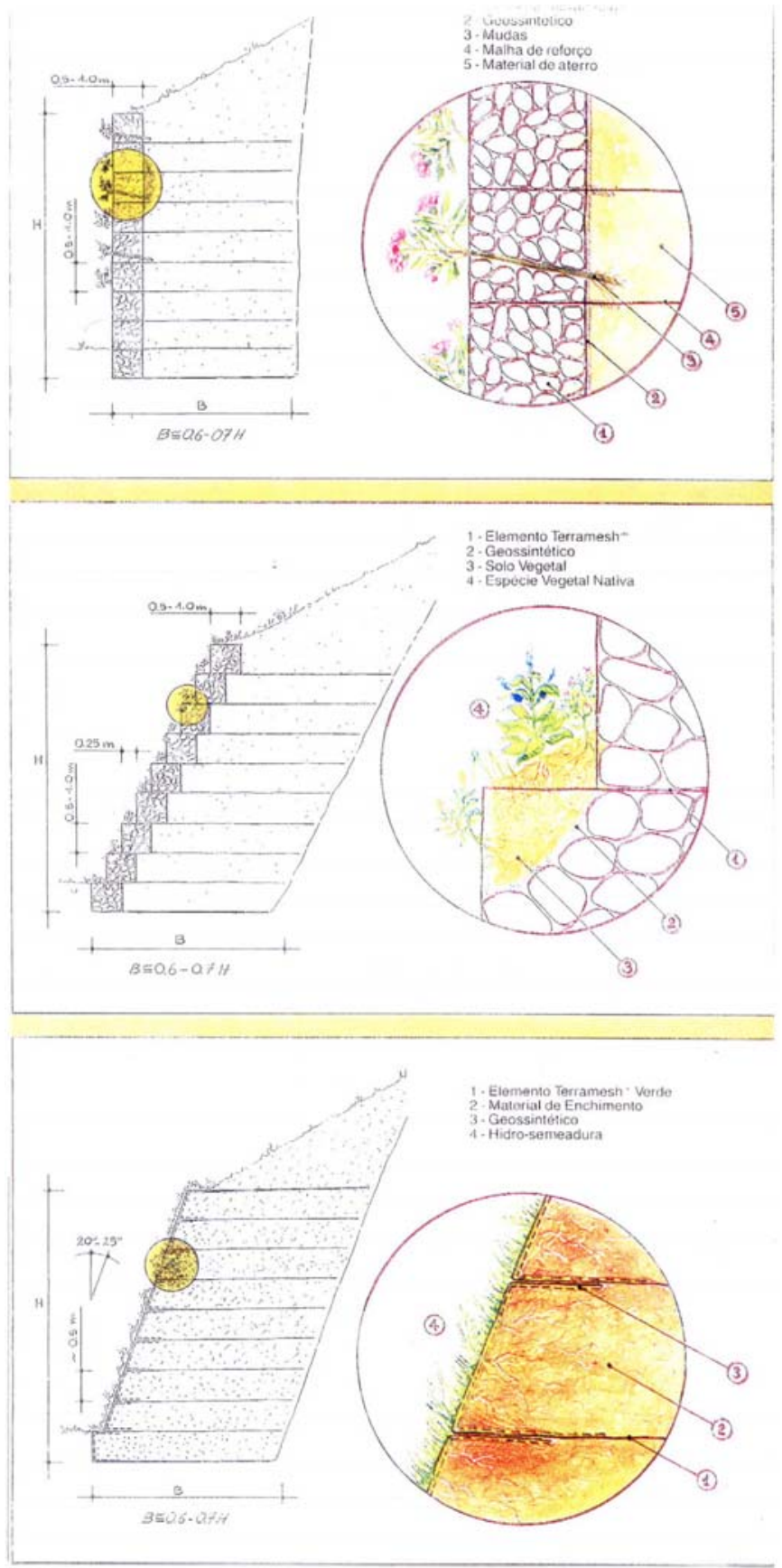

Figura 73 - Obras de Sustentação - Sistema Terramesh Fonte: MACCAFERRI. (2000). 
Muros

São estruturas corridas de contenção constituídas de parede vertical ou quase vertical apoiada num dos seguintes tipos de fundação: direta rasa e corrida ou profunda (tubulão); indireta (estacas). Podem ser construídos em alvenarias (de tijolos ou pedras) ou em concreto (

Muro de Gravidade, segundo Nagib \& Saad (1991)

São estruturas corridas massudas, que se opõe aos empuxos horizontais pelo peso próprio. Em geral são empregados para conter desníveis pequenos ou médios, inferiores a cerca de $5 \mathrm{~m}$.

São construídos para conter terraplenos, devendo neste caso, ser executado integralmente para receber o maciço ao final de sua construção ou à medida que forem sendo erguidas. Ver figura 74.

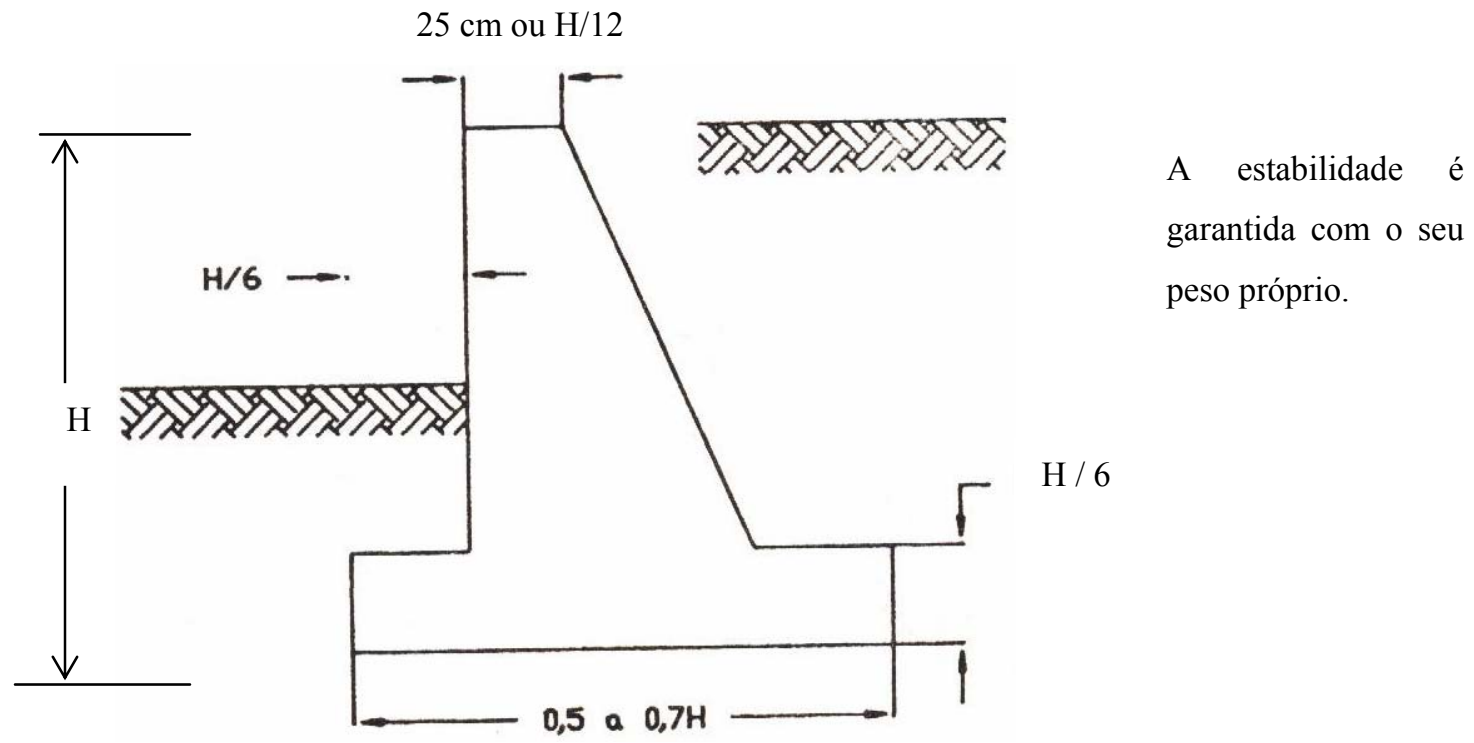

Figura 74 - Muro de gravidade.

Fonte: NAGIB \& SAAD. (1991). 
Muros Atirantados, segundo Moliterno (1987)

São estruturas em concreto ou mistas, isto é, em concreto com alvenaria de blocos de concreto ou tijolos, com barras quase horizontais, contidas em planos verticais, perpendiculares ao paramento do muro, funcionando como tirantes, amarrando o paramento a outros elementos embutidos no maciço, como blocos, vigas longitudinais ou estacas. São construções de baixo custo, utilizadas para alturas de cerca de $3 \mathrm{~m}$. Ver figura 75.

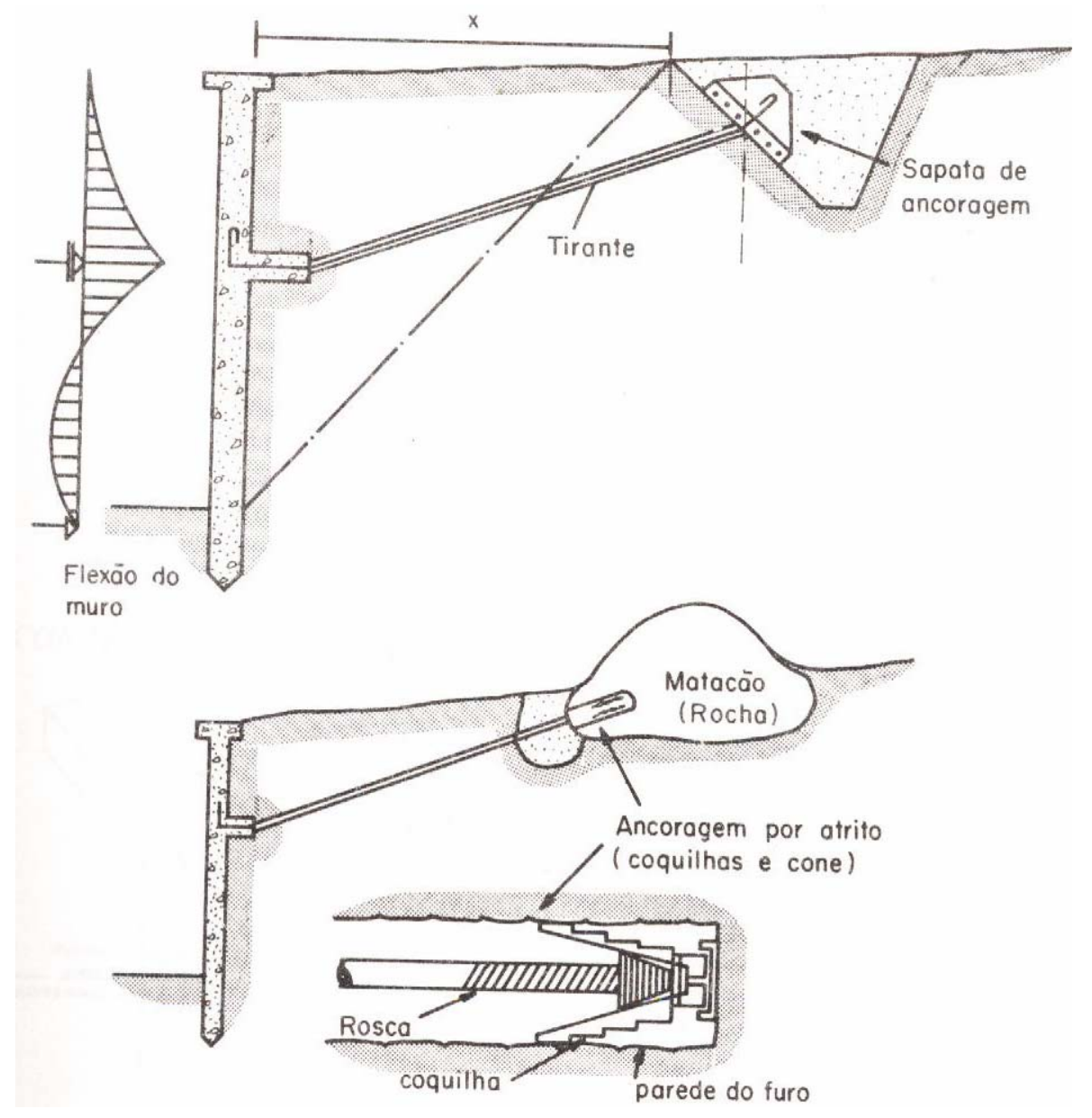

Figura 75 - Muro Atirantado.

Fonte: MOLITERNO. (1987). 
Muros de Flexão, segundo Nagib \& Saad (1991)

São estruturas esbeltas com seção transversal em forma de "L" que resistem aos empuxos por flexão, utilizando parte do peso próprio do maciço arrimado que se apóia sobre a base do "L" para manter-se em equilíbrio. Na maioria das vezes são construídos em concreto armado, tornando-se em geral antieconômicos para alturas acima de 5 a $7 \mathrm{~m}$. Ver figura 76.

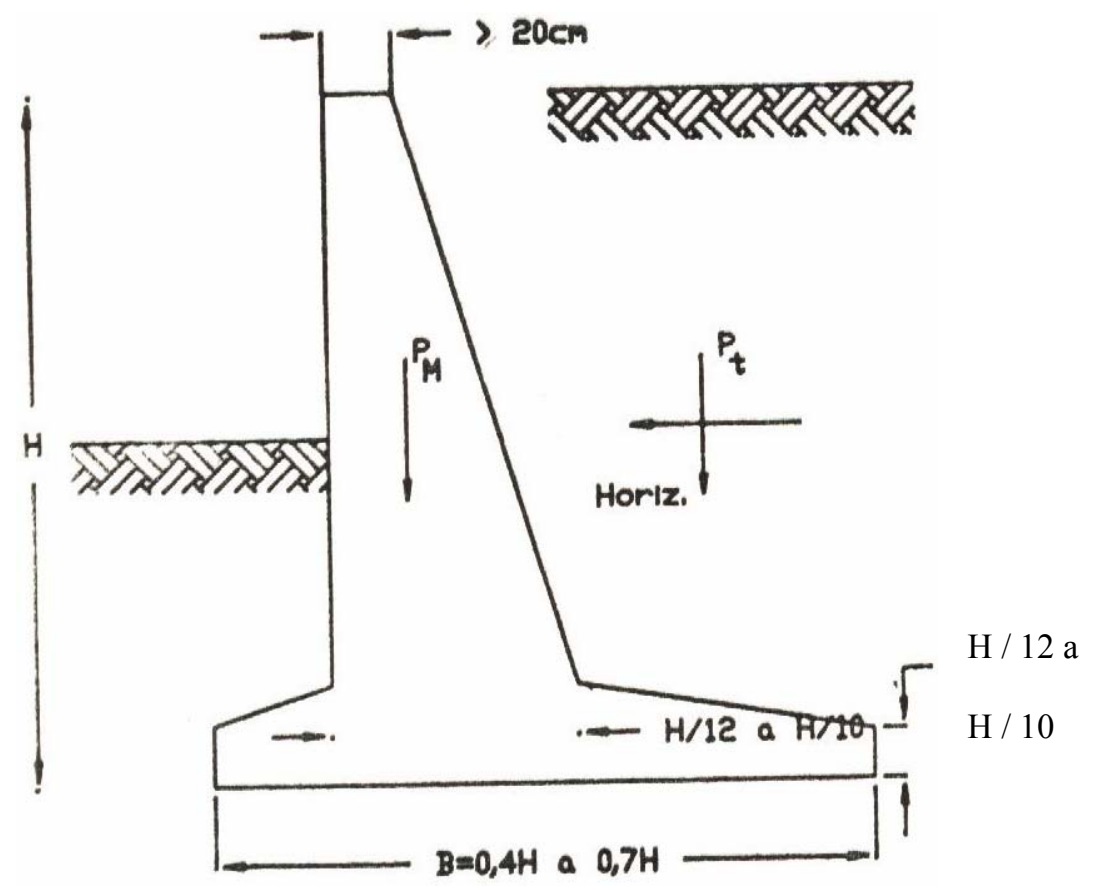

Figura 76 - Muro de flexão.

Fonte: NAGIB \& SAAD. (1991).

Muros Mistos

São muros com características intermediárias, entre muros: gravidade, atirantado e de flexão, que funcionam, portanto, parcialmente pelo peso próprio e parcialmente a flexão, utilizando parte do terrapleno como peso para atingir uma condição global de equilíbrio. 
Muros de Contraforte, segundo Moliterno (1987)

São os que possuem elementos verticais de maior porte, chamados contrafortes ou gigantes, espaçado em planta de alguns metros e, destinados a suportar os esforços de flexão pelo engastamento na fundação. $\mathrm{O}$ paramento do muro, nesse caso, é formado por lajes verticais que se apóiam nesses contrafortes.

Como nos muros de flexão, o equilíbrio externo da estrutura é conseguido tirando-se proveito do peso próprio do maciço arrimado, o qual se apóia sobre a sapata. corrida ou laje de fundação. A diferença em relação aos muros de flexão é essencialmente estrutural. Os gigantes ou contrafortes são embutidos no terrapleno arrimado (margem do rio). Ver figura 77.

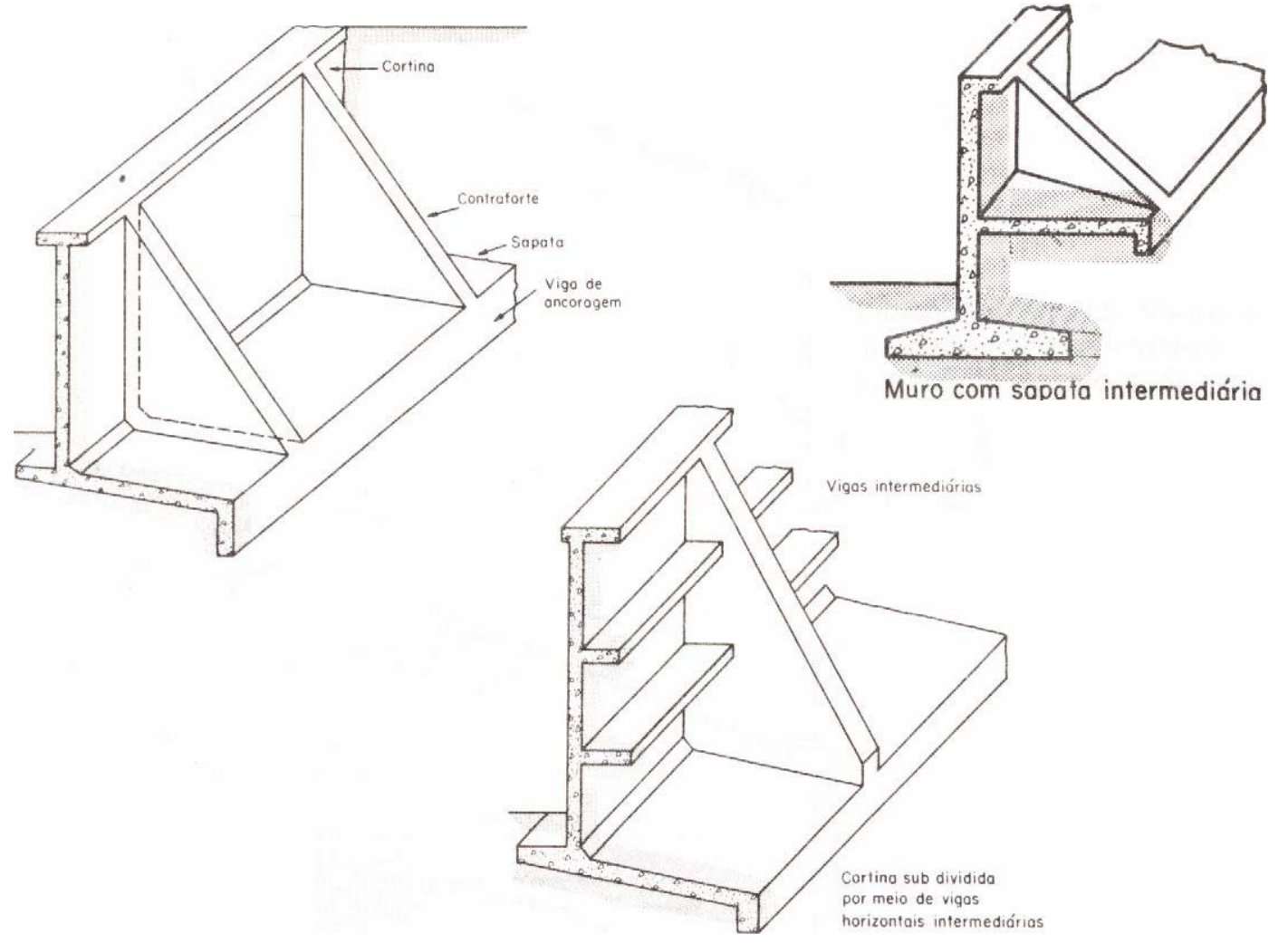

Figura 77 - Muros de contraforte.

Fonte: MOLITERNO. (1987). 
Muros de Gabiões ( do italiano Gabbioni = Gaiolões)

São muros de gravidade construídos pela superposição de "gaiolões" de malhas de arame galvanizado, cheios com pedras, cujos diâmetros mínimos devem ser superiores a abertura da malha das gaiolas. São empregados para faixas de alturas da mesma ordem de grandeza das dos muros de gravidade.

Nesta tese, daremos especial atenção aos muros de gabiões, por serem estruturas que atendem no mais das vezes, a viabilidade ambiental do projeto.

\ Flexíveis (gabiões), segundo Maccaferri (2002)

$\rightarrow$ Apresentação

O gabião caixa é uma estrutura metálica, em forma de paralelepípedo, cujas três medidas são da mesma magnitude. Um único elemento, produzido com malha hexagonal de dupla torção, forma a base, a tampa, e as paredes laterais. Ao elemento de base são unidos, durante a fabricação, as duas paredes de extremidades e os diafragmas, assim encaixado e devidamente desdobrado na obra, assume a forma de um paralelepípedo.

O seu interior é preenchido com pedras, não friáveis, com bom peso específico e tamanho na medida do possível regular, bem distribuídas e com dimensões variadas, compreendida entre a dimensão maior da malha e o dobro. Ver figura 78 .

A tela é produzida com arames de aço de baixo conteúdo de carbono, revestido com liga de zinco (95\%), alumínio (5\%) e terras raras (revestimento Galfan), que confere uma proteção contra corrosão de pelo menos cinco vezes a oferecida pela zincagem pesada tradicional.

Para conferir a adequada resistência e flexibilidade, as dimensões das aberturas da tela são aproximadamente $8 \times 10 \mathrm{~cm}$, enquanto o diâmetro dos arames metálicos é de 2,7 mm (arame com revestimento Galfan) e 2,4 mm (arame com 
revestimento Galfan e plastificado), e o diâmetro dos arames de borda é de 3,4 mm e 3,0 $\mathrm{mm}$ respectivamente. Quando em contato com a água, é aconselhável que seja utilizado o arame com revestimento plástico, o qual oferece uma proteção definitiva contra a corrosão.

São estruturas flexíveis adequadas para a construção de proteções descontínuas como espigões e obras de sustentação, do tipo muro de arrimo. Ver figura 79.

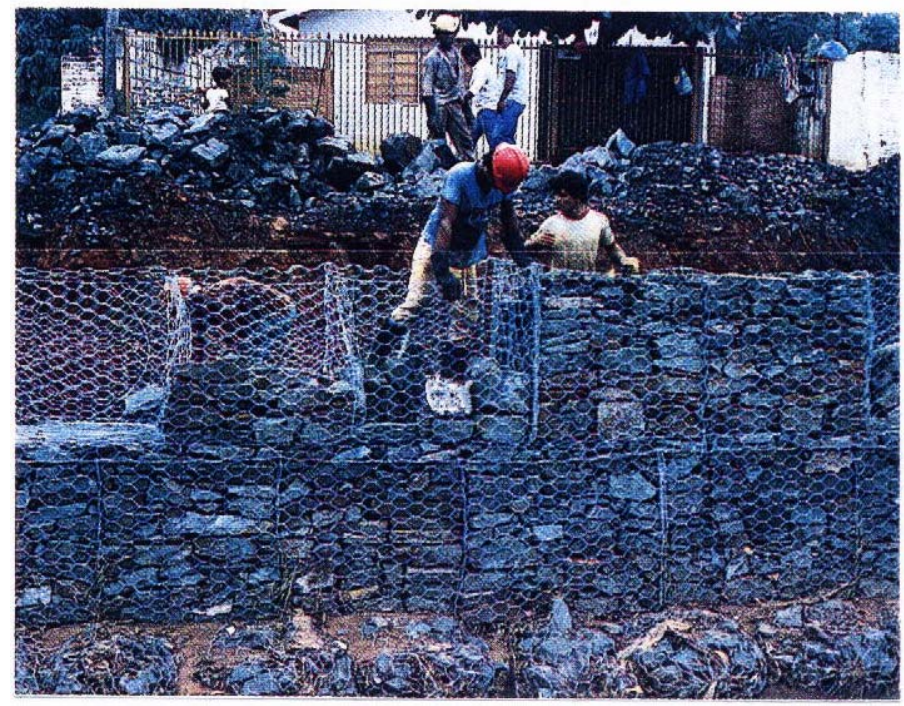

Figura 78 - Obras de Sustentação - Gabiões: Detalhe de enchimento de gabiões, apoiados sobre plataforma de sacos.

Fonte: MACCAFERRI. (2000).

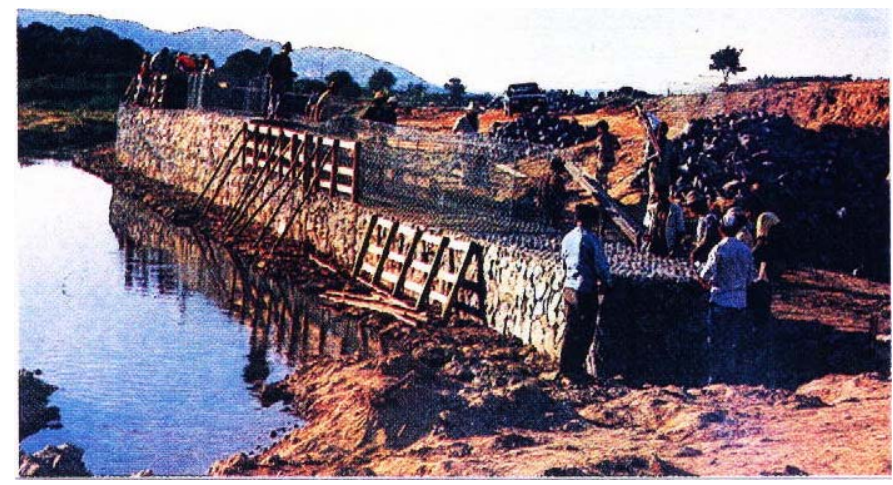

Figura 79 - Obras de Sustentação - Gabiões: Vista de execução de muro em gabiões; vê-se o gabarito de madeira que auxilia no alinhamento e acabamento de face da obra.

Fonte: MACCAFERRI. (2000). 
$\rightarrow$ Características do Gabião Caixa

As estruturas em gabiões apresentam diversas características, dentre as quais podemos citar como as mais destacáveis:

Dxtrema flexibilidade, que permite a adaptação da estrutura às acomodações e movimentos do terreno, mantendo sua estabilidade e eficiência;

DElevada resistência estrutural, graças à notável massa, ao atrito entre as pedras, sua resistência à compressão e a grande resistência à tração suportada pela malha (com pequena deformação);

D Adequada permeabilidade que facilita a drenagem das águas de percolação na margem taludada, eliminando empuxo hidrostático.

D A execução da obra em gabião é extremamente simples e econômico, não requerendo nem equipamentos nem mão-de-obra especializados. Pode ser utilizado no enchimento seixo rolado de rio ou pedra de pedreira. A operação de enchimento pode ser executada manualmente ou com auxílio de equipamentos convencionais de canteiro.

D gabião integra-se harmoniosamente à paisagem, permitindo o desenvolvimento da vegetação sem que esta traga inconveniente, assegurando pela evolução da natureza a integridade da obra.

$\rightarrow$ Dimensões

As dimensões dos gabiões caixa são padronizadas. O comprimento, sempre múltiplo de $1 \mathrm{~m}$, vária de 1 a $6 \mathrm{~m}$, com exceção do gabião de $1,5 \mathrm{~m}$, enquanto a largura é sempre de $1 \mathrm{~m}$. A altura pode ser de $0,50 \mathrm{~m}$ ou $1,00 \mathrm{~m}$. Através de pedido, podem ser fabricados gabiões caixa de medidas diferentes das padronizadas. 
\ Gabiões Tipo Saco, segundo Maccaferri (2002)

$\rightarrow$ Apresentação

O s gabiões saco são estruturas metálicas, em forma de cilindro, constituídos por um único pano de malha hexagonal de dupla torção, que em suas bordas livres apresentam um arame especial que passa alternadamente pelas malhas para permitir a montagem da peça na obra. Ver figura 80.

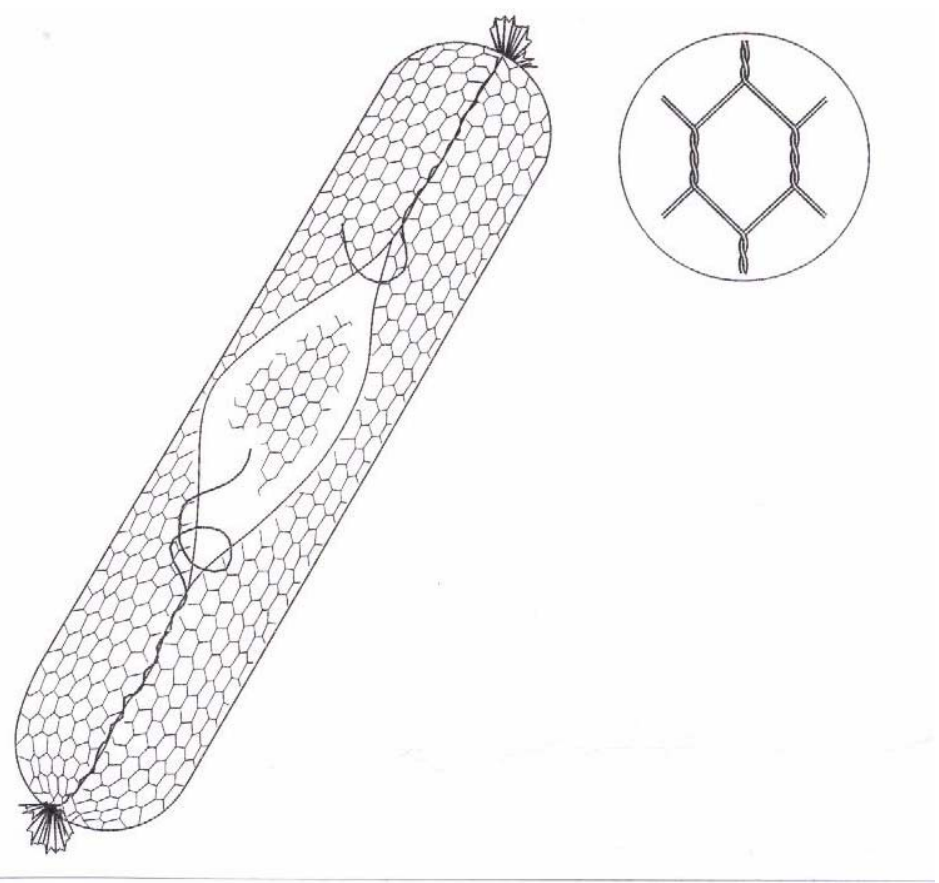

Figura 80 - Proteção Direta - Esquema do gabião saco.

Fonte: MACCAFERRI. (2002).

É um tipo de gabião extremamente versátil devido ao seu formato cilíndrico e método construtivo, pois as operações de montagem e enchimento são realizadas no canteiro para posterior aplicação com auxílio de equipamentos mecânicos. É empregado, geralmente, em locais de difícil acesso, em presença de água ou em solos de baixa capacidade de suporte devido a extrema facilidade de colocação. 
Essas características fazem do gabião saco, ferramenta fundamental em obras emergenciais, em locais de difícil acesso, submersas, ou apoiadas em solos com baixa capacidade de suporte.

O enchimento com pedras não assume a mesma importância tomada pelos gabiões caixa e pelos colchões Reno, devido às características próprias das obras em que estes são empregados. A dimensão menor das pedras nunca deve ser menor que a da abertura de malha. As amarrações entre os gabiões saco não são necessárias.

A tela, formada de uma malha hexagonal de dupla torção, é produzida com arames com baixo conteúdo de carbono, revestido com uma liga de zinco (95\%), alumínio (5\%) e terras raras (revestimento Galfan) que confere proteção contra a corrosão. A tela é confeccionada com arame plastificado, devido aos gabiões saco sempre estarem em contato com a água e colocados em posição de difícil manutenção.

Para conferir a adequada resistência e flexibilidade, as dimensões das aberturas da tela, são de aproximadamente $8 \times 10 \mathrm{~cm}$, e o diâmetro dos arames metálicos é de 2,4 mm, $3 \mathrm{~mm}$ para as bordas e 3,4 $\mathrm{mm}$ para os arames de fechamento.

\section{$\rightarrow$ Dimensões}

As dimensões do gabião saco são padronizadas, sendo que os comprimentos são de 2,0 m, 3,0 m, 4,0 m e 5,0 m, com diâmetro de 0,65 m. Através de pedidos podem ser fabricados gabiões saco de medidas diferentes das padronizadas.

\section{$\rightarrow$ Características}

D Flexibilidade - permite à estrutura acompanhar recalques diferenciais sem comprometê-las;

DPermeabilidade - permite o alívio das cargas das cargas hidrostáticas;

DResistência a Empuxos - quando aplicado em canais de seção retangular 
$\rightarrow$ Aplicações referentes a cursos d'água

D Canalizações - quando utilizado em canalizações, protegem as margens e o fundo dos canais contra erosão, ver figura 81;

D Obras de Fundações - quando executadas de modo a assemelhar-se a "fundações", isto é, com a capacidade de transmitir ao solo as cargas de outros elementos estruturais;

D Obras emergenciais - para intervenções emergenciais em obras hidráulicas, recorre-se a utilização do gabião saco, que pode, especialmente, ser instalado em presença de água. Ver figura 82.

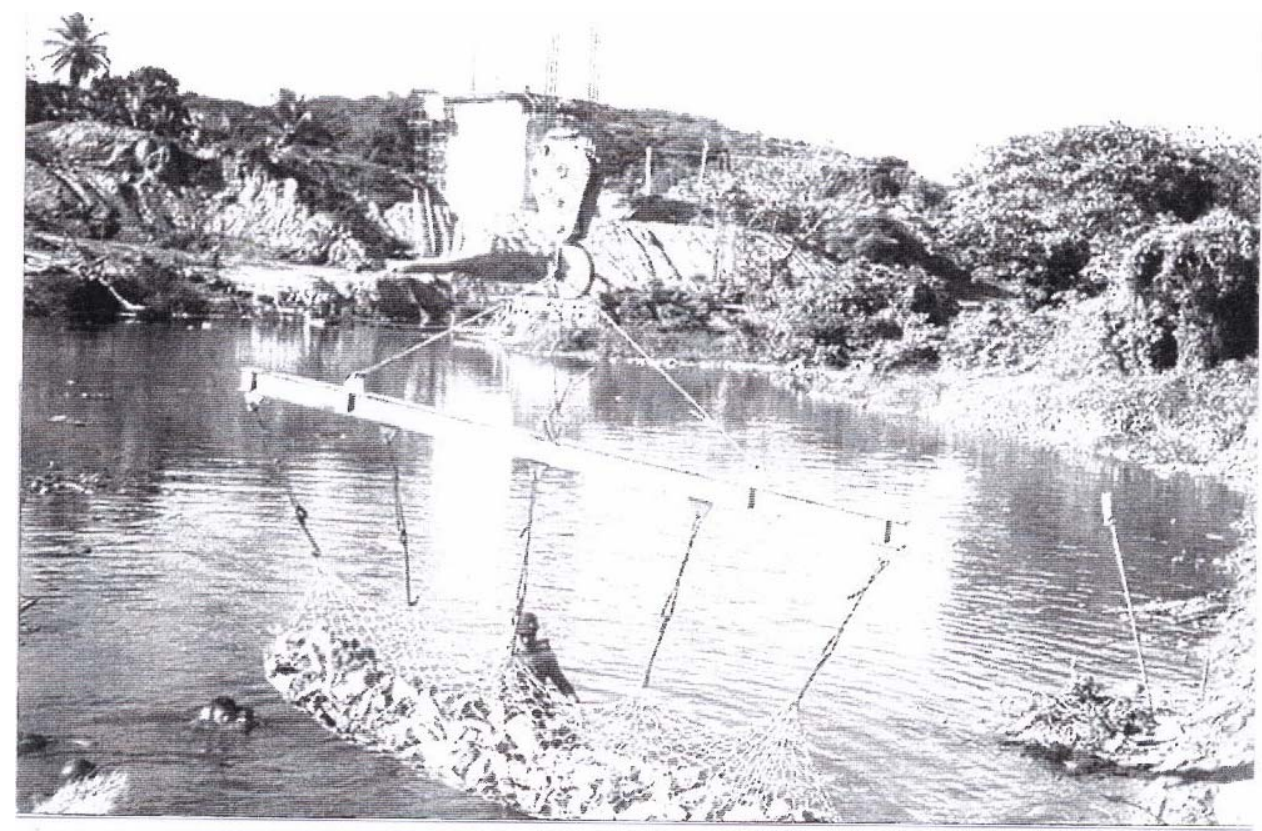

Figura 81 - Proteção Direta - Gabião saco - colocação em presença d'água. Fonte: MACCAFERRI. (2002). 


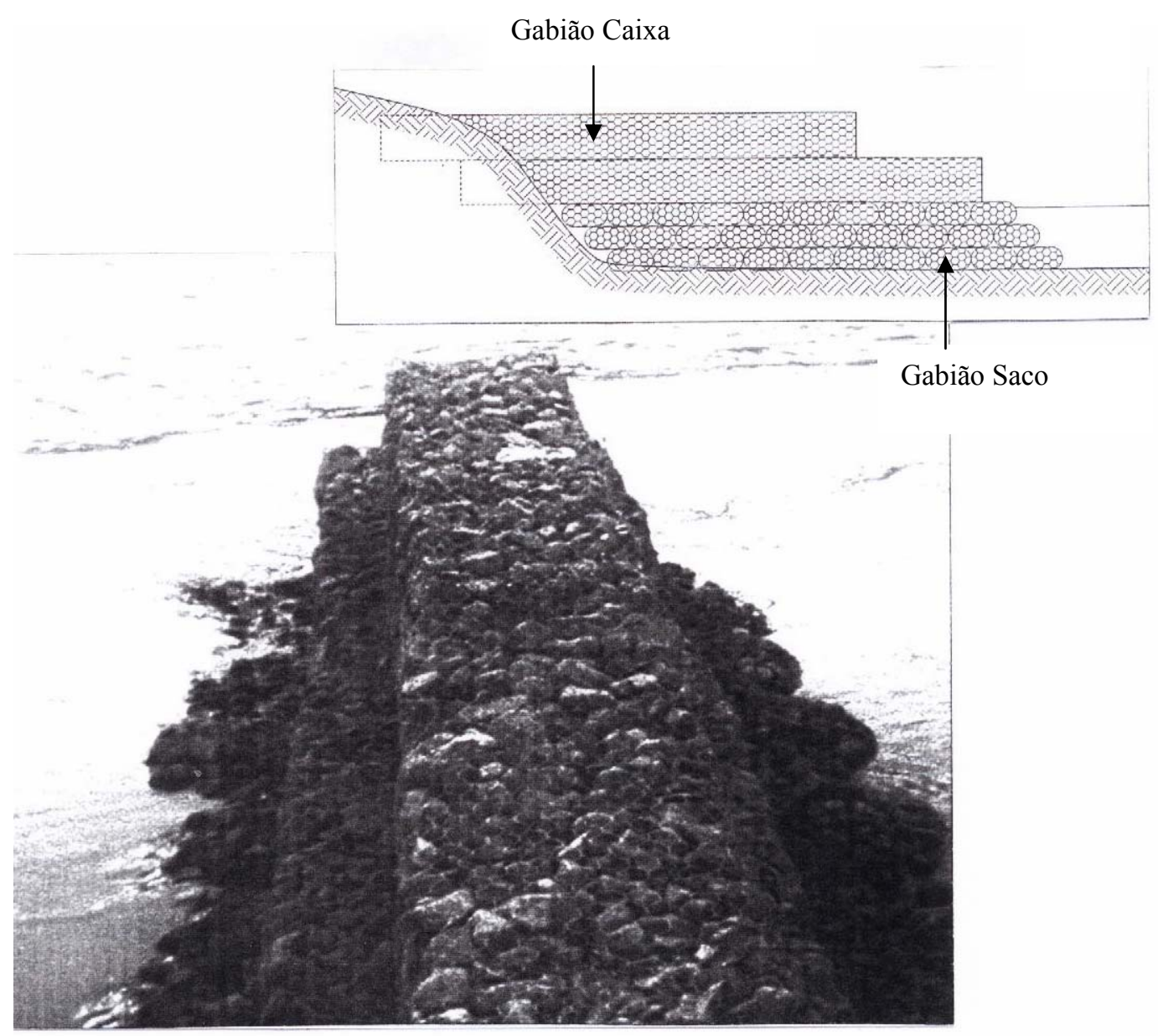

Figura 82 - Proteção Direta - Gabião saco, empregado como "base" para o gabião caixa - Espigão. Fonte: MACCAFERRI. (2002). 


\section{Rimo Bloco}

São blocos pré-moldados com um sistema de encaixe por ajustamento das próprias peças. Os painéis são ancorados no solo por meio de alavancas moldadas “ïn loco", armadas com uma barra de aço ( $\varnothing$ 3/8" ). A amarração das alavancas nos blocos, dá-se por efeito de cunha, enchendo-se de concreto o orifício cônico entre os blocos. O solo é perfurado com trado, movido a motor elétrico. Ver figura 83.

Esta solução apresenta as seguintes vantagens: redução do peso próprio em relação aos muros convencionais; drenagem perfeita; acabamento perfeito apresentando a formação de mosaicos; facilidade de colocação, dispensando pessoas especializadas; soluço econômica.

Emprega-se este sistema para solucionar problemas de execução de muros de arrimo, revestimento de taludes e de canais.

Esta solução apresenta as seguintes desvantagens: não existe uma metodologia teórica para quantificar os esforços e demonstrar a estabilidade; trata-se portanto de uma solução eminentemente empírica, baseada na experiência da firma detentora da patente.

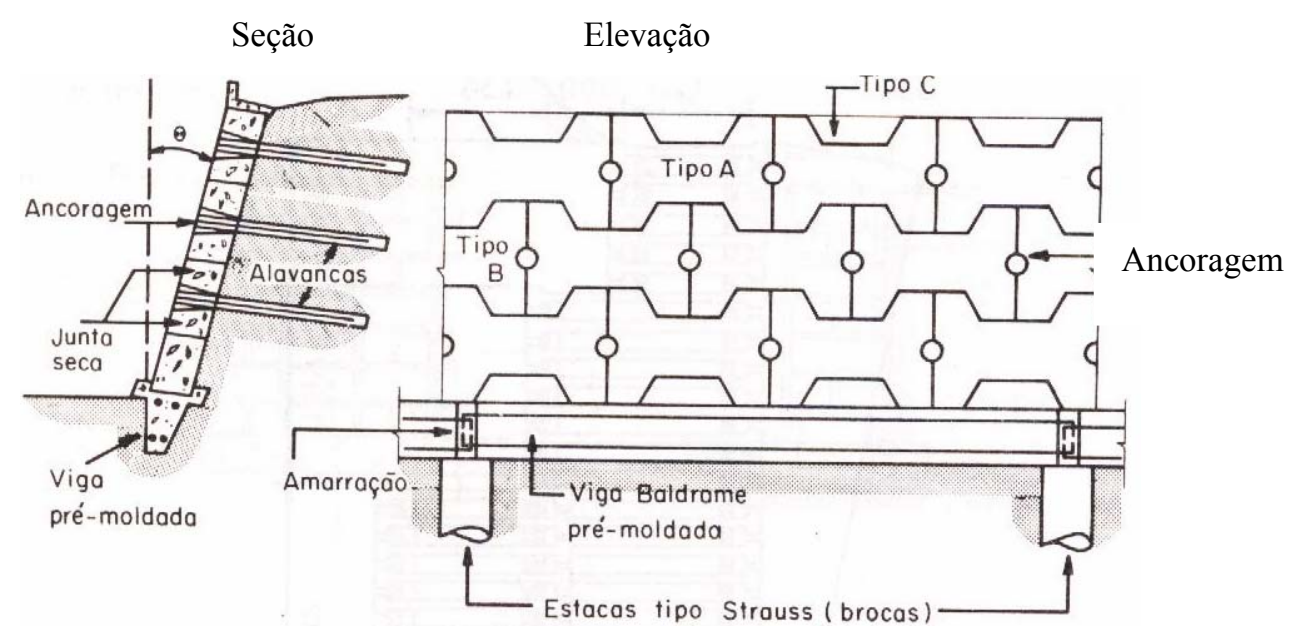

Figura 83 - Rimo bloco

Fonte: MOLITERNO. (1987). 
Crib - Wall ( Parede de engradados )

São estruturas formadas por elementos pré-moldados de concreto armado, madeira ou aço, que são montados no local, em forma de "fogueiras" ou "gaiolas" justapostas e interligadas longitudinalmente, cujo espaço interno é cheio de preferência com material granular graúdo (brita grossa ou pedra de mão); são estruturas flexíveis. Ver figura 84.

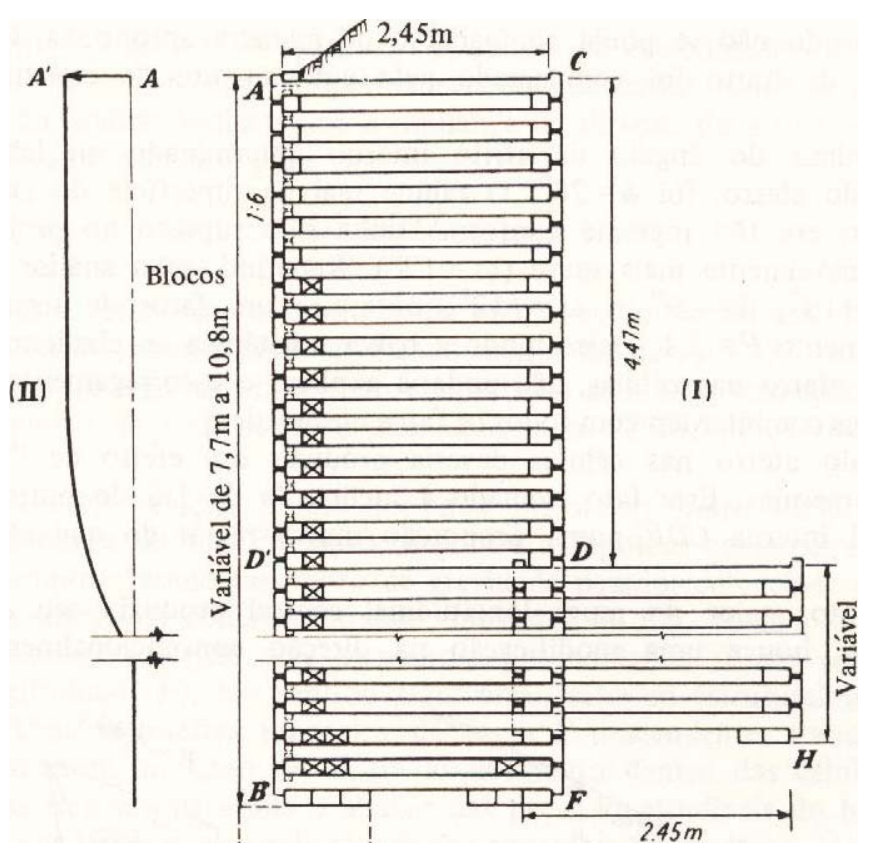

A

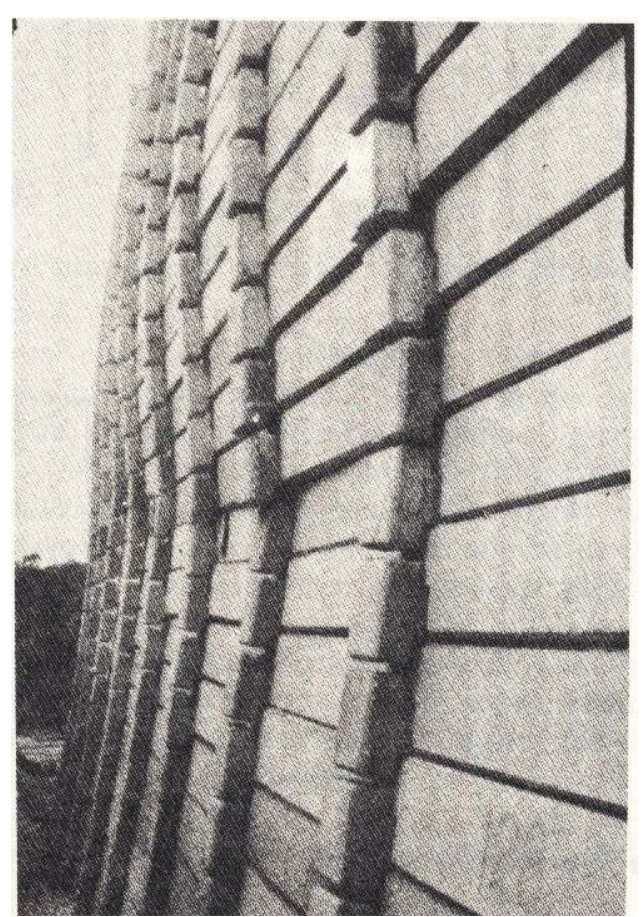

B

Figura 84 - Crib - Wall - A - Seção transversal do muro em fogueira de célula dupla; B Estufamento da parete superior de muro em fogueira concâvo.

Fonte: TSCHEBOTARIOFF. (1978). 


\section{Paredes Diafragmas, segundo Moliterno (1987)}

Originariamente empregadas na construção dos diafragmas de barragens de terra, posteriormente estendidas para galerias dos metropolitano (metrô de Milão), hoje tem ampla aplicação na contenção de solos.

O processo executivo, em linhas gerais, consiste em: escavação de uma valeta pouco profunda ao longo do eixo do muro (valeta guia), feita com "clamshel" e, constantemente a vala vai sendo cheia com a lama trixotrópica (bentonita + água), até ser atingida a profundidade indicada em projeto, terminada a escavação, a vala se mantém escorada com a própria lama provocando pressão hidrostática equilibrante e, ao mesmo tempo por ação química, impermeabiliza as paredes da vala, que aos poucos são ocupadas pelo concreto. Ver figura 85.

\section{ETAPAS DE EXECUÇÃO - ELEVAÇÃO}

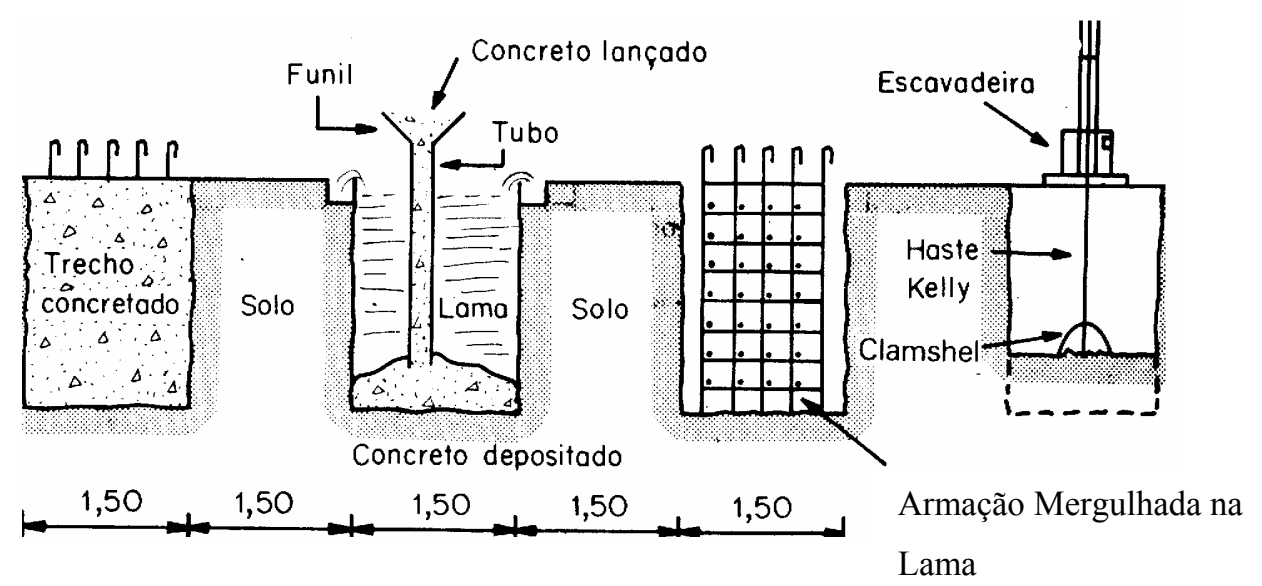

Figura 85 - Paredes Diafragma - Etapas de execução.

Fonte: MOLITERNO. (1987). 
Estacas Pranchas Metálicas, segundo Moliterno (1987)

Conhecidas no passado como estacas "LARSEN", eram perfis especiais laminados com ranhuras para acoplamento entre si, mantendo-se no prumo durante a a cravação e permitindo perfeita estanqueidade da escavação. Hoje empregamos estacas similares de perfis de chapa dobrada a fio, conhecidas comercialmente como tipo ARMCO, embora existam várias outras similares. As estacas pranchas de aço são cravadas com martelo de ar comprimido ou de vibração. Ver figura 86.

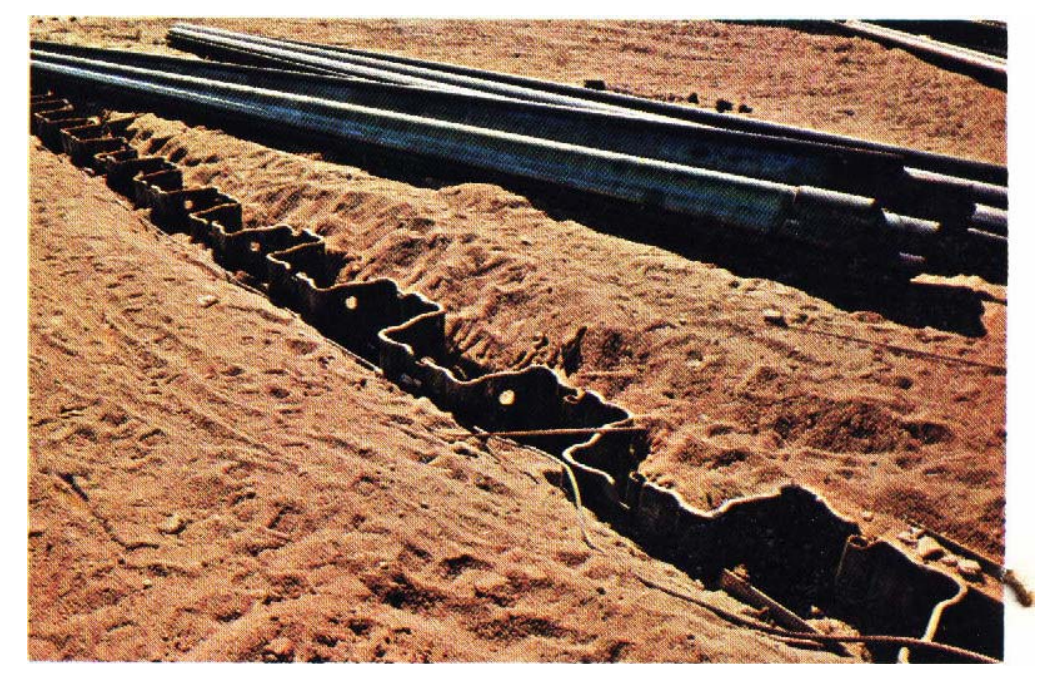

Detalhe de uma parede, antes da sua escavação.

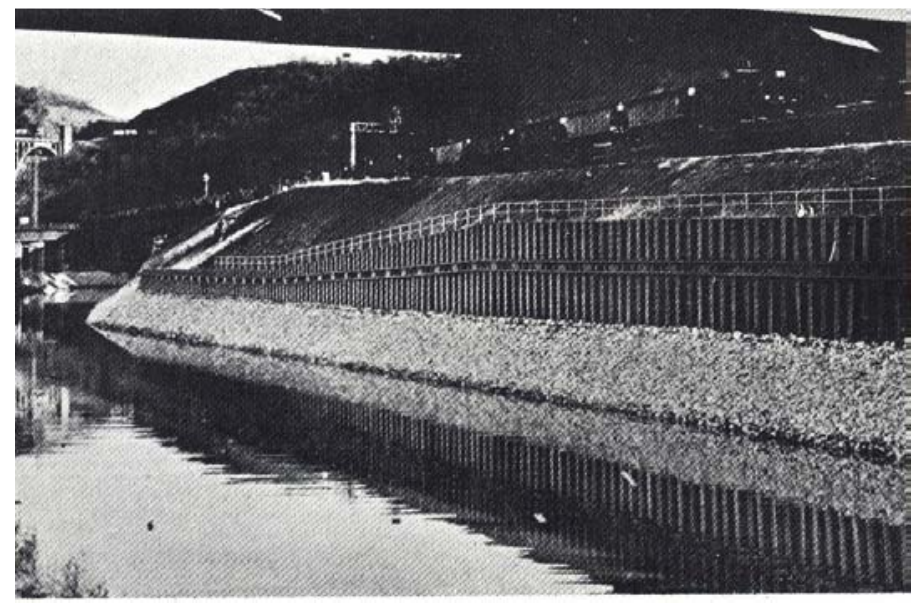

Contenção de margem com estacas prancha

Figura 86 - Estacas - prancha.

Fonte: BRAFÉR INDUSTRIAL S/A. 
Paredes de Estacões ou Tubulões, segundo Moliterno (1987)

Empregam-se tubulões pneumáticos ou por meio de cravação de camisa de aço, cheia de bentonita, ou mesmo estacas com diâmetro $\geq 0,70 \mathrm{~m}$, quando se torna necessário, além de arrimar a terra, escorar uma construção de porte razoável, com fundação rasa e influenciada pela cunha de escorregamento. O cálculo das armações dessas peças dependem da quantificação do empuxo de terra. Ver figura 87.

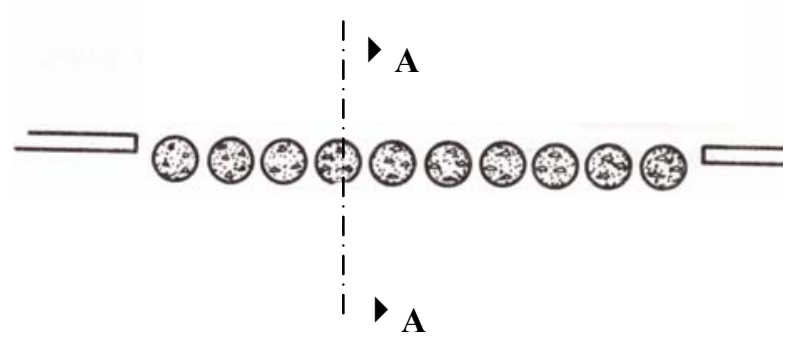

Paredes de Estacões - Vista em Planta

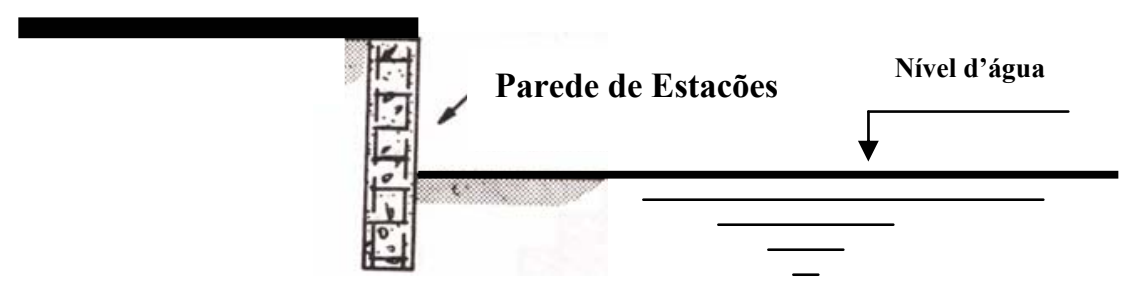

Paredes de Estacões - Corte AA

Figura 87 - Paredes de Estacões.

Fonte: MOLITERNO. (1987). 


\subsection{Proteção Indireta (Descontínua)}

São obras construídas com o objetivo de afastar o escoamento junto a margem ou direcionar o escoamento. A execução destas obras tem como conseqüências:

- Menor velocidade do escoamento, portanto, não há erosão (ação do escoamento);

- Provocar a sedimentação de material sólido, transportado pela água;

- Direcionar de forma conveniente o escoamento;

- No caso da ocorrência de instabilidade geotécnica (escorregamentos, percolação, etc.), permanece o material no local, pois, a água não tem energia e nem velocidade para arrastá-lo;

- Não protegem, totalmente, a margem das ondas, que ocorrem quando há navegação, isto é, não eliminam a ação das ondas sobre as margens;

- Evitam o transporte do material das margens, isto é, o material erodido e instabilizado pelas ondas, permanece no local, devido às baixas velocidades.

As obras de proteção descontínua, mais usadas são: Espigões e Diques. É importante destacar, que em função do tipo de obra executada, temos como conseqüência diferentes impactos na porção bio-geo-física do meio ambiente.

\section{a) Espigões}

São obras transversais, que avançam desde a margem em direção ao leito do rio, até a nova linha de margem que pretende-se formar. Funcionam como defletores do escoamento, afastando-o da margem.

O principal uso dos espigões, reside na proteção das margens, combatendo a erosão. Normalmente executa-se um campo de espigões, isto é, uma série de espigões que se protegem mutuamente, evitando-se assim os efeitos erosivos que ocorrem no espigão isolado. 
Tipos de Espigões, segundo Brighetti (2000)

น Espigão Isolado - destina-se a empurrar a corrente líquida para longe da margem. São utilizados quando se deseja:

\. Proteção do talude de ensecadeira;

N Direcionamento da corrente líquida para vertedores de barragens;

\. Afastamento do escoamento de estruturas localizadas.

Espigões de Repulsão - destinam-se a impelir a corrente líquida para longe da margem. Apresentam as seguintes características:

\. Evitam os efeitos erosivos que ocorrem no espigão isolado;

\$ Uma série de espigões, se protegem mutuamente;

\ De um modo geral, o comprimento dos espigões crescem de montante para jusante;

\ São impermeáveis ou permeáveis;

N Muitas vezes, tornam-se mais caros que a proteção direta.

Espigões de Sedimentação - permitem que substâncias minerais ou rochosas, ou substâncias de origem orgânica, se depositem em ambiente aquoso. Apresentam as seguintes características:

\ Criação de depósito de material sólido entre os espigões que protegerá a margem da erosão;

\ São permeáveis;

\. Devem ser curtos e nivelados abaixo do nível d'água para evitar a formação de turbilhões;

\ $\mathrm{O}$ inconveniente de só poderem ser utilizados em rios de grande transporte de sedimentos. 
- Características dos Espigões, segundo Brighetti (2000)

맘 Quanto ao ângulo de orientação do espigão em relação a corrente líquida:

Normais ou Ortogonais

Usado em terrenos resistentes, para evitar o perigo das socavações, devidas aos turbilhões que se formam na extremidade de montante [ Ver figura 89 (a) ]

、 Ângulo de $90^{\circ}$ com a tangente a margem no ponto de ancoragem;

\$ Geralmente curtos;

\. Executado nas margens côncavas;

\. Muito usado em rios com maré.

Declinante ou para Jusante; ou ainda Divergente

Preferível aos normais, pois orientam para o centro do álveo, as águas de enchentes, que vertem acima do coroamento [ Ver figura 89 (b) ]

、 Ângulo menor que $90^{\circ}$ com a tangente a margem no ponto de ancoragem;

\. Cuidado na sua utilização pois a tendência de erosão nas extremidades dos espigões pode atingir a margem;

\. Quando galgado tende a dirigir o escoamento na direção da margem.

Inclinante ou para Montante; ou ainda Convergente

Adequado para terrenos fixos, em virtude da escassa importância dos fenômenos de escavação [ Ver figura 89 (c) ]

\ Ângulo maior que $90^{\circ}$ com a tangente a margem no ponto de ancoragem;

\. Favorece o desvio de sedimentos do canal navegável para a zona entre os espigões na época de águas altas, exigindo menos proteção nessa face do espigão;

\. Menores espaçamentos exigindo maior número para mesmo comprimento de proteção.

Os espigões podem ser colocados só na margem côncava ou em ambas as margens. 
No primeiro caso, tem apenas função protetora em face da erosão. No segundo caso, fixam-se os entreixos em relação a largura da superfície livre do álveo regularizado, na cota de coroamento. Indicamos na Tabela XVIII valores, obtidos a partir de estudos cognitivos e práticos desenvolvidos por diversos pesquisadores, para espaçamento dos espigões. As referidas distâncias são medidas ao longo do “thalweg”, em relação ao qual, as extremidades (cabeças) de dois espigões opostos devem resultar simétricas; isto quer dizer, que os eixos dos mesmos espigões devem encontrar-se no próprio thalweg.

As linhas que unem as extremidades dos espigões, situados no mesmo lado, objetivam respectivamente, os limites das margens do álveo regularizado.

Estas margens tornam-se contínuas pelos aterros que vão ocupar os espaços entre os espigões, onde as águas turvas do rio perdem velocidade e sedimentam. 
Tabela XVIII - Distâncias entre os eixos (espaçamento) de espigões.

\begin{tabular}{|c|c|c|c|c|}
\hline \multirow[t]{2}{*}{ Autor } & \multicolumn{2}{|c|}{$\begin{array}{l}\text { Relação de espaçamento } \\
\text { recomendada }\end{array}$} & \multirow[t]{2}{*}{$\begin{array}{l}\text { Tipo de } \\
\text { margem }\end{array}$} & \multirow[t]{2}{*}{ Observações } \\
\hline & $\mathbf{S} / \mathbf{L}$ & $\mathbf{S} / \mathbf{B}$ & & \\
\hline \multirow{2}{*}{$\begin{array}{l}\text { Nações Unidas } \\
\text { (1953) }\end{array}$} & 1 & & Côncava & Prática geral \\
\hline & 2 a 2,5 & & Convexa & Prática geral \\
\hline \multirow[t]{2}{*}{ Ahmad (1951) } & 4,29 & & Reta & \\
\hline & 5 & & Curva & \\
\hline Joglekar (1971) & 2 a 2,5 & & & $\begin{array}{l}\text { Espigões inclinados } \\
\text { para montante }\end{array}$ \\
\hline US Army (1984a) & 2 & & & Rio Mississipi \\
\hline Mathes (1956) & 1,5 & & & \\
\hline Strom (1962) & 3 a 5 & & & \\
\hline Acheson (1968) & 3 a 4 & & & $\begin{array}{l}\text { Varia dependendo } \\
\text { da curvatura e } \\
\text { inclinação da linha } \\
\text { d'água. }\end{array}$ \\
\hline \multirow[t]{3}{*}{ Altunin (1962) } & 4 & & Reta & $\alpha>75^{\circ}$ \\
\hline & 3 & & & Para $0,005<\mathrm{I}<0,01$ \\
\hline & 2 & & & Para $\mathrm{I}>0,01$ \\
\hline \multirow[t]{3}{*}{$\begin{array}{l}\text { Richardson } \\
\text { et al. (1975) }\end{array}$} & 2 a 6 & & & $\begin{array}{l}\text { Para proteção de } \\
\text { bancos }\end{array}$ \\
\hline & 3 a 4 & & & $\begin{array}{l}\text { Espigões para canais } \\
\text { de navegação }\end{array}$ \\
\hline & 1,5 a 2 & & & $\begin{array}{l}\text { Canais profundos } \\
\text { para navegação }\end{array}$ \\
\hline Mamak (1956) & 2 a 3 & 1 & & \\
\hline \multirow{3}{*}{ Macura } & & 0,5 & Côncava & \\
\hline & & $5 / 4$ & Convexa & \\
\hline & & $3 / 4$ a 1 & Reta & \\
\hline $\begin{array}{l}\text { Jansen } \\
\text { et al. (1979) } \\
\end{array}$ & & $\begin{array}{l}1 \mathrm{a} 2 \\
0,5 \text { a } 1\end{array}$ & & Em rios estreitos \\
\hline $\begin{array}{l}\text { Blench } \\
\text { et al. }\end{array}$ & 3,5 & & & \\
\hline
\end{tabular}


Tabela XVIII - Distâncias entre os eixos (espaçamento) de espigões. (continuação)

\begin{tabular}{|c|c|c|c|c|}
\hline \multirow[t]{2}{*}{ Autor } & \multicolumn{2}{|c|}{$\begin{array}{l}\text { Relação de espaçamento } \\
\text { recomendada }\end{array}$} & \multirow[t]{2}{*}{$\begin{array}{l}\text { Tipo de } \\
\text { margem }\end{array}$} & \multirow[t]{2}{*}{ Observações } \\
\hline & $S / L$ & $\mathbf{S} / \mathbf{B}$ & & \\
\hline Copeland (1983) & $>3$ & & Côncava & \\
\hline $\begin{array}{l}\text { Akantisz } \\
\text { et al. (1983, 1986, } \\
\text { 1989). }\end{array}$ & & $\begin{array}{l}0,9 \text { a } 1 \\
1,1 \\
1,1 \text { a } 0,9\end{array}$ & & $\begin{array}{c}\text { Para } \Phi=45^{\circ} \\
\mathrm{R} / \mathrm{B}=8 \text { a } 13,5 \\
\text { Para } \Phi=55^{\circ} \mathrm{R} / \mathrm{B}=8 \\
\text { Para } \Phi=55^{\circ} \mathrm{R} / \mathrm{B}=13,5\end{array}$ \\
\hline Kovacs et al.(1971) & 1 a 2 & & & Rio Danúbio \\
\hline Mohan and & 5 & & & Espigões submersos \\
\hline Agraval (1979) & & & & $\begin{array}{l}\text { - altura do espigão } \\
1 / 3 \text { da profundidade } \\
\end{array}$ \\
\hline Maza & 5,1 a 6,3 & & Reta & espigões com crista \\
\hline Alvares (1989) & 2,5 a 4 & & Curva & $\begin{array}{l}\text { inclinada para } \\
\text { proteção da margem }\end{array}$ \\
\hline
\end{tabular}

Fonte: BRIGHETTI. (2000).

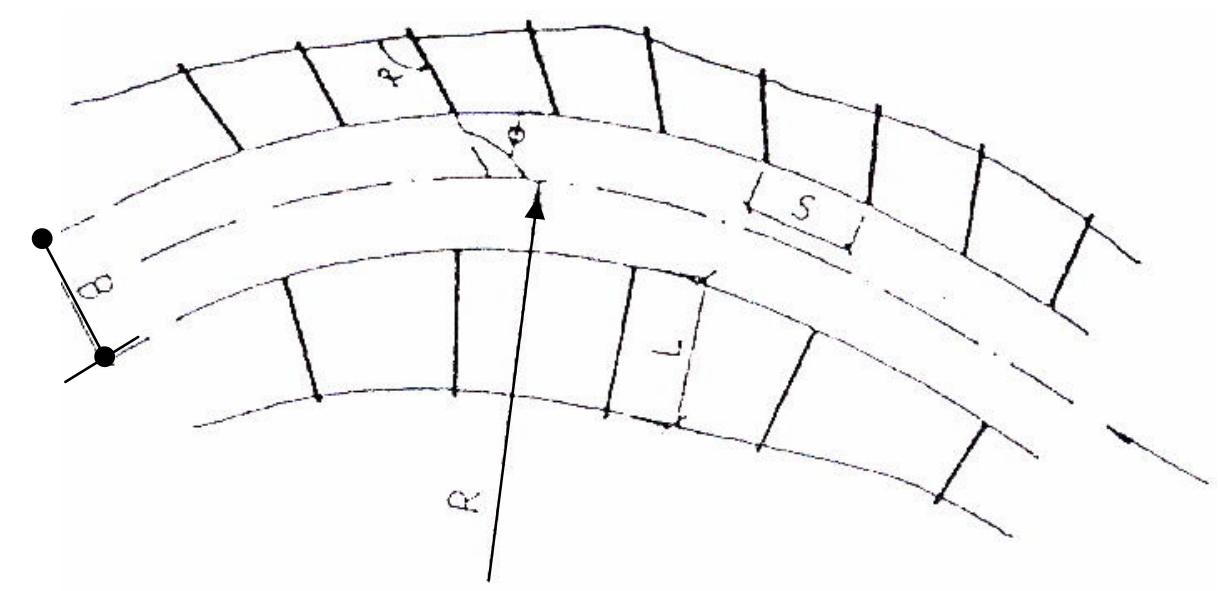

Figura 88 - Notação adotada nas Tabelas XVIII e XIX

Fonte: BRIGHETTI. (2000). 


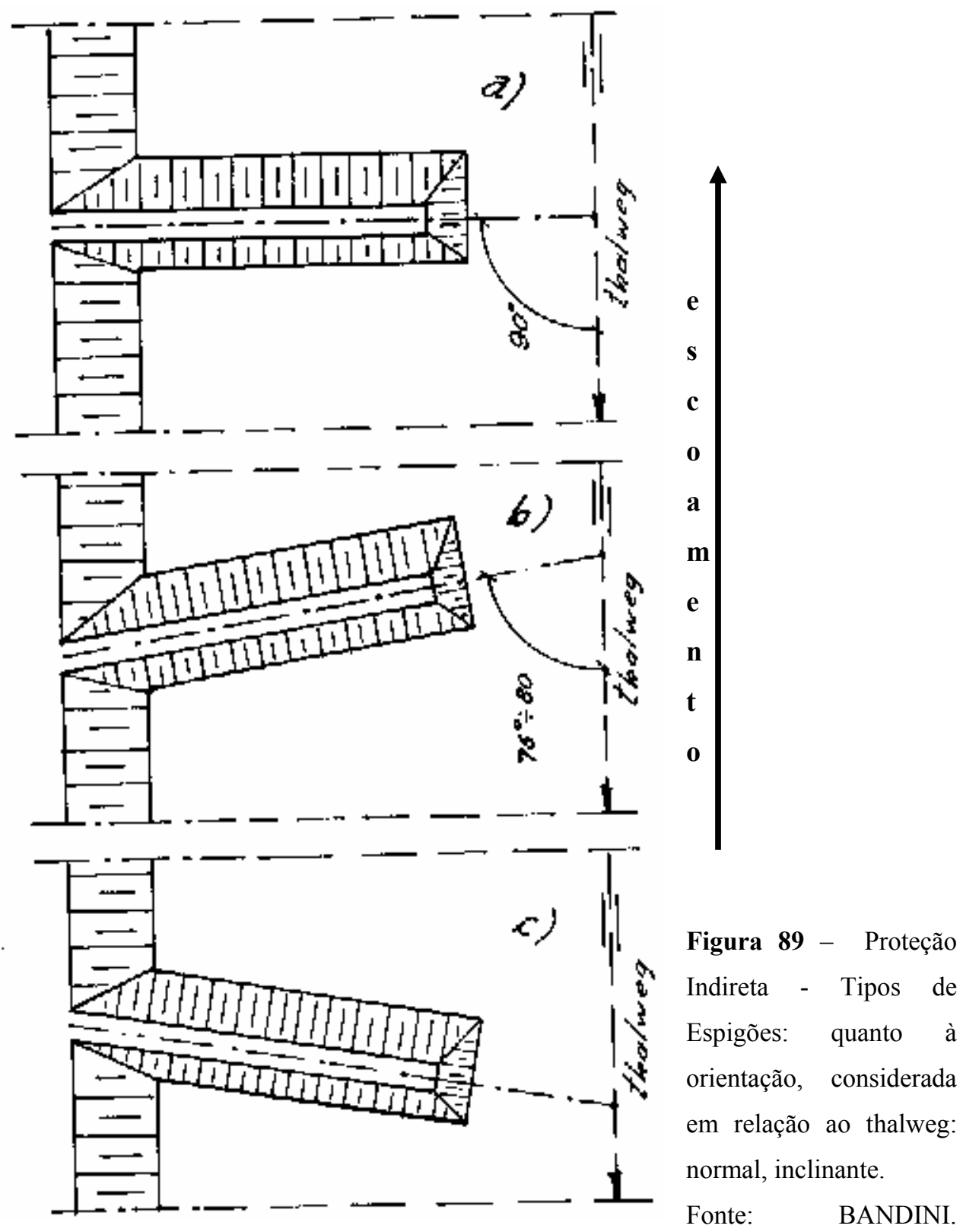

(1958).

Se os espigões, traçados de acordo com os critérios, supra referidos, resultarem muito próximos entre si, poderão ser substituídos por estruturas chamadas 
de "martelo" que constam de um espigão e de um dique longitudinal que constitui , praticamente, um alargamento da extremidade do mesmo espigão. Ver figura 90.
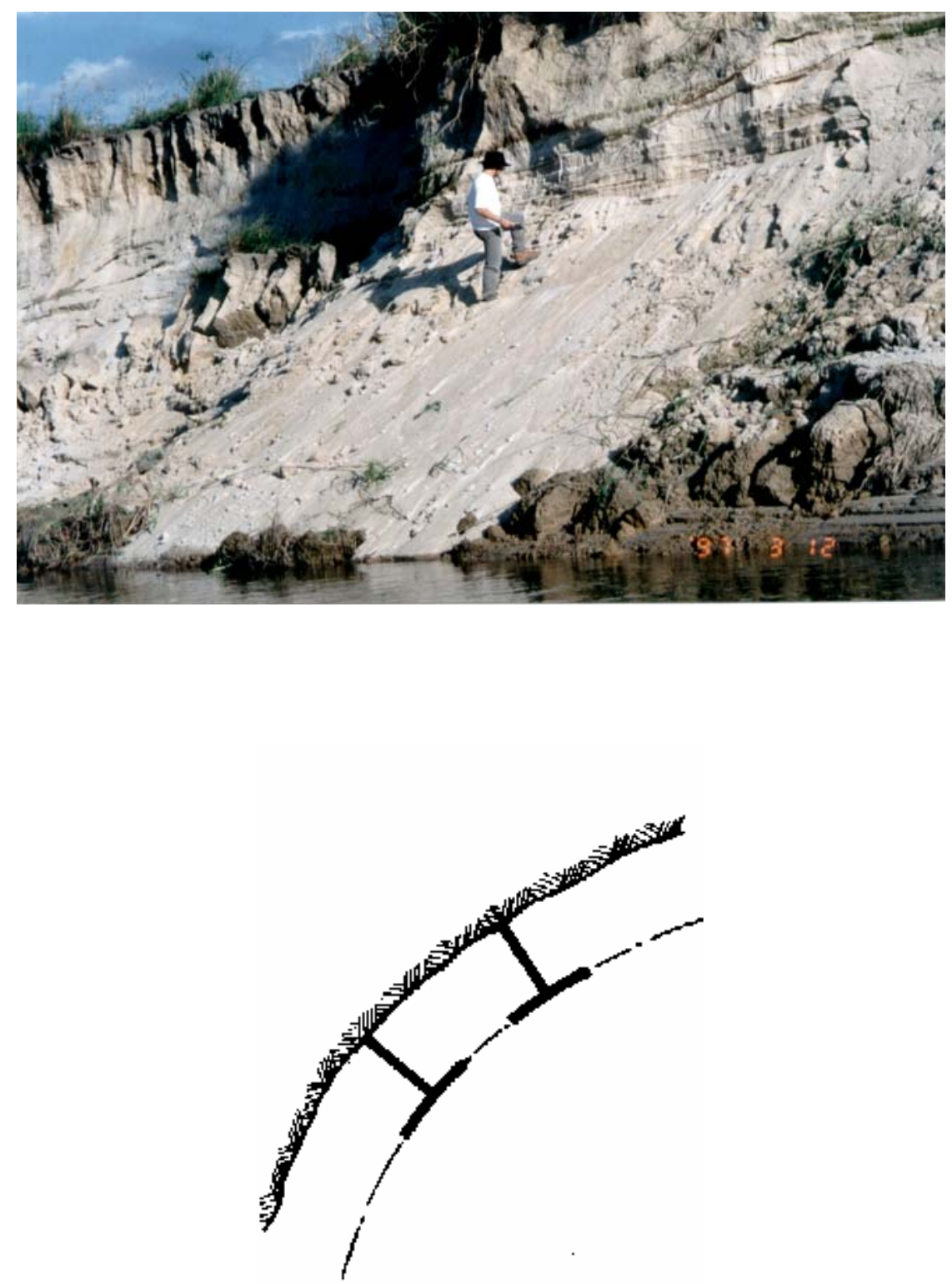

Figura 90 - Proteção Indireta - Ribanceira, podendo receber a aplicação de espigão tipo martelo. Fonte: $1^{\circ}$ EVENTO MONTENA DE ENGENHARIA CIVIL (2003); BANDINI. (1958). 
Quanto a permeabilidade:

Ło Impermeáveis ou plenos

N Modificação da direção da corrente, isto é, defletem a corrente, são mais eficientes em termos de mudança de direção.

( Utilizados em rios que transportam mais areias e seixo que sedimentos em suspensão;

\ Podem ser compactos ou maleáveis;

N Exigem cuidados especiais de manutenção devido aos fortes esforços nas extremidades.

Permeáveis

\ São mais efetivos em rios aluviais com taxas consideráveis de transporte de sedimentos de fundo e em suspensão, que favorecem uma rápida deposição ao redor dos espigões. Esta sedimentação é alcançada pela obstrução do fluxo e redução das velocidades. Entretanto, eles também podem ser usados em rios relativamente limpos onde o abaixamento da velocidade da corrente é suficiente para prevenir a erosão da margem local;

(M Menos robusto que os plenos;

N Exigem bastante manutenção;

凡 São na maioria fabricados com estacas, bambus ou madeira;

\ Constituem-se pontos de observação a velocidade residual e os custos devido a manutenção.

Quanto a declividade e elevação da crista (Ver figuras 91 e 92)

\. Declividade para dentro do rio;

太 Elevação inicial: altura da margem ou a altura da superfície livre que escorre a vazão dominante ou de projeto; 
\ A extremidade do espigão deverá ter alturas máximas de $50 \mathrm{~cm}$ sobre o fundo atual;

凡 Declividades de 0,05 a 0,25 ;

$\Rightarrow$ Dantagens de declividades grandes:

DNão há solapamento local no extremo do espigão;

Denor quantidade de material se comparado ao espigão de crista horizontal;

D Se o espigão é construído com paredes verticais, há apenas uma ligeira erosão na sua face de montante.

Dificuldade quanto a execução, em função do material utilizado

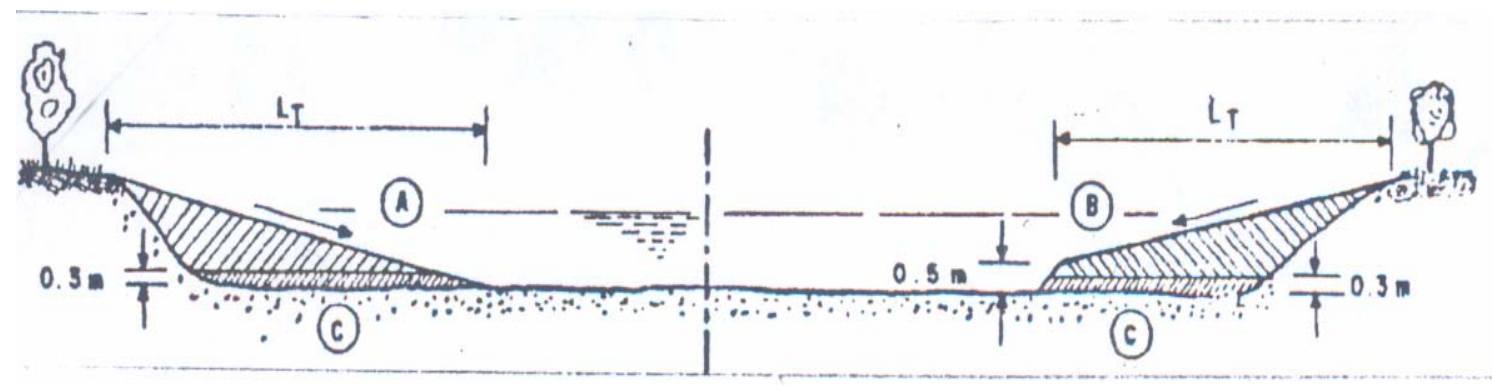

Figura 91 - Proteção Indireta - Colocação de um espigão, quando a margem não está muita elevada. Vista da face lateral do espigão. A forma $\underline{\mathbf{A}}$, permite construir espigões mais econômicos; o desenho $\underline{\text { B }}$ também tem apresentado bons resultados; a base (fundação) $\underline{\mathbf{C}}$, dos espigões devem ser construídas primeiro, de modo a evitar erosões locais durante a construção, se a velocidade for maior que $50 \mathrm{~cm} / \mathrm{seg}$.

Fonte: ALVAREZ. (1990).

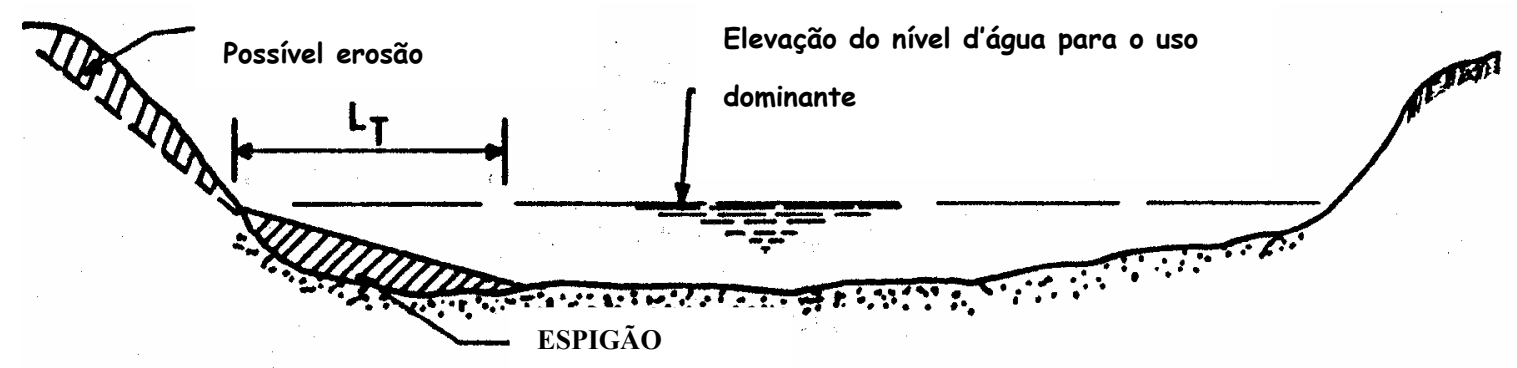

Figura 92 - - Proteção Indireta - Colocação de um espigão, quando a margem está muita elevada.

Vista da face lateral do espigão.

Fonte: ALVAREZ. (1990). 
- Critérios de Dimensionamento, segundo Brighetti (2000)

Traçar em planta o eixo do rio e nas margens delinear uma linha paralela ao eixo, a qual chegarão os extremos dos espigões;

Comprimento do espigão, é a distância real a esta linha;

Comprimento total: comprimento de enraizamento + comprimento de trabalho;

Comprimento de trabalho: $\mathbf{h} \leq \mathbf{L t} \leq \mathrm{B} / \mathbf{4}$

Largura média do canal $=\mathbf{B}$

Altura média $=\mathbf{h}$

Espaçamento entre os espigões: entre 1 a 2 vezes o comprimento do espigão ou conforme a metodologia de Maza Alvares, levando em conta a curvatura da margem, a velocidade de escoamento, o ângulo de ataque e o comprimento efetivo.

Orientação dos espigões: a orientação recomendada é $\alpha$ maior ou igual a $90^{\circ}$, ou entre $60^{\circ}$ e $70^{\circ}$ (com cuidados) segundo o método de Maza Alvares.

\section{Inclinação dos Espigões}

Os espigões devem ser sempre feitos em um número considerável, pois, um ou poucos espigões visando desviar os filetes é mais inconveniente que favorável, porque passa a existir o risco do espigão não desviar a corrente e, nem provocar assoreamentos a montante ou a jusante.

Em princípio deve-se esperar o assoreamento entre os espigões e desta maneira "atrair" para sua extremidade.

Os espigões podem ser normais à margem (mais curtos) ou inclinados, para montante ou para jusante. Sempre em sua extremidade há uma tendência a erosões devidas a turbilhões numa direção perpendicular ao espigão. Devido a este fato, no caso de ser o espigão inclinado para jusante há uma tendência a erodir a margem, não devendo por isto ser utilizado, a menos que o espigão seguinte seja suficientemente próximo para impedir o perigo, ou seja enraizado (engastado) na margem. Ver figura 93. 
Os espigões inclinados, ver Tabela XIX, para montante, formam ângulos de $10^{\circ}$ a $30^{\circ}$ com o eixo.

Convém lembrar que estas obras são executadas para direcionar ou concentrar o fluxo para as condições de vazões baixas, sendo galgados para vazões acima das de projeto, devem ser estáveis para estas condições. No caso de espigões direcionados para jusante, há a tendência quando galgados de direcionar o fluxo para a margem, o que não ocorre nos outros casos.

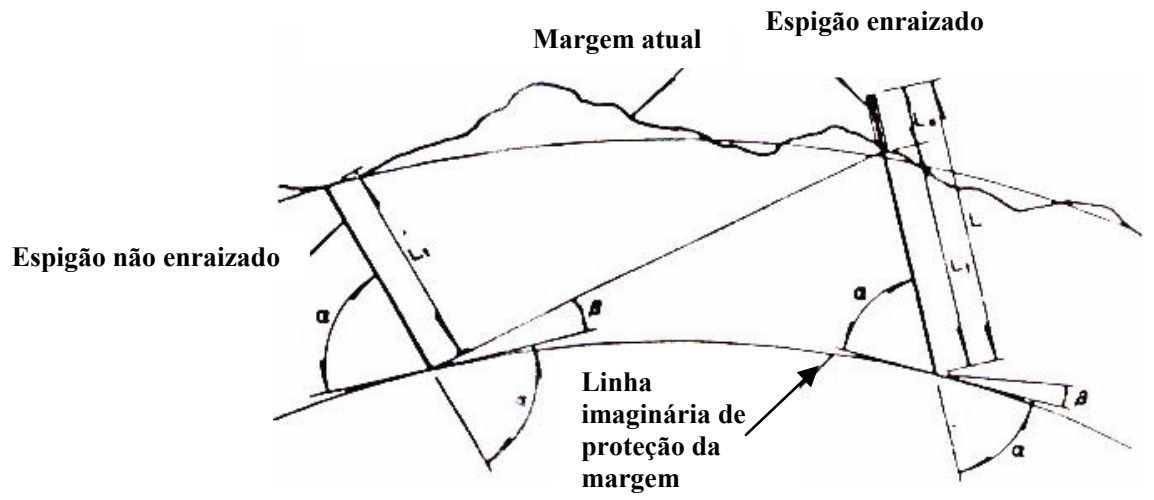

Detalhe de Proteção Indireta com Espigões Inclinados, enraizados (engastados) ou não na rocha da margem atual
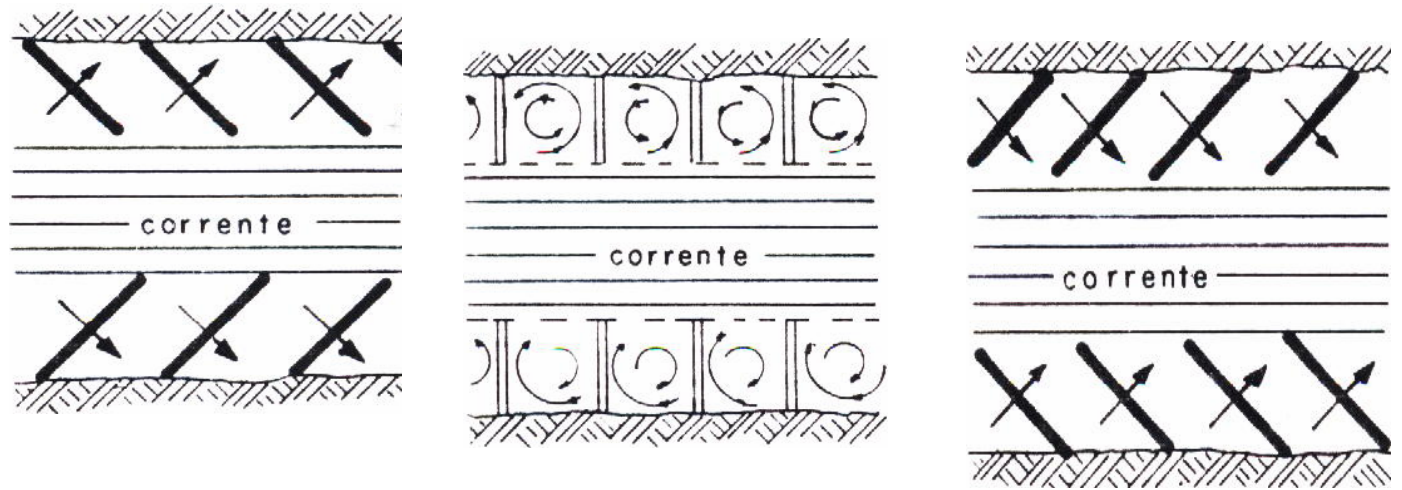

Figura 93 - Proteção Indireta - Detalhe e exemplos de aplicação de Espigões: normal e inclinado. Fonte: ALVAREZ. (1990) ; BRIGHETTI. (2000). 
Tabela XIX - Inclinação dos espigões em relação ao escoamento $(\Phi)$

\begin{tabular}{l|c|l}
\hline Autor & Inclinação recomendada & \multicolumn{1}{c}{ Observações } \\
\hline Nações Unidas (1953) & $100^{\circ}$ a $120^{\circ}$ & Espigão inclinado para montante \\
\hline Mamak (1956) & $100^{\circ}$ a $110^{\circ}$ & \\
\hline Joglekar (1971) & $100^{\circ}$ a $120^{\circ}$ & \\
\hline Macura (1966) & $30^{\circ}$ a $60^{\circ}$ & \\
\hline $110^{\circ}$ & Margem côncava \\
& $100^{\circ}$ & Trecho reto \\
\hline Copeland (1993) & $90^{\circ}$ & Margem convexa \\
\hline Akantisz et al. (1983, & $90^{\circ}$ & \\
1986, 1989) & $65^{\circ}$ & Para $=45^{\circ}$ a 55 e R/B $=8$ a 13,5 \\
\hline Maza Alvares & $110^{\circ}$ & - margem convexa. \\
\hline
\end{tabular}

Fonte: BRIGHETTI. (2000).

\section{Posicionamento dos Espigões - Metodologia de Mazza Alvares}

Localização em planta - no caso de retificação de um trecho do rio ou defesa das curvas e, sendo as margens arenosas, é conveniente que os raios de curvatura $\mathbf{r}$ medidos até o eixo do rio estejam entre os limites: $\mathbf{2 B} \leq \mathbf{r} \leq \mathbf{8 B}$. Ver figura 94 .

Comprimento de trabalho do espigão - o comprimento máximo não deve estrangular o fluxo em mais de $20 \%$. Ver figura 94.

Caso não tenha comprimento de engaste, deve-se fazer proteções laterais de $3 \mathrm{a}$ $5 \mathrm{~m}$ de cada lado do espigão.

comprimento de engaste - no máximo 1/4 do comprimento de trabalho.

¿ Orientação dos espigões - a orientação dos espigões recomendada é de $\alpha$ entre $60^{\circ}$ e $70^{\circ}$ (orientados para jusante). Ver figura 95.

Separação entre os espigões - para calcular a separação entre os espigões é necessário levar em conta a expansão teórica que sofre a corrente ao passar pelo extremo dos espigões. 
Em modelos hidráulicos, tem-se observado que o ângulo de expansão $\beta$ varia entre os seguintes limites: $\mathbf{9}^{\circ} \leq \beta \leq \mathbf{1 4}^{\mathbf{0}}$.

Quando utilizam-se espigões em trechos retos e sem engasgamentos na margem, a separação deverá ser de 5 a 6 vezes o comprimento de trabalho.

LINHA QUE UNE OS EXTREMOS DOS ESPIGÕES

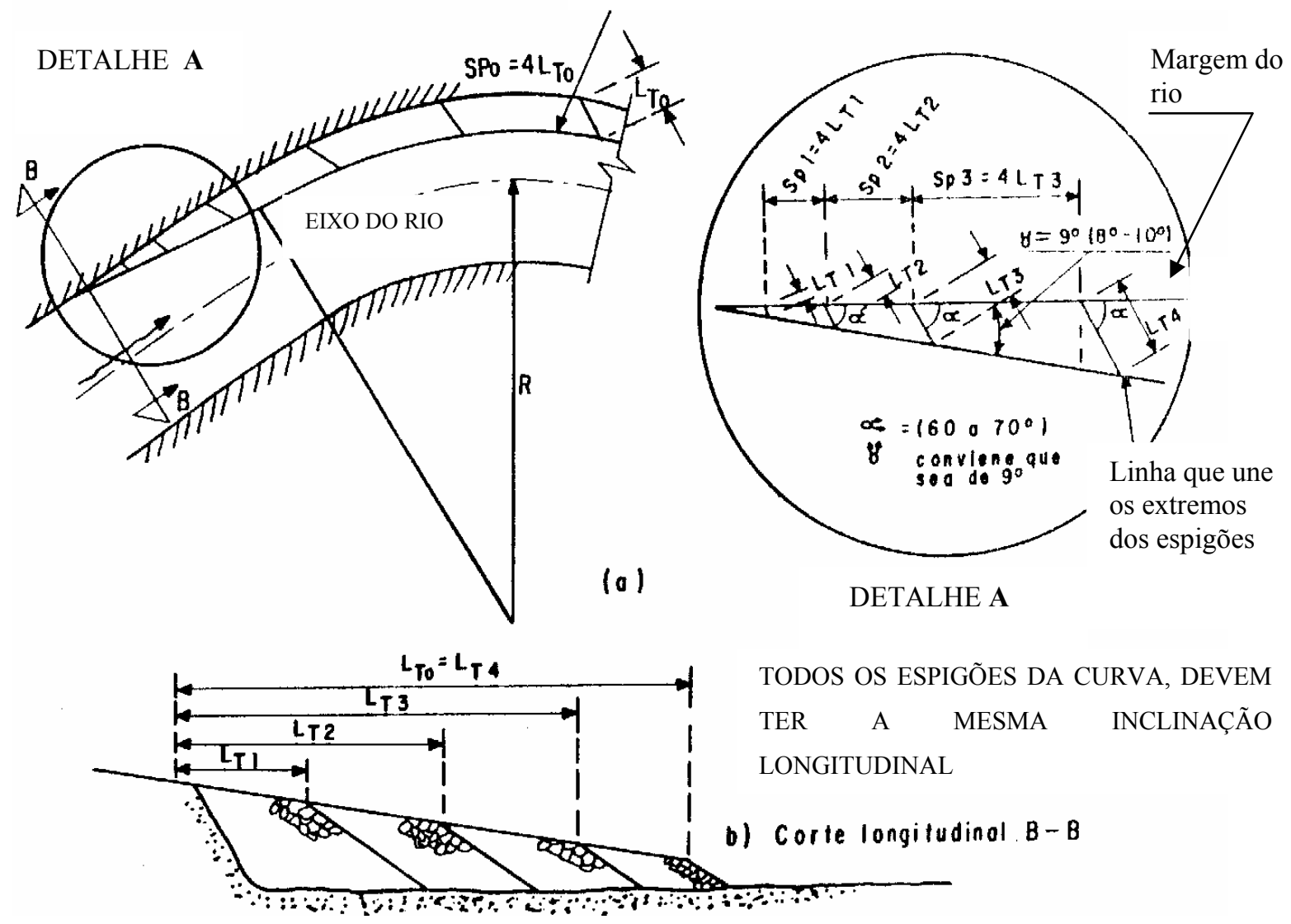

Figura 94 - Proteção Indireta - Localização e comprimento dos primeiros espigões, na margem de um rio, a ser protegida.

Fonte: GÓIS \& ARAÚJO. (2000). 


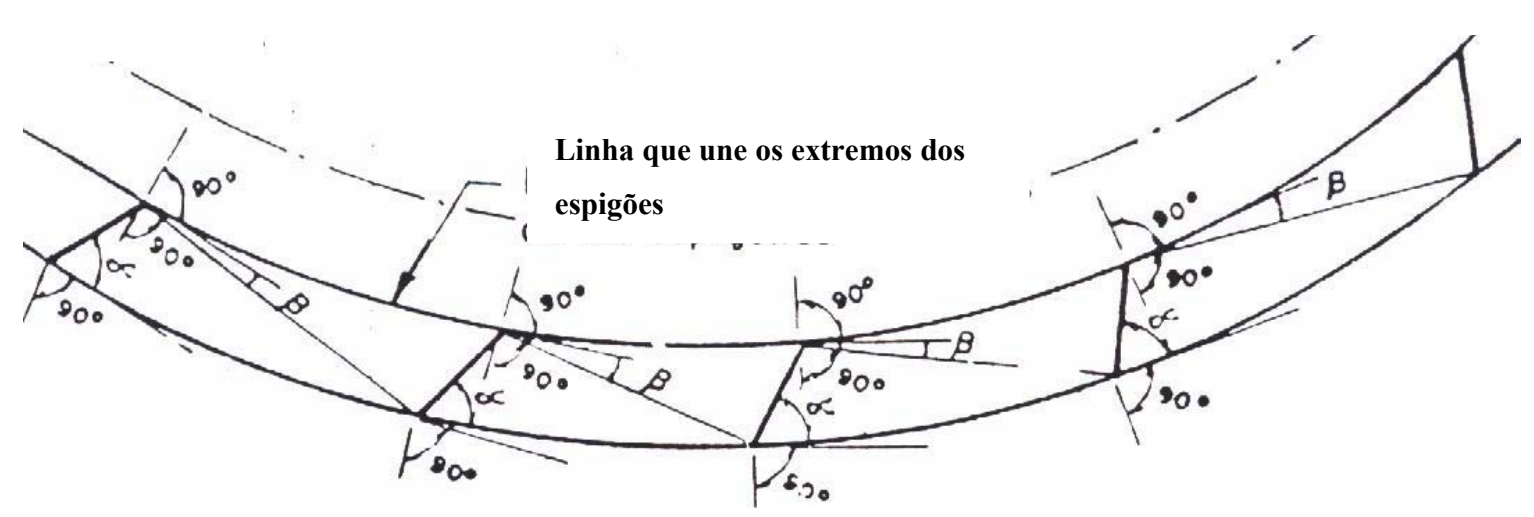

Figura 95 - Proteção Indireta - Detalhe da orientação dos espigões.

Fonte: GÓIS \& ARAÚJO. (2000).

\section{Materiais Utilizados na Construção}

$\leftrightarrow$ Espigões Plenos ou Impermeáveis

Os termos permeável e impermeável são auto explicativos e são diferenciados pela capacidade do material de construção em transmitir o fluxo.

Os espigões plenos ou impermeáveis, funcionam provocando correntes secundárias e turbilhões entre eles, com tendência ao assoreamento (lento). Ver figura 96.

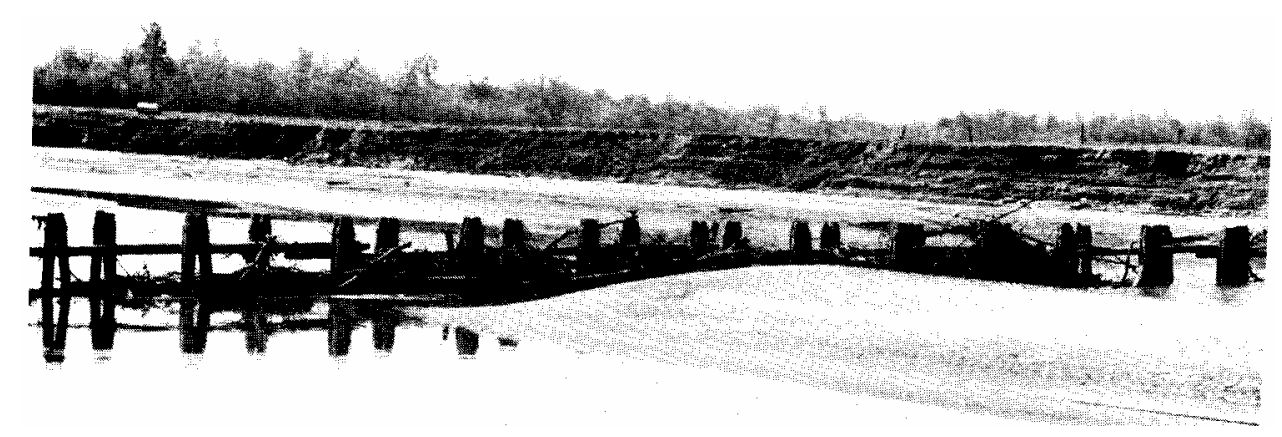

Figura 96 - Proteção Indireta - Deposição de sedimentos, devido a construção de espigão de troncos, vedado com varas finas, favorecendo a formação de uma nova margem.

Fonte: PETERSEN. (1986). 
Exatamente por isso seu extremo é sujeito a fortes esforços exigindo cuidados especiais de manutenção. Podem, inclusive, formar contracorrentes que atinjam a margem antes de se formarem depósitos protetores. Como exemplos de materiais empregados na construção de espigões impermeáveis ou plenos, podemos citar:

\section{tolsas ou Sacos de Solo Cimento}

Sacos de papel, sacos de plástico ou ainda produtos com melhor resistência a esforços mecânicos, tais como bolsas de nylon, são cheios de solo cimento no teor de 8 a 10\% de cimento, convenientemente empilhados, de cuja composição resulta num maciço funcionando por gravidade. Esta opção tem a grande vantagem de ser conhecido o peso unitário dos vários sacos e, consequentemente, conduz o cálculo de estabilidade de maneira mais criteriosa, quanto ao aspecto técnico, tem sido empregados sacos para capacidade de 35 litros, aproximadamente $60 \mathrm{~kg}$. Ver figuras 97 e 98 .

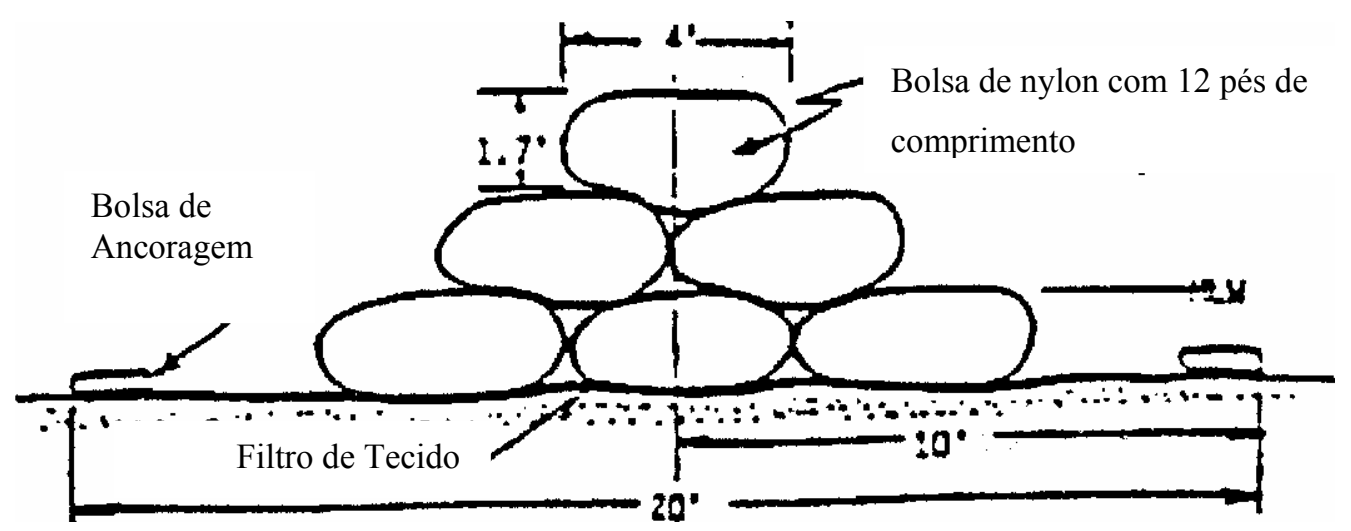

Figura 97 - Proteção Indireta - Seção de espigão de bolsas empilhadas.

Fonte: GÓIS \& ARAÚJO. (2000). 


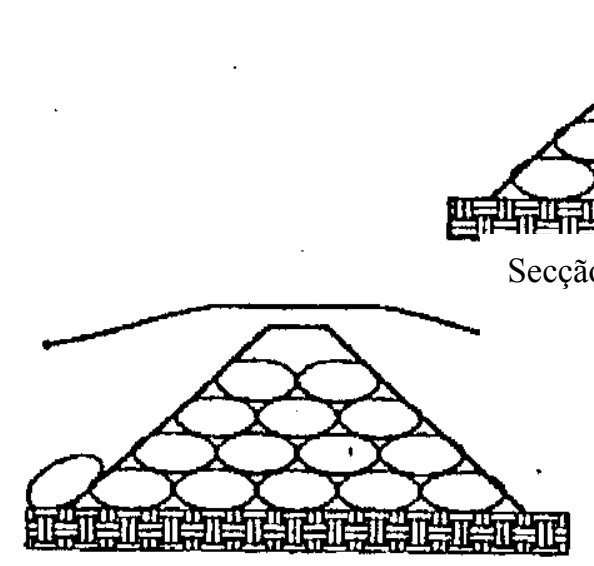

Estabilidade Hidráulica

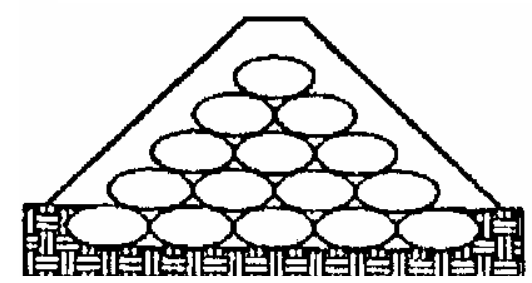

Estabilidade Frontal

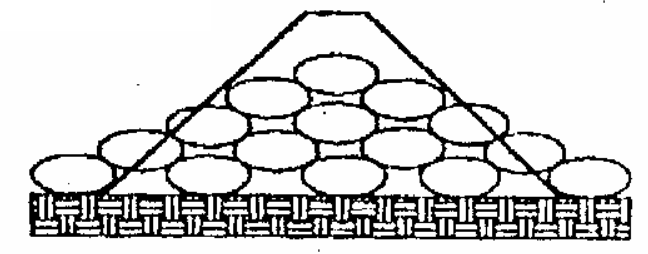

Estabilidade Interna

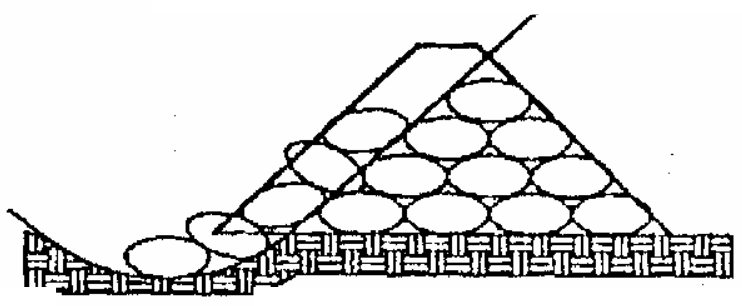

Estabilidade Geotécnica

Figura 98 - Proteção Indireta - Principais problemas de estabilidade com seções compostas por bolsas: problemas hidráulicos (ondas, correntes), problema de estabilidade interna (inclinação do talude não adequada para determinado tipo de bolsa), problemas de recalque e problemas de estabilidade geotécnica.

Fonte: GÓIS \& ARAÚJO. (2000).

\section{Geotubos}

O geotubo é uma forma têxtil de vários tamanhos padronizados, confeccionados com tecidos de combinações poliméricas, com fios de alta tração, retorcidos e fibrilizados semi-permeável para moldagem "in-loco" dentro ou fora d'água, com micro concreto usinado, argamassa de cimento e areia ou solo cimento injetável. Destaca-se sobretudo pelo dispositivo de microfiltragem "unifluxo", que garante a drenagem do excesso de água da massa de enchimento sem migração de colóides (nata de cimento) e impede a entrada d'água do exterior do geotubo para 
dentro garantindo a qualidade do microconcreto usinado, argamassa de cimento e areia ou solo cimento, no que se refere a textura, estrutura, resistência à tração e resistência nos ensaios de durabilidade.

Os geotubos devem ser moldados com bombas injetoras e não com bombas de concreto comum (concreteira), as quais provocam incorporação de ar, formação de ninhos e não estabelecem o embricamento entre os módulos sobrepostos, fundamental para a completa estabilidade da obra. Ver figuras 99, 100 e 101.

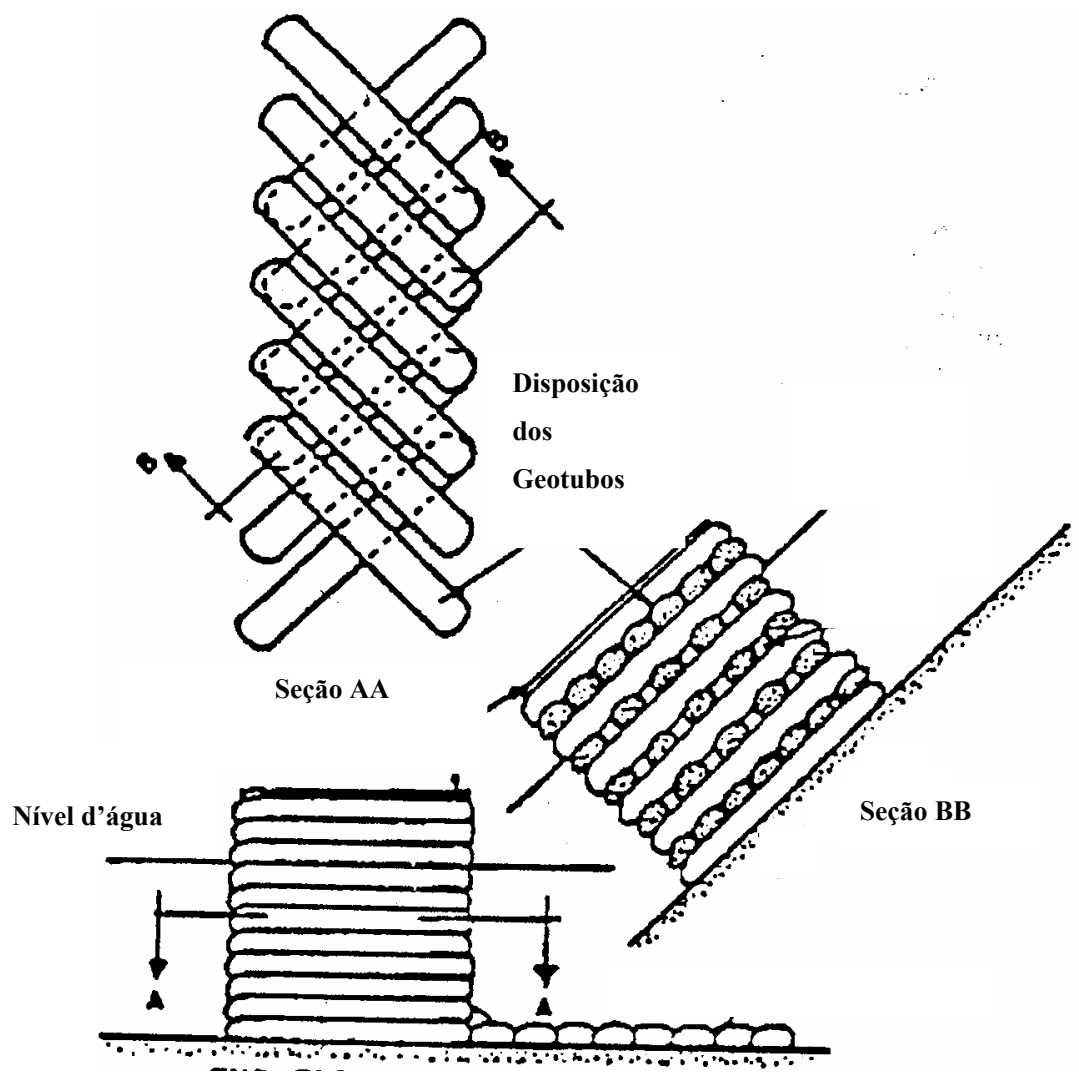

Figura 99 - Proteção Indireta - Espigões Impermeáveis - Disposição de geotubos. Fonte: GÓIS \& ARAÚJO. (2000). 


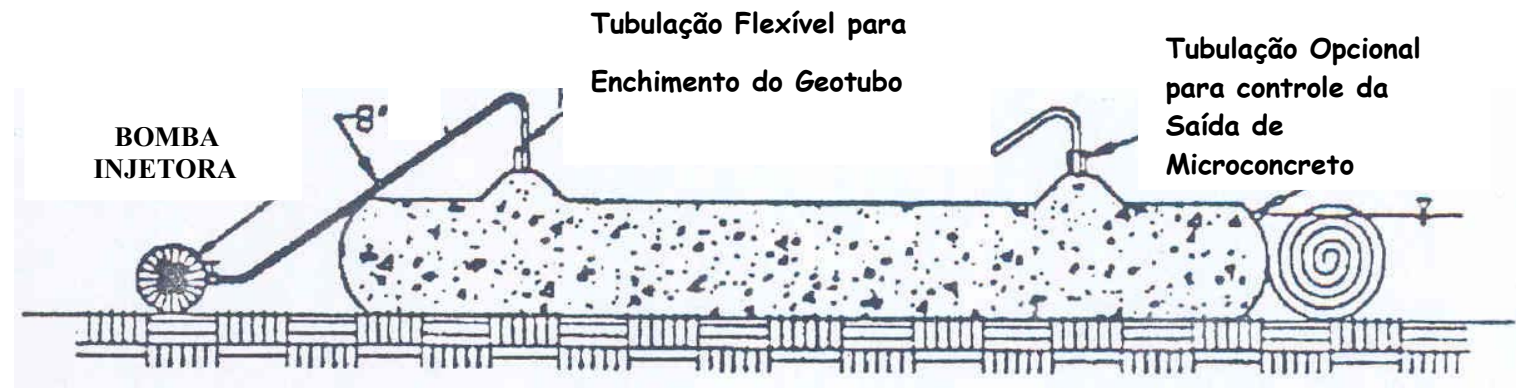

Figura 100 - Proteção Indireta - Espigões Impermeáveis - Processo de enchimento de geotubos. Fonte: GÓIS \& ARAÚJO. (2000).

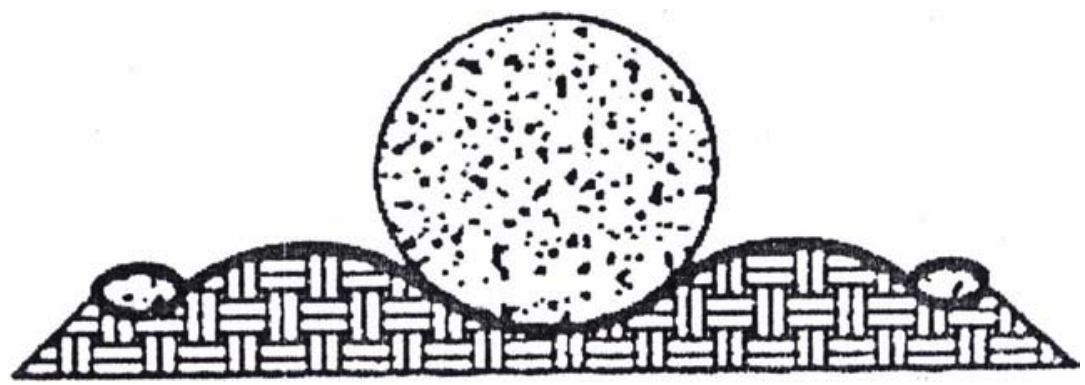

Figura 101 - Proteção Indireta - Espigões Impermeáveis - Posicionamento de geotubo, com a utilização de um tecido filtro com pequenos tubos costurados ao lado para reduzir o potencial de erosão no pé e, os pequenos tubos para manterem o tecido no lugar.

Fonte: GÓIS \& ARAÚJO. (2000).

땂 Espigões Permeáveis

Os espigões permeáveis tem a vantagem de reduzir as velocidades da corrente em vez de desviá-las, o que acelera a sedimentação, sendo particularmente eficazes em rios com muito transporte em suspensão podem ser feitos de diversos tipos de elementos pré-fabricados de concreto etc., ou blocos iguais de dimensões convenientes, imbricados entre si, deixando vazios; armações de bambu; por estacas de madeira (cravadas 5 a $8 \mathrm{~m}$ para garantir a estabilidade e proteção contra as erosões, o que é difícil em leitos com pedregulho ou matacões), faxinas leves, etc.. São menos robustos que os plenos (em geral) e exigem bastante manutenção. 
As estacas parecem ser o melhor tipo de estrutura permeável, porém resistem mal as cheias se não forem bem cuidadas (atirantadas à margem, ou ancoradas com blocos de concreto através das longarinas principais, ou ainda cravadas inclinadas). Devem ser resistentes, de modo a suportar choques de corpos flutuantes. Alguns exemplos de construção de espigões permeáveis com os materiais citados, seguem abaixo.

\section{Madeira}

A utilização da madeira, sobre a forma de troncos e/ou tábuas para a construção de espigões tem a sua utilização restrita pelo fato da durabilidade da madeira ser pequena quando não imersa em água, sendo seu uso recomendável apenas quando se dispõe da abundância de troncos. Ver figuras 102 e 103.
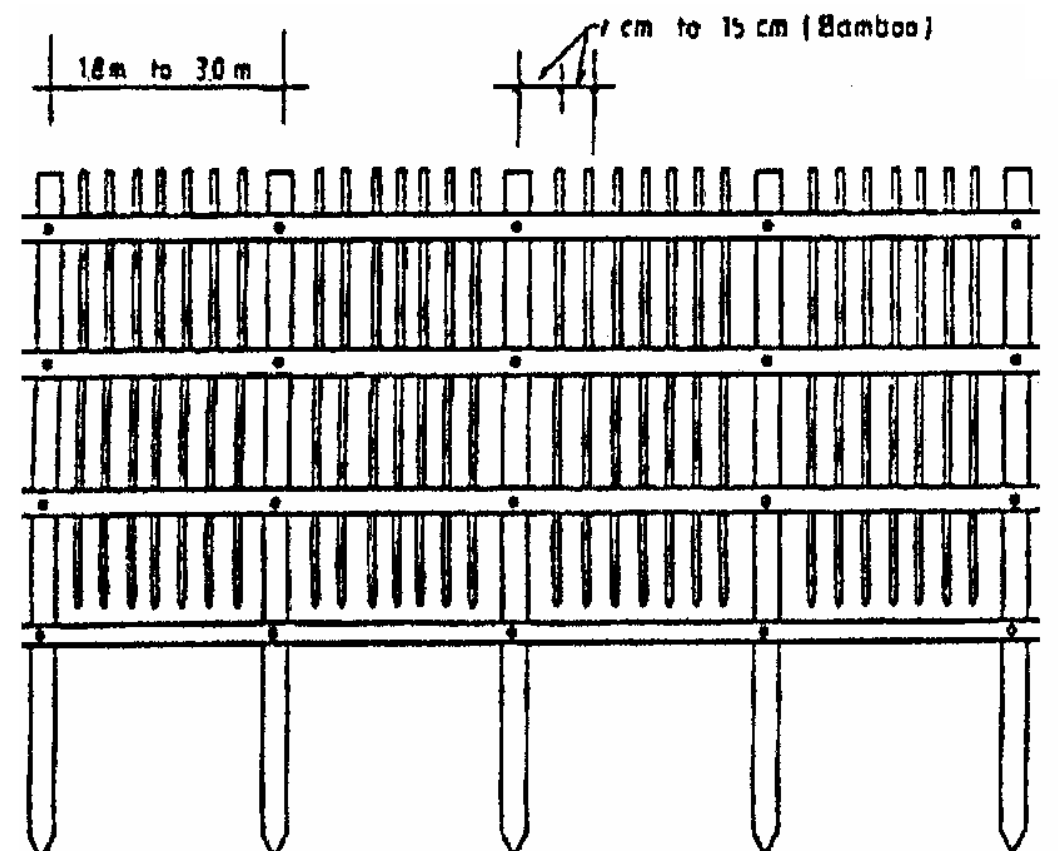

Figura 102 - Proteção Indireta - Espigão permeável, confeccionado com madeira e bambu Fonte: GÓIS \& ARAÚJO. (2000). 

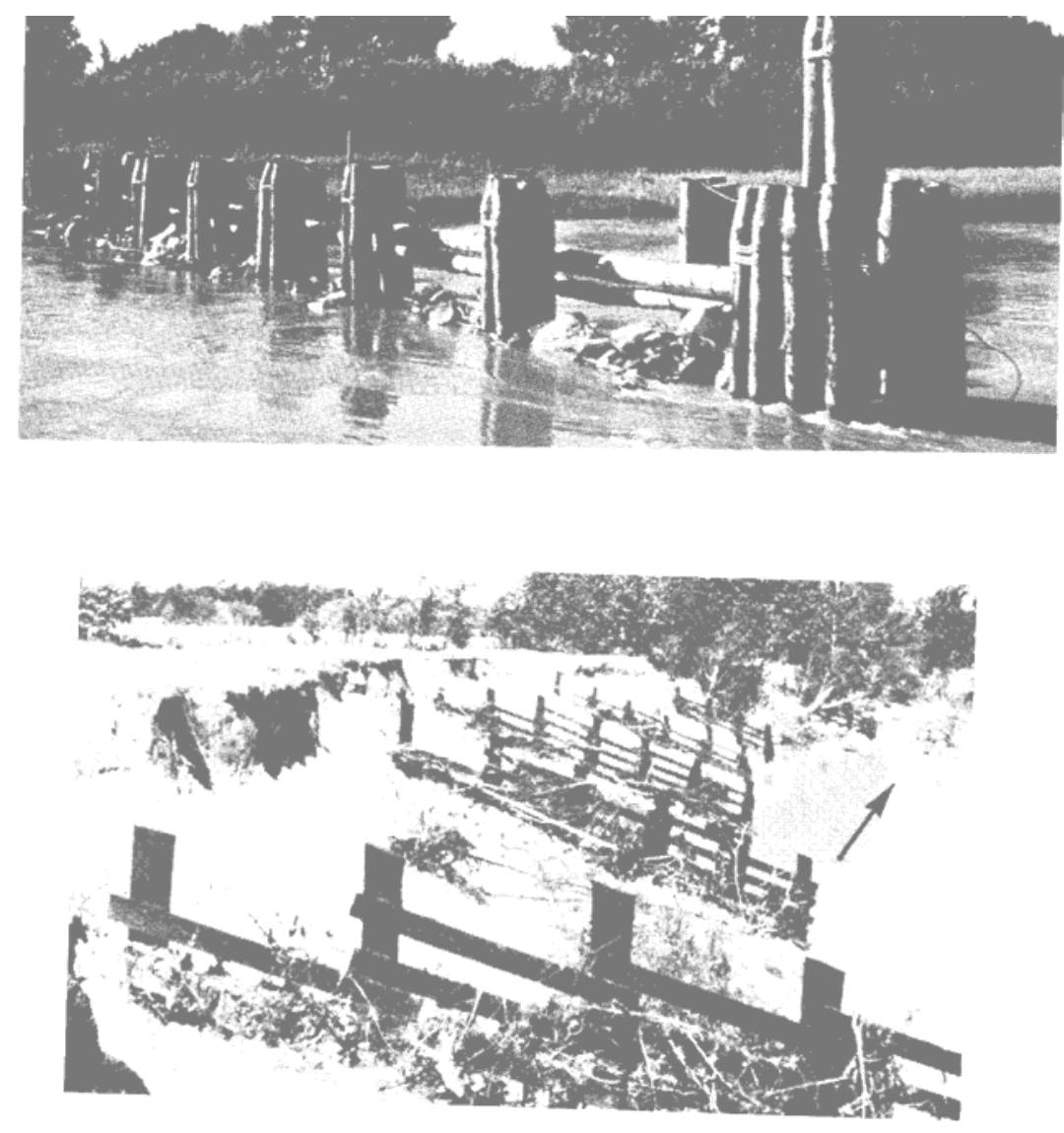

Figura 103 - Proteção Indireta - Espigões permeável, confeccionado com madeira (troncos e/ou tábuas).

Fonte: PETERSEN. (1986).

Pedra

A existência de pedras soltas e de boa qualidade, permite a sua utilização para a construção de espigões. As pedras devem ajustar-se umas às outras para formarem uma massa compacta. Se a vazão, do curso d'água, for grande ou as pedras pequenas elas deverão ser encerradas dentro de telas metálicas (gaiolas). Ver figuras $104,105,106,107,108$ e 109. 


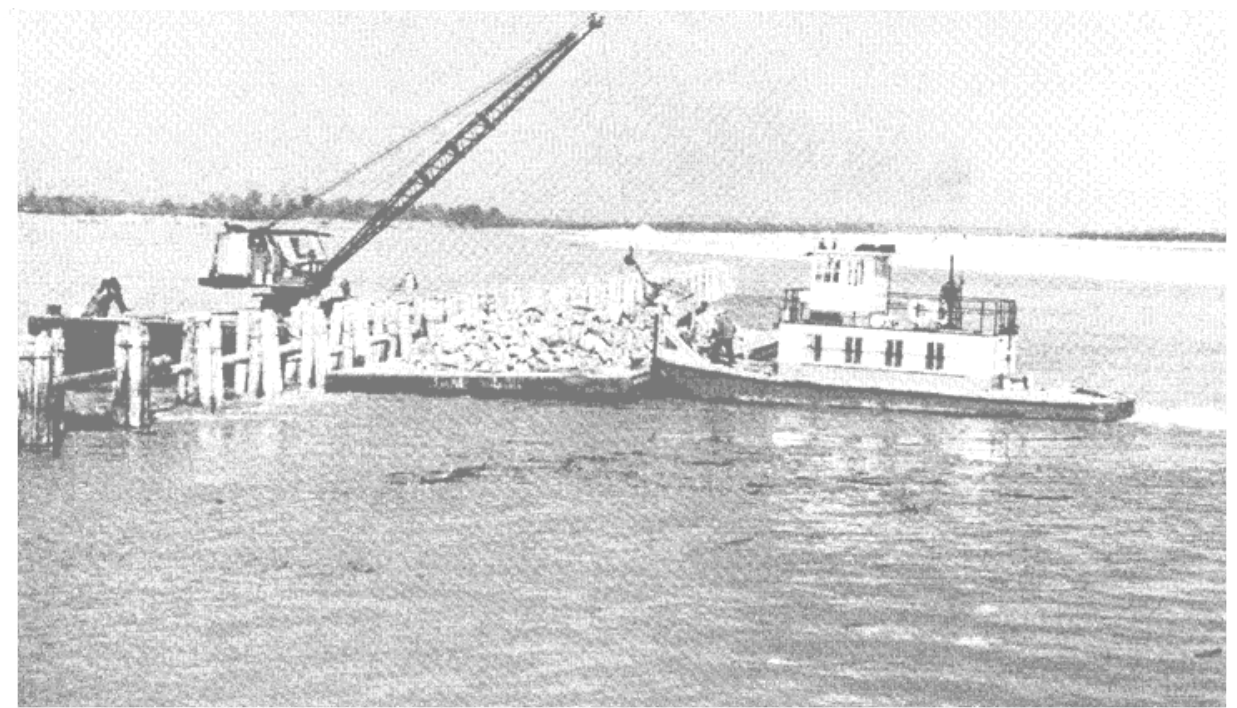

Figura 104 - Proteção Indireta - Transporte de pedras para a construção de espigões permeáveis. Fonte: PETERSEN. (1986).

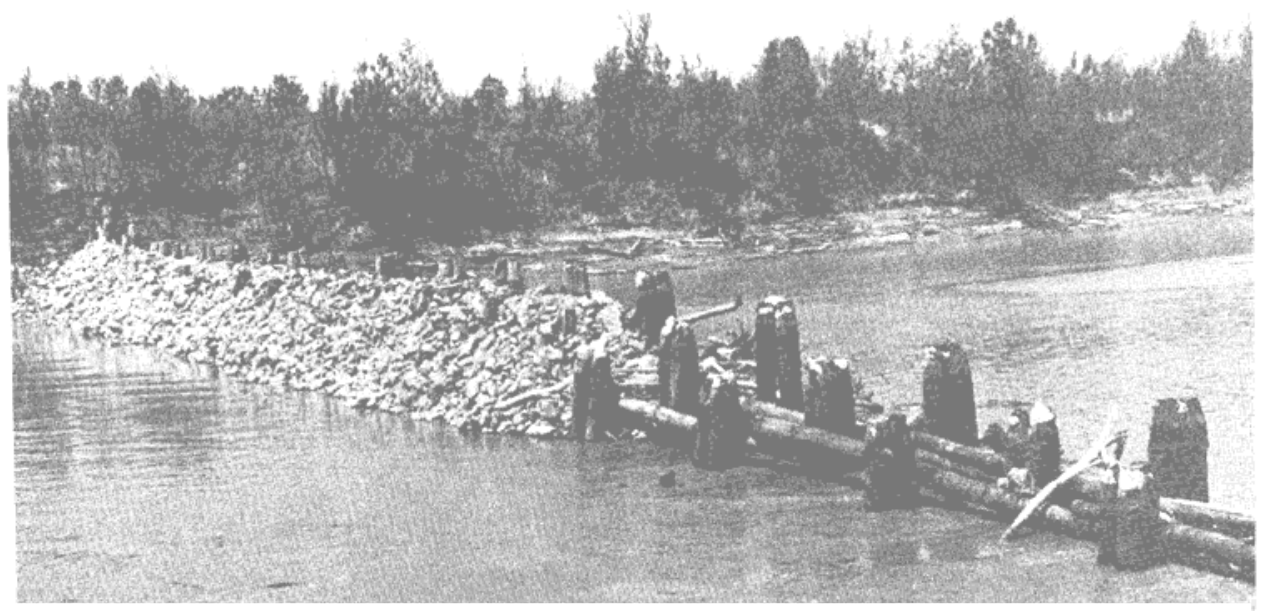

Figura 105 - Proteção Indireta - Construção de espigão permeável com troncos e pedras. Fonte: PETERSEN. (1986). 

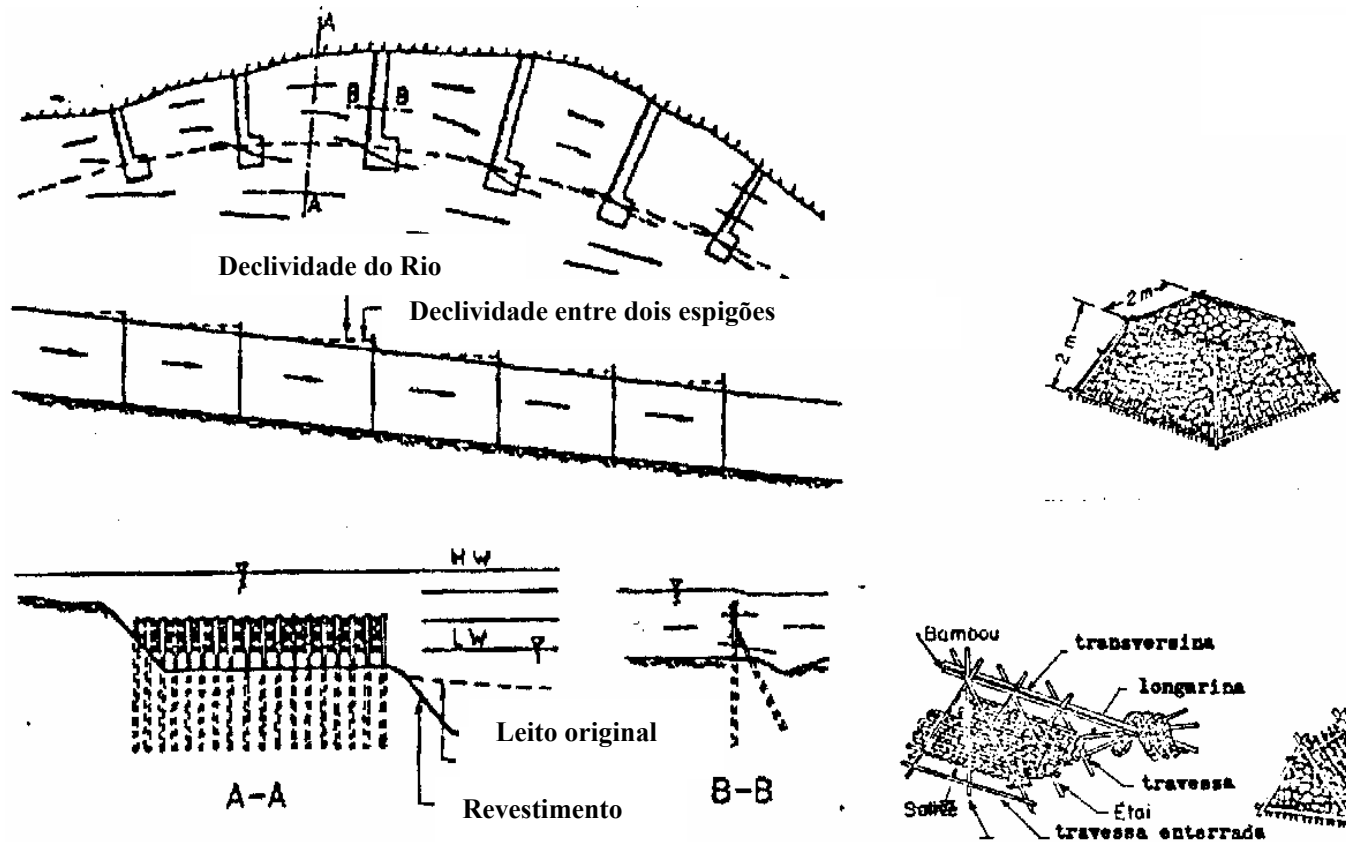

Figura 106 - Proteção Indireta - Exemplos de espigões permeáveis, usados no Japão. Fonte: GÓIS \& ARAÚJO. (2000).
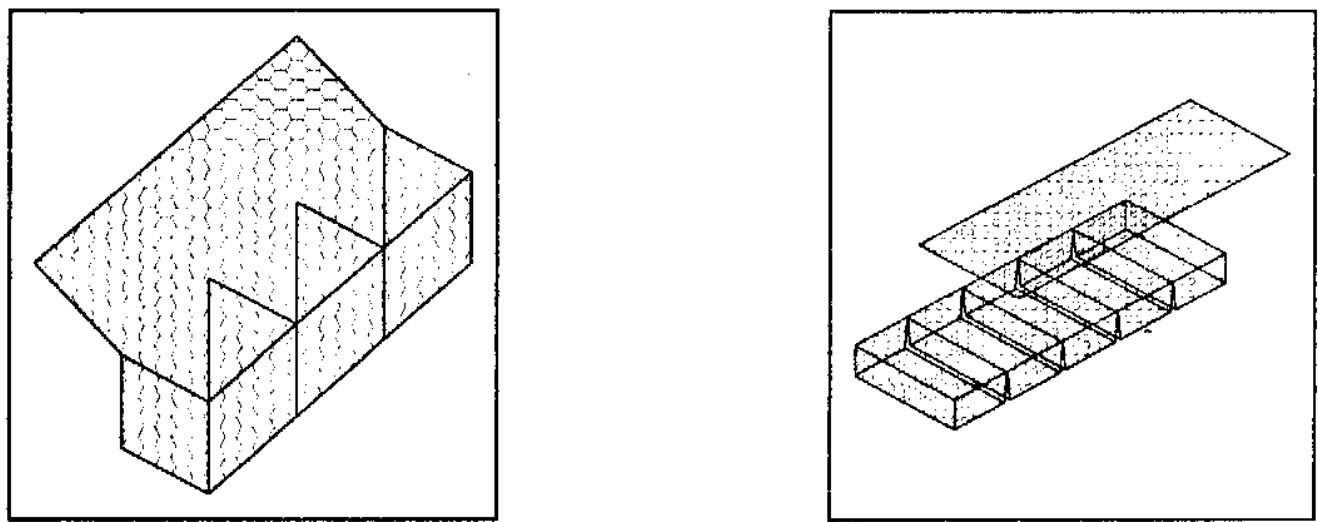

Figura 107 - Proteção Indireta - Gaiolas de arame (gabiões) para encerrar pedras pequenas Fonte: GÓIS \& ARAÚJO. (2000). 


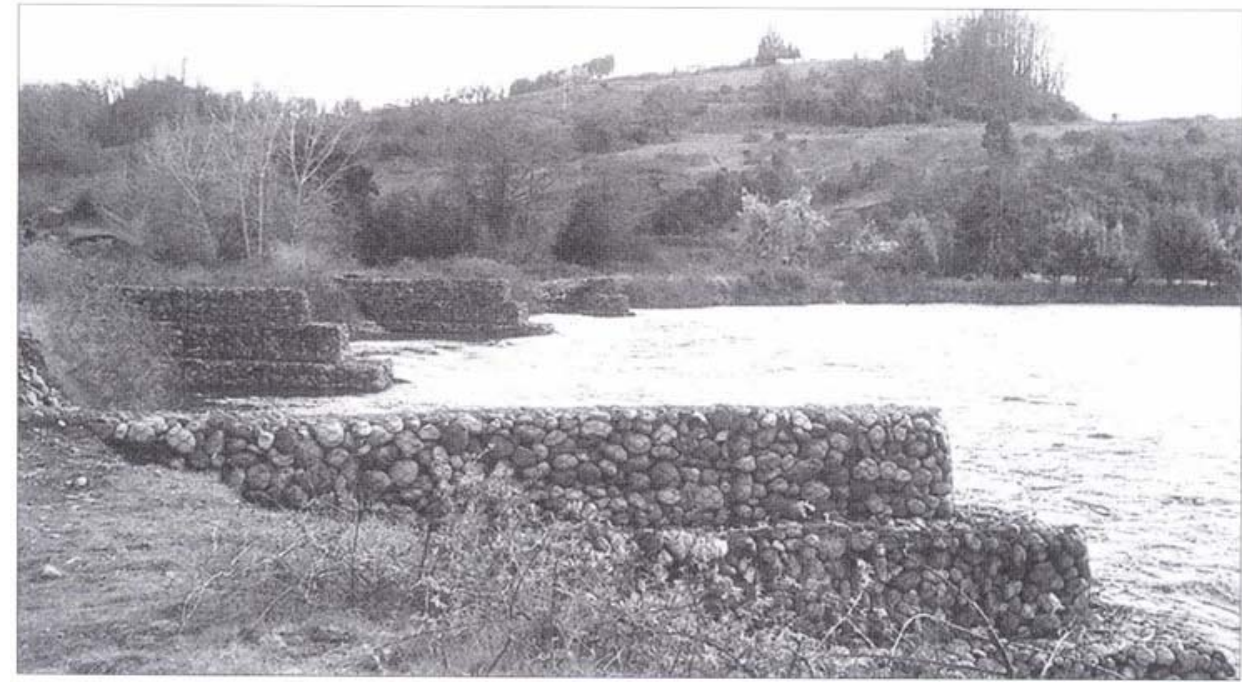

Figura 108 - Proteção Indireta - localização e funcionamento de espigões.

Fonte: MACCAFERRI. (2002).
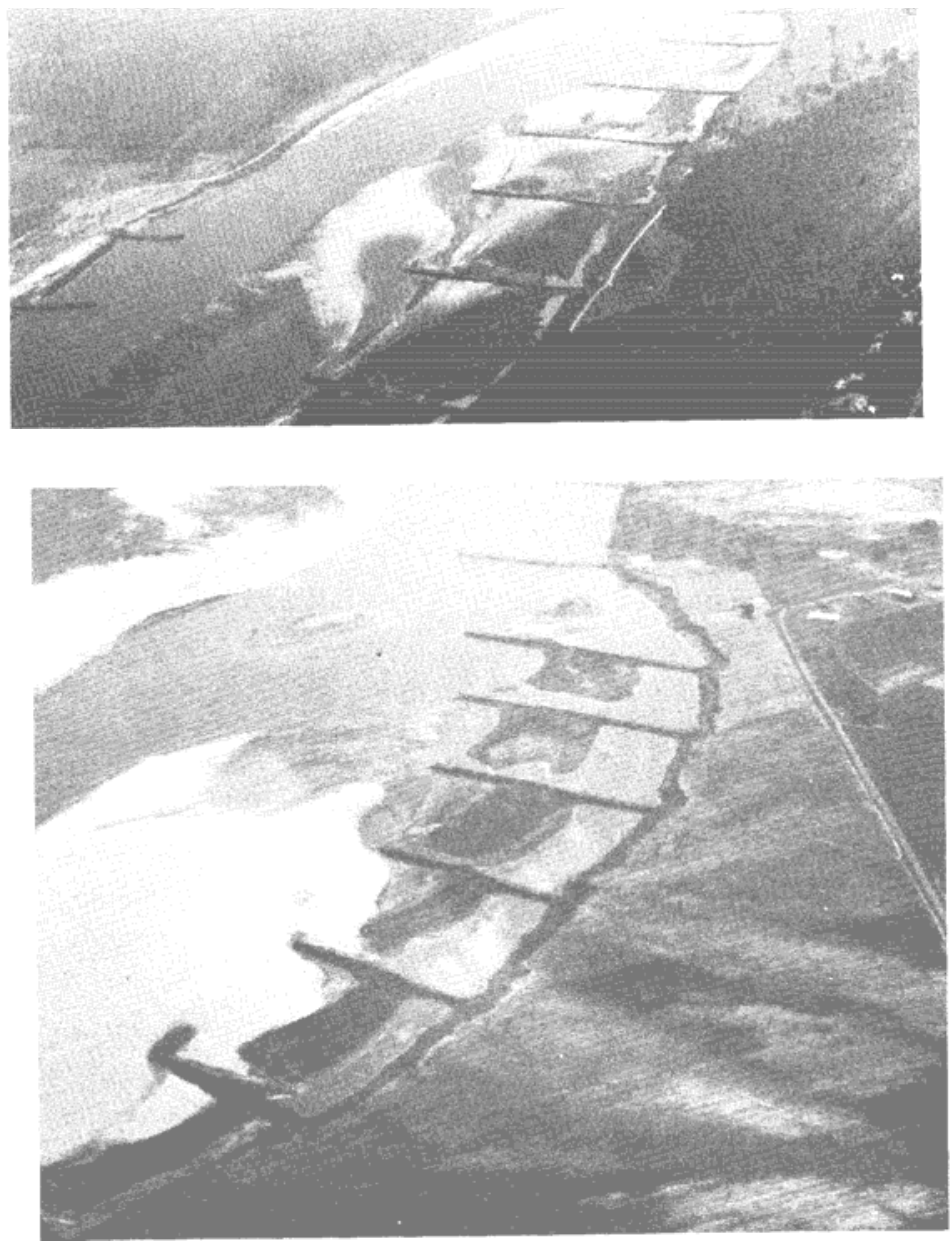

Figura 109 - Proteção Indireta - Vista em planta da localização e funcionamento de espigões. Fonte: PETERSEN. (1986). 
b) Diques

São construções longitudinais ao rio e, no caso de serem "apoiados" na margem (confundem-se com a margem) existente, constituem de fato, proteções ou revestimentos de margens. Muitas vezes, quando os diques são distantes da margem, constrói-se "espigões" interiores visando reforçá-los e impedir a formação de novos canais, se o dique romper ou for contornado e, ao mesmo tempo favorecer a deposição de material. Servem também para facilitar a construção. Ver figura 110.

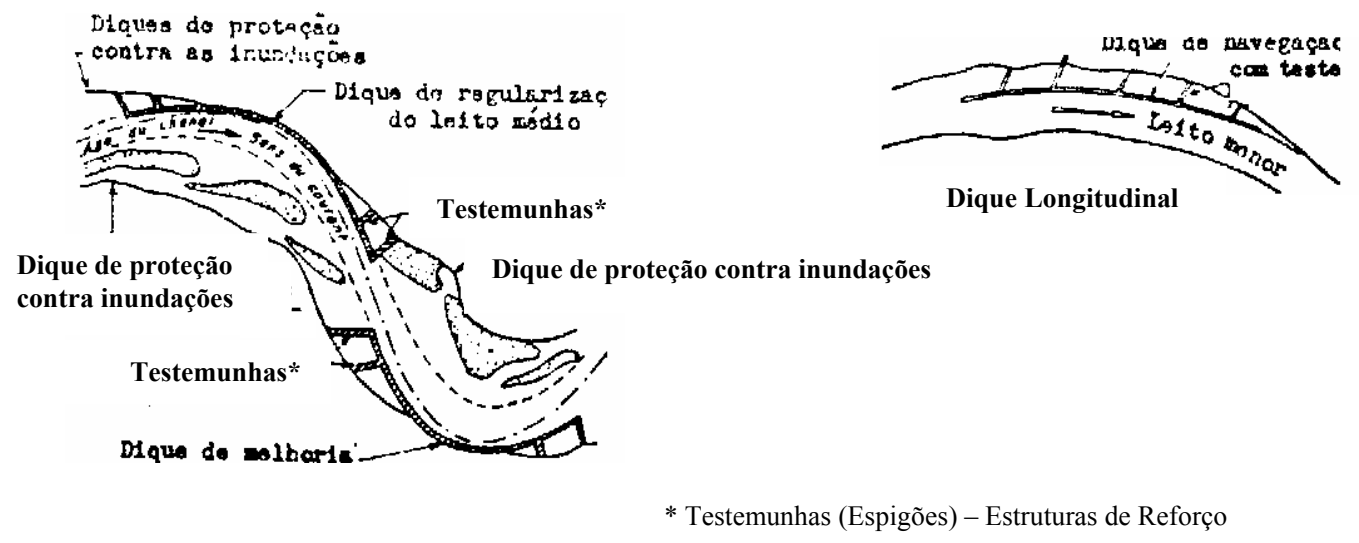

Figura 110 - Proteção Indireta - Dique - modalidades de construção.

Fonte: BRIGHETTI. (2000).

Os diques, assim como os espigões, desviam e orientam o fluxo de forma contínua, protegendo a margem e ao mesmo tempo definindo um melhor traçado ao canal, geralmente, visando a navegação do trecho.

\section{- Classificação dos Diques}

물iques Plenos ou Impermeáveis

São construídos em enrocamento ou com um núcleo de terra e revestido de pedra ou faxinas (os mais comuns). Em casos muito especiais podem ser verdadeiras cortinas plenas de concreto ou de estacas. Por vezes são interrompidos de espaço em 
espaço, visando favorecer o assoreamento na parte posterior, porém estas aberturas podem causar dificuldades para manutenção. Cuidado especial deve ser tomado nos extremos que devem concordar com a margem, com curvas apropriadas, ou então ligadas à mesma por espigões reforçados (normais à margem). Neste caso deve-se ter sempre uma série de espigões dando a concordância conveniente.

a Diques Permeáveis

São construídos em geral quando as margens estão sendo erodidas para facilitar a manutenção de uma continuidade até a nova margem. Usa-se por exemplo, estacas de bambu, entrelaçados de bambu ou outros vegetais, que formam painéis facilitando a sedimentação e formando verdadeiros diques de pestana nos rios de muito transporte sólido em suspensão. Ver figuras 111 e 112 . Usa-se também faxinas, estacas, etc. Blocos isolados são pouco usados como diques longitudinais.

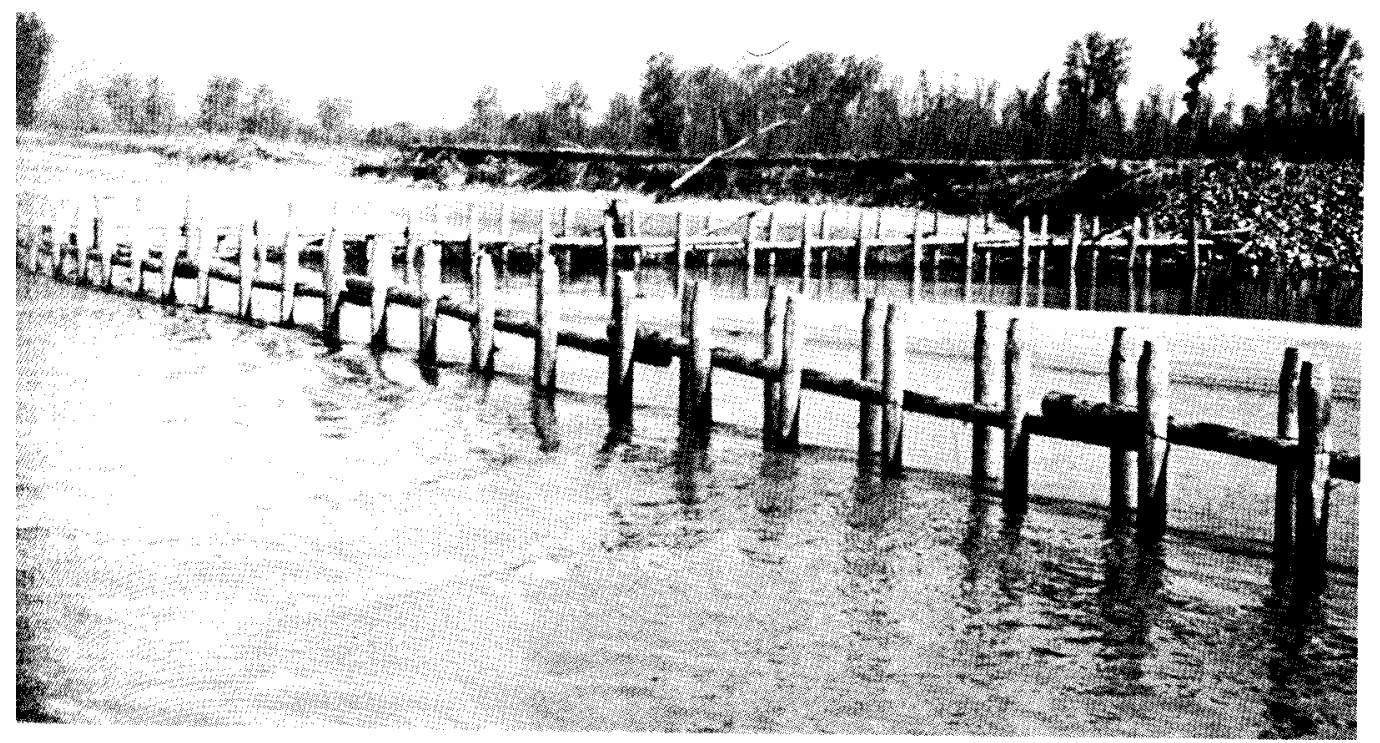

Figura 111 - - Proteção Indireta - Construção de diques em troncos de madeira. Fonte: PETERSEN. (1986). 


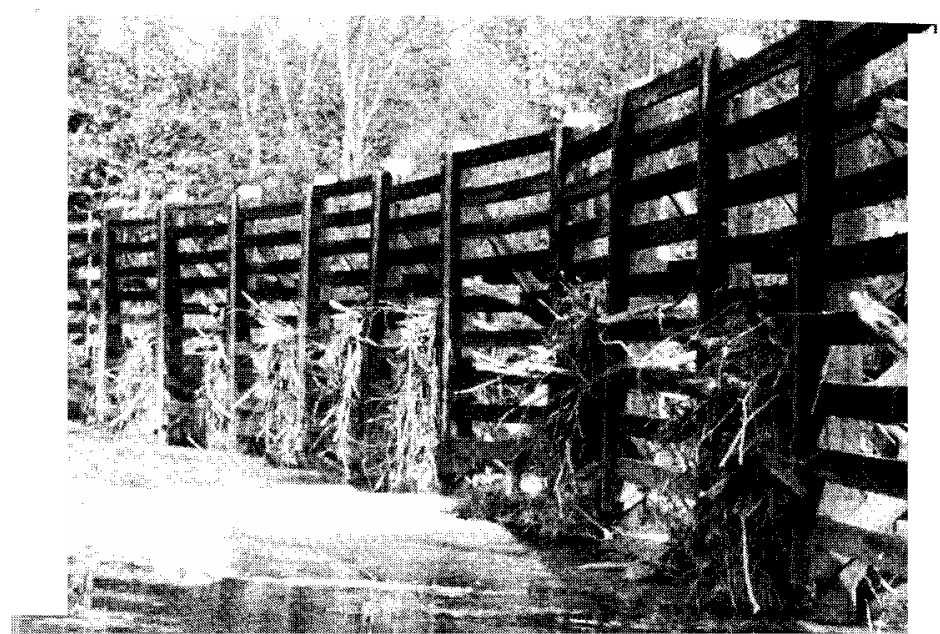

Figura 112 - - Proteção Indireta - Construção de diques com troncos e tábuas. Fonte: PETERSEN. (1986).

Escolha entre Diques e Espigões

Sendo os espigões distantes entre si de uma distância maior que seu comprimento, em geral estes são mais econômicos ( inclusive ficam em profundidade menores). Os diques podem ficar sujeitos a pressões em toda a sua extensão ( níveis d'água diferentes entre as duas faces ) o que exige proteção e maior espessura em toda a sua extensão. Os espigões tem mesmo nível d'água nas duas faces e só precisam ser protegidas em seus extremos.

A vantagem principal dos espigões, é poderem ser aumentados facilmente e adaptados às necessidades, como já indicado anteriormente. Tem como principal inconveniente as perturbações que causam ao escoamento e o perigo para a navegação. Exigem grandes cuidados de fiscalização e reparação, sobretudo nas margens côncavas, onde podem causar fortes erosões no extremo e mesmo na margem durante as cheias. Comparando-se com os espigões, os diques apresentam vantagens e desvantagens, sendo elas:

마일 Vantagens

Łixação definitiva do novo traçado;

Menor perda de carga;

Proteção contra ondas. 
㽞Desvantagens :

Pode ocorrer destruição total; Maior cuidado na proteção; Maior volume de material; Manutenção maior.

Seqüência de projeto:

araçado; Forma; Cota de coroamento.

c) Soleiras de Fundo

Costuma-se prolongar os espigões por diques de fundo ou construir soleiras ao longo dos diques, sempre que as profundidades locais são maiores que as teóricas. Estas soleiras funcionam como proteção de pé das proteções de margem, evitando erosões localizadas e distribuindo melhor a energia d'água a longo da curva.

Podem ser de enrocamento (o mais comum), gabiões ou faxinas de diferentes tipos e materiais. Devem ser bastante próximas, no caso de diques submersos, para evitar as erosões que inclusive, podem levar à sua destruição. Ver figura 113.

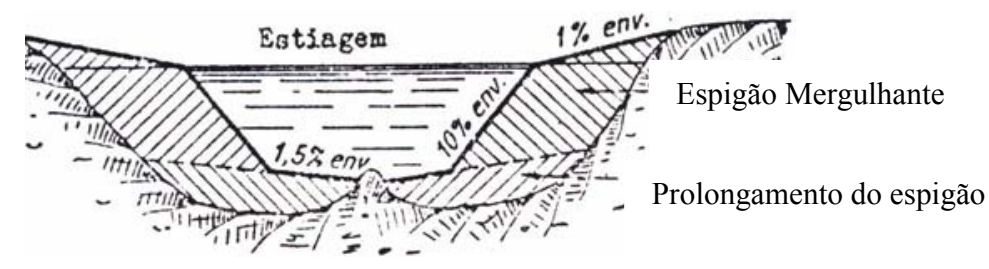

Figura 113 - Proteção Indireta - Prolongamento do espigão, é um exemplo de soleira de fundo Fonte: BRIGHETTI. (2000).

d) Umbrais de fundo

São obras transversais, podendo ficar completamente aprofundadas no álveo ou sobressair do mesmo. A cota $\left(\mathrm{C}_{\mathrm{i}}\right)$ do plano de fundação depende da erosão do trecho de jusante; a cota de coroamento $\left(\mathrm{C}_{\mathrm{m}}\right)$ depende da cota do álveo ou da altura da camada de sedimentação de montante. 
Os umbrais de fundo unem, em geral, dois espigões opostos e localizam-se, com preferência, na correspondência das soleiras. Ver figura 114.
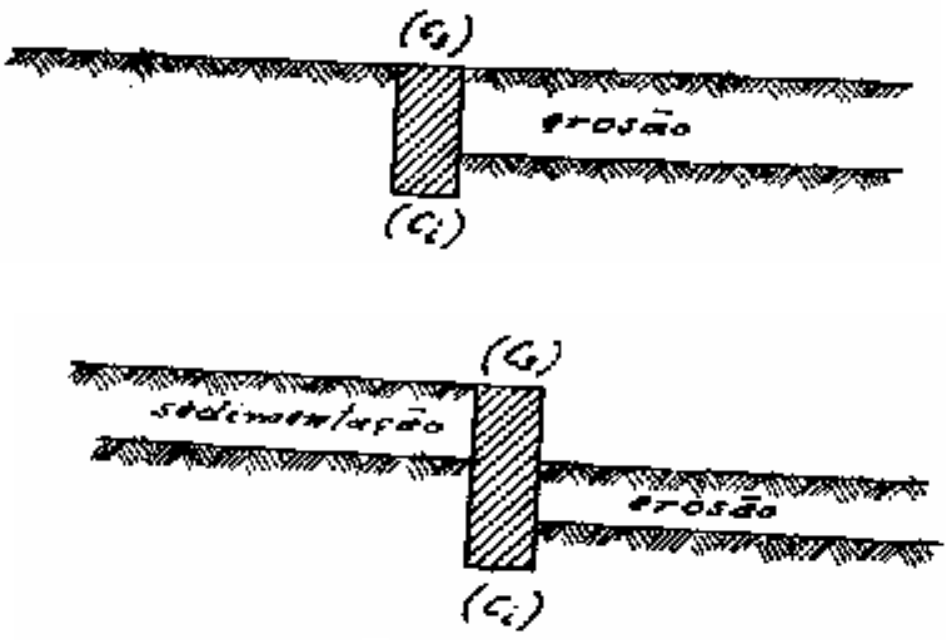

Figura 114 - Proteção Indireta - Umbrais de Fundo Fonte: BANDINI. (1958).

e) Retificação de Meandros

Quando do estudo da classificação dos rios, vimos a definição de meandro, de uma forma bem sucinta, bem como a sua formação.

A obra hidroviária, retificação de meandros, tem por objetivo tornar reto, dispor em linha reta ou alinhar o leito curvo ou meandrante do rio.

Os meandros de um rio provocam alongamentos consideráveis do traçado entre dois pontos do curso d'água. Aumentos de 10 a $20 \%$ são freqüentes, encontram-se, por vezes, aumentos de 40 a $60 \%$ e, em certos casos, podem atingir, ou mesmo ultrapassar os $100 \%$.

Execução da Retificação de Rios 
Numa retificação de um curso d'água, o fato do rio estar meandrando, não significa que ele está instável, mas sim, que ele está procurando o equilíbrio.

A figura 115, mostra um exemplo de rio meandrante, onde há a necessidade de retificação do trecho meandrante, desse rio.

A retificação do curso, reside no isolamento das alças mais acentuadas, por meio de um canal, aproveitando-se por exemplo o material proveniente da abertura desse canal para o aterro do leito abandonado.

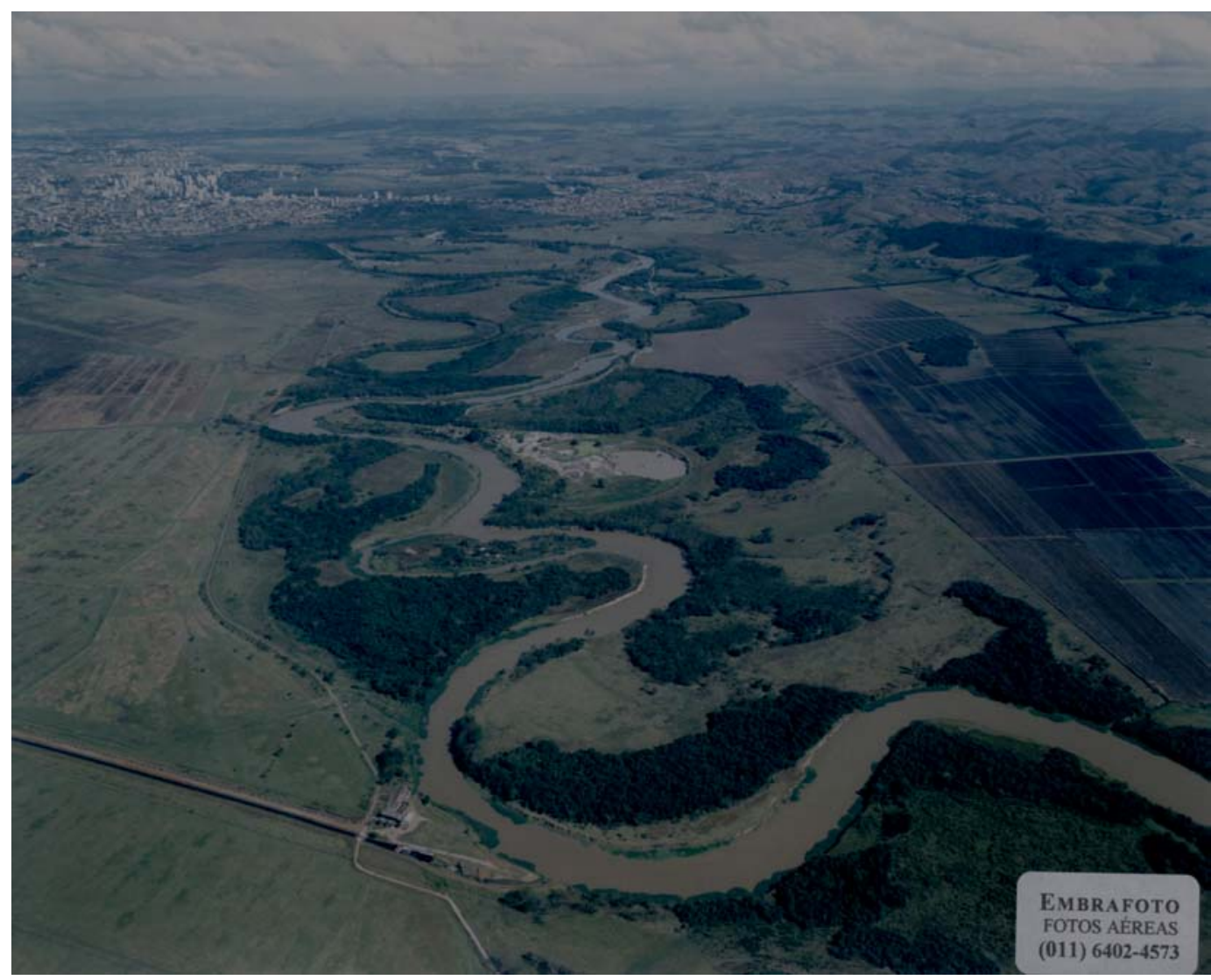

Rio Paraíba do Sul, exemplo de rio meandrante, nasce em São Paulo, paralelo à costa, entre a Serra da Mantiqueira e a Serra do Mar. Encachoeirado em rochas cristalinas e tranqüilo e meândrico na bacia sedimentar. É um rio cujo regime é tropical com máximas anuais variando de três a quatro meses. 


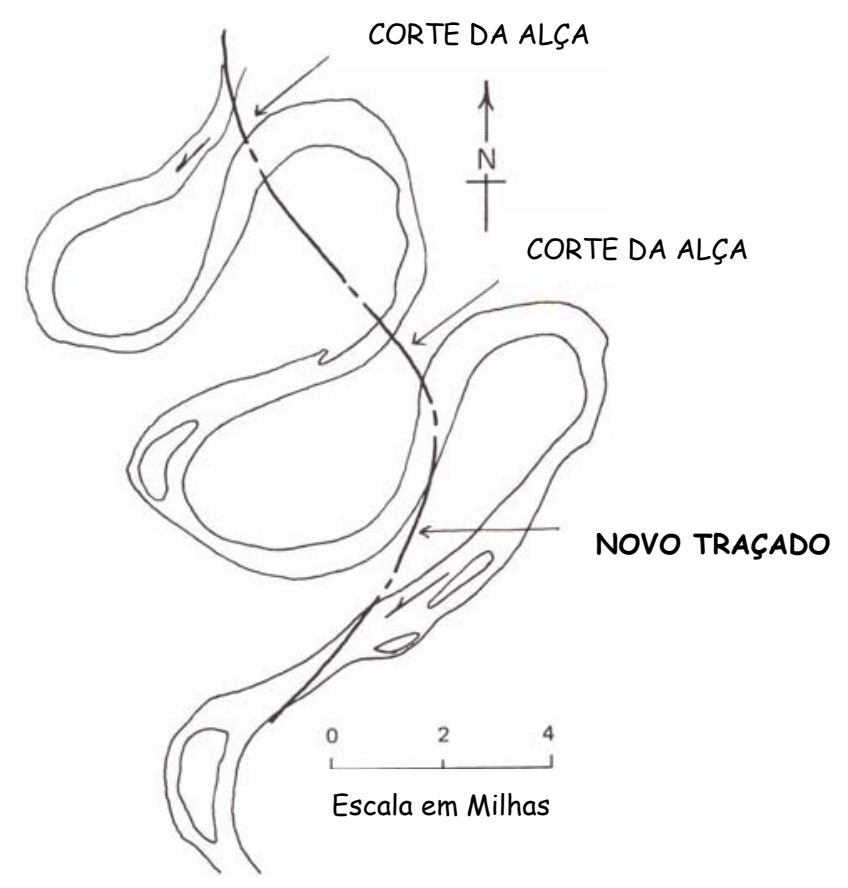

Figura 115 - Retificação do trecho meandrante do rio - novo traçado

Fonte: $1^{\circ}$ EVENTO MONTENA DE ENGENHARIA CIVIL (2003); PETERSEN (1986).

Como exemplos de retificação de meandros, podemos citar:

$\Rightarrow$ A obra de retificação na seção do rio Tietê, entre a Penha e Osasco, reduziu entre esses dois pontos, o curso sinuoso do rio de cerca de 46,3 $\mathrm{km}$ para apenas $26 \mathrm{~km}$, por meio de um canal trapezoidal com talude 1:2, de $45 \mathrm{~m}$ de largura de fundo, no trecho entre a Penha e a foz do Tamanduateí; e $56 \mathrm{~m}$ de largura de fundo no trecho que vai deste último ponto até Osasco, com profundidades de águas mínimas, médias e máximas respectivas de $1,50 \mathrm{~m}, 4,50 \mathrm{~m}$ e $5,70 \mathrm{~m}$, além de melhorar as condições de drenagem urbana. (Spencer, 1974).

$\Rightarrow$ As obras de melhoramentos realizadas na Hidrovia do Marajó, especificamente no rio Anajás, visaram a retificação da rota de navegação, no trecho contínuo do rio entre o km 96,42 e o km 101,38, ou seja, entre o emboque do Canal Artificial e a desembocadura do Córrego da Flecheira, além da necessidade de um corte na curva do $\mathrm{km} \mathrm{121,00} \mathrm{(} \mathrm{S} 7 / \mathrm{S} 10$ ) na margem esquerda, por meio de um 
canal com cerca de $220 \mathrm{~m}$ de extensão, retificando três curvas de pequeno raio. A retificação resultou numa curva de $900 \mathrm{~m}$ de raio.

O estudo da retificação de um curso d'água, deverá atender:

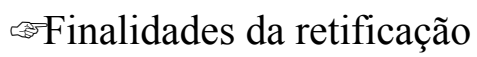

A retificação do curso d'água tem por finalidade: o controle das cheias (baixar o nível d'água de enchentes); a melhoria do traçado para a navegação (redução do percurso para a navegação); a construção de avenida em fundo de vale, facilitar a utilização da várzea para fins de agricultura (recuperação de terras marginais, através do rebaixamento do lençol freático); o polder (áreas protegidas para a irrigação), outros casos como por exemplo: utilizar o meandro, como lagoa, para tratamento de esgoto.

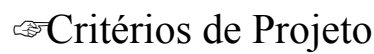

Os critérios de projeto a serem atendidos, referem-se a finalidades e cuidados.

딱inalidades

Estabilidade hidráulica - deverá atender: capacidade de vazão no que se refere aos parâmetros: seção, declividade e traçado (no que refere ao traçado, ele não deverá ser reto, deverá apresentar curva e contra curva, isto é sinuoso, nos trechos retos ou de tangente o comprimento entre duas curvas consecutivas deverá ser no mínimo 2 a 3 vezes a largura do rio); estabilidade.

Ło Navegação - deverá atender: traçado; seção (compreende essencialmente a largura e a profundidade); velocidades ( limites nas cheias ), estes parâmetros estão ligados diretamente a embarcação. 


\section{Obras Contraproducentes}

Nem sempre as obras hidroviárias executadas visando melhorar as condições de navegabilidade de um rio, alcançam o fim colimado, mas ao contrário, resultam muitas vezes serem contraproducentes. $\mathrm{O}$ rio que se pretendia melhorar, oferece ao fim de pouco tempo, condições ainda mais precárias à navegação e, o que em muitos casos é ainda mais grave.

O exposto no parágrafo acima, é facilmente aplicável a retificação de rios meandrantes, pois, é necessário apresentar precauções às seguintes conseqüências:

No trecho retificado, ocorre: um aumento da declividade, aumento na intensidade da força erosiva da corrente, aparecimento da erosão no trecho retificado e assoreamento no trecho a jusante.

Na retificação do curso d'água, temos uma redução do volume de retenção e, consequentemente um aumento do pico de vazão para jusante. $\mathrm{O}$ cuidado reside na proteção da várzea do rio a jusante.

\section{Método Construtivo de Retificação de Meandros}

Corte Direto

A abertura do canal pode ser feita diretamente a seco para a seção total prevista, conservando-se as extremidades através de ensecadeira, iniciando-se o serviço com a limpeza da superfície (destocamento).

Poderá ser utilizado equipamento de terraplanagem até encontrar-se o lençol freático. A draga (mecânica ou hidráulica), será utilizada, de preferência, quando a situação for subaquática. Deverá ser verificada a necessidade de derrocamento. Ver figura 116. 
À vantagem do corte direto, reside nas facilidades dos trabalhos de fixação das margens. Enquanto que a desvantagem, reside no fato do fundo do canal "poder" ficar abaixo do lençol freático, o que leva a necessidade de realizar as obras, nos períodos de estiagem.

Outra maneira de se fazer um corte direto é através de dragagem, partindo-se de jusante para montante

Cuidado especial, deverá ser dado na interligação de duas curvas consecutivas, sendo o comprimento mínimo entre elas 2 a 3 vezes a largura do curso d'água, no trecho após a retificação.

Em síntese, o corte direto, entende a necessidade do movimento de terra.

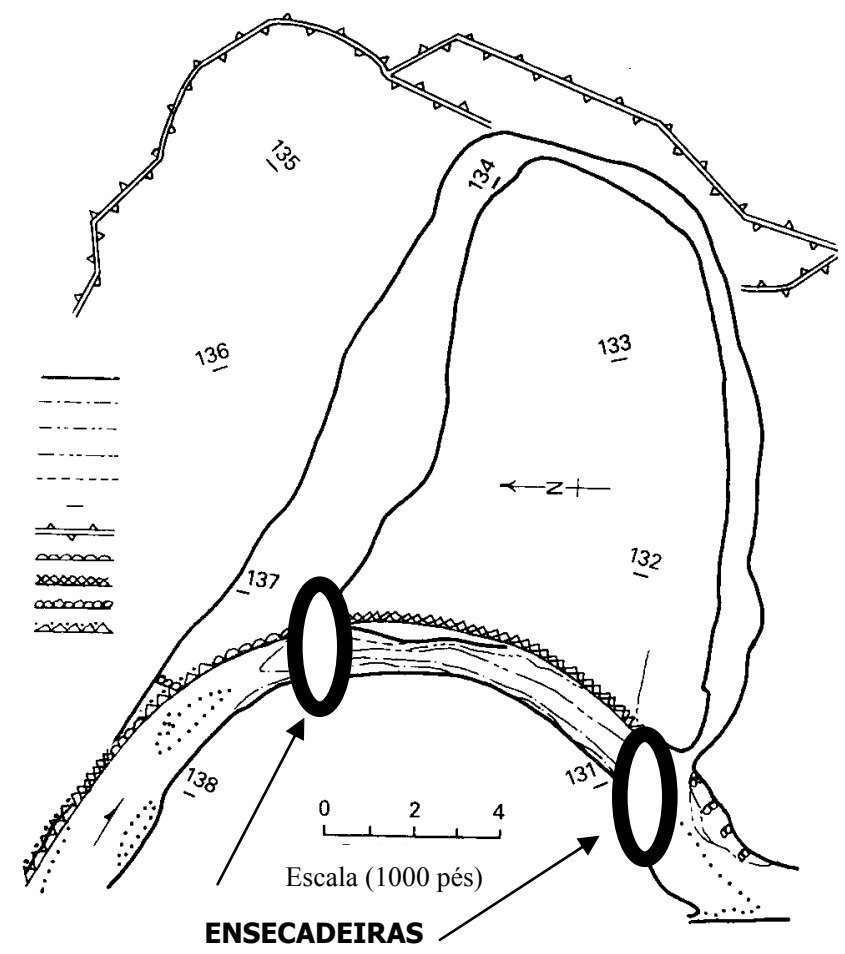

Figura 116 - Retificação de rio meandrante - corte direto

Fonte: PETERSEN. (1986). 
Canal Piloto

Constitui um caso particular de retificação de meandro. Consiste na abertura de um canal de pequena seção no local do corte, identificado como canal piloto, que será alargado pela capacidade da água em erodir e, transportar o material erodido para jusante, até atingir a seção definitiva. Ver figura 117.

As vazões pelo canal piloto e pelo meandro podem ser controladas através da colocação de estacas de madeira em ambas as margens do canal piloto e do trecho final da alça a se obstruída.

Pela abertura sistemática do controle de montante, conjugada com o fechamento do controle de jusante, é possível obter o assoreamento da alça do meandro, controlando ao mesmo tempo a erosão do canal piloto, ocasionando inclusive um mínimo de transporte de material sólido para jusante. Ver figura 117.

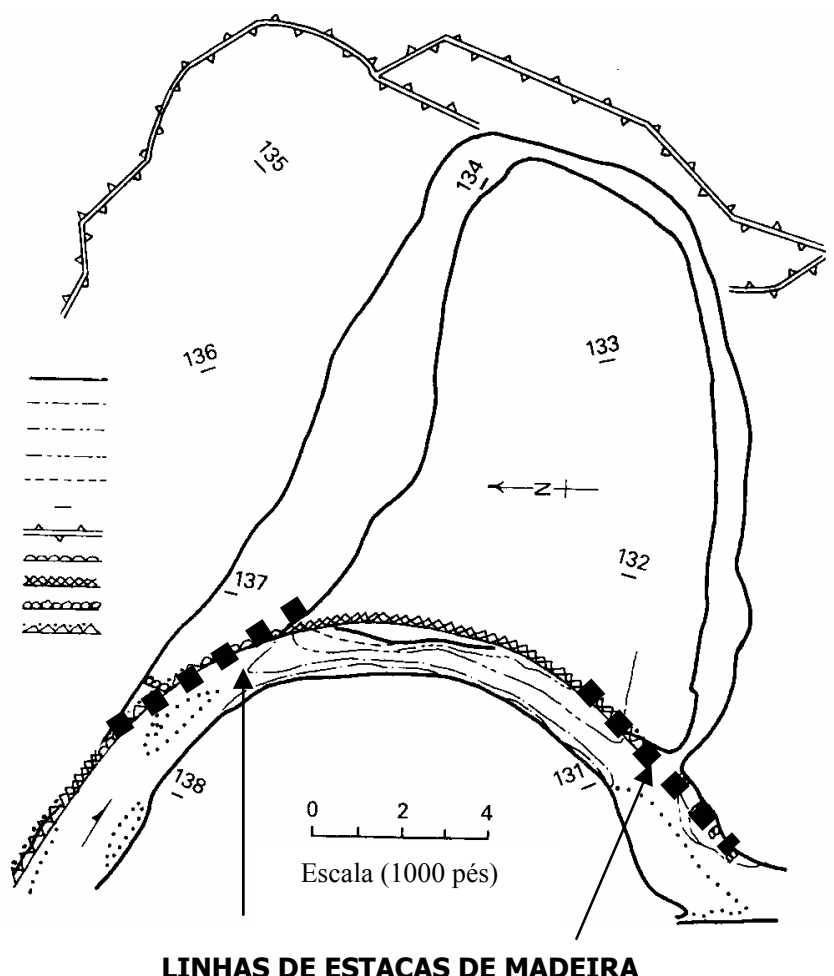

Figura 117 - Retificação de Meandro - canal piloto

Fonte: PETERSEN (1986); BANZINI. (1988). 
Muitas vezes, também, pode ser oportuno fixar uma soleira de fundo na entrada do canal piloto a fim de restringir a erosão de montante.

No caso de retificação de meandro através de canal piloto, pode-se utilizar enrocamento empilhado conveniente ou pedra em vala, ver figura 118, que irão fixar as margens deslizando sobre as mesmas ao final do processo de erosão. Outro processo é a fixação através de estacas cravadas.

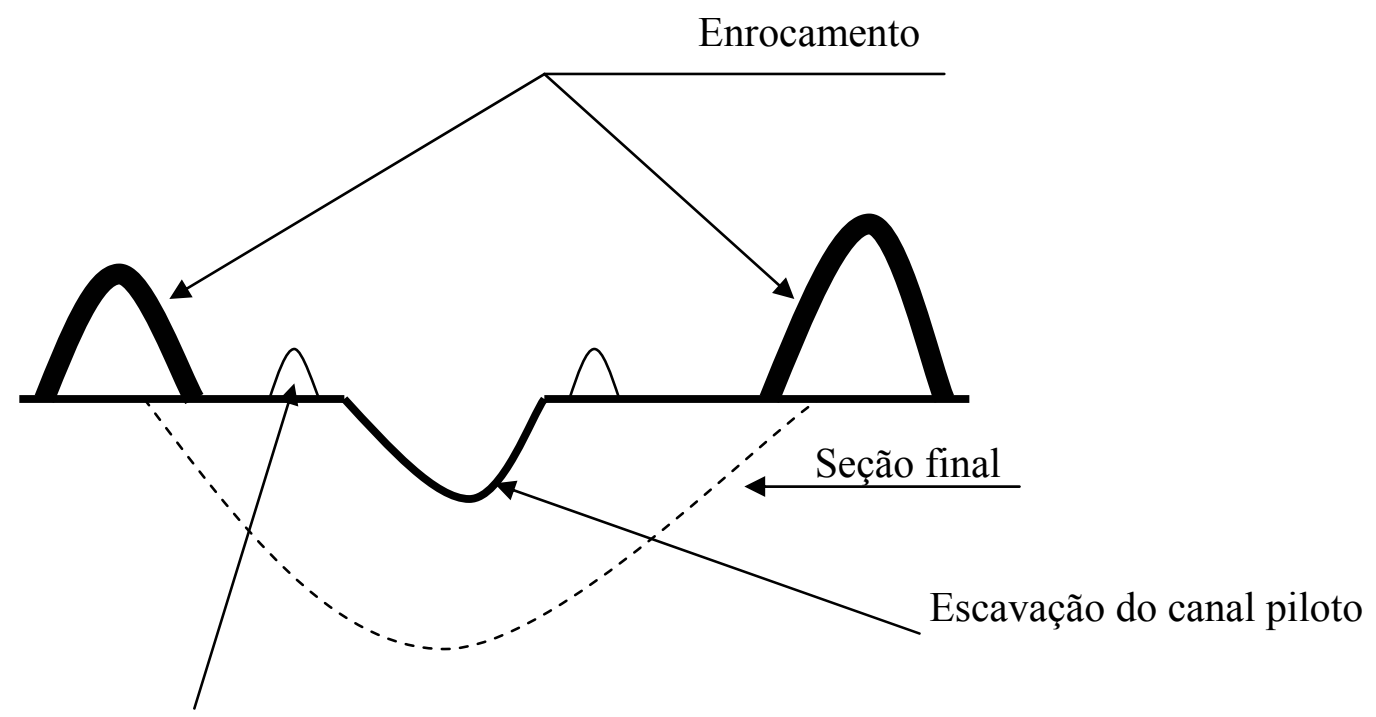

Deposição do material escavado para concentração de vazões

Figura 118 - Retificação de rio meandrante - Canal piloto

Fonte: BANZINI. (1988).

\section{Cuidados}

Se a erosão for muito rápida e o carreamento excessivo, a declividade à jusante do corte, pode ser insuficiente para escoar a descarga sólida correspondente e, em conseqüência o leito à jusante irá sofrer assoreamento, tendendo a reduzir o processo de erosão no canal e, como outros inconvenientes dificultar o escoamento das cheias ou a navegação.

Por outro lado se o canal não aumenta com suficiente rapidez, poderá haver assoreamento do leito natural a montante do corte por falta de condições de 
escoamento para toda a descarga sólida que chega. À jusante haverá então rebaixamento do fundo e consequentemente aumento da declividade que irá provocar o aumento da erosão à montante, compensando aos poucos o desequilíbrio havido, entretanto, este processo poderá durar vários anos, com evidentes inconvenientes, ficando sempre na dependência das alternâncias imprevisíveis do ciclo hidrológico.

f) Regularização dos Leitos

Estas obras visam utilizar a energia das águas para fixar o traçado do leito, melhorar o escoamento e as condições de navegabilidade do rio, modificando para tanto: a largura, as curvaturas, a profundidade e a direção dos filetes de água, utilizando-se diques, espigões e soleiras ou diques de fundo. As modificações de traçado obedecem a fórmula de Chézy e as Leis de Fargue e visam principalmente uma variação contínua das curvaturas e a formação de rampas e contra rampas no fundo, de maneira contínua. Outro princípio é o de "Girardon", que é a "Regularização por Conservação de Soleiras", que consiste em conservar os bancos, dando uma "boa passagem" entre eles. A boa passagem obtém-se sempre através da construção de diques e espigões nas regiões dos bancos e soleiras de fundo nas fossas, também, aplicando-se as leis de Fargue (Del Grande, 1989).

\section{- Princípios Gerais}

Define-se como regularização de um rio as obras construídas no leito para concentrar e/ou dirigir as correntes, especialmente nas estiagens, visando a obtenção de um leito estável, segundo um certo traçado, e um perfil transversal determinado, a fim de corrigir e regularizar as imperfeições naturais, obtendo-se as profundidades desejadas.

Através da regularização procura-se atingir um ou vários dos objetivos seguintes: 
a Escoamento rápido e seguro das águas nas cheias;

q Estabilidade do curso de água, com um mínimo de erosão das margens;

* Orientação da corrente líquida em um trecho determinado do curso d'água;

arofundidade suficiente e percurso satisfatório para a navegação;

Transporte eficaz dos sedimentos em suspensão e, principalmente dos depósitos de fundo.

Basicamente, pela regularização transforma-se um trecho do curso de água em estado de erosão ou de assoreamento em um trecho com largura, profundidade e traçado adequados para a navegação, não esquecendo a capacidade de escoar as próprias vazões. $\quad \mathrm{O}$ inconveniente básico da regularização dos rios de fundo móvel é a introdução de obstáculos, que ficarão submersos para a vazão maior, ocasionando uma perda de carga complementar, afetando, assim, a lei cota/vazão. Estas obras devem interferir o mínimo possível na cota do nível d'água, de modo a não provocar inundação. Ver figura 119.

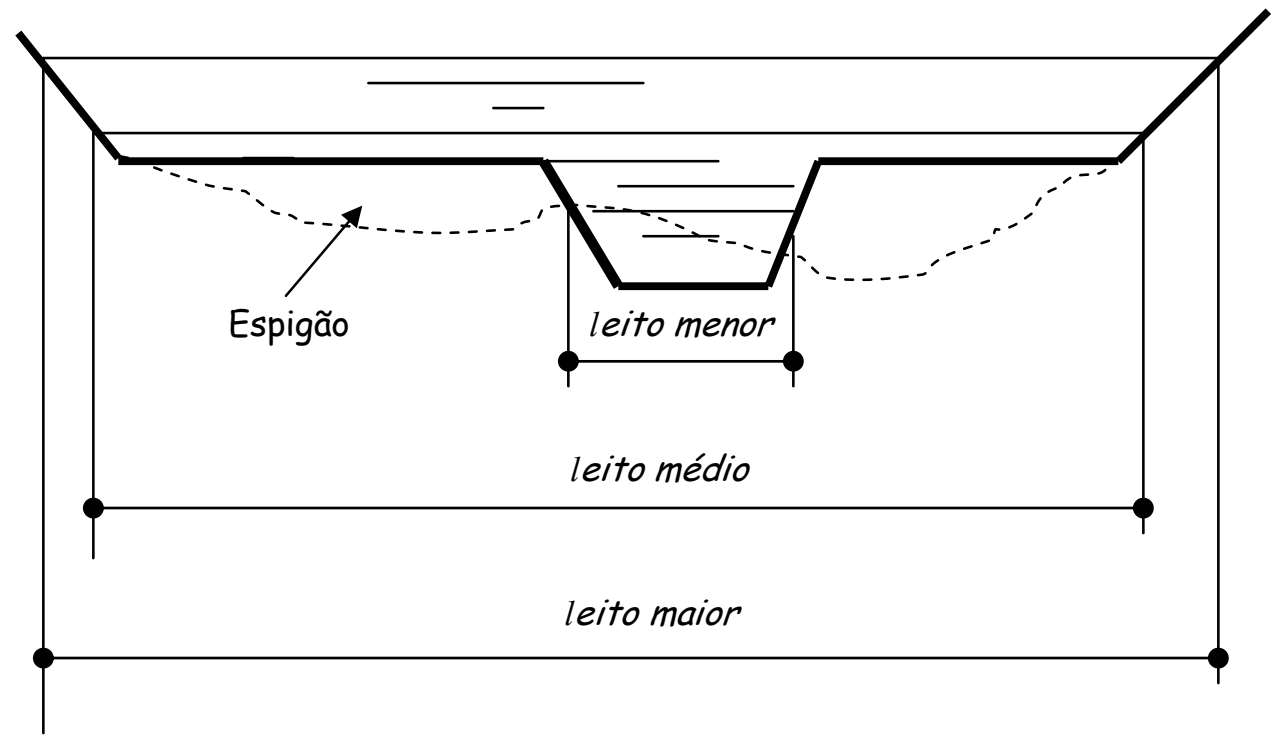

Figura 119 - Regularização dos leitos.

Fonte: BRIGHETTI. (2000). 
As obras de regularização não são exclusivas para a navegação, mas também, podem ser utilizadas para direcionar o escoamento e/ou viabilizar a captação de água, sempre nas condições de estiagem.

Um conhecimento bastante aprofundado da Hidráulica Fluvial e das condições físicas e hidráulicas do rio é necessário para a obtenção de todos os resultados desejados da regularização. Os modelos físicos e matemáticos são instrumentos muito úteis para a elaboração do projeto destas obras e, pode-se dizer, obrigatórios quando se trata de obras importantes. Não são porém ainda suficientes para resolver todos os problemas que surgem, especialmente no que diz respeito aos detalhes, pois seus custos tornam-se facilmente proibitivos quando as extensões a reproduzir são grandes e o grau de detalhamento é elevado. Por este motivo, e também pela dificuldade de reprodução correta e segura de todos os elementos naturais, costuma-se ainda hoje executar as obras de regularização por etapas, procurando-se "sentir", em cada estágio, as reações do rio.

Evidentemente deve-se no traçado destas obras seguir os princípios da Hidráulica Fluvial, especialmente as chamadas "Leis de Fargue" que possibilitam a realização da regularização na melhor concordância possível com as condições da natureza.

Atualmente dispõe-se porém de conhecimentos mais profundos sobre a Hidráulica Fluvial, que permitem abandonar as regras e normas empíricas que durante dezenas de anos comandaram os projetos de regularização.

Teorias para Regularização dos Rios

As obras que visam modificar ou regularizar os álveos dos rios, podem ser agrupadas em três categorias, a saber:

a) Obras destinadas a regularizar o andamento planimétrico e altimétrico do álveo de estiagem, isto é, do álveo que nas condições naturais, veicula as vazões de estiagem. Estas obras objetivam, em geral, criar condições favoráveis à navegação; 
b) Obras destinadas a alterar o álveo de enchente, para limitar a extensão das zona inundadas;

c) Obras mistas, isto é, obras que visam resolver o dois problemas indicados nas alíneas $\underline{\mathbf{a}}$ e $\underline{\mathbf{b}}$.

Nesta tese, abordaremos somente a alínea $\underline{\mathbf{a}}$, isto é, as obras que visam melhorar as condições de navegação nas vazões mínimas ou de estiagem, através da utilização da energia d'água para atender os objetivos desejados.

As obras destinadas a regularizar o andamento planimétrico e altimétrico do álveo de estiagem são: direcionamento do escoamento e concentração do escoamento.

国-Regularização dos Rios de Fundo Móvel - (Métodos Clássicos)

No caso da regularização de rios de fundo móvel, poderá ser efetuada de duas formas, a saber: uma direcionando o fluxo para ser obtido o traçado do curso d'água com as condições exigidas, no qual se destaca o Método de Girardon, e a outra reside na técnica de concentrar o escoamento, aumentando a sua carga e energia, de modo a se obter as condições desejadas para a navegação.

Direcionamento do fluxo

O melhor direcionamento do fluxo, tem por objetivo a obtenção de um curso d'água estável e com traçado adequado a: navegação, tomadas d'água e proteções localizadas, sendo obtido com a aplicação de método mais racional, dito de Girardon, que age sobre os três fatores, eliminando as chamadas "más passagens". 
Pontos de Inflexão - Boas e Más Passagens

Como sabemos, as maiores profundidades em um leito sinuoso, situam-se sempre ao longo das margens côncavas (externas). A linha de talvegue cruza o rio próximo ao ponto de inflexão. Se o cruzamento é brusco, tem-se uma "má passagem", se suave uma "boa passagem".

O método consiste em transformar as "más passagens" em "boas passagens", partindo do princípio que os bancos das inflexões formam "soleiras" que dificultam o escoamento e a navegação. Ver figura 120. Procura-se isto, adaptando-se as obras às condições da natureza: Curvas e contra curvas concordantes e de curvatura variável; Perfil transversal assimétrico nas curvas; Perfil longitudinal com sucessão de bancos e fossas. Deve-se obter a fixação das fossas e dos bancos dando curvaturas suficientes nas margens côncavas ( de preferência por meio de diques longitudinais ou espigões ) formando-se depósitos que afastam as profundidades na margem convexa (por meio de espigões, de preferência). Para evitar que as fossas se sobreponham, impõe-se, parcialmente, as formas dos perfis transversais de trecho em trecho (por meio de espigões, diques e, soleiras de fundo), obrigando a passagem progressiva da forma da seção assimétrica na curva à forma trapezoidal e simétrica no banco.
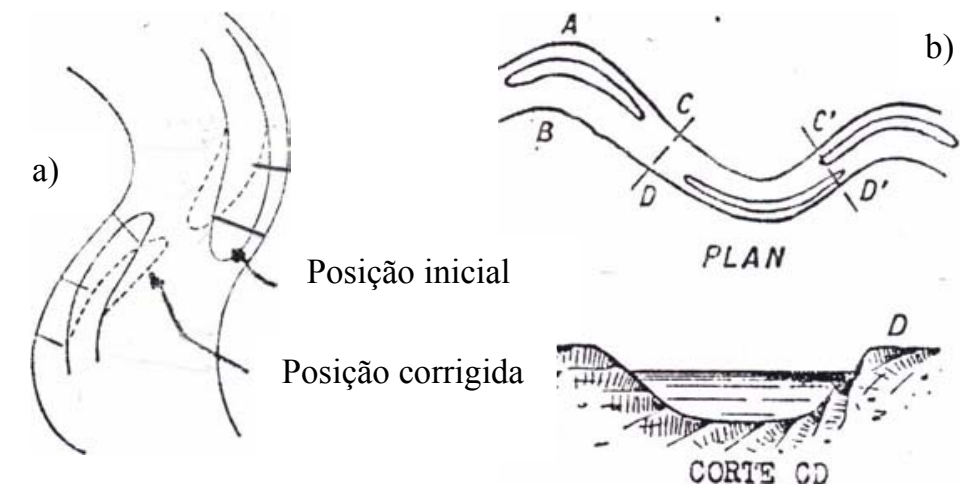

b)

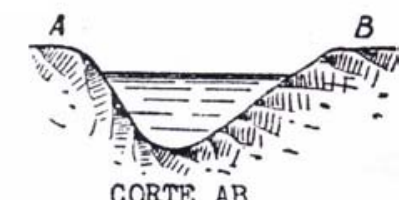
CORTE $A B$

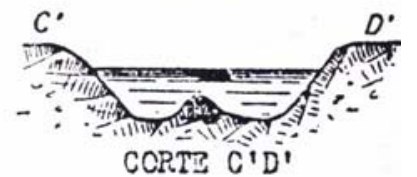

Figura 120 - Regularização dos leitos - a) Melhoramento do perfil transversal; b) Planta e perfis típicos de duas curvas sucessivas.

Fonte: BRIGHETTI. (2000). 
No perfil longitudinal evitam-se grandes variações de velocidade d'água por soleiras de fundo nas fossas, que conduzem a maior declividade da linha d'água e nível mais elevado nos bancos durante as estiagens, ao mesmo tempo que evitam, nos períodos de cheias a erosão das fossas e portanto a tendência de aumento dos bancos.

A variação contínua da curvatura das margens, do vértice à inflexão da curva é importante para garantir a continuidade necessária. Para tanto, pode-se utilizar os gabaritos de Fargue (Método Gráfico) ou utilizar a laminiscata de Bernoulli ( que permite ajuste analítico mais fácil).

As seguintes regras devem ser observadas para o projeto das obras:

\ Sendo $\mathbf{L}$ a largura do rio (referida ao nível de água de referência) e $\mathbf{R}_{\mathbf{m}} \mathbf{o}$ raio de curvatura no vértice, portanto: $\mathbf{3} \mathbf{L}<\mathbf{R}_{\mathbf{m}}<\mathbf{5} \mathbf{L}$

\. Sendo A área da seção transversal (referida ao nível de água médio), portanto:

$50 . A^{1 / 2} \leq R_{m} \leq 110 A^{1 / 2}$.

\ As inflexões das margens não devem se defrontar, a margem convexa deve ser mais longa.

\ Os trechos retilíneos devem ser evitados e terão no máximo $3 \mathbf{L}$ de comprimento.

N Sendo $\mathbf{C}_{\mathbf{m}}$ a curvatura média $\left(\mathbf{C}_{\mathbf{m}}=\mathbf{w} / \mathbf{a}\right.$ onde: $\mathbf{w}$ igual ao ângulo entre as tangentes, medido em radianos, e a igual a distância entre as inflexões), portanto:

\section{$\mathrm{L} / 6<\mathrm{L} / \mathrm{C}_{\mathrm{m}}<\mathrm{L} / 12$}

\ As larguras nos bancos devem crescer, lentamente, de montante para jusante; nas fossas as larguras devem ser maiores que nos banco.

Calcula-se a relação entre a cota e as vazões das novas seções transversais típicas e verifica-se se o nível d'água e as velocidades da corrente convém à navegação. A cota de coroamento destas obras, deve ser o mais baixo possível, para evitar sobrelevação dos níveis d'água no período das vazões máximas. 
Deve-se ainda determinar a vazão sólida carreada anualmente na nova seção típica e compará-la à do perfil normal do rio, à montante do trecho regularizado, para verificar-se se não há possibilidade de assoreamento.

Modifica-se a seção transversal e repetem-se os cálculos acima até que o nível d'água e a velocidade da corrente, correspondentes aos valores procurados, a que a vazão sólida anual iguale à da seção normal do rio em estado natural.

\section{Concentração das águas}

O primeiro passo a ser realizado é a concentração das águas, nos níveis médios ou de estiagem, em um único leito, quando o rio se subdivide em diversos braços. Para tanto, construem-se diques de fechamento dos bracos secundários com coroamento aproximadamente no nível médio das águas. Ver figura 121.

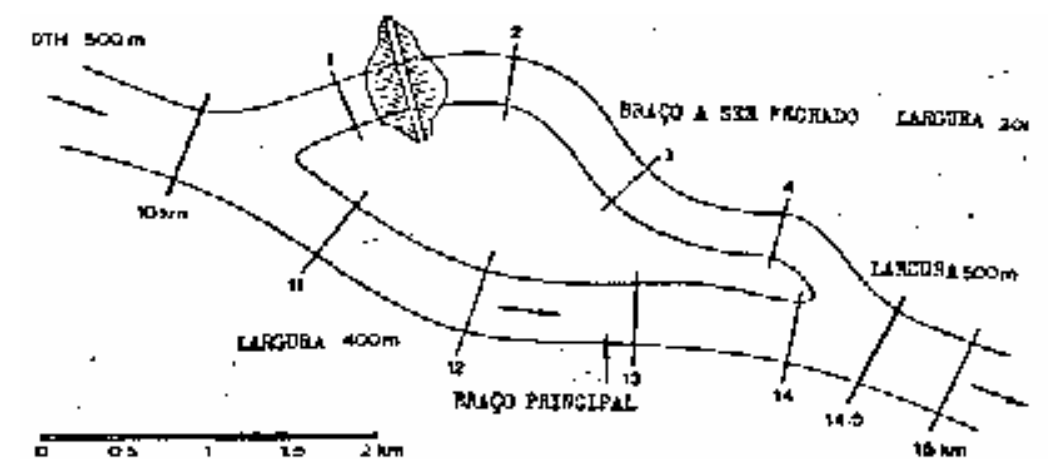

Figura 121 - Concentração das águas em um único leito.

Fonte: BRIGHETTI. (2000).

Uma vez unificado o leito, pode-se agir isoladamente, ou em conjunto, na conformação em planta (Método de Fargue), nos perfis transversais (Método de "Normalizacão") ou no perfil longitudinal.

A concentração do escoamento tem por objetivo, a definição no período de estiagem de um curso estável para navegação. 
Assim a determinação da seção transversal do álveo regularizado pode depender de elementos puramente hidráulicos, eventualmente, ligados à estabilidade do mesmo, como também, das exigências impostas pela navegação.

No primeiro caso (elementos puramente hidráulicos) trata-se, em geral, de veicular num único curso, um trecho pluricursal ou de estabilizar trechos sujeitos a fases violentas de modelação. Será útil examinar outras partes do rio, onde o álveo está em fase de compensação (trechos padrões) e, fixar condições análogas para os trechos a serem regularizados, levando em conta, naturalmente, a natureza do material de fundo.

Fixa-se, inicialmente, a vazão para a qual se queira projetar a regularização; esta vazão passa, então, a ser identificada como vazão de projeto e, corresponde a vazão mínima ou vazão de estiagem, para o qual a seção apresenta a altura de água, correspondente a vazão de projeto.

Em geral, para os trechos regularizados, ver figura 122 , será possível assimilar a seção real (ABCDE) a um tipo geométrico definido, para o qual o coeficiente de forma, depende de parâmetros de forma bem objetivados , considerando por exemplo uma seção equivalente trapezoidal (AFGE).

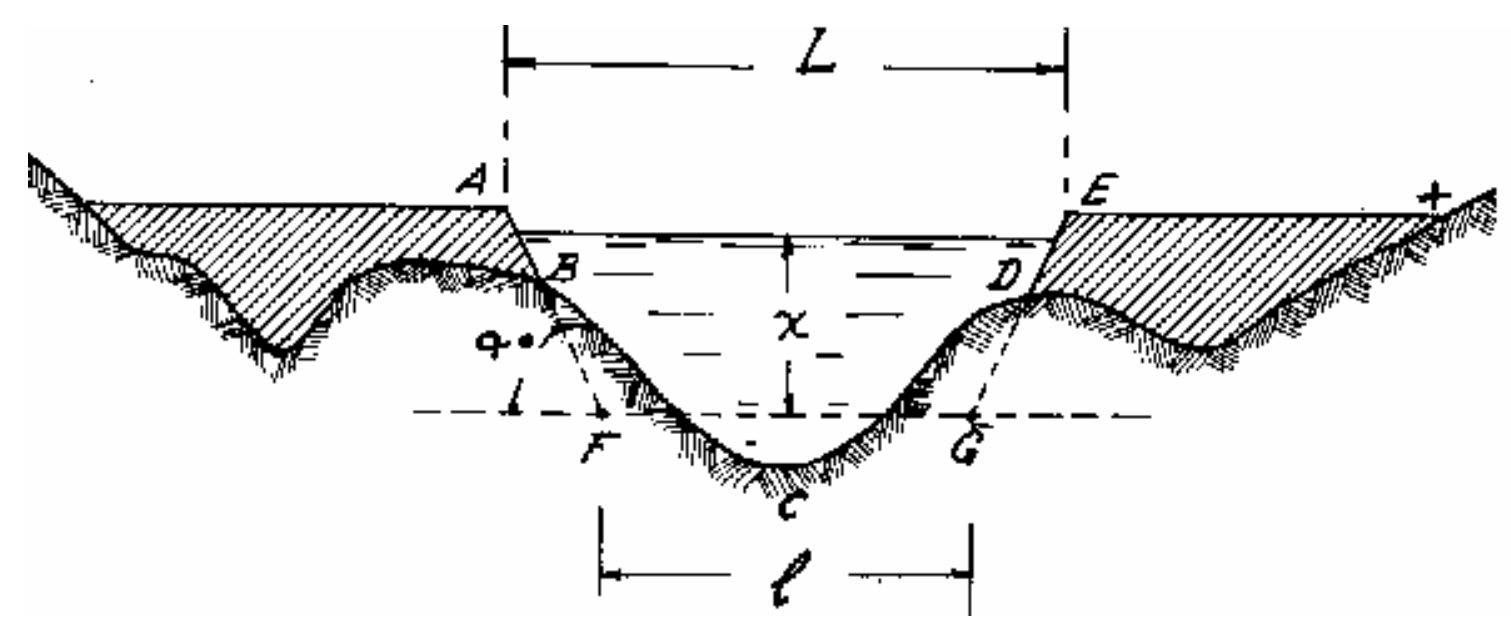

Figura 122 - Concentração das águas em um único leito - seção transversal Fonte: BANDINI. (1958). 
As exigências de navegação fixam um valor mínimo ao calado, na correspondência das soleiras.

Os métodos usuais fixam, como elemento característico dos trechos em condições de equilíbrio estável ou de compensação, a largura (L) da superfície livre.

Este elemento, porém, não representa, de um modo completo, as condições de escoamento que se produzem em virtude da vazão (Q), de declividade (i) e de rugosidade e, constitui uma base incerta para fixar a configuração mais conveniente das seções transversais, nos trechos a serem regularizados. De modo a atender o “critério hidráulico", a seção dimensionada (forma) permitirá escoar as vazões de projeto, isto é, as vazões mínimas ou de estiagem.

A substituição da largura pelo coeficiente de forma ( $R$ ), permite estender vantagens, aos cursos de água, pois permitem, além de, objetivar as características significativas do escoamento nos trechos de equilíbrio, projetar a regularização das seções transversais de um modo mais racional e correspondente às necessidades reais.

말egularização dos Rios de Fundo Resistente

Considera-se rios de fundo resistente aqueles em que a força erosiva é sempre inferior à força erosiva crítica do material constituinte do leito $\left(\tau<\tau_{\mathbf{c}}\right)$.

O princípio básico de regularização destes rios é estreitar as seções para elevar o nível de água, aumentando portando, as profundidades disponíveis. Essa solução não invalida a execução de um derrocamento parcial, de modo a minimizar o estrangulamento.

As conseqüências do estrangulamento das seções pode ser determinada através da aplicação das fórmulas do escoamento uniforme (por exemplo, a fórmula de Chézy), numa primeira aproximação, dividindo-se o trecho a ser regularizado em sub-trechos com características uniformes, e considerando-se os parâmetros geométricos médios em cada trecho. Ver figura 123. Considerar o escoamento permanente e uniforme, é uma simplificação adaptada na fase de planejamento e pré- 
projeto. Nas demais fases, do projeto, é aconselhável utilizar as equações do escoamento permanente variado.

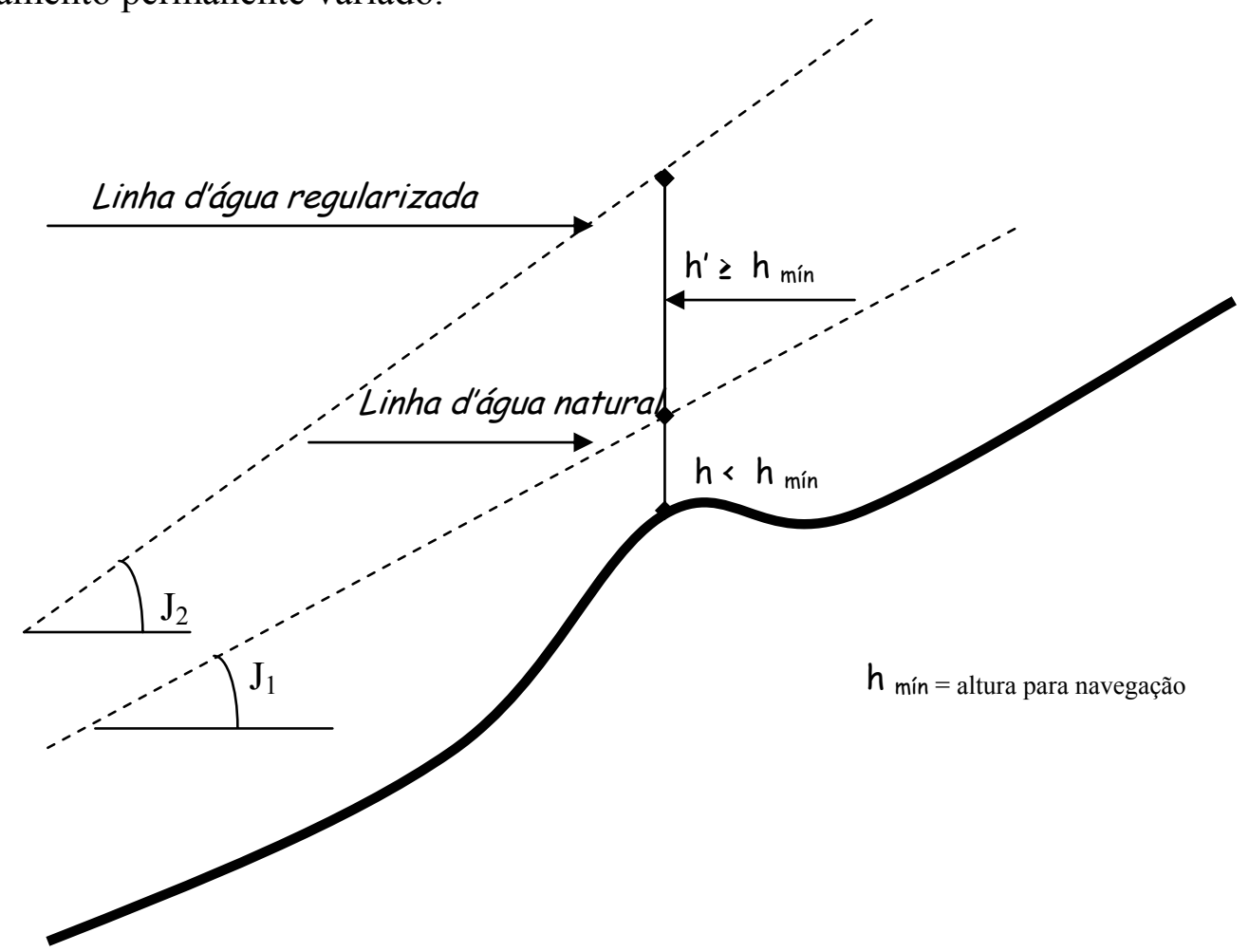

Figura 123 - Regularização dos leitos - Identificação dos parâmetros geométricas médios.

Fonte: BRIGHETTI. (2000).

Sendo $\mathbf{L}$ a largura entre as margens pela fórmula de Chézy:

$\mathbf{Q}=\mathbf{A} \cdot \mathbf{v}$

Onde: $\mathbf{v}=\mathbf{C} \cdot \mathbf{R}_{\mathbf{h}}{ }^{1 / 2} \cdot \mathbf{i}^{1 / 2}$ (i= declividade do fundo; $\mathbf{J}=$ declividade da lâmina d'água; considerando-se $\mathbf{J}=$ i)

$A$ = área da seção do canal, igual a largura do canal

(L) vezes a profundidade do canal (h)

$Q=L \cdot h \cdot C \cdot R_{h}{ }^{1 / 2} \cdot J^{1 / 2}$

Observação: Canais relação $L / h \geq 20$ a 30, tem-se $R_{h}=h$

$Q=L \cdot h \cdot C \cdot h^{1 / 2} \cdot J^{1 / 2}$

$Q=L \cdot C \cdot h^{3 / 2} \cdot J^{1 / 2}$, portanto: $L=Q / C \cdot h^{3 / 2} \cdot J^{1 / 2}$ 
Estreitando-se $\mathbf{L}$ aumenta $\mathbf{J}\left(\mathbf{J}_{\mathbf{2}}>\mathbf{J}_{\mathbf{1}}\right)$, sendo assim possível impor a profundidade desejada no local crítico ( $\mathbf{h}<\mathbf{h}_{\text {mín }}$ ), que é igual ou maior a profundidade mínima necessária.

A maior dificuldade do cálculo é a escolha do coeficiente $\mathbf{C}$ de Chézy que é conhecido nas condições naturais (pela medida das características do escoamento) mas não nas novas condições de nível de água mais elevado.

O cálculo deve ser feito por tentativas, levando-se em conta as limitações de velocidade máxima d'água (1,5 a 2,0 m/s no máximo, para navegação, por exemplo), e largura compatível com a embarcação.

Deve-se lembrar que um trecho todo, deve ser estrangulado de forma a ser obtida uma declividade regular, pois o simples estrangulamento de uma seção provocaria a elevação total do nível d'água, com forte declividade e velocidades. Nos extremos do trecho regularizado deve-se fazer alargamentos graduais de modo a evitar mudanças não convenientes da linha d'água.

Caso não seja possível obter o nível d'água desejado no local crítico, devido às limitações referidas, a solução é estender a regularização para jusante, como é fácil perceber pelo esquema acima.

A regularização dos leitos resistentes é obtida pela construção de diques e espigões auxiliados por eventuais dragagens ou derrocamentos em locais muito críticos.

Cabe lembrar que nestas obras não há necessidade de serem obedecidas as condições de traçado para uma navegação segura e eficaz.

\section{- Tipos de Obras para Regularização do Leito}

Nos métodos clássicos de regularização de leito, emprega-se normalmente, diques e espigões e, eventualmente, soleiras de fundo, dragagens e derrocamento.

Uma vez estabelecido o novo traçado do leito ordinário e as dimensões e formas das novas seções transversais, o que normalmente deverá ser feito em trechos isolados onde o rio apresenta características excepcionais ou anormais, resta escolher 
os tipos de obras a serem empregadas e realizar seus projetos, incluindo a escolha do material a ser utilizado. As características do leito (fixo ou móvel) interferem na escolha dos materiais das obras. Neste estágio deve ainda ser calculado o perfil da linha d'água regularizada, a fim de serem fixadas as cotas de coroamento das obras em função de uma certa vazão de dimensionamento. Isto pode ser feito mediante emprego de modelo matemático, como já mencionado, ou por cálculo direto (em geral admitindo-se fixo).

Quase sempre os rios de fundo móvel são muito largos e pouco profundo e se remedeia os defeitos daí decorrentes pelo estrangulamento do leito. A erosão das margens é a causa principal destas conformações e a proteção das mesmas é parte importante dos trabalhos, nos trechos em que será feito o estrangulamento ou a correção de curvas ou então quando as obras de estrangulamento são realizadas em uma só margem. Ver figuras 124, 125, 126, 127.

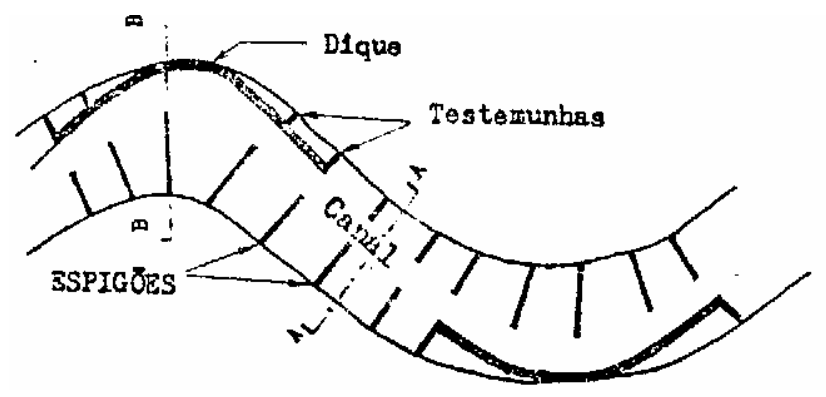

Planta

Figura 124 - Regularização dos leitos - Disposição em planta dos diques e espigões. Planta. Fonte: BRIGHETTI. (2000).

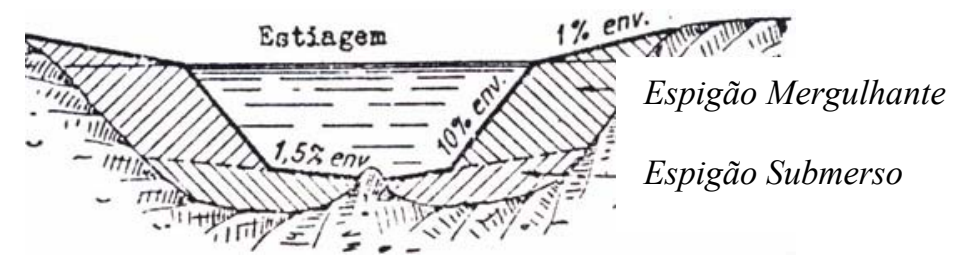

Seção $A-A$

Figura 125 - Regularização dos leitos - Disposição em planta dos diques e espigões. Seção.

Fonte: BRIGHETTI. (2000). 


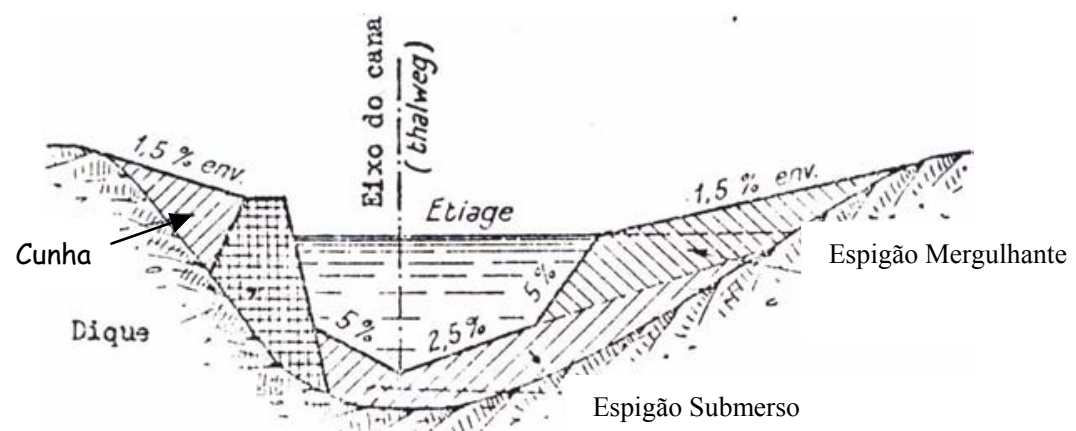

Seção B-B

Figura 126 - Regularização dos leitos - Disposição em planta dos diques e espigões. Seção Fonte: BRIGHETTI. (2000).

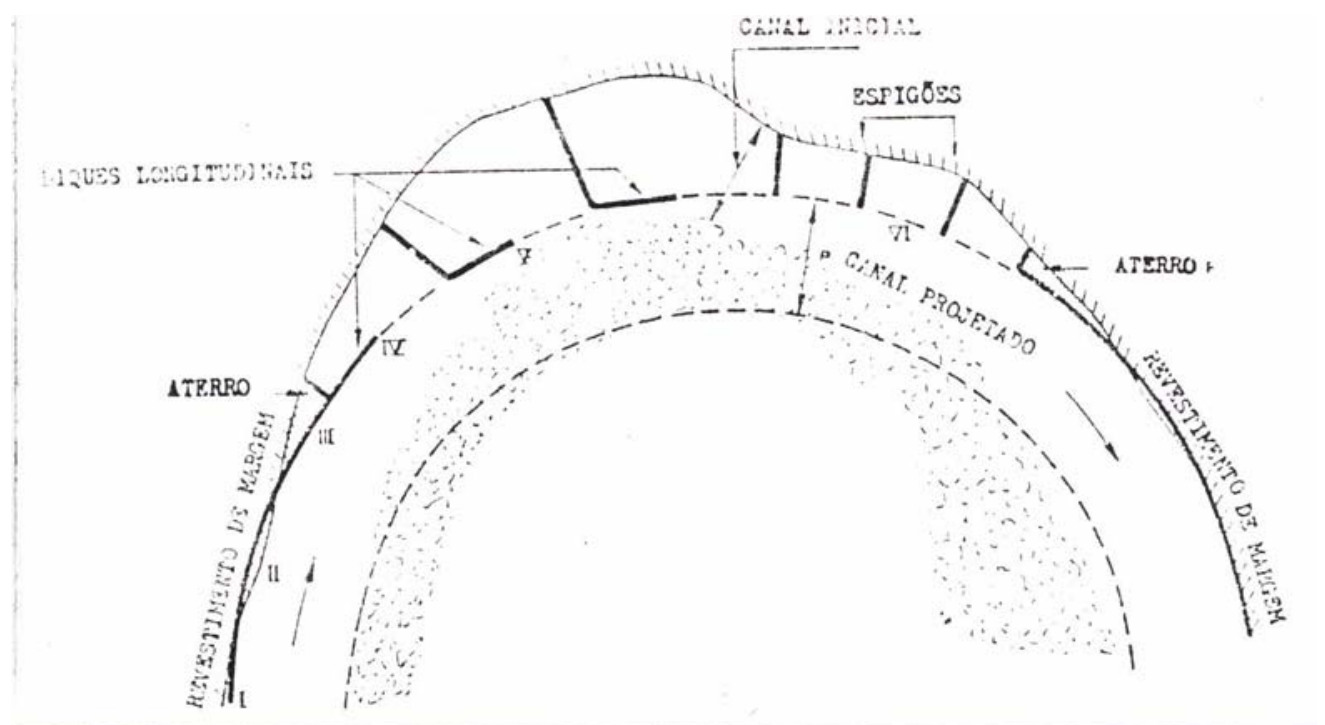

Figura 127 - Regularização dos leitos - Disposição em planta dos diques e espigões. Planta. Fonte: BRIGHETTI \& ALMEIDA. (2002).

g) Derrocamento Fluviais, segundo Brighetti \& Almeida (2002)

Entende-se por derrocamento, os trabalhos destinados a remover materiais rochosos submersos, assumindo-se como materiais rochosos, aqueles cuja dureza não permita a retirada pelos processos normais de dragagem, particularmente de rios e canais submersos ou não, através de seu fraturamento e ou rompimento. Ver figuras 128 e 129. 


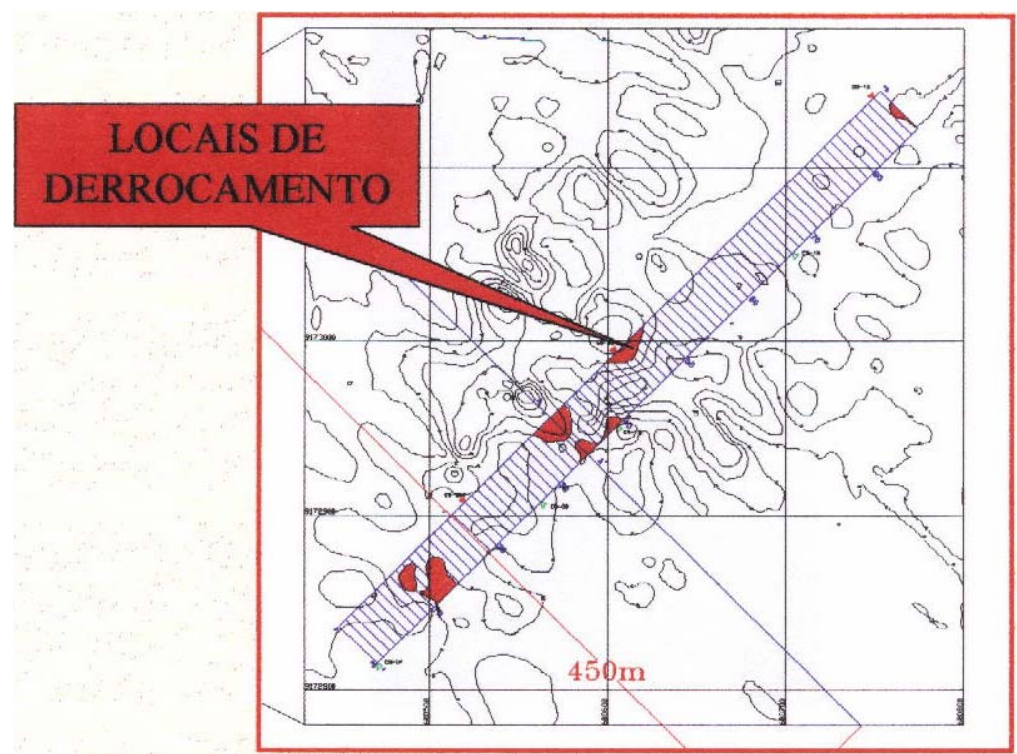

Figura 128 - Derrocamento típico.

Fonte: SOBENA. (2001).

$2^{\circ}$ Seminário Nacional de Transporte Hidroviário.

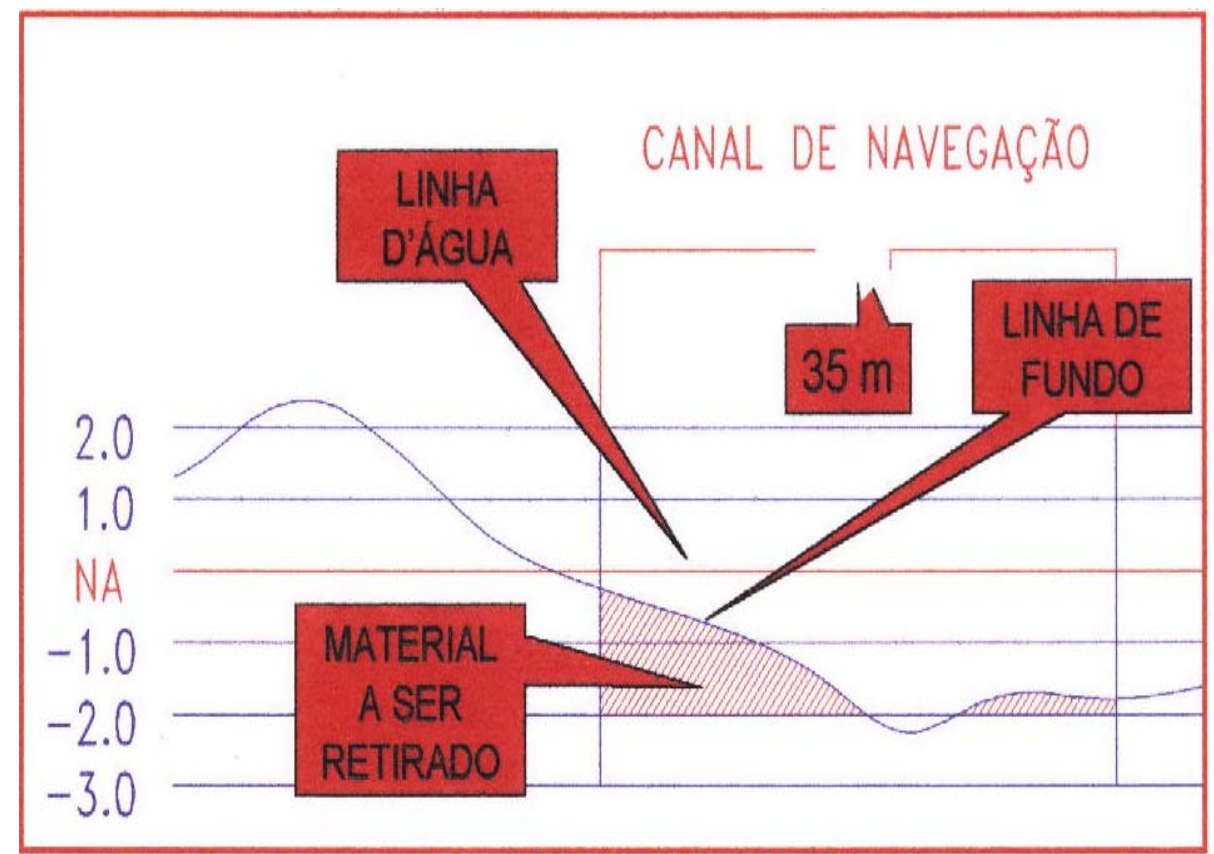

Figura 129 - Derrocamento típico e dragagem.

Fonte: SOBENA. (2000).

2ํㅗำ Seminário Nacional de Transporte Hidroviário. 
Deve-se, desde logo, distinguir duas situações distintas:

- Derrocamento de pedroços (matacões) isolados nos cursos d'água navegáveis, destinado a melhorar as condições de navegabilidade;

- Derrocamentos de abertura de canais em longos afloramentos rochosos.

As diferenças de volume a serem removidos em uma ou noutra situação, faz com que os métodos de trabalho, e mesmo, os equipamentos utilizados, sejam distintos. As considerações a seguir dizem respeito a derrocamentos de grandes volumes de rocha que compensam o emprego de equipamentos pesados.

Por outro lado, o derrocamento de matacão tem pouco interferência (praticamente nenhuma) no regime de escoamento, ao contrário da abertura de canais.

O derrocamento de pedroços isolados, é quase sempre feitos por processos fortuitos, podendo seus problemas serem facilmente compreendidos, com base no que será descrito nos parágrafos a seguir.

Os serviços de derrocamento, são executados em quatro fase distintas, a saber: desmonte do material resistente, retirada do material desagregado do leito, o transporte do mesmo e a sua deposição.

\$ Desmonte do material resistente

O desmonte da rocha, é feito com técnicas específicas, que tem por objetivo o fraturamento ou rompimento do material de dragagem. Operação que pode ser realizada com o emprego de explosivos ou por percussão direta. Nota-se que, ambos os casos, a desagregação é obtida por ondas de choque.

$\rightarrow$ Derrocagem por explosivos

Normalmente o derrocamento fluvial, utilizando-se explosivos, é feito com a introdução da carga em "minas" aberta na rocha. 
O desmonte é feito colocando-se o explosivo diretamente na superfície da rocha e se utiliza a pressão d'água para concentrar as ondas de choque ou se emprega campânulas pesadas com a mesma finalidade. Este procedimento usual em derrocamentos marítimos, não é comum em rios devido às pequenas profundidades e à correnteza das águas. Eventualmente estes métodos podem ser empregados nos períodos de cheia e em zonas de águas mortas. A detonação é sempre feita com espoletas de reação elétrica.

A perfuração das minas submersas, pode ser feita por escafandristas ou por mergulhadores em "sinos de mergulhadores", utilizando perfuratrizes especiais. Nos rios, em que as profundidades são pequenas, a perfuração das minas quase sempre é feita a partir da superfície de embarcações especiais ancoradas, com brocas especiais.

O desmonte por explosivos, é uma técnica altamente especializada que requer uma grande experiência e profundos conhecimentos da rocha local. A distribuição correta das cargas e do poder explosivo das mesmas, é essencial para a obtenção de um rendimento satisfatório e, sobretudo, de um fundo regular, sem descontinuidade, de difícil remoção posterior, bem como a obtenção de blocos de dimensões convenientes; isto só pode ser obtido por tentativas.

A dimensão máxima dos blocos depende, sobretudo, da distância entre os furos, do diâmetro dos mesmos e da carga total, devendo-se em princípio, conservar a carga total em relação ao volume da rocha.

A colocação do explosivo nas minas, normalmente, é feita por escafandristas. Em pequenas profundidades a carga pode ser colocada da superfície através de um tubo guia, que é cravado junto a perfuração.

\section{$\rightarrow$ Derrocagem por percussão}

O desmonte da rocha é obtido por percussões repetidas, ou seja pela queda livre de uma "haste de derrocagem", de grande peso ou por marteletes mecânicos. Em ambos os casos, interessa, basicamente, a energia de choque, que é função da altura de queda da haste (no caso da queda livre) ou da impulsão do martelete. 
Os equipamentos são montados em embarcações chamadas "derrocadores", que devem ter condições excepcionais devido à grande altura da torre ou lança-guia de percussão.

Os derrocadores de queda livre são recomendados para espessuras de rocha de até $1,00 \mathrm{~m}$ ou $1,50 \mathrm{~m}$.

Para rochas muito duras ou muito maleáveis o uso de derrocadores de queda livre não é muito satisfatório devido, seja a grande energia necessária, seja aos inconvenientes de encravamento das hastes. $\mathrm{O}$ trabalho com este equipamento tornase bastante penoso quando a rocha é entremeada de camadas de areia ou argila que entortam e prendem o trépano. Ver figura 130.

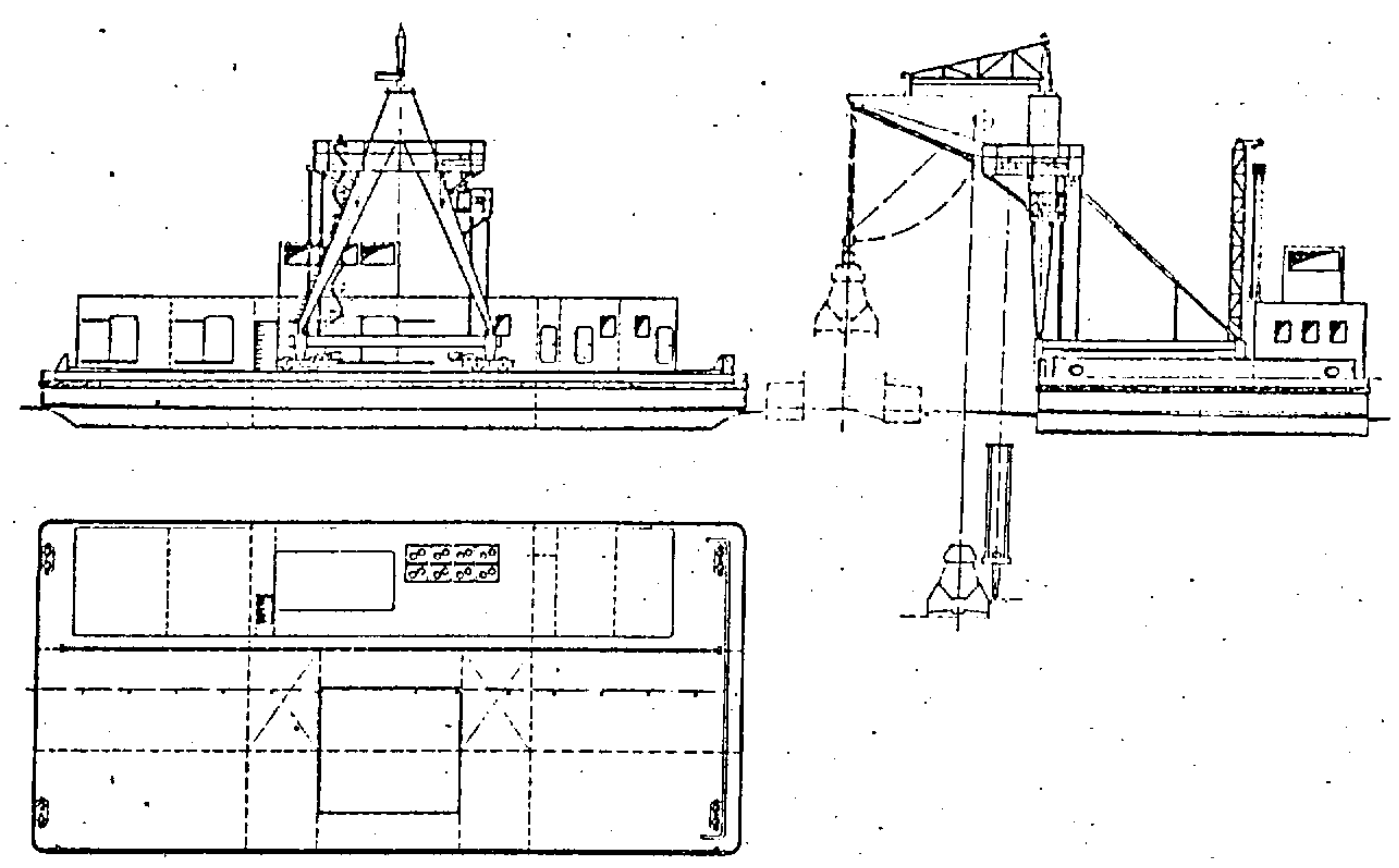

Figura 130 - Derrocador de Percussão - Derrocador de queda livre Fonte: BRIGHETTI \& ALMEIDA. (2002). 
\$ Retirada do material desagregado do leito

É feito, em geral, com o emprego de equipamentos de dragas de trabalho descontínuo do tipo pá mecânica ou de caçamba, empregam-se também dragas de alcatruzes. Eventualmente o material é retirado pela própria correnteza do rio, ou pode deixar de ser executado, limitando-se a um serviço de limpeza do canal, com o afastamento de blocos. O transporte do material derrocado (quando retirado) é feito, em geral, por batelões.

A deposição dos blocos apresenta problemas menores que no caso das dragagens por não haver retorno do material. Por outro lado, a deposição a seco, exige um sistema pesado de transbordo dos batelões para a terra.

No que diz respeito à influência dos trabalhos de derrocamento sobre o escoamento do curso d'água, são válidas as observações feitas para as dragagens, porém o caráter destas é definitivo, enquanto a dragagem muitas vezes é apenas temporário.

Os principais inconvenientes, que podem ocorrer, devido ao aprofundamento do leito por derrocamento são o aumento da velocidade das águas e da declividade, entretanto uma deposição conveniente dos blocos retirado, compensando a seção transversal nas zonas de trabalho, muitas vezes contornam esses inconvenientes.

Finalmente, cabe lembrar que a distinção de derrocamentos fluviais e marítimas, é que estes últimos atingem profundidades maiores e não tem o inconvenientes com a velocidade das correntes.

h) Dragagem

Entende-se por dragagem a remoção, transporte e disposição final do material, que pode ser resultante do derrocamento, areias, siltes, argilas, etc., do leito dos rios ou não, por equipamentos adequados em cada operação (processos mecânicos ou hidráulicos), de modo a criar condições mínimas à hidrovia. Ver figura 131. 


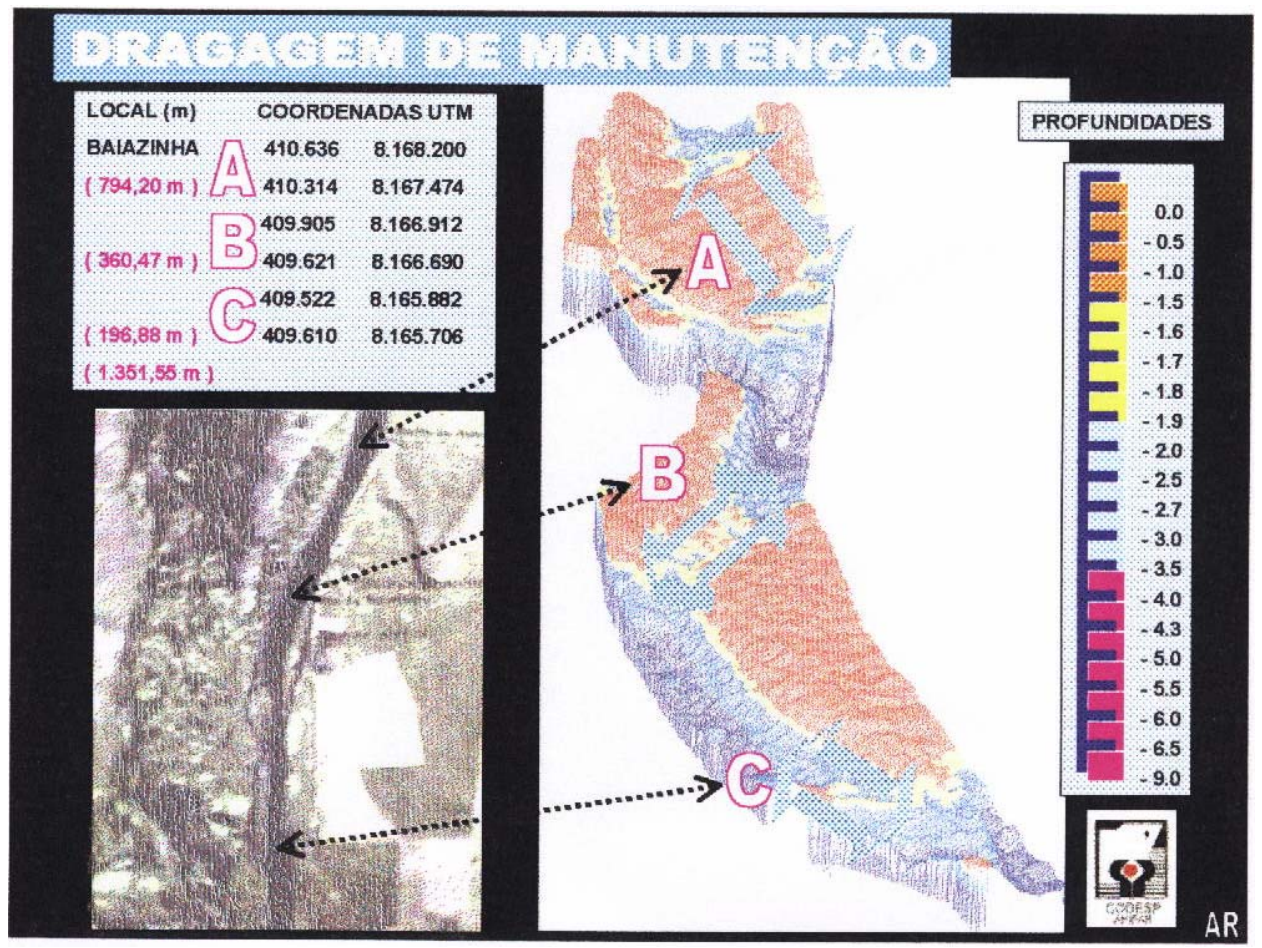

Figura 131 - Dragagem de manutenção.

Fonte: SOBENA. (2000).

2ํㅗㄹ Semírio Nacional de Transporte Hidroviário.

Os métodos normais de dragagem são aplicados para materiais pouco resistentes (sedimentos) porém eventualmente, pode-se dragar rochas friáveis (decompostas) e rochas sãs após desmonte por derrocamento.

As dragagens podem ser executadas em terrenos secos (canais artificiais, cortes de curvas, meandros, etc.).

As dragagens efetuadas em rios apesar de utilizar o mesmo equipamento das dragagens marítimas e dragagens de abertura de canais, apresentam algumas peculiaridades que as distinguem das demais. Estas peculiaridades são:

- Em geral atingem apenas pequenas profundidades (no máximo 4 a 5 m);

São feitas em águas tranqüilas (sem ondas), porém com correntes que podem atingir valores elevados (serão consideradas apenas correntes unidirecionais);

- Os valores movimentados não são muito elevados, o que impede o emprego de equipamentos de grande porte, etc. 
Estas peculiaridades têm importância considerável nos detalhes da operação e escolha de equipamentos. Como característica fundamental das dragagens fluviais deve ser apontada o assoreamento de canal aberto, seja pelo retorno de parte do material dragado, seja pelo transporte de material sólido normal do rio. Este fato faz com que as dragagens fluviais exijam sempre posteriores dragagens de manutenção e crie dificuldades especiais a medição dos trabalhos feitos. Ver figura 132.

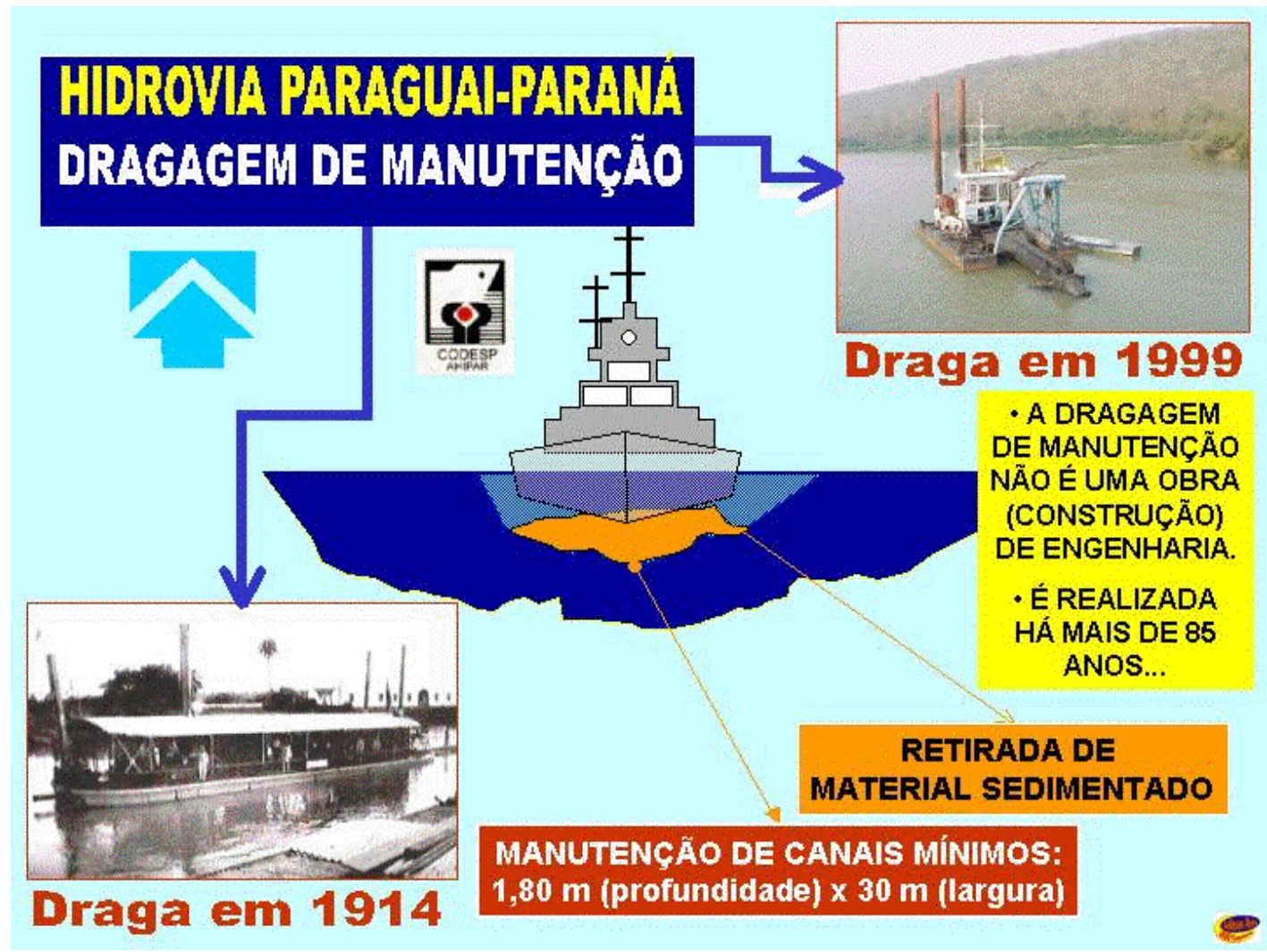

Figuras 132 - Dragagem de um curso d'água.

Fonte: http://www.caceres.com.br/adilsonreis

Cabe notar que estas dragagens de manutenção nem sempre serão no mesmo ponto da dragagem inicial, mas certamente no mesmo trecho do rio.

As dragagens fluviais quase sempre destinam-se a melhorar as condições de navegabilidade, decorrendo daí certas implicações operacionais para não haver prejuízo do tráfego. 
Podem também ser destinadas a melhorar o escoamento das águas, tendo em vista problemas de inundação, facilitar tomadas d'água, irrigação, drenagem (rebaixamento do lençol freático), redução de descargas sólidas, execução de obras (barragens, portos, espigões etc.) e outras finalidades. Por vezes as dragagens visam o aproveitamento do material retirado, para a construção e aterro de áreas marginais. Os trabalhos relacionados exclusivamente com esta finalidade, e não com o rio propriamente dito, são excluídos das considerações a seguir.

\section{Condições particulares, favoráveis à dragagem}

O regime hidrológico do rio e, o conhecimento da sua morfologia são importantes na definição das obras de dragagem. Na maioria dos casos pode-se admitir que todo o material a ser dragado foi depositado pelas correntes e que tenderá a ser substituído por outro de mesma origem. As alternâncias de vazão tem importância primordial para a morfologia fluvial e também para a operação de dragagem.

Do ponto de vista da manutenção dos canais dragados, os rios de regime bem regular, com períodos bem nítidos de cheias e estiagem, e variação gradual da vazão, são os mais favoráveis.

A análise das características de um trecho do rio a ser dragado, fornece importantes conclusões sobre o regime do rio e a constituição do seu leito. Nos trechos superiores, às variações de descarga são muito bruscas, as declividades (e as velocidades) muito elevadas e os materiais de fundo, grosseiros; nos trechos médios e baixos dos rios, por vezes os regimes são também variáveis devido à influência de afluentes, porém sempre as variações são menos bruscas, as velocidades e declividades são menores e o material de fundo mais fino. São estes trechos os mais sujeitos às dragagens e onde geralmente são feitos estes trabalhos.

Quanto a descarga sólida, é importante distinguir o "material em trânsito“ originado na erosão superficial dos terrenos constituintes da bacia hidrográfica e o material do leito propriamente dito. 
O material em trânsito é sempre muito fino e transportado em suspensão; só se deposita eventualmente nos trechos inferiores do rio (estuários e deltas), pouco influem na morfologia fluvial.

O material do leito é em parte transportado em suspensão e em parte por arrastamento e é responsável direto pela conformação do leito móvel do curso d'água.

O material em trânsito, normalmente, não cria problema de dragagem fluvial, do tipo aqui considerado. O material do leito, movimentado e em suspensão deposita-se quando é reduzida a turbulência das águas, isto acontecendo nos trechos de baixa declividade e, nos períodos que seguem as cheias etc. Os depósitos assim criados são bem localizados no tempo e no espaço e podem criar problemas que requerem dragagens. O material de arrastamento de fundo, apesar de ter em geral menor volume que os demais, é normalmente o que cria os problemas de dragagem pela deposição sistemática de areias.

Cabe lembrar que é difícil medir o transporte por arrastamento e que as fórmulas existentes para a sua determinação são pouco precisas. Sabe-se porém que as quantidades movimentadas nas estiagens e nas cheias são completamente diferentes. Assim é possível considerar que o leito do cursos d'água é utilizado por dois rios: o de estiagens e o de cheias, cada qual com seu caráter próprio, seu leito, sua profundidade e até mesmo, em certos casos, com seu sistema de meandros. Essa dupla função traz grandes dificuldades para a navegação e para os trabalhos de dragagem.

A execução de canal para a estiagem, é completamente destruído pelas cheias. Quando o regime é muito variável, os trabalhos de dragagem podem, mesmo não ter nenhum resultado prático.

Nos rios de grande descarga de cheia, a dragagem pode constituir um excelente recurso abrindo canais onde o rio de estiagem, ainda não o conseguiu fazer. A dificuldade está em saber onde localizar o canal, para este adaptar-se bem às condições naturais e ter maior durabilidade. Estas dragagens, de uma maneira geral, precisam ser refeitas anualmente. Nunca, porém, o canal terá absoluta 
estabilidade e trabalhos de manutenção, serão sempre necessários porque as profundidades serão maiores que as impostas pelas condições hidráulicas e porque mesmo o canal natural muda continuamente com o tempo.

Há alguns rios que apresentam seu leito principal, de cheia, relativamente retilíneo e largo. O leito de estiagem, muito mais estreito, serpenteia neste leito principal, entre os bancos de areia. Estes rios (ou trechos de rios) espraiados são muito desfavoráveis para a navegação, pois os leitos de estiagem são muito estáveis e sinuosos. Em geral não são feitas dragagens em rios desse tipo.

Nos rios de meandros, as dificuldades surgem quase sempre nos pontos de inflexão, nas desembocaduras dos afluentes, nos acidentes localizados como gargantas, afloramentos rochosos etc. (podem transformar os rios de meandros em rios espraiados). Às vezes para tomadas d'água, os problemas localizam-se nas curvas convexas.

Os baixios a serem dragados têm cada qual sua característica própria que dificilmente podem ser comparados a outros do mesmo curso d'água ou de outros cursos d'água. Sofrem modificações importantes de ano para ano e às vezes na mesma estação. Devem sempre ser considerados dentro do rio, e não isoladamente.

\section{- Dragagens - Aspectos técnicos}

A dragagem, que compreende: retirada, transporte e deposição do material submerso por processos mecânicos ou hidráulicos, apresenta os seguintes aspectos técnicos:

四Influência no regime hidráulico

A influência da dragagem no regime hidráulico do rio pode ser determinada através dos métodos clássicos da hidráulica fluvial, bastando admitir-se fórmulas do regime uniforme e pesquisar as conseqüências do aumento (e eventualmente modificações da forma) das seções transversais. 
O canal a ser dragado para aprofundar um baixio e, o aprofundamento de uns poucos metros em uma pequena parte da área da seção, ainda que mude ligeiramente a resistência ao escoamento, pouco pode influenciar na linha d'água.

Localmente podem ocorrer alguns desvios de filetes e mudanças na distribuição das forças erosivas e outras condições originais. Estas influências locais são reduzidas ao mínimo se o alinhamento do novo canal for convenientemente escolhido, respeitando a disposição geral do escoamento na estiagem. Sempre porém, haverá influências devido a mudanças na turbulência, efeitos de vórtices nas beiras dos canais, tendência ao escorregamento de partículas nos taludes do canal etc.

Alinhamento do Canal

A escolha do alinhamento do canal é muito importante, não havendo regras fixas, além das mencionadas acima. Somente a prática e a experiência do projetista, pode dar as indicações definitivas. O ideal, seria projetar o novo canal para atender as condições de equilíbrio morfológico, além das condições necessárias à navegação, se assim o for.

Deve-se porém ter em conta que se o canal não concordar com as correntes, haverá sempre um aumento na tendência à sedimentação. Além disso é mais fácil dragar, e as embarcações trafegam melhor em um canal que concorde com os filetes líqüidos. É quase impossível, em um grande rio, através de dragagens, modificar de tal forma o escoamento que o mesmo se adapte integralmente à nova situação evitando-se as dragagens de manutenção.

Por outro lado, é perigoso orientar a escolha do canal a dragar, considerandose unicamente os custos iniciais das obras, devido a dificuldade em estimar os volumes que deverão ser realmente dragados.

O estudo teórico, com base nas condições hidráulicas e descargas sólidas, é possível e útil, porém não leva a valores seguros que só podem ser obtidos por experiência (dragagem de prova) ou por comparação (difícil) com outras situações similares. 
Transporte do material dragado

Há quatro métodos para transportar o material dragado, são eles:

q Depósito nas cisternas da draga (auto transportadoras)

Este método só tem emprego em dragagens marítimas, em estuários ou em grandes rios. As dragas com suas tremonhas cheias tem grande calado, incompatível quase sempre com as condições fluviais; a perda de tempo para o transporte é antieconômica e o processo só se justifica quando os outros métodos não são exeqüíveis. Ver figura 133

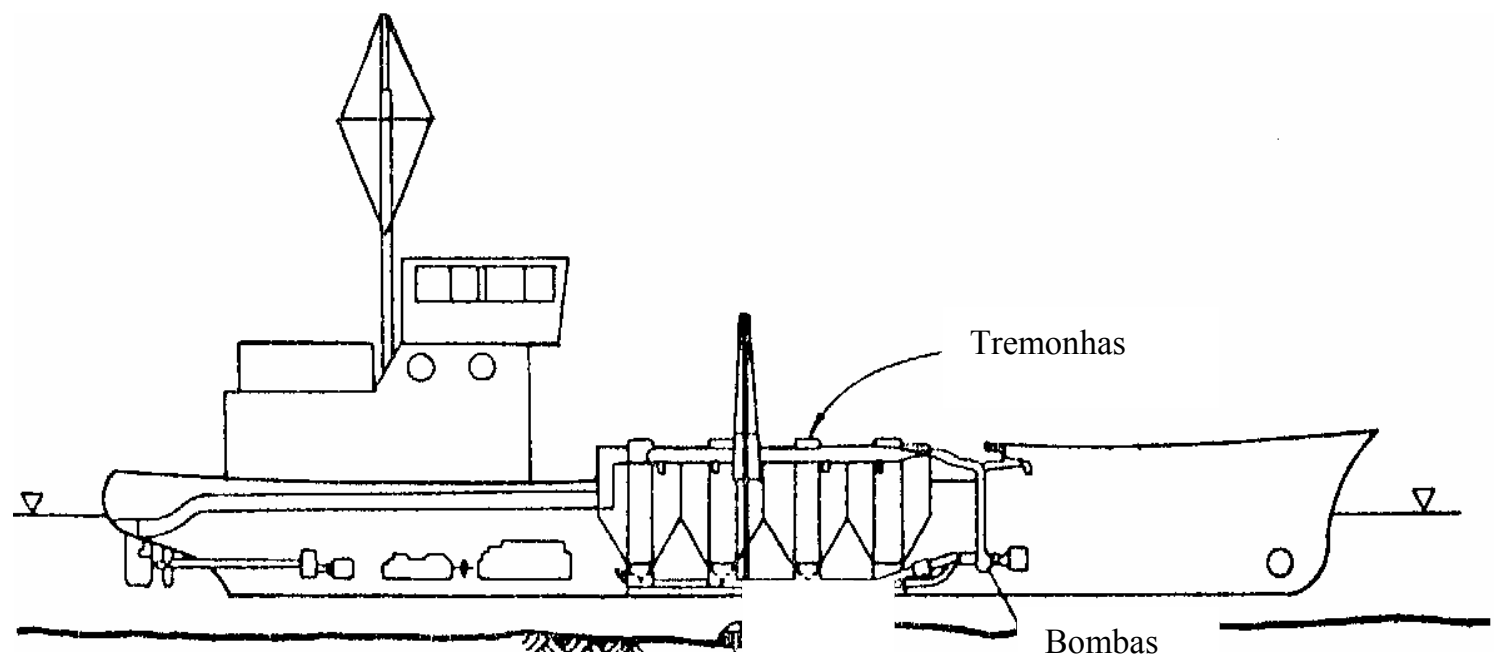

Figura 133 - Draga auto transportadora

Fonte: Department of the army corps of engineers office of the chie of engineers. ( 1983). 


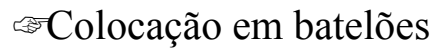

Este método, é o de menor custo e, viável, somente, quando a dragagem é feita por equipamento mecânico ou de caçambas, mas tem o inconveniente da manobra dos batelões; justificando-se quando o local de bota-fora é distante, o que normalmente não se dá em rios.

a Dragagem por agitação (Lançamento na água corrente, fora do canal)

A dragagem por agitação, só tem vantagem quando o material é muito fino e, o escoamento do rio é favorável, isto é, o material não se deposita em região na qual pode trazer problemas futuros. Não existe o bota-fora, que aliás é discutível quando o material é muito fino.

Recalque por tubulação

Na maior parte das vezes, usa-se o recalque por tubulação quando se deseja conduzir o material, exatamente, para um ponto conveniente no leito ou nas margens.

Se necessário, pode-se empregar estações intermediárias de recalque (busters) que permitem alongar de muito a distância de transporte ou, então, pode-se utilizar tubulação para lançar a mistura a uma certa distância, no próprio rio, combinando com o sistema de agitação (sempre para materiais finos).

\section{Despejo do material dragado}

A escolha correta do local de depósito do bota fora da dragagem é muito importante para o rendimento dos trabalhos e para minimizar os impactos.

Em princípio há três alternativas: 
Remoção para fora do leito

A remoção do material dragado, para fora do leito, é a alternativa mais fácil, desde que haja locais apropriados, pois elimina qualquer efeito desfavorável no leito do rio.

Esta alternativa, é de custo elevado, mesmo quando o material retirado pode ser vendido como material de construção, devido às dificuldades de aliar os interesses comerciais aos trabalhos do rio (finalidades muito diversas). É favorável quando o material pode ser usado para aterros marginais, porém esta situação pode não ser muito comum nos trechos médios dos rios ou, então, precisam ser definidas (preparadas) áreas específicas para a disposição deste material, avaliando os seus impactos ambientais.

따DDeposição do material dragado em um trecho do rio

A utilização do material dragado para orientar os filetes líquidos e favorecer o escoamento no baixio, exige o conhecimento muito preciso das condições locais, das forças em ação e as respostas da natureza à interferência humana. Mesmo ensaios em modelos em escala reduzida podem não levar a resultados satisfatórios, se faltar esta vivência do problema.

Se, porém, for obtido sucesso, o canal poderá vir a tornar-se muito estável, reduzindo-se as dragagens de manutenção pelo efeito do fluxo concentrado nas cheias. Em princípio, o material retirado deverá ser colocado formando banquetas laterais. Eventualmente, pode-se recorrer a "barreiras" de madeira e geotêxteis para reter o material onde for lançado.

Esta alternativa, é mais conveniente para o material de maior granulometria, que presta-se melhor ao estudo de movimentação que o material fino, transportado por suspensão.

* Deposição do material dragado nas margens 
A colocação do bota-fora nas margens visando a recuperação e aterro dos terrenos marginais exige alguns cuidados especiais. $\mathrm{Na}$ área a ser reservada para este fim, deve ser levada em conta a compactação do terreno suporte e do material dragado.

É quase sempre necessário prever diques de contenção que podem ser realizados de diferentes maneiras, desde enrocamentos até paliçadas de estacas de madeira, mas de maneira geral, com solo ou com o próprio material dragado. Por vezes usam-se diques permeáveis, contando-se com a colmatação pela própria mistura dragada. No caso do material ser dragado por sucção e recalque, sendo grande o volume de água lançada no bota-fora, deve ser planejado o retorno da água para o rio, com o menor aporte possível de sedimentos.

Geralmente é feita a compartimentação da área do bota-fora, visando dar um maior tempo de decantação pelo aumento do percurso d'água até o rio e, para obter maior sedimentação nos depósitos parciais.

A altura dos diques de contenção é problema técnico importante. Em princípio quanto mais elevado, melhor, porém, grandes alturas são caras e difíceis construtivamente de serem obtidas. $\mathrm{O}$ nível final do aterro deve ser previsto acima do nível médio das águas e de preferência mesmo, acima do nível da máxima enchente. Quando, porém, tal não é possível, devido por exemplo à altura manométrica requerida, a superfície final deve ser protegida, por exemplo pela plantação de gramíneas, que impedem o retorno do material pouco resistente ao curso d'água. Proteção especial deve ser dada também ao talude final do aterro. Esta alternativa, é geralmente a de menor custo e de fácil operação.

점 Dragagem por agitação

Na dragagem por agitação, o material é simplesmente colocado em suspensão para que as correntes o levem. Este método pode ser recomendável, para materiais finos (silte, vasa) porém para a areia é necessário verificar se ficará em suspensão o tempo necessário para ser levado além da área a ser escavada. 
A deposição devido o retorno de uma parte do material, ainda na área a ser dragada pode, porém, ser aceitável face a economia do transporte. Sempre, porém (e qualquer que seja o método seguido), é conveniente efetuar a dragagem de montante para jusante. A "repassada" da draga pode viabilizar o transporte para além da área a ser dragada.

- Profundidade a ser dragada

A fixação da profundidade a ser dragada, é sobretudo um problema econômico ligado aos problemas específicos a serem resolvidos; calado econômico da embarcação.

Para a navegação a profundidade é fixada em função da melhoria das condições de navegabilidade na estiagem. Deve-se porém, ter em conta que as dragagens não devem ser executadas visando uma modificação de frota, devido ao caráter precário da melhoria obtida por este método; pode ser admitida uma navegação com menor calado neste período.

A experiência mostra que é difícil e muito oneroso garantir, através de dragagens fluviais, um aumento permanente de profundidade da ordem de $1,0 \mathrm{~m}$ em rios de médios e grande porte.

\section{Execução da dragagem}

Os trabalhos de dragagem devem ser, de preferência iniciados assim que o nível d'água começa a baixar e que surgem os primeiros problemas por falta de profundidade. Esses pontos, de maneira geral, são conhecidos quando das primeiras dragagens.

A boa técnica é de iniciar os trabalhos por uma simples raspagem, acompanhando a reação do rio, e só aprofundar o canal quando constatado que o alinhamento adotado é de fato satisfatório. Não se deve porém demorar muito para 
atingir o objetivo colimado, pois somente quando totalmente aberto o canal é que este virá de fato a funcionar.

Como a draga tem elevado custo, há interesse em mantê-la em operação contínua, com o pessoal trabalhando em turnos. Entretanto, em rios é difícil o trabalho noturno devido aos custos elevados de iluminação, tripulação e principalmente dificuldades em manter o alinhamento e fazer o despejo à noite. Geralmente é mais econômico reservar o período noturno para manutenção da draga e trabalhar no máximo 12 a 14 horas por dia e 24 dias por mês.

É necessário lembrar as perdas de tempo para levar a draga de um baixio a outro (dificilmente um único baixio ou conjunto de baixios tem volume suficiente para manter uma draga durante toda a estação em um trecho do rio). Estas perdas de tempo muitas vezes fazem com que, em dragagens fluviais seja mais econômico o uso de várias dragas pequenas em vez de uma grande, de maior rendimento; um estudo econômico deve esclarecer sempre este ponto, lembrando inclusive a facilidade de navegação.

Para o cálculo do rendimento final da dragagem é necessário também lembrar as perdas de tempo devido a: variações do nível d'água, de velocidade de correntes e outras características do rio.

따을 Controle de dragagem

O controle da dragagem é muito importante, sobretudo pelas dificuldades de medição dos trabalhos como será posteriormente indicada. De preferência este controle deverá ser feito no campo, instalando-se locais apropriados para a apuração dos levantamentos ecobatimétricos e um pequeno laboratório de análise dos materiais.

Inicialmente deve-se efetuar os levantamentos que permitam caracterizar bem o terreno, incluindo a batimetria detalhada, característica, tais como: densidade específica "in situ"; expansão provocada pela extração; coesão e ângulo de atrito 
natural do terreno; estabilidade dos taludes na zona dragada e no bota-fora etc., do material de fundo e sondagens profundas (até $1 \mathrm{~m}$ abaixo da cota a ser dragada).

A classificação do material a ser dragado é outro aspecto importante, por levar em conta as características geotécnicas, como por exemplo a resistência do material, o que não se obtém pela simples classificação granulométrica.

O acompanhamento e controle das dragagens deve ser feito através de amostragens sistemáticas do material dragado e levantamentos batimétricos.

A fim de permitir uma acomodação do terreno e evitar que um grande assoreamento venha a modificar o canal, deve ser dado um intervalo razoável entre a dragagem e o levantamento batimétrico.

O controle da dragagem deve, também, objetivar a minimização das alterações na porções físicas do meio ambiente.

Equipamentos de Dragagem

A escolha do equipamento de dragagem, além das observações acima, é extremamente importante. São elementos básicos para esta escolha: o tipo de material a ser dragado (quase sempre areia); velocidade e flexibilidade com que deverá ser executado o serviço. Não se deve perder de vista que normalmente os volumes a serem dragados em um trecho de rio não são suficientes para dar serviço permanente ao equipamento, não sendo conveniente optar por um equipamento muito especializado que não poderá servir para certos serviços ( corte de meandros, retificação de curvas, etc. ), que muito provavelmente deverão ser realizados, mesmo que não previstos inicialmente.

Há uma grande variedade de equipamentos o que por um lado possibilita a seleção do mais apropriado para as circunstâncias particulares, mas que por outro lado dificulta a escolha. As dragas dos diferentes tipos podem ser auto propulsoras ou não. A escolha sob este ponto de vista depende sobretudo de condições econômicas que justificam a instalação do sistema propulsor, sempre, bastante oneroso e que obriga a dimensões maiores, face ao uso que terá na movimentação 
entre vários baixios a serem dragados. Se os mesmos são próximos e os volumes a serem retirados em cada são elevados, será certamente mais conveniente movimentar a draga com rebocadores.

Tipos de equipamentos de dragagem

Do ponto de vista do princípio do funcionamento do equipamento, pode-se distinguir dois tipos principais de dragagem: por via mecânica e por via hidráulica.

\. Dragas mecânicas

As dragas mecânicas são de dois modelos fundamentais: as de alcatruzes e as de trabalho descontínuo ( de caçamba, escavadeira, pá mecânica, etc.).

$\rightarrow$ Dragas de alcatruzes

A draga de alcatruzes consta de uma corrente sem-fim de caçambas, que correm do local de escavação a um ponto acima do nível d'água. Cada caçamba escava sua própria carga e a traz a superfície. Ao passar sobre o tombo superior, a caçamba despeja seu conteúdo e, volta ao local da escavação. O ciclo de trabalho contínuo torna a draga de alcatruzes mais eficiente do que os demais tipos de dragas mecânicas.

As dragas de alcatruzes são adaptadas para materiais coesivos moles ou não coesivos e, retiram do leito do rio mais sedimentos do que água. Por outro lado, exigem sempre o emprego de batelões para o transporte e, o bota-fora deve ser de fácil acesso. Ver figura 134.

O esvaziamento dos batelões em lugares rasos é problemático ou mesmo impossível, o que impede o uso do material dragado para aprofundar o canal e para aterro (direto) dos terrenos marginais. 
Deve-se ainda lembrar que as dragas de alcatruzes são bastante delicadas e requerem muita manutenção. Estas dragas só apresentam alto rendimento quando são de grande capacidade e dragam material bastante homogêneo.

Todos estes motivos fazem com que as dragas de alcatruzes sejam sobretudo indicadas para os trechos marítimos dos rios (estuários) ou para cursos d'água de excepcional porte (rios Paraná e Amazonas, etc.).

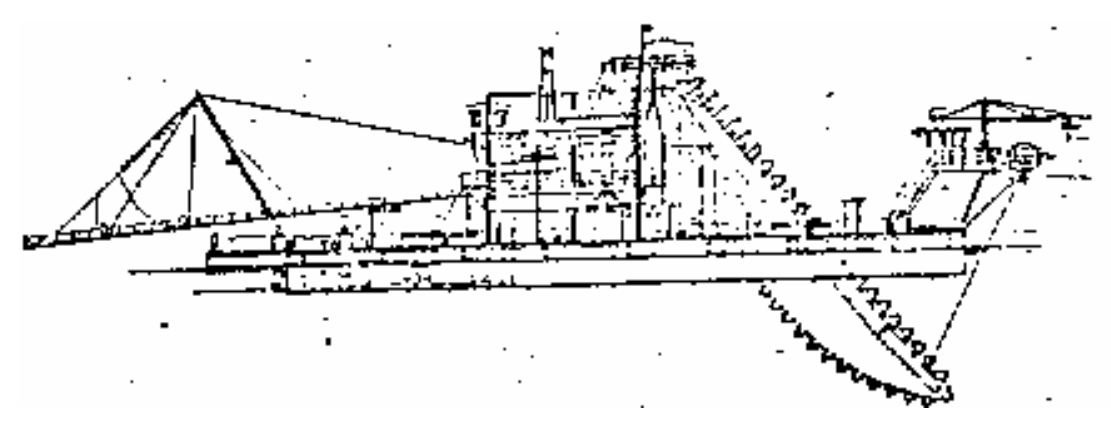

Figura 134 - Draga de alcatruzes

Fonte: BRIGHETTI \& ALMEIDA. (2002).

$\rightarrow$ Dragas de trabalho descontínuo ( de caçamba, escavadeira, pá mecânica, etc.)

De um modo geral, as dragas descontínuas tem pequena capacidade de escavação em relação a seu custo e, só são empregadas em casos especiais, sobretudo de retirada de blocos de maior dimensão (produto de desmonte por derrocamento), etc., quando utilizadas em trabalhos normais de manutenção de profundidade em rios, não apresentam bom rendimento.

A draga de colher é essencialmente uma escavadeira cuja principal vantagem se encontra na alta potência da lança, que força a caçamba a penetrar no terreno e escavar. É empregada, principalmente, na escavação de materiais duros e compactos, isto é, na abertura de novos canais, além da retirada de rochas ou formações similares, não é recomendada para a manutenção de canais. Ver figuras 135 e 136. 
A draga clamshell é equipada com uma caçamba clamshell, suspensa de uma lança rotativa. O tipo de material que pode ser removido por uma draga clamshell é limitado. Quando opera em depósitos muito finos a tendência do material é de escapar da caçamba, ao trabalhar em materiais sólidos a penetração possivelmente não será suficiente para encher a caçamba. A grande vantagem das dragas clamshell está no fato de poderem operar em áreas restritas, perto de cais, molhes, etc. Ver figura 137.

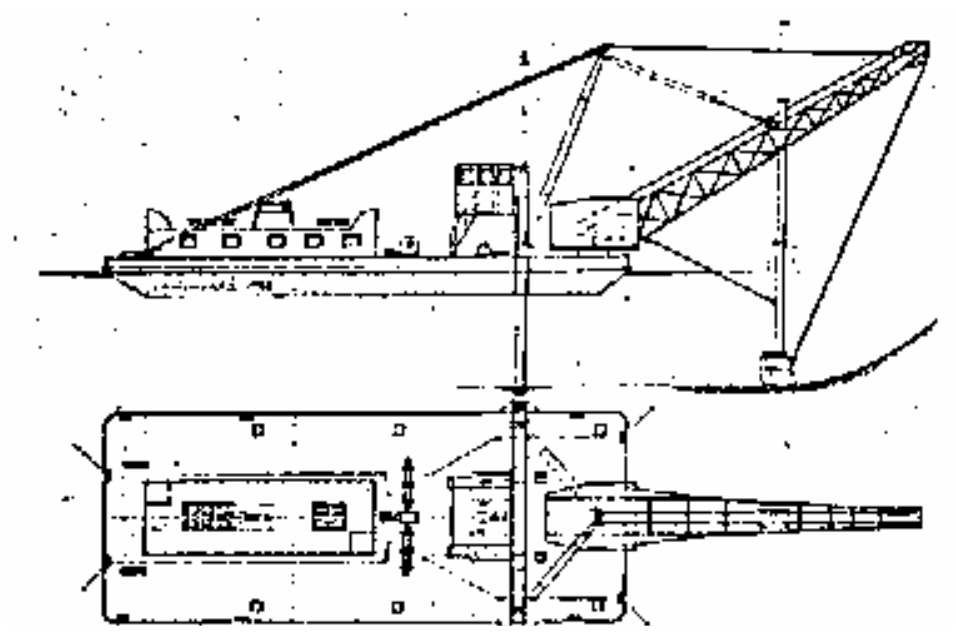

Figura 135 - Draga de colher

Fonte: BRIGHETTI \& ALMEIDA. (2002).

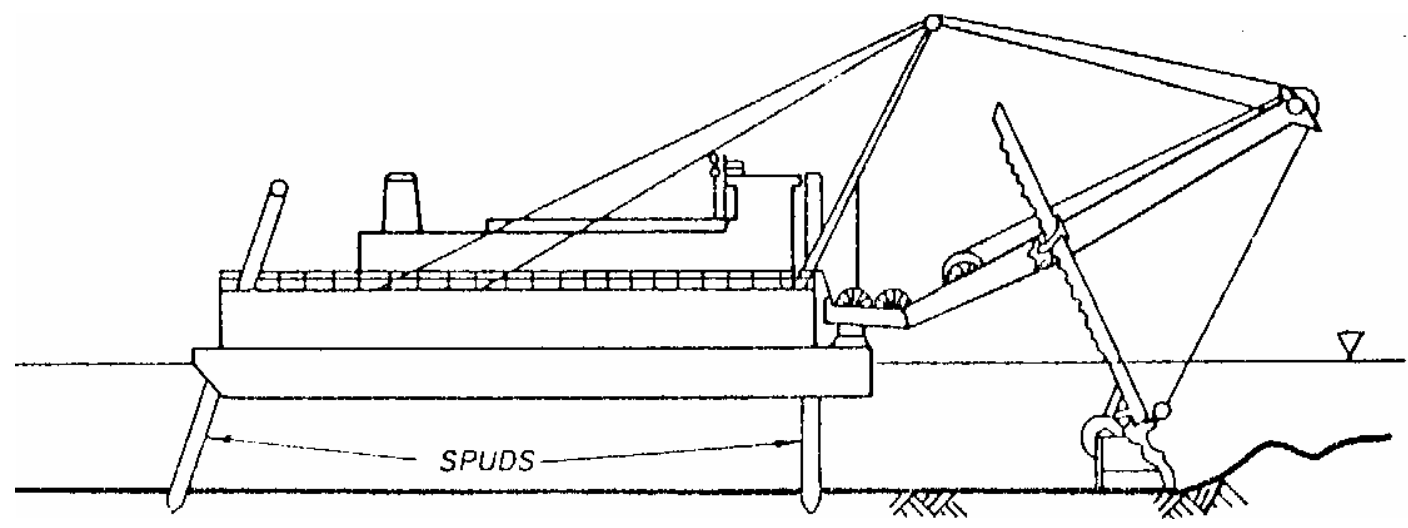

Figura 136 - Draga de colher

Fonte: Department of the army corps of engineers office of the chie of engineers. (1983). 


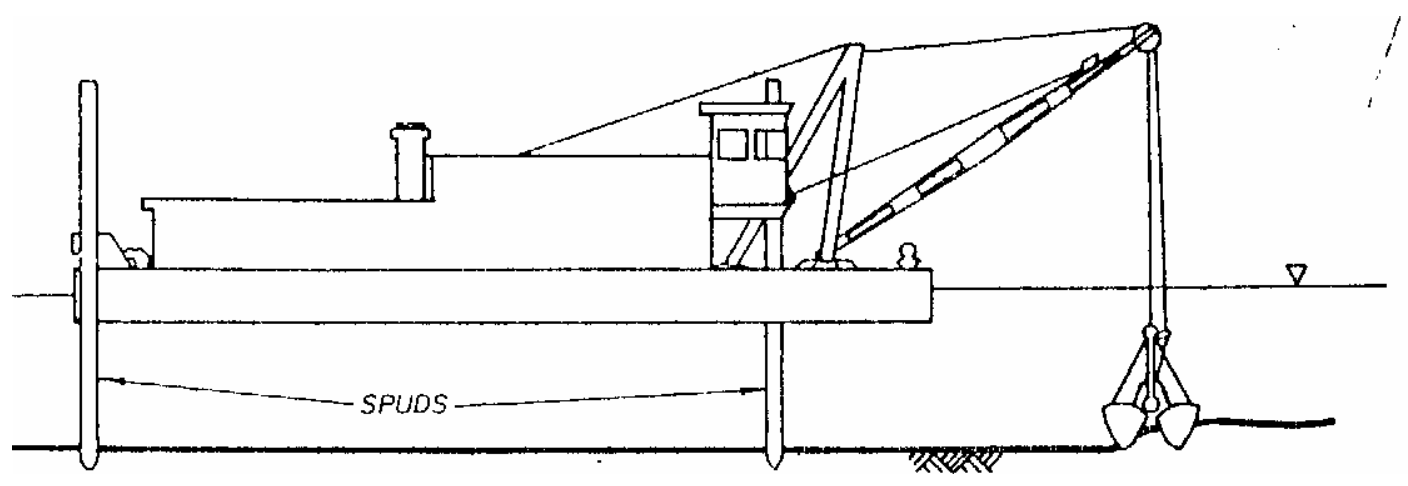

Figura 137 - Draga de clamshell

Fonte: Department of the army corps of engineers office of the chie of engineers. (1983).

\ Dragas hidráulicas ou de sucção

As dragas hidráulicas ou de sucção são as mais apropriadas para os trabalhos normais em rios.

Funcionam basicamente pela sucção de uma mistura de água (80\% a 90\%) e material sólido (10\% a 20\%) arrancado do leito. A quantidade do material retirado é função da concentração do material sólido na mistura que por sua vez depende da desagregação das partículas do leito ou seja, da força de arrancamento e da resistência oferecida a esta força.

A resistência é característica do material do leito ou seja, da sua coesão e do peso das partículas.

Nas dragas mais primitivas, providas apenas de um simples tubo de sucção, o arrancamento das partículas era devido somente à depressão provocada pela sucção

Processo semelhante é usado em certas dragas marítimas do tipo de arraste (“hopper") nas quais os tubos (1 ou 2) são arrastados, apontados para trás, nestas dragas as vezes é dada uma forma ao tubo de sucção para facilitar o arrancamento.

$\rightarrow$ Funcionamento da draga de sucção

Desagregador giratório 
É uma espécie de broca ou coroa que gira em frente do tubo de sucção, rompendo o solo em pequenos blocos facilmente succionados. Há diferentes formas de desagregadores, quase sempre porém, são providos de lâminas removíveis (para facilitar a manutenção) de material extremamente duro. Com os desagregadores giratórios, pode-se dragar bem, de areia até argila muito compacta e mesmo rocha macia ou decomposta. Ver figura 138 e 139.

As dragas de sução e recalque com desagregador são as mais usadas entre todos os tipos. São equipadas com um desagregador rotativo, que solta o material a ser dragado. Este é então misturado com água, aspirado por uma bomba de dragagem e descarregado através de uma tubulação. Podem escavar e bombear material de aluvião, argila, tabatinga e outros depósitos similares.

Nas dragagens de desassoreamento (manutenção do canal) o material a ser retirado é solto (areia, argila e silte) não necessitando de desagregadores, entretanto seu uso pode aumentar o rendimento de sucção. Em geral, o desagregador tem diâmetro de 2 a 2,5 vezes o diâmetro do tubo de sucção e em cada passagem é cortada uma fatia com espessura um pouco superior ao diâmetro, obtendo-se um fundo bem liso e plano. A operação é feita com a draga fixa, girando em torno de um dos dois "spuds" (charutos), o outro servindo para a movimentação que é feita por "passos". O movimento giratório é obtido por cabos ancorados no leito (ou fixados na margem) e guinchos. Ver figura 140.

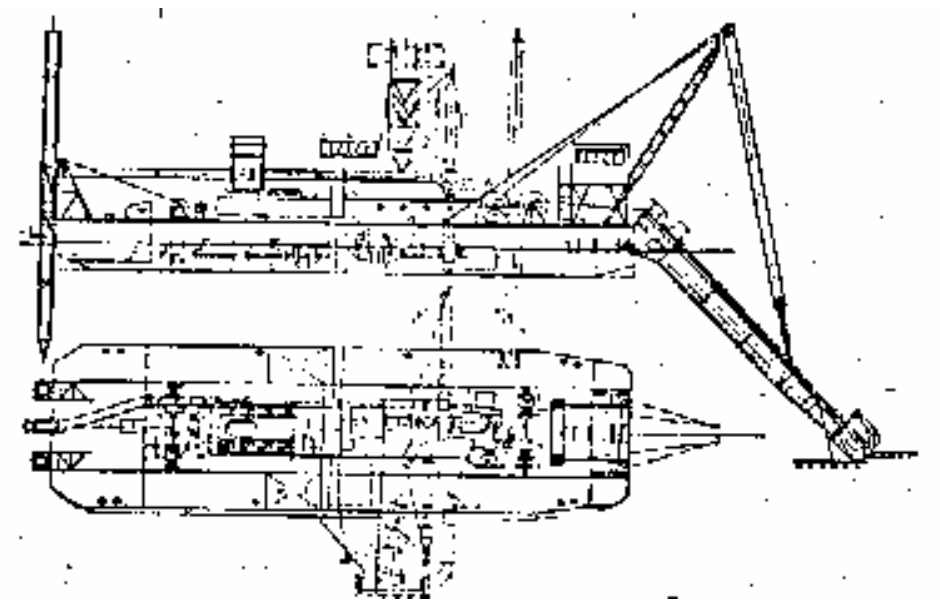

Figura 138 - Draga de sução e recalque com desagregador.

Fonte: BRIGHETTI \& ALMEIDA. (2002). 


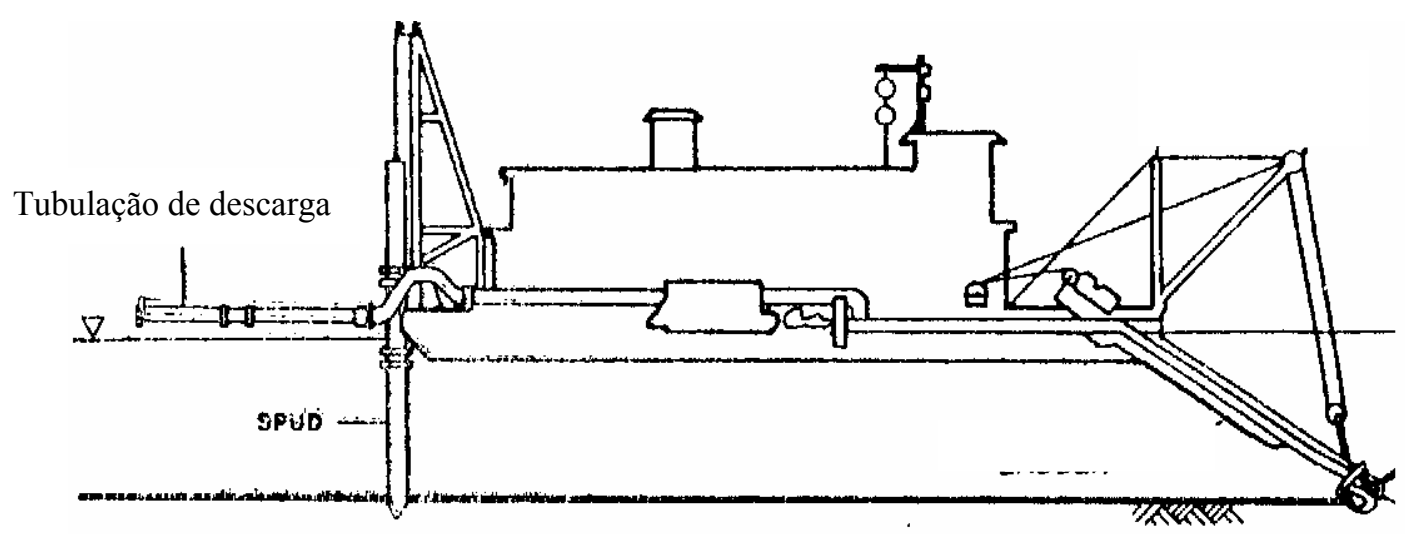

Figura 139 - Draga de sução e recalque com desagregador

Fonte: Department of the army corps of engineers office of the chie of engineers. (1983).

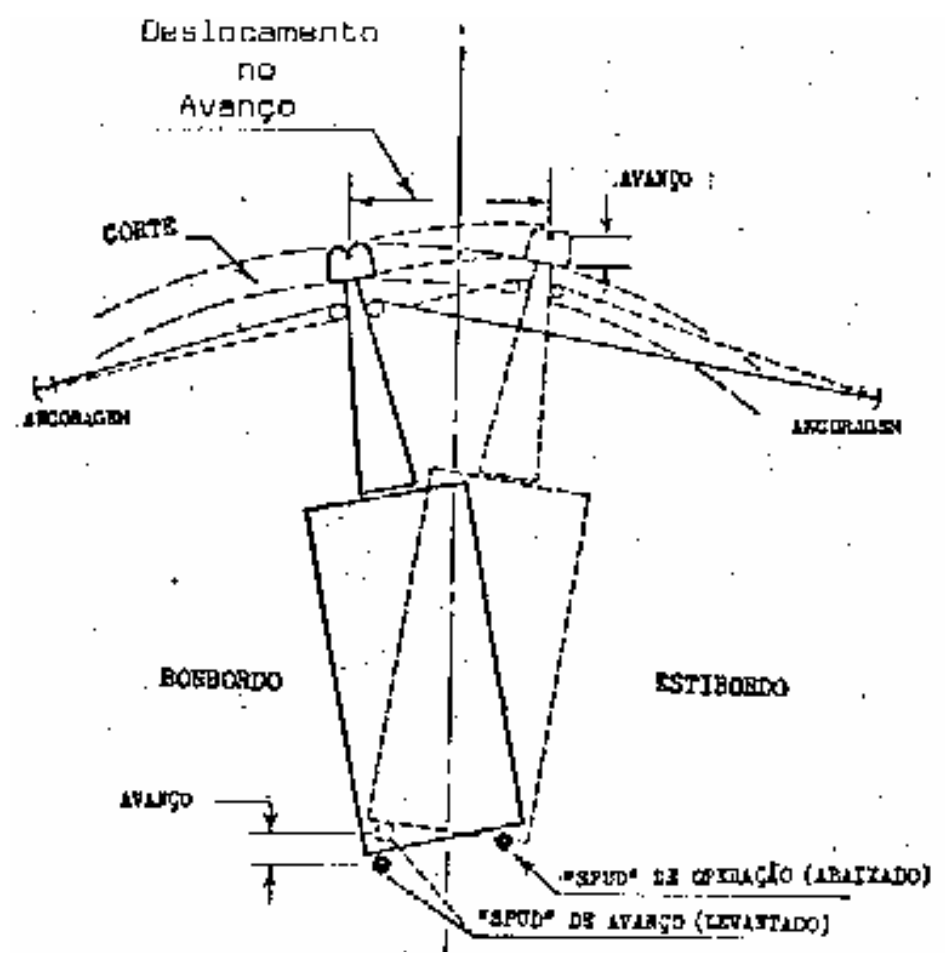

Figura 140 - Movimentação da draga.

Fonte: BRIGHETTI \& ALMEIDA. (2002). 
DPá de sucção (Jatos de Emulsionamento do Material do Leito)

A pá de sucção, utiliza energia hidráulica através de um certo número de jatos d'água, lançados violentamente na entrada do tubo de sucção, que coloca em suspensão as partículas do fundo por turbulência. A boca do tubo de sucção é alargada com dimensão da ordem de grandeza da boca da draga, e conta com diversas fendas entre as quais saem os jatos d'água. Esta boca é ligada rigidamente à draga e empurrada na sua frente. Os jatos d'água dão uma distribuição uniforme à entrada do material, impedindo o entupimento; provocam em conjunto com a sucção um turbilhão de eixo horizontal que desgasta o talude e carrega o material para o tubo.

O sistema dá bons resultados para a areia pura ou argila, porém dá resultados precários para solos totalmente argilosos. A faixa dragada em cada passagem não é muito espessa, sendo o processo apropriado sobretudo quando o aprofundamento a ser obtido não é muito grande, como muitas vezes ocorre para efeito de navegação.

Os cortes são feitos em longas faixas retilíneas paralelas, puxando-se a draga por cabos ancorados avante.

As dragagens podem ser feitas a favor ou contra a corrente. Se feitas contra a corrente há o inconveniente do retorno do material para o canal dragado, porém, os riscos da operação são menores (sobretudo com as pás de sucção).

As força de arrancamento pode ser aumentada por diferentes processos, sendo os mais importantes o desagregador giratório e a pá de sucção.

Dombas de areia

A bomba de areia é o elemento mais importante da draga de sucção. Dela depende o desempenho de todo o equipamento. Deve ser projetada de forma que os blocos de dimensões consideráveis passem pelo rotor, com pouco desgaste e fácil manutenção. São sempre usadas bombas centrífugas. 
A vazão da bomba depende da altura piezométrica necessária para vencer a perda de carga na tubulação de recalque. Se a vazão é elevada, a velocidade também o é, e todo o material sólido escoa na tubulação sem grandes problemas.

Se a vazão porém é bruscamente reduzida, por exemplo em conseqüência de uma obstrução na entrada, a velocidade cai e parte do material sólido pode decantar na tubulação, reduzindo a seção de escoamento. Se a redução da seção de escoamento resultante provocar um aumento de perda de carga e, devido à redução da vazão, a altura piezométrica disponível pode sofrer um aumento que tende a limpar a tubulação. Caso contrário, a sedimentação na tubulação cada vez mais, até causar o bloqueio completo, o que é extremamente inconveniente e obriga a trabalhoso serviço de desentupimento.

Uma solução seria levantar a lança de forma a succionar água limpa para lavar a tubulação porém o processo de bloqueio é muito rápido e não há tempo para lançar mão deste artifício. Para contornar este sério inconveniente, trabalha-se com a bomba na zona de sua curva característica em que a redução da vazão corresponde a grande variação da altura piezométrica, com evidente perda de rendimento.

Cabe lembrar que as condições de operação mudam constantemente, e que para cada comprimento de tubulação de recalque tem-se um ponto de operação na curva característica. Pode-se utilizar vários rotores com diâmetros diferentes, um para cada comprimento da tubulação de recalque ou mesmo duas bombas em série e paralelo com características bem diversas, de forma a trabalhar sempre na zona favorável da curva característica (solução cara).

Dubulação de recalque

Na tubulação deve-se sempre manter uma velocidade de escoamento superior à velocidade crítica de sedimentação da mistura. Esta velocidade crítica é função da granulometria do material e, não é sempre bem definida devido a variação da granulometria do material. Dependendo esta velocidade crítica, também, da concentração e do diâmetro da tubulação. 
Grandes velocidades na tubulação aumentam a perda de carga e os desgastes na bomba e nos tubos, e em conseqüência o custo de operação; reduzem porém as possibilidades de bloqueio e permitem o emprego de tubulação de menor diâmetro e portanto mais leves, o que é conveniente quando a tubulação é flutuante, pois diminui o calado dos flutuantes de sustentação, além de custarem menos.

As tubulações flutuantes podem ser rígidas ou flexíveis. A flexibilidade, que possibilita movimento entre a draga e o ponto de lançamento é obtido por meio de juntas móveis do tipo esférico ou elástico. Um número elevado de juntas móveis permite que a tubulação adquira conformação suave e reduz os esforços de flexão, devido à corrente e ao vento. A flexibilidade total, porém, causa dificuldades e torna necessário ancorar a tubulação, sendo neste caso melhor reduzir o número de juntas móveis porque as âncoras dificultam a operação.

As tubulações flutuantes rígidas são usadas quando o material é lançado no próprio leito do rio. Há então, apenas uma articulação junto à draga. Neste caso, pode-se controlar a posição da tubulação por meio do jato livre da extremidade do lançamento.

Com a colocação de um defletor controlado à distância pode-se orientar o jato de forma conveniente e colocar a tubulação na posição desejada. Ver figura 141.

Evidentemente, para que o controle pelo jato seja possível, é necessário que a quantidade de movimento do jato supere a quantidade de movimento da resistência oferecida pelos flutuantes ao escoamento e ao vento.

A condição de rigidez da tubulação, impõe condições de robustez, aumentando seu custo.

\ Dragas de flecha (Dragas de Sucção e Recalque com Lançamento Direto)

As dragas de flecha, dispõem de uma lança lateral que atingem até $100 \mathrm{~m}$ de comprimento, através da qual o material é jogado na corrente fora do canal. 


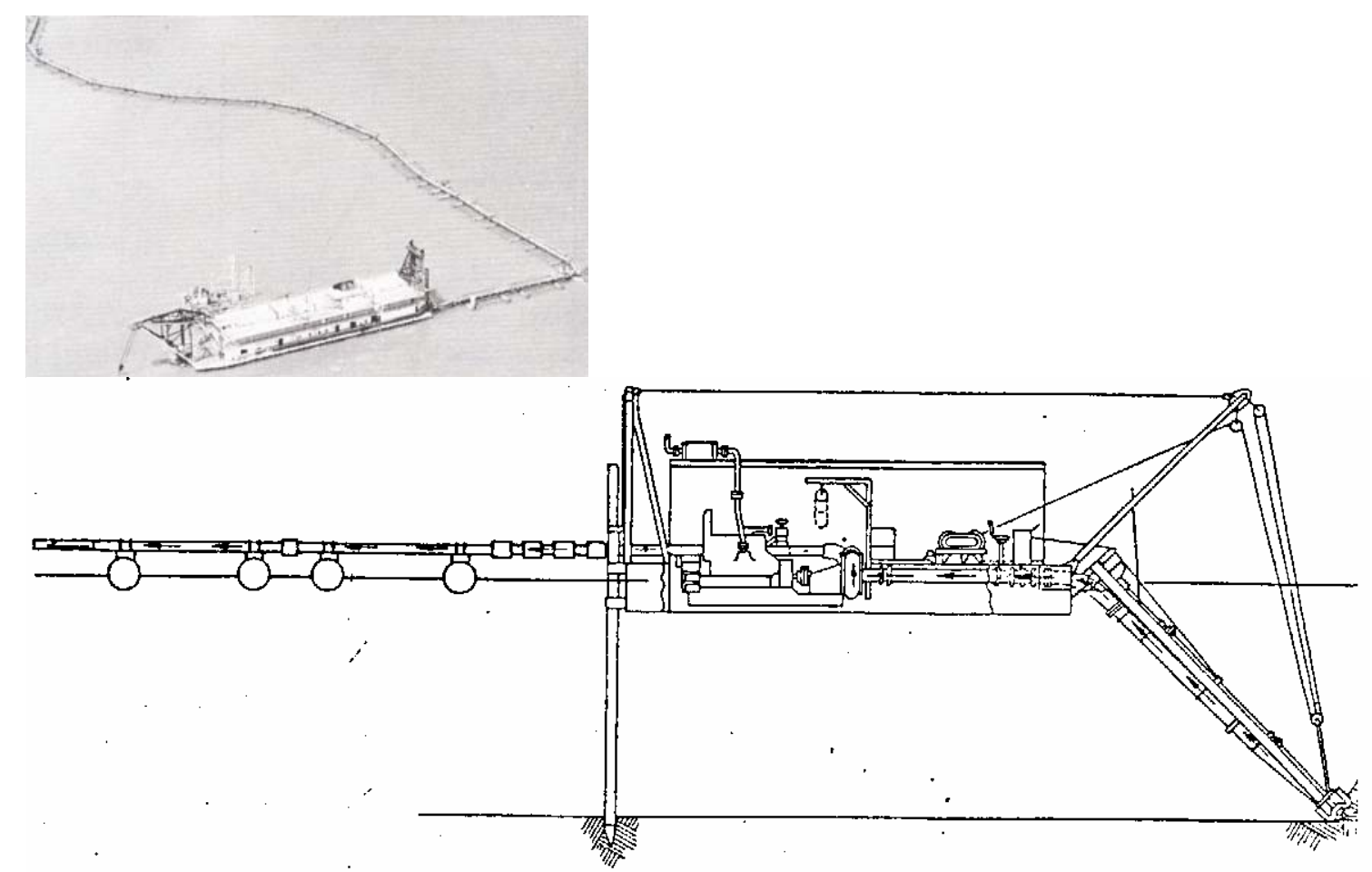

Figura 141 - Draga de sução e recalque com tubulação flutuante.

Fonte: Department of the army corps of engineers office of the chie of engineers. ( 1983).

i) Canais Artificiais, segundo Oliveira \& Brito (1998)

O dicionário Aurélio da Língua Portuguesa, entende a canalização como o ato ou efeito de canalizar, isto é, dirigir ou encaminhar por meio de canais, valas ou canos.

A importância dos canais construídos ou adaptados pelo homem, vem desde a antigüidade. Há mais de 4.000 anos os egípcios já empregavam canais para ligar o Rio Nilo ao Mar Vermelho e para a prática da agricultura irrigada. No final do século XVIII, Napoleão Bonaparte considerava a abertura de um canal ligando os mares Mediterrâneo e Vermelho, projeto que, em 1869, viria a ser o Canal de Suez, encurtando em 9.700 km a distância marítima entre a Inglaterra e a Índia. Em 1914, inaugurou-se o Canal do Panamá, interligando os oceanos Atlântico e Pacífico. A cidade de Nova Iorque consolidou-se como o centro financeiro do país em 
decorrência da construção, em 1925, do Canal do Eire, de 584 km, ligando os Grandes Lagos ao Atlântico.

No Brasil, alguns projetos merecem destaque, particularmente como exemplo de obras de engenharia diversificadas, cada uma com um conjunto de especificidades, quanto às necessidades do empreendimento e do meio físico envolvido:

Canal da Cosipa na Baixada Litorânea de Santos (SP), submerso nas águas do estuário do Rio Cubatão, aberto por dragagem de sedimentos inconsolidados e utilizado para a navegação;

Canal de Jaíba, no sertão árido mineiro, ao longo do Rio São Francisco, escavado em sedimentos recentes sobre rochas calcárias e empregado para a irrigação, com uma vazão de até $80 \mathrm{~m}^{3} / \mathrm{s}$;

Canal de Pereira Barreto, no Oeste Paulista, aberto em sedimento arenoso, com diferentes graus de coerência, interligando os lagos das usinas de Três Irmãos (Rio Tietê) e Ilha Solteira (Rio Paraná) para navegação e geração de energia;

Canal do rio Tietê, na zona urbana da cidade de São Paulo, uma retificação com rebaixamento de leito para o controle das enchentes, escavado em sedimentos inconsolidados, recentes e terciários e, soleiras de rochas cristalinas.

HCanais - Conceito

Os canais são condutos artificiais, destinados a escoar as águas, em superfície livre. São construídos tanto ao longo dos próprios cursos d'água da rede hidrográfica, modificados de acordo com as necessidades, como escavados em diferentes tipos de solo.

Tipos de Canais 
Os canais mais comuns são: hidrovias, canais de irrigação, canais de adução para abastecimento, canais para drenagem de áreas encharcadas, canais de retificação de cursos naturais para os mais diversos fins, canais emissários de águas pluviais e efluentes em zonas urbanas e rurais, canais de adução e fuga de usinas hidrelétricas e outras instalações. Nesta tese estudaremos, somente, os canais de navegação.

Critérios de Projeto, segundo Oliveira \& Brito (1998)

A finalidade do uso d'água, conduzida por um canal, determina vários critérios básicos, como o de admitir ou não perdas d'água. Canais de navegação e de retificação de rios, por exemplo, em geral admitem tais perdas; enquanto aqueles que aduzem água, seja para o abastecimento urbano ou para irrigação, em geral não podem perder esse recurso.

Outros critérios, a título de exemplificação, são apresentados a seguir, para alguns tipos de canais:

\ Canais de Navegação, são classificados em canais de acesso (aproximação ou saída de embarcações de alguma obra fluvial) e canais de navegação propriamente ditos, quando são projetado para garantir condições mínimas em qualquer ponto da hidrovia, estes canais fazem parte de um sistema mais complexo que compreende eclusas, barragens e portos. Em interligações de bacias, costuma-se chamar o canal de navegação de Canal de Partilha. Nestas interligações, geralmente, há falta de água para manutenção das condições mínimas, exigindo que sejam abastecidos.

\ Canais de Retificação, podem ser concebidos para controle de cheias, para a organização do espaço visando o uso do solo, para o controle de processos erosivos-deposicionais, etc. Cada uma destas finalidades e as características do meio físico e do uso do solo, determinam os respectivos aspectos básicos; entretanto, um aspecto comum é a necessidade de manutenção, que exige limpeza ou mesmo dragagens freqüentes, especialmente em áreas urbanas. 
\ Canais de Irrigação, devem facilitar o escoamento d'água sem provocar erosão ou deposição de sedimentos. Em geral, os canais de irrigação e maior porte, que aduzem e distribuem água até os lotes irrigados, são dotados de revestimentos para evitar importantes perdas d'água.

^ Canal de Desvio, é uma solução que pode ser adotada quando da construção de uma barragem, pois há a necessidade do isolamento da área, para permitir o trabalho sem a interferência d'água. É adotado quando as condições geológicas são favoráveis para a construção de uma canal de derivação para desvio de uma vazão em torno do local da obra, sendo que outros tipos de obras de desvio, tais como: ensecadeiras, túneis, adufas, desvio através do vertedor principal concretado, desvio pelo circuito hidráulico de geração; são insuficientes para as necessidades de escoamento da vazão de projeto. Estes canais de desvio podem ser escavados nas ombreiras do rio, sendo este esquema de desvio adequado quando se conta com material das ombreiras resistentes a erosão. A abertura desses, podem ser projetadas para ser uma obra permanente, destinada por exemplo à navegação.

j) Obras de Canalização dos Cursos D’água

O rio fica transformado em uma série de patamares, que são também chamado de "estirões", por meio de barragens implantadas a intervalos planejados, que permitem, através de "obras de transposição de desnível”, a ligação contínua do meio líquido para a navegação. Ver figuras 142.

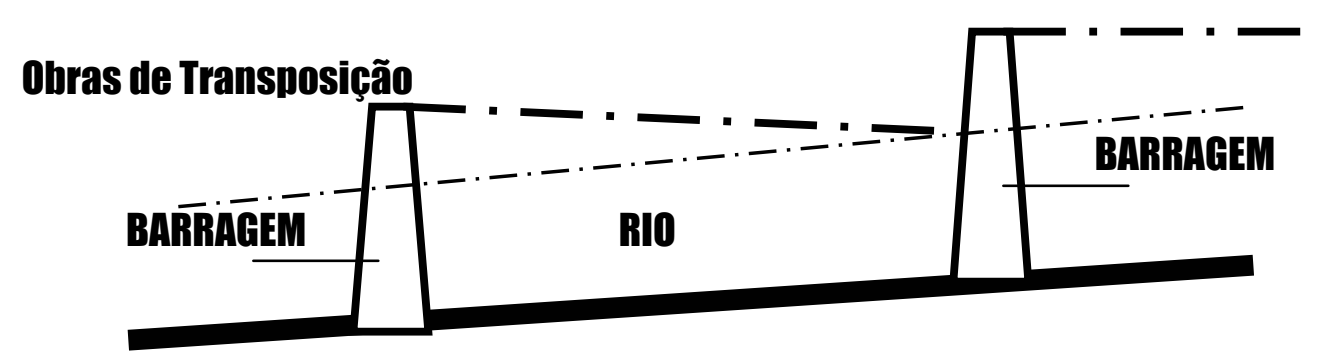

Figuras 142 - Obras de transposição.

Fonte: DEL GRANDE. (1989). 
Localização das Barragens

É função de um conjunto de estudos topográficos, geológicos e hidrológicos junto ao leito do rio; são também estudadas as possíveis áreas de inundação e o custo das desapropriações, etc.; a posição fica determinada geometricamente, através da linha de remanso, ou seja, o calado mínimo junto a barragem de montante (geralmente de três metros).

As obras de canalização apresentam como vantagens:

¿ São possíveis de serem realizadas em qualquer curso d'água;

Propiciam maiores profundidades (portanto maiores calados e menor resistência ao movimento das embarcações);

to Diminuem a velocidade das águas (daí, menor tempo de percurso de ida e volta);

Diminuem o percurso, com a retificação e melhoria das curvas;

Tráfego quase ininterrupto todo o ano;

Facilidade para posicionamento dos portos (constância do nível d'água);

Possibilitam o aproveitamento múltiplo dos recursos hídricos (energia elétrica, controle de cheias, abastecimento, navegação, etc.)

As obras de canalização apresentam como desvantagens:

Custo elevado de maneira geral;

Elevação do nível d'água [inundação de áreas úteis (desapropriações), perda de pontes e estradas];

Tráfego lento e reduzido junto às obras de transposição de desnível;

Capacidade de tráfego limitada às obras

(2) São exemplos de obras de canalização, segundo Veras Junior (1975) 


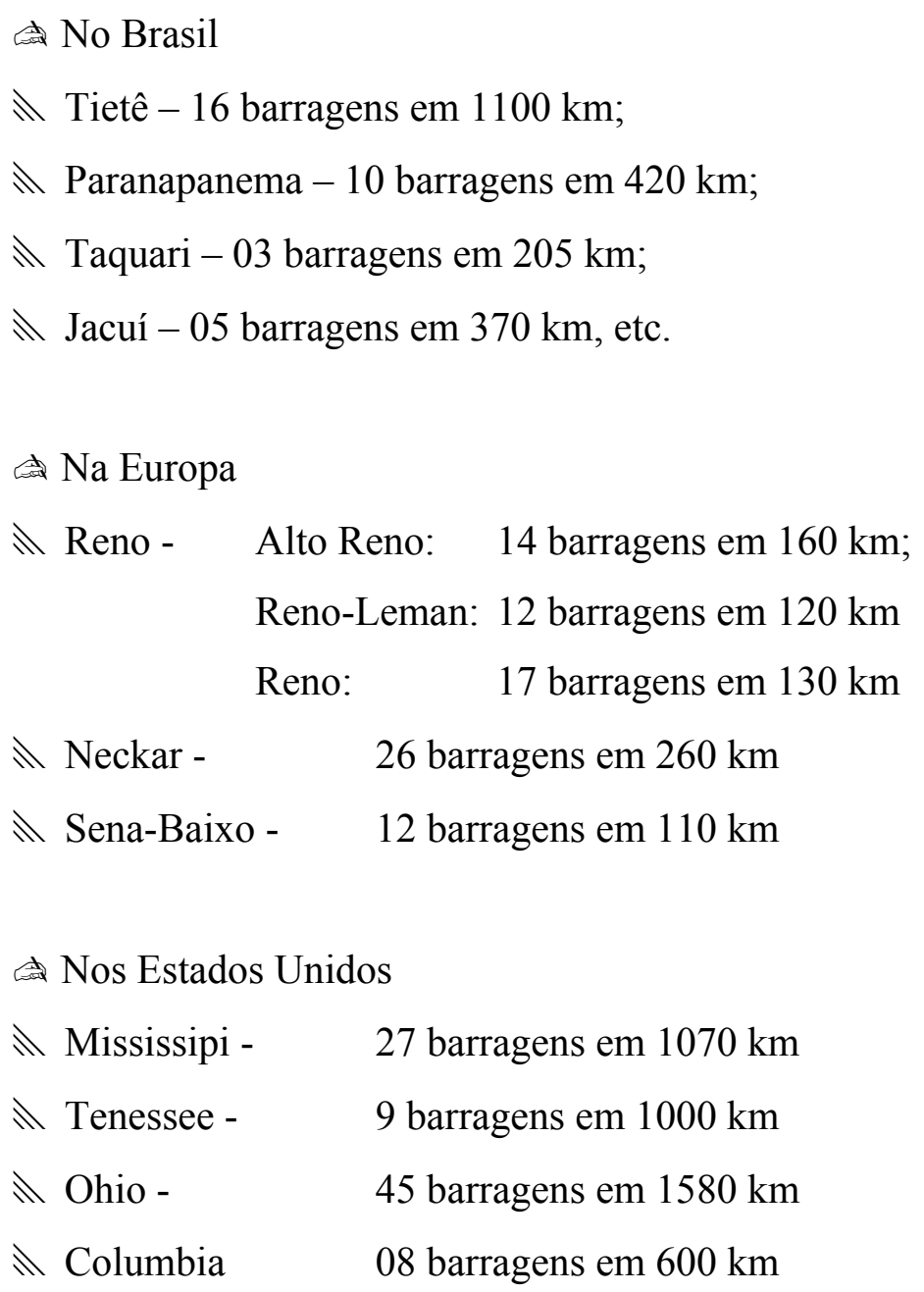

Normalmente, projetam as obras de canalização em função das finalidade principais a atender, depois adaptam-se as instalações para servir as finalidades ditas secundárias, tudo no entanto, durante a fase de projetos. São exemplos dessas finalidades:

\ Produção de energia elétrica;

\Navegação;

\Abastecimento [urbano, rural (irrigação) e industrial];

\. Controle de enchentes;

\. Controle da poluição; 
\. Tratamento de esgotos;

\ Conservação da fauna e flora;

\Industrialização de peixes;

\ Turismo e recreação;

、 Conservação do solo, etc.

Esta pesquisa, não tem o objetivo de elaborar um estudo abrangente das obras de canalização, pois entendemos que este tipo de obra, constitui-se em uma das obras de engenharia de maior proveito para o homem, devido a implantação de barragens e, ao mesmo tempo lhe é atribuído causas denotáveis mudanças e modificações nos rios onde são construídas.

A contenda, que ora se instala a respeito das obras de canalização, é portanto objetivo de uma outra pesquisa. 


\section{CAPÍtULO 6.}

\section{CORRELAÇÕES ENTRE AS VARIÁVEIS}

\section{ESTADOS UNIDOS DA AMÉRICA}

Em 1854, o Governo dos Estados Unidos tentava convencer o chefe indígena Seatle a vender suas terras. Como resposta, o chefe enviou uma carta ao presidente que se tornou famosa em todo o mundo. Seu conteúdo merece uma reflexão atenta pois é uma lição que deve ser cultivada por todos, por esta e pelas futuras gerações. Decorridos quase dois séculos da carta do cacique indígena Seatle ao Presidente do Estados Unidos, suas lições permanecem atuais e proféticas, para todos aqueles que sabem enxergar no fundo do conteúdo de sua mensagem. A carta do cacique Seatle é uma lição inesgotável de amor à natureza e à vida, que permanece na consciência de milhões de pessoas em todas as partes do mundo. É o hino de todos aqueles que amam a natureza e tudo o que nela vive. A cada leitura, renovamos os ensinamentos que ali estão. Serve para ler e reler e passar adiante para que todos a conheçam. No Brasil, existiam em torno de 4 milhões de indígenas, quando os colonizadores chegaram. Hoje, restam cerca de 200 mil! Embora o indígena tenha contribuído de forma essencial para a miscigenação da raça brasileira, é certo que foram sendo expulsos de suas terras pelos exploradores e eliminados por doenças contraídas através do convívio com os brancos. Atualmente, continuam sofrendo a invasão de suas terras por madeireiros, fazendeiros e garimpeiros, seus principais algozes. É fundamental que seja preservada a riqueza de sua cultura, suas danças, ritos, conhecimentos sobre as plantas e animais e as formas de viver em harmonia com a natureza. Os indígenas possuem uma sabedoria milenar que precisamos aprender a ouvir. A história dos indígenas em cada país onde existiam, antes do homem branco, é diferente nas suas particularidades, mas no seu conteúdo são iguais. Nos Estados Unidos ou no Brasil, os problemas enfrentados pelos indígenas foram os mesmos. Daí esse sentimento de solidariedade e cooperação que existe entre os diferentes povos indígenas e essa sabedoria milenar da qual todos nós temos muito que aprender. 
6.

\section{CORRELAÇÕES ENTRE AS VARIÁVEIS}

\subsection{AS CORRELAÇÕES}

As obras hidroviárias (variável controlada), são tipos de obras civis necessárias à implantação e operação de uma hidrovia (variável independente), com intervenção direta e/ou indireta em um rio navegável. Embora, as obras hidroviárias estejam associadas diretamente as hidrovias, tornou-se usual associar a elas, seja por desconhecimento ou por segundos interesses, impactos negativos. Neste capítulo, identificaremos tantos os impactos negativos como também os positivos (variável dependente), oriundos de tais obras, fazendo-se verificar que muitas vezes estas obras são necessárias para manter a estabilidade do rio, que foi quebrada por um outro agente qualquer, que não a hidrovia.

$\mathrm{O}$ estabelecimento das correlações entre: variável independente (hidrovias) $\mathrm{x}$ variável dependente (impactos ambientais), variável independente (hidrovias) $\mathrm{x}$ variável controlada (obras hidroviárias), variável dependente (impactos ambientais) x variável controlada (obras hidroviárias), demonstra a evolução da aprendizagem, isto é, o desenvolvimento de habilidades para a abordar o tema apresentado, além de se constituir em instrumento de ligação entre o virtual (teórico) e o real, pois as variáveis, são materializadas no meio ambiente e, não ocorrem isoladamente, ocorrem sim, simultaneamente e, muitas vezes em mais de uma porção física do meio ambiente, definindo a existência de um Modelo Físico.

O produto resultante das correlações entre as variáveis, define nesta tese as Planilhas Ambientais.As Planilhas Ambientais, deverão ser entendidas como o modelo, pois refletem o comportamento do sistema [dados x habilidades x saída (atitudes/respostas)].

A utilização dessa tese, formada pelo sistema $x$ modelo, permite identificar os impactos ambientais de uma hidrovia, bem como os procedimentos a serem adotados 
de modo a tornar verdadeiro e principalmente viáveis dos pontos de vista: técnico, econômico, financeiro, político, jurídico, social e ambiental, os objetivos desta tese.

\subsection{A ADVERTÊNCIA}

Antes da apresentação das planilhas ambientais, faz-se necessário observar a advertência apresentada nos parágrafos abaixo.

Identificar a ocorrência de um impacto ambiental, bem como o seu acompanhamento, não é das atividades mais simples e, quem o faz deve estar munido de curiosidade científica. Como exemplo, podemos citar o fato de constatar-se a ocorrência que a mudança na intensidade da velocidade das águas num trecho de um rio, não se constitui simplesmente num dado de entrada para um modelo matemático que permite por exemplo, determinar a vazão numa seção transversal deste rio, mas a ocorrência desta mudança, vai muito além, no entendimento do porquê da sua ocorrência, isto é, a sua origem e que alterações ela poderá trazer à porção bio-geofisica do meio-ambiente.

Estudar um impacto ambiental não se resume em dizer: daqui a quinze minutos obteremos um resultado; é um trabalho de equipe, envolve conhecimento teórico e, durante este estudo, cada profissional troca conhecimentos, é algo contínuo, pois as observações de um pesquisador constitui-se na base de estudo para o outro e assim segue, fazendo-se ciência.

O pesquisador, que espera medir um impacto ambiental, assim como mede-se uma vazão, ou que espera ficar a margem de um rio, olhando e aguardando um impacto ambiental, infelizmente, não possui informações conceituais sobre a pesquisa que, ora, desenvolve; falta esta, que poderia ter sido corrigida com uma parcela "conceitual", no corpo do seu trabalho.

\subsection{IMPACTO AMBIENTAL - ENUNCIAÇÃO}


IMPACTO AMBIENTAL, segundo a Resolução CONAMA № 01, é qualquer alteração das propriedades físicas, químicas e biológicas do meio ambiente, causada por qualquer forma de matéria ou energia, resultantes das atividades humanas que, direta ou indiretamente afetam: a saúde, a segurança e o bem estar da população, ou as atividades sociais e econômicas, a biota, as condições estéticas e sanitárias do meio ambiente, a qualidade dos recursos ambientais.

\subsection{DETALHAMENTO E CLASSIFICAÇÃO DOS IMPACTOS AMBIENTAIS}

As obras hidroviárias, executadas pelo homem, provocam alterações, que podem ser significativas ou desprezíveis, nas características dos meios físico, biótico e antrópico, sendo portanto, necessário identificar e classificar estas alterações que também são denominadas impactos ambientais.

Os impactos ambientais para efeito de análise poderão ser classificados quanto: Ao Tipo; Ao Modo; A Magnitude; Ao Alcance; Ao Efeito; A Reversibilidade.

Impactos Ambientais - Quanto Ao Tipo

$\begin{array}{ll}\longleftrightarrow \text { Positivo (Benéfico) } & -\mathbf{P} \\ \longleftrightarrow \text { Negativo (Adverso) } & -\mathbf{N}\end{array}$

Segundo Mota (1997), nem sempre é fácil predizer e avaliar os impactos ambientais de uma dada ação. Sob determinado enfoque, um impacto pode ser considerado como positivo, mas, sob outro, ser admitido como negativo. Por exemplo, a erosão na ribanceira de um rio, resultante de fenômenos naturais, isto é, não está referida a ação do homem, é minimizada por uma obra de revestimento da margem. Constituindo-se, portanto, esta ação de revestimento em um impacto ambiental positivo, pois além de estabilizar a margem, em função do material utilizado, pode permitir a recuperação da fauna e flora. 
Impactos Ambientais - Quanto Ao Modo

$\begin{array}{ll}\infty \text { Direto } & -\mathbf{D} \\ \text { Indireto } & -\mathbf{I}\end{array}$

Considerou-se na elaboração das planilhas que um impacto ambiental pode ser direto, quando se relaciona a uma outra determinada ação inicial, ou indireto, quando decorre de uma conseqüência de primeira ordem. Uma determinada ação pode desencadear uma cadeia de impactos, uns resultando dos outros. Por exemplo, a ação inicial de retirada de material em um determinado trecho do leito de um rio, provoca alteração das qualidades física e química d'água, impacto direto, devido a ressuspensão do material do leito, resultando nos seguintes impactos indiretos: aumento de material particulado em suspensão; contaminação das redes alimentares, no caso de existirem produtos tóxicos; aumento da mortande de peixes; redução da penetração dos raios solares, diminuindo a produção de oxigênio pelas algas, refletindo-se na redução da fauna aquática.

Impactos Ambientais - Quanto A Magnitude

Baixa intensidade - B

códia Intensidade - M

Grande Intensidade- $\mathbf{G}$

Entende-se por Magnitude do Impacto, a grandeza em escala espacial e temporal, isto é, a extensão, também, identificada com intensidade daquele impacto, sobre o meio ambiente. Por exemplo, o derrocamento do leito de um rio, com a utilização de explosivos, tem como conseqüência a destruição da fauna e flora aquática, durante o tempo em que ocorre e, nas proximidades da explosão, devido as ondas de choque. Identifica-se um espaço e um tempo, relativamente pequenos, durante o qual, temos a ocorrência de um impacto de grande intensidade 
Impactos Ambientais - Quanto Ao Alcance

$\begin{array}{ll}\text { Local } & -\mathbf{L} \\ \text { Regional } & -\mathbf{R} \\ \text { Nacional } & -\mathbf{N A}\end{array}$

O alcance deve ser entendido como a distância máxima, a que pode chegar o impacto ambiental. Nesta tese ele será local, quando alcançar no máximo o trecho do rio no qual se desenvolve a obra. Será regional, quando alcançar todo o rio e, nacional quando o impacto ambiental alcançar a bacia hidrográfica do qual faz parte. Por exemplo, a retificação do curso d'água de um rio, com o isolamento de uma alça, mais acentuada, por meio de um canal, aproveitando-se o material proveniente da abertura desse canal para aterro do leito abandonado, constitui-se num impacto de alcance local, tendo em vista que: o isolamento da alça alcança no máximo o trecho do rio onde se desenvolve a obra, sendo porém regional quando consideramos a redução do volume de retenção e consequente aumento do pico de vazão para jusante dessa obra.

- Impactos Ambientais - Quanto Ao Efeito

$\begin{array}{ll}\text { Curto Prazo } & -\mathbf{C P} \\ \text { Médio Prazo } & - \text { MP } \\ \text { Longo Prazo } & -\mathbf{L P}\end{array}$

O resultado da ação proposta - Obra Hidroviária, é um impacto ambiental, a este resultado chamamos de efeito e, associado a ele temos um espaço de tempo, prazo, durante o qual o impacto está presente. Por exemplo, alguns impactos ambientais devido ao derrocamento do leito de um rio, são quanto a magnitude, de grande intensidade, mas quanto ao efeito, às vezes, são de curto prazo, isto é ocorrem quando da execução da obra, podendo ser citado o aumento da suspensão de material particulado, aumento mortande de peixes, redução da fauna e flora aquática, etc. 
:- Impactos Ambientais - Quanto A Reversibilidade

Reversível - RE

Irreversível - IR

A porção física do meio ambiente que sofreu alteração, isto é, um impacto, pode retornar ou retorna ao seu primitivo estado ao que chamamos de "reversível", ou não pode retornar ao seu estado primitivo, ao que chamamos de "irreversível". Por exemplo, o retaludamento da margem, ocorre com a necessidade da definição e fixação de uma vegetação, o que lhe permite retornar ao seu estado primitivo, sendo nesta situação o impacto ambiental, produzido, reversível. 


\subsection{PLANILHAS AMBIENTAIS}

- MODELO OBTIDO A PARTIR DAS CORRELAÇÕES ENTRE:

М VARIÁVEL INDEPENDENTE ( HIDROVIAS)

M VARIÁVEL CONTROLADA (OBRAS HIDROVIÁRIAS)

М VARIÁVEL DEPENDENTE (IMPACTOS AMBIENTAIS). 
AÇÃO PROPOSTA - OBRA HIDRÁULICA FLUVIAL

Tipo de Obra Hidráulica Fluvial - Proteção das Margens - A proteção das margens tem por finalidade a proteção de terrenos marginais, fixação do traçado e redução da descarga sólida; em cursos d'água naturais, hidrovias e canais (drenagem, irrigação, adução, etc.)

As obras de proteção das margens mais utilizadas são:

Obras Contínuas ou de Proteção Direta: retaludamento, revestimento com materiais mais resistentes, obras de sustentação (muros de arrimo) para proteção e suporte dos terrenos marginais.

\begin{tabular}{|c|c|c|c|c|c|c|c|c|c|c|c|c|c|c|c|c|}
\hline \multirow[t]{2}{*}{ Ação Proposta } & \multirow[t]{2}{*}{ Impacto Ambiental } & \multicolumn{15}{|c|}{ Classificação do Impacto Ambiental } \\
\hline & & $\mathbf{P}$ & $\mathbf{N}$ & D & I & B & $\mathbf{M}$ & G & $\mathbf{C P}$ & MP & $\mathbf{L P}$ & RE & IR & $\mathbf{L}$ & $\mathbf{R}$ & NA \\
\hline $\begin{array}{l}\text { Rio sem Intervenção, isto é, } \\
\text { sem ação direta do homem. }\end{array}$ & $\begin{array}{l}\text { * Os impactos ambientais, identificados a } \\
\text { seguir, são devidos a fenômenos naturais. }\end{array}$ & & & & & & & & & & & & & & & \\
\hline $\begin{array}{l}\text { - Ação de Agentes Internos ou } \\
\text { Geotécnicos. }\end{array}$ & $\begin{array}{l}\text { Aumento do aporte de sólidos na corrente } \\
\text { liquida. }\end{array}$ & & & & & & & & & & & & & & & \\
\hline Percolação: Responsável pelo & Desagregação da margem. & & & & & & & & & & & & & & & \\
\hline $\begin{array}{l}\text { arraste dos finos do solo e } \\
\text { desagregação das margens. }\end{array}$ & $\begin{array}{l}\text { Escorregamento do solo e cobertura } \\
\text { Vegetal. }\end{array}$ & & & & & & & & & & & & & & & \\
\hline Saturação: Responsável pela & Assoreamento do leito do rio. & & & & & & & & & & & & & & & \\
\hline $\begin{array}{l}\text { Instabilidade Geotécnica da } \\
\text { margem taludada (margem rompe }\end{array}$ & $\begin{array}{l}\text { Alteração das características físicas } \\
\text { d'água (cor e turbidez). }\end{array}$ & & & & & & & & & & & & & & & \\
\hline por saturação do solo ). & Mudança no traçado do rio. & & & & & & & & & & & & & & & \\
\hline & Erosão das Margens & & & & & & & & & & & & & & & \\
\hline
\end{tabular}


Planilha № 01 - Continuação - Impacto Ambiental das Ações Propostas - Classificação do Impacto Ambiental

\begin{tabular}{|c|c|c|c|c|c|c|c|c|c|c|c|c|c|c|c|c|}
\hline \multirow[t]{2}{*}{ Ação Proposta } & \multirow[t]{2}{*}{ Impacto Ambiental } & \multicolumn{15}{|c|}{ Classificação do Impacto Ambiental } \\
\hline & & $\mathbf{P}$ & $\mathbf{N}$ & D & I & B & $\mathbf{M}$ & $\mathbf{G}$ & $\mathbf{C P}$ & MP & $\mathbf{L P}$ & $\mathbf{R E}$ & IR & $\mathbf{L}$ & $\mathbf{R}$ & NA \\
\hline \multirow{5}{*}{$\begin{array}{l}\text { Ação de Agentes Externos } \\
\text { Escoamento } \\
\text { Ação do Escoamento sobre o } \\
\text { material da margem [ solapamento } \\
\text { do "pé" e na margem exterior dos } \\
\text { trechos curvos (talude)]. }\end{array}$} & $\Leftrightarrow$ Instabilidade da margem. & & & & & & & & & & & & & & & \\
\hline & $\begin{array}{l}\text { Aumento do aporte de sedimento no } \\
\text { escoamento. }\end{array}$ & & & & & & & & & & & & & & & \\
\hline & $\begin{array}{l}\text { Assoreamento do leito do rio (bancos de } \\
\text { areia). }\end{array}$ & & & & & & & & & & & & & & & \\
\hline & Destruição da cobertura vegetal. & & & & & & & & & & & & & & & \\
\hline & $\begin{array}{l}\text { Alteração das características físicas } \\
\text { d'água (cor e turbidez). }\end{array}$ & & & & & & & & & & & & & & & \\
\hline \multirow{5}{*}{$\begin{array}{l}\text { Ondas } \\
\text { Devido a ação do vento } \\
\text { (principalmente em rios muito } \\
\text { largos ou reservatórios) } \\
\text { Devido a passagem de } \\
\text { embarcações de recreio ou de }\end{array}$} & $\begin{array}{l}\text { Instabilidade da margem na superfície da } \\
\text { linha d'água. }\end{array}$ & & & & & & & & & & & & & & & \\
\hline & Aumento do transporte de sedimentos. & & & & & & & & & & & & & & & \\
\hline & $\begin{array}{l}\text { Assoreamento do leito do rio (bancos de } \\
\text { areia ). }\end{array}$ & & & & & & & & & & & & & & & \\
\hline & Destruição da cobertura vegetal. & & & & & & & & & & & & & & & \\
\hline & $\begin{array}{l}\text { Alteração das características físicas } \\
\text { d'água (cor e turbidez). }\end{array}$ & & & & & & & & & & & & & & & \\
\hline
\end{tabular}


Planilha № 01 - Continuação - Impacto Ambiental das Açães Propostas - Classificação do Impacto Ambiental

\begin{tabular}{|c|c|c|c|c|c|c|c|c|c|c|c|c|c|c|c|c|}
\hline \multirow[t]{2}{*}{ Ação Proposta } & \multirow[t]{2}{*}{ Impacto Ambiental } & \multicolumn{15}{|c|}{ Classificação do Impacto Ambiental } \\
\hline & & $\mathbf{P}$ & $\mathbf{N}$ & D & I & B & $\mathbf{M}$ & G & $\mathbf{C P}$ & MP & $\mathbf{L P}$ & $\mathbf{R E}$ & IR & $\mathbf{L}$ & $\mathbf{R}$ & NA \\
\hline & $\begin{array}{l}\text { Aumento da inclinação do talude de } \\
\text { margem, para atingir o equilíbrio ( formação } \\
\text { de praia). }\end{array}$ & & & & & & & & & & & & & & & \\
\hline
\end{tabular}


Planilha № 02 - Impacto Ambiental das Ações Propostas - Classificação do Impacto Ambiental

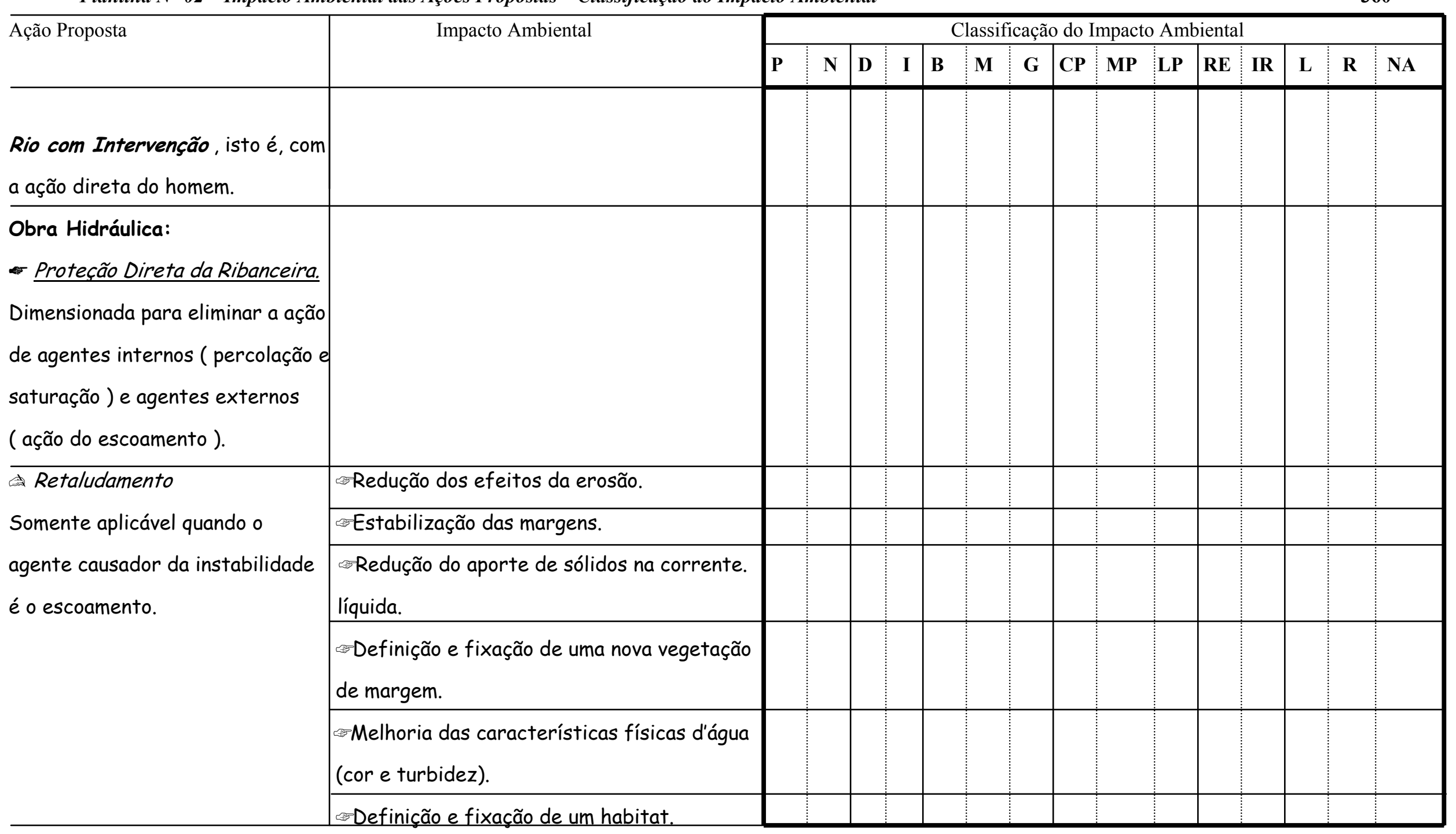


Planilha № 02 - Continuação - Impacto Ambiental das Ações Propostas - Classificação do Impacto Ambiental

\begin{tabular}{|c|c|c|c|c|c|c|c|c|c|c|c|c|c|c|c|c|}
\hline \multirow[t]{2}{*}{ Ação Proposta } & \multirow[t]{2}{*}{ Impacto Ambiental } & \multicolumn{15}{|c|}{ Classificação do Impacto Ambiental } \\
\hline & & $\mathbf{P}$ & $\mathbf{N}$ & D & $\mathbf{I}$ & B & $\mathbf{M}$ & $\mathbf{G}$ & $\mathbf{C P}$ & MP & $\mathbf{L P}$ & $\mathbf{R E}$ & IR & $\mathbf{L}$ & $\mathbf{R}$ & NA \\
\hline \multirow{10}{*}{$\begin{array}{l}\text { Revestimento das Margens } \\
\text { Faxinas }\end{array}$} & $\Leftrightarrow$ Definição de um habitat. & & & & & & & & & & & & & & & \\
\hline & $\begin{array}{l}\text { Definição e fixação de uma nova vegetação } \\
\text { de margem. }\end{array}$ & & & & & & & & & & & & & & & \\
\hline & Estabilização das margens. & & & & & & & & & & & & & & & \\
\hline & $\begin{array}{l}\text { Extinção ou minimização da diversidade } \\
\text { da fauna nas margens. }\end{array}$ & & & & & & & & & & & & & & & \\
\hline & $\begin{array}{l}\text { Impossibilidade de desenvolvimento ou } \\
\text { crescimento de uma vegetação de margem. }\end{array}$ & & & & & & & & & & & & & & & \\
\hline & $\begin{array}{l}\text { Melhoria das características físicas d'água } \\
\text { (cor e turbidez). }\end{array}$ & & & & & & & & & & & & & & & \\
\hline & * Recuperação da vegetação primitiva. & & & & & & & & & & & & & & & \\
\hline & $\begin{array}{l}\text { Proteção das margens contra a ação das } \\
\text { ondas. }\end{array}$ & & & & & & & & & & & & & & & \\
\hline & $\begin{array}{l}\text { Redução do aporte sólido na corrente, } \\
\text { líquida. }\end{array}$ & & & & & & & & & & & & & & & \\
\hline & Redução dos efeitos da erosão. & & & & & & & & & & & & & & & \\
\hline
\end{tabular}


Planilha № 02 - Continuação - Impacto Ambiental das Ações Propostas - Classificação do Impacto Ambiental

\begin{tabular}{|c|c|c|c|c|c|c|c|c|c|c|c|c|c|c|c|c|}
\hline \multirow[t]{2}{*}{ Ação Proposta } & \multirow[t]{2}{*}{ Impacto Ambiental } & \multicolumn{15}{|c|}{ Classificação do Impacto Ambiental } \\
\hline & & $\mathbf{P}$ & $\mathbf{N}$ & D & $\mathbf{I}$ & B & $\mathbf{M}$ & $\mathbf{G}$ & $\mathbf{C P}$ & MP & $\mathbf{L P}$ & $\mathbf{R E}$ & IR & $\mathbf{L}$ & $\mathbf{R}$ & NA \\
\hline Revestimento das Margens & Definição de um habitat. & & & & & & & & & & & & & & & \\
\hline \multirow[t]{9}{*}{ Y Substituição do Solo. } & $\begin{array}{l}\Leftrightarrow \text { Definição e fixação de uma nova vegetação } \\
\text { de margem. }\end{array}$ & & & & & & & & & & & & & & & \\
\hline & Estabilização das margens. & & & & & & & & & & & & & & & \\
\hline & $\begin{array}{l}\text { Extinção ou minimização da diversidade } \\
\text { da fauna nas margens. }\end{array}$ & & & & & & & & & & & & & & & \\
\hline & $\begin{array}{l}\text { Impossibilidade de desenvolvimento ou } \\
\text { crescimento de uma vegetação de margem. }\end{array}$ & & & & & & & & & & & & & & & \\
\hline & $\begin{array}{l}\text { Melhoria das características físicas d'água } \\
\text { (cor e turbidez). }\end{array}$ & & & & & & & & & & & & & & & \\
\hline & Recuperação da vegetação primitiva. & & & & & & & & & & & & & & & \\
\hline & $\begin{array}{l}\text { Proteção das margens contra a ação das } \\
\text { ondas. }\end{array}$ & & & & & & & & & & & & & & & \\
\hline & $\begin{array}{l}\text { Redução do aporte sólido na corrente, } \\
\text { líquida. }\end{array}$ & & & & & & & & & & & & & & & \\
\hline & Redução dos efeitos da erosão. & & & & & & & & & & & & & & & \\
\hline
\end{tabular}


Planilha № 02 - Continuação - Impacto Ambiental das Ações Propostas - Classificação do Impacto Ambiental

\begin{tabular}{|c|c|c|c|c|c|c|c|c|c|c|c|c|c|c|c|c|}
\hline \multirow[t]{2}{*}{ Ação Proposta } & \multirow[t]{2}{*}{ Impacto Ambiental } & \multicolumn{15}{|c|}{ Classificação do Impacto Ambiental } \\
\hline & & $\mathbf{P}$ & $\mathbf{N}$ & D & $\mathbf{I}$ & B & M & $\mathbf{G}$ & $\mathbf{C P}$ & MP & $\mathbf{L P}$ & $\mathbf{R E}$ & IR & $\mathbf{L}$ & $\mathbf{R}$ & NA \\
\hline \multirow{10}{*}{$\begin{array}{l}\text { Revestimento das Margens } \\
\text { Pintura Asfáltica }\end{array}$} & 响efinição de um habitat. & & & & & & & & & & & & & & & \\
\hline & $\begin{array}{l}\Leftrightarrow \text { Definição e fixação de uma nova vegetação } \\
\text { de margem. }\end{array}$ & & & & & & & & & & & & & & & \\
\hline & Estabilização das margens. & & & & & & & & & & & & & & & \\
\hline & $\begin{array}{l}\text { Extinção ou minimização da diversidade } \\
\text { da fauna nas margens. }\end{array}$ & & & & & & & & & & & & & & & \\
\hline & $\begin{array}{l}\text { Impossibilidade de desenvolvimento ou } \\
\text { crescimento de uma vegetação de margem. }\end{array}$ & & & & & & & & & & & & & & & \\
\hline & $\begin{array}{l}\text { Melhoria das características físicas d'água } \\
\text { (cor e turbidez). }\end{array}$ & & & & & & & & & & & & & & & \\
\hline & Recuperação da vegetação primitiva. & & & & & & & & & & & & & & & \\
\hline & $\begin{array}{l}\text { Proteção das margens contra a ação das } \\
\text { ondas. }\end{array}$ & & & & & & & & & & & & & & & \\
\hline & $\begin{array}{l}\text { Redução do aporte sólido na corrente, } \\
\text { líquida. }\end{array}$ & & & & & & & & & & & & & & & \\
\hline & $\leftrightarrow R$ Redução dos efeitos da erosão. & & & & & & & & & & & & & & & \\
\hline
\end{tabular}


Planilha № 02 - Continuação - Impacto Ambiental das Ações Propostas - Classificação do Impacto Ambiental

\begin{tabular}{|c|c|c|c|c|c|c|c|c|c|c|c|c|c|c|c|c|}
\hline \multirow[t]{2}{*}{ Ação Proposta } & \multirow[t]{2}{*}{ Impacto Ambiental } & \multicolumn{15}{|c|}{ Classificação do Impacto Ambiental } \\
\hline & & $\mathbf{P}$ & $\mathbf{N}$ & D & $\mathbf{I}$ & B & $\mathbf{M}$ & $\mathbf{G}$ & $\mathbf{C P}$ & MP & $\mathbf{L P}$ & $\mathbf{R E}$ & IR & $\mathbf{L}$ & $\mathbf{R}$ & NA \\
\hline \multirow{10}{*}{$\begin{array}{l}\text { Revestimento das Margens } \\
\text { Enrocamento ( pedra lançada ). }\end{array}$} & Definição de um habitat. & & & & & & & & & & & & & & & \\
\hline & $\begin{array}{l}\rightarrow \text { Definição e fixação de uma nova vegetação } \\
\text { de margem. }\end{array}$ & & & & & & & & & & & & & & & \\
\hline & Estabilização das margens. & & & & & & & & & & & & & & & \\
\hline & $\begin{array}{l}\text { Extinção ou minimização da diversidade } \\
\text { da fauna nas margens. }\end{array}$ & & & & & & & & & & & & & & & \\
\hline & $\begin{array}{l}\text { Impossibilidade de desenvolvimento ou } \\
\text { crescimento de uma vegetação de margem. }\end{array}$ & & & & & & & & & & & & & & & \\
\hline & $\begin{array}{l}\text { Melhoria das características físicas d'água } \\
\text { (cor e turbidez). }\end{array}$ & & & & & & & & & & & & & & & \\
\hline & Recuperação da vegetação primitiva. & & & & & & & & & & & & & & & \\
\hline & $\begin{array}{l}\text { Proteção das margens contra a ação das } \\
\text { ondas. }\end{array}$ & & & & & & & & & & & & & & & \\
\hline & $\begin{array}{l}\text { Redução do aporte sólido na corrente, } \\
\text { líquida. }\end{array}$ & & & & & & & & & & & & & & & \\
\hline & Redução dos efeitos da erosão. & & & & & & & & & & & & & & & \\
\hline
\end{tabular}


Planilha № 02 - Continuação - Impacto Ambiental das Ações Propostas - Classificação do Impacto Ambiental

\begin{tabular}{|c|c|c|c|c|c|c|c|c|c|c|c|c|c|c|c|c|}
\hline \multirow[t]{2}{*}{ Ação Proposta } & \multirow[t]{2}{*}{ Impacto Ambiental } & \multicolumn{15}{|c|}{ Classificação do Impacto Ambiental } \\
\hline & & $\mathbf{P}$ & $\mathbf{N}$ & D & $\mathbf{I}$ & B & M & $\mathbf{G}$ & $\mathbf{C P}$ & MP & $\mathbf{L P}$ & $\mathbf{R E}$ & IR & $\mathbf{L}$ & $\mathbf{R}$ & NA \\
\hline \multirow{10}{*}{$\begin{array}{l}\text { Revestimento das Margens } \\
\text { Gabião ( tipo colchão ). }\end{array}$} & Definição de um habitat. & & & & & & & & & & & & & & & \\
\hline & $\begin{array}{l}\Leftrightarrow \text { Definição e fixação de uma nova vegetação } \\
\text { de margem. }\end{array}$ & & & & & & & & & & & & & & & \\
\hline & Estabilização das margens. & & & & & & & & & & & & & & & \\
\hline & $\begin{array}{l}\text { Extinção ou minimização da diversidade } \\
\text { da fauna nas margens. }\end{array}$ & & & & & & & & & & & & & & & \\
\hline & $\begin{array}{l}\text { Impossibilidade de desenvolvimento ou } \\
\text { crescimento de uma vegetação de margem. }\end{array}$ & & & & & & & & & & & & & & & \\
\hline & $\begin{array}{l}\text { Melhoria das características físicas d'água } \\
\text { (cor e turbidez). }\end{array}$ & & & & & & & & & & & & & & & \\
\hline & Recuperação da vegetação primitiva. & & & & & & & & & & & & & & & \\
\hline & $\begin{array}{l}\text { Proteção das margens contra a ação das } \\
\text { ondas. }\end{array}$ & & & & & & & & & & & & & & & \\
\hline & $\begin{array}{l}\text { Redução do aporte sólido na corrente, } \\
\text { líquida. }\end{array}$ & & & & & & & & & & & & & & & \\
\hline & $\leftrightarrow R$ Redução dos efeitos da erosão. & & & & & & & & & & & & & & & \\
\hline
\end{tabular}


Planilha № 02 - Continuação - Impacto Ambiental das Ações Propostas - Classificação do Impacto Ambiental

\begin{tabular}{|c|c|c|c|c|c|c|c|c|c|c|c|c|c|c|c|c|}
\hline \multirow[t]{2}{*}{ Ação Proposta } & \multirow[t]{2}{*}{ Impacto Ambiental } & \multicolumn{15}{|c|}{ Classificação do Impacto Ambiental } \\
\hline & & $\mathbf{P}$ & $\mathbf{N}$ & D & $\mathbf{I}$ & B & $\mathbf{M}$ & $\mathbf{G}$ & $\mathbf{C P}$ & MP & $\mathbf{L P}$ & $\mathbf{R E}$ & IR & $\mathbf{L}$ & $\mathbf{R}$ & NA \\
\hline \multirow{10}{*}{$\begin{array}{l}\text { Revestimento das Margens } \\
\text { Gabião ( tipo colchão, } \\
\text { consolidado ou impermeabilizado } \\
\text { com mastique de betume). }\end{array}$} & Definição de um habitat. & & & & & & & & & & & & & & & \\
\hline & $\begin{array}{l}\rightarrow \text { Definição e fixação de uma nova vegetação } \\
\text { de margem. }\end{array}$ & & & & & & & & & & & & & & & \\
\hline & Estabilização das margens. & & & & & & & & & & & & & & & \\
\hline & $\begin{array}{l}\text { Extinção ou minimização da diversidade } \\
\text { da fauna nas margens. }\end{array}$ & & & & & & & & & & & & & & & \\
\hline & $\begin{array}{l}\text { Impossibilidade de desenvolvimento ou } \\
\text { crescimento de uma vegetação de margem. }\end{array}$ & & & & & & & & & & & & & & & \\
\hline & $\begin{array}{l}\text { Melhoria das características físicas d'água } \\
\text { (cor e turbidez). }\end{array}$ & & & & & & & & & & & & & & & \\
\hline & Recuperação da vegetação primitiva. & & & & & & & & & & & & & & & \\
\hline & $\begin{array}{l}\text { Proteção das margens contra a ação das } \\
\text { ondas. }\end{array}$ & & & & & & & & & & & & & & & \\
\hline & $\begin{array}{l}\text { Redução do aporte sólido na corrente, } \\
\text { líquida. }\end{array}$ & & & & & & & & & & & & & & & \\
\hline & Redução dos efeitos da erosão. & & & & & & & & & & & & & & & \\
\hline
\end{tabular}


Planilha № 02 - Continuação - Impacto Ambiental das Ações Propostas - Classificação do Impacto Ambiental

\begin{tabular}{|c|c|c|c|c|c|c|c|c|c|c|c|c|c|c|c|c|}
\hline \multirow[t]{2}{*}{ Ação Proposta } & \multirow[t]{2}{*}{ Impacto Ambiental } & \multicolumn{15}{|c|}{ Classificação do Impacto Ambiental } \\
\hline & & $\mathbf{P}$ & $\mathbf{N}$ & D & $\mathbf{I}$ & B & $\mathbf{M}$ & $\mathbf{G}$ & $\mathbf{C P}$ & MP & $\mathbf{L P}$ & $\mathbf{R E}$ & IR & $\mathbf{L}$ & $\mathbf{R}$ & NA \\
\hline \multirow{10}{*}{$\begin{array}{l}\text { Revestimento das Margens } \\
\text { Bolsacreto }\end{array}$} & $\Leftrightarrow$ Definição de um habitat. & & & & & & & & & & & & & & & \\
\hline & $\begin{array}{l}\text { Definição e fixação de uma nova vegetação } \\
\text { de margem. }\end{array}$ & & & & & & & & & & & & & & & \\
\hline & Estabilização das margens. & & & & & & & & & & & & & & & \\
\hline & $\begin{array}{l}\text { Extinção ou minimização da diversidade } \\
\text { da fauna nas margens. }\end{array}$ & & & & & & & & & & & & & & & \\
\hline & $\begin{array}{l}\text { Impossibilidade de desenvolvimento ou } \\
\text { crescimento de uma vegetação de margem. }\end{array}$ & & & & & & & & & & & & & & & \\
\hline & $\begin{array}{l}\text { Melhoria das características físicas d'água } \\
\text { (cor e turbidez). }\end{array}$ & & & & & & & & & & & & & & & \\
\hline & * Recuperação da vegetação primitiva. & & & & & & & & & & & & & & & \\
\hline & $\begin{array}{l}\text { Proteção das margens contra a ação das } \\
\text { ondas. }\end{array}$ & & & & & & & & & & & & & & & \\
\hline & $\begin{array}{l}\text { Redução do aporte sólido na corrente, } \\
\text { líquida. }\end{array}$ & & & & & & & & & & & & & & & \\
\hline & Redução dos efeitos da erosão. & & & & & & & & & & & & & & & \\
\hline
\end{tabular}


Planilha № 02 - Continuação - Impacto Ambiental das Ações Propostas - Classificação do Impacto Ambiental

\begin{tabular}{|c|c|c|c|c|c|c|c|c|c|c|c|c|c|c|c|c|}
\hline \multirow[t]{2}{*}{ Ação Proposta } & \multirow[t]{2}{*}{ Impacto Ambiental } & \multicolumn{15}{|c|}{ Classificação do Impacto Ambiental } \\
\hline & & $\mathbf{P}$ & $\mathbf{N}$ & D & $\mathbf{I}$ & B & $\mathbf{M}$ & $\mathbf{G}$ & $\mathbf{C P}$ & MP & $\mathbf{L P}$ & $\mathbf{R E}$ & IR & $\mathbf{L}$ & $\mathbf{R}$ & NA \\
\hline \multirow{10}{*}{$\begin{array}{l}\text { Revestimento das Margens } \\
\text { Colchacreto }\end{array}$} & $\Leftrightarrow$ Definição de um habitat. & & & & & & & & & & & & & & & \\
\hline & $\begin{array}{l}\text { Definição e fixação de uma nova vegetação } \\
\text { de margem. }\end{array}$ & & & & & & & & & & & & & & & \\
\hline & Estabilização das margens. & & & & & & & & & & & & & & & \\
\hline & $\begin{array}{l}\text { Extinção ou minimização da diversidade } \\
\text { da fauna nas margens. }\end{array}$ & & & & & & & & & & & & & & & \\
\hline & $\begin{array}{l}\text { Impossibilidade de desenvolvimento ou } \\
\text { crescimento de uma vegetação de margem. }\end{array}$ & & & & & & & & & & & & & & & \\
\hline & $\begin{array}{l}\text { Melhoria das características físicas d'água } \\
\text { (cor e turbidez). }\end{array}$ & & & & & & & & & & & & & & & \\
\hline & * Recuperação da vegetação primitiva. & & & & & & & & & & & & & & & \\
\hline & $\begin{array}{l}\text { Proteção das margens contra a ação das } \\
\text { ondas. }\end{array}$ & & & & & & & & & & & & & & & \\
\hline & $\begin{array}{l}\text { Redução do aporte sólido na corrente, } \\
\text { líquida. }\end{array}$ & & & & & & & & & & & & & & & \\
\hline & $\rightarrow$ Redução dos efeitos da erosão. & & & & & & & & & & & & & & & \\
\hline
\end{tabular}


Planilha № 02 - Continuação - Impacto Ambiental das Ações Propostas - Classificação do Impacto Ambiental

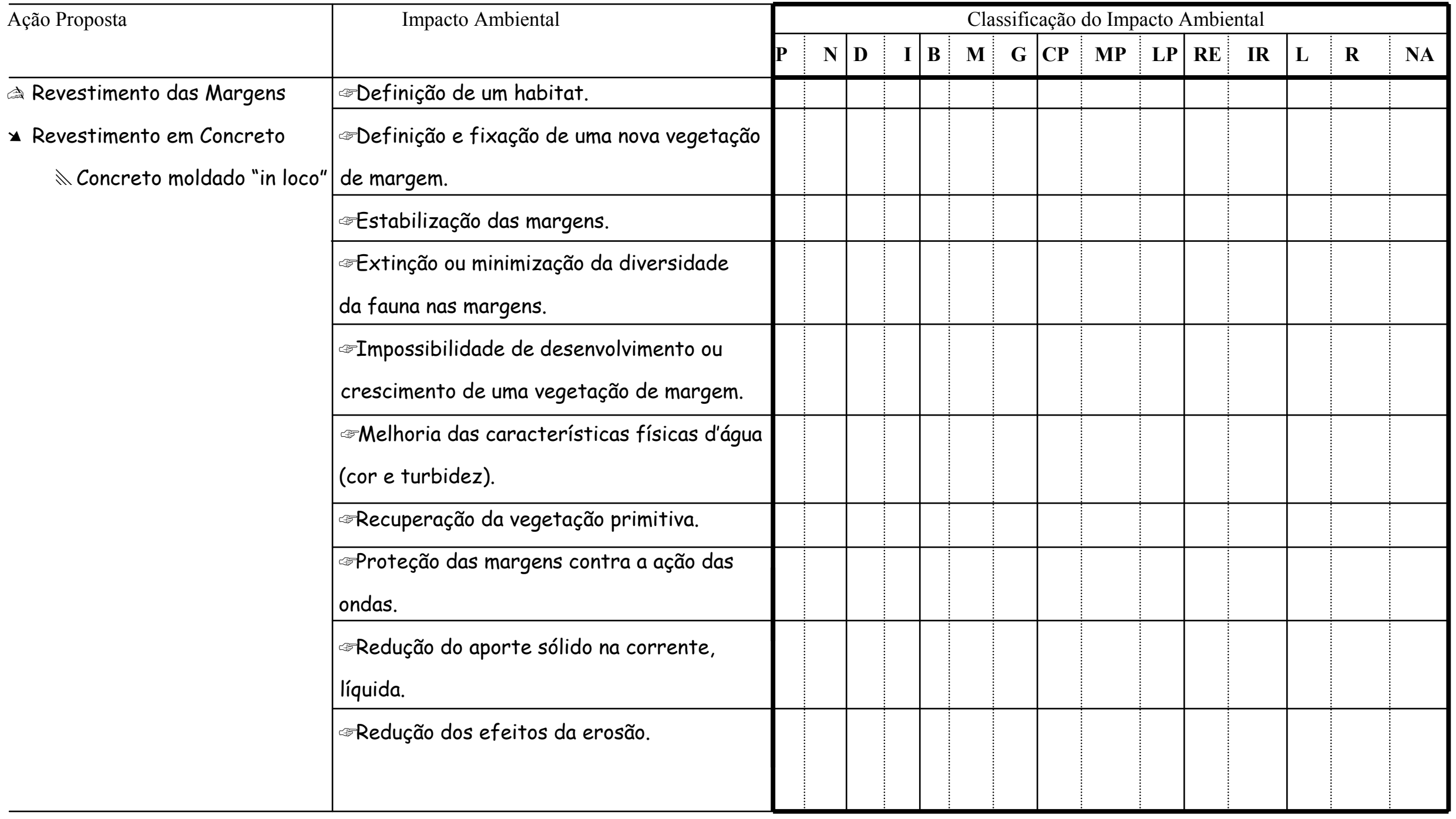


Planilha № 02 - Continuação - Impacto Ambiental das Ações Propostas - Classificação do Impacto Ambiental

\begin{tabular}{|c|c|c|c|c|c|c|c|c|c|c|c|c|c|c|c|c|}
\hline \multirow[t]{2}{*}{ Ação Proposta } & \multirow[t]{2}{*}{ Impacto Ambiental } & \multicolumn{15}{|c|}{ Classificação do Impacto Ambiental } \\
\hline & & $\mathbf{P}$ & $\mathbf{N}$ & D & I & B & M & G & $\mathbf{C P}$ & MP & LP & RE & IR & $\mathbf{L}$ & $\mathbf{R}$ & NA \\
\hline \multirow{8}{*}{$\begin{array}{l}\text { Revestimento das Margens } \\
\text { Revestimento em Concreto } \\
\text { Neças pré-moldadas. }\end{array}$} & Definição de um habitat. & & & & & & & & & & & & & & & \\
\hline & Definição e fixação de uma nova vegetação & & & & & & & & & & & & & & & \\
\hline & de margem. & & & & & & & & & & & & & & & \\
\hline & Estabilização das margens. & & & & & & & & & & & & & & & \\
\hline & $\begin{array}{l}\text { Impossibilidade de desenvolvimento ou } \\
\text { crescimento de uma vegetação de margem. }\end{array}$ & & & & & & & & & & & & & & & \\
\hline & $\begin{array}{l}\text { Melhoria das características físicas d'água } \\
\text { (cor e turbidez). }\end{array}$ & & & & & & & & & & & & & & & \\
\hline & $\begin{array}{l}\text { Redução do aporte sólido na corrente, } \\
\text { líquida. }\end{array}$ & & & & & & & & & & & & & & & \\
\hline & $\Leftrightarrow$ Redução dos efeitos da erosão. & & & & & & & & & & & & & & & \\
\hline
\end{tabular}


Planilha № 02 - Continuação - Impacto Ambiental das Ações Propostas - Classificação do Impacto Ambiental

\begin{tabular}{|c|c|c|c|c|c|c|c|c|c|c|c|c|c|c|c|c|}
\hline \multirow[t]{2}{*}{ Ação Proposta } & \multirow[t]{2}{*}{ Impacto Ambiental } & \multicolumn{15}{|c|}{ Classificação do Impacto Ambiental } \\
\hline & & $\mathbf{P}$ & $\mathbf{N}$ & D & I & B & M & $\mathbf{G}$ & CP & MP & LPP & $\mathbf{R E}$ & IR & $\mathbf{L}$ & $\mathbf{R}$ & NA \\
\hline \multirow{7}{*}{$\begin{array}{l}\text { Revestimento das Margens } \\
\text { Solo-cimento. }\end{array}$} & Definição de um habitat. & & & & & & & & & & & & & & & \\
\hline & $\begin{array}{l}\text { Definição e fixação de uma nova vegetação } \\
\text { de margem. }\end{array}$ & & & & & & & & & & & & & & & \\
\hline & Estabilização das margens. & & & & & & & & & & & & & & & \\
\hline & $\begin{array}{l}\text { Impossibilidade de desenvolvimento ou } \\
\text { crescimento de uma vegetação de margem. }\end{array}$ & & & & & & & & & & & & & & & \\
\hline & $\begin{array}{l}\text { Melhoria das características físicas d'água } \\
\text { (cor e turbidez). }\end{array}$ & & & & & & & & & & & & & & & \\
\hline & $\begin{array}{l}\text { Redução do aporte sólido na corrente, } \\
\text { líquida. }\end{array}$ & & & & & & & & & & & & & & & \\
\hline & Redução dos efeitos da erosão. & & & & & & & & & & & & & & & \\
\hline
\end{tabular}


Planilha № 02 - Continuação - Impacto Ambiental das Ações Propostas - Classificação do Impacto Ambiental

\begin{tabular}{|c|c|c|c|c|c|c|c|c|c|c|c|c|c|c|c|c|}
\hline \multirow[t]{2}{*}{ Ação Proposta } & \multirow[t]{2}{*}{ Impacto Ambiental } & \multicolumn{15}{|c|}{ Classificação do Impacto Ambiental } \\
\hline & & $\mathbf{P}$ & $\mathbf{N}$ & D & I & B & M & G & $\mathbf{C P}$ & MP & LP & RE & IR & $\mathbf{L}$ & $\mathbf{R}$ & NA \\
\hline \multirow{7}{*}{$\begin{array}{l}\text { Revestimento das Margens } \\
\text { Sistema Eco-estrutural } \\
\text { pneumático. }\end{array}$} & Definição de um habitat. & & & & & & & & & & & & & & & \\
\hline & $\begin{array}{l}\text { Definição e fixação de uma nova vegetação } \\
\text { de margem. }\end{array}$ & & & & & & & & & & & & & & & \\
\hline & Estabilização das margens. & & & & & & & & & & & & & & & \\
\hline & $\begin{array}{l}\text { Impossibilidade de desenvolvimento ou } \\
\text { crescimento de uma vegetação de margem. }\end{array}$ & & & & & & & & & & & & & & & \\
\hline & $\begin{array}{l}\text { Melhoria das características físicas d'água } \\
\text { (cor e turbidez). }\end{array}$ & & & & & & & & & & & & & & & \\
\hline & $\begin{array}{l}\text { Redução do aporte sólido na corrente, } \\
\text { líquida. }\end{array}$ & & & & & & & & & & & & & & & \\
\hline & $\leftrightarrow$ Redução dos efeitos da erosão. & & & & & & & & & & & & & & & \\
\hline
\end{tabular}


Planilha № 02 - Continuação - Impacto Ambiental das Ações Propostas - Classificação do Impacto Ambiental

\begin{tabular}{|c|c|c|c|c|c|c|c|c|c|c|c|c|c|c|c|c|}
\hline \multirow[t]{2}{*}{ Ação Proposta } & \multirow[t]{2}{*}{ Impacto Ambiental } & \multicolumn{15}{|c|}{ Classificação do Impacto Ambiental } \\
\hline & & $\mathbf{P}$ & $\mathbf{N}$ & $\mathbf{D}$ & I & B & M & G & CP & MP & LP & $\mathbf{R E}$ & IR & $\mathbf{L}$ & $\mathbf{R}$ & $\mathbf{N A}$ \\
\hline \multirow{7}{*}{$\begin{array}{l}\text { Revestimento das Margens } \\
\text { Geossintéticos }\end{array}$} & Definição de um habitat. & & & & & & & & & & & & & & & \\
\hline & $\begin{array}{l}\text { Definição e fixação de uma nova vegetação } \\
\text { de margem. }\end{array}$ & & & & & & & & & & & & & & & \\
\hline & Estabilização das margens. & & & & & & & & & & & & & & & \\
\hline & $\begin{array}{l}\text { Impossibilidade de desenvolvimento ou } \\
\text { crescimento de uma vegetação de margem. }\end{array}$ & & & & & & & & & & & & & & & \\
\hline & $\begin{array}{l}\text { Melhoria das características físicas d'água } \\
\text { (cor e turbidez). }\end{array}$ & & & & & & & & & & & & & & & \\
\hline & $\begin{array}{l}\text { Redução do aporte sólido na corrente, } \\
\text { líquida. }\end{array}$ & & & & & & & & & & & & & & & \\
\hline & Redução dos efeitos da erosão. & & & & & & & & & & & & & & & \\
\hline
\end{tabular}


Planilha № 02 - Continuação - Impacto Ambiental das Ações Propostas - Classificação do Impacto Ambiental

\begin{tabular}{|c|c|c|c|c|c|c|c|c|c|c|c|c|c|c|c|c|}
\hline \multirow[t]{2}{*}{ Ação Proposta } & \multirow[t]{2}{*}{ Impacto Ambiental } & \multicolumn{15}{|c|}{ Classificação do Impacto Ambiental } \\
\hline & & $\mathbf{P}$ & $\mathbf{N}$ & D & $\mathbf{I}$ & B & $\mathbf{M}$ & $\mathbf{G}$ & $\mathbf{C P}$ & MP & $\mathbf{L P}$ & $\mathbf{R E}$ & IR & $\mathbf{L}$ & $\mathbf{R}$ & NA \\
\hline \multirow[t]{10}{*}{ Revestimento das Margens } & Definição de um habitat. & & & & & & & & & & & & & & & \\
\hline & $\begin{array}{l}\Leftrightarrow \text { Definição e fixação de uma nova vegetação } \\
\text { de margem. }\end{array}$ & & & & & & & & & & & & & & & \\
\hline & Estabilização das margens. & & & & & & & & & & & & & & & \\
\hline & $\begin{array}{l}\text { Extinção ou minimização da diversidade } \\
\text { da fauna nas margens. }\end{array}$ & & & & & & & & & & & & & & & \\
\hline & $\begin{array}{l}\text { Impossibilidade de desenvolvimento ou } \\
\text { crescimento de uma vegetação de margem. }\end{array}$ & & & & & & & & & & & & & & & \\
\hline & $\begin{array}{l}\text { Melhoria das características físicas d'água } \\
\text { (cor e turbidez). }\end{array}$ & & & & & & & & & & & & & & & \\
\hline & Recuperação da vegetação primitiva. & & & & & & & & & & & & & & & \\
\hline & $\begin{array}{l}\text { W Proteção das margens contra a ação das } \\
\text { ondas. }\end{array}$ & & & & & & & & & & & & & & & \\
\hline & $\begin{array}{l}\text { Redução do aporte sólido na corrente, } \\
\text { líquida. }\end{array}$ & & & & & & & & & & & & & & & \\
\hline & $\leftrightarrow$ Redução dos efeitos da erosão. & & & & & & & & & & & & & & & \\
\hline
\end{tabular}


Planilha № 02 - Continuação - Impacto Ambiental das Ações Propostas - Classificação do Impacto Ambiental

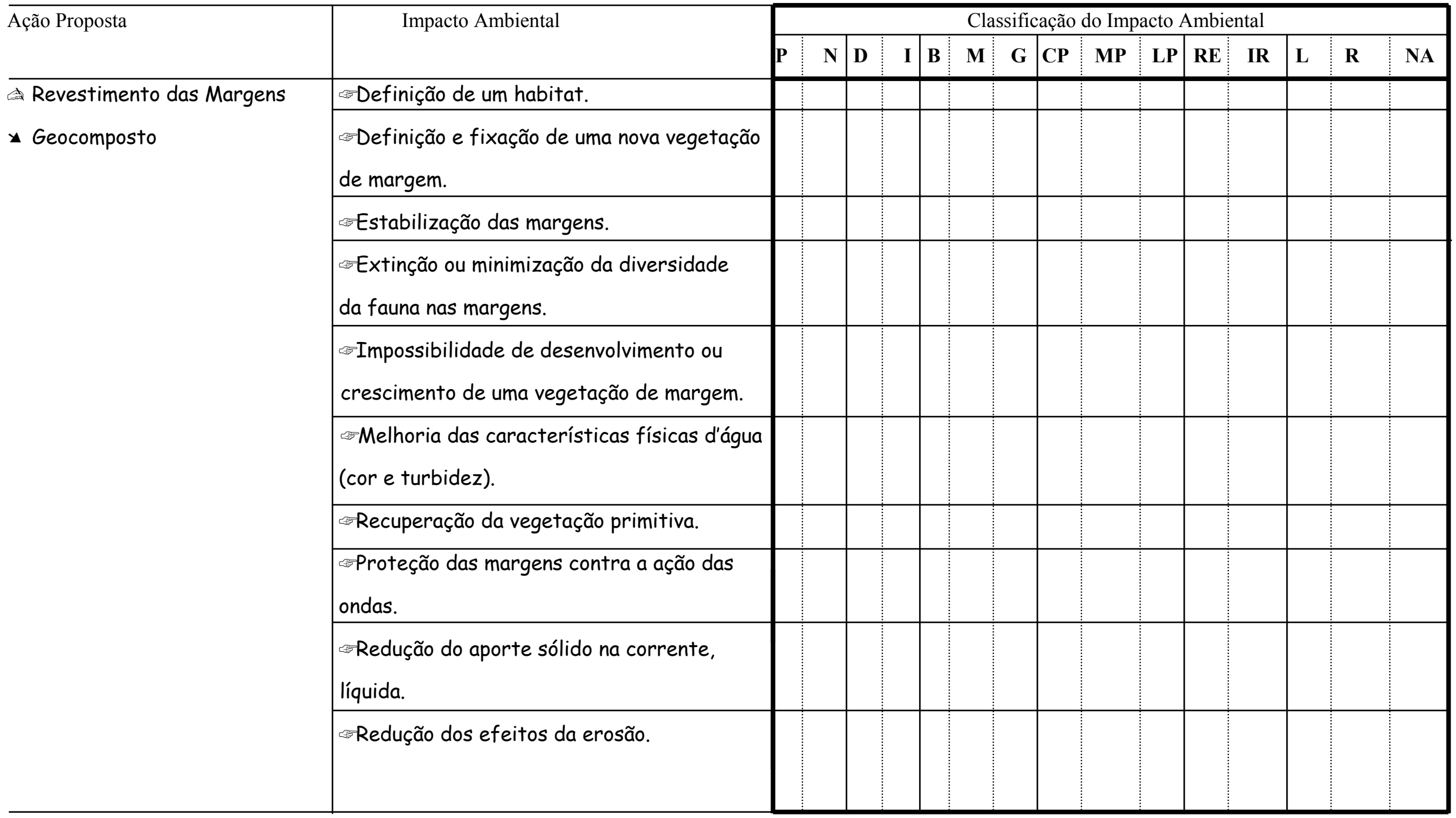


Planilha № 02 - Continuação - Impacto Ambiental das Ações Propostas - Classificação do Impacto Ambiental

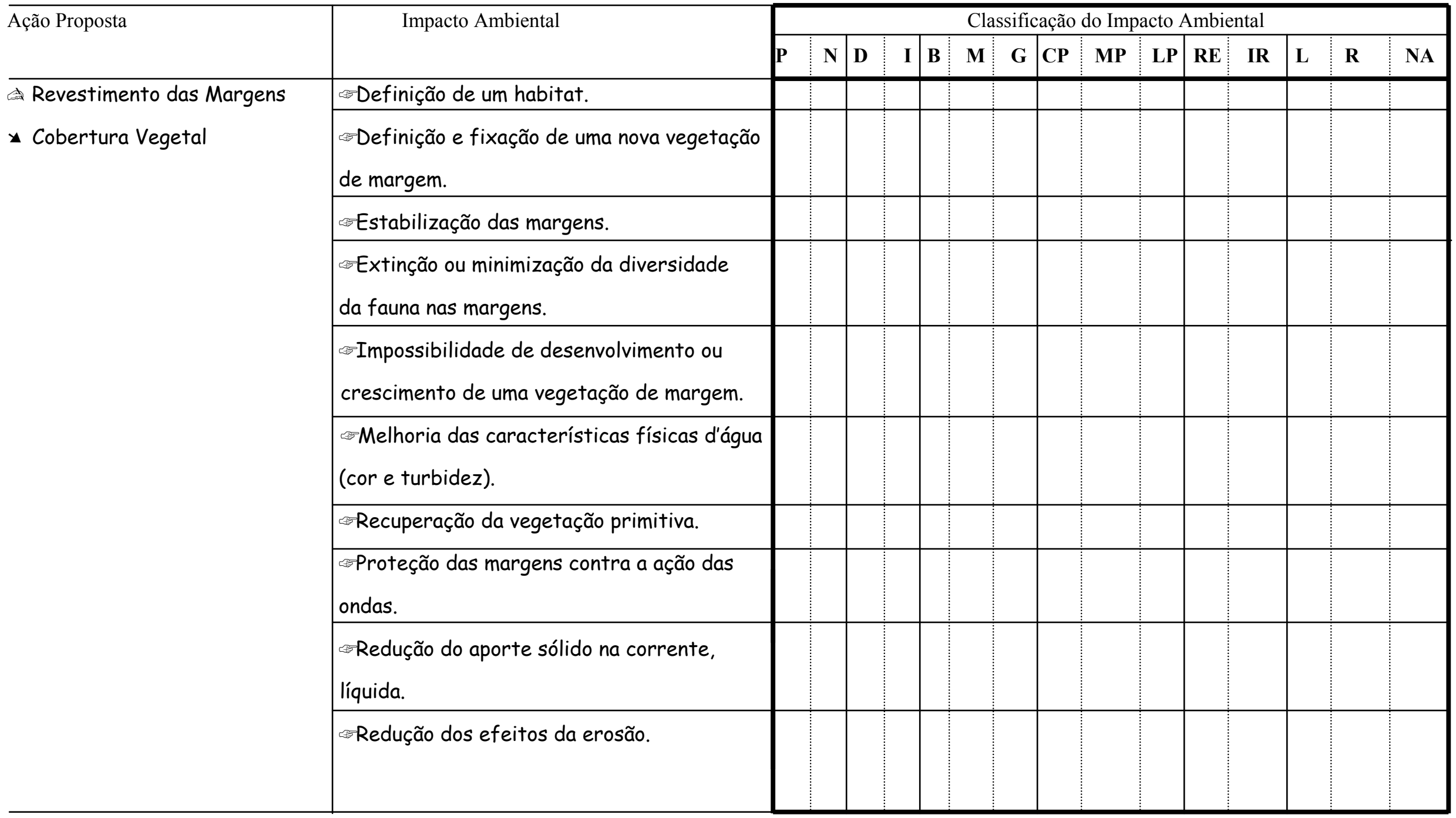


Planilha № 02 - Continuação - Impacto Ambiental das Ações Propostas - Classificação do Impacto Ambiental

\begin{tabular}{|c|c|c|c|c|c|c|c|c|c|c|c|c|c|c|c|c|}
\hline \multirow[t]{2}{*}{ Ação Proposta } & \multirow[t]{2}{*}{ Impacto Ambiental } & \multicolumn{15}{|c|}{ Classificação do Impacto Ambiental } \\
\hline & & $\mathbf{P}$ & $\mathbf{N}$ & D & $\mathbf{I}$ & B & $\mathbf{M}$ & $\mathbf{G}$ & $\mathbf{C P}$ & MP & $\mathbf{L P}$ & RE & IR & $\mathbf{L}$ & $\mathbf{R}$ & NA \\
\hline \multirow{10}{*}{$\begin{array}{l}\text { Revestimento das Margens } \\
\text { de rochertura Vegetal e Blocos de } \\
\text { enrocamento e vegetação natural) }\end{array}$} & Definição de um habitat. & & & & & & & & & & & & & & & \\
\hline & $\begin{array}{l}\text { Definição e fixação de uma nova vegetação } \\
\text { de margem. }\end{array}$ & & & & & & & & & & & & & & & \\
\hline & Estabilização das margens. & & & & & & & & & & & & & & & \\
\hline & $\begin{array}{l}\text { Extinção ou minimização da diversidade } \\
\text { da fauna nas margens. }\end{array}$ & & & & & & & & & & & & & & & \\
\hline & $\begin{array}{l}\text { Impossibilidade de desenvolvimento ou } \\
\text { crescimento de uma vegetação de margem. }\end{array}$ & & & & & & & & & & & & & & & \\
\hline & $\begin{array}{l}\text { Melhoria das características físicas d'água } \\
\text { (cor e turbidez). }\end{array}$ & & & & & & & & & & & & & & & \\
\hline & Recuperação da vegetação primitiva. & & & & & & & & & & & & & & & \\
\hline & $\begin{array}{l}\text { Proteção das margens contra a ação das } \\
\text { ondas. }\end{array}$ & & & & & & & & & & & & & & & \\
\hline & $\begin{array}{l}\text { Redução do aporte sólido na corrente, } \\
\text { líquida. }\end{array}$ & & & & & & & & & & & & & & & \\
\hline & Redução dos efeitos da erosão. & & & & & & & & & & & & & & & \\
\hline
\end{tabular}


Planilha № 03 - Impacto Ambiental das Ações Propostas - Classificação do Impacto Ambiental

\begin{tabular}{|c|c|c|c|c|c|c|c|c|c|c|c|c|c|c|c|c|}
\hline \multirow[t]{2}{*}{ Ação Proposta } & \multirow[t]{2}{*}{ Impacto Ambiental } & \multicolumn{15}{|c|}{ Classificação do Impacto Ambiental } \\
\hline & & $\mathbf{P}$ & $\mathbf{N}$ & D & $\mathbf{I}$ & B & $\mathbf{M}$ & $\mathbf{G}$ & $\mathbf{C P}$ & MP & $\mathbf{L P}$ & $\mathbf{R E}$ & IR & $\mathbf{L}$ & $\mathbf{R}$ & NA \\
\hline Obras de Sustentação & Definição de um habitat. & & & & & & & & & & & & & & & \\
\hline $\begin{array}{l}\text { ( A berma, recebe cargas, } \\
\text { provocando instabilidade da }\end{array}$ & $\begin{array}{l}\text { Definição e fixação de uma nova vegetação } \\
\text { de margem. }\end{array}$ & & & & & & & & & & & & & & & \\
\hline ribanceira ). & Estabilização das margens. & & & & & & & & & & & & & & & \\
\hline $\begin{array}{l}\text { Terra Armada } \\
\text { Muro de Gravidade }\end{array}$ & $\begin{array}{l}\text { Extinção ou minimização da diversidade } \\
\text { da fauna nas margens. }\end{array}$ & & & & & & & & & & & & & & & \\
\hline $\begin{array}{l}\text { Muros Atirantados } \\
\text { Muros de Flexão }\end{array}$ & $\begin{array}{l}\text { Impossibilidade de desenvolvimento ou } \\
\text { crescimento de uma vegetação de margem }\end{array}$ & & & & & & & & & & & & & & & \\
\hline $\begin{array}{l}\text { Muros de Contraforte } \\
\text { Rimobloco }\end{array}$ & $\begin{array}{l}\text { Melhoria das características físicas d'água } \\
\text { (cor e turbidez). }\end{array}$ & & & & & & & & & & & & & & & \\
\hline Crib-wall & Recuperação da vegetação primitiva. & & & & & & & & & & & & & & & \\
\hline $\begin{array}{l}\text { Parede Diafragma } \\
\text { Estacas Pranchas Metálicas }\end{array}$ & $\begin{array}{l}\text { Proteção das margens contra a ação das } \\
\text { ondas. }\end{array}$ & & & & & & & & & & & & & & & \\
\hline $\begin{array}{l}\text { Paredes de Estacões ou } \\
\text { Tubulões }\end{array}$ & $\begin{array}{l}\rightarrow \text { Redução do aporte sólido na corrente, } \\
\text { líquida. }\end{array}$ & & & & & & & & & & & & & & & \\
\hline & Redução dos efeitos da erosão. & & & & & & & & & & & & & & & \\
\hline & Criação de uma margem artificial & & & & & & & & & & & & & & & \\
\hline
\end{tabular}


Planilha № 03 - Continuação - Impacto Ambiental das Ações Propostas - Classificação do Impacto Ambiental

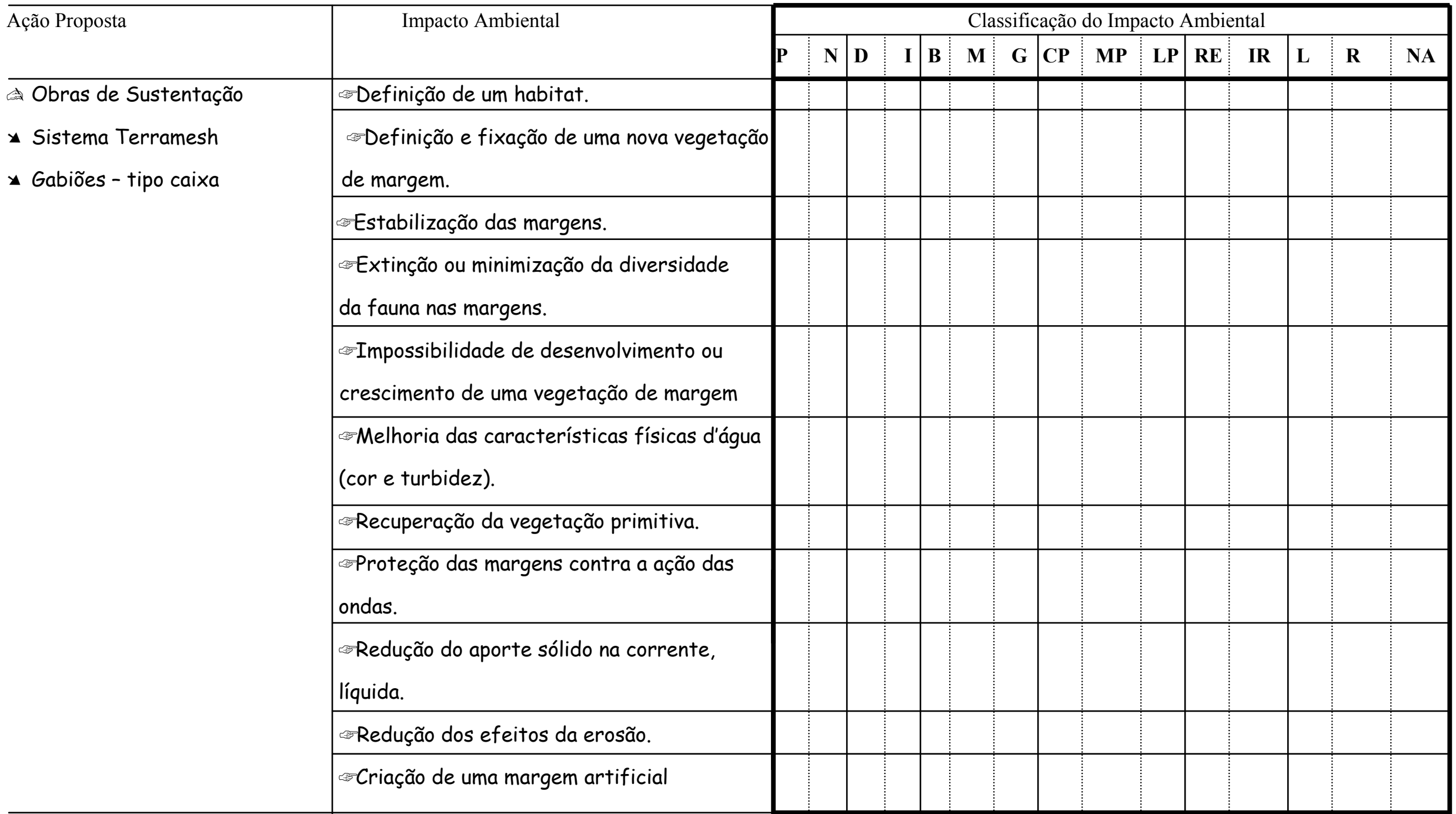




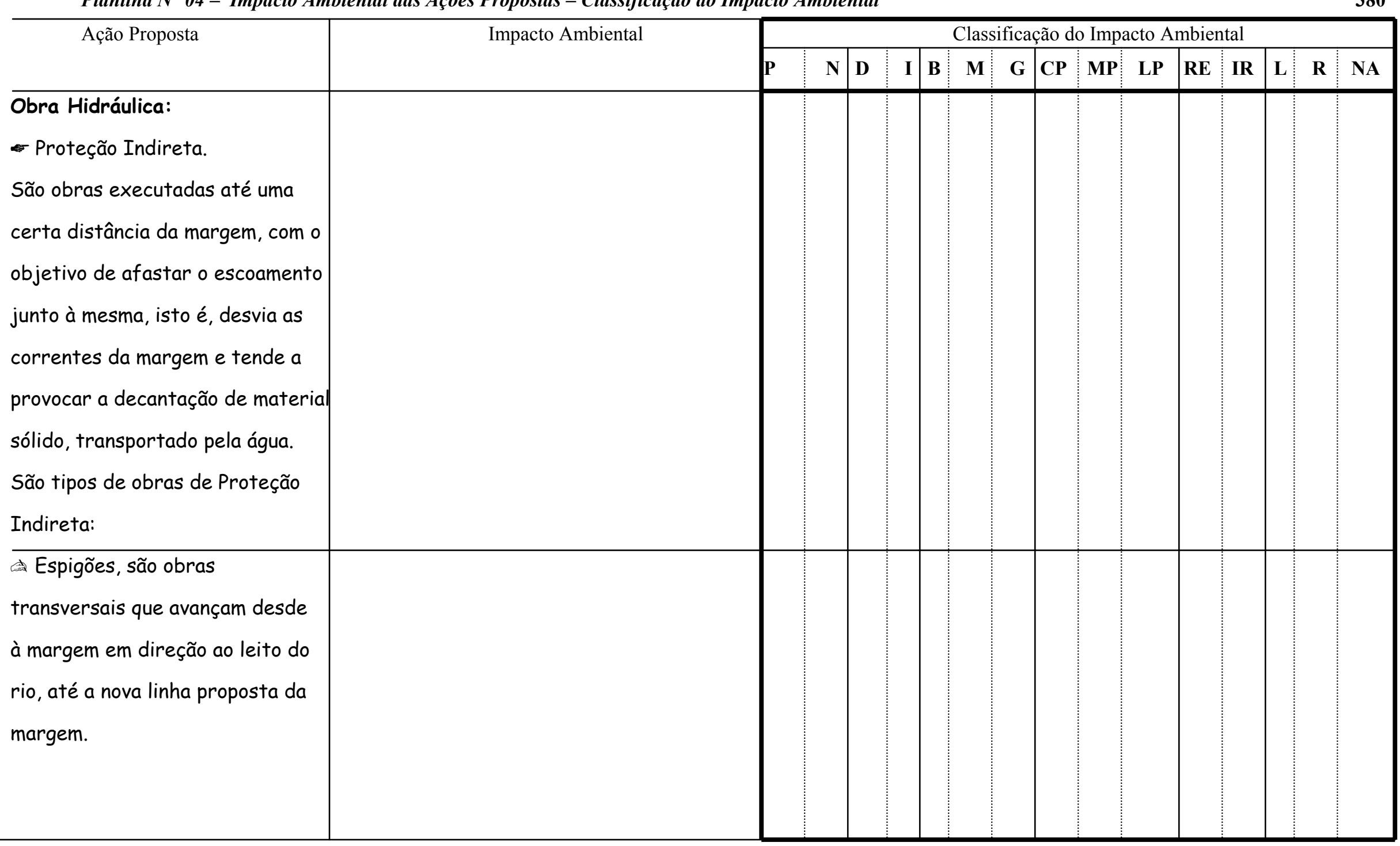


Planilha № 04 - Continuação - Impacto Ambiental das Ações Propostas - Classificação do Impacto Ambiental

\begin{tabular}{|c|c|c|c|c|c|c|c|c|c|c|c|c|c|c|c|c|}
\hline \multirow[t]{2}{*}{ Ação Proposta } & \multirow[t]{2}{*}{ Impacto Ambiental } & \multicolumn{15}{|c|}{ Classificação do Impacto Ambiental } \\
\hline & & $\mathbf{P}$ & $\mathbf{N}$ & D & I & B & M & G & $\mathbf{C P}$ & MP & $\mathbf{L P}$ & $\mathbf{E}$ & IR & $\mathbf{L}$ & $\mathbf{R}$ & NA \\
\hline \multirow[t]{6}{*}{ Espigão Permeável } & $\begin{array}{l}\text { A deposição de sedimentos, entre eles, } \\
\text { define a evolução de uma nova linha de } \\
\text { margem. }\end{array}$ & & & & & & & & & & & & & & & \\
\hline & $\begin{array}{l}\text { Não protege a margem da ação das ondas, } \\
\text { mas retém os sedimentos das margens } \\
\text { erodidas, isto é, o material não é arrastado } \\
\text { pelo rio. }\end{array}$ & & & & & & & & & & & & & & & \\
\hline & $\begin{array}{l}\text { Possibilidade de ocorrência de instabilidade } \\
\text { geotécnica, porém, o material movimentado } \\
\text { permanece entre os espigões. }\end{array}$ & & & & & & & & & & & & & & & \\
\hline & $\begin{array}{l}\text { Alteração da vegetação, nas margens dos } \\
\text { rios, com incremento no seu desenvolvimento. }\end{array}$ & & & & & & & & & & & & & & & \\
\hline & Alteração do habitat das margens. & & & & & & & & & & & & & & & \\
\hline & $\begin{array}{l}\text { As baixas velocidades do escoamento entre } \\
\text { eles, facilitam o desenvolvimento de um habitat } \\
\text { com a evolução da fauna e flora fluviais. }\end{array}$ & & & & & & & & & & & & & & & \\
\hline
\end{tabular}


Planilha № 04 - Continuação - Impacto Ambiental das Açães Propostas - Classificação do Impacto Ambiental

\begin{tabular}{|c|c|c|c|c|c|c|c|c|c|c|c|c|c|c|c|c|}
\hline \multirow[t]{2}{*}{ Ação Proposta } & \multirow[t]{2}{*}{ Impacto Ambiental } & \multicolumn{15}{|c|}{ Classificação do Impacto Ambiental } \\
\hline & & $\mathbf{P}$ & $\mathbf{N}$ & D & $\mathbf{I}$ & B & $\mathbf{M}$ & G & CP & MP & LP & $\mathbf{R E}$ & IR & $\mathbf{L}$ & $\mathbf{R}$ & NA \\
\hline & $\begin{array}{l}\text { A deposição de sedimentos, entre eles, } \\
\text { define a evolução de uma nova linha de } \\
\text { margem. }\end{array}$ & & & & & & & & & & & & & & & \\
\hline & $\begin{array}{l}\text { Não protege a margem da ação das ondas, } \\
\text { mas retém os sedimentos das margens } \\
\text { erodidas, isto é, o material não é arrastado } \\
\text { pelo rio. }\end{array}$ & & & & & & & & & & & & & & & \\
\hline & $\begin{array}{l}\text { Definição de um canal que favorece o } \\
\text { escoamento e o desenvolvimento das } \\
\text { condições de navegação (hidrovia) }\end{array}$ & & & & & & & & & & & & & & & \\
\hline
\end{tabular}


Planilha № 04 - Continuação - Impacto Ambiental das Ações Propostas - Classificação do Impacto Ambiental

\begin{tabular}{|c|c|c|c|c|c|c|c|c|c|c|c|c|c|c|c|c|}
\hline \multirow[t]{2}{*}{ Ação Proposta } & \multirow[t]{2}{*}{ Impacto Ambiental } & \multicolumn{15}{|c|}{ Classificação do Impacto Ambiental } \\
\hline & & $\mathbf{P}$ & $\mathbf{N}$ & D & $\mathbf{I}$ & B & $\mathbf{M}$ & $\mathbf{G}$ & $\mathbf{C P}$ & MP & $\mathbf{L P}$ & RE & IR & $\mathbf{L}$ & $\mathbf{R}$ & NA \\
\hline \multirow[t]{6}{*}{ ע Espigão Impermeável } & $\begin{array}{l}\text { A deposição de sedimentos, entre eles, } \\
\text { define a evolução de uma nova linha de } \\
\text { margem. }\end{array}$ & & & & & & & & & & & & & & & \\
\hline & $\begin{array}{l}\text { Não protege a margem da ação das ondas, } \\
\text { mas retém os sedimentos das margens } \\
\text { erodidas, isto é, o material não é arrastado } \\
\text { pelo rio. }\end{array}$ & & & & & & & & & & & & & & & \\
\hline & $\begin{array}{l}\text { possibilidade de ocorrência de instabilidade } \\
\text { geotécnica, porém, o material movimentado } \\
\text { permanece entre os espigões. }\end{array}$ & & & & & & & & & & & & & & & \\
\hline & $\begin{array}{l}\text { Alteração da vegetação, nas margens dos } \\
\text { rios, com incremento no seu desenvolvimento. }\end{array}$ & & & & & & & & & & & & & & & \\
\hline & Alteração do habitat das margens. & & & & & & & & & & & & & & & \\
\hline & $\begin{array}{l}\text { As baixas velocidades do escoamento entre } \\
\text { eles, facilitam o desenvolvimento de um habitat } \\
\text { com a evolução da fauna e flora fluviais. }\end{array}$ & & & & & & & & & & & & & & & \\
\hline
\end{tabular}


Planilha № 04 - Continuação - Impacto Ambiental das Ações Propostas - Classificação do Impacto Ambiental

\begin{tabular}{|c|c|c|c|c|c|c|c|c|c|c|c|c|c|c|c|c|}
\hline \multirow[t]{2}{*}{ Ação Proposta } & \multirow[t]{2}{*}{ Impacto Ambiental } & \multicolumn{15}{|c|}{ Classificação do Impacto Ambiental } \\
\hline & & $\mathbf{P}$ & $\mathbf{N}$ & D & I & B & M & $\mathbf{G}$ & $\mathbf{C P}$ & MP & $\mathbf{L P}$ & $\mathbf{R E}$ & IR & $\mathbf{L}$ & $\mathbf{R}$ & NA \\
\hline & $\begin{array}{l}\text { A deposição de sedimentos, entre eles, } \\
\text { define a evolução de uma nova linha de } \\
\text { margem. }\end{array}$ & & & & & & & & & & & & & & & \\
\hline & $\begin{array}{l}\text { Não protege a margem da ação das ondas, } \\
\text { mas retém os sedimentos das margens } \\
\text { erodidas, isto é, o material não é arrastado } \\
\text { pelo rio. }\end{array}$ & & & & & & & & & & & & & & & \\
\hline & $\begin{array}{l}\text { Definição de um canal que favorece o } \\
\text { escoamento e o desenvolvimento das } \\
\text { condições de navegação (hidrovia) }\end{array}$ & & & & & & & & & & & & & & & \\
\hline
\end{tabular}


Planilha № 05 - Impacto Ambiental das Ações Propostas - Classificação do Impacto Ambiental

\begin{tabular}{|c|c|c|c|c|c|c|c|c|c|c|c|c|c|c|c|c|}
\hline \multirow[t]{2}{*}{ Ação Proposta } & \multirow[t]{2}{*}{ Impacto Ambiental } & \multicolumn{15}{|c|}{ Classificação do Impacto Ambiental } \\
\hline & & $\mathbf{P}$ & $\mathbf{N}$ & D & I & B & $\mathbf{M}$ & G & $\mathbf{C P}$ & MP & $\mathbf{L P}$ & $\mathbf{R E}$ & IR & $\mathbf{L}$ & $\mathbf{R}$ & NA \\
\hline \multirow{4}{*}{$\begin{array}{l}\text { - Diques, são construções } \\
\text { longitudinais ao curso d'água, } \\
\text { constituindo uma margem } \\
\text { artificial (avanço da margem), } \\
\text { com redução da área hidráulica } \\
\text { da seção do canal ( com } \\
\text { confinamento e direcionamento }\end{array}$} & $\begin{array}{l}\text { Aumento da velocidade do fluxo, devido a } \\
\text { redução da área hidráulica. }\end{array}$ & & & & & & & & & & & & & & & \\
\hline & Alteração do regime de escoamento. & & & & & & & & & & & & & & & \\
\hline & $\begin{array}{l}\text { po aumento da velocidade de escoamento, } \\
\text { pode erodir o leito, incrementando o } \\
\text { transporte de sedimentos. }\end{array}$ & & & & & & & & & & & & & & & \\
\hline & Cria uma linha de margem. & & & & & & & & & & & & & & & \\
\hline \multirow[t]{2}{*}{ do escoamento ). } & Protege a margem da ação das ondas. & & & & & & & & & & & & & & & \\
\hline & $\begin{array}{l}\text { Definição de um canal que favorece o } \\
\text { escoamento e o desenvolvimento das } \\
\text { condições de navegação (hidrovia). }\end{array}$ & & & & & & & & & & & & & & & \\
\hline
\end{tabular}


AÇÃO PROPOSTA - Obra Hidráulica Fluvial

Tipo de Obra Hidráulica Fluvial - Retificação de Rios Sinuosos e Meandros - A Retificação de Meandros, tem por objetivo tornar retilíneo o leito curvo do rio, melhorando as condições do escoamento. Só terá êxito a partir dos conhecimentos específicos dos meandros fluviais, tais como: origem dos meandros, mecanismo de formação de meandros, localização dos meandros, caracterização do meandro.

\begin{tabular}{|c|c|c|c|c|c|c|c|c|c|c|c|c|c|c|c|c|}
\hline \multirow[t]{2}{*}{ Ação Proposta } & \multirow[t]{2}{*}{ Impacto Ambiental } & \multicolumn{15}{|c|}{ Classificação do Impacto Ambiental } \\
\hline & & $\mathbf{P}$ & $\mathbf{N}$ & $\mathbf{D}$ & I & B & M & $\mathbf{G}$ & $\mathbf{C P}$ & MP & $\mathbf{L P}$ & RE & IR & $\mathbf{L}$ & $\mathbf{R}$ & NA \\
\hline \multicolumn{17}{|l|}{$\begin{array}{l}\text { Obra Hidráulica: } \\
\text { - Retificação de Rios Sinuosos } \\
\text { e Meandros }\end{array}$} \\
\hline \multirow{5}{*}{$\begin{array}{l}\text { Controle da Inundação no } \\
\text { trecho, conseqüente proteção dos } \\
\text { terrenos marginais. }\end{array}$} & $\begin{array}{l}\leftrightarrow \text { Permite a utilização da várzea para fins } \\
\text { de agricultura. }\end{array}$ & & & & & & & & & & & & & & & \\
\hline & $\begin{array}{l}\text { Alteração da vegetação das margens dos } \\
\text { cursos d' água nos trechos retificados. }\end{array}$ & & & & & & & & & & & & & & & \\
\hline & $\begin{array}{l}\text { A proteção do terrenos marginais, facilita } \\
\text { o desenvolvimento da irrigação, através da } \\
\text { implantação de "Polder". }\end{array}$ & & & & & & & & & & & & & & & \\
\hline & $\begin{array}{l}\text { Tendência do aumento do pico de vazão } \\
\text { para jusante do trecho retificado. }\end{array}$ & & & & & & & & & & & & & & & \\
\hline & Alteração do regime de escoamento. & & & & & & & & & & & & & & & \\
\hline
\end{tabular}


Planilha № 06 - Continuação - Impacto Ambiental das Ações Propostas - Classificação do Impacto Ambiental

\begin{tabular}{|c|c|c|c|c|c|c|c|c|c|c|c|c|c|c|c|c|}
\hline \multirow[t]{2}{*}{ Ação Proposta } & \multirow[t]{2}{*}{ Impacto Ambiental } & \multicolumn{15}{|c|}{ Classificação do Impacto Ambiental } \\
\hline & & $\mathbf{P}$ & $\mathbf{N}$ & D & $\mathbf{I}$ & B & $\mathbf{M}$ & $\mathbf{G}$ & $\mathrm{CP}$ & MP & $\mathbf{L P}$ & $\mathbf{R E}$ & IR & $\mathbf{L}$ & $\mathbf{R}$ & NA \\
\hline & $\begin{array}{l}\text { Aumento da velocidade de fluxo e da ação } \\
\text { erosiva sobre leito (margens e fundo). }\end{array}$ & & & & & & & & & & & & & & & \\
\hline & $\begin{array}{l}\text { Permite a "definição" de um habitat com } \\
\text { a fixação de áreas inundáveis ou não, bem } \\
\text { definidos. }\end{array}$ & & & & & & & & & & & & & & & \\
\hline & $\begin{array}{l}\text { Alteração do curso d'água, no que se } \\
\text { refere ao volume d'água e conformação do } \\
\text { leito. }\end{array}$ & & & & & & & & & & & & & & & \\
\hline & $\begin{array}{l}\text { Modificação nas rotas de migração de } \\
\text { peixes. }\end{array}$ & & & & & & & & & & & & & & & \\
\hline & Alteração no habitat das margens. & & & & & & & & & & & & & & & \\
\hline & $\begin{array}{l}\text { Utilização da alça proveniente da retificação } \\
\text { do curso d'água, para tratamento de águas } \\
\text { residuárias, criação de peixes, recreação, etc. }\end{array}$ & & & & & & & & & & & & & & & \\
\hline & Alteração no habitat das alça. & & & & & & & & & & & & & & & \\
\hline \multirow[t]{2}{*}{$\begin{array}{l}\text { Melhoria do Traçado } \\
\text { ( para fins de navegação) }\end{array}$} & $\begin{array}{l}\text { Alteração da vegetação das margens dos } \\
\text { cursos d'água, nos trechos retificados. }\end{array}$ & & & & & & & & & & & & & & & \\
\hline & Aumento da ação de escoamento. & & & & & & & & & & & & & & & \\
\hline
\end{tabular}


Planilha № 06 - Continuação - Impacto Ambiental das Ações Propostas - Classificação do Impacto Ambiental

\begin{tabular}{|c|c|c|c|c|c|c|c|c|c|c|c|c|c|c|c|c|}
\hline \multirow[t]{2}{*}{ Ação Proposta } & \multirow[t]{2}{*}{ Impacto Ambiental } & \multicolumn{15}{|c|}{ Classificação do Impacto Ambiental } \\
\hline & & $\mathbf{P}$ & $\mathbf{N}$ & $\mathbf{D}$ & $\mathbf{I}$ & B & $\mathbf{M}$ & $\mathbf{G}$ & $\mathbf{C P}$ & MP & $\mathbf{L P}$ & RE & IR & $\mathbf{L}$ & $\mathbf{R}$ & NA \\
\hline & $\begin{array}{l}\text { wFormação de ondas com a passagem de } \\
\text { embarcação. }\end{array}$ & & & & & & & & & & & & & & & \\
\hline & $\begin{array}{l}\Leftrightarrow \text { Definição de um canal que favorece o } \\
\text { desenvolvimento da navegação (hidrovia) }\end{array}$ & & & & & & & & & & & & & & & \\
\hline & $\begin{array}{l}\text { Modificação nas rotas de migração de } \\
\text { peixes. }\end{array}$ & & & & & & & & & & & & & & & \\
\hline & Alteração no habitat das margens. & & & & & & & & & & & & & & & \\
\hline & $\begin{array}{l}\text { Utilização da alça resultante da retificação } \\
\text { do curso d'água, para tratamento de águas } \\
\text { residuárias, criação de peixes, recreação, etc. }\end{array}$ & & & & & & & & & & & & & & & \\
\hline & Alteração no habitat das alça. & & & & & & & & & & & & & & & \\
\hline \multirow[t]{3}{*}{ Drenagem Urbana } & $\begin{array}{l}\text { Alteração da vegetação das margens dos } \\
\text { cursos d'água. }\end{array}$ & & & & & & & & & & & & & & & \\
\hline & Aumento da velocidade do fluxo das águas. & & & & & & & & & & & & & & & \\
\hline & $\begin{array}{l}\text { Ocupação das margens para a implantação } \\
\text { de vias terrestres em fundo de vale. }\end{array}$ & & & & & & & & & & & & & & & \\
\hline
\end{tabular}


Planilha № 06 - Continuação - Impacto Ambiental das Ações Propostas - Classificação do Impacto Ambiental

\begin{tabular}{|c|c|c|c|c|c|c|c|c|c|c|c|c|c|c|c|c|}
\hline \multirow[t]{2}{*}{ Ação Proposta } & \multirow[t]{2}{*}{ Impacto Ambiental } & \multicolumn{15}{|c|}{ Classificação do Impacto Ambiental } \\
\hline & & $\mathbf{P}$ & $\mathbf{N}$ & D & $\mathbf{I}$ & B & $\mathbf{M}$ & $\mathbf{G}$ & $\mathbf{C P}$ & MP & $\mathbf{L P}$ & $\mathbf{R E}$ & IR & $\mathbf{L}$ & $\mathbf{R}$ & $\mathbf{N A}$ \\
\hline \multirow{9}{*}{$\begin{array}{l}\text { A Corte de Meandro, através de } \\
\text { Canal Piloto (é um canal com } \\
\text { pequenas dimensões, que evolui a } \\
\text { partir da capacidade d'água em } \\
\text { erodir ). }\end{array}$} & $\begin{array}{l}\text { Aumento do volume de sedimentos lançados } \\
\text { a jusante (necessidade de se limitar a } \\
\text { escavação, do novo canal, por ação d'água). }\end{array}$ & & & & & & & & & & & & & & & \\
\hline & $\begin{array}{l}\text { * Alteração da vegetação das margens dos } \\
\text { cursos d'água nos trechos retificados. }\end{array}$ & & & & & & & & & & & & & & & \\
\hline & $\begin{array}{l}\text { Tendência do aumento do pico de vazão } \\
\text { para jusante do trecho retificado. }\end{array}$ & & & & & & & & & & & & & & & \\
\hline & Alteração do regime de escoamento. & & & & & & & & & & & & & & & \\
\hline & $\begin{array}{l}\text { Aumento da velocidade de fluxo e da } \\
\text { ação erosiva sobre o leito (margem e fundo). }\end{array}$ & & & & & & & & & & & & & & & \\
\hline & $\begin{array}{l}\text { Alteração do curso d'água, no que se refere } \\
\text { ao volume d'água e conformação do leito. }\end{array}$ & & & & & & & & & & & & & & & \\
\hline & $\begin{array}{l}\text { Modificação nas rotas de migração de } \\
\text { peixes. }\end{array}$ & & & & & & & & & & & & & & & \\
\hline & Alteração no habitat das alças. & & & & & & & & & & & & & & & \\
\hline & Alteração no habitat das margens. & & & & & & & & & & & & & & & \\
\hline
\end{tabular}




\begin{tabular}{|c|c|c|c|c|c|c|c|c|c|c|c|c|c|c|c|c|}
\hline \multirow[t]{2}{*}{ Ação Proposta } & \multirow[t]{2}{*}{ Impacto Ambiental } & \multicolumn{15}{|c|}{ Classificação do Impacto Ambiental } \\
\hline & & $\mathbf{P}$ & $\mathbf{N}$ & D & $\mathbf{I}$ & B & $\mathbf{M}$ & $\mathbf{G}$ & $\mathbf{C P}$ & MP & $\mathbf{L P}$ & $\mathbf{R E}$ & IR & $\mathbf{L}$ & $\mathbf{R}$ & NA \\
\hline & $\begin{array}{l}\text { retilização da alça proveniente da } \\
\text { retão do curso d'água, para tratamento } \\
\text { de águas residuárias, criação de peixes, } \\
\text { recreação, etc. }\end{array}$ & & & & & & & & & & & & & & & \\
\hline
\end{tabular}


AÇÃO PROPOSTA - Obra Hidráulica Fluvial

Tipo de Obra Hidráulica Fluvial - Derrocamento e Dragagem - O derrocamento é a operação que consiste no desmonte (fraturamento, rompimento ) de rochas, particularmente do leito de rios ou canais, para desobstrui-los. Após desmonte, dá-se a remoção da rocha.. O desmonte da rocha, é feito com técnicas específicas, que consistem em romper o maciço rochoso, que pode se realizar, com a utilização de explosivos (ondas de choque), por percussão (marreta, soquete, ariete) ou por perfuração e percussão (martelete) e, finalmente promover a remoção do material rompido, que quando no leito de rios ou canais, será retirado através de dragas. Entende-se por dragagem a retirada, transporte e disposição final, do material, que pode ser resultante do derrocamento, areias, siltes, argilas, etc., do leito dos rios ou não, por equipamentos adequados em cada operação.

\begin{tabular}{|c|c|c|c|c|c|c|c|c|c|c|c|c|c|c|c|c|}
\hline \multirow[t]{2}{*}{ Ação Proposta } & \multirow[t]{2}{*}{ Impacto Ambiental } & \multicolumn{15}{|c|}{ Classificação do Impacto Ambiental } \\
\hline & & $\mathbf{P}$ & $\mathbf{N}$ & $\mathbf{D}$ & I. & B & $\mathbf{M}$ & $\mathbf{G}$ & $\mathbf{C P}$ & MP & $\mathbf{L P}$ & RE & IR & $\mathbf{L}$ & $\mathbf{R}$ & NA \\
\hline \multicolumn{17}{|c|}{$\begin{array}{l}\text { Obra Hidráulica } \\
\text { - Derrocamento e Dragagem }\end{array}$} \\
\hline \multirow[t]{2}{*}{$\begin{array}{l}\text { Derrocamento } \\
\text { Com Explosivos }\end{array}$} & $\begin{array}{l}\text { Destruição da fauna e flora aquática, nas } \\
\text { proximidades da explosão, devido as ondas de } \\
\text { choque. }\end{array}$ & & & & & & & & & & & & & & & \\
\hline & $\begin{array}{l}\text { Aumento do volume de material fragmentado, } \\
\text { e conseqüente redução da seção transversal } \\
\text { num determinado trecho e num determinado } \\
\text { intervalo de tempo. }\end{array}$ & & & & & & & & & & & & & & & \\
\hline
\end{tabular}


Planilha No 07 - Impacto Ambiental das Ações Propostas - Classificação do Impacto Ambiental

\begin{tabular}{|c|c|c|c|c|c|c|c|c|c|c|c|c|c|c|c|c|}
\hline \multirow[t]{2}{*}{ Ação Proposta } & \multirow[t]{2}{*}{ Impacto Ambiental } & \multicolumn{15}{|c|}{ Classificação do Impacto Ambiental } \\
\hline & & $\mathbf{P}$ & $\mathbf{N}$ & D & $\mathbf{I}$ & B & $\mathbf{M}$ & $\mathbf{G}$ & $\mathbf{C P}$ & MP & $\mathbf{L P}$ & RE & IR & $\mathbf{L}$ & $\mathbf{R}$ & NA \\
\hline & Alteração das características físicas d'água. & & & & & & & & & & & & & & & \\
\hline \multirow[t]{3}{*}{ ^ Com Martelete e Percussão } & Aumento do nível de ruído. & & & & & & & & & & & & & & & \\
\hline & $\begin{array}{l}\text { Aumento do volume de material fragmentado, } \\
\text { e conseqüiente redução da seção transversal } \\
\text { num determinado trecho e num determinado } \\
\text { intervalo de tempo. }\end{array}$ & & & & & & & & & & & & & & & \\
\hline & * Alteração das características físicas d'água. & & & & & & & & & & & & & & & \\
\hline \multicolumn{17}{|l|}{ Dragagem } \\
\hline \multirow{3}{*}{\multicolumn{17}{|c|}{$\begin{array}{l}\text { A operação de dragagem, } \\
\text { compreende: retirada, transporte } \\
\text { e disposição final do material. }\end{array}$}} \\
\hline & & & & & & & & & & & & & & & & \\
\hline & & & & & & & & & & & & & & & & \\
\hline \multirow[t]{3}{*}{ « Retirada do material do leito. } & $\begin{array}{l}\text { Alteração da paisagem ( no caso, bancos de } \\
\text { areia ou rochas aparentes ). }\end{array}$ & & & & & & & & & & & & & & & \\
\hline & $\begin{array}{l}\text { Melhoria das condições de escoamento, } \\
\text { devido o aumento da seção. }\end{array}$ & & & & & & & & & & & & & & & \\
\hline & Aumento na velocidade do fluxo das águas. & & & & & & & & & & & & & & & \\
\hline
\end{tabular}


Planilha No 07 - Impacto Ambiental das Ações Propostas - Classificação do Impacto Ambiental

\begin{tabular}{|c|c|c|c|c|c|c|c|c|c|c|c|c|c|c|c|c|}
\hline \multirow[t]{2}{*}{ Ação Proposta } & \multirow[t]{2}{*}{ Impacto Ambiental } & \multicolumn{15}{|c|}{ Classificação do Impacto Ambiental } \\
\hline & & $\mathbf{P}$ & $\mathbf{N}$ & D & $\mathbf{I}$ & B & $\mathbf{M}$ & $\mathbf{G}$ & $\mathbf{C P}$ & MP & $\mathbf{L P}$ & $\mathbf{R E}$ & IR & $\mathbf{L}$ & $\mathbf{R}$ & $\mathbf{N A}$ \\
\hline & Alteração dinâmica do pulso de inundação. & & & & & & & & & & & & & & & \\
\hline & Abaixamento do nível d'água. & & & & & & & & & & & & & & & \\
\hline & $\begin{array}{l}\text { A remoção do material pode alterar a } \\
\text { composição e o tamanho da partícula do } \\
\text { material do leito. }\end{array}$ & & & & & & & & & & & & & & & \\
\hline & Aprofundamento do canal. & & & & & & & & & & & & & & & \\
\hline N Equipamentos de Dragagem & $\rightarrow$ Diminuição da produtividade de algas. & & & & & & & & & & & & & & & \\
\hline $\begin{array}{l}\text { Dragas Mecânicas } \\
\text { - Dragas de Alcatruzes }\end{array}$ & $\begin{array}{l}\text { Contaminação das redes alimentares, no caso } \\
\text { de existirem produtos tóxicos. }\end{array}$ & & & & & & & & & & & & & & & \\
\hline A corrente sem-fim de caçambas & Destruição de hábitats da fauna bentônica. & & & & & & & & & & & & & & & \\
\hline $\begin{array}{l}\text { quando escava a sua própria } \\
\text { carga, provoca: }\end{array}$ & $\begin{array}{l}\text { aliminuição da complexidade das redes } \\
\text { alimentares. }\end{array}$ & & & & & & & & & & & & & & & \\
\hline & $\begin{array}{l}\text { Aumento da mortande de peixes por } \\
\text { asfixia e intoxicação. }\end{array}$ & & & & & & & & & & & & & & & \\
\hline & $\begin{array}{l}\text { Perda da diversidade de espécies de } \\
\text { fitoplâncton, bentos e peixes. }\end{array}$ & & & & & & & & & & & & & & & \\
\hline
\end{tabular}


Planilha No 07 - Impacto Ambiental das Ações Propostas - Classificação do Impacto Ambiental

\begin{tabular}{|c|c|c|c|c|c|c|c|c|c|c|c|c|c|c|c|c|}
\hline \multirow[t]{2}{*}{ Ação Proposta } & \multirow[t]{2}{*}{ Impacto Ambiental } & \multicolumn{15}{|c|}{ Classificação do Impacto Ambiental } \\
\hline & & $\mathbf{P}$ & $\mathbf{N}$ & D & $\mathbf{I}$ & B & $\mathbf{M}$ & G & $\mathbf{C P}$ & MP & $\mathbf{L P}$ & $\mathbf{R E}$ & IR & $\mathbf{L}$ & $\mathbf{R}$ & NA \\
\hline & Alteração da qualidade física d'água. & & & & & & & & & & & & & & & \\
\hline & $\begin{array}{l}\text { Incorporação de substâncias tóxicas do } \\
\text { sedimento para a coluna d'água, se existentes, } \\
\text { (alteração da qualidade química da água) }\end{array}$ & & & & & & & & & & & & & & & \\
\hline & $\begin{array}{l}\text { Decréscimo na densidade de organismos } \\
\text { aquáticos. }\end{array}$ & & & & & & & & & & & & & & & \\
\hline Dragas de Trabalho & $\Leftrightarrow$ Diminuição da produtividade de algas. & & & & & & & & & & & & & & & \\
\hline $\begin{array}{l}\text { Descontínuo ( pá-mecânica, } \\
\text { caçamba, escavadeira). }\end{array}$ & $\begin{array}{l}\text { Contaminação das redes alimentares, no caso } \\
\text { de existirem produtos tóxicos. }\end{array}$ & & & & & & & & & & & & & & & \\
\hline A escavação com colher e/ou & Destruição de hábitats da fauna bentônica. & & & & & & & & & & & & & & & \\
\hline caçamba clamshell, provoca: & $\begin{array}{l}\text { Diminuição da complexidade das redes } \\
\text { alimentares. }\end{array}$ & & & & & & & & & & & & & & & \\
\hline & $\begin{array}{l}\text { Aumento da mortande de peixes por } \\
\text { asfixia e intoxicação. }\end{array}$ & & & & & & & & & & & & & & & \\
\hline & $\begin{array}{l}\text { Herda da diversidade de espécies de } \\
\text { fitoplâncton, bentos e peixes. }\end{array}$ & & & & & & & & & & & & & & & \\
\hline
\end{tabular}


Planilha No 07 - Impacto Ambiental das Ações Propostas - Classificação do Impacto Ambiental

\begin{tabular}{|c|c|c|c|c|c|c|c|c|c|c|c|c|c|c|c|c|}
\hline \multirow[t]{2}{*}{ Ação Proposta } & \multirow[t]{2}{*}{ Impacto Ambiental } & \multicolumn{15}{|c|}{ Classificação do Impacto Ambiental } \\
\hline & & $\mathbf{P}$ & $\mathbf{N}$ & D & $\mathbf{I}$ & B & $\mathbf{M}$ & $\mathbf{G}$ & $\mathbf{C P}$ & MP & $\mathbf{L P}$ & $\mathbf{R E}$ & IR & $\mathbf{L}$ & $\mathbf{R}$ & $\mathbf{N A}$ \\
\hline & Alteração da qualidade física d'água. & & & & & & & & & & & & & & & \\
\hline & $\begin{array}{l}\text { Incorporação de substâncias tóxicas do } \\
\text { sedimento para a coluna d'água, se existentes, } \\
\text { (alteração da qualidade química da água) }\end{array}$ & & & & & & & & & & & & & & & \\
\hline & $\begin{array}{l}\text { Decréscimo na densidade de organismos } \\
\text { aquáticos. }\end{array}$ & & & & & & & & & & & & & & & \\
\hline$\Rightarrow$ Dragas de Sucção & $\leftrightarrow$ Diminuição da produtividade de algas. & & & & & & & & & & & & & & & \\
\hline $\begin{array}{l}\text { A sucção de uma mistura de água } \\
(80 \% \text { a } 90 \%) \text { e material sólido }\end{array}$ & $\begin{array}{l}\text { Contaminação das redes alimentares, no caso } \\
\text { de existirem produtos tóxicos. }\end{array}$ & & & & & & & & & & & & & & & \\
\hline$(20 \%$ a $10 \%)$ arrancado do leito & Destruição de hábitats da fauna bentônica. & & & & & & & & & & & & & & & \\
\hline do rio, provoca: & $\begin{array}{l}\text { Diminuição da complexidade das redes } \\
\text { alimentares. }\end{array}$ & & & & & & & & & & & & & & & \\
\hline & $\begin{array}{l}\text { Aumento da mortande de peixes por } \\
\text { asfixia e intoxicação. }\end{array}$ & & & & & & & & & & & & & & & \\
\hline & $\begin{array}{l}\text { Perda da diversidade de espécies de } \\
\text { fitoplâncton, bentos e peixes. }\end{array}$ & & & & & & & & & & & & & & & \\
\hline
\end{tabular}


Planilha Noo 07 - Impacto Ambiental das Ações Propostas - Classificação do Impacto Ambiental

\begin{tabular}{|c|c|c|c|c|c|c|c|c|c|c|c|c|c|c|c|c|}
\hline \multirow[t]{2}{*}{ Ação Proposta } & \multirow[t]{2}{*}{ Impacto Ambiental } & \multicolumn{15}{|c|}{ Classificação do Impacto Ambiental } \\
\hline & & $\mathbf{P}$ & $\mathbf{N}$ & D & I & B & $\mathbf{M}$ & G & $\mathbf{C P}$ & MP & $\mathbf{L P}$ & RE & IR & $\mathbf{L}$ & $\mathbf{R}$ & NA \\
\hline & Alteração da qualidade física d'água. & & & & & & & & & & & & & & & \\
\hline & $\begin{array}{l}\text { af Incorporação de substâncias tóxicas do } \\
\text { sedimento para a coluna d'água, se existentes } \\
\text { (alteração da qualidade química da água). }\end{array}$ & & & & & & & & & & & & & & & \\
\hline & $\begin{array}{l}\text { QDecréscimo na densidade de organismos } \\
\text { aquáticos. }\end{array}$ & & & & & & & & & & & & & & & \\
\hline \multicolumn{17}{|l|}{$\begin{array}{l}\text { - Disposição final do material } \\
\text { (Alternativas) }\end{array}$} \\
\hline \multirow{4}{*}{$\begin{array}{l}\text { Material dragado, volta a ser } \\
\text { lançado no rio. Esta alternativa, } \\
\text { compreende, somente, os materiais } \\
\text { finos que podem ser transportados } \\
\text { em suspensão para jusante. }\end{array}$} & $\leftrightarrow$ Aumento do material em suspensão. & & & & & & & & & & & & & & & \\
\hline & $\begin{array}{l}\text { Alteração do regime de escoamento, a } \\
\text { jusante do lançamento, o que favorece o } \\
\text { transporte. }\end{array}$ & & & & & & & & & & & & & & & \\
\hline & $\begin{array}{l}\text { Alteração na velocidade do fluxo das águas } \\
\text { a jusante do lançamento do material, o que } \\
\text { favorece o transporte. }\end{array}$ & & & & & & & & & & & & & & & \\
\hline & $\begin{array}{l}\text { Contaminação das redes alimentares, no } \\
\text { caso de existirem produtos tóxicos. }\end{array}$ & & & & & & & & & & & & & & & \\
\hline
\end{tabular}


Planilha № 07 - Impacto Ambiental das Ações Propostas - Classificação do Impacto Ambiental

\begin{tabular}{|c|c|c|c|c|c|c|c|c|c|c|c|c|c|c|c|c|}
\hline \multirow[t]{2}{*}{ Ação Proposta } & \multirow[t]{2}{*}{ Impacto Ambiental } & \multicolumn{15}{|c|}{ Classificação do Impacto Ambiental } \\
\hline & & $\mathbf{P}$ & $\mathbf{N}$ & D & I & B & $\mathbf{M}$ & G & $\mathbf{C P}$ & MP & $\mathbf{L P}$ & $\mathbf{R E}$ & IR & $\mathbf{L}$ & $\mathbf{R}$ & $\mathbf{N A}$ \\
\hline & $\begin{array}{l}\text { Perda de ecossistemas, como baias, } \\
\text { vazantes e corixos, quando o material } \\
\text { transportado se deposita nestes ambientes. }\end{array}$ & & & & & & & & & & & & & & & \\
\hline & $\begin{array}{l}\text { Incorporação de substâncias tóxicas do } \\
\text { sedimento para a coluna d'água, se existentes, } \\
\text { (alteração da qualidade química da água) }\end{array}$ & & & & & & & & & & & & & & & \\
\hline & Alteração da qualidade física d'água. & & & & & & & & & & & & & & & \\
\hline & $\Leftrightarrow$ Diminuição da produtividade de algas. & & & & & & & & & & & & & & & \\
\hline & Destruição de hábitats da fauna bentônica. & & & & & & & & & & & & & & & \\
\hline & $\begin{array}{l}\text { Diminuição da complexidade das redes } \\
\text { alimentares. }\end{array}$ & & & & & & & & & & & & & & & \\
\hline & $\begin{array}{l}\text { Aumento da mortande de peixes por } \\
\text { asfixia e intoxicação. }\end{array}$ & & & & & & & & & & & & & & & \\
\hline & $\begin{array}{l}\text { Perda da diversidade de espécies de } \\
\text { fitoplâncton, bentos e peixes. }\end{array}$ & & & & & & & & & & & & & & & \\
\hline & $\begin{array}{l}\text { Decréscimo na densidade de organismos } \\
\text { aquáticos. }\end{array}$ & & & & & & & & & & & & & & & \\
\hline
\end{tabular}


Planilha № 07 - Impacto Ambiental das Ações Propostas - Classificação do Impacto Ambiental

\begin{tabular}{|c|c|c|c|c|c|c|c|c|c|c|c|c|c|c|c|c|}
\hline \multirow[t]{2}{*}{ Ação Proposta } & \multirow[t]{2}{*}{ Impacto Ambiental } & \multicolumn{15}{|c|}{ Classificação do Impacto Ambiental } \\
\hline & & $\mathbf{P}$ & $\mathbf{N}$ & D & $\mathbf{I}$ & B & $\mathbf{M}$ & $\mathbf{G}$ & $\mathbf{C P}$ & MP & $\mathbf{L P}$ & $\mathbf{R E}$ & IR & $\mathbf{L}$ & $\mathbf{R}$ & NA \\
\hline \multirow{7}{*}{$\begin{array}{l}\text { Material dragado depositado } \\
\text { linearmente ao longo: do canal } \\
\text { principal; trecho com margem } \\
\text { descontínua; alargamentos; zonas } \\
\text { de circulação ou baixíssima } \\
\text { velocidade. }\end{array}$} & Poderá resultar numa margem emersa. & & & & & & & & & & & & & & & \\
\hline & $\begin{array}{l}\text { A margem emersa resultante poderá ser } \\
\text { ocupada por assentamentos humanos, sem } \\
\text { nenhum controle ou planejamento prévio. }\end{array}$ & & & & & & & & & & & & & & & \\
\hline & $\begin{array}{l}\text { marte do material volta ao fluxo do rio, a } \\
\text { menos que seja limitado por estruturas (diques, } \\
\text { aterros). }\end{array}$ & & & & & & & & & & & & & & & \\
\hline & $\begin{array}{l}\text { Ampliação dos efeitos da concentração, } \\
\text { diluição de nutrientes }\end{array}$ & & & & & & & & & & & & & & & \\
\hline & $\begin{array}{l}\text { Aumento da exportação da biomassa e } \\
\text { nutrientes. }\end{array}$ & & & & & & & & & & & & & & & \\
\hline & $\begin{array}{l}\text { Aumento do material em suspensão e } \\
\text { resíduos sólidos na coluna d'água. }\end{array}$ & & & & & & & & & & & & & & & \\
\hline & $\rightarrow$ Decréscimo na produtividade fitoplânctonica. & & & & & & & & & & & & & & & \\
\hline $\begin{array}{l}\text { Material dragado depositado } \\
\text { na margem em lagoas, braços } \\
\text { mortos, depressões. }\end{array}$ & $\begin{array}{l}\text { Alteração do equilíbrio local: drenagem, flora } \\
\text { e fauna local. }\end{array}$ & & & & & & & & & & & & & & & \\
\hline
\end{tabular}


Planilha No 07 - Impacto Ambiental das Ações Propostas - Classificação do Impacto Ambiental

\begin{tabular}{|c|c|c|c|c|c|c|c|c|c|c|c|c|c|c|c|c|}
\hline \multirow[t]{2}{*}{ Ação Proposta } & \multirow[t]{2}{*}{ Impacto Ambiental } & \multicolumn{15}{|c|}{ Classificação do Impacto Ambiental } \\
\hline & & $\mathbf{P}$ & $\mathbf{N}$ & D & I & B & M & $\mathbf{G}$ & $\mathbf{C P}$ & MP & $\mathbf{L P}$ & RE & IR & $\mathbf{L}$ & $\mathbf{R}$ & NA \\
\hline & $\begin{array}{l}\text { Parte dos sedimentos podem voltar com a } \\
\text { água da dragagem ou chuva. }\end{array}$ & & & & & & & & & & & & & & & \\
\hline \multirow{2}{*}{$\begin{array}{l}\text { - Desobstrução e limpeza com } \\
\text { dragas ( adequadas ), com o } \\
\text { objetivo de promover a Remoção } \\
\text { de Estruturas (troncos de } \\
\text { árvores), que retém entulhos } \\
\text { orgânicos. }\end{array}$} & $\begin{array}{l}\text { Alteração no hábitat dos organismos } \\
\text { aquáticos. }\end{array}$ & & & & & & & & & & & & & & & \\
\hline & $\begin{array}{l}\text { A matéria orgânica que é processada, pelos } \\
\text { organismos aquáticos, sofre alteração no seu } \\
\text { processo de retenção. }\end{array}$ & & & & & & & & & & & & & & & \\
\hline \multirow{4}{*}{$\begin{array}{l}\text { M Transporte do material dragad } \\
\text { para bota-fora. } \\
\text { - Transporte Rodoviário com } \\
\text { veículo pesado caminhão (fonte } \\
\text { móvel), utilizando como } \\
\text { combustível óleo diesel. }\end{array}$} & $\begin{array}{l}\text { Lançamento de fumaça preta na atmosfera, } \\
\text { resultando em danos a fauna e a flora. }\end{array}$ & & & & & & & & & & & & & & & \\
\hline & $\begin{array}{l}\text { Aumento de material particulado (poeira) na } \\
\text { atmosfera, resultando em danos a fauna e a } \\
\text { flora }\end{array}$ & & & & & & & & & & & & & & & \\
\hline & $\begin{array}{l}\text { Mudanças meteorológicas (instabilidade } \\
\text { atmosférica, inversão térmica). }\end{array}$ & & & & & & & & & & & & & & & \\
\hline & $\begin{array}{l}\text { Alterações na economia (controle da } \\
\text { das emissões no fonte) }\end{array}$ & & & & & & & & & & & & & & & \\
\hline
\end{tabular}


Planilha № 07 - Impacto Ambiental das Ações Propostas - Classificação do Impacto Ambiental

400

\begin{tabular}{|c|c|c|c|c|c|c|c|c|c|c|c|c|c|c|c|c|}
\hline \multirow[t]{2}{*}{ Ação Proposta } & \multirow[t]{2}{*}{ Impacto Ambiental } & \multicolumn{15}{|c|}{ Classificação do Impacto Ambiental } \\
\hline & & $\mathbf{P}$ & $\mathbf{N}$ & $\mathbf{D}$ & $\mathbf{I}$ & B & $\mathbf{M}$ & G & $\mathbf{C P}$ & MP & $\mathbf{L P}$ & $\mathbf{R E}$ & IR & $\mathbf{L}$ & $\mathbf{R}$ & NA \\
\hline \multirow{5}{*}{$\begin{array}{l}\text { Transporte Fluvial (fonte } \\
\text { móvel), usando o óleo diesel } \\
\text { como combustível. }\end{array}$} & $\begin{array}{l}\text { Lançamento de fumaça preta na atmosfera, } \\
\text { resultando em danos a fauna e flora. }\end{array}$ & & & & & & & & & & & & & & & \\
\hline & $\begin{array}{l}\text { Aumento de material particulado (poeira) na } \\
\text { atmosfera, resultando em danos a fauna e a } \\
\text { flora. }\end{array}$ & & & & & & & & & & & & & & & \\
\hline & $\begin{array}{l}\text { Mudanças meteorológicas (instabilidade } \\
\text { atmosférica, inversão térmica). }\end{array}$ & & & & & & & & & & & & & & & \\
\hline & $\begin{array}{l}\text { Alterações na economia (controle da } \\
\text { das emissões no fonte) }\end{array}$ & & & & & & & & & & & & & & & \\
\hline & $\begin{array}{l}\text { Aumento da ação das ondas nas margens, } \\
\text { pela passagem devido a passagem de } \\
\text { embarcações }\end{array}$ & & & & & & & & & & & & & & & \\
\hline
\end{tabular}


AÇÃO PROPOSTA - Obra Hidráulica Fluvial

Tipo de Obra Hidráulica Fluvial - Regularização do Leito - As obras de regularização em um curso d'água, são definidas como sendo àquelas que visam a utilizar a energia das águas para: fixar o leito, direcionando o escoamento ou concentrando o escoamento para melhorar as condições de navegabilidade; operação de tomadas de água, etc., modificando para tanto: a largura, as curvaturas, a profundidade e a direção dos filetes de água. Normalmente são utilizadas para fixar o leito do curso d'água durante os meses de estiagem

\begin{tabular}{|c|c|c|c|c|c|c|c|c|c|c|c|c|c|c|c|c|}
\hline \multirow[t]{2}{*}{ Ação Proposta } & \multirow[t]{2}{*}{ Impacto Ambiental } & \multicolumn{15}{|c|}{ Classificação do Impacto Ambiental } \\
\hline & & $\mathbf{P}$ & $\mathbf{N}$ & $\mathbf{D}$ & I & B & $\mathbf{M}$ & $\mathbf{G}$ & CP & MP & LP & RE & IR & $\mathbf{L}$ & $\mathbf{R}$ & NA \\
\hline \multicolumn{17}{|l|}{$\begin{array}{l}\text { Obra Hidráulica } \\
\text { - Regularização do Leito }\end{array}$} \\
\hline \multirow{6}{*}{$\begin{array}{l}\text { Leito Móvel ( constituído por } \\
\text { material erodivel ). } \\
\text { Com a utilização de espigões e } \\
\text { diques, que operam para N.A } \\
\text { baixos. Na cheia ficam } \\
\text { submersos. }\end{array}$} & $\begin{array}{l}\text { Alteram o leito de estiagem com modificação } \\
\text { e estabilização das suas margens. }\end{array}$ & & & & & & & & & & & & & & & \\
\hline & $\rightarrow$ Provoca o assoreamento entre eles. & & & & & & & & & & & & & & & \\
\hline & $\begin{array}{l}\text { Tendência a formar uma berma com } \\
\text { vegetação entre os obstáculos. }\end{array}$ & & & & & & & & & & & & & & & \\
\hline & $\begin{array}{l}\text { escoamentôncia a aumentar a velocidade do } \\
\text { assoreamentos a jusante. }\end{array}$ & & & & & & & & & & & & & & & \\
\hline & $\leftrightarrow$ Pode elevar o nível de água de estiagem. & & & & & & & & & & & & & & & \\
\hline & Alteração da fauna e flora das margens. & & & & & & & & & & & & & & & \\
\hline
\end{tabular}


Planilha $N^{o} 08$ - Impacto Ambiental das Ações Propostas - Classificação do Impacto Ambiental

402

\begin{tabular}{|c|c|c|c|c|c|c|c|c|c|c|c|c|c|c|c|c|}
\hline \multirow[t]{2}{*}{ Ação Proposta } & \multirow[t]{2}{*}{ Impacto Ambiental } & \multicolumn{15}{|c|}{ Classificação do Impacto Ambiental } \\
\hline & & $\mathbf{P}$ & $\mathbf{N}$ & D & I & B & $\mathbf{M}$ & G & $\mathbf{C P}$ & MP & $\mathbf{L P}$ & $\mathbf{R E}$ & IR & $\mathbf{L}$ & $\mathbf{R}$ & $\mathbf{N A}$ \\
\hline & $\begin{array}{l}\text { * Pode provocar a elevação do N.A de cheia } \\
\text { ( altera a curva Cota } \times \text { Vazão ). }\end{array}$ & & & & & & & & & & & & & & & \\
\hline \multirow{8}{*}{$\begin{array}{l}\text { Leito Fixo ( material do leito } \\
\text { não erodivel naturalmente ) } \\
\text { Com a utilização de espigões e }\end{array}$} & $\begin{array}{l}\text { Alteram o leito de estiagem com modificação } \\
\text { das suas margens. }\end{array}$ & & & & & & & & & & & & & & & \\
\hline & $\leftrightarrow$ Provoca o assoreamento entre eles. & & & & & & & & & & & & & & & \\
\hline & $\begin{array}{l}\text { Tendência a formar uma berma com } \\
\text { vegetação entre os obstáculos. }\end{array}$ & & & & & & & & & & & & & & & \\
\hline & $\begin{array}{l}\text { Tendência a aumentar a velocidade do } \\
\text { escoamento. }\end{array}$ & & & & & & & & & & & & & & & \\
\hline & $\rightarrow$ Pode elevar o nível de água de estiagem. & & & & & & & & & & & & & & & \\
\hline & $\begin{array}{l}\text { n:Pode provocar a elevação do N.A de cheia } \\
\text { ( altera a curva Cota } \times \text { Vazão ). }\end{array}$ & & & & & & & & & & & & & & & \\
\hline & $\begin{array}{l}\text { Estreitamento das seções para elevar o nível } \\
\text { d'água aumentando as profundidades, sem } \\
\text { aprofundamento sensível do leito, obtido a } \\
\text { partir da construção de diques e espigões. }\end{array}$ & & & & & & & & & & & & & & & \\
\hline & Alteração da fauna e flora das margens. & & & & & & & & & & & & & & & \\
\hline
\end{tabular}




\subsection{RESULTADO DO QUESTIONAMENTO}

A devolução do instrumento de coleta de dados "Planilhas Ambientais", iguais àquelas apresentadas no item 6.5., sobre a forma de questionamento, enviadas aos sujeitos da pesquisa, não ocorreu.

O não recebimento de nenhuma planilha ambiental, deixo-nos perplexo, uma vez que o tema "Hidrovias" e questões tais como: obras de melhoramentos e impactos ambientais, ambos referentes a Hidrovias, tem sido abordado em pesquisas, seminários, conferências, simpósios, palestras, workshops, etc.; diferentemente da perplexidade primeira que nos conduziu a ação de preparar a planilha ambiental. Acreditávamos na existência de profissionais com conhecimentos específicos do tema.

O material coletado, a partir das planilhas ambientais, consiste em comentários e análises, elaborados a partir daquelas, sendo este material de extrema riqueza, pois nos conduziu a um resultado adverso ao esperado.

Tínhamos diante de nós, uma realidade que não existia, acredite, o cenário real era aquele com uma realidade virtual!

Então por onde começar ? Procuramos investigar como ocorre a nossa educação formal, aquela das Universidades, pois, existe uma enorme semelhança entre a forma como se desenvolve esta educação e a forma como desenvolvemos o nosso exercício profissional.

A nossa aprendizagem é "compartimentalizada", isto é, recebemos blocos de informações, denominados disciplinas, as quais não seria demais traduzir para a linguagem informatizada como arquivos, ou seja, recebemos arquivos que são armazenados nas nossas mentes. Este conjunto de arquivos forma o nosso conhecimento, mas não a nossa aprendizagem.

No instante do envio do instrumento para a coleta de dados, já havíamos identificado o elevado nível de conhecimento do sujeito da pesquisa, o que de fato foi confirmado quando da devolução daquele material. 
Em continuidade a análise, verifica-se que o sujeito da pesquisa desenvolve sua atividade profissional, à semelhança do seu processo de aprendizagem, isto é, de um modo cognitivo ou dentro de uma área de conhecimento. A seguinte resposta ao questionamento:

"O assunto é muito estranho para mim, de modo que eu possa ser de alguma utilidade. Não estou capacitado para identificar os impactos em qualquer ação ou falta de ação do homem. Existe impacto mesmo em rios sem intervenção ?"

é exemplo de uma aprendizagem dentro do modo cognitivo, pois ela tem por base as informações que o sujeito da pesquisa dispõe, executa a generalização destas para as mais diversas e/ou diferentes situações, tenta trabalhar os conceitos e seus interrelacionamentos, busca soluções para problemas em níveis cada vez mais criativos. Em síntese, o sujeito da pesquisa só opera de forma satisfatória, aquilo que ele conhece e compreende. A esta primeira análise chamaremos categoria 1.

A seguir, identificaremos um segundo processo que chamaremos de categoria 2 , onde o sujeito da pesquisa modifica suas atitudes, isto é, os valores que dá ao que conhece, sentimentos que experimenta diante de fatos e idéias.

A partir das respostas recebidas, podemos exemplificar a categoria 2, da seguinte maneira:

O sujeito $\underline{\boldsymbol{A}}$ da pesquisa sabe como executar as obras hidroviárias; o sujeito $\underline{\boldsymbol{B}}$ da pesquisa conhece a legislação ambiental no que se refere a impactos ambientais e, também sabe como executar as obras hidroviárias. Atitudinalmente, o sujeito $\underline{\boldsymbol{A}}$ da pesquisa tem uma atitude negativa (desvaloriza, não vê significado) em relação aos impactos ambientais; o sujeito $\underline{\boldsymbol{B}}$ da pesquisa tem uma atitude positiva (acha que é bom, sente-se bem) em relação à sua participação em pequenos grupos que estudam uma possível correlação entre impactos ambientais e as obras hidroviárias ". 
Há ainda uma categoria 3, a das habilidades, quando o sujeito de pesquisa aprende a fazer, a lidar com situações (problemas) novas.

As respostas, a seguir, apresentadas no questionamento, nos permitem verificar as tentativas: em, fazer, em lidar com as situações novas.

“ Gostaria de poder ajudá-lo no seu trabalho preenchendo a matriz enviada, porém acho uma tarefa inviável. Por exemplo: você fala de erosão e assoreamento, mudança de características físico-químicas etc. de forma extremamente generalizada.

Um assoreamento de uma ação é um impacto? Depende. Da quantidade, da qualidade, do estado dos cursos fluviais que recebem o material particulado, etc. Não posso, genericamente, decidir sobre os critérios de qualificação se não sei as condições em que os fenômenos estão ocorrendo e em que tipo de meio. Mudanças de características da água, por exemplo, ocorrem independentemente da ação da engenharia. Elas podem chegar a evidenciar impactos, dependendo de grau de mudança estabelecida. Onde estão os números para que eu possa avaliar? Não sei se estou sendo suficientemente clara. Por esta razão não respondo seu questionamento. Sinto-me perdida. Seria algo como “eu acho ... ”. É óbvio que, se não dou uma resposta relativamente firme, sob o prisma técnico, eu induzo desvios incríveis nos valores médios do seu questionário. Em suma, seria um chute grotesco da minha parte. Espero que perdoe minha decisão. Paralelamente, quero dizer que achei o levantamento das relações ação-efeito muito bem elaborado. Parabéns!".

"Gostaria de uma explicação: detalhe a diferença entre impacto direto e indireto; impacto ambiental pode ser direto, quando se relaciona a uma outra determinada ação inicial, ou indireto, quando decorre de uma conseqüência de primeira ordem. O que seria uma conseqüencia de primeira ordem? Para mim não ficou claro." 
"Iniciei a resposta, mas fiquei com muitas dúvidas. Pode ser porque não estou acostumado ao tipo de planilha, mas tudo parece igual. Não me senti confortável com a resposta que estava dando. Comecei a desconfiar que tudo que fiz estava inconsistente e, parei."

Após analisar as respostas, às planilhas ambientais, ficou evidenciado que aprender não significa “ aprender" somente o cognitivo, mas também aprender em termos de atitudes e habilidades. Se o sujeito da pesquisa tiver em mente que há a necessidade de aprender todas estas categorias e, que elas estão intimamente interligadas, exercendo, portanto, fundamental importância no resultado global do questionamento, então, ele terá aprendido a abrir arquivos, estabelecer relações entre eles e, estará produzindo conhecimento.

Entendemos que a forma mais viável de dar continuidade a esta aprendizagem é dotar o sujeito da pesquisa de conhecimentos econômicos, financeiros, jurídicos, sociais, políticos e ambientais, através do trabalho em equipes multidisciplinares, onde será compartilhado, por cada membro da equipe, o conhecimento das diversas áreas que a compõe. O exercício de identificarem juntos, situações possíveis de receberem estes conhecimentos, resultará na adoção de atitudes e desenvolvimento de habilidades.

É possível separar esta tese em dois instantes: o atual, onde o sujeito da pesquisa sabe das suas limitações, que ora é documentada por sua dificuldade em responder o questionamento; o futuro, que tem início no presente, verificando-se a formação de equipes multidisciplinares para tratar sobre um determinado assunto, tendo em vista que uma única área de conhecimento, não é mais suficiente para o seu estudo. Exemplos dessas formações estão presentes nas nossas livrarias, em nossas revistas e tantos outros documentos escritos, onde se verifica não mais a presença de um único autor, mais diversos autores compartilhando um mesmo assunto. Atualmente, temos grupos de pesquisadores, que se reúnem para dissecar um determinado assunto. 
O tema dessa pesquisa, que ora é complexo para o instante atual, conduz a necessidade, cada vez mais freqüente da formação dessas equipes ou grupos e, continuar trabalhando de forma adversa a essa, é atestar que tudo ocorre lentamente, é negar a relação entre as porções que formam o meio ambiente, é negar a ligação entre as diversas áreas do conhecimento, é tomar o homem, com todo cuidado pela mão e, conduzi-lo novamente à caverna, armá-lo com um ponteiro e permitir que ele relate ali nas rochas, o seu desenvolvimento atual. 


\subsection{MODELO DE PLANILHAS AMBIENTAIS - INSTRUMENTO PARA A CLASSIFICAÇÃO DE IMPACTOS AMBIENTAIS}

O não recebimento de nenhuma planilha ambiental, preenchida pelo sujeito de pesquisa, conduziu-nos a preparação de um modelo de preenchimento de planilhas ambientais, visando somente classificar os impactos ambientais das obras hidroviárias.

As planilhas ambientais apresentadas a seguir, são passíveis de ajustes, pois devem ser preenchidas por uma equipe multidisciplinar. A simples apresentação, constitui-se num "instrumento de partida" para discussões, críticas e futura geração de conhecimentos. 
AÇÃO PROPOSTA - OBRA HIDRÁULICA FLUVIAL

Tipo de Obra Hidráulica Fluvial - Proteção das Margens - A proteção das margens tem por finalidade a proteção de terrenos marginais, fixação do traçado e redução da descarga sólida; em cursos d'água naturais, hidrovias e canais (drenagem, irrigação, adução, etc.)

As obras de proteção das margens mais utilizadas são:

Obras Contínuas ou de Proteção Direta: retaludamento, revestimento com materiais mais resistentes, obras de sustentação (muros de arrimo) para proteção e suporte dos terrenos marginais.

\begin{tabular}{|c|c|c|c|c|c|c|c|c|c|c|c|c|c|c|c|c|}
\hline \multirow[t]{2}{*}{ Ação Proposta } & \multirow[t]{2}{*}{ Impacto Ambiental } & \multicolumn{15}{|c|}{ Classificação do Impacto Ambiental } \\
\hline & & $\mathbf{P}$ & $\mathbf{N}$ & D & $\mathbf{I}$ & B & $\mathbf{M}$ & $\mathbf{G}$ & $\mathbf{C P}$ & MP & $\mathbf{L P}$ & $\mathbf{R E}$ & IR & $\mathbf{L}$ & $\mathbf{R}$ & NA \\
\hline $\begin{array}{l}\text { Rio sem Intervenção, isto é, } \\
\text { sem ação direta do homem. }\end{array}$ & $\begin{array}{l}\text { * Os impactos ambientais, identificados a } \\
\text { seguir, são devidos a fenômenos naturais. }\end{array}$ & & & & & & & & & & & & & & & \\
\hline $\begin{array}{l}\text { - Ação de Agentes Internos ou } \\
\text { Geotécnicos. }\end{array}$ & $\begin{array}{l}\text { Aumento do aporte de sólidos na corrente } \\
\text { liquida. }\end{array}$ & & * & * & & $\star$ & & & & & $\star$ & & $\star$ & * & & \\
\hline Percolação: Responsável pelo & Desagregação da margem. & & * & $\star$ & & & & $\star$ & & & $\star$ & & * & $\star$ & & \\
\hline $\begin{array}{l}\text { arraste dos finos do solo e } \\
\text { desagregação das margens. }\end{array}$ & $\begin{array}{l}\text { Escorregamento do solo e cobertura } \\
\text { Vegetal. }\end{array}$ & & * & * & & & & * & & & $\star$ & & $\star$ & * & & \\
\hline Saturação: Responsável pela & Assoreamento do leito do rio. & & $\star$ & * & & & & $\star$ & & & * & & * & & * & \\
\hline $\begin{array}{l}\text { Instabilidade Geotécnica da } \\
\text { margem taludada (margem rompe }\end{array}$ & $\begin{array}{l}\text { Alteração das características físicas } \\
\text { d'água (cor e turbidez). }\end{array}$ & & * & * & & & $\star$ & & & & * & & * & & * & \\
\hline por saturação do solo ). & Mudança no traçado do rio. & & * & $\star$ & & & & $\star$ & & & $\star$ & & $\star$ & $\star$ & & \\
\hline & Favorece a erosão das Margens & & * & * & & $\star$ & & & & & * & & * & $\star$ & & \\
\hline
\end{tabular}


Planilha № 01 - Continuação - Impacto Ambiental das Ações Propostas - Classificação do Impacto Ambiental

\begin{tabular}{|c|c|c|c|c|c|c|c|c|c|c|c|c|c|c|}
\hline \multirow[t]{2}{*}{ Ação Proposta } & \multirow[t]{2}{*}{ Impacto Ambiental } & \multicolumn{13}{|c|}{ Classificação do Impacto Ambiental } \\
\hline & & $\mathbf{P}$ & $\mathbf{N}$ & D 1 I & $\mathbf{B}: \mathbf{M}:$ & $\mathbf{G}$ & $\mathbf{C P}$ & MP & $\mathbf{L P}$ & $\mathbf{R E}$ & IR & $\mathbf{L}$ & $\mathbf{R}$ & NA \\
\hline \multirow{5}{*}{$\begin{array}{l}\text { Ação de Agentes Externos } \\
\text { Escoamento } \\
\text { A Ação do Escoamento sobre o } \\
\text { material da margem [ solapamento } \\
\text { do "pé" e na margem exterior dos } \\
\text { trechos curvos (talude)]. }\end{array}$} & Erosão (instabilidade) da margem. & & * & * & & * & & & * & & * & * & & \\
\hline & $\begin{array}{l}\text { Aumento do aporte de sedimento no } \\
\text { escoamento. }\end{array}$ & & * & * & : & & & * & & * & & * & & \\
\hline & $\begin{array}{l}\text { Assoreamento do leito do rio (bancos de } \\
\text { areia). }\end{array}$ & & * & * & & * & & & * & & * & & * & \\
\hline & Destruição da cobertura vegetal. & & $\star$ & * & & * & & & * & & * & * & & \\
\hline & $\begin{array}{l}\text { Alteração das características físicas } \\
\text { d'água (cor e turbidez). }\end{array}$ & & * & $\star$ & & & * & & & * & & & * & \\
\hline \multirow{5}{*}{$\begin{array}{l}\text { Ondas } \\
\text { Devido a ação do vento } \\
\text { (principalmente em rios muito }\end{array}$} & $\begin{array}{l}\text { Instabilidade da margem na superfície da } \\
\text { linha d'água. }\end{array}$ & & $\star$ & $\star$ & $i^{\star}$ & & & * & & & * & * & & \\
\hline & Aumento do transporte de sedimentos. & & * & * & $i^{\prime}$ & & & * & & & * & * & & \\
\hline & $\begin{array}{l}\text { Assoreamento do leito do rio (bancos de } \\
\text { areia). }\end{array}$ & & * & * & $!^{*}$ & & & & $\star$ & & * & * & & \\
\hline & Destruição da cobertura vegetal. & & $\star$ & 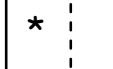 & 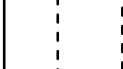 & : & & & * & & $\star$ & * & & \\
\hline & $\begin{array}{l}\text { Alteração das características físicas } \\
\text { d'água (cor e turbidez). }\end{array}$ & & * & $\star \vdots \vdots$ & : & & $\star$ & & & * & & & & \\
\hline
\end{tabular}


Planilha № 01 - Continuação - Impacto Ambiental das Ações Propostas - Classificação do Impacto Ambiental

\begin{tabular}{|c|c|c|c|c|c|c|c|c|c|c|c|c|c|c|c|c|}
\hline \multirow[t]{2}{*}{ Ação Proposta } & \multirow[t]{2}{*}{ Impacto Ambiental } & \multicolumn{15}{|c|}{ Classificação do Impacto Ambiental } \\
\hline & & $\mathbf{P}$ & $\mathbf{N}$ & D & I & B & M & G & CP & MP & LP & RE & IR & $\mathbf{L}$ & $\mathbf{R}$ & NA \\
\hline & $\begin{array}{l}\text { Aumento da inclinação do talude de } \\
\text { margem, na região de erosão, e formação } \\
\text { de praia na região de deposição. }\end{array}$ & & * & * & & * & & & & & * & & * & * & & \\
\hline
\end{tabular}


Planilha № 02 - Impacto Ambiental das Ações Propostas - Classificação do Impacto Ambiental

\begin{tabular}{|c|c|c|c|c|c|c|c|c|c|c|c|c|c|c|c|c|}
\hline \multirow[t]{2}{*}{ Ação Proposta } & \multirow[t]{2}{*}{ Impacto Ambiental } & \multicolumn{15}{|c|}{ Classificação do Impacto Ambiental } \\
\hline & & $\mathbf{P}$ & $\mathbf{N}$ & D & $\mathbf{I}$ & B & $\mathbf{M}$ & $\mathbf{G}$ & $\mathbf{C P}$ & MP & $\mathbf{L P}$ & $\mathbf{R E}$ & IR & $\mathbf{L}$ & $\mathbf{R}$ & NA \\
\hline \multicolumn{17}{|l|}{$\begin{array}{l}\text { Rio com Intervenção, isto é, com } \\
\text { a ação direta do homem. }\end{array}$} \\
\hline \multicolumn{17}{|l|}{$\begin{array}{l}\text { Obra Hidráulica: } \\
\text { - Proteção Direta da Ribanceira. } \\
\text { Dimensionada para eliminar a ação } \\
\text { de agentes internos ( percolação e } \\
\text { saturação ) e agentes externos } \\
\text { ( ação do escoamento ). }\end{array}$} \\
\hline \multirow{6}{*}{$\begin{array}{l}\text { Retaludamento } \\
\text { Somente aplicável quando o } \\
\text { agente causador da instabilidade } \\
\text { é o escoamento. }\end{array}$} & Redução dos efeitos da erosão. & $t^{t}$ & & $\star$ & & $\star$ & & & $\star$ & & & $\star$ & & $\star$ & & \\
\hline & Estabilização das margens. & $\star$ & & $\star$ & & $\star$ & & & $\star$ & & & $\star$ & & $\star$ & & \\
\hline & 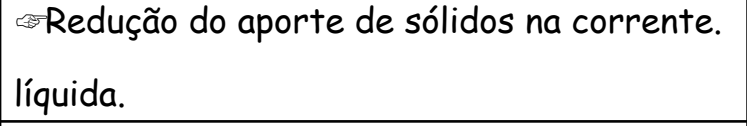 & $\star$ & & $\star$ & & & * & & & * & & * & & & $\star$ & \\
\hline & $\begin{array}{l}\text { Definição e fixação de uma nova vegetação } \\
\text { de margem. }\end{array}$ & $\star$ & & $\star$ & & & & * & & * & & $\star$ & & $\star$ & & \\
\hline & $\begin{array}{l}\text { Melhoria das características físicas d'água } \\
\text { (cor e turbidez). }\end{array}$ & $\star$ & & $\star$ & & & $\star$ & & & $\star$ & & * & & & $\star$ & \\
\hline & Definição e fixação de um habitat. & $\star$ & & $\star$ & & & & $\star$ & & $\star$ & & $\star$ & & & $\star$ & \\
\hline
\end{tabular}


Planilha № 02 - Continuação - Impacto Ambiental das Ações Propostas - Classificação do Impacto Ambiental

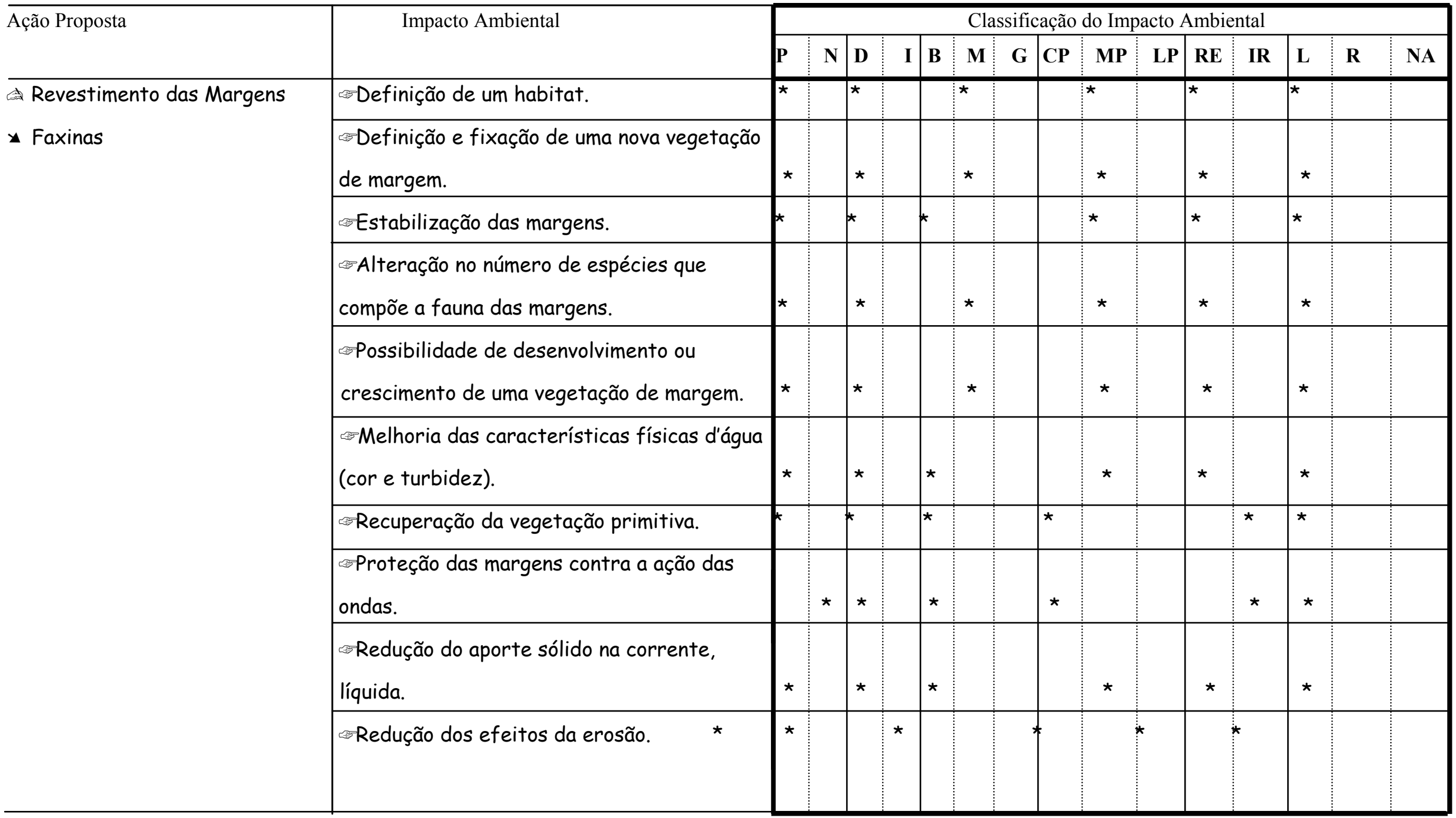


Planilha № 02 - Continuação - Impacto Ambiental das Ações Propostas - Classificação do Impacto Ambiental

\begin{tabular}{|c|c|c|c|c|c|c|c|c|c|c|c|c|c|c|c|c|}
\hline \multirow[t]{2}{*}{ Ação Proposta } & \multirow[t]{2}{*}{ Impacto Ambiental } & \multicolumn{15}{|c|}{ Classificação do Impacto Ambiental } \\
\hline & & $\mathbf{P}$ & $\mathbf{N}$ & D & I & B & $\mathbf{M}$ & $\mathbf{G}$ & $\mathbf{C P}$ & MP & $\mathbf{L P}$ & $\mathbf{R E}$ & IR & $\mathbf{L}$ & $\mathbf{R}$ & NA \\
\hline \multirow{10}{*}{$\begin{array}{l}\text { Revestimento das Margens } \\
\text { Substituição do Solo. }\end{array}$} & $\rightarrow$ Definição de um habitat. & + & & * & & & $\star$ & & & $\star$ & & $\star$ & & $\star$ & & \\
\hline & $\begin{array}{l}\text { Definição e fixação de uma nova vegetação } \\
\text { de margem. }\end{array}$ & $\star$ & & * & & & * & & & $\star$ & & * & & * & & \\
\hline & Estabilização das margens. & & & $\star$ & & & * & & & $\star$ & & * & & * & & \\
\hline & $\begin{array}{l}\text { Alteração no número de espécies que } \\
\text { compõe a fauna das margens. }\end{array}$ & $\star$ & & * & & & * & & & $\star$ & & * & & $\star$ & & \\
\hline & $\begin{array}{l}\text { a Possibilidade de desenvolvimento ou } \\
\text { crescimento de uma vegetação de margem. }\end{array}$ & * & & $\star$ & & & $\star$ & & & $\star$ & & $\star$ & & * & & \\
\hline & $\begin{array}{l}\text { Melhoria das características físicas d'água } \\
\text { (cor e turbidez). }\end{array}$ & & & & & & & & & & & & & & & \\
\hline & Recuperação da vegetação primitiva. & 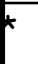 & & t & & & $\star$ & & & * & & $\star$ & & $\star$ & & \\
\hline & $\begin{array}{l}\text { Proteção das margens contra a ação das } \\
\text { ondas. }\end{array}$ & & $\star$ & * & & $\star$ & & & * & & & & * & $\star$ & & \\
\hline & $\begin{array}{l}\text { Redução do aporte sólido na corrente, } \\
\text { líquida. }\end{array}$ & * & & * & & & * & & * & & & $\star$ & & * & & \\
\hline & Redução dos efeitos da erosão. & t & & * & & & * & & 夫 & & & $\star$ & & $\star$ & & \\
\hline
\end{tabular}


Planilha № 02 - Continuação - Impacto Ambiental das Ações Propostas - Classificação do Impacto Ambiental

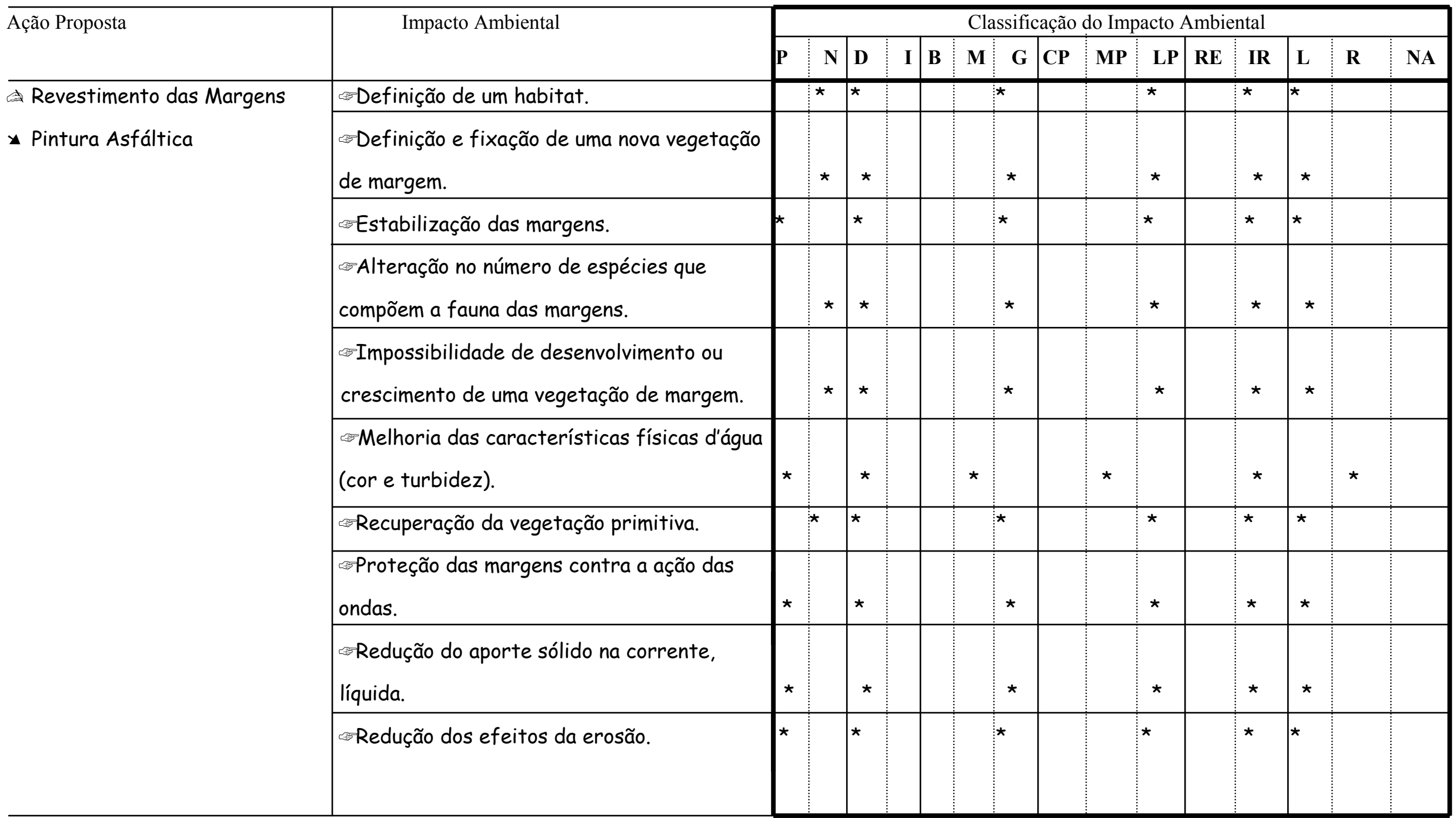


Planilha № 02 - Continuação - Impacto Ambiental das Ações Propostas - Classificação do Impacto Ambiental

\begin{tabular}{|c|c|c|c|c|c|c|c|c|c|c|c|c|c|c|c|c|}
\hline \multirow[t]{2}{*}{ Ação Proposta } & \multirow[t]{2}{*}{ Impacto Ambiental } & \multicolumn{15}{|c|}{ Classificação do Impacto Ambiental } \\
\hline & & $\mathbf{P}$ & $\mathbf{N}$ & D & $\mathbf{I}$ & B & $\mathbf{M}$ & $\mathbf{G}$ & $\mathbf{C P}$ & MP & $\mathbf{L P}$ & $\mathbf{R E}$ & IR & $\mathbf{L}$ & $\mathbf{R}$ & NA \\
\hline \multirow{10}{*}{$\begin{array}{l}\text { Revestimento das Margens } \\
\text { Enrocamento ( pedra lançada ). }\end{array}$} & Definição de um habitat. & 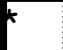 & & t & & & $\star$ & & & * & & * & & $\star$ & & \\
\hline & $\begin{array}{l}\text { Definição e fixação de uma nova vegetação } \\
\text { de margem. }\end{array}$ & * & & * & & & * & & & * & & * & & * & & \\
\hline & Estabilização das margens. & $\star$ & & $\star$ & & & * & & & * & & * & & * & & \\
\hline & $\begin{array}{l}\text { Alteração do número de espécies que } \\
\text { compõe a fauna das margens. }\end{array}$ & & $\star$ & * & & $\star$ & & & & * & & * & & * & & \\
\hline & $\begin{array}{l}\text { Possibilidade de desenvolvimento ou } \\
\text { crescimento de uma vegetação de margem. }\end{array}$ & * & & * & & & $\star$ & & & * & & * & & * & & \\
\hline & $\begin{array}{l}\text { Melhoria das características físicas d'água } \\
\text { (cor e turbidez). }\end{array}$ & $\star$ & & * & & & * & & & * & & * & & * & & \\
\hline & Recuperação da vegetação primitiva. & & $\star$ & $\star$ & & & $\star$ & & & * & & * & & $\star$ & & \\
\hline & $\begin{array}{l}\text { Proteção das margens contra a ação das } \\
\text { ondas. }\end{array}$ & * & & * & & & & * & & & * & & * & * & & \\
\hline & $\begin{array}{l}\text { Redução do aporte sólido na corrente, } \\
\text { líquida. }\end{array}$ & $\star$ & & * & & & & * & & & * & & $\star$ & * & & \\
\hline & $\leftrightarrow$ Redução dos efeitos da erosão. & $\star$ & & * & & & & * & & & * & & * & * & & \\
\hline
\end{tabular}


Planilha № 02 - Continuação - Impacto Ambiental das Ações Propostas - Classificação do Impacto Ambiental

\begin{tabular}{|c|c|c|c|c|c|c|c|c|c|c|c|c|c|c|c|c|}
\hline \multirow[t]{2}{*}{ Ação Proposta } & \multirow[t]{2}{*}{ Impacto Ambiental } & \multicolumn{15}{|c|}{ Classificação do Impacto Ambiental } \\
\hline & & $\mathbf{P}$ & $\mathbf{N}$ & D & $\mathbf{I}$ & B & M & G & $\mathbf{C P}$ & MP & $\mathbf{L P}$ & RE & IR & $\mathbf{L}$ & $\mathbf{R}$ & NA \\
\hline \multirow{6}{*}{$\begin{array}{l}\text { Revestimento das Margens } \\
\text { Gabião (tipo colchão ). }\end{array}$} & Definição de um habitat. & 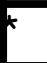 & & * & & & & & & & * & & $\star$ & $\star$ & & \\
\hline & Estabilização das margens. & $\star$ & & $\star$ & & & & * & & & * & & * & * & & \\
\hline & $\begin{array}{l}\text { Possibilidade de desenvolvimento ou } \\
\text { crescimento de uma vegetação de margem. }\end{array}$ & * & & $\star$ & & & & $\star$ & & & * & & $\star$ & * & & \\
\hline & $\begin{array}{l}\text { Melhoria das características físicas d'água } \\
\text { (cor e turbidez). }\end{array}$ & * & & * & & & * & & & & * & & * & & * & \\
\hline & $\begin{array}{l}\text { Redução do aporte sólido na corrente, } \\
\text { líquida. }\end{array}$ & * & & * & & & & * & & & * & * & & * & & \\
\hline & Redução dos efeitos da erosão. & * & & * & & & & t & & & * & & $\star$ & * & & \\
\hline
\end{tabular}


Planilha № 02 - Continuação - Impacto Ambiental das Ações Propostas - Classificação do Impacto Ambiental

\begin{tabular}{|c|c|c|c|c|c|c|c|c|c|c|c|c|c|c|c|c|}
\hline \multirow[t]{2}{*}{ Ação Proposta } & \multirow[t]{2}{*}{ Impacto Ambiental } & \multicolumn{15}{|c|}{ Classificação do Impacto Ambiental } \\
\hline & & $\mathbf{P}$ & $\mathbf{N}$ & D & I & B & M & $\mathbf{G}$ & $\mathbf{C P}$ & MP & $\mathbf{L P}$ & $\mathbf{R E}$ & IR & $\mathbf{L}$ & $\mathbf{R}$ & NA \\
\hline \multirow{10}{*}{$\begin{array}{l}\text { Revestimento das Margens } \\
\text { Gabião ( tipo colchão, } \\
\text { consolidado ou impermeabilizado }\end{array}$} & Definição de um habitat. & & $\star$ & $\star$ & & & & * & & & $\star$ & & * & * & & \\
\hline & $\begin{array}{l}\Leftrightarrow \text { Definição e fixação de uma nova vegetação } \\
\text { de margem. }\end{array}$ & & * & * & & & & * & & & * & & * & $\star$ & & \\
\hline & Estabilização das margens. & * & & * & & & & $*$ & & & * & & $\star$ & $\star$ & & \\
\hline & $\begin{array}{l}\text { Alteração do número de espécies que } \\
\text { compõe a fauna das margens. }\end{array}$ & & $\star$ & $\star$ & & & & $\star$ & & & $\star$ & & $\star$ & $\star$ & & \\
\hline & $\begin{array}{l}\text { Impossibilidade de desenvolvimento ou } \\
\text { crescimento de uma vegetação de margem. }\end{array}$ & & $\star$ & * & & & & $\star$ & & & * & & $\star$ & * & & \\
\hline & $\begin{array}{l}\text { Melhoria das características físicas d'água } \\
\text { (cor e turbidez). }\end{array}$ & $\star$ & & $\star$ & & & $\star$ & & & & * & & $\star$ & & * & \\
\hline & Recuperação da vegetação primitiva. & & $\star$ & $\star$ & & & & * & & & * & & $\star$ & $\star$ & & \\
\hline & $\begin{array}{l}\text { Proteção das margens contra a ação das } \\
\text { ondas. }\end{array}$ & * & & * & & & & * & & & * & & * & * & & \\
\hline & $\begin{array}{l}\text { Redução do aporte sólido na corrente, } \\
\text { líquida. }\end{array}$ & * & & * & & & & * & & & * & & * & * & & \\
\hline & $\leftrightarrow$ Redução dos efeitos da erosão. & * & & $\star$ & & & & $\star$ & & & * & & * & * & & \\
\hline
\end{tabular}


Planilha № 02 - Continuação - Impacto Ambiental das Ações Propostas - Classificação do Impacto Ambiental

\begin{tabular}{|c|c|c|c|c|c|c|c|c|c|c|c|c|c|c|c|c|}
\hline \multirow[t]{2}{*}{ Ação Proposta } & \multirow[t]{2}{*}{ Impacto Ambiental } & \multicolumn{15}{|c|}{ Classificação do Impacto Ambiental } \\
\hline & & $\mathbf{P}$ & $\mathbf{N}$ & D & $\mathbf{I}$ & B & $\mathbf{M}$ & G & $\mathbf{C P}$ & MP & $\mathbf{L P}$ & $\mathbf{R E}$ & IR & $\mathbf{L}$ & $\mathbf{R}$ & NA \\
\hline \multirow{10}{*}{$\begin{array}{l}\text { Revestimento das Margens } \\
\text { Bolsacreto }\end{array}$} & $\leftrightarrow$ Definição de um habitat. & . & $\star$ & * & & & & 太 & & & $\star$ & & $\star$ & $\star$ & & \\
\hline & $\begin{array}{l}\rightarrow \text { Definição e fixação de uma nova vegetação } \\
\text { de margem. }\end{array}$ & & * & * & & & & * & & & * & & * & * & & \\
\hline & Estabilização das margens. & $\star$ & & $\star$ & & & & * & & & $\star$ & & * & * & & \\
\hline & $\begin{array}{l}\text { Alteração do número de espécies que } \\
\text { compõe a fauna das margens. }\end{array}$ & & * & * & & & & * & & & * & & * & * & & \\
\hline & $\begin{array}{l}\text { Impossibilidade de desenvolvimento ou } \\
\text { crescimento de uma vegetação de margem. }\end{array}$ & * & & * & & & & * & & & * & & * & * & & \\
\hline & $\begin{array}{l}\text { Melhoria das características físicas d'água } \\
\text { (cor e turbidez). }\end{array}$ & * & & * & & & & * & & & * & & * & & * & \\
\hline & Recuperação da vegetação primitiva. & & * & $\star$ & & & & * & & & $\star$ & & $\star$ & $\star$ & & \\
\hline & $\begin{array}{l}\text { Proteção das margens contra a ação das } \\
\text { ondas. }\end{array}$ & * & & * & & & & * & & & * & & * & * & & \\
\hline & $\begin{array}{l}\text { Redução do aporte sólido na corrente, } \\
\text { líquida. }\end{array}$ & * & & * & & & & * & & & * & & * & * & & \\
\hline & $\leftrightarrow$ Redução dos efeitos da erosão. & * & & $\star$ & & & & * & & & * & & * & * & & \\
\hline
\end{tabular}


Planilha № 02 - Continuação - Impacto Ambiental das Ações Propostas - Classificação do Impacto Ambiental

\begin{tabular}{|c|c|c|c|c|c|c|c|c|c|c|c|c|c|c|c|c|}
\hline \multirow[t]{2}{*}{ Ação Proposta } & \multirow[t]{2}{*}{ Impacto Ambiental } & \multicolumn{15}{|c|}{ Classificação do Impacto Ambiental } \\
\hline & & $\mathbf{P}$ & $\mathbf{N}$ & D & $\mathbf{I}$ & B & $\mathbf{M}$ & $\mathbf{G}$ & $\mathbf{C P}$ & MP & $\mathbf{L P}$ & $\mathbf{R E}$ & IR & $\mathbf{L}$ & $\mathbf{R}$ & NA \\
\hline \multirow[t]{10}{*}{ Revestimento das Margens } & Definição de um habitat. & & * & $\star$ & & & & * & & & * & & * & * & & \\
\hline & $\begin{array}{l}\rightarrow \text { Definição e fixação de uma nova vegetação } \\
\text { de margem. }\end{array}$ & & * & * & & & & * & & & * & & * & * & & \\
\hline & Estabilização das margens. & $\star$ & & * & & & & $\star$ & & & * & & $\star$ & * & & \\
\hline & $\begin{array}{l}\text { Alteração do número de espécies que } \\
\text { compõe a fauna das margens. }\end{array}$ & & $\star$ & * & & & & * & & & $\star$ & & $\star$ & * & & \\
\hline & $\begin{array}{l}\text { Impossibilidade de desenvolvimento ou } \\
\text { crescimento de uma vegetação de margem. }\end{array}$ & & * & * & & & & $\star$ & & & $\star$ & & * & $\star$ & & \\
\hline & $\begin{array}{l}\text { Melhoria das características físicas d'água } \\
\text { (cor e turbidez). }\end{array}$ & * & & * & & & & * & & & * & & * & & $\star$ & \\
\hline & Recuperação da vegetação primitiva. & & * & * & & & & $\star$ & & & * & & * & * & & \\
\hline & $\begin{array}{l}\text { Proteção das margens contra a ação das } \\
\text { ondas. }\end{array}$ & * & & * & & & & * & & & * & & * & * & & \\
\hline & $\begin{array}{l}\text { Redução do aporte sólido na corrente, } \\
\text { líquida. }\end{array}$ & * & & $\star$ & & & & * & & & * & & * & * & & \\
\hline & $\rightarrow$ Redução dos efeitos da erosão. & * & & $\star$ & & & & * & & & * & & * & * & & \\
\hline
\end{tabular}


Planilha № 02 - Continuação - Impacto Ambiental das Ações Propostas - Classificação do Impacto Ambiental

\begin{tabular}{|c|c|c|c|c|c|c|c|c|c|c|c|c|c|c|c|c|}
\hline \multirow[t]{2}{*}{ Ação Proposta } & \multirow[t]{2}{*}{ Impacto Ambiental } & \multicolumn{15}{|c|}{ Classificação do Impacto Ambiental } \\
\hline & & $\mathbf{P}$ & $\mathbf{N}$ & D & $\mathbf{I}$ & B & $\mathbf{M}$ & G & $\mathbf{C P}$ & MP & $\mathbf{L P}$ & $\mathbf{R E}$ & IR & $\mathbf{L}$ & $\mathbf{R}$ & NA \\
\hline \multirow{10}{*}{$\begin{array}{l}\text { Revestimento das Margens } \\
\text { Revestimento em Concreto } \\
\text { Concreto moldado "in loco" }\end{array}$} & Definição de um habitat. & & $\star$ & $\star$ & & & & 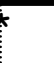 & & & * & & $\star$ & $\star$ & & \\
\hline & $\begin{array}{l}\text { Definição e fixação de uma nova vegetação } \\
\text { de margem. }\end{array}$ & & * & * & & & & * & & & * & & * & * & & \\
\hline & Estabilização das margens. & $\star$ & & $\star$ & & & & $\hat{t}$ & & & * & & * & * & & \\
\hline & $\begin{array}{l}\text { Alteração do número de espécies que } \\
\text { compõe a fauna das margens. }\end{array}$ & & * & * & & & & $\star$ & & & * & & * & * & & \\
\hline & $\begin{array}{l}\text { Impossibilidade de desenvolvimento ou } \\
\text { crescimento de uma vegetação de margem. }\end{array}$ & * & & * & & & & * & & & * & & * & * & & \\
\hline & $\begin{array}{l}\text { Melhoria das características físicas d'água } \\
\text { (cor e turbidez). }\end{array}$ & * & & * & & & & * & & & * & & * & & * & \\
\hline & Recuperação da vegetação primitiva. & & $\star$ & $\star$ & & & & $\star$ & & & * & & * & * & & \\
\hline & $\begin{array}{l}\text { Proteção das margens contra a ação das } \\
\text { ondas. }\end{array}$ & * & & * & & & & * & & & * & & * & * & & \\
\hline & $\begin{array}{l}\text { Redução do aporte sólido na corrente, } \\
\text { líquida. }\end{array}$ & * & & * & & & & * & & & * & & * & * & & \\
\hline & $\leftrightarrow$ Redução dos efeitos da erosão. & $\star$ & & * & & & & $*$ & & & * & & * & * & & \\
\hline
\end{tabular}


Planilha № 02 - Continuação - Impacto Ambiental das Ações Propostas - Classificação do Impacto Ambiental

\begin{tabular}{|c|c|c|c|c|c|c|c|c|c|c|c|c|c|c|c|c|}
\hline \multirow[t]{2}{*}{ Ação Proposta } & \multirow[t]{2}{*}{ Impacto Ambiental } & \multicolumn{15}{|c|}{ Classificação do Impacto Ambiental } \\
\hline & & $\mathbf{P}$ & $\mathbf{N}$ & D & $\mathbf{I}$ & B & $\mathbf{M}$ & $\mathbf{G}$ & $\mathbf{C P}$ & MP & $\mathbf{L P}$ & $\mathbf{R E}$ & IR & $\mathbf{L}$ & $\mathbf{R}$ & NA \\
\hline \multirow{10}{*}{$\begin{array}{l}\text { Revestimento das Margens } \\
\text { Revestimento em Concreto } \\
\text { \ Peças pré-moldadas. }\end{array}$} & Definição de um habitat. & & * & * & & & & * & & & $\star$ & & * & $\star$ & & \\
\hline & $\begin{array}{l}\Leftrightarrow \text { Definição e fixação de uma nova vegetação } \\
\text { de margem. }\end{array}$ & & $\star$ & * & & & & * & & & * & & * & * & & \\
\hline & Estabilização das margens. & $\star$ & & * & & & & * & & & * & & * & & & \\
\hline & $\begin{array}{l}\text { Alteração do número de espécies que } \\
\text { compõe a fauna das margens. }\end{array}$ & & * & * & & & & * & & & * & & * & * & & \\
\hline & $\begin{array}{l}\text { Impossibilidade de desenvolvimento ou } \\
\text { crescimento de uma vegetação de margem. }\end{array}$ & & * & * & & & & * & & & * & & * & * & & \\
\hline & $\begin{array}{l}\text { Melhoria das características físicas d'água } \\
\text { (cor e turbidez). }\end{array}$ & * & & * & & & & * & & & * & & * & & * & \\
\hline & Recuperação da vegetação primitiva. & & * & * & & & & $\star$ & & & * & & * & * & & \\
\hline & $\begin{array}{l}\text { Proteção das margens contra a ação das } \\
\text { ondas. }\end{array}$ & $\star$ & & * & & & & * & & & * & & * & * & & \\
\hline & $\begin{array}{l}\text { Redução do aporte sólido na corrente, } \\
\text { líquida. }\end{array}$ & $\star$ & & * & & & & $\star$ & & & $\star$ & & * & * & & \\
\hline & $\leftrightarrow$ Redução dos efeitos da erosão. & $\star$ & & $\star$ & & & & $*$ & & & * & & * & * & & \\
\hline
\end{tabular}


Planilha № 02 - Continuação - Impacto Ambiental das Ações Propostas - Classificação do Impacto Ambiental

\begin{tabular}{|c|c|c|c|c|c|c|c|c|c|c|c|c|c|c|c|c|}
\hline \multirow[t]{2}{*}{ Ação Proposta } & \multirow[t]{2}{*}{ Impacto Ambiental } & \multicolumn{15}{|c|}{ Classificação do Impacto Ambiental } \\
\hline & & $\mathbf{P}$ & $\mathbf{N}$ & D & I & B & $\mathbf{M}$ & G & $\mathbf{C P}$ & MP & $\mathbf{L P}$ & RE & IR & $\mathbf{L}$ & $\mathbf{R}$ & NA \\
\hline \multirow{6}{*}{$\begin{array}{l}\text { Revestimento das Margens } \\
\text { Solo-cimento. }\end{array}$} & $\circledast$ Definição de um habitat. & & * & * & & & & * & & & 夫 & & * & $\star$ & & \\
\hline & Estabilização das margens. & * & & * & & & & * & & & * & & * & * & & \\
\hline & $\begin{array}{l}\text { Impossibilidade de desenvolvimento ou } \\
\text { crescimento de uma vegetação de margem. }\end{array}$ & & * & * & & & & * & & & * & & * & * & & \\
\hline & $\begin{array}{l}\text { Melhoria das características físicas d'água } \\
\text { (cor e turbidez). }\end{array}$ & * & & * & & & & * & & & * & & * & & * & \\
\hline & $\begin{array}{l}\text { Redução do aporte sólido na corrente, } \\
\text { líquida. }\end{array}$ & * & & * & & & & * & & & * & & * & * & & \\
\hline & Redução dos efeitos da erosão. & * & & * & & & & * & & & * & & * & * & & \\
\hline
\end{tabular}


Planilha № 02 - Continuação - Impacto Ambiental das Ações Propostas - Classificação do Impacto Ambiental

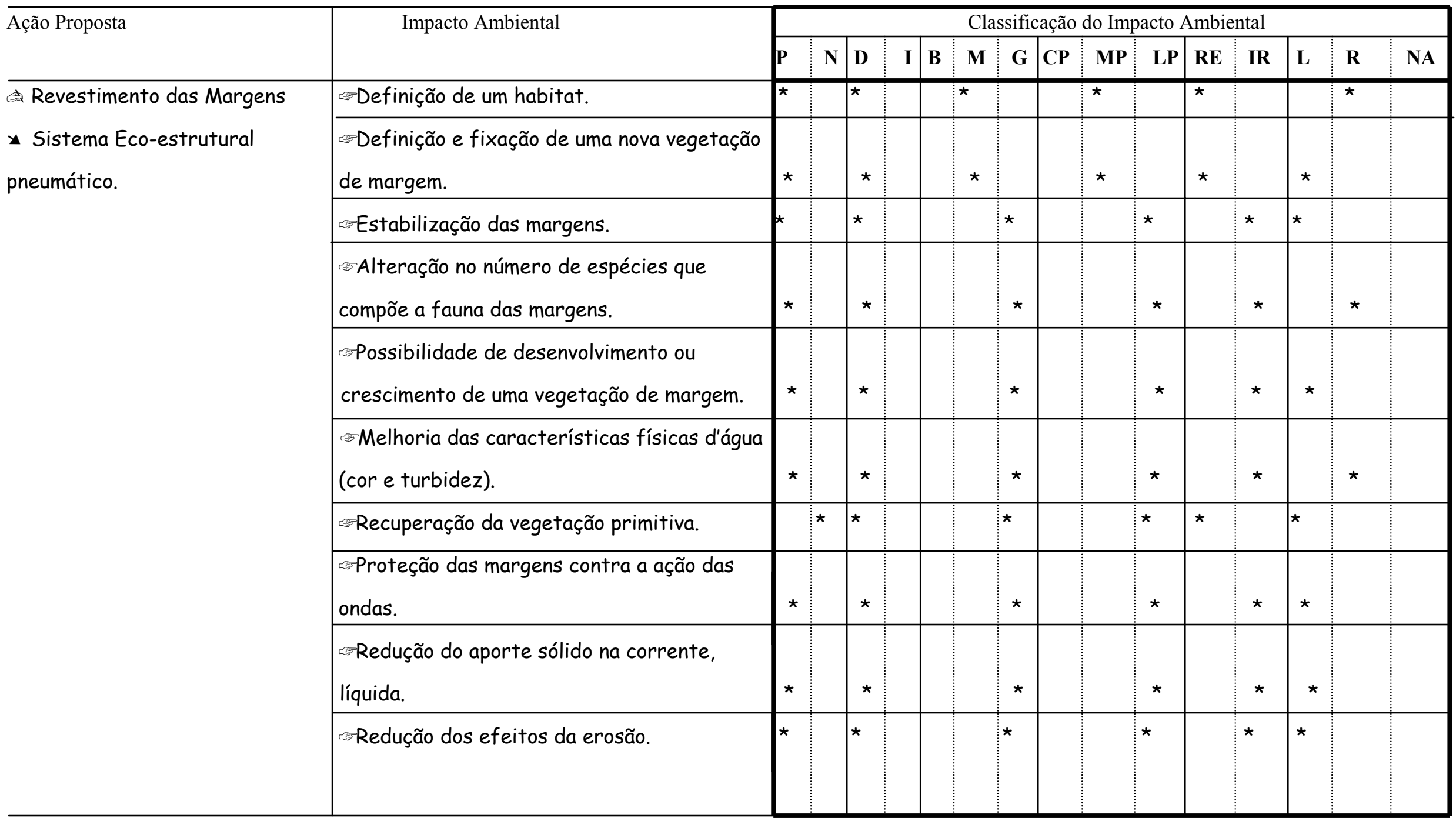


Planilha № 02 - Continuação - Impacto Ambiental das Ações Propostas - Classificação do Impacto Ambiental

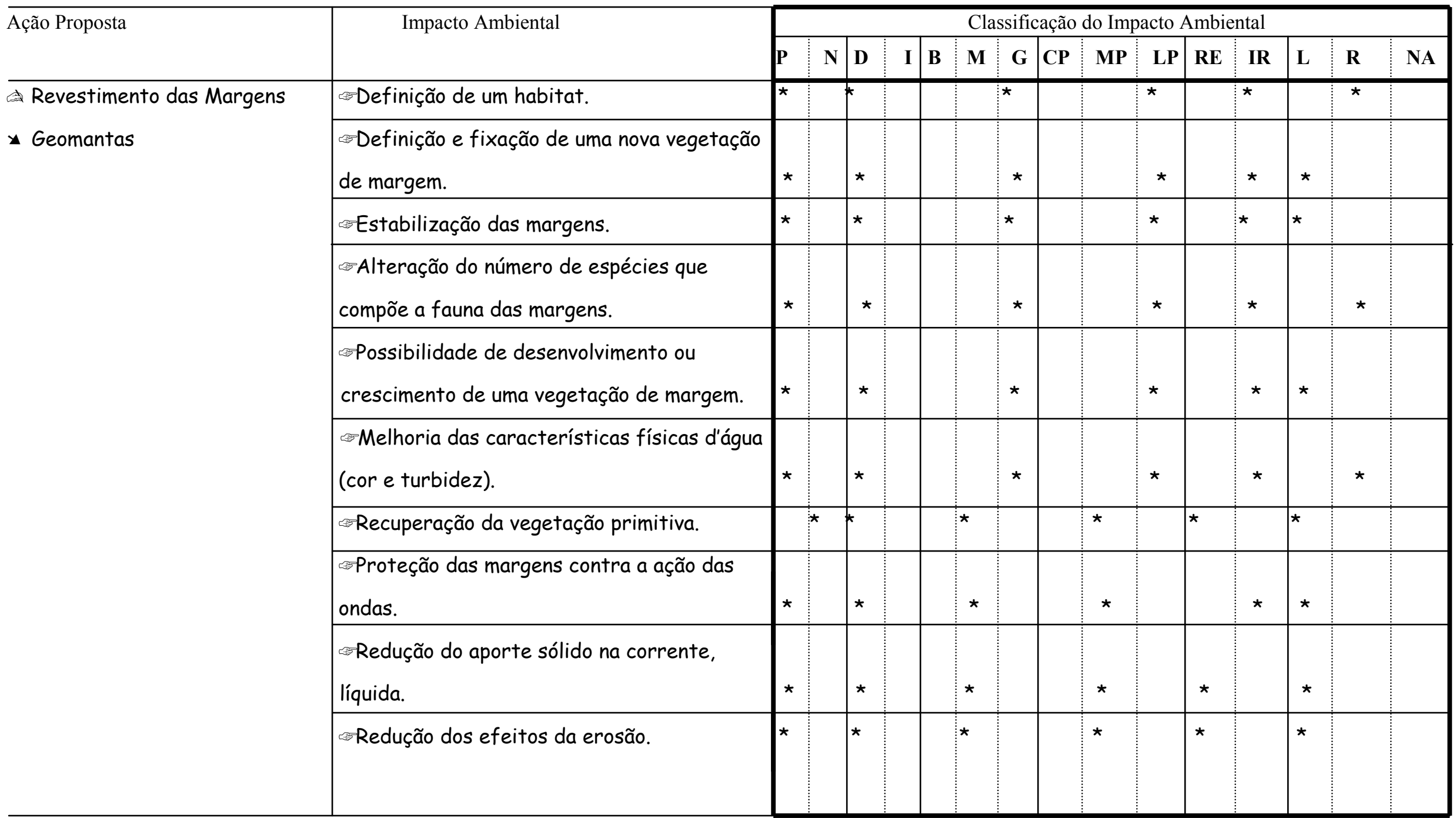


Planilha № 02 - Continuação - Impacto Ambiental das Ações Propostas - Classificação do Impacto Ambiental

\begin{tabular}{|c|c|c|c|c|c|c|c|c|c|c|c|c|c|c|c|c|}
\hline \multirow[t]{2}{*}{ Ação Proposta } & \multirow[t]{2}{*}{ Impacto Ambiental } & \multicolumn{15}{|c|}{ Classificação do Impacto Ambiental } \\
\hline & & $\mathbf{P}$ & $\mathbf{N}$ & D & $\mathbf{I}$ & B & $\mathbf{M}$ & G & $\mathbf{C P}$ & MP & $\mathbf{L P}$ & $\mathbf{R E}$ & IR & $\mathbf{L}$ & $\mathbf{R}$ & NA \\
\hline \multirow{10}{*}{$\begin{array}{l}\text { Geotêxteis; Geomalhas: } \\
\text { Geomembranas }\end{array}$} & Definição de um habitat. & & * & $\star$ & & & & $\star$ & & & $\star$ & $\star$ & & & $\star$ & \\
\hline & $\begin{array}{l}\rightarrow \text { Definição e fixação de uma nova vegetação } \\
\text { de margem. }\end{array}$ & & $\star$ & * & & & & * & & & $\star$ & $\star$ & & & & \\
\hline & Estabilização das margens. & * & & * & & & & * & & & * & $\star$ & & $\star$ & & \\
\hline & $\begin{array}{l}\text { Alteração do número de espécie que } \\
\text { compõe a fauna das margens. }\end{array}$ & * & & $\star$ & & & & $\star$ & & * & & $\star$ & & & $\star$ & \\
\hline & $\begin{array}{l}\text { r } \rightarrow \text { Possibilidade de desenvolvimento ou } \\
\text { crescimento de uma vegetação de margem. }\end{array}$ & & $\star$ & * & & & * & & & $\star$ & & $\star$ & & * & & \\
\hline & $\begin{array}{l}\text { Melhoria das características físicas d'água } \\
\text { (cor e turbidez). }\end{array}$ & * & & * & & & $\star$ & & & $\star$ & & $\star$ & & & $\star$ & \\
\hline & Recuperação da vegetação primitiva. & & $\star$ & * & & & & * & & & * & * & & $\star$ & & \\
\hline & $\begin{array}{l}\text { Proteção das margens contra a ação das } \\
\text { ondas. }\end{array}$ & & $\star$ & * & & & & * & & & * & * & & & * & \\
\hline & $\begin{array}{l}\text { Redução do aporte sólido na corrente, } \\
\text { líquida. }\end{array}$ & * & & * & & & & * & & & * & * & & & * & \\
\hline & $\leftrightarrow$ Redução dos efeitos da erosão. & t & & $\star$ & & & & $\star$ & & & * & $\star$ & & $\star$ & & \\
\hline
\end{tabular}


Planilha № 02 - Continuação - Impacto Ambiental das Ações Propostas - Classificação do Impacto Ambiental

\begin{tabular}{|c|c|c|c|c|c|c|c|c|c|c|c|c|c|c|c|c|}
\hline \multirow[t]{2}{*}{ Ação Proposta } & \multirow[t]{2}{*}{ Impacto Ambiental } & \multicolumn{15}{|c|}{ Classificação do Impacto Ambiental } \\
\hline & & $\mathbf{P}$ & $\mathbf{N}$ & D & I & B & M & G & CP & MP & LP & RE & IR & $\mathbf{L}$ & $\mathbf{R}$ & NA \\
\hline \multirow{6}{*}{$\begin{array}{l}\text { Revestimento das Margens } \\
\text { Geobarras; Geocélulas }\end{array}$} & Definição de um habitat. & * & & * & & * & & & & * & & * & & & * & \\
\hline & Estabilização das margens. & t & & * & & & & * & & & * & & * & * & & \\
\hline & $\begin{array}{l}\text { Possibilidade de desenvolvimento ou } \\
\text { crescimento de uma vegetação de margem. }\end{array}$ & * & & * & & & & * & & & * & * & & * & & \\
\hline & $\begin{array}{l}\text { Melhoria das características físicas d'água } \\
\text { (cor e turbidez). }\end{array}$ & * & & * & & * & & & & * & & * & & & * & \\
\hline & $\begin{array}{l}\text { Redução do aporte sólido na corrente, } \\
\text { líquida. }\end{array}$ & * & & * & & * & & & & * & & * & & & * & \\
\hline & $\Leftrightarrow$ Redução dos efeitos da erosão. & & & * & & * & & & & * & & & * & * & & \\
\hline
\end{tabular}


Planilha № 02 - Continuação - Impacto Ambiental das Ações Propostas - Classificação do Impacto Ambiental

\begin{tabular}{|c|c|c|c|c|c|c|c|c|c|c|c|c|c|c|c|c|}
\hline \multirow[t]{2}{*}{ Ação Proposta } & \multirow[t]{2}{*}{ Impacto Ambiental } & \multicolumn{15}{|c|}{ Classificação do Impacto Ambiental } \\
\hline & & $\mathbf{P}$ & $\mathbf{N}$ & D & $\mathbf{I}$ & $\mathbf{B}$ & $\mathbf{M}$ & G & $\mathbf{C P}$ & MP & $\mathbf{L P}$ & RE & IR & $\mathbf{L}$ & $\mathbf{R}$ & NA \\
\hline \multirow{10}{*}{$\begin{array}{l}\text { Revestimento das Margens } \\
\text { Cobertura Vegetal }\end{array}$} & $\leftrightarrow$ Definição de um habitat. & $\star$ & & $\star$ & & & & $\star$ & & & $\star$ & & $\star$ & $\star$ & & \\
\hline & $\begin{array}{l}\rightarrow \text { Definição e fixação de uma nova vegetação } \\
\text { de margem. }\end{array}$ & * & & * & & & & * & & & * & * & & * & & \\
\hline & Estabilização das margens. & $\star$ & & $\star$ & & & 夫 & & & * & & * & & $\star$ & & \\
\hline & $\begin{array}{l}\text { Alteração do número de espécies que } \\
\text { compõe a fauna das margens. }\end{array}$ & * & & * & & & & * & & & * & & * & * & & \\
\hline & $\begin{array}{l}\text { Impossibilidade de desenvolvimento ou } \\
\text { crescimento de uma vegetação de margem. }\end{array}$ & * & & * & & & & * & & & * & & * & * & & \\
\hline & $\begin{array}{l}\text { Melhoria das características físicas d'água } \\
\text { (cor e turbidez). }\end{array}$ & * & & * & & & * & & & * & & * & & & * & \\
\hline & Recuperação da vegetação primitiva. & 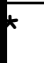 & & $\star$ & & & & $\star$ & & & $\star$ & & $\star$ & * & & \\
\hline & $\begin{array}{l}\text { Proteção das margens contra a ação das } \\
\text { ondas. }\end{array}$ & & * & * & & & & * & & & * & & * & * & & \\
\hline & $\begin{array}{l}\text { Redução do aporte sólido na corrente, } \\
\text { líquida. }\end{array}$ & * & & * & & & * & & & * & & * & & * & & \\
\hline & $\leftrightarrow$ Redução dos efeitos da erosão. & & & * & & * & & & $\star$ & & & & $\star$ & $\star$ & & \\
\hline
\end{tabular}


Planilha № 02 - Continuação - Impacto Ambiental das Ações Propostas - Classificação do Impacto Ambiental

\begin{tabular}{|c|c|c|c|c|c|c|c|c|c|c|c|c|c|c|c|c|}
\hline \multirow[t]{2}{*}{ Ação Proposta } & \multirow[t]{2}{*}{ Impacto Ambiental } & \multicolumn{15}{|c|}{ Classificação do Impacto Ambiental } \\
\hline & & $\mathbf{P}$ & $\mathbf{N}$ & D & $\mathbf{I}$ & B & M & $\mathbf{G}$ & $\mathbf{C P}$ & MP & $\mathbf{L P}$ & RE & IR & $\mathbf{L}$ & $\mathbf{R}$ & NA \\
\hline $\begin{array}{l}\text { Revestimento das Margens } \\
\text { Cobertura Vegetal e Blocos de } \\
\text { de rocha ( reparo com }\end{array}$ & Definição de um habitat. & $\star$ & & * & & & & $x$ & & & $\star$ & & * & & $\star$ & \\
\hline \multirow[t]{5}{*}{ enrocamento e vegetação natural) } & Estabilização das margens. & $\star$ & & * & & & & * & & & * & & * & $\star$ & & \\
\hline & $\begin{array}{l}\rightleftarrows \text { Possibilidade de desenvolvimento ou } \\
\text { crescimento de uma vegetação de margem. }\end{array}$ & * & & * & & & & * & & & * & & * & * & & \\
\hline & $\begin{array}{l}\text { Melhoria das características físicas d'água } \\
\text { (cor e turbidez). }\end{array}$ & * & & * & & & & * & & & * & & * & & * & \\
\hline & $\begin{array}{l}\text { Redução do aporte sólido na corrente, } \\
\text { líquida. }\end{array}$ & * & & * & & & & * & & & * & & * & * & & \\
\hline & Redução dos efeitos da erosão. & * & & * & & & & * & & & * & & * & * & & \\
\hline
\end{tabular}


Planilha № 03 - Impacto Ambiental das Ações Propostas - Classificação do Impacto Ambiental

\begin{tabular}{|c|c|c|c|c|c|c|c|c|c|c|c|c|c|c|c|c|}
\hline \multirow[t]{2}{*}{ Ação Proposta } & \multirow[t]{2}{*}{ Impacto Ambiental } & \multicolumn{15}{|c|}{ Classificação do Impacto Ambiental } \\
\hline & & $\mathbf{P}$ & $\mathbf{N}$ & D & $\mathbf{I}$ & B & $\mathbf{M}$ & $\mathbf{G}$ & $\mathbf{C P}$ & MP & $\mathbf{L P}$ & $\mathbf{R E}$ & IR & $\mathbf{L}$ & $\mathbf{R}$ & NA \\
\hline Obras de Sustentação & Definição de um habitat. & 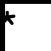 & & $\star$ & & & $\star$ & & & & $\star$ & & $\star$ & & * & \\
\hline $\begin{array}{l}\text { ( A estrutura vertical é } \\
\text { dimensionada para suportar os }\end{array}$ & $\begin{array}{l}\text { Definição e fixação de uma nova vegetação } \\
\text { de margem. }\end{array}$ & * & & $\star$ & & & $\star$ & & & & $\star$ & & $\star$ & $\star$ & & \\
\hline empuxos de solo ). & Estabilização das margens. & $\star$ & & $\star$ & & & & $\star$ & & & $\star$ & & * & $\star$ & & \\
\hline $\begin{array}{l}\text { N Grupo A } \\
\text { \erra Armada }\end{array}$ & $\begin{array}{l}\text { Alteração do número de espécies que } \\
\text { compõem a fauna das margens. }\end{array}$ & * & & $\star$ & & & $\star$ & & & & * & & * & & $\star$ & \\
\hline $\begin{array}{l}\text { Muro de Gravidade } \\
\text { Muros Atirantados }\end{array}$ & $\begin{array}{l}\text { Possibilidade de desenvolvimento ou } \\
\text { crescimento de uma vegetação de margem. }\end{array}$ & 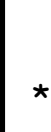 & & * & & * & & & & & * & & $\star$ & * & & \\
\hline $\begin{array}{l}\text { Muros de Flexão } \\
\text { Muros de Contraforte }\end{array}$ & $\begin{array}{l}\text { Melhoria das características físicas d'água } \\
\text { (cor e turbidez). }\end{array}$ & * & & * & & & & $\star$ & & & * & & * & & $\star$ & \\
\hline Rimobloco & Recuperação da vegetação primitiva. & t & & * & & $\star$ & & & & * & & & $\star$ & $\star$ & & \\
\hline $\begin{array}{l}\text { Crib-wall } \\
\text { Parede Diafragma }\end{array}$ & $\begin{array}{l}\text { Proteção das margens contra a ação das } \\
\text { ondas. }\end{array}$ & $\star$ & & * & & & & $\star$ & & & $\star$ & & $\star$ & * & & \\
\hline $\begin{array}{l}\text { Estacas Pranchas Metálicas } \\
\text { Paredes de Estacões ou }\end{array}$ & $\begin{array}{l}\text { Redução do aporte sólido na corrent } \\
\text { líquida. }\end{array}$ & $\begin{array}{l}f_{1} \\
\star\end{array}$ & & $\star$ & & & & * & & & $\star$ & & $\star$ & * & & \\
\hline Tubulões & Redução dos efeitos da erosão. & $\star$ & & $\star$ & & & & $*$ & & & $\star$ & & $\star$ & * & & \\
\hline & Descontinuidade do talude. & & & * & $\star$ & & & * & & & & $\star$ & & & $\star$ & * \\
\hline
\end{tabular}




\begin{tabular}{|c|c|c|c|c|c|c|c|c|c|c|c|c|c|c|c|c|}
\hline \multirow[t]{2}{*}{ Ação Proposta } & \multirow[t]{2}{*}{ Impacto Ambiental } & \multicolumn{15}{|c|}{ Classificação do Impacto Ambiental } \\
\hline & & $\mathbf{P}$ & $\mathbf{N}$ & D & I & B & M & G & $\mathbf{C P}$ & MP & LP & RE & IR & $\mathbf{L}$ & $\mathbf{R}$ & NA \\
\hline \multirow{7}{*}{$\begin{array}{l}\text { Obras de Sustentação } \\
\text { M Grupo B } \\
\text { Sistema Terramesh } \\
\text { Gabiões - tipo caixa }\end{array}$} & Definição de um habitat. & F & & * & & & & * & & & * & & * & & r & \\
\hline & Estabilização das margens. & $\star$ & & * & & & & * & & & * & & * & * & & \\
\hline & $\begin{array}{l}\text { pressibilidade de desenvolvimento ou } \\
\text { crescimento de uma vegetação de margem }\end{array}$ & * & & * & & & & * & & & * & & * & * & & \\
\hline & $\begin{array}{l}\text { Melhoria das características físicas d'água } \\
\text { (cor e turbidez). }\end{array}$ & * & & * & & & & * & & & * & & * & & * & \\
\hline & $\begin{array}{l}\text { Redução do aporte sólido na corrente, } \\
\text { líquida. }\end{array}$ & * & & * & & & & * & & & * & & * & * & & \\
\hline & Redução dos efeitos da erosão. & * & & * & & & & * & & & * & & * & * & & \\
\hline & Criação de uma margem artificial & * & & * & & & & * & & & * & & * & * & & \\
\hline
\end{tabular}




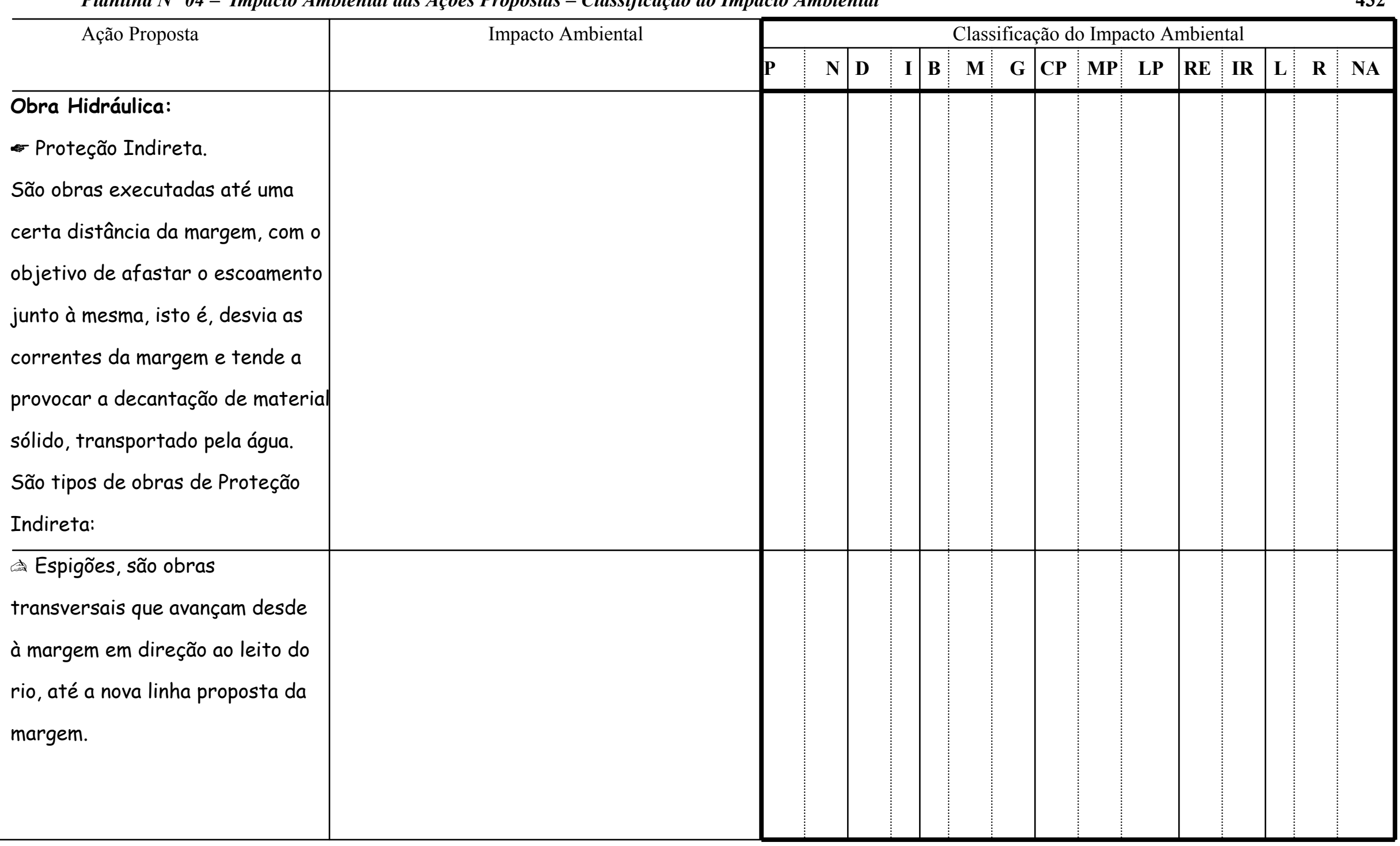


Planilha № 04 - Continuação - Impacto Ambiental das Ações Propostas - Classificação do Impacto Ambiental

\begin{tabular}{|c|c|c|c|c|c|c|c|c|c|c|c|c|c|c|c|c|}
\hline \multirow[t]{2}{*}{ Ação Proposta } & \multirow[t]{2}{*}{ Impacto Ambiental } & \multicolumn{15}{|c|}{ Classificação do Impacto Ambiental } \\
\hline & & $\mathbf{P}$ & $\mathbf{N}$ & D & I & B & $\mathbf{M}$ & $\mathbf{G}$ & $\mathbf{C P}$ & MP & $\mathbf{L P}$ & RE & IR & $\mathbf{L}$ & & NA \\
\hline \multirow{6}{*}{$\begin{array}{l}\text { ( Espigão Permeável } \\
\text { (Parte significativa d'água } \\
\text { continua escoando entre os } \\
\text { elementos do espigão. Podemos } \\
\text { citar como exemplo o } \\
\text { estaqueamento de madeira). }\end{array}$} & $\begin{array}{l}\text { A deposição de sedimentos, entre eles, } \\
\text { define a evolução de uma nova linha de } \\
\text { margem. }\end{array}$ & * & & * & & & * & & & * & & & * & & & \\
\hline & $\begin{array}{l}\text { Não protege a margem da ação das ondas, } \\
\text { mas retém os sedimentos das margens } \\
\text { erodidas, isto é, o material não é arrastado } \\
\text { pelo rio. }\end{array}$ & & * & * & & & * & & & * & & $\star$ & & * & & \\
\hline & $\begin{array}{l}\text { geotécnica, porém, o material movimentado } \\
\text { permanece entre os espigões. }\end{array}$ & & $\star$ & $\star$ & & & $\star$ & & & $\star$ & & * & & * & & \\
\hline & $\begin{array}{l}\text { Alteração da vegetação, nas margens dos } \\
\text { rios, com incremento no seu desenvolvimento. }\end{array}$ & $\star$ & & $\star$ & & & & * & & & * & & $\star$ & 夫 & & \\
\hline & Alteração do habitat das margens. & * & & $\star$ & & & & * & & & $\star$ & & $\star$ & & & \\
\hline & $\begin{array}{l}\text { As baixas velocidades do escoamento entre } \\
\text { eles, facilitam o desenvolvimento de um habitat } \\
\text { com a evolução da fauna e flora fluviais. }\end{array}$ & * & & * & & & & $\star$ & & & $\star$ & & $\star$ & & & \\
\hline
\end{tabular}


Planilha № 04 - Continuação - Impacto Ambiental das Ações Propostas - Classificação do Impacto Ambiental

\begin{tabular}{|c|c|c|c|c|c|c|c|c|c|c|c|c|c|c|c|c|}
\hline \multirow[t]{2}{*}{ Ação Proposta } & \multirow[t]{2}{*}{ Impacto Ambiental } & \multicolumn{15}{|c|}{ Classificação do Impacto Ambiental } \\
\hline & & $\mathbf{P}$ & $\mathbf{N}$ & D & $\mathbf{I}$ & B & $\mathbf{M}$ & G & $\mathbf{C P}$ & MP & $\mathbf{L P}$ & RE & IR & $\mathbf{L}$ & $\mathbf{R}$ & $\mathbf{N A}$ \\
\hline & $\begin{array}{l}\text { Aumento da velocidade do fluxo, devido } \\
\text { a redução da área hidráulica. }\end{array}$ & & * & * & & & & * & & * & & * & & $\star$ & & \\
\hline & Alteração do regime de escoamento. & & * & * & & & * & & & * & & * & & * & & \\
\hline & $\begin{array}{l}\text { pode aumento da velocidade de escoamento, } \\
\text { transporte de sedimentos. }\end{array}$ & & * & * & & & * & & & $\star$ & & * & & & * & \\
\hline & $\begin{array}{l}\text { Desenvolvimento de vegetação sobre o } \\
\text { espigão. }\end{array}$ & * & & * & & & & * & & & * & & * & * & & \\
\hline & $\begin{array}{l}\text { Definição de um canal que favorece o } \\
\text { escoamento e o desenvolvimento das } \\
\text { condições de navegação (hidrovia) }\end{array}$ & * & & * & & & & * & & & * & & * & * & & \\
\hline
\end{tabular}


Planilha № 04 - Continuação - Impacto Ambiental das Ações Propostas - Classificação do Impacto Ambiental

\begin{tabular}{|c|c|c|c|c|c|c|c|c|c|c|c|c|c|c|c|c|}
\hline \multirow[t]{2}{*}{ Ação Proposta } & \multirow[t]{2}{*}{ Impacto Ambiental } & \multicolumn{15}{|c|}{ Classificação do Impacto Ambiental } \\
\hline & & $\mathbf{P}$ & $\mathbf{N}$ & D & I & B & $\mathbf{M}$ & G & $\mathbf{C P}$ & MP & $\mathbf{L P}$ & RE & IR & $\mathbf{L}$ & $\mathbf{R}$ & NA \\
\hline \multirow{6}{*}{$\begin{array}{l}\text { ( Espigão Impermeável } \\
\text { ( O escoamento d'água entre o } \\
\text { material do espigão é mínimo, } \\
\text { isto é, desprezível. Podemos } \\
\text { citar como exemplo os geotubos) }\end{array}$} & $\begin{array}{l}\text { A deposição de sedimentos, entre eles, } \\
\text { define a evolução de uma nova linha de } \\
\text { margem. }\end{array}$ & * & & * & & & & * & & & * & & * & * & & \\
\hline & $\begin{array}{l}\text { Não protege a margem da ação das ondas, } \\
\text { mas retém os sedimentos das margens } \\
\text { erodidas, isto é, o material não é arrastado } \\
\text { pelo rio. }\end{array}$ & & * & * & & & * & & & * & & * & & * & & \\
\hline & $\begin{array}{l}\text { possibilidade de ocorrência de instabilidade } \\
\text { geotécnica, porém, o material movimentado } \\
\text { permanece entre os espigões. }\end{array}$ & & * & * & & & * & & & * & & * & & * & & \\
\hline & $\begin{array}{l}\text { Alteração da vegetação, nas margens dos } \\
\text { rios, com incremento no seu desenvolvimento. }\end{array}$ & * & & & * & & & * & & & * & & * & * & & \\
\hline & Alteração do habitat das margens. & 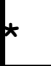 & & & * & & & * & & & * & & * & * & & \\
\hline & $\begin{array}{l}\text { As baixas velocidades do escoamento entre } \\
\text { eles, facilitam o desenvolvimento de um habitat } \\
\text { com a evolução da fauna e flora fluviais. }\end{array}$ & * & & * & & & & * & & & * & & * & * & & \\
\hline
\end{tabular}


Planilha № 04 - Continuação - Impacto Ambiental das Açães Propostas - Classificação do Impacto Ambiental

\begin{tabular}{|c|c|c|c|c|c|c|c|c|c|c|c|c|c|c|c|c|}
\hline \multirow[t]{2}{*}{ Ação Proposta } & \multirow[t]{2}{*}{ Impacto Ambiental } & \multicolumn{15}{|c|}{ Classificação do Impacto Ambiental } \\
\hline & & $\mathbf{P}$ & $\mathbf{N}$ & D & $\mathbf{I}$ & B & $\mathbf{M}$ & $\mathbf{G}$ & CP & MP & $\mathbf{L P}$ & RE & IR & $\mathbf{L}$ & $\mathbf{R}$ & NA \\
\hline & $\begin{array}{l}\text { Aumento da velocidade do fluxo, devido a } \\
\text { redução da área hidráulica. }\end{array}$ & & * & * & & & & * & & & * & * & & * & & \\
\hline & Alteração do regime de escoamento. & & $\star$ & $\star$ & & & * & & & * & & * & & $\star$ & & \\
\hline & $\begin{array}{l}\text { Oaumento da velocidade de escoamento, } \\
\text { pode erodir o leito, incrementando o } \\
\text { transporte de sedimentos. }\end{array}$ & & * & * & & & * & & & $\star$ & & * & & * & & \\
\hline & $\begin{array}{l}\text { 中esenvolvimento de vegetação sobre o } \\
\text { espigão. }\end{array}$ & & $\star$ & * & & & * & & & * & & * & & * & & \\
\hline & $\begin{array}{l}\text { Definição de um canal que favorece o } \\
\text { escoamento e o desenvolvimento das } \\
\text { condições de navegação (hidrovia). }\end{array}$ & * & & * & & & & $\star$ & & & $\star$ & & * & $\star$ & & \\
\hline
\end{tabular}




\begin{tabular}{|c|c|c|c|c|c|c|c|c|c|c|c|c|c|c|c|c|}
\hline \multirow[t]{2}{*}{ Ação Proposta } & \multirow[t]{2}{*}{ Impacto Ambiental } & \multicolumn{15}{|c|}{ Classificação do Impacto Ambiental } \\
\hline & & $\mathbf{P}$ & $\mathbf{N}$ & $\mathbf{D}$ & I & B & $\mathbf{M}$ & G & $\mathbf{C P}$ & MP & $\mathbf{L P}$ & RE & IR & $\mathbf{L}$ & $\mathbf{R}$ & $\mathbf{N A}$ \\
\hline \multirow{8}{*}{$\begin{array}{l}\text { - Diques, são construções } \\
\text { longitudinais ao curso d'água, } \\
\text { constituindo uma margem } \\
\text { artificial (avanço da margem), } \\
\text { com redução da área hidráulica } \\
\text { da seção do canal ( com } \\
\text { confinamento e direcionamento }\end{array}$} & $\begin{array}{l}\text { Aumento da velocidade do fluxo, devido a } \\
\text { redução da área hidráulica. }\end{array}$ & & * & * & & & & * & & $\star$ & & * & & * & & \\
\hline & Alteração do regime de escoamento. & & * & * & & & & * & & * & & $\star$ & & $\star$ & & \\
\hline & $\begin{array}{l}\text { pode aumento da velocidade de escoamento, } \\
\text { transporte de sedimentos. }\end{array}$ & & * & * & & & & * & & * & & * & & * & & \\
\hline & Cria uma linha de margem. & * & & * & & & & * & & & * & & * & * & & \\
\hline & Protege a margem da ação das ondas. & * & & * & & & & $\star$ & & & * & & * & $\star$ & & \\
\hline & $\begin{array}{l}\text { Definição de um canal que favorece o } \\
\text { escoamento e o desenvolvimento das } \\
\text { condições de navegação (hidrovia). }\end{array}$ & * & & * & & & & * & & & * & & * & * & & \\
\hline & $\begin{array}{l}\text { Alteração da vegetação das margens dos } \\
\text { rios, com incremento no seu desenvolvimento. }\end{array}$ & * & & & * & & & * & & & * & * & & * & & \\
\hline & Alteração do habitat das margens. & * & & & * & & & $\star$ & & & * & * & & & $\star *$ & \\
\hline
\end{tabular}


AÇÃO PROPOSTA - Obra Hidráulica Fluvial

Tipo de Obra Hidráulica Fluvial - Retificação de Rios Sinuosos e Meandros - A Retificação de Meandros, tem por objetivo tornar retilíneo o leito curvo do rio, melhorando as condições do escoamento. Só terá êxito a partir dos conhecimentos específicos dos meandros fluviais, tais como: origem dos meandros, mecanismo de formação de meandros, localização dos meandros, caracterização do meandro.

\begin{tabular}{|c|c|c|c|c|c|c|c|c|c|c|c|c|c|c|c|c|}
\hline \multirow[t]{2}{*}{ Ação Proposta } & \multirow[t]{2}{*}{ Impacto Ambiental } & \multicolumn{15}{|c|}{ Classificação do Impacto Ambiental } \\
\hline & & $\mathbf{P}$ & $\mathbf{N}$ & D & I & B & $\mathbf{M}$ & $\mathbf{G}$ & CP & MP & LP & RE & IR & $\mathbf{L}$ & $\mathbf{R}$ & NA \\
\hline \multicolumn{17}{|l|}{$\begin{array}{l}\text { Obra Hidráulica: } \\
\text { - Retificação de Rios Sinuosos } \\
\text { e Meandros }\end{array}$} \\
\hline \multirow{5}{*}{$\begin{array}{l}\text { ¿ Controle da Inundação no } \\
\text { trecho, conseqüente proteção dos } \\
\text { terrenos marginais. }\end{array}$} & $\begin{array}{l}\rightarrow \text { Permite a utilização da várzea para fins } \\
\text { de agricultura. }\end{array}$ & * & & $\star$ & & & $\star$ & & & * & & $\star$ & & $\star$ & & \\
\hline & $\begin{array}{l}\text { Alteração da vegetação das margens dos } \\
\text { cursos d' água nos trechos retificados. }\end{array}$ & & * & $\star$ & & & & $\star$ & & & * & $\star$ & & * & & \\
\hline & $\begin{array}{l}\text { A proteção do terrenos marginais, facilita } \\
\text { o desenvolvimento da irrigação, através da } \\
\text { implantação de "Polder". }\end{array}$ & $\star$ & & $\star$ & & & $\star$ & & & $\star$ & & $\star$ & & * & & \\
\hline & $\begin{array}{l}\text { Tendência do aumento do pico de vazão } \\
\text { para jusante do trecho retificado. }\end{array}$ & & * & * & & & $\star$ & & & $\star$ & & $\star$ & & & * & \\
\hline & Alteração do regime de escoamento. & & $\star$ & $\star$ & & & $\star$ & & & * & & * & & & $\star$ & \\
\hline
\end{tabular}


Planilha № 06 - Continuação - Impacto Ambiental das Ações Propostas - Classificação do Impacto Ambiental

\begin{tabular}{|c|c|c|c|c|c|c|c|c|c|c|c|c|c|c|c|c|}
\hline \multirow[t]{2}{*}{ Ação Proposta } & \multirow[t]{2}{*}{ Impacto Ambiental } & \multicolumn{15}{|c|}{ Classificação do Impacto Ambiental } \\
\hline & & $\mathbf{P}$ & $\mathbf{N}$ & D & $\mathbf{I}$ & B & $\mathbf{M}$ & $\mathbf{G}$ & $\mathbf{C P}$ & MP & $\mathbf{L P}$ & $\mathbf{R E}$ & IR & $\mathbf{L}$ & $\mathbf{R}$ & NA \\
\hline & $\begin{array}{l}\text { Aumento da velocidade de fluxo e da ação } \\
\text { erosiva sobre leito (margens e fundo). }\end{array}$ & & $\star$ & * & & & & $\star$ & & & * & & $\star$ & $\star$ & & \\
\hline & $\begin{array}{l}\text { Permite a "definição" de um habitat com } \\
\text { a fixação de áreas inundáveis ou não, bem } \\
\text { definidos. }\end{array}$ & * & & * & & & & * & & & $\star$ & * & & & $\star$ & \\
\hline & $\begin{array}{l}\text { Alteração do curso d'água, no que se } \\
\text { refere ao volume d'água e conformação do } \\
\text { leito. }\end{array}$ & & * & * & & & & $\star$ & & & $\star$ & & $\star$ & * & & \\
\hline & $\begin{array}{l}\text { Modificação nas rotas de migração de } \\
\text { peixes. }\end{array}$ & & $\star$ & * & & & & * & & & $\star$ & & $\star$ & $\star$ & & \\
\hline & Alteração no habitat das margens. & & * & $\star$ & & & * & & & * & & $\star$ & & & * & \\
\hline & $\begin{array}{l}\text { Utilização da alça proveniente da retificação } \\
\text { do curso d'água, para tratamento de águas } \\
\text { residuárias, criação de peixes, recreação, etc. }\end{array}$ & * & & $\star$ & & & & * & & & $\star$ & $\star$ & & * & & \\
\hline & Alteração no habitat das alça. & * & & $\star$ & & & & $\star$ & & & $\star$ & $\star$ & & $\star$ & & \\
\hline \multirow[t]{2}{*}{$\begin{array}{l}\text { Melhoria do Traçado } \\
\text { ( para fins de navegação) }\end{array}$} & $\begin{array}{l}\text { Alteração da vegetação das margens dos } \\
\text { cursos d'água, nos trechos retificados. }\end{array}$ & & $\star$ & * & & & & $\star$ & & & $\star$ & * & & * & & \\
\hline & Aumento da ação de escoamento. & & $*$ & $\star$ & & & & $\star$ & & & $\star$ & $\star$ & & $\star$ & & \\
\hline
\end{tabular}


Planilha № 06 - Continuação - Impacto Ambiental das Ações Propostas - Classificação do Impacto Ambiental

\begin{tabular}{|c|c|c|c|c|c|c|c|c|c|c|c|c|c|c|c|c|}
\hline \multirow[t]{2}{*}{ Ação Proposta } & \multirow[t]{2}{*}{ Impacto Ambiental } & \multicolumn{15}{|c|}{ Classificação do Impacto Ambiental } \\
\hline & & $\mathbf{P}$ & $\mathbf{N}$ & $\mathbf{D}$ & $\mathbf{I}$ & B & $\mathbf{M}$ & $G$ & $\mathbf{C P}$ & MP & $\mathbf{L P}$ & $\mathbf{R E}$ & IR & $\mathbf{L}$ & $\mathbf{R}$ & NA \\
\hline & $\begin{array}{l}\text { Formação de ondas com a passagem de } \\
\text { embarcação. }\end{array}$ & & * & * & & & & * & * & & & & * & & * & \\
\hline & $\begin{array}{l}\Leftrightarrow \text { Definição de um canal que favorece o } \\
\text { desenvolvimento da navegação (hidrovia) }\end{array}$ & * & & * & & & & * & & & * & & * & & * & \\
\hline & $\begin{array}{l}\text { Modificação nas rotas de migração de } \\
\text { peixes. }\end{array}$ & & * & * & & & & * & & & * & & * & * & & \\
\hline & Alteração no habitat das margens. & & * & * & & & * & & & * & & * & & & * & \\
\hline & $\begin{array}{l}\text { Utilização da alça resultante da retificação } \\
\text { do curso d'água, para tratamento de águas } \\
\text { residuárias, criação de peixes, recreação, etc. }\end{array}$ & * & & * & & & & * & & & * & * & & * & & \\
\hline & Alteração no habitat das alça. & * & & * & & & & * & & & * & $\star$ & & $\star$ & & \\
\hline \multirow[t]{3}{*}{ Drenagem Urbana } & $\begin{array}{l}\text { Alteração da vegetação das margens dos } \\
\text { cursos d'água. }\end{array}$ & & * & * & & & & * & & & * & * & & * & & \\
\hline & Aumento da velocidade do fluxo das águas. & & * & * & & & * & & & * & & * & & * & & \\
\hline & $\begin{array}{l}\text { Ocupação das margens para a implantação } \\
\text { de vias terrestres em fundo de vale. }\end{array}$ & & * & * & & & & * & & & * & * & & & * & \\
\hline
\end{tabular}


Planilha № 06 - Continuação - Impacto Ambiental das Ações Propostas - Classificação do Impacto Ambiental

\begin{tabular}{|c|c|c|c|c|c|c|c|c|c|c|c|c|c|c|c|c|}
\hline \multirow[t]{2}{*}{ Ação Proposta } & \multirow[t]{2}{*}{ Impacto Ambiental } & \multicolumn{15}{|c|}{ Classificação do Impacto Ambiental } \\
\hline & & $\mathbf{P}$ & $\mathbf{N}$ & D & $\mathbf{I}$ & B & $\mathbf{M}$ & $\mathbf{G}$ & $\mathbf{C P}$ & MP & $\mathbf{L P}$ & $\mathbf{R E}$ & IR & $\mathbf{L}$ & $\mathbf{R}$ & $\mathbf{N A}$ \\
\hline \multirow{9}{*}{$\begin{array}{l}\text { Corte de Meandro, através de } \\
\text { Canal Piloto (é um canal com } \\
\text { pequenas dimensões, que evolui a } \\
\text { partir da capacidade d'água em } \\
\text { erodir. }\end{array}$} & $\begin{array}{l}\text { Aumento do volume de sedimentos lançados } \\
\text { a jusante [ necessidade de se limitar (fixar), a } \\
\text { escavação, do novo canal, por ação d'água ]. }\end{array}$ & & * & * & & & & * & & & $\star$ & * & & & * & \\
\hline & $\begin{array}{l}\text { Alteração da vegetação das margens dos } \\
\text { cursos d'água nos trechos retificados. }\end{array}$ & & * & * & & & & * & & & * & * & & * & & \\
\hline & $\begin{array}{l}\text { Tendência do aumento do pico de vazão } \\
\text { para jusante do trecho retificado. }\end{array}$ & & * & * & & & & * & & & * & & * & & * & \\
\hline & Alteração do regime de escoamento. & & * & * & & & & $\star$ & & & * & * & & $\star$ & & \\
\hline & $\begin{array}{l}\text { Aumento da velocidade de fluxo e da } \\
\text { ação erosiva sobre o leito (margem e fundo). }\end{array}$ & & * & * & & & & * & & & * & & * & * & & \\
\hline & $\begin{array}{l}\text { Alteração do curso d'água, no que se refere } \\
\text { ao volume d'água e conformação do leito. }\end{array}$ & & * & * & & & & * & & & * & & * & * & & \\
\hline & $\begin{array}{l}\text { Modificação nas rotas de migração de } \\
\text { peixes. }\end{array}$ & & * & * & & & & * & & & * & & * & * & & \\
\hline & Alteração no habitat das alças. & * & & * & & & & * & & & * & * & & * & & \\
\hline & Alteração no habitat das margens. & & * & * & & & * & & & * & & * & & & * & \\
\hline
\end{tabular}


Planilha № 06 - Continuação - Impacto Ambiental das Ações Propostas - Classificação do Impacto Ambiental

\begin{tabular}{|c|c|c|c|c|c|c|c|c|c|c|c|c|c|c|c|c|}
\hline \multirow[t]{2}{*}{ Ação Proposta } & \multirow[t]{2}{*}{ Impacto Ambiental } & \multicolumn{15}{|c|}{ Classificação do Impacto Ambiental } \\
\hline & & $\mathbf{P}$ & $\mathbf{N}$ & D & $\mathbf{I}$ & B & M & $\mathbf{G}$ & $\mathbf{C P}$ & MP & $\mathbf{L P}$ & $\mathbf{R E}$ & IR & $\mathbf{L}$ & $\mathbf{R}$ & NA \\
\hline & $\begin{array}{l}\text { Utilização da alça proveniente da } \\
\text { retificação do curso d'água, para tratamento } \\
\text { de águas residuárias, criação de peixes, } \\
\text { recreação, etc. }\end{array}$ & $\star$ & & * & & & & * & & & * & * & & * & & \\
\hline
\end{tabular}


AÇÃO PROPOSTA - Obra Hidráulica Fluvial

Tipo de Obra Hidráulica Fluvial - Derrocamento e Dragagem - O derrocamento é a operação que consiste no desmonte (fraturamento, rompimento ) de rochas, particularmente do leito de rios ou canais, para desobstrui-los. Após desmonte, dá-se a remoção da rocha.. O desmonte da rocha, é feito com técnicas específicas, que consistem em romper o maciço rochoso, que pode se realizar, com a utilização de explosivos (ondas de choque), por percussão (marreta, soquete, ariete) ou por perfuração e percussão (martelete) e, finalmente promover a remoção do material rompido, que quando no leito de rios ou canais, será retirado através de dragas. Entende-se por dragagem a retirada, transporte e disposição final, do material, que pode ser resultante do derrocamento, areias, siltes, argilas, etc., do leito dos rios ou não, por equipamentos adequados em cada operação.

\begin{tabular}{|c|c|c|c|c|c|c|c|c|c|c|c|c|c|c|c|c|}
\hline \multirow[t]{2}{*}{ Ação Proposta } & \multirow[t]{2}{*}{ Impacto Ambiental } & \multicolumn{15}{|c|}{ Classificação do Impacto Ambiental } \\
\hline & & $\mathbf{P}$ & $\mathbf{N}$ & D & & B & M & G & $\mathbf{C P}$ & MP & $\mathbf{L P}$ & $\mathbf{R E}$ & IR & $\mathbf{L}$ & $\mathbf{R}$ & NA \\
\hline \multicolumn{17}{|c|}{$\begin{array}{l}\text { Obra Hidráulica } \\
\text { - Derrocamento e Dragagem }\end{array}$} \\
\hline \multirow[t]{2}{*}{$\begin{array}{l}\text { Derrocamento } \\
\text { Com Explosivos }\end{array}$} & $\begin{array}{l}\text { Destruição da fauna e flora aquática, nas } \\
\text { proximidades da explosão, devido as ondas de } \\
\text { choque. }\end{array}$ & & * & * & & & & * & & & * & & * & & * & \\
\hline & $\begin{array}{l}\text { e conseqüente redução da seção transversal } \\
\text { num determinado trecho e num determinado } \\
\text { intervalo de tempo (até a sua remoção). }\end{array}$ & & $\star$ & $\star$ & & $\star$ & & & $\star$ & & & $\star$ & & * & & \\
\hline
\end{tabular}


Planilha No 07 - Impacto Ambiental das Ações Propostas - Classificação do Impacto Ambiental

\begin{tabular}{|c|c|c|c|c|c|c|c|c|c|c|c|c|c|c|c|c|}
\hline \multirow[t]{2}{*}{ Ação Proposta } & \multirow[t]{2}{*}{ Impacto Ambiental } & \multicolumn{15}{|c|}{ Classificação do Impacto Ambiental } \\
\hline & & $\mathbf{P}$ & $\mathbf{N}$ & D & $\mathbf{I}$ & B & $\mathbf{M}$ & $\mathbf{G}$ & $\mathbf{C P}$ & MP & $\mathbf{L P}$ & $\mathbf{R E}$ & IR & $\mathbf{L}$ & $\mathbf{R}$ & NA \\
\hline & Alteração das características físicas d'água. & & $\star$ & $\star$ & & 夫 & & & * & & & $\star$ & & & * & \\
\hline \multirow[t]{3}{*}{ ^ Com Martelete e Percussão } & Aumento do nível de ruído. & & * & * & & & & * & * & & & * & & & * & \\
\hline & $\begin{array}{l}\text { Aumento do volume de material fragmentado, } \\
\text { e consequiente redução da seção transversal } \\
\text { num determinado trecho e num determinado } \\
\text { intervalo de tempo (até a sua remoção). }\end{array}$ & & * & * & & * & & & * & & & * & & * & & \\
\hline & Alteração das características físicas d'água. & & * & $\star$ & & * & & & * & & & * & & & $\star$ & \\
\hline $\begin{array}{l}\text { Dragagem } \\
\text { A operação de dragagem, } \\
\text { compreende: retirada, transport } \\
\text { e disposição final do material. }\end{array}$ & & & & & & & & & & & & & & & & \\
\hline \multirow[t]{3}{*}{ \$ Retirada do material do leito. } & $\begin{array}{l}\text { Alteração da paisagem ( no caso, bancos de } \\
\text { areia ou rochas aparentes ). }\end{array}$ & * & & * & & & & * & & * & & * & & * & & \\
\hline & $\begin{array}{l}\text { Melhoria das condições de escoamento, } \\
\text { devido o aumento da seção. }\end{array}$ & * & & * & & & $\star$ & & & * & & * & & $\star$ & & \\
\hline & $\leftrightarrow$ Aumento na velocidade do fluxo das águas. & & $\star$ & * & & & $\star$ & & & $\star$ & & $\star$ & & $\star$ & & \\
\hline
\end{tabular}


Planilha No 07 - Impacto Ambiental das Ações Propostas - Classificação do Impacto Ambiental

\begin{tabular}{|c|c|c|c|c|c|c|c|c|c|c|c|c|c|c|c|c|}
\hline \multirow[t]{2}{*}{ Ação Proposta } & \multirow[t]{2}{*}{ Impacto Ambiental } & \multicolumn{15}{|c|}{ Classificação do Impacto Ambiental } \\
\hline & & $\mathbf{P}$ & $\mathbf{N}$ & $\mathbf{D}$ & $\mathbf{I}$ & B & $\mathbf{M}$ & G & $\mathbf{C P}$ & MP & $\mathbf{L P}$ & RE & IR & $\mathbf{L}$ & $\mathbf{R}$ & $\mathbf{N A}$ \\
\hline & Alteração dinâmica do pulso de inundação. & & * & $\star$ & & & & t* & & & $\star$ & * & & & * & \\
\hline & Abaixamento do nível d'água. & & * & * & & & & $\star$ & & & $\star$ & * & & & * & \\
\hline & $\begin{array}{l}\text { A remoção do material pode alterar a } \\
\text { composição e o tamanho da partícula do } \\
\text { material do leito. }\end{array}$ & & * & * & & & * & & & * & & * & & * & & \\
\hline & Aprofundamento do canal. & & * & * & & & & * & & & $\star$ & $\star$ & & * & & \\
\hline \multirow{6}{*}{$\begin{array}{l}\text { A Equipamentos de Dragagem } \\
\text { - Dragas Mecânicas } \\
\text { \ Dragas de Alcatruzes } \\
\text { A corrente sem-fim de caçambas }\end{array}$} & $\leftrightarrow$ Diminuição da produtividade de algas. & & * & $\star$ & & & $\star$ & & * & & & $\star$ & & * & & \\
\hline & $\begin{array}{l}\text { Contaminação das redes alimentares, no caso } \\
\text { de existirem produtos tóxicos. }\end{array}$ & & * & * & & & & * & & * & & * & & & * & \\
\hline & Destruição de hábitats da fauna bentônica. & & * & $\star$ & & & $\star$ & & * & & & * & & $\star$ & & \\
\hline & $\begin{array}{l}\text { Diminuição da complexidade das redes } \\
\text { alimentares. }\end{array}$ & & * & * & & & * & & & * & & * & & * & & \\
\hline & $\begin{array}{l}\text { Aumento da mortande de peixes por } \\
\text { asfixia e intoxicação. }\end{array}$ & & * & * & & & * & & * & & & * & & * & & \\
\hline & $\begin{array}{l}\text { Perda da diversidade de espécies de } \\
\text { fitoplâncton, bentos e peixes. }\end{array}$ & & * & * & & & * & & * & & & * & & & * & \\
\hline
\end{tabular}


Planilha No 07 - Impacto Ambiental das Ações Propostas - Classificação do Impacto Ambiental

\begin{tabular}{|c|c|c|c|c|c|c|c|c|c|c|c|c|c|c|c|c|}
\hline \multirow[t]{2}{*}{ Ação Proposta } & \multirow[t]{2}{*}{ Impacto Ambiental } & \multicolumn{15}{|c|}{ Classificação do Impacto Ambiental } \\
\hline & & $\mathbf{P}$ & $\mathbf{N}$ & $\mathbf{D}$ & $\mathbf{I}$ & B & $\mathbf{M}$ & G & $\mathbf{C P}$ & MP & $\mathbf{L P}$ & RE & IR & $\mathbf{L}$ & $\mathbf{R}$ & NA \\
\hline & Alteração da qualidade física d'água. & & $*$ & $\star$ & & & $\star$ & & & * & & * & & & $*$ & \\
\hline & $\begin{array}{l}\text { Incorporação de substâncias tóxicas do } \\
\text { sedimento para a coluna d'água, se existentes, } \\
\text { (alteração da qualidade química da água) }\end{array}$ & & * & * & & & * & & & * & & $\star$ & & * & & \\
\hline & $\begin{array}{l}\text { Decréscimo na densidade de organismos } \\
\text { aquáticos. }\end{array}$ & & $\star$ & * & & & * & & & $\star$ & & * & & & * & \\
\hline Y Dragas de Trabalho & Diminuição da produtividade de algas. & & * & * & & $\star$ & & & * & & & * & & $\star$ & & \\
\hline $\begin{array}{l}\text { Descontínuo ( pá-mecânica, } \\
\text { caçamba, escavadeira). }\end{array}$ & $\begin{array}{l}\text { Contaminação das redes alimentares, no caso } \\
\text { de existirem produtos tóxicos. }\end{array}$ & & * & * & & * & & & & $\star$ & & * & & & * & \\
\hline A escavação com colher e/ou & Destruição de hábitats da fauna bentônica. & & * & $\star$ & & * & & & * & & & $\star$ & & $\star$ & & \\
\hline caçamba clamshell, provoca: & $\begin{array}{l}\text { Diminuição da complexidade das redes } \\
\text { alimentares. }\end{array}$ & & * & * & & * & & & & * & & * & & $\star$ & & \\
\hline & $\begin{array}{l}\text { Aumento da mortande de peixes por } \\
\text { asfixia e intoxicação. }\end{array}$ & & * & * & & * & & & * & & & * & & * & & \\
\hline & $\begin{array}{l}\text { Perda da diversidade de espécies de } \\
\text { fitoplâncton, bentos e peixes. }\end{array}$ & & $\star$ & * & & * & & & * & & & * & & & $\star$ & \\
\hline
\end{tabular}


Planilha No 07 - Impacto Ambiental das Ações Propostas - Classificação do Impacto Ambiental

\begin{tabular}{|c|c|c|c|c|c|c|c|c|c|c|c|c|c|c|c|c|}
\hline \multirow[t]{2}{*}{ Ação Proposta } & \multirow[t]{2}{*}{ Impacto Ambiental } & \multicolumn{15}{|c|}{ Classificação do Impacto Ambiental } \\
\hline & & $\mathbf{P}$ & $\mathbf{N}$ & D & $\mathbf{I}$ & B & $\mathbf{M}$ & $\mathbf{G}$ & $\mathbf{C P}$ & MP & $\mathbf{L P}$ & RE & IR & $\mathbf{L}$ & $\mathbf{R}$ & $\mathbf{N A}$ \\
\hline & Alteração da qualidade física d'água. & & $\star$ & * & & $\star$ & & & $\star$ & & & * & & & * & \\
\hline & $\begin{array}{l}\text { Incorporação de substâncias tóxicas do } \\
\text { sedimento para a coluna d'água, se existentes, } \\
\text { (alteração da qualidade química da água) }\end{array}$ & & * & * & & * & & & * & & & * & & * & & \\
\hline & $\begin{array}{l}\text { Decréscimo na densidade de organismos } \\
\text { aquáticos. }\end{array}$ & & $\star$ & * & & $\star$ & & & * & & & * & & & * & \\
\hline \multirow{2}{*}{$\begin{array}{l}\text { Dragas de Sucção } \\
\text { A sucção de uma mistura de água } \\
(80 \% \text { a } 90 \%) \text { e material sólido }\end{array}$} & $\leftrightarrow$ Diminuição da produtividade de algas. & & $\star$ & * & & & $\star$ & & * & & & $\star$ & & $\star$ & & \\
\hline & $\begin{array}{l}\text { Contaminação das redes alimentares, no caso } \\
\text { de existirem produtos tóxicos. }\end{array}$ & & * & $\star$ & & & & * & & * & & * & & & * & \\
\hline \multirow[t]{4}{*}{$(20 \%$ a $10 \%)$ arrancado do leito } & Destruição de hábitats da fauna bentônica. & & $\star$ & * & & & & $\star$ & & $\star$ & & * & & $\star$ & & \\
\hline & $\begin{array}{l}\text { Diminuição da complexidade das redes } \\
\text { alimentares. }\end{array}$ & & * & * & & & & * & & * & & * & & * & & \\
\hline & $\begin{array}{l}\text { Aumento da mortande de peixes por } \\
\text { asfixia e intoxicação. }\end{array}$ & & * & $\star$ & & & & * & & * & & * & & * & & \\
\hline & $\begin{array}{l}\text { Perda da diversidade de espécies de } \\
\text { fitoplâncton, bentos e peixes. }\end{array}$ & & * & * & & & & * & & * & & * & & & * & \\
\hline
\end{tabular}


Planilha Noo 07 - Impacto Ambiental das Ações Propostas - Classificação do Impacto Ambiental

\begin{tabular}{|c|c|c|c|c|c|c|c|c|c|c|c|c|c|c|c|c|}
\hline \multirow[t]{2}{*}{ Ação Proposta } & \multirow[t]{2}{*}{ Impacto Ambiental } & \multicolumn{15}{|c|}{ Classificação do Impacto Ambiental } \\
\hline & & $\mathbf{P}$ & $\mathbf{N}$ & D & $\mathbf{I}$ & B & $\mathbf{M}$ & $\mathbf{G}$ & $\mathbf{C P}$ & MP & $\mathbf{L P}$ & RE & IR & $\mathbf{L}$ & $\mathbf{R}$ & $\mathbf{N A}$ \\
\hline & Alteração da qualidade física d'água. & & $\star$ & $\star$ & & $\star$ & & & * & & & $\star$ & & & * & \\
\hline & $\begin{array}{l}\text { Incorporação de substâncias tóxicas do } \\
\text { sedimento para a coluna d'água, se existentes } \\
\text { (alteração da qualidade química da água). }\end{array}$ & & * & * & & & * & & * & & & * & & * & & \\
\hline & $\begin{array}{l}\text { Decréscimo na densidade de organismos } \\
\text { aquáticos. }\end{array}$ & & * & * & & * & & & * & & & $\star$ & & & * & \\
\hline \multicolumn{17}{|l|}{$\begin{array}{l}\text { - Disposição final do material } \\
\text { (Alternativas) }\end{array}$} \\
\hline \multirow{4}{*}{$\begin{array}{l}\text { Material dragado, volta a ser } \\
\text { lançado no rio. Esta alternativa, } \\
\text { compreende, somente, os materiais } \\
\text { finos que podem ser transportados } \\
\text { em suspensão para jusante. }\end{array}$} & Aumento do material em suspensão. & & $\star$ & * & & $\star$ & & & * & & & $\star$ & & * & & \\
\hline & $\begin{array}{l}\text { Alteração do regime de escoamento, a } \\
\text { jusante do lançamento, o que favorece o } \\
\text { transporte. }\end{array}$ & & * & * & & $\star$ & & & $\star$ & & & $\star$ & & & * & \\
\hline & $\begin{array}{l}\text { Alteração na velocidade do fluxo das águas } \\
\text { a jusante do lançamento do material, o que } \\
\text { favorece o transporte. }\end{array}$ & & * & * & & $\star$ & & & * & & & * & & & * & \\
\hline & $\begin{array}{l}\text { Contaminação das redes alimentares, no } \\
\text { caso de existirem produtos tóxicos. }\end{array}$ & & $\star$ & * & & & & * & & & $\star$ & $\star$ & & & * & \\
\hline
\end{tabular}


Planilha № 07 - Impacto Ambiental das Ações Propostas - Classificação do Impacto Ambiental

\begin{tabular}{|c|c|c|c|c|c|c|c|c|c|c|c|c|c|c|c|c|}
\hline \multirow[t]{2}{*}{ Ação Proposta } & \multirow[t]{2}{*}{ Impacto Ambiental } & \multicolumn{15}{|c|}{ Classificação do Impacto Ambiental } \\
\hline & & $\mathbf{P}$ & $\mathbf{N}$ & $\mathbf{D}$ & $\mathbf{I}$ & B & $\mathbf{M}$ & $\mathbf{G}$ & $\mathbf{C P}$ & MP & $\mathbf{L P}$ & $\mathbf{R E}$ & $\mathbf{I R}$ & $\mathbf{L}$ & $\mathbf{R}$ & NA \\
\hline & $\begin{array}{l}\text { Perda de ecossistemas, como baias, } \\
\text { vazantes e corixos, quando o material } \\
\text { transportado se deposita nestes ambientes. }\end{array}$ & & $\star$ & * & & & & $\star$ & & & * & & * & & $\star$ & \\
\hline & $\begin{array}{l}\text { Incorporação de substâncias tóxicas do } \\
\text { sedimento para a coluna d'água, se existentes, } \\
\text { (alteração da qualidade química da água) }\end{array}$ & & * & * & & & & * & $\star$ & & & * & & & * & \\
\hline & Alteração da qualidade física d'água. & & $\star$ & * & & & * & & $\star$ & & & $\star$ & & & $\star$ & \\
\hline & Wiminuição da produtividade de algas. & & $\star$ & $\star$ & & & $\star$ & & $\star$ & & & $\star$ & & & $\star$ & \\
\hline & Destruição de hábitats da fauna bentônica. & & $\star$ & $\star$ & & & $\star$ & & $\star$ & & & $\star$ & & & $\star$ & \\
\hline & $\begin{array}{l}\leftrightarrow \text { Diminuição da complexidade das redes } \\
\text { alimentares. }\end{array}$ & & $\star$ & $\star$ & & & $\star$ & & $\star$ & & & * & & & $\star$ & \\
\hline & $\begin{array}{l}\text { Aumento da mortande de peixes por } \\
\text { asfixia e intoxicação. }\end{array}$ & & $\star$ & $\star$ & & & & $\star$ & $\star$ & & & $\star$ & & & * & \\
\hline & $\begin{array}{l}\text { Perda da diversidade de espécies de } \\
\text { fitoplâncton, bentos e peixes. }\end{array}$ & & $\star$ & $\star$ & & & & $\star$ & $\star$ & & & $\star$ & & & * & \\
\hline & $\begin{array}{l}\text { Decréscimo na densidade de organismos } \\
\text { aquáticos. }\end{array}$ & & * & * & & * & & & $\star$ & & & $\star$ & & & $\star$ & \\
\hline
\end{tabular}


Planilha № 07 - Impacto Ambiental das Ações Propostas - Classificação do Impacto Ambiental

\begin{tabular}{|c|c|c|c|c|c|c|c|c|c|c|c|c|c|c|c|c|}
\hline \multirow[t]{2}{*}{ Ação Proposta } & \multirow[t]{2}{*}{ Impacto Ambiental } & \multicolumn{15}{|c|}{ Classificação do Impacto Ambiental } \\
\hline & & $\mathbf{P}$ & $\mathbf{N}$ & D & I & B & $\mathbf{M}$ & $\mathbf{G}$ & $\mathbf{C P}$ & MP & $\mathbf{L P}$ & $\mathbf{R E}$ & IR & $\mathbf{L}$ & $\mathbf{R}$ & NA \\
\hline \multirow{7}{*}{$\begin{array}{l}\text { Material dragado depositado } \\
\text { linearmente ao longo: do canal } \\
\text { principal; trecho com margem } \\
\text { descontínua; alargamentos; zonas }\end{array}$} & Poderá resultar numa margem emersa. & & $\star$ & * & & & & $\star$ & & & $\star$ & & $\star$ & $\star$ & & \\
\hline & $\begin{array}{l}\text { A margem emersa resultante poderá ser } \\
\text { ocupada por assentamentos humanos, sem } \\
\text { nenhum controle ou planejamento prévio. }\end{array}$ & & $\star$ & $\star$ & & & & * & & & * & * & & * & & \\
\hline & $\begin{array}{l}\text { marte do material volta ao fluxo do rio, a } \\
\text { menos que seja limitado por estruturas (diques, } \\
\text { aterros). }\end{array}$ & & $\star$ & $\star$ & & * & & & * & & & * & & * & & \\
\hline & $\begin{array}{l}\text { Ampliação dos efeitos da concentração, } \\
\text { diluição de nutrientes }\end{array}$ & & * & $\star$ & & * & & & & * & & * & & & * & \\
\hline & $\begin{array}{l}\text { Aumento da exportação da biomassa e } \\
\text { nutrientes. }\end{array}$ & & $\star$ & $\star$ & & $\star$ & & & & $\star$ & & $\star$ & & & $\star$ & \\
\hline & $\begin{array}{l}\text { Aumento do material em suspensão e } \\
\text { resíduos sólidos na coluna d'água. }\end{array}$ & & $\star$ & * & & & * & & & $\star$ & & * & & & $\star$ & \\
\hline & Decréscimo na produtividade fitoplânctonica. & & * & $\star$ & & & $\star$ & & & * & & * & & & $\star$ & \\
\hline $\begin{array}{l}\text { Material dragado depositado } \\
\text { na margem em lagoas, braços } \\
\text { mortos, depressões. }\end{array}$ & $\begin{array}{l}\text { Alteração do equilíbrio local: drenagem, flora } \\
\text { e fauna local. }\end{array}$ & & $\star$ & $\star$ & & & & $\star$ & & & $\star$ & & $\star$ & $\star$ & & \\
\hline
\end{tabular}


Planilha No 07 - Impacto Ambiental das Ações Propostas - Classificação do Impacto Ambiental

\begin{tabular}{|c|c|c|c|c|c|c|c|c|c|c|c|c|c|c|c|c|c|}
\hline \multirow[t]{2}{*}{ Ação Proposta } & \multirow[t]{2}{*}{ Impacto Ambiental } & \multicolumn{15}{|c|}{ Classificação do Impacto Ambiental } & \\
\hline & & $\mathbf{P}$ & $\mathbf{N}$ & D & $\mathbf{I}$ & B & $\mathbf{M}$ & G & CP & MP & $\mathbf{L P}$ & RE & IR & $\mathbf{L}$ & & & $\mathbf{N A}$ \\
\hline & $\begin{array}{l}\text { Parte dos sedimentos podem voltar com a } \\
\text { água da dragagem ou chuva. }\end{array}$ & & $\star$ & $\star$ & & & $\star$ & & & * & & & $\star$ & x & & & \\
\hline \multirow{2}{*}{$\begin{array}{l}\text { - Desobstrução e limpeza com } \\
\text { dragas ( adequadas ), com o } \\
\text { objetivo de promover a Remoção } \\
\text { de Estruturas (troncos de } \\
\text { árvores), que retém entulhos } \\
\text { orgânicos. }\end{array}$} & $\begin{array}{l}\text { Alteração no hábitat dos organismos } \\
\text { aquáticos. }\end{array}$ & & $\star$ & * & & & & $\star$ & & & * & $\star$ & & * & & & \\
\hline & $\begin{array}{l}\text { A matéria orgânica que é processada, pelos } \\
\text { organismos aquáticos, sofre alteração no seu } \\
\text { processo de retenção. }\end{array}$ & & * & * & & & * & & & * & & * & & * & & & \\
\hline \multirow{4}{*}{$\begin{array}{l}\text { N Transporte do material dragad } \\
\text { para bota-fora. } \\
\text { - Transporte Rodoviário com } \\
\text { veículo pesado caminhão (fonte } \\
\text { móvel), utilizando como } \\
\text { combustível óleo diesel. }\end{array}$} & $\begin{array}{l}\text { Lançamento de fumaça preta na atmosfera, } \\
\text { resultando em danos a fauna e a flora. }\end{array}$ & & * & * & & & * & & & $\star$ & & * & & & & & \\
\hline & $\begin{array}{l}\text { Aumento de material particulado (poeira) na } \\
\text { atmosfera, resultando em danos a fauna e a } \\
\text { flora }\end{array}$ & & * & * & & & * & & & * & & * & & & & & \\
\hline & $\begin{array}{l}\text { Mudanças meteorológicas (instabilidade } \\
\text { atmosférica, inversão térmica). }\end{array}$ & & * & * & & & * & & & * & & * & & & & & \\
\hline & $\begin{array}{l}\text { Alterações na economia (controle das } \\
\text { emissões no fonte) }\end{array}$ & & $\star$ & $\star$ & & & $\star$ & & & $\star$ & & * & & * & & & \\
\hline
\end{tabular}


Planilha № 07 - Impacto Ambiental das Ações Propostas - Classificação do Impacto Ambiental

\begin{tabular}{|c|c|c|c|c|c|c|c|c|c|c|}
\hline \multirow[t]{2}{*}{ Ação Proposta } & \multirow[t]{2}{*}{ Impacto Ambiental } & \multicolumn{9}{|c|}{ Classificação do Impacto Ambiental } \\
\hline & & $\begin{array}{l:ll}\mathbf{P} & \mathbf{N} \\
\end{array}$ & D $:$ I & $\begin{array}{l:l:l}\mathbf{B} & \mathbf{M} & \mathbf{G} \\
\end{array}$ & $\mathbf{C P}$ & $\begin{array}{l:l}\mathbf{M P} & \mathbf{L P} \\
\end{array}$ & $\mathbf{R E}$ & IR & $\begin{array}{l:l}\mathbf{L} & \mathbf{R} \\
\end{array}$ & $\begin{array}{ll}\mathbf{N A} \\
\end{array}$ \\
\hline & Maior consumo de combustível. & * & * & $\star \vdots$ & & $\star \vdots$ & * & & $\star \vdots$ & $\vdots$ \\
\hline & Interferência na malha viária. & * & * & $i \star$ & $\star$ & & $\star$ & & & \\
\hline & Alteração no tempo de manutenção da via. & & * & * & * & & & * & & \\
\hline \multirow{6}{*}{$\begin{array}{l}\text { Transporte Fluvial (fonte } \\
\text { móvel), usando o óleo diesel } \\
\text { como combustível. }\end{array}$} & $\begin{array}{l}\text { Lançamento de fumaça preta na atmosfera } \\
\text { resultando em danos a fauna e flora. }\end{array}$ & * & $\star \vdots$ & * & & i & * & & & \\
\hline & $\begin{array}{l}\text { Aumento de material particulado (poeira) na } \\
\text { atmosfera, resultando em danos a fauna e a } \\
\text { flora. }\end{array}$ & * & $\star$ & * & & * & $\star$ & & 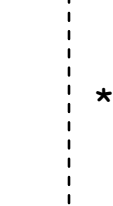 & \\
\hline & $\begin{array}{l}\text { Mudanças meteorológicas (instabilidade } \\
\text { atmosférica, inversão térmica). }\end{array}$ & * & $\begin{array}{r:} \\
\vdots \\
\vdots \\
\vdots\end{array}$ & $\star$ & & * & $\star$ & & & \\
\hline & $\begin{array}{l}\text { Alterações na economia (controle da } \\
\text { das emissões no fonte). }\end{array}$ & : & * & & & $\begin{array}{c}1 \\
1 \\
1 \\
1 \\
1 \\
1\end{array}$ & & & & \\
\hline & $\begin{array}{l}\text { Aumento da ação das ondas nas margens, } \\
\text { pela passagem devido a passagem de } \\
\text { embarcações. }\end{array}$ & $\star$ & 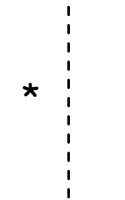 & * & & * & $\star$ & & & \\
\hline & Maior consumo de combustível. & $\begin{array}{l}i^{*} \\
\vdots\end{array}$ & * & : * & & i* & * & & * & \\
\hline
\end{tabular}


AÇÃO PROPOSTA - Obra Hidráulica Fluvial

Tipo de Obra Hidráulica Fluvial - Regularização do Leito - As obras de regularização em um curso d'água, são definidas como sendo àquelas que visam a utilizar a energia das águas para: fixar o leito, direcionando o escoamento ou concentrando o escoamento para melhorar as condições de navegabilidade; operação de tomadas de água, etc., modificando para tanto: a largura, as curvaturas, a profundidade e a direção dos filetes de água.

Normalmente são utilizadas para fixar o leito do curso d'água durante os meses de estiagem

\begin{tabular}{|c|c|c|c|c|c|c|c|c|c|c|c|c|c|c|c|c|}
\hline \multirow[t]{2}{*}{ Ação Proposta } & \multirow[t]{2}{*}{ Impacto Ambiental } & \multicolumn{15}{|c|}{ Classificação do Impacto Ambiental } \\
\hline & & $\mathbf{P}$ & $\mathbf{N}$ & D & $\mathbf{I}$ & B & $\mathbf{M}$ & G & $\mathbf{C P}$ & MP & LP & RE & IR & $\mathbf{L}$ & $\mathbf{R}$ & NA \\
\hline \multicolumn{17}{|l|}{$\begin{array}{l}\text { Obra Hidráulica } \\
\text { - Regularização do Leito }\end{array}$} \\
\hline \multirow{6}{*}{$\begin{array}{l}\text { Leito Móvel ( constituído por } \\
\text { material erodivel ). } \\
\text { Com a utilização de espigões e } \\
\text { diques, que operam para N.A } \\
\text { baixos. Na cheia ficam } \\
\text { submersos. }\end{array}$} & $\begin{array}{l}\text { Alteram o leito de estiagem com modificação } \\
\text { e estabilização das suas margens. }\end{array}$ & * & & * & & & & * & & & * & & * & * & & \\
\hline & $\leftrightarrow$ Provoca o assoreamento entre eles. & * & & * & & & 夫 & & & * & & * & & * & & \\
\hline & $\begin{array}{l}\text { vendência a formar uma berma com } \\
\text { vegetação entre os obstáculos. }\end{array}$ & * & & * & & & * & & & * & & * & & * & & \\
\hline & $\begin{array}{l}\text { Tendência a aumentar a velocidade do } \\
\text { escoamento no trecho, com erosão e possíveis } \\
\text { assoreamentos a jusante. }\end{array}$ & & * & * & & & & * & & & * & & * & & * & \\
\hline & $\leftrightarrow$ Pode elevar o nível de água de estiagem. & & $\star *$ & * & & & * & & * & & & * & & & * & \\
\hline & Alteração da fauna e flora das margens. & $\star$ & $\star$ & & $\star$ & & & & & $\star$ & & $\star$ & & & $\star$ & \\
\hline
\end{tabular}


Planilha $N^{o} 08$ - Impacto Ambiental das Ações Propostas - Classificação do Impacto Ambiental

\begin{tabular}{|c|c|c|c|c|c|c|c|c|c|c|c|c|c|c|c|c|}
\hline \multirow[t]{2}{*}{ Ação Proposta } & \multirow[t]{2}{*}{ Impacto Ambiental } & \multicolumn{15}{|c|}{ Classificação do Impacto Ambiental } \\
\hline & & $\mathbf{P}$ & $\mathbf{N}$ & D & $\mathbf{I}$ & B & $\mathbf{M}$ & $\mathbf{G}$ & $\mathbf{C P}$ & MP & $\mathbf{L P}$ & $\mathbf{R E}$ & IR & $\mathbf{L}$ & $\mathbf{R}$ & $\mathbf{N A}$ \\
\hline & $\begin{array}{l}\text { Mode provocar a elevação do N.A de cheia } \\
\text { (altera a Curva Cota } \times \text { Vazão ). }\end{array}$ & & * & $\star$ & & & * & & & $\star$ & & $\star$ & & & * & \\
\hline $\begin{array}{l}\text { Leito Fixo (material do leito } \\
\text { não erodivel naturalmente ) }\end{array}$ & $\begin{array}{l}\text { Alteram o leito de estiagem com modificação } \\
\text { e estabilização das suas margens. }\end{array}$ & * & & $\star$ & & & * & & & * & & & * & * & & \\
\hline \multirow{2}{*}{$\begin{array}{l}\text { Com a utilização de espigões e } \\
\text { diques, que operam para N.A }\end{array}$} & $\Leftrightarrow$ Provoca o assoreamento entre eles. & * & & * & & & $*$ & & & * & & * & & $\star$ & & \\
\hline & $\begin{array}{l}\text { Tendência a formar uma berma com } \\
\text { vegetação entre os obstáculos. }\end{array}$ & * & & * & & & * & & & * & & * & & * & & \\
\hline \multirow[t]{5}{*}{$\begin{array}{l}\text { submersos ( com eventuais } \\
\text { derrocamentos de rochas }\end{array}$} & $\begin{array}{l}\text { Tendência a aumentar a velocidade do } \\
\text { escoamento. }\end{array}$ & & * & * & & * & & & & * & & & * & * & & \\
\hline & r Pode elevar o nível de água de estiagem. & & * & * & & & * & & & * & & * & & & * & \\
\hline & $\begin{array}{l}\text { wode provocar a elevação do N.A de cheia } \\
\text { ( altera a Curva Cota } \times \text { Vazão ). }\end{array}$ & & * & * & & & * & & & * & & * & & & * & \\
\hline & $\begin{array}{l}\text { Estreitamento das seções para elevar o nível } \\
\text { d'água aumentando as profundidades, sem } \\
\text { aprofundamento sensível do leito, obtido a } \\
\text { partir da construção de diques e espigões. }\end{array}$ & * & & * & & & * & & & & $\star$ & & * & * & & \\
\hline & Alteração da fauna e flora das margens. & $\star$ & & * & & & $*$ & & & & * & * & & & $\star$ & \\
\hline
\end{tabular}




\subsection{VALORAÇÃO DE IMPACTOS AMBIENTAIS}

As planilhas ambientais, apresentadas, procuram identificar os impactos ambientais das obras hidroviárias, possibilitando ainda, uma avaliação qualitativa, entendida nesta tese, simplesmente, como avaliação e uma avaliação quantitativa, identificada nesta tese como valoração. A valoração dos impactos ambientais é uma atividade que merece ser trabalhada sobre três enfoques.

O primeiro deles, refere-se a implantação da(s) obra(s) hidroviária(s) para minimização dos impactos ambientais, não oriundos da hidrovia. Nessa situação, atribuem-se valores aos impactos ambientais antes e após a implantação dessa(s) obra(s). Sobre esse enfoque, a análise da obra hidroviária deverá ser executada sobre a resultante da diferença dos impactos e, dificilmente, o resultado da implantação de uma obra hidroviária para minimizar os impactos ambientais resultará em valor negativo, isto é, adverso, desde que sejam elaborados estudos preliminares para definição e implantação da(s) obra(s) hidroviária(s).

O segundo, refere-se a implantação da(s) obra(s) hidroviária(s) para minimizar os impactos ambientais oriundos da hidrovia. Também, nessa situação atribuem-se valores aos impactos ambientais antes e após a implantação dessa(s) obra(s).

O terceiro, refere-se aos impactos ambientais oriundos da execução da(s) obra(s) hidroviária(s) para a implantação da hidrovia.

Cabe ressaltar, que os impactos ambientais identificados quando da implantação de obras de hidroviárias, e que posteriormente receberão uma valoração, são impactos estudados, somente, na porção bio-geo-física do meio ambiente, isto é, água, ar, solo e viventes. Não é objetivo desta tese, o estudo dos impactos devido a implantação de obras fluviais, na porção sócio-econômico cultural do meio ambiente.

A tese, ora desenvolvida, trabalha sobre este terceiro enfoque e, tem por base o MÉTODO DAS MATRIZES DE INTERAÇÃO e, mais especificamente a MATRIZ DE LEOPOLD. 
Ao longo do desenvolvimento das planilhas ambientais, obtivemos conhecimentos que nos permitem propor alterações, quais sejam:

- O não entendimento, nessa tese de impactos ambientais quanto a magnitude ( grandeza em escala espacial e temporal do impacto ) e, quanto a importância ( intensidade do efeito, relacionando um dado fator ambiental, com outros impactos ou com determinadas características, como: direto/indireto; local/regional; imediato ou médio/longo prazo; temporário/permanente; reversível/irreversível), como atributos principais; sendo assim, os impactos ambientais classificados e listados nas planilhas ambientais, são todos de igual interesse, não existindo atributos principais. A valoração de cada impacto ambiental, à forma apresentada nas planilhas ambientais, facilita em muito a valoração dos impactos.

- Entender os impactos ambientais, quanto: ao tipo; ao modo; ao alcance; ao efeito, e a reversibilidade como um único atributo, "a importância", em algumas situações exige uma grande experiência do "avaliador", principalmente no que se refere a tecer a relação entre o fator ambiental e os impactos ambientais, não é a medida mais apropriada, devido a extensão e complexidade dos impactos, aqui estudados.

- Cabe, ainda, fazer uma observação no que se refere a relação entre "aquilo que contribui para um impacto" (fator ambiental) com os outros impactos, são relações que ocorrem em planos distintos, isto é, causa e efeito. A associação da causa de um impacto com o efeito do outro, não nos parece a análise mais apropriada, pois, a identificação de um impacto, já considerou a sua causa e a valoração, é elaborada sobre o efeito no meio ambiente, que é o impacto.

- Uma última observação, refere-se a magnitude do impacto, entendida como a grandeza em escala espacial e temporal, que não é objetiva no seu entendimento, permitindo muitas vezes a sobreposição destes impactos com os impactos quanto ao efeito e ao alcance. Consideramos a magnitude como um espaço (área) que pode ser alcançado de uma forma lenta ou rápida (tempo) por um efeito. 


\subsubsection{PROPOSTA DE VALORAÇÃO DOS IMPACTOS AMBIENTAIS}

A análise quantitativa (valoração), apresentada nas planilhas ambientais, é desenvolvida a partir de uma escala de 0 a 10, atribuídos a magnitude, obtidos de fontes, tais como: Braga et al. (2002); Mota (1995); Tommasi (1993), enquanto que a valoração para os demais tipos de impactos, é uma proposta dessa tese. Ver Tabela XX.

Tabela XX - Proposta de valores para os impactos ambientais classificados.

\begin{tabular}{|c|c|c|}
\hline Impactos Ambien & Classificados & Valores \\
\hline Quanto ao tipo & $\begin{array}{l}\text { Positivo (Benéfico) } \\
\text { Negativo (Adverso) }\end{array}$ & $\begin{array}{l}+ \\
-\end{array}$ \\
\hline Quanto ao Modo & $\begin{array}{l}\text { Direto } \\
\text { Indireto }\end{array}$ & $\begin{array}{l}1 \text { a } 10 \\
1 \text { a } 10\end{array}$ \\
\hline Quanto a Magnitude & $\begin{array}{l}\text { Baixa Intensidade } \\
\text { Média Intensidade } \\
\text { Grande Intensidade }\end{array}$ & $\begin{array}{l}1 \text { a } 4 \\
4 \text { a } 7 \\
7 \text { a } 10\end{array}$ \\
\hline Quanto ao Alcance & $\begin{array}{l}\text { Local } \\
\text { Regional } \\
\text { Nacional }\end{array}$ & $\begin{array}{l}1 \text { a } 4 \\
4 \text { a } 7 \\
7 \text { a } 10\end{array}$ \\
\hline Quanto ao Efeito & $\begin{array}{l}\text { Curto Prazo } \\
\text { Médio Prazo } \\
\text { Longo Prazo }\end{array}$ & $\begin{array}{l}1 \text { a } 4 \\
4 \text { a } 7 \\
7 \text { a } 10\end{array}$ \\
\hline Quanto a Reversibilidade & $\begin{array}{l}\text { Reversível } \\
\text { Irreversível }\end{array}$ & $\begin{array}{l}1 \text { a } 10 \\
1 \text { a } 10\end{array}$ \\
\hline
\end{tabular}


Os valores da escala, serão positivos, quando o impacto ambiental for benéfico e, negativo, quando o impacto ambiental for adverso.

\subsubsection{PROPOSTA DE EXPRESSÕES MATEMÁTICAS}

Calculamos a média geral de cada ação proposta, referente aos impactos ambientais antropogênicos da seguinte maneira:

- Uma ação proposta apresenta diversos impactos ambientais e, cada um desses impactos, recebeu uma avaliação qualitativa (classificação do impacto ambiental) e uma avaliação quantitativa (valoração).

- Tomamos, por exemplo, os diferentes impactos ambientais classificados de uma ação proposta e, procedemos a soma dos valores $\left(\mathrm{V}_{\mathrm{i} \text { IA }}\right)$ de cada um dos impactos ambientais classificados, afetados de sinal $(+)$ ou ( - ), obtendo-se, assim, para cada um deles uma somatória $n$

$$
\begin{aligned}
& \text { ( } \left.\sum \mathbf{V}_{\text {i IA }}\right) \text {. } \\
& \mathrm{i}=1
\end{aligned}
$$

- A determinação do valor de um impacto ambiental no meio ambiente ( $E_{\text {i IA }}$ ) é igual ao quociente da somatória dos valores de um impacto ambiental classificado pelo seu, respectivo, número de impactos ambientais classificados $\left(\mathrm{n}_{\mathrm{IA}}\right)$.

- A média geral de cada ação proposta ( I n IA ), referente aos impactos ambientais antropogênicos, é igual ao quociente da somatória dos valores de um impacto ambiental da ação proposta $n$

$$
\underset{i=1}{\left(\mathbf{E}_{\mathbf{i} \text { IA }}\right) \text { pelo número de impactos ambientais }}
$$

provocados pela ação proposta ( $\mathrm{N}_{\text {i IA }}$ ). 
Esta tese propõe as seguinte expressões matemáticas:

$$
\mathrm{E}_{\mathrm{i} \text { IA }}=\sum_{\mathrm{i}=1}^{\mathrm{n}}\left(\mathrm{V}_{\mathrm{i} \text { IA }}\right) / \mathrm{n}_{\text {IA }}
$$

Onde: $\mathrm{E}_{\mathrm{i} \text { IA }}=$ Valor de um impacto ambiental no meio ambiente;

$\mathrm{V}_{\text {i IA }}=$ Valor de um impacto ambiental da ação proposta;

$\mathrm{n}_{\text {IA }}=$ Número de impactos ambientais classificados.

$$
\mathrm{I}_{\mathrm{i} \text { IA }}=\sum_{\mathrm{i}=1}^{\mathrm{n}}\left(\mathrm{E}_{\mathrm{i} \text { IA }}\right) / \mathrm{N}_{\text {IA }}
$$

( EQUAÇÃO 02 )

Onde: $\mathrm{I}_{\text {i IA }}$ = Valor geral do impacto ambiental de uma ação proposta;

$\mathrm{E}_{\text {i IA }}=$ Valor de um impacto ambiental da ação proposta;

$\mathrm{N}_{\mathrm{i} \text { IA }}=$ Número de impactos ambientais provocados pela ação proposta.

A aplicação dos modelos matemáticos propostos, pode ser exemplificada nas planilhas de № 02 e № 06 , escolhidas aleatoriamente .

A interpretação do valor da ação proposta com referência aos impactos ambientais, não deve ser subjetivo, para tanto, propomos a seguinte interpretação:

- Caso a ação proposta com referência aos impactos ambientais, atenda as viabilidades: técnica, econômica, financeira, política, jurídica, social, positivamente, mas no que se refere a ambiental, é negativa, devemos entender que há a necessidade de uma ação proposta complementar. A soma das ações propostas, agora, deverá atender a todas as viabilidades listadas, apresentando valor posito.

- Caso a ação proposta com referência aos impactos ambientais, atenda as viabilidades: técnica, econômica, financeira, política, jurídica, social e ambiental, positivamente, devemos entender que não há necessidade de ação proposta complementar (medidas mitigadoras). 
- Caso uma determinada situação, tenha apresentado como solução: dois tipos diferentes de obras hidroviárias, atendendo igualmente a cada uma das viabilidades: técnica, econômica, financeira, política, jurídica e social, é possível, adotar o valor geral de uma ação proposta, como um instrumento dentro da viabilidade ambiental, responsável pela promoção do desempate daquelas soluções.

6.9. MODElO DE PlANilHAS AMBIENTAIS - VAlORAÇÃO DE IMPACTOS AMBIENTAIS 
Planilha № 02 - Continuação - Impacto Ambiental das Ações Propostas - Classificação do Impacto Ambiental

\begin{tabular}{|c|c|c|c|c|c|c|c|c|c|c|c|c|c|c|c|c|}
\hline \multirow[t]{2}{*}{ Ação Proposta } & \multirow[t]{2}{*}{ Impacto Ambiental } & \multicolumn{15}{|c|}{ Classificação do Impacto Ambiental } \\
\hline & & $\mathbf{P}$ & $\mathbf{N}$ & D & I & B & $\mathbf{M}$ & $\mathbf{G}$ & $\mathbf{C P}$ & MP & $\mathbf{L P}$ & $\mathbf{R E}$ & IR & $\mathbf{L}$ & $\mathbf{R}$ & NA \\
\hline \multirow{10}{*}{$\begin{array}{l}\text { Revestimento das Margens } \\
\text { Gabião ( tipo colchão ). }\end{array}$} & Definição de um habitat. & 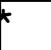 & & $\star$ & & & & * & & & $\star$ & & * & $\star$ & & \\
\hline & $\begin{array}{l}\rightarrow \text { Definição e fixação de uma nova vegetação } \\
\text { de margem. }\end{array}$ & * & & * & & & & * & & & * & & * & * & & \\
\hline & Estabilização das margens. & $\star$ & & $\star$ & & & & $\star$ & & & * & & * & * & & \\
\hline & $\begin{array}{l}\text { Alteração no número de espécies que } \\
\text { compõe a fauna das margens. }\end{array}$ & * & & $\star$ & & & & * & & & * & & * & & * & \\
\hline & $\begin{array}{l}\text { Possibilidade de desenvolvimento ou } \\
\text { crescimento de uma vegetação de margem. }\end{array}$ & * & & * & & & & $\star$ & & & * & & * & * & & \\
\hline & $\begin{array}{l}\text { Melhoria das características físicas d'água } \\
\text { (cor e turbidez). }\end{array}$ & $\star$ & & * & & & * & & & & * & & * & & * & \\
\hline & Recuperação da vegetação primitiva. & & * & t & & & & t & & & * & & * & $\star$ & & \\
\hline & $\begin{array}{l}\text { Proteção das margens contra a ação das } \\
\text { ondas. }\end{array}$ & * & & * & & & & * & & & * & & * & * & & \\
\hline & $\begin{array}{l}\text { Redução do aporte sólido na corrente, } \\
\text { líquida. }\end{array}$ & $\star$ & & $\star$ & & & & * & & & $\star$ & * & & * & & \\
\hline & $\rightarrow$ Redução dos efeitos da erosão. & $\star$ & & * & & & & * & & & * & & * & * & & \\
\hline
\end{tabular}


Planilha № 02 - Continuação - Impacto Ambiental das Ações Propostas - Classificação do Impacto Ambiental

\begin{tabular}{|c|c|c|c|c|c|c|c|c|c|c|c|c|c|c|c|c|}
\hline \multirow[t]{2}{*}{ Ação Proposta } & \multirow[t]{2}{*}{ Impacto Ambiental } & \multicolumn{15}{|c|}{ Classificação do Impacto Ambiental } \\
\hline & & $\mathbf{P}$ & $\mathbf{N}$ & D & $\mathbf{I}$ & B & M & $\mathbf{G}$ & $\mathbf{C P}$ & MP & $\mathbf{L P}$ & $\mathbf{R E}$ & IR & $\mathbf{L}$ & $\mathbf{R}$ & NA \\
\hline \multirow{10}{*}{$\begin{array}{l}\text { Revestimento das Margens } \\
\text { Gabião ( tipo colchão ). }\end{array}$} & Definição de um habitat. & ${ }^{*}$ & & $\star$ & & & 7 & & & 7 & & & 8 & 4 & & \\
\hline & $\begin{array}{l}\Leftrightarrow \text { Definição e fixação de uma nova vegetação } \\
\text { de margem. }\end{array}$ & * & & * & & & & 8 & & & 8 & & 8 & 4 & & \\
\hline & Estabilização das margens. & $\star$ & & $\star$ & & & & 10 & & & 9 & & 9 & 4 & & \\
\hline & $\begin{array}{l}\text { Alteração no número de espécies que } \\
\text { compõe a fauna das margens. }\end{array}$ & & * & * & & & & 10 & & 6 & & 3 & & & 6 & \\
\hline & $\begin{array}{l}\text { r } \rightarrow \text { Possibilidade de desenvolvimento ou } \\
\text { crescimento de uma vegetação de margem. }\end{array}$ & * & * & & & & 6 & & & 6 & & & 8 & 4 & & \\
\hline & $\begin{array}{l}\text { Melhoria das características físicas d'água } \\
\text { (cor e turbidez). }\end{array}$ & * & & * & & & & 8 & & & 9 & & 9 & & 6 & \\
\hline & Recuperação da vegetação primitiva. & & $\star$ & $\star$ & & & 6 & & & 6 & & 4 & & 4 & & \\
\hline & $\begin{array}{l}\text { Proteção das margens contra a ação das } \\
\text { ondas. }\end{array}$ & * & & * & & & & 9 & & & 9 & & 8 & 4 & & \\
\hline & $\begin{array}{l}\text { Redução do aporte sólido na corrente, } \\
\text { líquida. }\end{array}$ & $\star$ & & * & & & & 8 & & & 9 & & 9 & & 6 & \\
\hline & $\leftrightarrow$ Redução dos efeitos da erosão. & * & & * & & & & 10 & & & 9 & & 9 & 4 & & \\
\hline
\end{tabular}


Planilha No 02 - Revestimento das Margens - Gabião (tipo colchão).

\begin{tabular}{|c|c|c|c|c|c|c|c|c|c|c|c|c|c|c|c|c|c|c|c|c|}
\hline \multirow[t]{2}{*}{ Impacto Ambiental } & \multicolumn{15}{|c|}{ Valoração do Impacto Ambiental ( $\left.\mathrm{V}_{\mathrm{IA}}\right)$} & \multirow[b]{2}{*}{$\sum\left(\mathrm{V}_{\mathrm{IA}}\right)$} & \multirow[b]{2}{*}{$\mathrm{n}_{\mathrm{IA}}$} & \multirow{2}{*}{$\frac{\sum\left(\mathrm{V}_{\text {IA }}\right)}{n_{\text {IA }}}$} & \multirow[b]{2}{*}{$\mathrm{N}_{\text {IA }}$} & \\
\hline & $\mathbf{P}$ & $\mathbf{N}$ & D & $\mathbf{I}$ & B & M & $\mathbf{G}$ & $\mathbf{C P}$ & MP & $\mathbf{L P}$ & $\mathbf{R E}$ & IR & $\mathbf{L}$ & $\mathbf{R}$ & NA & & & & & \\
\hline Definição de um habitat. & * & & * & & & 7 & & & 7 & & & 8 & 4 & & & +26 & 4 & $+6,5$ & 1 & \\
\hline$\leftrightarrow$ Definição e fixação de uma nova & & & & & & & & & & & & & & & & & & & & \\
\hline vegetação de margem. & * & & * & & & & 8 & & & 8 & & 8 & 4 & & & +28 & 4 & $+7,0$ & 2 & \\
\hline Estabilização das margens. & * & & * & & & & 10 & & & 9 & & 9 & 4 & & & +32 & 4 & $+8,0$ & 3 & $2 \mathrm{E}_{\mathrm{IA}}$ \\
\hline Alteração no número de espécies que & & & & & & & & & & & & & & & & & & & & $\mathbf{N}_{\text {IA }}$ \\
\hline compõe a fauna das margens. & & * & * & & & & 10 & & 6 & & 3 & & & 6 & & -25 & 4 & $-6,2$ & 4 & $=$ \\
\hline$\rightarrow$ Possibilidade de desenvolvimento ou & & & & & & & & & & & & & & & & & & & & 47.8 \\
\hline crescimento de uma vegetação de margem. & * & & * & & & 6 & & & 6 & & & 8 & 4 & & & +24 & 4 & $+6,0$ & 5 & 10 \\
\hline Melhoria das características físicas & & & & & & & & & & & & & & & & & & & & $=$ \\
\hline d'água(cor e turbidez). & * & & * & & & & 8 & & & 9 & & 9 & & 6 & & +32 & 4 & $+8,0$ & 6 & $+4,78$ \\
\hline Recuperação da vegetação primitiva. & & * & $\star$ & & & 6 & & & 6 & & & & 4 & & & -20 & 4 & $-5,0$ & 7 & \\
\hline Proteção das margens contra a ação das & & & & & & & & & & & & & & & & & & & & \\
\hline ondas. & * & & * & & & & 9 & & & 9 & & 8 & 4 & & & +30 & 4 & $+7,5$ & 8 & \\
\hline Redução do aporte sólido na corrente, & & & & & & & & & & & & & & & & & & & & \\
\hline líquida. & * & & * & & & & 8 & & & 9 & & 9 & & 6 & & +32 & 4 & $+8,0$ & 9 & \\
\hline$\leftrightarrow$ Redução dos efeitos da erosão. & $\star$ & & $\star$ & & & & 10 & & & 9 & & 9 & 4 & & & +32 & 4 & $+8,0$ & 10 & \\
\hline$\sum \mathrm{E}_{\mathrm{IA}}$ & & & & & & & & & & & & & & & & & & $+47,8$ & & \\
\hline
\end{tabular}


Planilha № 06 - Continuação - Impacto Ambiental das Ações Propostas - Classificação do Impacto Ambiental

\begin{tabular}{|c|c|c|c|c|c|c|c|c|c|c|c|c|c|c|c|c|}
\hline \multirow[t]{2}{*}{ Ação Proposta } & \multirow[t]{2}{*}{ Impacto Ambiental } & \multicolumn{15}{|c|}{ Classificação do Impacto Ambiental } \\
\hline & & $\mathbf{P}$ & $\mathbf{N}$ & D & $\mathbf{I}$ & B & $\mathbf{M}$ & $\mathbf{G}$ & $\mathbf{C P}$ & MP & $\mathbf{L P}$ & $\mathbf{R E}$ & IR & $\mathbf{L}$ & $\mathbf{R}$ & NA \\
\hline & $\begin{array}{l}\text { Aumento da velocidade de fluxo e da ação } \\
\text { erosiva sobre leito (margens e fundo). }\end{array}$ & & $\star$ & * & & & & $\star$ & & & * & & $\star$ & $\star$ & & \\
\hline & $\begin{array}{l}\text { Permite a "definição" de um habitat com } \\
\text { a fixação de áreas inundáveis ou não, bem } \\
\text { definidos. }\end{array}$ & * & & * & & & & * & & & $\star$ & * & & & $\star$ & \\
\hline & $\begin{array}{l}\text { Alteração do curso d'água, no que se } \\
\text { refere ao volume d'água e conformação do } \\
\text { leito. }\end{array}$ & & * & * & & & & $\star$ & & & $\star$ & & $\star$ & * & & \\
\hline & $\begin{array}{l}\text { Modificação nas rotas de migração de } \\
\text { peixes. }\end{array}$ & & $\star$ & * & & & & * & & & $\star$ & & $\star$ & $\star$ & & \\
\hline & Alteração no habitat das margens. & & * & $\star$ & & & * & & & * & & $\star$ & & & * & \\
\hline & $\begin{array}{l}\text { Utilização da alça proveniente da retificação } \\
\text { do curso d'água, para tratamento de águas } \\
\text { residuárias, criação de peixes, recreação, etc. }\end{array}$ & * & & $\star$ & & & & * & & & $\star$ & $\star$ & & * & & \\
\hline & Alteração no habitat das alça. & * & & $\star$ & & & & $\star$ & & & $\star$ & $\star$ & & $\star$ & & \\
\hline \multirow[t]{2}{*}{$\begin{array}{l}\text { Melhoria do Traçado } \\
\text { ( para fins de navegação) }\end{array}$} & $\begin{array}{l}\text { Alteração da vegetação das margens dos } \\
\text { cursos d'água, nos trechos retificados. }\end{array}$ & & $\star$ & * & & & & $\star$ & & & $\star$ & * & & * & & \\
\hline & Aumento da ação de escoamento. & & $*$ & $\star$ & & & & $\star$ & & & $\star$ & $\star$ & & $\star$ & & \\
\hline
\end{tabular}


Planilha № 06 - Continuação - Impacto Ambiental das Ações Propostas - Classificação do Impacto Ambiental

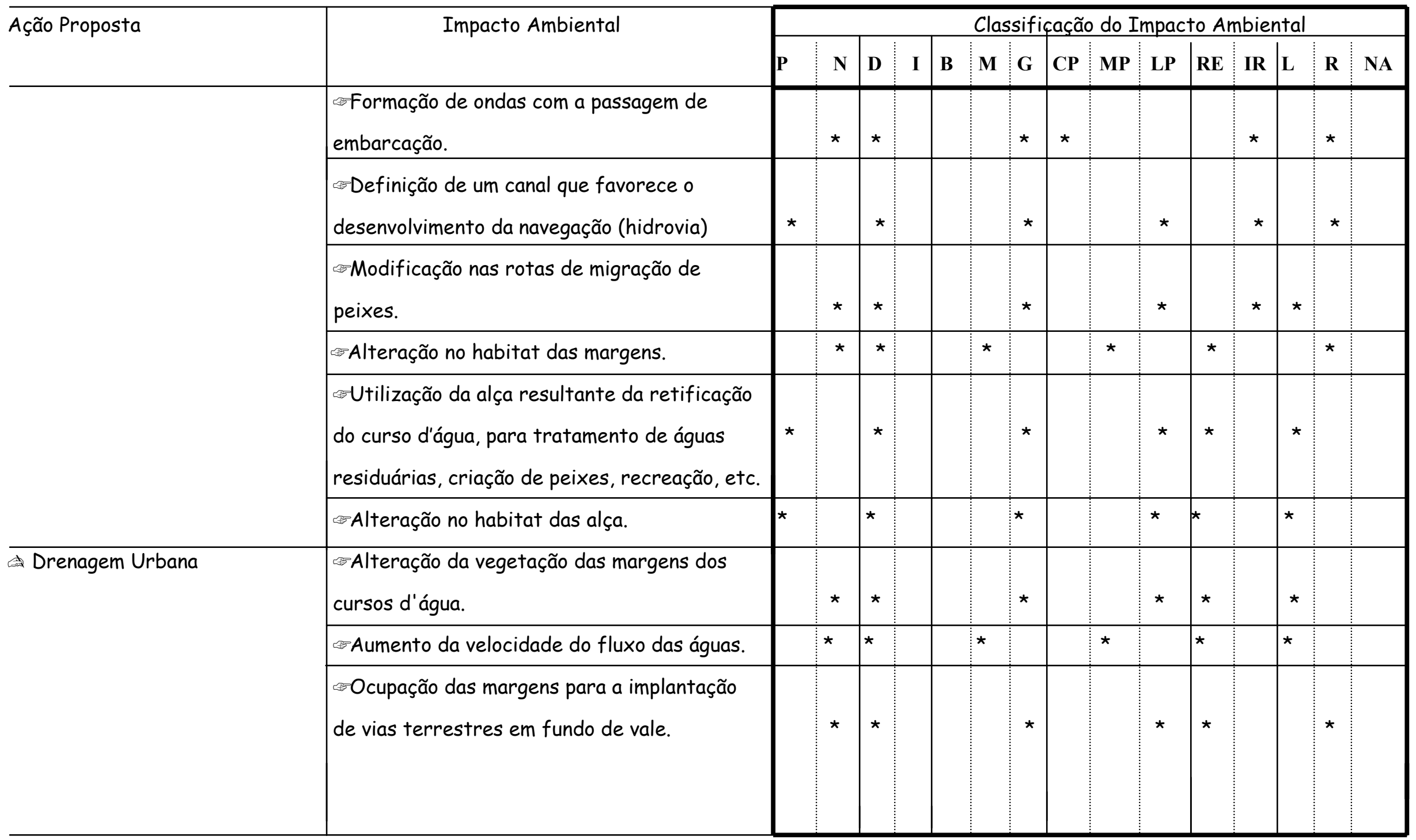


Planilha № 06 - Continuação - Impacto Ambiental das Ações Propostas - Classificação do Impacto Ambiental

\begin{tabular}{|c|c|c|c|c|c|c|c|c|c|c|c|c|c|c|c|c|}
\hline \multirow[t]{2}{*}{ Ação Proposta } & \multirow[t]{2}{*}{ Impacto Ambiental } & \multicolumn{15}{|c|}{ Classificação do Impacto Ambiental } \\
\hline & & $\mathbf{P}$ & $\mathbf{N}$ & D & $\mathbf{I}$ & B & $\mathbf{M}$ & $\mathbf{G}$ & $\mathbf{C P}$ & MP & $\mathbf{L P}$ & $\mathbf{R E}$ & IR & $\mathbf{L}$ & $\mathbf{R}$ & NA \\
\hline & $\begin{array}{l}\text { Aumento da velocidade de fluxo e da ação } \\
\text { erosiva sobre leito (margens e fundo). }\end{array}$ & & $\star$ & * & & & & $\star$ & & & * & & $\star$ & $\star$ & & \\
\hline & $\begin{array}{l}\text { Permite a "definição" de um habitat com } \\
\text { a fixação de áreas inundáveis ou não, bem } \\
\text { definidos. }\end{array}$ & * & & * & & & & * & & & $\star$ & * & & & $\star$ & \\
\hline & $\begin{array}{l}\text { Alteração do curso d'água, no que se } \\
\text { refere ao volume d'água e conformação do } \\
\text { leito. }\end{array}$ & & * & * & & & & $\star$ & & & $\star$ & & $\star$ & * & & \\
\hline & $\begin{array}{l}\text { Modificação nas rotas de migração de } \\
\text { peixes. }\end{array}$ & & $\star$ & * & & & & * & & & $\star$ & & $\star$ & $\star$ & & \\
\hline & Alteração no habitat das margens. & & * & $\star$ & & & * & & & * & & $\star$ & & & * & \\
\hline & $\begin{array}{l}\text { Utilização da alça proveniente da retificação } \\
\text { do curso d'água, para tratamento de águas } \\
\text { residuárias, criação de peixes, recreação, etc. }\end{array}$ & * & & $\star$ & & & & * & & & $\star$ & $\star$ & & * & & \\
\hline & Alteração no habitat das alça. & * & & $\star$ & & & & $\star$ & & & $\star$ & $\star$ & & $\star$ & & \\
\hline \multirow[t]{2}{*}{$\begin{array}{l}\text { Melhoria do Traçado } \\
\text { ( para fins de navegação) }\end{array}$} & $\begin{array}{l}\text { Alteração da vegetação das margens dos } \\
\text { cursos d'água, nos trechos retificados. }\end{array}$ & & $\star$ & * & & & & $\star$ & & & $\star$ & * & & * & & \\
\hline & Aumento da ação de escoamento. & & $*$ & $\star$ & & & & $\star$ & & & $\star$ & $\star$ & & $\star$ & & \\
\hline
\end{tabular}


Planilha № 06 - Continuação - Impacto Ambiental das Ações Propostas - Classificação do Impacto Ambiental

\begin{tabular}{|c|c|c|c|c|c|c|c|c|c|c|c|c|c|c|c|c|}
\hline \multirow[t]{2}{*}{ Ação Proposta } & \multirow[t]{2}{*}{ Impacto Ambiental } & \multicolumn{15}{|c|}{ Classificação do Impacto Ambiental } \\
\hline & & $\mathbf{P}$ & $\mathbf{N}$ & D & $\mathbf{I}$ & B & $\mathbf{M}$ & $\mathbf{G}$ & $\mathbf{C P}$ & MP & $\mathbf{L P}$ & RE & IR & $\mathbf{L}$ & $\mathbf{R}$ & NA \\
\hline & $\begin{array}{l}\text { Formação de ondas com a passagem de } \\
\text { embarcação. }\end{array}$ & & $\star$ & $\star$ & & & & $\star$ & $\star$ & & & & * & & * & \\
\hline & $\begin{array}{l}\text { Definição de um canal que favorece o } \\
\text { desenvolvimento da navegação (hidrovia) }\end{array}$ & * & & * & & & & * & & & $\star$ & & * & & * & \\
\hline & $\begin{array}{l}\text { Modificação nas rotas de migração de } \\
\text { peixes. }\end{array}$ & & * & * & & & & * & & & * & & $\star$ & * & & \\
\hline & Alteração no habitat das margens. & & * & * & & & * & & & * & & * & & & * & \\
\hline & $\begin{array}{l}\text { Utilização da alça resultante da retificação } \\
\text { do curso d'água, para tratamento de águas } \\
\text { residuárias, criação de peixes, recreação, etc. }\end{array}$ & * & & * & & & & * & & & * & $\star$ & & * & & \\
\hline & Alteração no habitat das alça. & $\star$ & & * & & & & * & & & $\star$ & $\star$ & & * & & \\
\hline \multirow[t]{3}{*}{ Drenagem Urbana } & $\begin{array}{l}\text { Alteração da vegetação das margens dos } \\
\text { cursos d'água. }\end{array}$ & & $\star$ & $\star$ & & & & * & & & * & * & & * & & \\
\hline & Aumento da velocidade do fluxo das águas. & & $\star$ & $\star$ & & & $\star$ & & & * & & $\star$ & & * & & \\
\hline & $\begin{array}{l}\text { Ocupação das margens para a implantação } \\
\text { de vias terrestres em fundo de vale. }\end{array}$ & & $\star$ & $\star$ & & & & * & & & * & * & & & * & \\
\hline
\end{tabular}




\begin{tabular}{|c|c|c|c|c|c|c|c|c|c|c|c|c|c|c|c|c|c|c|c|}
\hline \multirow[t]{2}{*}{ Impacto Ambiental } & \multicolumn{15}{|c|}{ Valoração do Impacto Ambiental ( $\left.\mathrm{V}_{\mathrm{IA}}\right)$} & \multirow[b]{2}{*}{$\sum\left(\mathrm{V}_{\text {IA }}\right)$} & \multirow[b]{2}{*}{$\mathrm{n}_{\text {IA }}$} & $\sum\left(\mathrm{V}_{\mathrm{IA}}\right)$ & \multirow[b]{2}{*}{$\mathrm{N}_{\text {IA }}$} \\
\hline & $\mathbf{P}$ & $\mathbf{N}$ & D & $\mathbf{I}$ & B & M & $\mathbf{G}$ & $\mathbf{C P}$ & MP & $\mathbf{L P}$ & $\mathbf{R E}$ & IR & $\mathbf{L}$ & $\mathbf{R}$ & NA & & & $\mathrm{n}_{\text {IA }}$ & \\
\hline \multicolumn{20}{|c|}{ Aumento da velocidade de fluxo e da } \\
\hline \multicolumn{20}{|c|}{ ação erosiva sobre o leito (margem e fundo). } \\
\hline \multicolumn{20}{|c|}{ Permite a "definição" de um habitat com } \\
\hline \multicolumn{20}{|c|}{ a fixação de áreas inundáveis ou não, bem } \\
\hline \multicolumn{20}{|l|}{ definidos. } \\
\hline \multicolumn{20}{|c|}{ Alteração do curso d'água, no que se } \\
\hline \multicolumn{20}{|c|}{ refere ao volume d'água e conformação do } \\
\hline \multicolumn{20}{|l|}{ leito. } \\
\hline \multicolumn{20}{|c|}{ Modificação na rota de migração dos } \\
\hline \multicolumn{20}{|l|}{ peixes. } \\
\hline \multicolumn{20}{|l|}{ Alteração no habitat das margens } \\
\hline \multicolumn{20}{|l|}{ Utilização da alça resultante da } \\
\hline \multicolumn{20}{|c|}{ retificação do curso d'água, para tratamento } \\
\hline \multicolumn{20}{|c|}{ de águas residuárias, criação de peixes } \\
\hline \multicolumn{20}{|l|}{ recreação. } \\
\hline Alteração no habitat das alças & & & & & & & & & & & & & & & & & & & \\
\hline
\end{tabular}




\begin{tabular}{|c|c|c|c|c|c|c|c|c|c|c|c|c|c|c|c|c|c|c|c|c|}
\hline \multirow[t]{2}{*}{ Impacto Ambiental } & \multicolumn{15}{|c|}{ Valoração do Impacto Ambiental ( $\mathrm{V}_{\mathrm{IA}}$ ) } & \multirow[b]{2}{*}{$\sum\left(\mathrm{V}_{\mathrm{IA}}\right)$} & \multirow[b]{2}{*}{$\mathrm{n}_{\mathrm{IA}}$} & \multirow{2}{*}{$\frac{\sum\left(\mathrm{V}_{\mathrm{IA}}\right)}{\mathrm{n}_{\mathrm{IA}}}$} & \multirow[b]{2}{*}{$\mathrm{N}_{\mathrm{IA}}$} & \\
\hline & $\mathbf{P}$ & $\mathbf{N}$ & D & $\mathbf{I}$ & B & $\mathbf{M}$ & G & $\mathbf{C P}$ & MP & $\mathbf{L P}$ & $\mathbf{R E}$ & IR & $\mathbf{L}$ & $\mathbf{R}$ & NA & & & & & \\
\hline $\begin{array}{l}\text { Alteração da vegetação das margens dos } \\
\text { cursos d'água, nos trechos retificados. }\end{array}$ & & * & * & & & 6 & & & 6 & & 4 & & 4 & & & -20 & 4 & $-5,0$ & 1 & \\
\hline Aumento da ação de escoamento. & & $\star$ & * & & 4 & & & & & 9 & & 9 & 4 & & & -26 & 4 & $-6,5$ & 2 & \\
\hline $\begin{array}{l}\text { Formação de ondas com a passagem de } \\
\text { embarcação. }\end{array}$ & & $\star$ & * & & 4 & & & 4 & & & & 8 & 4 & & & -20 & 4 & $-5,0$ & 3 & $\frac{\sum \mathrm{E}_{\text {IA }}}{\mathbf{N}_{\text {IA }}}$ \\
\hline $\begin{array}{l}\Leftrightarrow \text { Definição de um canal que favorece o } \\
\text { desenvolvimento da navegação ( hidrovia) }\end{array}$ & * & & * & & & & 9 & & & 9 & & 8 & & 6 & & +32 & 4 & $+8,0$ & 4 & $\begin{array}{l}= \\
-9,00\end{array}$ \\
\hline $\begin{array}{l}\text { Modificação nas rotas de migração de } \\
\text { peixes. }\end{array}$ & & * & $\star$ & & 4 & & & 4 & & & & 8 & 4 & & & -20 & 4 & $-5,0$ & 5 & $\begin{array}{r}8 \\
\cong\end{array}$ \\
\hline Alteração no habitat das margens & & $\star$ & * & & & 6 & & & 6 & & 4 & & & 6 & & -22 & 4 & $-5,5$ & 6 & $-1,13$ \\
\hline $\begin{array}{l}\text { Utilização da alça resultante da } \\
\text { retificação do curso d'água, para tratamento } \\
\text { de águas residuárias, criação de peixes } \\
\text { recreação. }\end{array}$ & * & & * & & 4 & & & & & 9 & 5 & & 4 & & & +22 & 4 & $+5,0$ & 7 & \\
\hline Alteração no habitat das alças & * & & * & & 4 & & & & & 9 & 5 & & 4 & & & +22 & 4 & $+5,0$ & 8 & \\
\hline$\sum \mathrm{E}_{\mathrm{IA}}$ & & & & & & & & & & & & & & & & & & $-9,0$ & & \\
\hline
\end{tabular}


Planilha № 06 - Melhoria do Traçado ( Para Fins de Navegação)

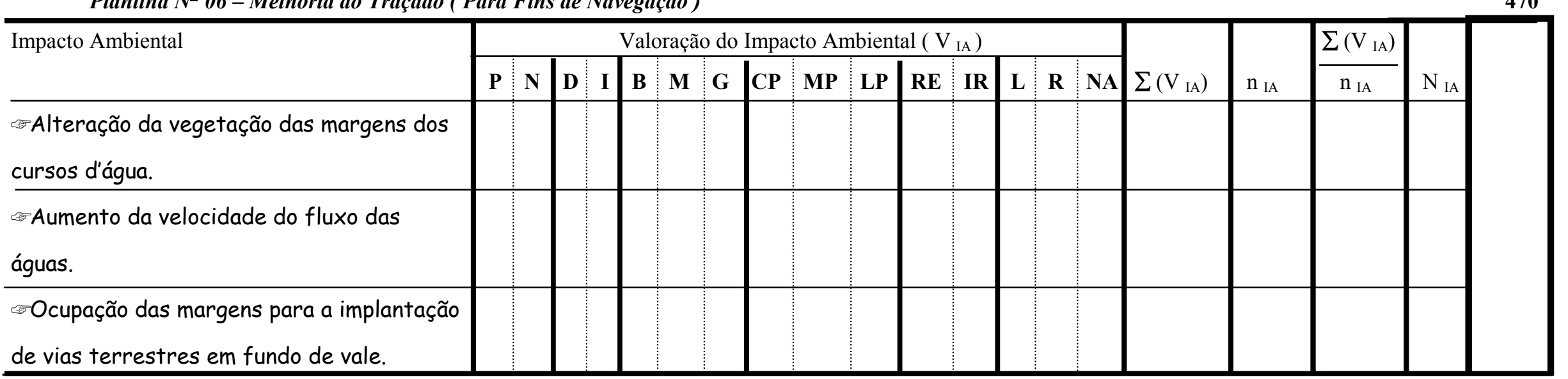




\section{CAPÍtUL07.}

\section{ÍNTEGRA DA CARTA DO CHEFE INDÍGENA SEATLE}

"O ar é precioso para o homem vermelho, pois todas as coisas compartilham o mesmo sopro: o animal, a árvore, o homem, todos compartilham o mesmo sopro. Parece que o homem branco não sente o ar que respira. Como um homem agonizante há vários dias, é insensível ao mau cheiro (...). Portanto, vamos meditar sobre sua oferta de comprar nossa terra. Se decidirmos aceitar, imporei uma condição: o homem deve tratar os animais desta terra como seus irmãos (...) O que é o homem sem os animais? Se os animais se fossem, o homem morreria de uma grande solidão de espírito. Pois o que ocorre com os animais, breve acontece com o homem. Há uma ligação em tudo. Vocês devem ensinar às suas crianças que o solo a seus pés é a cinza de nossos avós. Para que respeitem a Terra, digam a seus filhos que ela foi enriquecida com as vidas de nosso povo. Ensinem às suas crianças o que ensinamos às nossas, que a Terra é nossa mãe. Tudo o que acontecer à Terra, acontecerá aos filhos da Terra. Se os homens cospem no solo estão cuspindo em si mesmos. Isto sabemos: a Terra não pertence ao homem; o homem pertence à Terra. Isto sabemos: todas as coisas estão ligadas, como o sangue que une uma família. Há uma ligação em tudo. O que ocorre com a terra recairá sobre os filhos da terra. $\mathrm{O}$ homem não teceu o tecido da vida: ele é simplesmente um de seus fios. Tudo o que fizer ao tecido, fará a si mesmo. Mesmo o homem branco, cujo Deus caminha e fala com ele de amigo para amigo, não pode estar isento do destino comum. É possível que sejamos irmãos, apesar de tudo. Veremos. De uma coisa estamos certos ( e o homem branco poderá vir a descobrir um dia): nosso Deus é o mesmo Deus. Vocês podem pensar que o possuem, como desejam possuir nossa terra, mas não é possível. Ela é o Deus do homem e sua compaixão é igual para o homem branco e para o homem vermelho. A terra lhe é preciosa e feri-la é desprezar o seu Criador. Os brancos também passarão; talvez mais cedo do que todas as outras tribos. Contaminem suas camas, e uma noite serão sufocados pelos próprios dejetos. Mas quando de sua desaparição, vocês brilharão intensamente, iluminados pela força do Deus que os trouxe a esta terra e por alguma razão especial lhes deu o domínio sobre a terra e sobre o homem vermelho. Esse destino é um mistério para nós, pois não compreendemos que todos os búfalos sejam exterminados, os cavalos bravios todos domados, os recantos secretos da floresta densa impregnados do cheiro de muitos homens, e a visão dos morros obstruída por fios que falam. Onde está a árvore? Desapareceu. Onde está a água? Desapareceu. É o final da vida e o início da sobrevivência. Como é que se pode comprar ou vender o céu, o calor da terra? Essa idéia nos parece um pouco estranha. Se não possuímos o frescor do ar e o brilho da água como é possível comprá-los? Cada pedaço desta terra é sagrado para meu povo. Cada ramo brilhante de um pinheiro, cada punhado de areia das praias, a penumbra na floresta densa, cada clareira, cada inseto a zumbir é sagrado na memória e experiência do meu povo. A seiva que percorre o corpo das árvores carrega consigo as lembranças do homem vermelho (...). Essa água brilhante que corre nos rios não é apenas água, mas a idéia nos parece um pouco estranha. Se não possuímos o frescor 
do ar e o brilho da água como é possível comprá-los? Cada pedaço desta terra é sagrado para meu povo. Cada ramo brilhante de um pinheiro, cada punhado de areia das praias, a penumbra na floresta densa, cada clareira, cada inseto a zumbir é sagrado na memória e experiência do meu povo. A seiva que percorre o corpo das árvores carrega consigo as lembranças do homem vermelho (...). Essa água brilhante que corre nos rios não é apenas água, mas o sangue de nossos antepassados. Se vendermos a terra, vocês devem lembrar-se de que ela é sagrada, devem ensinar às crianças que ela é sagrada e que cada reflexo nas águas límpidas dos lagos fala de acontecimentos e lembranças da vida do meu povo. O murmúrio das águas é a voz dos meus ancestrais. Os rios são nossos irmãos, saciam nossa sede. Os rios carregam nossas canoas e alimentam nossas crianças. Se lhes vendermos nossa terra, vocês devem lembrar e ensinar a seus filhos que os rios são nossos irmãos e seus também. $\mathrm{E}$, portanto, vocês devem dar aos rios a bondade que dedicariam a qualquer irmão. Sabemos que o homem branco não compreende nossos costumes. Uma porção de terra, para ele, tem o mesmo significado que qualquer outra, pois é um forasteiro que vem à noite e extrai da terra aquilo de que necessita. A terra não é sua irmã, mas sua inimiga e, quando ele a conquista, prossegue seu caminho. Deixa para trás os túmulos de seus antepassados e não se incomoda. Rapta da terra aquilo que seria de seus filhos e não se importa (...). Seu apetite devorará a terra, deixando somente um deserto. Eu não sei. Nossos costumes são diferentes dos seus. A visão de suas cidades fere os olhos do homem vermelho. Talvez porque o homem vermelho é um selvagem e não compreenda. Não há lugar quieto nas cidades do homem branco. Nenhum lugar onde se possa ouvir o desabrochar de folhas na primavera ou o bater de asas de um inseto. Mas talvez seja porque eu sou um selvagem e não compreendo. O ruído parece apenas insultar os ouvidos. E o que resta da vida de um homem, se não pode ouvir o choro solitário de uma ave ou o debate dos sapos ao redor de uma lagoa, à noite? Eu sou um homem vermelho e não compreendo. $\mathrm{O}$ índio prefere o suave murmúrio do vento encrespando a face do lago, e o próprio vento, limpo por uma chuva diurna ou perfumado pelos pinheiros." Sabemos que o homem branco não compreende nossos costumes. Uma porção de terra, para ele, tem o mesmo significado que qualquer outra, pois é um forasteiro que vem à noite e extrai da terra aquilo de que necessita. A terra não é sua irmã, mas sua inimiga e, quando ele a conquista, prossegue seu caminho. Deixa para trás os túmulos de seus antepassados e não se incomoda. Rapta da terra aquilo que seria de seus filhos e não se importa (...). Seu apetite devorará a terra, deixando somente um deserto. 
7.

\section{MATERIAIS E MÉTODOS}

As informações teóricas, apresentadas nos capítulos anteriores, nos permitem formar o conhecimento.

Em cada profissional, o conhecimento é dosado quantitativamente e qualitativamente de forma diferente. A transferência destes conhecimentos, quando extremamente específicos, tem como veículo, a pesquisa. Na pesquisa, a permuta de informações nos conduz à fazer investigação, que é um empreendimento humano e, portanto, passível de erros.

Sendo esta tese, um trabalho de investigação, alguns tantos erros cometeremos, mas outros, tais como: desqualificar trabalhos, ignorar opiniões e sugestões e até mesmo desqualificar a pessoa do pesquisador, "tentaremos" ao máximo evitar, pois só assim, estaremos produzindo conhecimento.

A atitude direcionada à esta (intenção), reside no fato de manter constante comunicação com outros pesquisadores ou quaisquer outros profissionais que tenham algum conhecimento sobre o tema desta tese.

\subsection{METODOLOGIA}

O capítulo "materiais e métodos", tem por objetivo fornecer informações em quantidade e qualidade, suficientes. de modo a permitir que outro(s) profissional(is), com o mínimo de igual capacidade/competência, possam reproduzir esse trabalho.

As informações (dados) as correlações (habilidades) e os resultados (respostas), apresentadas nos capítulos anteriores, acrescidas das informações fornecidas nesse capítulo, torna esse trabalho passível de ser reproduzido, portanto, podendo ser considerado um trabalho científico. 


\subsection{LOCAL DE ESTUDO}

Curso de água natural, de extensão mais ou menos considerável, que se desloca de um nível mais elevado para outro mais baixo, aumentando progressivamente seu volume até desaguar no mar, num lago, ou noutro rio e, cujas características dependem do relevo, do regime de águas, etc.

Nesta pesquisa identificaremos os cursos de água, com as características anteriormente descritas, simplesmente, como rios.

\subsection{DELINEAMENTO DO LOCAL DE ESTUDO}

Rios, com um grau maior de intervenção de engenharia, proporcionando segurança à navegação diuturna a qualquer tempo para os veículos fluviais adequados aos padrões da via (sinalização, balizamento, carta eletrônica de navegação, navegação satelital, estação de rádio controle, etc.). Estes rios, serão identificados na presente pesquisa, como hidrovia interior.

\subsection{DELINEAMENTO DO ESTUdO DAS AÇÕES PROPOSTAS E IMPACTOS AMBIENTAIS}

As obras de engenharia necessárias à implantação e operação de uma hidrovia, com intervenção direta e indireta no rio navegável, serão identificadas como ações propostas.

As alterações das propriedades físicas, químicas e biológicas do meio ambiente, causadas por qualquer forma de matéria ou energia, resultantes das atividades humanas que, direta ou indiretamente, afetam: a saúde, a segurança e o bem estar da população, ou as atividades sociais e econômicas, a biota, as condições estéticas e sanitárias do meio ambiente, a qualidade dos recursos ambientais, serão identificadas como impactos ambientais. 


\subsection{PREVISÃO DE COLETA DE DADOS}

\subsubsection{Sujeitos da Pesquisa}

A seleção dos sujeitos da pesquisa, deu-se a partir de informações coletadas junto as Universidades Estaduais, em número de duas, com a identificação de nove pesquisadores; Universidade Federais, em número de nove, com a identificação de dezessete pesquisadores; Universidades Privadas, em número de uma, com a identificação de um pesquisador; Institutos de Pesquisas Tecnológicas, em número de um, com a identificação de um pesquisador; Instituto de Pesquisas Hidráulicas, com a identificação de dois pesquisadores; Cooperativas Hidroviárias, em número de uma, com a identificação de um profissional que trabalha com o tema da tese, Administração de Hidrovias, em número de cinco; Sociedades Brasileiras Navais, em número de uma: Ministério, em número de um, com a identificação de um profissional que trabalha com tema da tese; Organizações não governamentais: Empresas de Engenharia Civil, em número de duas; e outros órgãos, não menos importantes, de modo a identificar a existência de profissionais com conhecimento sobre o assunto tratado nesta tese.

A partir da identificação do(s) profissional(is), procedeu-se o envio do material de questionamento, que recebeu o título de "PLANILHA AMBIENTAL".

\subsubsection{Instrumento de Coleta de Dados}

Para a coleta de dados, utilizou-se os seguintes instrumentos:

- Pesquisa de documentos tais como: livros, normas técnicas, revistas técnicas, artigos técnicos, jornais, documentos provenientes de conferências e seminários, boletins técnicos.

Planilha Ambiental, apresentada sobre a forma de questionamento e, enviadas ( arquivo identificado como Planilha Ambiental ) aos sujeitos da pesquisa através da rede internet. 


\subsection{MÉTODO DE PESQUISA}

A busca do conhecimento, nos faz perceber a necessidade de sua materialização e, através do método, conseguimos documentar o conhecimento.

O método adotado nesta pesquisa para a sua documentação, é o questionamento.

\subsection{TIPO DE PESQUISA}

Segundo Ab' Sáber (2003) - 'Não se pode falar em potencialidades paisagísticas sem pensar no grande dilema dos tempos modernos: o economismo e o ecologismo. Enquanto o economismo é de um imediatismo por vezes criminoso, o ecologismo, tomado em seus termos mais simples, é de uma ingenuidade e puerilidade tão grandes que chega a prejudicar qualquer causa que vise à proteção dos recursos naturais ditos renováveis, na maioria dos casos de muito problemática reconstrução".

A paisagem é entendida como o complexo dos elementos que compõem e configuram um lugar determinado e que tem estreita vinculação com a vida que nele se desenvolve. A paisagem se específica pelo meio geográfico e pelos ecossistemas que ali se encontram, fatores predominantes. Entre os elementos que compõem e configuram um lugar determinado, encontram-se os rios.

Acreditamos que a advertência do ilustre mestre, tem um extensão sem limites, alcançando inclusive o tema desta tese, permitindo-nos então: Não pode falar em potencialidade hidroviária dos nossos cursos d'água, rios, sem considerar o grande dilema dos tempos modernos: o economismo e o ecologismo. Enquanto o economismo é de um imediatismo por vezes criminoso, o ecologismo, tomado em seus termos mais simples, é de uma ingenuidade e puerilidade tão grandes que chega a prejudicar qualquer causa que vise à proteção dos recursos naturais ditos renováveis, na maioria dos casos de muito problemática reconstrução. 
Acreditamos que o desenvolvimento de uma pesquisa cientifica, não está mais restrita exclusivamente a uma área do conhecimento, sendo assim a relevância científica, será tanto maior, quanto maior o número de áreas de conhecimento que ela conseguir atingir; para tanto exige a necessidade de alterações, no seu método de elaboração, principalmente no que se refere ao fornecimento de informações básicas/ou conceituais.

A possibilidade de desenvolver uma tese, não mais restrita, por exemplo, a área de engenharia hidráulica, especificamente hidráulica fluvial, mas fundamentada sobre ela, pode permitir o entendimento desta tese por outras áreas do conhecimento, pois é uma tese multidisciplinar, tendo exigido para a sua elaboração, conhecimentos de outras áreas, tais como: biologia, ecologia, economia, administração, geografia, química, direito, engenharia naval, engenharia de transportes e outras não menos importantes.

Verifica-se, então, que o tipo de pesquisa, adotado, é exemplo de pesquisa correlacional. O documento identificado como "Planilha Ambiental", adotado como instrumento de coleta de dado, investigará a correlação entre os fenômenos em estudo, também, denominados variáveis ( dependente, independente e controlada), exigindo para a sua boa execução um conhecimento não mais restrito a engenharia.

\subsection{MODALIDADE DA PESQUISA}

A pesquisa é conduzida de forma a apresentar características que permitam distinguir alterações devido a uma ação das outras e de lhes determinar a natureza, bem como atribuir valores a estas ações, isto é, uma pesquisa com enfoques qualitativo e quantitativo. 


\title{
eAPítuLO 8.
}

\section{IMPACTOS AMBIENTAIS EM VERSOS}

\author{
Pensem nas crianças \\ Mudas telepáticas \\ Pensem nas meninas
}

Cegas inexatas

Pensem nas mulheres

Rotas alteradas

Pensem nas feridas

Como rosas cálidas

Mas oh! não se esqueçam

Da rosa, da rosa

Da rosa de Hiroshima

A rosa hereditária

A rosa radioativa

Estúpida e inválida

A rosa com cirrose

A anti-rosa atômica

Sem cor sem perfume

Sem rosa sem nada. 
8.

\section{DISCUSSÃO}

No capítulo 5, item 5.2.7., Identificação dos Impactos Ambientais por Ambientalistas, Especialistas e Pesquisadores, devido a hidrovia, desta tese, inúmeras vezes discordamos dos impactos ambientais identificados, pois em muitos, não se considerou definições, conceitos e fundamentações da Morfologia Fluvial, sendo então, um impacto natural considerado, por aqueles, um impacto produzido pelas obras hidroviárias. Mas mesmo discordando, transcrevemos estes impactos, na sua integra, pois a cada instante sempre procuramos atender aos quatro princípios da moral, conforme Lichtenberg (2000) apud Cunha (2000), a saber: O FILOSÓFICO faça o bem pelo próprio bem; O RELIGIOSO - faça o bem porque é a vontade de Deus; O HUMANO - faça o bem porque seu bem-estar requer e: O POLÍTICO faça o bem porque exige a sociedade da qual você faz parte

As Planilhas Ambientais, elaboradas a partir da correlação das variáveis, constitui-se em nosso instrumento de coleta de dados e, a sua devolução, acompanhada de comentários, análises e sugestões, elaborados pelos sujeitos da pesquisa, conduziu-nos a:

Pensar em tomar como sujeitos da pesquisa, profissionais, ambientalistas e pesquisadores, internacionais. Quanto a identificação de um novo sujeito de pesquisa, agora externo às nossas variáveis, classificamos como extremamente inviável, pois numa simulação desta possibilidade, verificouse: distorção, já, no entendimento da hidrovia como um modal de transporte; distorção ao preencher a Planilha Ambiental, devido principalmente a interesses políticos e econômicos, o que nos induziria a desvios incríveis nesta pesquisa.

Pensar em um novo instrumento de coleta de dados, pois acreditávamos que a devolução das planilhas ambientais preenchidas era "algo certo", o que 
nos forneceria , inclusive, dados para um estudo estatístico. A discordância entre o "aguardado" (devolução das planilhas ambientais preenchidas) e o "ocorrido" (devolução das planilhas ambientais não preenchidas), nos fez romper com o fascínio de certas idéias, fazendo-nos desistir da teimosia de pesquisador, que permanece à procura de uma resposta que não existe.

Os dados apontavam na direção contrária a esperada, fazendo-nos conduzir o nosso foco de pesquisa nessa direção, ou seja, entender o porquê (dúvidas, dificuldades, desconhecimento etc.) do não preenchimento das planilhas ambientais.

Alguns dos objetivos específicos propostos, principalmente no que se refere a valoração dos impactos ambientais, não puderam ser alcançados, no presente, pois faltam aos sujeitos da pesquisa, principalmente a habilidade para identificar situações em que a teoria referente a Impactos Ambientais, pode ser aplicada. 


\section{CAPÍtulo 9.}

CONCLUSÃO

“ O ser humano não é nada mais

do que a educação fez dele ".

"Kant" 
9.

\section{CONCLUSÃO}

Já não é mais possível, não acreditar que o desenvolvimento tem direção e sentido. As bacias hidrográficas, em número de cinco, segundo Santos \& Silveira (2001) e, em número de seis, segundo Rebouças et al. (1999), constituem a realidade desta orientação e sentido, isto é, são eixos, identificados segundo Brito (2001) apud Capobianco et al. (2001) como eixos de integração.

Eixos de integração, que existem em parte, naturalmente, mas a sua totalidade compreende a execução de algumas obras, tais como, obras hidroviárias, definindo caminhos e consequentemente hidrovias.

Verifica-se atualmente, a existência de um consenso, pois inúmeros documentos elaborados a partir de pesquisas, palestras, seminários, conferências, workshops e outros, atestam que o desenvolvimento do Brasil, tem por caminho a hidrovia. Afirmação esta, que coincide com aquela feita por nós na apresentação desta tese.

Este consenso, vai além, isto é na triste conclusão, que reside nas dificuldades que se tem para a materialização deste caminho.

Dificuldades que afloram a partir da:

Inexistência de uma bibliografia específica sobre o assunto hidrovias;

- Obtenção de dados/informações sobre as obras necessárias à implantação de hidrovias;

Procedimentos que envolvem boas técnicas para a execução destas obras (gerais ou de normalização - desobstrução e limpeza, limitação dos leitos, fechamento de braços secundários, proteção das margens - retificação de meandros, regularização dos leitos, derrocamento, dragagem, canalização dos curso d'água).

Identificação de profissionais que tenham vivenciado a execução de hidrovias e que se encontrem dispostos a transmitir a sua experiência; 
- Identificação de profissionais com habilidade para "associar" as obras hidroviárias, com os seus impactos ambientais;

Inexistência de "documentos" que relacionem as obras hidroviárias e seus impactos.

Cabe fazer uma ressalva sobre existência de alguns poucos documentos que atribuem às hidrovias, impactos ambientais que não lhes pertencem, atribuídos a elas, ora por puro desconhecimento, ora por algum interesse, são eles:

Inexistência de documentos que transportem para os dias de hoje, os impactos ambientais produzidos por hidrovias, já executadas;

Existência de profissionais que militam sobre o tema referente a questões ambientais, mais especificamente sobre impactos ambientais, com formação estritamente restrita, mas que detêm em suas mãos o poder da decisão para a implantação ou não de um empreendimento, como por exemplo uma hidrovia;

- Identificação de profissionais com perfil para a formação e manutenção de equipe multidisciplinar, que possam no "futuro" desenvolver trabalhos sobre o tema.

Acreditamos que a elaboração das Planilhas Ambientais, referente a Obras Hidroviárias, é uma sugestão futurista - um futuro bem próximo, talvez amanhã principalmente quando existir espaço para o atendimento de objetivos traçados, bem como para objetivos propostos.

As Planilhas Ambientais poderão se constituir em um instrumento de Projeto, a ser considerado, ainda na fase de Estudo Preliminar, pois permitirão não só avaliar a habilidade dos profissionais para abordar ao assunto, bem como, permitir à profissionais das diferentes áreas do conhecimento, envolvidos com a questão ambiental "entender" o desenvolvimento do projeto de expansão de uma determinada região a partir da origem de um sistema de eixos, identificado segundo BRITO (2001, apud CAPOBIANCO et al., 2001), como eixos de integração. 
Conceitualmente, o sistema de eixos teria a sua origem nas Planilhas Ambientais, que em síntese é a hidrovia; diferenciando-se de tudo que já foi realizado, pois é um trabalho com embasamento científico e, a expansão de uma determinada região, não seria mais aleatória e desordenada, mas sim direcionada e monitorada a partir de um eixo, tendo-se como conseqüência imediata, uma melhoria na qualidade de vida, na área de influência do eixo de integração, pois segundo Brito (2001) apud Capobianco et al. (2001), haverá:

- Incentivo à produção nacional, e integrando interna e internacionalmente o Brasil, ampliando, desse modo, as suas fronteiras de desenvolvimento;

Abertura de caminho à indústria, à agropecuária e ao comércio, que gradualmente chegarão a lugares distantes;

Formação de corredores de transporte e produção, encurtando, assim, o caminho das exportações para os mercados americano e europeu;

- Possibilidade de comunicação com o Oceano Pacífico;

- Geração de pólos de produção;

- Grandes culturas (soja e milho), pecuária, atividade madeireira e agricultura poderão ser incentivadas pela diminuição de custos de transporte e produção.

Não abordamos, nesta tese, somente assuntos de caráter inédito, mas principalmente procuramos recuperar conceitos que permitam, a quem deste trabalho fizer uso, obter um embasamento teórico sobre dois enfoques: o curso d'água sem a hidrovia e, o mesmo curso d'água com as interferências e alterações nas porções biogeo-física e sócio-econômico-cultural do meio ambiente, devido às obras hidroviárias, que definem o traçado e as dimensões de uma hidrovia e, segundo Brito (2001) apud Capobianco et al.(2001), resultam na questão ambiental, tornandose o grande impecilho para a implantação da hidrovia, nos eixos referenciados, anteriormente.

Por fim, esperamos que a leitura e o entendimento de tudo que foi exposto neste trabalho, inclusive quantitativamente, permitam verificar que os objetivos 
traçados, são verdadeiros e, que a relevância científica desta pesquisa, possibilite alcançar um desenvolvimento social, fazendo, assim, com que as obras hidroviárias deixem de ser um "mito do impecilho" para este desenvolvimento. 


\section{Gapítulo 10.}

"Se tiveres que tratar com água, consulta primeiro a experiência e depois a razão !’.

"Leonardo da Vinci" 
ANEXO A

LEGISLAÇÃO AMBIENTAL 


\title{
HIDROVIAS E A LEGISLAÇÃO AMBIENTAL
}

A pesquisa da legislação, para a elaboração deste trabalho, nos fez destacar, dentro da legislação, pontos específicos referentes a hidrovias, os quais são apresentados, de maneira bem sintética, permitindo aos estudiosos do assunto, verificar que a hidrovia é um modal de transporte considerado na legislação, antes mesmo da ênfase da legislação ambiental.

\section{DECRETO № 24.643, DE 10 DE JULHO DE 1943 DECRETA O CÓDIGO DE ÁGUAS}

\author{
LIVRO I \\ ÁGUAS EM GERAL E SUA PROPRIEDADE
}

Título I

ÁGUAS, ÁLVEO E MARGENS

CAPÍTULO I

ÁGUAS PÚBLICAS

Art. $2^{\circ}$. São águas públicas de uso comum:
a) os mares territoriais, nos mesmos incluídos os golfos, baías, enseadas e portos;
b) as correntes, canais, lagos e lagoas navegáveis ou flutuáveis;
c) as correntes de que se façam estas águas;
d) as fontes e reservatórios públicos;
e) as nascentes quando forem de tal modo consideráveis, que por si só, constituam o caput fluminis;
f) os braços de quaisquer correntes públicas, desde que os mesmos influam na navegabilidade ou flutuabilidade. 
$\S 1^{\circ}$. Uma corrente navegável ou flutuável se diz feita por outra quando se torna navegável logo depois de receber essa outra.

\title{
CAPÍTULO II \\ ÁGUAS COMUNS
}

Art. $7^{\circ}$. São comuns as correntes não navegáveis ou flutuáveis e de que essas não se façam.

\author{
LIVRO II \\ APROVEITAMENTO DAS ÁGUAS \\ Título II \\ APROVEITAMENTO DAS ÁGUAS PÚBLICAS \\ CAPÍTULO I \\ NAVEGAÇÃO
}

Art. 37. O uso das águas públicas se deve realizar, sem prejuízo da navegação salvo a hipótese do art. 48, e seu parágrafo único.

Art. 38. As pontes serão construídas, deixando livre a passagem das embarcações.

Parágrafo único. Assim, estas não devem ficar na necessidade de arriar mastreação, salvo se o contrário é uso local.

Art. 39. A navegação de cabotagem será feita por navios nacionais.

Art. 40. Em lei ou leis especiais, serão reguladas:

I - A navegação ou flutuação dos mares territoriais, das correntes, canais e lagos do domínio da União; 
II - A navegação das correntes, canais e lagos:

a) que fizerem parte do plano geral de viação da República;

b) que, futuramente, forem considerados de utilidade nacional por satisfazerem as necessidades estratégicas ou corresponderem a elevados interesses de ordem pública ou administrativa.

III - A navegação ou flutuação das demais correntes, canais e lagos do território nacional.

Parágrafo único. A legislação atual sobre a navegação e flutuação só será revogada à medida que forem sendo promulgadas as novas leis.

\section{CAPÍTULO II PORTOS}

Art. 41. O aproveitamento e os melhoramentos e uso dos portos, bem como a respectiva competência federal, estadual ou municipal serão regulados por leis especiais.

\section{CAPÍTULO IV DERIVAÇÃO}

Art. 48. A concessão, como a autorização, deve ser feita sem prejuízo da navegação, salvo:

a) no caso de uso para as primeiras necessidades da vida:

b) no caso da lei especial que, atendendo a superior interesse público, o permita.

Parágrafo único. Além dos casos previstos nas letras a e b deste artigo se o interesse público superior o exigir, a navegação poderá ser preterida sempre que ela não sirva efetivamente ao comércio. 


\author{
LIVRO III \\ FORÇAS HIDRÁULICAS \\ REGULAMENTAÇÃO \\ DA INDÚSTRIA HIDRELÉTRICA \\ Título I \\ CAPÍTULO I
}

\title{
ENERGIA HIDRÁULICA E SE APROVEITAMENTO
}

Art. 143. Em todos os aproveitamentos de energia hidráulica serão satisfeitas exig6encias acauteladoras dos interesses gerais:
a) da alimentação e das necessidades das populações ribeirinhas;
b) da salubridade pública;
c) da navegação;
d) da irrigação;
e) da proteção contra as inundações;
f) da conservação e livre circulação dos peixes;
g) escoamento e rejeição das águas.

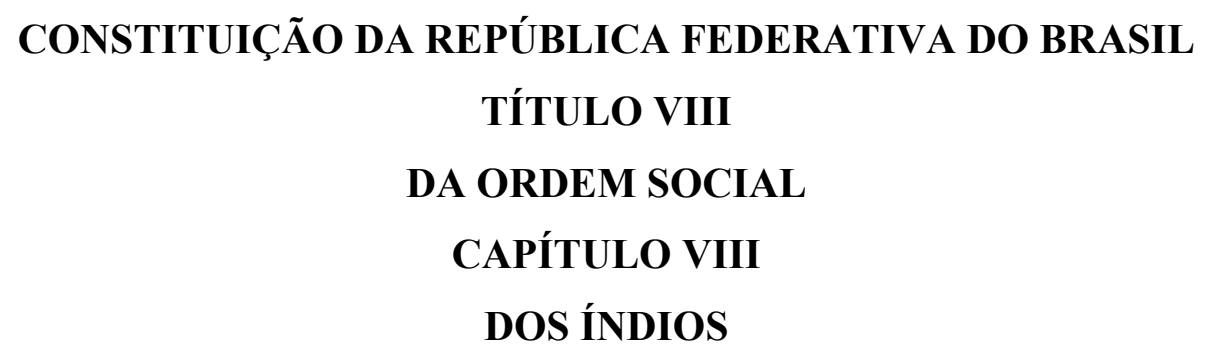


Art. 231. São reconhecidos aos índios sua organização social, costumes, línguas, crenças e tradições, e os direitos originários sobre as terras que tradicionalmente ocupam, competindo à União demarcá-las, proteger e fazer respeitar todos os seus bens.

$\S 3^{\circ}$. O aproveitamento dos recursos hídricos, incluídos os potenciais energéticos, a pesquisa e a lavra das riquezas minerais em terras indígenas só podem ser efetivados com a autorização do Congresso Nacional, ouvidas as comunidades afetadas, ficando-lhes assegurada participação nos resultados da lavra, na forma da lei.

\section{LEI № 9.611 DE 19/02/1998}

DISPÕE SOBRE O TRANSPORTE MULTIMODAL DE CARGAS

\section{CAPÍTULO II}

Art. $5^{\circ}$. "O operador de Transporte Multimodal é a pessoa jurídica contratada como principal para a realização do transporte Multimodal de Cargas da origem até o destino, por meios próprios ou por intermédio de terceiros"

Parágrafo único. "O operador de Transporte Multimodal poderá ser transportador ou não transportador".

Art. $7^{\circ}$. "Cabe ao operador de Transporte Multimodal emitir o Conhecimento de Transporte Multimodal de Carga".

DECRETO № 3.411, DE 12/04/2000 REGULAMENTA A LEI № 9.611, DE 19/02/1998 


\section{CAPÍTULO I}

Art. $7^{0}$. "O registro de Operador de Transporte Multimodal, suas responsabilidades e o controle aduaneiro das operações obedecerão ao disposto na LEI № 9.611 , DE 19/02/1998 e nesse decreto".

\section{CAPÍTULO II}

DO REGISTRO DO OPERADOR DE TRANSPORTE MULTIMODAL

Art. $2^{\circ}$. "Para exercer a atividade de Operador de Transporte Multimodal, serão necessários a habilitação prévia e o registro na Secretaria Executiva do Ministério dos Transportes".

\section{RESOLUÇÃO CONAMA № 20, DE 18 DE JUNHO DE 1986 \\ ESTABELECE A CLASSIFICAÇÃO PARA AS ÁGUAS DOCES, SOLOBRAS E SALINAS DO TERRITÓRIO NACIONAL}

\section{ÁGUAS DOCES}

V. Classe 4 - Águas destinadas:

a) à navegação;

b) à harmonia paisagística;

c) aos usos menos exigentes.

ÁGUAS SALGADAS

VII. Classe 6 - Águas destinadas:
a) à navegação comercial;
b) à harmonia paisagística;
c) à recreação de contato secundário 


\section{AGUAS SALOBRAS}

VIII - Classe 8 - Águas destinadas:

a) à navegação comercial;

b) à harmonia paisagística;

c) à recreação de contato secundário

\section{MINISTÉRIO DO DESENVOLVIMENTO URBANO E MEIO AMBIENTE CONSELHO NACIONAL DO MEIO AMBIENTE RESOLUÇÃO № 1 - DE 23 DE JANEIRO DE 1986}

Art. 1. ${ }^{\circ}$ Para efeito desta Resolução, considera-se impacto ambiental qualquer alteração das propriedades físicas, químicas e biológicas do meio ambiente, causada por qualquer forma de matéria ou energia resultante das atividades humanas que direta, ou indiretamente, afetam:

I - a saúde, a segurança e o bem-estar da população;

II - as atividades sociais e econômicas;

III - a biota;

IV - as condições estéticas e sanitárias do meio ambiente;

$\mathrm{V}-\mathrm{a}$ qualidade dos recursos ambientais.

Art. 2. ${ }^{\circ}$ Dependerá de elaboração de Estudo de Impacto Ambiental - EIA e respectivo Relatório de Impacto Ambiental - RIMA, a serem, submetidos à aprovação do órgão estadual competente, e da SEMA em caráter supletivo, o licenciamento de atividades modificadoras do meio ambiente, tais como:

III - portos e terminais de minério, petróleo e produtos químicos;

VII - obras hidráulicas para a exploração de recursos hídricos, tais como: barragem para fins hidrelétricos, acima de 10MW, de saneamento ou de irrigação, abertura de canais para navegação, drenagem e irrigação, retificação de cursos d'água, abertura de barras e embocaduras, transposição de bacias e diques. 
ANEXO B

GEOSSINTÉTICOS 
Tabela XXI - Geossintéticos e principais funções.

\begin{tabular}{|c|c|c|c|c|c|}
\hline Geossintético & \multicolumn{5}{|c|}{ Função } \\
\hline & Separação & Reforço & Filtração & Drenagem & $\begin{array}{l}\text { Barreira } \\
\text { Impermeável }\end{array}$ \\
\hline Geotêxtil & 1 ou 2 & 1 ou 2 & 1 ou 2 & 1 ou 2 & 1 ou 2 * \\
\hline Geogrelha & 2 & 1 & $n / a$ & $n / a$ & $n / a$ \\
\hline Geomalha & 2 & $n / a$ & $n / a$ & 1 & $n / a$ \\
\hline Geomembrana & 2 & $n / a$ & $n / a$ & $n / a$ & 1 \\
\hline Geocomposto & 1 ou 2 & 1 ou 2 & 1 ou 2 & 1 ou 2 & 1 ou 2 \\
\hline \multicolumn{6}{|c|}{ * Quando impregnado com asfalto } \\
\hline \multirow[t]{3}{*}{ Legenda: } & \multicolumn{5}{|c|}{1 - Função Principal } \\
\hline & \multicolumn{5}{|c|}{2 - Função Secundária } \\
\hline & \multicolumn{5}{|c|}{$n / a-N a ̃ o ~ s e ~ a p l i c a$} \\
\hline
\end{tabular}

Fonte: Hachich et al. (1998). 
ANEXO C

COMPARAÇÃO ENTRE OBRAS HIDROVIÁRIAS 
Tabela XXII - Comparação entre as obras de proteção direta e indireta.

\begin{tabular}{|c|c|c|}
\hline Obras & Proteção Direta & Proteção Indireta \\
\hline Vantagens & $\begin{array}{l}\Rightarrow \text { Não há diminuição da } \\
\text { área hidráulica do rio; } \\
\Rightarrow \text { Normalmente mais eficientes; } \\
\Rightarrow \text { Maior garantia da fixação } \\
\text { definitiva das margens; }\end{array}$ & $\begin{array}{l}\Rightarrow \text { Normalmente são mais } \\
\text { econômicas; } \\
\Rightarrow \text { Custos da manutenção } \\
\text { diminuem no tempo; } \\
\Rightarrow \text { Destruição em trecho } \\
\text { da obra não põe em } \\
\text { perigo todo o resto; } \\
\Rightarrow \text { Podem ser construídas } \\
\text { por etapas; } \\
\Rightarrow \text { A retenção de } \\
\text { sedimentos proporciona } \\
\text { uma proteção adicional. }\end{array}$ \\
\hline Desvantagens & $\begin{array}{l}\text { - Construção mais complicada } \\
\text { e precisa, encarecendo a obra; } \\
\rightarrow \text { Necessidade de manutenção } \\
\text { cuidadosa para não se colocar } \\
\text { em perigo toda proteção. }\end{array}$ & $\begin{array}{l}\Rightarrow \text { Menos eficazes e de } \\
\text { menor garantia; } \\
\Rightarrow \text { Diminuem a área } \\
\text { hidráulica; } \\
\Rightarrow \text { Aumentam a rugosidade } \\
\text { das margens; } \\
\Rightarrow \text { Produzem perdas de } \\
\text { carga adicionais; } \\
\Rightarrow \text { Não são aconselhadas } \\
\text { para raios menores ou } \\
\text { iguais a duas vezes a } \\
\text { largura do curso d'água; } \\
\Rightarrow \text { Podem não fixar a } \\
\text { margem entre elas }\end{array}$ \\
\hline
\end{tabular}

Fonte: Brighetti. (2000). 


\section{Capítulo 11.}

\section{UM RIO - RIO PARANAPANEMA}

Rio da minha terra natal

Tão bonito ...

Azul infinito!

Tua cor é a cor do teu céu,

Se é tarde, o sol tinge de ouro tuas águas

se é noite, o luar te envolve em prata.

Meu grande rio

meu pequeno mar.

Rio Paranapanema!

Vejo-te na manhã tranqüila

da minha vida e me emociono.

Tuas águas

são uma prece cantante que avança

na terra dos homens (...)

Teu presente, são praias

são barcos movidos

é mocidade

em desfile colorido

são usinas transformando

em quilowatts

a força das tuas águas. 
Manancial inesgotável

de equilíbrio e riqueza

de harmonia e beleza!

Avança Paranapanema

Rumo da vida

Presença de Deus!

"Noemia Pires de Paula" 


\section{1.}

\section{BIBLIOGRAFIA}

1. AB'SÁBER, A. N. Os domínios de natureza no Brasil: potencialidades paisagísticas. São Paulo: Ateliê Editorial, 2003. 159p.

2. ALBANESE, V. Apostila: Técnica e economia dos transportes. Santos/SP: Universidade Santa Cecília dos Bandeirantes, 1987. 23p.

3. AlBANESE, V. Notas de aula: Portos e construções portuárias. Santos/SP: Universidade Santa Cecília dos Bandeirantes, 1989.

4. ALFREDINI, P. Apostila: Curso de pós-graduação na área de concentração Engenharia Hidráulica. Hidráulica Estuarina. São Paulo: Escola Politécnica da Universidade de São Paulo, 1999. 253p.

5. ALMEIDA, C. Apostila: Hidráulica Fluvial. São Paulo: Escola Politécnica da Universidade de São Paulo, Laboratório de Hidráulica. 1969. 100p.

6. AlmeIDA, C.; BRIGHETTI, G. Apostila: Navegação Interior e Portos Marítimos. São Paulo: Escola Politécnica da Universidade de São Paulo, 2002. Fascículo I. 143p.

7. ALTAN, V. D. Técnica "CCP" de consolidação de solos por cimentação a jato. Revista A Construção São Paulo. Editora Pini, São Paulo, n. 20/3, p. 25, 1986.

8. ALVAREZ, J. A. M. Contribucion al diseño de espigones - hidráulica fluvial y marítima. Montivideo, 1990. XIV Congresso Latinoamericano de Hidráulica. 
9. ALVES, F. E. Eco-engenharia: pneus ambientalmente corretos. Revista Saneamento Ambiental. São Paulo, n. 45, p. 11, maio/junho 1997.

10. ASSOCIAÇÃO BRASILEIRA DE CIMENTO PORTLAND. Ruas de solocimento: Prática de construção - BT 86. São Paulo, Ano 1984. 10p.

11. ASSOCIAÇÃO BRASILEIRA DE NORMAS TÉCNICAS. Glossário de poluição das águas - NBR 9896. São Paulo, 1993.

12. AUGUSTO JÚNIOR, F. Manual de pavimentação urbana. São Paulo: Instituto Tecnológico de São Paulo, 1992. 238p.

13. AZEVEDO NETO et al. Manual de hidráulica. 8. ed. São Paulo: Edgard Blücher, 1978. v. 2. 333p.

14. BANDINI, A. Apostila: Hidráulica fluvial. São Carlos/SP: Universidade de São Paulo - Escola de Engenharia de São Carlos, 1958. 142p.

15. BAPTISTA, M. B.; COELHO, M. M. L. P. Fundamentos de engenharia hidráulica. Belo Horizonte: Editora UFMG - Escola de Engenharia da UFMG, 2002. 440p.

16. BARBIERI, J. C. Desenvolvimento e meio ambiente - As estratégias de mudanças da Agenda 21. São Paulo: 1. ed. Editora Vozes, 1997. 156p.

17. BERZIN, G. Apostila: Hidráulica Fluvial e Marítima. Santos/SP: Universidade Santa Cecília dos Bandeirantes, 1988. 12p.

18. BIGALLIET, Alii. (2000). Rivestimenti flessibili in geocompositi. Itália: Revista L'ACQUA. n. 3. 
19. BOLEA, M. T. E. Evaluacion del impacto ambiental. Madrid - Espanha; Fundación Mapfre - Editorial Mapfre S/A, 1984. 609p.

20. BRAFÉR INDUSTRIAL S/A. Estacas - prancha. Manual Técnico. 16p.

21. BRASIL. Legislação federal: controle da poluição ambiental. São Paulo: CETESB, 1994.

22. BRASIL. Lei $\mathbf{n}^{\mathbf{0}} \mathbf{9 . 6 0 5}$, de fevereiro de 1998. Dispõe sobre sanções penais e administrativas derivadas de condutas e atividades lesivas do meio ambiente, e dá outras providências. Encarte da Revista Saneamento Ambiental, São Paulo: n. 55. 1998.

23. BRASIL. Lei $\mathbf{n}^{\mathbf{0}} \mathbf{9 . 9 8 4}$, de julho de 2000. Dispõe sobre a criação da Agência Nacional das Águas - ANA, entidade federal de implementação da política nacional de recursos hídricos e coordenação do sistema nacional de gerenciamento de recursos hídricos, e dá outras providências. Encarte da Revista Saneamento Ambiental, São Paulo: n. 67. 2000.

24. BRIGHETTI, G. Notas de aula: Curso de Pós-graduação na área de concentração - Engenharia Hidráulica. Obras Fluviais. São Paulo: Escola Politécnica da Universidade de São Paulo, 2000.

25. BUCHER, E. H. et al. Hidrovia: Análise ambiental inicial da via fluvial Paraguai - Paraná. Humedales para Las Américas, Manomet, Massachusets, USA e Buenos Aires, Argentina, 1994. 73p.

26. BULFINCH, T. O livro de ouro da mitologia: ( a idade da fábula ). histórias de deuses e heróis. 22. ed. Rio de Janeiro: Ediouro Publicações S.A, 2001. 417p. 
27. CAJAZEIRAS, J. E. R. ISO 14001 - Manual de implantação. 1. ed. Rio de Janeiro: Qualitymark Editora, 1998. 117p.

28. CAMARGO JUNIOR, A. Sistema de gestão ambiental em terminais hidroviários e comboios fluviais: contribuições para o desenvolvimento sustentável na hidrovia Tietê - Paraná. 2000. 179 p. Tese (Doutorado) - Instituto de Geociências e Ciências Exatas, da Universidade Estadual Paulista. São Paulo.

29. CAPOBIANCO, J. P. R. et al. Biodiversidade na Amazônia Brasileira. São Paulo: Estação Liberdade: Instituto Socioambiental, 2001. 540p.

30. CARVALHO, B. A. Glossário de saneamento e ecologia. 1. ed. Rio de Janeiro: ABES - Associação Brasileira de Engenharia Sanitária e Ambiental, 1981. 203p.

31. CIRILO, J. A.; COELHO, M. M. L. P.; BAPTISTA, M. B. Hidráulica aplicada. Porto Alegre: ABRH, 2001. 619p.

32. COMMELIN, P. Mitologia grega e romana. 2. ed. São Paulo: Martins Fontes, 1977. 433p.

33. CONSTRUSERV - SISTEMAS DE CONTROLE DE EROSÃO E COM. LTDA. Bolsacreto. São Paulo: Manual Técnico de Execução, 2001. 37p.

34. - SISTEMAS DE CONTROLE DE EROSÃO E COM. LTDA.

Colchacreto. São Paulo: Manual Técnico de Execução, 2001. 37p.

35. CUNHA, G. R. Meteorologia: fatos \& mitos 2. Passo Fundo: Embrapa Trigo, 2000. 294p. 
36. DEL GRANDE, D. Apostila: Transporte fluvial e marítimo. Santos/SP: Universidade Santa Cecília dos Bandeirantes., 1989. v. 1. 41p.

37. Apostila: Transporte fluvial e marítimo. Santos/SP: Universidade Santa Cecília dos Bandeirantes, 1989. v.2. 28p.

38. DERISIO, J. C. Introdução ao controle da poluição ambiental. 1. ed. São Paulo: Companhia de Tecnologia de Saneamento Ambiental, 1992. 210p.

39. DEPARTAMENTO DE ÁGUAS E ENERGIA ELÉTRICA. (DAEE). Nota técnica - 01 - 014/99: Vertedouro da barragem do Valo Grande Monitoramento do complexo estuarino - lagunar de Iguape - Cananéia. Escola Politécnica da Universidade de São Paulo.

40. DEPARTMENT OF THE ARMY CORPS OF ENGINEERS OFFICE OF THE CHIEF OF ENGINEERS. Dredging and dredged material disposal. D.C. 20314 EM 1110-2-5025. Washington. 1983.

41. DREER, C. A vaca louca das hidrovias. O Estado de São Paulo, 14 mar 2001. Artigo.

42. ENGEPOL S.A. Polimantas - geomembranas de polietileno de alta densidade. São Paulo: Manual técnico, 1999. 31p.

43. FENDRICH, R. et al. Drenagem e controle da erosão urbana. 4 ed. Curitiba: Editora Universitária Champagnat, 1997. 485p.

44. FERREIRA, A. B. H. Novo dicionário da língua portuguesa. 2 ed. São Paulo: Editora Nova Fronteira. 1986. 1838p. 
45. FREEMAN et al. The economics of environmental policy.. New York: John Wiley, 1992.

46. FREIRIA, N. T.; GARCIAS, C. M. Censo e contra-senso de um país mais urbano. BIO - Revista Brasileira de Saneamento e Meio Ambiente. Rio de Janeiro. ABES - Associação Brasileira de Engenharia Sanitária e Ambiental, n.30, 2001.

47. GÓIS, J. S.; ARAÚJO, R. N. Apostila: Curso de Pós-graduação na área de concentração - Engenharia Hidráulica. Espigões: características em função dos materiais utilizados na sua construção. São Paulo: Escola Politécnica da Universidade São Paulo, 2000. 32p.

48. GUIDICINI, G.; NIEBLE, C. M. Estabilidade de taludes naturais e de escavação. 2. ed. São Paulo: Edgard Blücher, 1993. 194p.

49. HACHICH, W. et al. Fundações - Teoria e Prática. São Paulo: Editora Pini, 1998. 751p.

50. HÜBNER. M. M. Guia para a elaboração de monografias e projetos de dissertação de mestrado e doutorado. 1. ed. São Paulo: Editora Pioneira \& Editora Mackenzie, 1998. 76p.

51. $1^{\circ}$ FÓRUM NACIONAL - IMPACTO AMBIENTAL NA IMPLANTAÇÃO DE HIDROVIAS NO BRASIL, São Paulo, 2001. Impacto Ambiental ma Implantação de Hidrovias no Brasil. São Paulo: IBC - International Business Communications, 2001 .

52. CONFERÊNCIA - OPERAÇÃO DO TRANSPORTE HIDROVIÁRIO NO BRASIL, São Paulo, 2001. Operação do Transporte Hidroviário no Brasil. São Paulo: IBC - International Business Communications, 2001. 
53. JAME, G. Travaux Fluviaux. Collection de la direction des Etudes et Recherches d'Electricité de France. 1.ed. Paris: Eyrolles Editeur, 1974.

54. LEINZ, V.; AMARAL, S. E. Geologia geral. 7. ed. São Paulo: Editora Nacional, 1978. 397p.

55. LENCASTRE, A. Manual de hidráulica geral. 2. ed. Lisboa: Técnica, 1972.

56. LEXIKON, H. Dicionário de símbolos. 13. ed. São Paulo: Editora Cultrix, $214 \mathrm{p}$.

57. LIBANORI, A. Notas de aula: Curso de Pós-graduação na área de concentração - Saneamento Ambiental. Gerenciamento Ambiental. São Paulo: Universidade Mackenzie, 1995.

58. - Notas de aula: Curso de Pós-graduação na área de concentração - Saneamento Ambiental. Impacto Ambiental. São Paulo: Universidade Mackenzie, 1996.

59. MACCAFERRI DO BRASIL LTDA. Reforço de Solos - Geogrelhas Soldadas. São Paulo: Manual Técnico de Execução, 2001. 11p.

60. Revestimentos flexíveis em colchões

Reno e gabiões de canais e cursos de água canalizados. São Paulo: Manual Técnico de Execução, 2001.31p.

61. Proteção contra erosões superficiais \& Revestimentos de margens para fluxos de baixa velocidade. São Paulo: Manual Técnico de Execução, 2001. 
62. Sistema Terramesh. São Paulo: Manual Técnico de Execução, 2001.27p.

63. MENDES, J. B. Curso de Pós-graduação na área de concentração - Engenharia Hidráulica. Meandros fluviais. São Paulo: Escola Politécnica da Universidade São Paulo, 2001. 15p.

64. MIRRA, A. L. V. Impacto Ambiental - Aspectos da legislação brasileira. 1. ed. São Paulo: Editora Oliveira Mendes, 1998. 69p.

65. MOLITERNO, A. Caderno de muros de arrimo. São Paulo: Edgard Bücher, 1980. 194p.

66. MOTA, S. Preservação e conservação de recursos hídricos. 2. ed. Rio de Janeiro: ABES, 1995. 187p.

67. MÜLLER, A. C. Hidrelétricas, meio ambiente e desenvolvimento. 1. ed. São Paulo: Makron Books, 1995. 412p.

68. NAGIB, J.; SAAD, A. L. Apostila: Muros de Arrimo. São Paulo: Faculdade de Tecnologia de São Paulo - FATEC/SP, 1991. 27p.

69. OliVEIRA, A. M. S.; BRITO, S. N. A. Geologia de Engenharia. 1. ed. São Paulo: Associação Brasileira de Geologia de Engenharia (ABGE), 1998. 586p.

70. OLIVEIRA, M. M. H. Ciência e pesquisa em psicologia: uma introdução. São Paulo. Editora Pedagógica e Universitária (EPU) Ltda., 1984. 103 p.: il.; 20,5 cm. 
71. PEREIRA, A. Domador de rios: história e perfil de Kokei Uehara. 1. ed. Rio de Janeiro: Expressão e Cultura; São Paulo: Associação dos Antigos Alunos da Escola Politécnica, 1994. 125p.

72. PEREIRA, P. A. S. Rios, redes e regiões: a sustentabilidade a partir do enfoque integrado dos recursos terrestres. 1. ed. Porto Alegre: Editora AGE Ltda, 2000. 348p.

73. PETERSEN, M. S. River engineering. 1.ed. New Jersey/USA, 1986. 580p.

74. PETRUCCI, E. G. R. Materiais de construção. 3. ed. Porto Alegre: Editora Globo, 1978. 435p.

75. PETRY, B.; BOERIU, P. Environmental impact assessment. Delft - The Netherlands: IHE - International Institute for Infrastructural, Hydraulic and Environmental Engineering, 1999. 210p.

76. PETRY, B.; BOERIU, P. Environmental impact assessment - annex. Delft The Netherlands: IHE - International Institute for Infrastructural, Hydraulic and Environmental Engineering, 1999. 210p.

77. PITTA, M. R. (2000). Solo-cimento para revestimento de barragens de terra, diques e reservatórios - ET - 34. 4.ed.rev.atual. São Paulo: ABCP - Associação Brasileira de Cimento Portland, 2000.

78. PORTOBRÁS - EMPRESA DE PORTOS DO BRASIL. Plano nacional de vias navegáveis interiores - Bacia do Tocantis/Araguaia. Brasília - DF. 1989.

79. PORTO, R. M. Hidráulica Básica. 1. ed. São Carlos/SP: Escola de Engenharia de São Carlos/USP, 1998. 519p. 
80. PORTO, R. L. L. (Org.). Técnicas quantitativas para o gerenciamento de recursos hídricos. 1.ed. Porto Alegre: Associação Brasileira de Recursos Hídricos (ABRH), Ed. Universidade - UFRGS, 1997. 419p.

81. 1ํ․ ENCONTRO MONTENA DE ENGENHARIA CIVIL, São Paulo, 2002. MONTENA - Areia e Pedra. 1 CR-ROM.

82. QUINTELA, A. C. Hidráulica. 7. ed. Lisboa/Portugal: Edição da Fundação Calouste Gilbenkian, 2000. 539p.

83. QUIRINO, T. R.; IRIAS, L. J. M.; WRIGHT, J. T. C. Impacto agroambiental: perspectivas, problemas e prioridades. 1. ed. São Paulo: Editora Edgard Blücher Ltda, 1999. 184p.

84. REBOUÇAS, et al. Águas doces no Brasil: capital ecológico, uso e conservação. 1. ed. São Paulo: Escrituras Editora, 1999. 717p.

85. RICARDO, H. S.; CATALANI, G. Manual prático de escavação (Terraplanagem e Escavação em Rocha). São Paulo: McGraw-Hill do Brasil, 1977. 488p.

86. RHODIA. Bidim - drenos, princípios básicos. São Paulo: Manual técnico, 1980. 64p.

87. SANTOS, M.; SILVEIRA, M. L. O Brasil: território e sociedade no início do século XXI. 2. ed. Rio de Janeiro: Editora Record, 2001. 473p.

88. SÃO PAULO (SP). Legislação estadual: controle de poluição ambiental Estado de São Paulo. São Paulo: CESTESB, 1994. 300p. 
89. SÃO PAULO/SPH - SERVIÇO DE PESQUISAS HIDRÁULICAS / LABORATÓRIO DE HIDRÁULICA DA EPUSP / DAEE / SERVIÇO DO VALE DO RIBEIRA / GEOBRÁS. Relatório: Complexo Valo Grande-Mar Pequeno Rio Ribeira de Iguape. São Paulo. 1966.

90. SETTI, A. A.; CABRAL, B. O tratado de cooperação Amazônica como instrumento institucional e legal para o gerenciamento de recursos hídricos da bacia Amazônica. Senado Federal. Brasília, 2001. 52p.

91. SILVEIRA, R.S.A., MOREIRA, I.V.D. Métodos e Técnicas. Curso de introdução à elaboração de estudos e relatórios de impacto ambiental. FEEMA. 1985.

92. $2^{\circ}$. SEMINÁRIO NACIONAL DE TRANSPORTE HIDROVIÁRIO INTERIOR, Jahu/SP, 2001. Hidrovia Interior. Jahu/São Paulo: Faculdade de Tecnologia de Jahu - Centro Paula Souza. 2 CD-ROM.

93. SCHOKLITSCH, A. Tratado de arquitectura hidráulica. Trad. de B. Bassegodá Musté. Barcelona: Gustavo Gili Editor, 1935.

94. TERRA ARMADA S.A. COMÉRCIO E INDÚSTRIA. Terra armada. São Paulo: Manual Técnico de Execução. 20p.

95. TOMMASI, L. R. Estudo de Impacto Ambiental. 1. ed. São Paulo: CETESB: Terragraph Artes e Informática, 1993. 355p.

96. TSCHEBOTARIOFF, G. P. Fundações, estruturas de arrimo e obras de terra. Tradutor Eda Freitas de Quadros. Revisão técnica Renato Armando silva Leme. São Paulo: McGraw Hill do Brasil, 1978. 513p. 
97. VAlENTE, W. Apostila: Estradas e transportes. São Paulo: Escola de Engenharia Mauá. v. 1. 100p.

98. VERAS JUNIOR, M. S. Apostila: Portos, rios e canais. São Paulo: Escola de Engenharia Mauá., 1975. v. 1. 30p.

99. VIANA, G. A polêmica sobre a hidrovia Paraguai - Paraná e o Porto de Morrinhos. 1. ed. Mato Grosso: Assembléia Legislativa do Estado de Mato Grosso, 2001. 121p.

100. VIEIRA, J. L. Código de água: decreto n⿳⺈ $\mathbf{2 4 . 6 4 3}$ de já de julho de 1934 e legislação complementar. 2. ed. Bauru/SP: Edipro, 1996. 87p.

101. VIEIRA, S. Como escrever uma tese. 5. ed. São Paulo: Pioneira Thomson Learning, 2002. 102p.

102. WOLLE, C. M. Notas de aula: Curso de Pós-graduação na área de concentração - Engenharia Hidráulica. Estabilidade de Taludes em Solo. São Paulo: Escola Politécnica da Universidade de São Paulo, 2000.

103. WORKSHOP - MODELOS ESTRANGEIROS E NACIONAIS DE OPERAÇÕES DE HIDROVIAS, São Paulo, 2001.Workshop - Modelos estrangeiros e nacionais de operações de hidrovias. São Paulo: IBC - International Business Communications, 2001.

104. ZOCCHI, P. Paranapanema: da nascente à foz. São Paulo: Audichromo, 2002. 132p. 


\section{INTERNET}

1. AHIMOC - Administração das Hidrovias da Amazônia Ocidental. Disponível em: $<$ http://www.ahimoc.com.br $>$. Acesso em: 2002.

2. AHIMOR - Administração das Hidrovias da Amazônia Oriental. Disponível em:

$<$ http://www.ahimor.gov.br>. Acesso em: 2002

3. AHIPAR - Administração da Hidrovia do Paraguai. Disponível em:

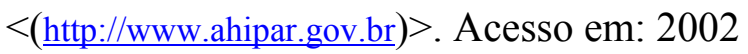

4. AHITAR - Administração da Hidrovia do Tocantins - Araguaia. Disponível em: $<$ http://www.ahitar.com.br>. Acesso em: 2002.

5. AHSFRA - Administração da Hidrovia do São Francisco. Disponível em: $<$ http://www.ahsfra.gov.br $>$. Acesso em: 2002.

6. CINCO - Companhia Interamericana de Navegação e Comércio. Disponível em:

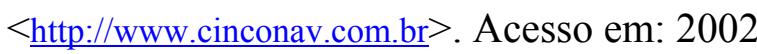

7. FUNAI - FUNDAÇÃO NACIONAL DO ÍNDIO. Disponível em:

$<$ http://www.funai.gov.br>. Acesso em 2003.

8. GOVERNO DE MATO GROSSO. Disponível em: < http://www.mt.gov.br>. Acesso em 2001

9. ITAMARATY - DIVISÃO AMÉRICA MERIDIONAL I - DAM I. Disponível em: $<$ http://www.mre.gov.br>. Acesso em 2001. 
10. MATO GROSSO INFOGRÁFICO. Disponível em:

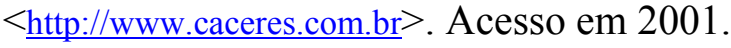

11. MATO GROSSO INFOGRÁFICO. Disponível em:

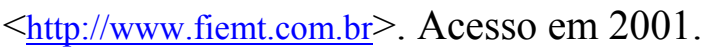

12. MINISTÉRIO DOS TRANSPORTES. Disponível em:

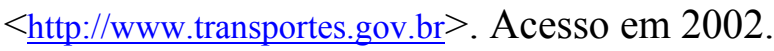

13. PROGRAMA BRASIL EM AÇÃO. HIDROVIA TOCANTINS - Araguaia.

Disponível em: < http://www.transportes.gov.br>. Acesso em 1999. 


\section{CAPÍTULO 12.}


12.

REFERÊNCIAS BIBLIOGRAFICAS

1. CANTER, L.W. Environmental impact assesment. Nova York: McGraw Hill, Inc., 1977.

2. CANTER, L.W. Environmental impact of water resources projects. $2^{\underline{a}}$ ed. Chelsea, Michigan. United States of Ámerica: Lewis Publishers, Inc., 352p.

3. CHANG, H. H. Fluvial processes in river engeneering. New York: A WileyIntersience Publication, 1987. 432p.

4. CHAUDHRY, M. H. Open-channel flow. Englewood cliffs: Prentice Hall, 1993. $483 p$.

5. DAVIS, M. L.; CORNWELL, D.A. Introduction to environmental engineering. Nova York: McGraw Hill, Inc., 1991.

6. ESCARAMEIA, M. River and channel revestments - a design manual. London: Thomas Elford Publications Ltd., 1998. 245p.

7. FLORENZANO, T. G. Imagens de satélite para estudos ambientais. São Paulo: $1^{\mathrm{a}}$ ed. Oficina de textos, 2002.95p.

8. FREEDMAN, B. Environmental ecology. The ecological effects of pollution, disturbance e other stress. San Diego, Texas: Academ Press, 1995.

9. GRAF, W. H.; ALTINAKAR, M. S. Hidraulique Fluviale. Lausane: Presses Polytechniques et Universitaires Romandes, 1993. 442p. 
10. JAIN, R. K. et al. Environmental assesment. Nova York: McGraw Hill, Inc., 1977.

11. JANSEN, P. P. et al. Principles of river engineering. Thenon-tidal alluvial rives. Editorial Board. Pitman - London - San Francisco - Melbourne, 1979.

12. LEBRETON, J. C. Dynamique Fluviale. Collection de la direction des études et recherches d'electricité de France. Eyrolles, 1974.

13. LEOPOLD, L. B. et al. A procedure for evaluating environmental impact.Washington: U. S. Geol. Surv. Cire, 1971.

14. MUNN, R. E. Environmental impact assesment. Nova York: John Wiley and Sons, 1975.

15. QUESNEL, P.B. Traité d'hidraulique fluviale appliquée: cours d'eau non navigables. $3^{\underline{a}}$ ed. Paris: Eyrolles Editeur Paris, 1980. 325p.

16. TEIXEIRA, W. et al. Decifrando a terra. $1^{-\underline{a}}$ ed. São Paulo: Oficina de Textos, 2001. 568p.

17. WORLD COMMISION ON ENVIRONMENT AND DEVELOPMENT.

Sustainable development: A guide to our commom future. Genova, Switzerland, 1990. 
capítulo 13. 
13.

GLOSSÁRIO

GLOSSÁRIO DE SANEAMENTO E ECOLOGIA, SEGUNDO CARVALHO (1981)

A apresentação deste glossário, tem por objetivo, facilitar o entendimento dos Impactos Ambientais, principalmente no que se refere a sua parte conceitual, pois, sendo um assunto multidisciplinar, envolve termos que são pouco comuns a algumas áreas do conhecimento.

Bentos - o termo bentos, que significa "profundo" ou "fundo do mar" é utilizado para designar a comunidade de organismos que habitam o substrato do mar, de rios, de lagos, podendo ocorrer em sistemas de transporte ou de armazenamento de água. Esta comunidade é, em geral, composta por nematodas, anelídeos, crustáceos e larvas de inseto. A macrofauna bêntica é composta por organismos omnívoros , carnívoros ou herbívoros e em um ecossistema bem balanceado todos os três tipos poderão estar presentes.

Biologia - é a ciência dos seres vivos, estuda a reprodução, crescimento, interrelações, metabolismo, estruturas, estímulos, comportamento e hereditariedade.

Biocenose - é o conjunto de populações de animais ou vegetais, ou de ambos, que habitam e exploram um determinado território ou espaço geográfico.

Bioma - é a comunidade dos grandes ecossistemas.

Bioma Terrestre - é aquele que tem sua fisionomia determinada pela vegetação que apresenta: tundra, taiga, floresta temperada, floresta tropical, campos e desertos. 
Bioma Aquático - é aquele que tem sua fisionomia determinada pela água doce ou água salgada

Biótopo - é o local que contém recursos suficientes para abrigar as populações.

Comunidade - consiste de um conjunto de populações de vegetais e/ou animais, vivendo juntos em determinado local. O mesmo que biocenose ou geobiocenose, ou biota.

Conservação da natureza - significa a sabia utilização dos recursos naturais renováveis, segundo o qual o homem deveria buscar a manutenção do equilíbrio biológico entre as suas necessidades e a capacidade a longo prazo da natureza para satisfazê-las.

Contaminação - introdução no meio ambiente (água, solo ou ar) ou em alimentos de organismos patogênicos, de substâncias tóxicas ou radioativas em concentrações nocivas à saúde, ou de elementos que possam afetar a saúde do homem. É um caso particular de poluição.

Desenvolvimento sustentável - é aquele que busca atender às necessidades da geração presente sem impedir as gerações futuras de atender às suas próprias necessidades.

Ecologia - é a parte da biologia que estuda a interação dos organismos entre si e seu ambiente.

Ecossistema ou Sistema Ecológico - é o conjunto de dois elementos: a biocenose e o biótopo.

Fauna - conjunto de animais que vivem em um determinado lugar. 
Fitoplâncton - é o termo utilizado para se referir à comunidade de vegetais microscópicos que vivem em corpos d'água e que são constituídos principalmente por algas: cianofíceas, clorofíceas, diatomáceas e flagelados.

Flora - conjunto de espécies botânicas que ocupam determinada região.

Grupos Ecológicos - nos ambientes aquáticos, distinguem-se três grupos ecológicos: plâncton, bentos e necton. Entretanto, o plâncton de água doce é, em geral, muito mais pobre em quantidade de organismos e em diversidade de espécies, que o plâncton marinho.

Habitat - meio, ambiente, lugar característico de onde determinado organismo, população ou comunidade, consegue retirar energia para sobreviver. Há quem considere habitat sinônimo de nicho ecológico.

Lêntico - ambiente aquático onde predominam águas paradas ou de corrente reduzida, sem fluxo preferencial, onde barreiras (por exemplo- reservatórios) físicas levam ao acúmulo e maior tempo de permanência.

Lótico - sistemas aquático de águas predominantemente correntes, de fluxo contínuo e unidirecional, com dinâmica e estrutura organizados ao longo do eixo vertical. Tem capacidade de arraste de material em suspensão.

Meio ambiente - local (águas, ar ou solo) onde se desenvolve a vida dos homens, animais, plantas ou microrganismos, em estreita relação com um conjunto de circunstâncias externas, que se caracterizam não só pelas propriedades físicas, químicas e biológicas desse local, mas também por outros fatores que regem a vida, como os relacionados às associações dos seres vivos, em geral e particularmente dos seres humanos, tais como aspectos de ordem cultural, legal, e outros (NBR 9896: 1993). 
Necton - é constituído pelos organismos capazes de nadar ativamente contra a corrente, fazem parte deste grupo a grande maioria dos peixes, mamíferos aquáticos (baleia, peixe-boi, por exemplo), crustáceos (como camarão), e moluscos cefalópodes (como as lulas).

Preservação da natureza - o termo preservação aplicar-se-á de mais maneira mais restrita às áreas que não podem e não devem sofrer qualquer espécie de intervenção com vistas ao aproveitamento econômico.

Plâncton - a palavra foi introduzida por Hensen em 1887, para distinguir todos os organismos que flutuam passivamente na água, sejam animais ou vegetais. Costumase subdividir o plâncton em dois grupos: o fitoplâncton e o zooplâncton.

Poluição Ambiental - degradação da qualidade ambiental, resultante de atividades que direta ou indiretamente: prejudicam a saúde, segurança e o bem-estar das populações; criem condições adversas às atividades sociais e econômicas; afetem desfavoravelmente a biota; afetem as condições sanitárias do meio ambiente; lancem matérias ou energia em desacordo com os padrões de qualidade ambiental estabelecidos. A poluição ambiental é devida a presença, lançamento, ou liberação, nas águas, no ar ou no solo, de qualquer forma de matéria ou energia, com intensidade, quantidade, concentração ou características em desacordo com os padrões de qualidade ambiental estabelecidos por legislação, ocasionando, assim, interferência prejudicial aos usos preponderantes das águas, ar e solo. Em função do tipo de poluente, podem ser distinguidas diversas formas de poluição: poluição física, química, físico-química, bioquímica, biológica e radioativa. As diversas formas de poluição se interligam de modo que o controle da poluição da poluição deverá ser feito em conjunto; em outras palavras, o controle da poluição do solo, por exemplo, pode criar problemas para a qualidade das águas superficiais ou subterrâneas, se certas medidas não forem tomadas (NBR 9896: 1993). 
Recursos ambientais - recursos naturais constituído pela atmosfera; águas interiores, superficiais e subterrâneas, estuários, mar territorial; solo e subsolo; elementos da biosfera, tais como fauna e flora; e recursos contidos nos locais de lazer, de interesse paisagístico, histórico ou turístico (NBR 9896: 1993).

Zooplâncton - o termo zooplâncton se aplica a todos os animais que vivem livremente na água e que, devido à sua capacidade limitada de locomoção, são levados mais ou menos passivamente pelas correntes de água. Podem ocupar toda a coluna d'água, desde a superfície até as grandes profundidades. Nas comunidades de zooplâncton encontramos animais com hábitos alimentares diversos, ocupando vários níveis de uma cadeia trófica: herbívoros, carnívoros, omnívoros. 